\title{
2. SITES 438 AND 439: JAPAN DEEP SEA TERRACE, LEG 57
}

\author{
Shipboard Scientific Party ${ }^{1}$
}

\section{SITE 438 (HOLE 438)}

Date Occupied: 19 October 1977

Date Departed: 19 October 1977

Time on Hole: 1 day

Position: $40^{\circ} 37.75^{\prime} \mathrm{N} ; 143^{\circ} 13.90^{\prime} \mathrm{E}$

Water Depth (sea level): 1552 corrected meters, echo sounding Water Depth (rig floor): 1562 corrected meters, echo sounding Bottom Felt: 1557.5 meters, drill pipe

Penetration: 109.5 meters

Number of Cores: 12

Total Length of Cored Section: 109.5 meters

Total Core Recovery: 81.9 meters

Core Recovery: 75 per cent

Oldest Sediment Cored:

Depth sub-bottom: 109.5 meters

Nature: Olive-greenish mud

Age: Lower Pliocene

Measured velocity: 1.6 to $1.8 \mathrm{~km} / \mathrm{s}$

\section{SITE 438 (HOLE 438A)}

Date Occupied: 22 October 1977

Date Departed: 27 October 1977

Time on Hole: 6 days

Position: $40^{\circ} 37.79^{\prime} \mathrm{N}$; $143^{\circ} 14.15^{\prime} \mathrm{E}$

Water Depth (sea level): 1558 corrected meters, echo sounding

Water Depth (rig floor): 1568 corrected meters, echo sounding

Bottom Felt: 1568 meters, drill pipe

Penetration: 878.0 meters

Number of Cores: 86

I Roland von Huene (Co-Chief Scientist), U.S. Geological Survey, Menlo Park, California; Noriyuki Nasu (Co-Chief Scientist), University of Tokyo, Tokyo, Japan; Michael A. Arthur, U.S. Geological Survey, Denver, Colorado; John A. Barron, U.S. Geological Survey, Menlo Park, California; Gary D. Bell, Gary Bell and Associates, Westlake Village, California; Jean-Paul Cadet, Université d'Orléans, Orléans, France; Bob Carson, Lehigh University, Bethlehem, Pennsylvania; Kantaro Fujioka, University of Tokyo, Tokyo, Japan; Eiichi Honza, Geological Survey of Japan, Tsukuba, Japan; Gerta Keller, Stanford University, Stanford, California; George W. Moore, U.S. Geological Survey, Menlo Park, California; Richard Reynolds, Rice University, Houston Texas; Shunji Sato, Japan Petroleum Development Company, Tokyo, Japan: Bernard L. Shaffer, Gulf Research and Development Company, Houston, Texas.
Total Length of Cored Section: 878.0 meters

Total Core Recovery: 555.3 meters

Core Recovery: 63 per cent

Oldest Sediment Cored:

Depth sub-bottom: 868.5 meters

Nature: Claystone

Age: Lowest middle Miocene

Measured velocity: $1.95 \mathrm{~km} / \mathrm{s}$

SITE 438 (HOLE 438B)

Date Occupied: 27 October 1977

Date Departed: 2 November 1977

Time on Hole: 7 days

Position: $40^{\circ} 37.80^{\prime} \mathrm{N}$; $143^{\circ} 14.80^{\prime} \mathrm{E}$

Water Depth (sea level): 1564.5 corrected meters, echo sounding

Water Depth (rig floor): 1574.5 corrected meters, echo sounding

Bottom Felt: 1574.5 meters, drill pipe

Penetration: 1040.7 meters

Number of Cores: 24

Total Length of Cored Section: 215.9 meters

Total Core Recovery: 192.6 meters

Core Recovery: 45 per cent

Oldest Sediment Cored:

Depth sub-bottom: 1040.7 meters

Nature: Clayey siltstone

Age: Lower Miocene

Measured velocity: 2.0 to $3.5 \mathrm{~km} / \mathrm{s}$

\section{SITE 439 (HOLE 439)}

Date Occupied: 3 November 1977

Date Depared: 8 November 1977

Time on Hole: 6 days

Position: $40^{\circ} 37.61^{\prime} \mathrm{N}$; $143^{\circ} 18.63^{\prime} \mathrm{E}$

Water Depth (sea level): 1656 corrected meters, echo sounding

Water Depth (rig floor): 1666 corrected meters, echo sounding

Bottom Felt: 1666 meters, drill pipe

Penetration: 1157.5 meters

Number of Cores: 39

Total Length of Cored Section: 342.0 meters

Total Core Recovery: 163.1 meters

Core Recovery: 48 per cent 


\section{Oldest Sediment Cored:}

Depth sub-bottom: 1157.5 meters

Nature: Hard clayey siltstone

Age: Late Cretaceous

Measured velocity: About 4.2 maximum $\mathrm{km} / \mathrm{s}$

\section{Basement:}

Depth sub-bottom: as above

\section{Principal results:}

At Site 438 , three holes were drilled, the deepest to 1040 meters, and 122 cores were recovered. At maximum depth, rocks are of lower Miocene age, and the Pliocene and Pleistocene boundaries are at 380 and 52 meters, respectively. Hole 438 penetrated sandy, silty clay with erratic pebbles, and we stopped drilling at 110 meters because of a medical emergency. Hole 438A was cored and logged to 868 meters through a generally uniform diatomaceous silt and clay section divided as follows: 0 to 364 meters diatomaceous clay to diatom ooze with numerous ash layers and uniformly straight log traces; 364 to 593 meters, mostly upper Miocene diatomaceous claystone to clayey diatomite of variable induration which gave highly variable log traces; 593 to 818 meters, largely middle Miocene claystone, diatomaceous claystone, and calcareous claystone with some thin limestone beds; 818 to 878 meters, largely lower Miocene sandy and diatomaceous claystone, in part vitric, marked by a pronounced shift in all log traces. Hole $438 \mathrm{~B}$ was a re-entry hole washed to 850 meters and cored to 1040 meters prior to hole failure in highly fractured claystone. The section consists of lower Miocene diatomaceous claystone with highly vitric sand-silt claystones to 976 meters. From 976 meters to 1040 meters, samples consist of highly fractured, well-indurated, dark clayey siltstone. This section is similar to other Neogene sections drilled on northeastern Pacific margins. Hole $438 \mathrm{~B}$ ended 250 meters short of the acoustic basement, which was attained $5 \mathrm{~km}$ east at Site 439 .

Core logs from Site 439 extend from those at Site 438 to older rocks and acoustic basement near the top of the Japan trench inner wall. This reflective sequence, largely of Neogene age, is broken only by mild normal faulting. Rapid subsidence of a Paleogene landmass to bathyal depth by the early Miocene is indicated by the following sequence of lithologies near the bottom of the hole: Cretaceous dark silicified silty claystone cut by an erosion surface near or below the acoustic basement reflector; boulder conglomerate and breccia, 48 meters thick, in which most of the clasts are porphyritic dacite from a nearby source and dark silty claystone; massive Oligocene sandstone, 105 meters thick, with numerous megafossils, many still articulated, and upper bathyal benthonic foraminifera. The lithology then changes abruptly to an early Miocene fine-grained turbidite-claystone sequence, 78 meters thick, overlain by the approximately 850 -meter-thick sequence of hemipelagic diatomaceous claystone deposited at bathyal depth and studied at Site 438 . The sequence of environments interpreted from these lithologies begins with an Oligocene or older emergent terrain that includes the silicified claystone and volcanic outcrops. Subaerial conglomerate and breccia were covered in the Oligocene by sand transported from a nearby surf zone into quieter but shallow waters. As subsidence continued, the distance from sources of terrigenous material increased and turbidites became increasingly distal. The area of sites reached bathyal depth at the beginning of the early Miocene and was then essentially isolated from all but some very finegrained terrigenous materials until a renewed influx of terrigenous material in the late Pliocene and Pleistocene.

\section{BACKGROUND AND OBJECTIVES}

The drilling objectives at Sites 438 and 439 (Figure 1) were to determine the composition of crust at the outer part of the fore-arc basin landward of the inner slope and to study the geologic history of this portion of the deep sea terrace between the shelf and the Japan Trench inner slope. In the multichannel records, basement is represented by a series of strong diffractions that underlie the orderly sequence of reflections from a stratified sequence. This diffracting horizon can be traced from near shore to the midslope terrace of the trench inner slope. The sites were selected where acoustic basement could be penetrated by the Glomar Challenger.

A second objective was to sample the outer fore-arc basin sediment sequence and characterize its paleoenvironments. A Cenozoic tectonic history might thus be established from the combined geophysical and geological data that would reflect the subduction history along the Japan Trench and the convergence of the Pacific and Asian plates. In particular, the chronological sequence of volcanic ash might give a general history of nearby arc volcanism. The diagenetic history of the rock sequence on the shelf could be compared with diagenesis in the accreted wedge beneath the trench inner slope in order to separate the effects of tectonic consolidation and disruption from normal burial diagenesis. The sampling at this site was considered important in the overall transect across this continental margin to facilitate the integration of terrestrial and marine geologic studies.

\section{OPERATIONS}

\section{Predrilling Site Survey, Site 438}

The objectives of the predrilling site survey were to identify, if possible, any potential hydrocarbon-trapping structures that may have been missed previously and to locate the site in accord with the recommendations of the IPOD Safety and Pollution Panel (SPP) and the SIO Safety Panel. The recommendations had been based mainly on the Japan Petroleum Development Corporation (presently Japan National Oil Corporation) Multichannel Line 1 (JNOC-1). The panels recommended moving the proposed site to a more landward location between shot point (SP) 610 and SP 650 to avoid possible hydrocarbons that might have migrated upslope. No multichannel records existed which crossed JNOC-1 at right angles at the new location. In addition, the safety panels had advised that faults be avoided, because faults might enhance gas migration and provide small hydrocarbon traps. 


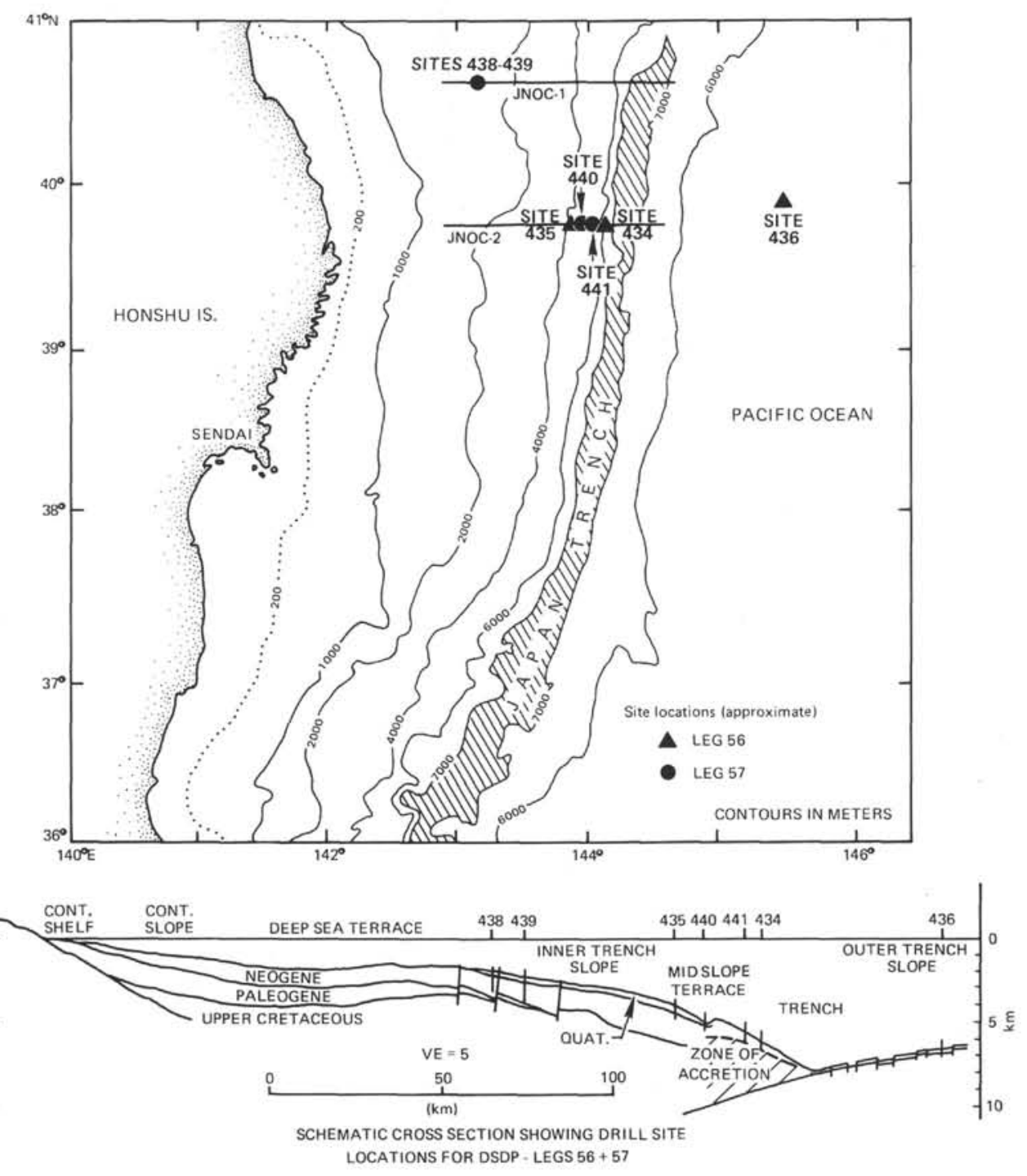

Figure 1. Location map showing position of sites drilled on Legs 56 and 57 and of JNOC multichannel seismic reflection profiles. Diagrammatic cross section of continental margin shown below (based largely on Ishiwada and Ogawa, 1976).

Two Ocean Research Institute (ORI) single-channel records along north-south transects crossed the main multichannel line on either side of the initially proposed site (Figure 2). One of the ORI lines indicated a shallow local unconformity that might provide a potential trap. Therefore we desired to establish the extent of the unconformity prior to drilling.

Glomar Challenger approached the site area from the south on a course parallel to, and between, the two ORI lines (Figure 2). About $20 \mathrm{~km}$ away a sonobuoy was released, but the hydrophones failed to deploy. The northern and southern limits of the unconformity were recorded on this line, and the crest of a broad anticline north of the site was defined before turning. A second seismic-reflection record was made just landward of the ORI lines on the second southbound track, which passed $0.5 \mathrm{~km}$ landward of the proposed site. This record did not pass through the site because navigational aids were not all receivable. During the subsequent northwest transit, all information was considered and we decided that the proposed site had low risk if the recommended safety program was followed during drilling. Glomar Challenger then turned along the main JNOC multichannel record section used to select Site 438 (predrilling site $\mathrm{J}-12$ ), and the beacon was dropped.

Drilling ended at Hole 438 because of a medical emergency that required the ship to dock at Hakodate, Hokkaido. During the return from Hakodate, a seismicreflection line was to be made along the crest of the structure on which the site is located; however, navigational aids were insufficient to locate the line well. Hole $438 \mathrm{~A}$ was located on the same beacon as 438,910 meters east along the JNOC multichannel line to avoid some deep faults. Hole 438A was a pilot hole for the re-entry hole $438 \mathrm{~B}$, which was placed 350 meters east, again to avoid as much faulting as possible in the lower interval to be cored. However, 438B may have been about 140 meters west of the desired position. 


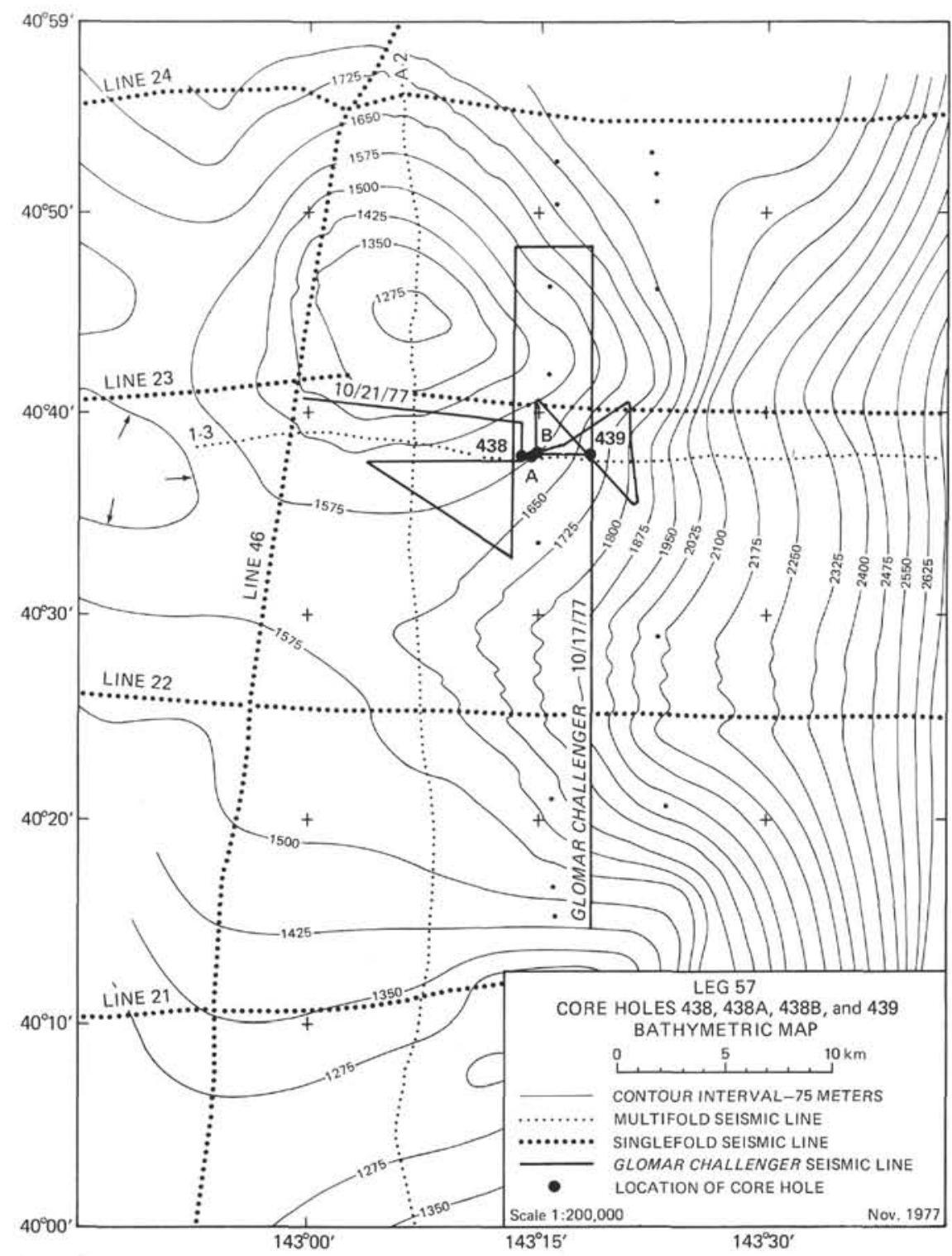

Figure 2. Bathymetric map of portion of Japan deep sea terrace showing location of Sites 438 and 439, tracklines of Glomar Challenger, and traces of other available seismic lines in area. Contours based on network of geophysical data as shown.

\section{Predrilling Site Survey, Site 439}

During the predrilling site survey, seismic reflection records were made to search for local unconformities in the upper part of the sedimentary sequence. The site was then established by steaming along the multichannel line and dropping the beacon at a predetermined distance from a major fault. The ship's track (Figure 2) was difficult to control because of a 3-knot $(5 \mathrm{~km} / \mathrm{sec})$ current and insufficient navigational aids. To gain sufficient navigational control, the ship returned to the beacon for Site 438 and then made a straight course for final positioning of the new beacon at Site $439,5 \mathrm{~km}$ east (Figure 2). Uncertainty in the ship's track during the first part of the survey is as much as $1.5 \mathrm{~km}$. However, we made the beacon drop within 150 meters of the desired loca- tion based on a satellite position of the Site 439 beacon after the ship had hove to at the site. The ship was offset from the beacon, and 25 good satellite fixes confirmed positioning over SP 760, JPDC-1.

After drilling and logging, we attempted a sonobuoyrefraction line across the site. The record failed to give refraction velocities because of instrument problems. However, we did obtain a good single-channel seismicreflection record along a northeast-trending line.

\section{Safety and Pollution Considerations}

The position of Site 438 in a basinal area of the continental slope required more than the usual amount of caution in monitoring hydrocarbons as drilling proceeded (Table 1). The structural setting of Site 438 was not fully known until after the seismic records made 
TABLE 1

Safety and Pollution Considerations: Suspected Gas Quantity Index

0 . No noticeable degassing or detectable hydrocarbons in core sample.

1. Detectable hydrocarbon gas but insufficient for reliable analysis. No notable pressure, separating, or bubbling.

2. Sufficient hydrocarbon gas for analysis of core tube samples. Widely scattered bubbling and/or separation.

3. In consolidated core the sound of gas bleeding ("frying," "fizzing," or "chirping"). Slight bulging of end caps in storage rack. Minor cracking in softer cores.

4. Pronounced bubbling of gas from core on retrieval. Numerous small separations in soft cores. Strong bulging of end caps. Dead oil staining.

5. Numerous large separations in soft cores. End caps blown off. Small amounts of soft core extruded from sections on rack. Consolidated cores with the same amount of gas will probably extrude sediments only when the core barrel is first opened. Oil fluorescence.

6. Indications of pressure before opening core barrel. Pronounced expansion of soft core on removal from barrel. Live oil staining.

7. Core catcher forcibly blown off. Good oil cut or "popping."

during the Glomar Challenger predrilling site survey and the ORI single-channel lines were integrated with the multichannel coverage. Study of the multichannel JNOC lines indicated a general correspondence between topography and the broad structural features of the deep sea terrace. Therefore, topography was used as a guide to a structure, because the lower seismic horizons were difficult to follow in the single-channel records.

Site 438 was found to be down the flank of a broadfaulted transverse-trending arch with local easterly plunging closure (Figure 2). High-angle faults with a presumed north-south trend cut the closure at 2- to $5-\mathrm{km}$ intervals. Vertical displacement along faults is perhaps as much as 200 to 300 meters at lower levels, but generally it is no more than 100 meters along the sea floor as seen in seismic-reflection records. Faulting appears to have been contemporaneous with sediment deposition. On a small scale, these faults might be traps for hydrocarbons. On a larger scale, the position of the site on the flank of the structure appears to be below the main area of closure. A fault seems to isolate the site from source areas downdip, if the fault zone is indeed a barrier. Local pods of tilted sediment occur along the flanks of some structures. Around some pods, unconformities have developed.

Prior to Leg 57, an oil company showed the shipboard staff the logs and seismic information of a deep hole drilled landward of the site. From the surface to the top of the Cretaceous, generally less than 1 per cent dry gas was measured in the hole. There were no reservoir sands and very low permeabilities above the Cretaceous-Tertiary boundary. Because, in addition, the section was expected to "shale out" seaward, encountering hydrocarbon reservoirs was thought to be even more unlikely at Site 438 than nearer shore.

Before drilling below 100 meters, the scientific staff reviewed all these consideration. Because faults might form small local traps, they were avoided as much as possible in locating the final hole position. Closed stratigraphic pinchouts probably exist at the truncated edge of local pods of sediment, but near the site pinchouts were probably not in communication with horizons deep enough to be in the thermal petroleum generation zone.

After drilling and logging $438 \mathrm{~A}$, it was concluded that the site was underlain by rocks of insufficient porosity and permeability to be hydrocarbon reservoirs. However, several of the units with intense fracturing and associated indigenous biogenic gas could have contributed to the caving that ultimately forced abandonment of Hole 438B. The organic carbon content and the fine-grained nature of the sediments generally preclude generation and storage of all but indigenous biogenic gas.

\section{LITHOSTRATIGRAPHY}

\section{Introduction}

Holes 438, 438A, 438B, and 439 were drilled on the deep sea terrace of the continental margin off northern Japan (Honshu) adjacent to the Japan trench. The major lithostratigraphic objective at Sites 438 and 439 was to core up to 1300 meters of a reflective sequence above "acoustic basement" and ascertain the nature of the basement, which was thought to be Cretaceous, prior to drilling, because it could be traced continuously from a Cretaceous unconformity near shore. Unfortunately, fractured rock caused hole instability problems which forced termination of drilling at a sub-bottom depth of 1047.0 meters in Hole 438B, preventing penetration of the acoustic basement. Therefore, the ship was moved to Site 439 , approximately $5 \mathrm{~km}$ to the east, where faulting appeared less intense in the seismic records.

Holes 438, 438A, and 438B and Site 439 are located along JNOC-1 in order and progressively deeper from west to east; 438B is about $1.3 \mathrm{~km}$ from 438 , and depth to sea floor ranges from 1552 to 1572 meters from Hole 438 to 438 B. From these three holes, a continuous sedimentary section was recovered from 0 to 1047 meters sub-bottom. Coring was continuous, and recovery generally good (see Figure 3 and Site Summary Chart, Sites 438 and 439 , back pocket).

The coring at Site 439 overlaps and continues to acoustic basement the section cored at Site 438 . The age and lithologic relationships between holes and a coring summary are shown in Table 2 and in Figure 3. A total of 7 lithologic units are defined on the basis of sediment character in Sites 438 and 439. Cores 439-1 and 439-2 are assigned to Sub-unit 2B and 439-3 and 439-4 to Subunit $2 \mathrm{C}$, as described at Site 438 and based on stratigraphic position and lithologic similarities. Continuous coring at Site 439 was undertaken beginning with 439-5, which contained sediment of the lower Miocene that is lithologically correlative with Unit 3 at Site 438 . The two sites are discussed together in the following because they represent drilling at essentially the same location and with the same objectives. 

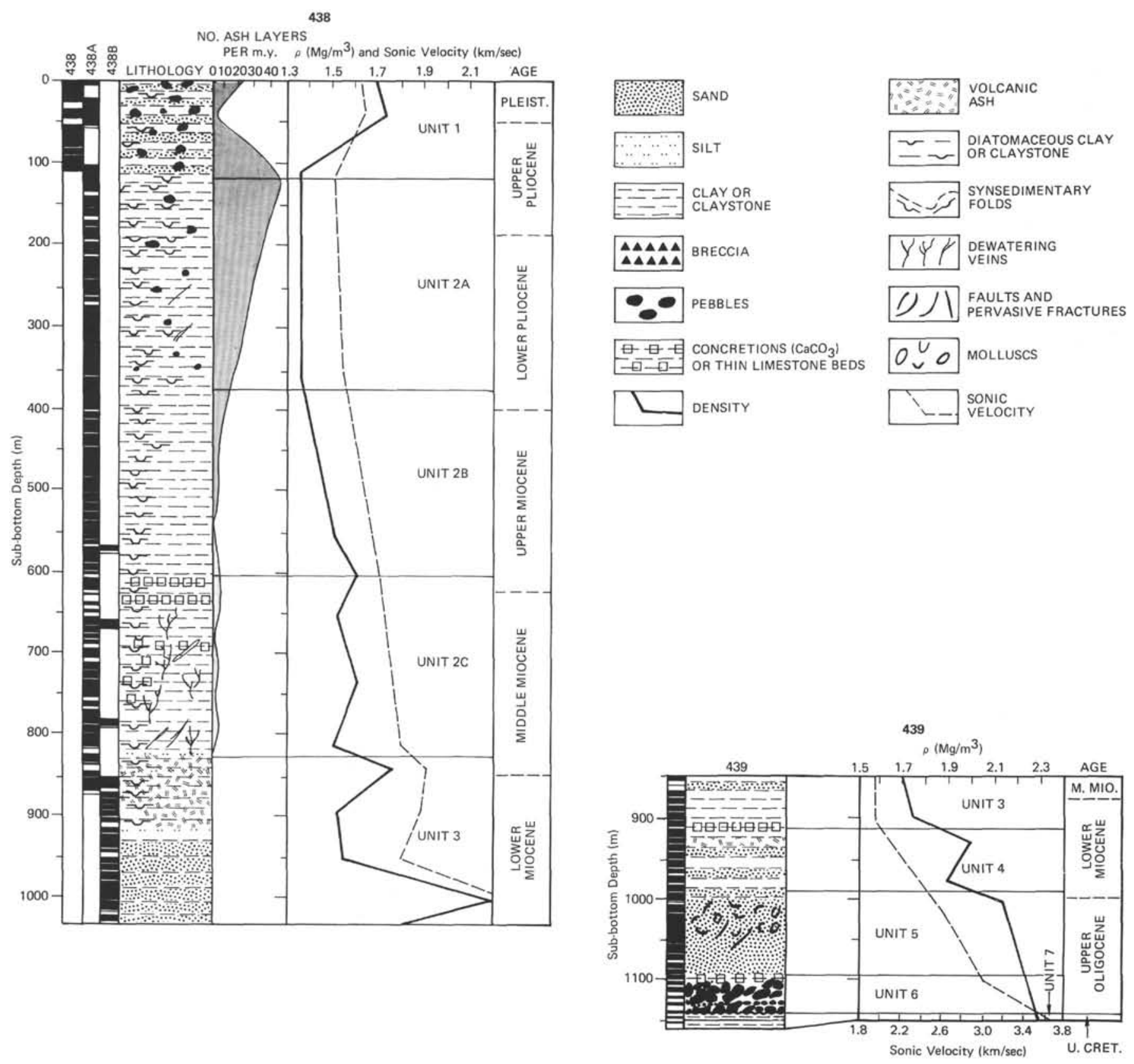

Figure 3. General lithology, lithologic units, core recovery, ash layer frequency, and physical properties from geophysical logs.

\section{Hole 438}

Lithostratigraphic Unit 1 (Cores 1-12, 0-107 m sub-bottom, upper Pliocene through Pleistocene)

This unit consists of olive gray (dark olive gray and dark gray, $5 \mathrm{Y} 4 / 2,3 / 2,3 / 1$ ) sandy, silty clay (sometimes pebbly); clayey sand and silt (also pebbly); and diatomaceous silty clay. Diatom content increases downward (to a maximum of $30 \%$ ), and sand content decreases markedly below 438-5 (see Site Summary Chart). Quartz and feldspar are the predominant sand and silt-sized components (up to $75 \%$ of total sediment); up to 10 per cent heavy minerals (including horn- blende, augite, magnetite), and about 10 per cent volcanic glass may also be present. Below 438-6, clay minerals and diatoms comprise the bulk of the sediment with a few interbedded sand and silt layers. Pebbles occurring within Unit 1 consist of rounded pumice up to 7 $\mathrm{cm}$ in diameter, but usually 2 to $5 \mathrm{~cm}$. Some rounded black, aphanitic, well-indurated pebbles also occur and are classified as graywacke and in some cases basalt. These are typically smaller in diameter than the pumice clasts.

Also abundant are ash layers, pockets, and mottles. Most of the ash layers are composed almost entirely of volcanic glass and contain only subordinate quartz, 
TABLE 2

Lithologic Units, Thickness, Age, and Description for Sites 438 and 439

\begin{tabular}{|c|c|c|c|c|c|}
\hline Hole & $\begin{array}{l}\text { Lithologic } \\
\text { Unit }\end{array}$ & $\begin{array}{l}\text { Core } \\
\text { Numbers }\end{array}$ & $\begin{array}{l}\text { Depth } \\
(\mathrm{m})\end{array}$ & Age & Lithology \\
\hline 438 & $\begin{array}{l}\text { Unit } 1 \\
(107.0 \mathrm{~m})\end{array}$ & 1 to 12 & $0.0-107.0$ & $\begin{array}{l}\text { Upper Pliocene } \\
\text { through } \\
\text { Pleistocene }\end{array}$ & $\begin{array}{l}\text { Diatomaceous sandy, silty clay and silt, pebbly (pumice and black } \\
\text { graywacke[?]), dark gray, olive gray, and dark olive gray }(5 Y 4 / 2- \\
3 / 2,3 / 1) \text {; numerous ash layers. }\end{array}$ \\
\hline $438 \mathrm{~A}$ & $\begin{array}{l}\text { Unit } 1 \\
(51.5 \mathrm{~m})\end{array}$ & 1 to 4 & $0.0-51.5$ & Pleistocene & $\begin{array}{l}\text { Diatomaceous sandy, silty, pebbly clay, olive gray to dark olive gray } \\
(5 Y 3 / 2-4 / 2) \text { in part; numerous ash layers. }\end{array}$ \\
\hline
\end{tabular}

Unit $2 \quad 5$ to $80 \quad 51.5-817.0$

Sub-unit $2 \mathrm{~A} \quad 5$ to $32 \quad 51.5-363.0$

$(312.5 \mathrm{~m})$

Sub-unit $2 \mathrm{~B} \quad 33$ to 56

$(230.0 \mathrm{~m})$

$363.0-593.0$

Upper Miocene

through lower

Pliocene (lowermost)

Sub-unit 2C 57 to 80

$(224.0 \mathrm{~m})$

Unit 3

80 to 86

$(61.0 \mathrm{~m})$

80
817.0-878.0 - Lower Miocene to lower middle Miocene

Middle Miocene through lower upper Miocene

\section{Sub-unit 2B 1,2 \\ Sub-unit $2 \mathrm{C} \quad 3,4$}

(Continuous coring begins)

Unit $3 \quad 5$ to 11

$(766.5 \mathrm{~m})$ 5 to 11

$849.5-916.0$

Lower to middle Miocene
Homogeneous to burrow-mottled (lower part) clayey diatom ooze, diatom ooze, and diatomaceous clay (soft to firm), mostly olive gray $(5 Y 4 / 2)$ with dark and very dark gray intervals $(5 Y 3 / 2,4 / 1)$ and olive mottling in lower part (5Y 5/3); numerous ash horizons (green-gray to gray), occasional pebbles (pumice), and siliceous sponge remains.

Diatomaceous claystone, clayey diatomite (silicified), burrowmottled throughout, minor ash layers in upper portion. Most of unit is olive gray, dark olive gray, gray to very dark gray. Sponge remains occur only in upper part. Lower part of unit silicified. Rare pebbles (pumice).

Mostly burrow-mottled claystone and diatomaceous claystone showing dewatering structures and some microfaults. Thin calcareous concretions and thin limestone beds common. Pebbles (pumice) and ash horizons rare. Unit $2 \mathrm{C}$ is predominantly dark gray, gray, and gray green $(5 Y 4 / 1-5 / 1$, and $5 G Y 5 / 1-4 / 1)$.

Sandy claystone and diatomaceous claystone, vitric in part. Clayey sandstone and siltstone alternates with claystone. Burrow-mottling common. Colors mostly gray to dark gray and gray green (5YG $5 / 1-4 / 1$ and 5 GY $4 / 1$ ).

Overlap with Site 438

Grayish olive green (5GY 3/2) and olive gray to dark olive gray (5Y $4 / 2-3 / 1$ ) claystone and vitric claystone; intensely burrow-mottled (5Y $6 / 4$ and $5 Y 4 / 3$ ), concretionary limestone layers, infrequent thin tuff layers, pumice clasts and fragments, microfaults and dewatering veins, tension fractures, sharp transition to next unit below.

\section{(-hiatus-)}

Unit 4

$(77.5 \mathrm{~m})$

\section{2 to $22-1$}

$916.0-993.5$

Lower Miocene

Interbedded turbidites and silty claystone, greenish black (5G $2 / 1$, $5 \mathrm{Y} 4 / 1$ ) to olive gray, Bouma sequences mostly as with a few ade and acde; medium-grained to fine-grained sand, silt grading upward to clay, sharp basal contacts, scoured; lithic wacke composition (microcrystalline quartz lithic fragments), some mollusc fragments. A few tuff layers, mottled clayey siltstone at base - sharp transition to next unit below.

$\begin{array}{llrl}\begin{array}{l}\text { Unit } 5 \\ (104.5 \mathrm{~m})\end{array} & \begin{array}{l}22-2 \\ 32-1\end{array} & 993.5-1098.0 & \text { Oligocene } \\ & & & \\ \text { Unit } 6 & 32-2 \text { to } & 1098.0-1145.5 & \text { Oligocene(?) } \\ (47.5 \mathrm{~m}) & 37-1 & & \end{array}$

Gray to olive gray (N5-5 Y $4 / 1$ and 2.5 Y $4 / 0$ ) massive sandstone and siltstone moderately well sorted, friable, no sedimentary structures, abundant molluscan debris and articulated pelecypods; sandstone calcite-cemented in lowest part of unit. Wood chips, quartz, lithic fragments (sands are lithic arenites) common.

Boulder to pebble conglomerate and breccia, mostly mudsupported, angular to subrounded clasts in clay-size matrix; boulder and smaller clasts of dacite (blue-gray to greenish gray) and pdbbles and granules of very dark gray silicified silty claystone (similar to Unit 7). Boulders up to $65-\mathrm{cm}$ diameter. Several individual conglomerate units. Basal $60 \mathrm{~cm}$ is olive gray $(5 \mathrm{Y} 4 / 1)$ plastic clay (firm).

(-hiatus-)

Unit $7 \quad 37-2$ to $\quad 1145.5-1157.5 \quad$ Cretaceous
Dark to very dark gray (N4-N2) well-indurated, silicified claystone and clayey siltstone with thin $(<1-\mathrm{cm})$ calcareous graded silt beds; contorted into slump folds but some horizontal bedding. 
feldspar (some zoned), hornblende, and biotite. Ash layers are up to $10 \mathrm{~cm}$ thick (average approximately 3 $\mathrm{cm}$ ) and range in grain size from fine silt to medium sand. Some are graded. Ash layers are generally dark gray to light gray (N-9 to N-2, 5G 4/1).

Sand and silt beds are poorly sorted and lack sedimentary structures. Only a few graded beds were noted. Wood fragments were found within some of the clayey sands.

\section{Hole 438A}

\section{Lithostratigraphic Unit 1 (Cores 1-4, 0-51.5 m sub-bottom, Pleistocene)}

Silty to sandy clay, silt, and sand predominate. Rounded pebbles of pumice and dark, aphanitic graywacke(?) up to $7 \mathrm{~cm}$ in diameter occur isolated in the muddy sediment. Typical colors are olive gray to dark olive gray ( $5 \mathrm{Y} 4 / 2-3 / 2)$. The sediment is diatomaceous (up to $25 \%$ ) and in part vitric (5-15\%). Glauconite is an important constituent $(5-21 \%)$ in some intervals of 438A-2, 438-3, and 438-4. Quartz and feldspar together make up an average of 30 per cent of the sediment in this unit. Heavy minerals (hornblende, augite) and authigenic pyrite are minor constituents. Clay minerals range from 25 to 50 per cent of the sediment.

As in Unit 1 of Hole 438, ash layers are common and similar in thickness and composition. Sand and silt layers are usually poorly sorted and massive. The Unit 1/ Unit 2 boundary in $438 \mathrm{~A}$ is placed at a rather sharp lithological change - the disappearance of pebbles and sand. Unit 1 in Hole 438 is thought to be lithologically correlative with Unit 1 in Hole 438A, although in Hole 438 the pebbly sand, silt, and interbedded diatomaceous clay seems to be thicker and to include slightly older strata than the equivalent in Hole 438A. In Hole 438A we did not core the interval from 51.5 to 106.5 meters; rather than the clayey diatom ooze in Core 5, this interval may contain the same pebbly, sandy silt and sandy, silty, and diatomaceous clay. The interval was logged through the drill pipe by the natural gamma-ray tool. The log indicates an increase in amount of sand from 62 to 68 meters and sand and silt to 85 meters. However, Unit 2 lithologic types occur in 438A-6, and therefore the Unit $1 /$ Unit 2 boundary has been drawn at the base of Core $4(51.5 \mathrm{~m})$. The difference in thickness and lithology in Unit 1 between Holes 438 and 438A may represent local topographic control on sand distribution during the late Pliocene and Pleistocene. Both holes are located on the flank of a structurally controlled topographic high that probably prevented accumulation of thick sequences of sand and silt during this time.

\section{Lithostratigraphic Unit 2 (Cores 5-80, 51.5-817.0 m sub-bottom, middle Miocene through upper Pliocene)}

This unit consists primarily of clayey diatom oozediatomite and diatomaceous clay-claystone of olive gray to gray color $(5 Y 4 / 2,3 / 2-4 / 1,3 / 1)$. It has been divided into three sub-units mainly on the basis of degree of lithification and changes in lithic character. The transition to claystone and initial signs of silica diagenesis mark the Sub-unit $2 \mathrm{~A} / 2 \mathrm{~B}$ boundary. Slight color change, increased carbonate content (as thin beds and nodules of calcareous limestone-chalk), and initial occurrence of dewatering structures (dark anastomosing veins) mark the transition from Unit $2 \mathrm{~B}$ to $2 \mathrm{C}$.

Sub-unit 2A (Cores 5-32, 51.5-363.0 m sub-bottom, lower Pliocene to upper Pliocene) contains mostly homogeneous clayey diatom ooze and diatomaceous clay that is olive gray $(5 Y 4 / 2)$ with some dark to very dark gray intervals $(5 Y 3 / 2,4 / 1)$. Olive ( 5 Y $5 / 3)$ burrow mottling becomes more prominent in this sub-unit below 438A-17 $(210 \mathrm{~m})$. The remains of small siliceous sponges (2-3 mm white radial spicule concentrations with pyritic centers) are typical below 438A-8 and become very common in the lower part of Sub-unit 2A. Sponge spicules are also an important (but usually $<10 \%$ ) component of the sediment.

Volcanic ash layers (predominantly glass) are abundant throughout Sub-unit $2 \mathrm{~A}$, especially above Core 438A-24. These ash layers are typically silt-sized, thin $(1-5 \mathrm{~cm}$, average $2 \mathrm{~cm})$, and in places graded. Ash-rich mottles occur commonly. These may either be lapilli or the result of bioturbation and disruption of ash layers. However, most ash horizons seem undisturbed.

Small, rounded pumice pebbles occur rarely in Subunit $2 \mathrm{~A}$. They are supported by the fine-grained diatomaceous clay matrix. Because most of this sub-unit is pre-Pleistocene, these pebbles may have floated on the sea surface and been transported by currents to the site before sinking to the bottom. There is no evidence for redeposition in the form of mud turbidites or debris flows.

Diatoms are very abundant (averaging over $40 \%$ ) in the lower part of Sub-unit 2A (Cores 438A-24-438A-32, lower Pliocene) and in the upper part (Cores 438A-5$438 \mathrm{~A}-17$ ) but average 20 to 25 per cent from $438 \mathrm{~A}-18$ to $438 \mathrm{~A}-24$. The clay mineral component increases at the expense of diatoms. No evidence exists for a change in sedimentation rate within Sub-unit $2 \mathrm{~A}$, and the variation in diatom content might therefore be due to varying preservation and silica diagenesis. However, no increase in cementation was noted in $438 \mathrm{~A}-18$ to $438 \mathrm{~A}-24$, where diatom percentages drop. Thus increased influx of clay minerals is suggested. Sedimentation rates derived from biostratigraphic studies indicate rates of $110 \mathrm{~m} / \mathrm{m} . \mathrm{y}$. or more. These rates are the highest for any lithostratigraphic interval in Sites 438 or 439 , except for a rate of $145 \mathrm{~m} / \mathrm{m}$.y. in the upper Pliocene section of Hole 438.

Quartz, feldspar, heavy minerals, and pyrite are present in very small amounts throughout Sub-unit $2 \mathrm{~A}$. Volcanic glass averages about 2 per cent in $438 \mathrm{~A}-6$ to $438 \mathrm{~A}-16$ and increases to slightly higher values in $438 \mathrm{~A}-17$ to $438 \mathrm{~A}-24$, becoming less abundant again from 438A-24 to 438A-32. Carbonate is essentially absent throughout.

Progressive induration downhole is evident in Subunit $2 \mathrm{~A}$. Diatomaceous clay and clayey diatom ooze is soft and easily deformed in core cutting and drilling in the upper two-thirds of the sub-unit but increasingly firm at the base.

Sub-unit $2 B$ (Cores 438A-33-438A-56, 363.0-593.0 $m$ sub-bottom, upper Miocene through lower lower Pli- 
ocene) has a rather gradational visual boundary with Sub-unit $2 \mathrm{~A}$ and is defined mainly on the basis of an increase in lithification. It coincides with a change from uniform to variable geophysical log character and a strong reflection in the seismic records, as well as with an increase in bulk density. The basic lithology differs little from that of Sub-unit 2A. Cores 438A-33 to 438A-44 are considered transitional in the diagenetic scheme of predominantly compaction processes to predominantly silica dissolution-cementation. The first olive gray to dark olive gray and gray to very dark gray (5Y 4/2, 4/1, 5/1,3/2,3/1) clayey diatomite and diatomaceous claystone occur (conventionally, the first core cut by saw) in 438A-39. Above that (438A-33-438A-39) alternating more- and less-indurated zones within the ooze and clay made cutting difficult and caused differential deformation of soft versus hard layers. The first noticeably silicified diatomaceous claystone occurs in $438 \mathrm{~A}-48$, and this lithologic type continues to the base of Sub-unit 2B.

Diatom content decreases markedly from a 35 per cent average at the top of Sub-unit 2B to between 10 per cent and 20 per cent in the lower part (below 438A-44). Preservation of diatoms decreases from good to moderate and poor below Core 438A-13 (Barron, this volume). This is the interval in which microcrystalline quartz and clay aggregates were noted. It is also notable that no volcanic ash layers are found below $438 \mathrm{~A}-46$, although a few occur (on the average of 1 per core) in $438 \mathrm{~A}-33$ to $438 \mathrm{~A}-46$. Background volcanic glass content also seems to decrease from 438A-43 to 438A-57. (Site Summary Chart). Thus, dissolution of opaline silica and reprecipitation as microcrystalline silica polymorphs may be an important process accounting for increased lithification within much of Sub-unit 2B. The abundant sponge skeletons higher up (within Sub-unit 2A) are less abundant at the top of Sub-unit 2B and disappear altogether below 438A-47. However, sponge spicules seem to increase (Site Summary Chart); this may be an effect of relative dissolution of diatom tests, leaving sponge spicules as a refractory element. The sedimentation-rate curve shows a pronounced inflection (Figure 12) at least $438 \mathrm{~A}-44$, some of which could be due to compactioncementation as well as to reduced sedimentation. However, Iijima and Matsumoto (this volume) in their samples did not find evidence for significant silica diagenesis above Core 438A-80.

Burrow mottling is pronounced throughout Sub-unit 2B. This is especially obvious below Core 438A-39; we sliced open all cores below this level with a diamond saw, thus enhancing the visibility of sedimentary structures. Rare rounded pumice pebbles, less than $0.5 \mathrm{~cm}$ in diameter were also noted. Several limey concretions (in places associated with volcanic ash) occur (e.g., 438A$33,35)$, and there are a few thin silty or sandy layers (e.g., 438A-35, 42).

Sub-unit 2C (Cores 438A, 57-80, 593.0-8.17.0 m subbottom, middle Miocene through lower upper Miocene) shows more variation than the homogeneous upper 442 meters of Lithostratigraphic Unit 2. In addition to dark gray, gray, and gray green (5Y 4/1-5/1, 5GY 5/1, 4/1, and 5G 4/1), highly burrow-mottled diatomaceous claystone and claystone, there are numerous nodular or thin-bedded well-cemented clayey limestone and calcareous claystone intervals. These calcareous intervals are generally less than $10 \mathrm{~cm}$ thick but seem to show up well on the sonic and neutron bulk-density logs as spikes. The carbonates consist primarily of nonbiogenic replacement carbonate minerals and cement, associated with clay, diatoms, and some volcanic components (see Moore, and Gieskes, this volume). Dewatering veins (see Arthur et al., this volume) are typically associated with these limestone intervals; they occur below and less commonly above them but are not restricted to these areas. This association suggests that the calcareous intervals may have intitially been more porous and acted as conduits for dewatering of the clay during compaction. The intervals were then gradually replaced and cemented by carbonate from the interstitial waters coursing through them. Some may once have been porous volcanic ash layers (now altered), because farther uphole carbonate concretions are associated with ash layers. This association has been noted in other North Pacific DSDP sites by Hein et al. (1978). Some dewatering veins may have later acted as microfaults because of differential compaction between clay and initially more porous carbonate layers (e.g., 438A-79) and concentration of stresses along the lubricated vertical fractures and veins.

A few volcanic ash layers, minor sand layers, and rare, rounded pumice pebbles are also noted in Sub-unit 2C. Quartz, feldspar, heavy minerals, and pyrite are very minor mineralogic phases. Volcanic glass averages 5 per cent and increases to 10 per cent, $438 \mathrm{~A}-74$ and 438A-80 (Site Summary Chart, back pocket). Clay minerals are the major mineral phase throughout the unit. Less than 20 per cent of the sediment is diatoms. Carbonate seems generally confined to thin layers or beds, which supports the idea of redistribution and concentration of diagenetic carbonate in originally more porous (vitric?) intervals.

\section{Holes 438A, 438B, 439}

Lithostratigraphic Unit 3 (Cores 438A-80-438A-86, 438B-4-438B-16, 439-5-439-11; 817.0-878.0 m, 853.3-975.7 m, 849.5-916 m sub-bottom; lower Miocene through lower middle Miocene)

(Note: Core $438 \mathrm{~B}-5$ corresponds to $438 \mathrm{~A}-83$ or 438A-84 biostratigraphically.)

The top of Unit 3 begins at a rather abrupt transition from claystone and diatomaceous claystone to vitric sandy claystone, vitric diatomaceous claystone, and some sandstone-siltstone beds. This occurs somewhere between the end of recovery in 438A-80 and 438A-81 and has been placed at 817 meters sub-bottom based on the downhole logs. In Cores 438A-82 through 438A-85 the volcanic glass component increases sharply (a trend possibly begun in 438A-76), diatoms decrease and quartz and feldspar remain about the same. Clay minerals rank high at over 60 per cent of the sediment; silt and sand grains are composed primarily of pumice and volcanic 
glass (a fact reflected less in smear slides but obvious in coarse-fraction study). However, below this initial increase in the volcanic component as sand and silt, the lithology again becomes predominantly grayish olive green $(5 G Y 3 / 2)$ to olive green (5Y 4/2) claystone and diatomaceous claystone with an average of only about 10 per cent volcanic glass. The unit is intensely burrowed throughout, and burrow mottles are dusky yellow green (10GY $3 / 2)$ to olive $(5 Y 5 / 2)$.

Microfaults, dewatering veins (?), and healed fractures are abundant. Fracturing and microbrecciation are particularly intense from 438B-11 to the base of Hole 438B. Most fracture or fault surfaces have been healed since original deformation, but in some places drilling appears to have rebrecciated cores along preexisting fracture surfaces. Offset along microfaults may amount to over $3 \mathrm{~cm}$ with both normal and reversed senses. As in Lithostratigraphic Unit 4, fracturing and intense brecciation seem to occur in an interval which is marked by faulting as interpreted on the JPDC multichannel seismic line (see Geophysics). No significant faulting was observed in cores above about 700 meters (438A$68)$.

Rare thin tuff layers also occur within Unit 3 . Thus it appears that volcanism was active on the Japan mainland during the early to early middle Miocene. The lack of an ash record suggests inactivity for most of the middle Miocene to the early late Miocene. However, this could also be due either to dispersion of the layers of bioturbation or, with less likelihood, to diagenetic alteration.

Core 438B-9 also contains poorly sorted, silty to sandy, vitric (including pumiceous) claystone or clayey sandstone, and siltstone. Woody plant fragments were also identified.

The lower part of Unit 3 is more similar to Unit 2 than to the upper part of Unit 3 in Holes $438 \mathrm{~A}$ and 438B. Cores 438B-11 through 438B-16 are composed predominantly of olive gray (5Y 4/2) diatomaceous claystone and vitric claystone (diatom content decreases steadily, disappearing completely by Core 438B-17), which are fairly homogeneous and intensely microfaulted and brecciated. The sediment of the lower part of Unit 3 is, in fact, very similar to that of Unit 2. Quartz and feldspar increase toward the base of Unit 3.

At Site 439 this unit consists mostly of homogeneous to intensely burrow-mottled olive gray (5Y 4/2), dark olive gray (5Y $3 / 1-3 / 2)$, and grayish olive green (5G $3 / 2$ ) claystone. Burrows range from dusky yellow (5Y $6 / 4)$ in the upper part of the unit to olive gray (5Y 4/3) in the lower part. Pumice, volcanic glass, and glauconite sand grains occur as concentrations in various portions of the unit. Quartz, feldspar, heavy minerals, and pyrite are persistent but minor components throughout, except near the base where quartz and feldspar contents, as well as that of sand- and silt-size detritus, abruptly increase. Clay minerals are the predominant component throughout the unit, averaging over 60 per cent.

Several limestone beds or concretions are present (e.g., 439-5-1) but not abundant. Tuff layers, some graded, ranging from 0.3 to $3.0 \mathrm{~cm}$ and ash pockets and mottles commonly occur (e.g., 439-7 and 439-8). Pumice fragments and pebbles up to $3 \mathrm{~cm}$ in diameter are common.

Dewatering veins, tension fractures (often sigmoidal), subhorizontal shear zones, and microfaults with both normal and reversed offsets occur throughout Unit 3. These attest either to synsedimentary deformation or to postdepositional, local deformation possibly related to larger faults cutting through the section at this depth.

As defined, Unit 3 has a sharp contact with Unit 4 below. A 140-cm-thick pumiceous glauconitic silty sandstone occurs just above the base. Associated with this sandstone are limestone concretions just below near the contact between Units 3 and 4 . No obvious unconformity lies at this lithologic contact but at least 100 meters of section found at Hole 438B were missing. At all sites, Unit 3 seems to represent primarily hemipelagic sediment deposited during a volcanic episode in the nearby Tohoku arc.

\section{Lithostratigraphic Unit 4 (Cores 438B-17-438-24, 975.5-1040.7 m sub-bottom, lower Miocene; Cores 439-12-439-22-1, 916.0-993.5 m sub-bottom, lower Miocene)}

The lowest lithotype encountered at Site 438 (Hole 438B) is black (SY2/1) to very dark gray (5Y 3/1) clayey siltstone. The siltstone is thick, predominantly massive, moderately to slightly bioturbated, and highly fractured (breaks with hackly fracture, with a basal parting in places; slickensides along some fracture surfaces). This unit is nearly barren of microfossils, although occasional molds of benthic foraminifers are noted in handlens examination.

Orientation of a few better-sorted silty or sandy laminae and lenses suggests structural dips up to $10^{\circ}$. However, these dips could be due to a crude crossbedding. Very few sedimentary structures diagnostic of mode of transport (graded bedding, cross-bedding) are visible; this is probably partly due to the highly fractured nature of the siltstone. Physical properties measurements show a pronounced increase in density and seismic velocity from Unit 3 to Unit 4 (see Physical Properties). Quartz (20 to $50 \%$ ), glauconite (up to $15 \%$ ), and feldspar $(10 \%)$ are the predominant minerals. Volcanic glass averages about 5 per cent, and clay minerals and microcrystalline quartz cement make up 35 to 70 per cent of the rock.

Wood fragments, abundant detrital minerals, and reworked Cretaceous radiolarians suggest erosion of "basement" outcrops and subsequent transport to the site. The base of this unit was not penetrated at Site 438B but was cored in its entirety at Site 439.

At Site 439 interbedded greenish black to olive gray (5G 2/1, 5Y 4/1) graded sandstone and siltstone beds and silty claystone characterize Unit 4 . The top of the unit is marked by a $185-\mathrm{cm}$-thick homogeneous graded siltstone (Bouma $\mathrm{T}_{\mathrm{ae}}$ ). Most other graded sequences, here interpreted as fine-grained turbidites, range from 10 to $80 \mathrm{~cm}$ in thickness. The basal contacts of each turbidite bed with underlying fine, silty claystone are usually sharp and irregular or scoured. Fine- to medium- 
grained sand and silt are typical for the basal sediment, grading upward to claystone or at times clayey siltstone. Sequences are usually Bouma $T_{a e}$ or $T_{d e}$, but some $T_{a b c d e}$ and $T_{\text {acde }}$ or $T_{\text {ade }}$ were noted. These sequences appear to become finer grained and slightly thinner toward the top of the unit, although no distinct trend exists.

The sandstone and siltstone are compositionally lithic wackes to lithic arenites and quartz wackes; quartz, feldspar, microcrystalline quartz-clay-lithic fragments, and some clay are the predominant components. Volcanic glass is also common. Heavy minerals, glauconite, carbonate minerals, diatoms, and sponge spicules are minor components. Diatoms and sponge spicules disappear near the base of Unit 4. Molluscan fragments occur rarely in the siltstone and claystone, and organic matter and large woody plant fragments are common to abundant in both the sandstone and claystone.

Faults with slickensided surfaces are common, and dewatering structures are less so than in shallower claystone units. Bioturbation occurs in the upper part of many graded sequences.

The components of turbidite sandstone beds of Unit 4 are nearly identical to those of the massive sandstone of Unit 5 below. An unconformity may separate the two units, but biostratigraphic information that might indicate a hiatus is sparse. Unit 4 is early Miocene, whereas Unit 5 is (probably late) Oligocene. Benthic foraminifers indicate a depositional setting in the upper middle bathyal realm (500-1500 m) for the turbidite sequence, whereas Unit 5 was probably deposited in water between 500 and 150 meters deep (see Foraminifers in site report and Keller, this volume). The same source is proposed for the sand of the two units.

\section{Lithostratigraphic Unit 5 (Cores 439-2-2 to 439-32-1, 993.5-1098.0 m sub-bottom, upper Oligocene)}

Unit 5 consists of extremely homogeneous or massive moderately well-sorted sandstone and siltstone that is medium to light gray and olive gray $(\mathrm{N}-5-\mathrm{N}-3,5 \mathrm{Y} 4 / 1$, $2.5 \mathrm{Y} 4 / 0$ ). Sedimentary structures are extremely rare in this unit of nearly 105 meters thickness. Characteristic are articulated pelecypods, well-preserved gastropods (Turitella), and numerous fragments of various mollusks. None of the articulated pelecypods were noted to be in growth position. Shell fragments are commonly aligned and imbricated in steeply dipping (up to $60^{\circ}$ ) sets, but no cross-lamination was noticeable in the sediment. The sandstone and siltstone are moderately to well-indurated to somewhat friable. There is calcite cement only near the contact with Unit 6, although articulated pelecypods commonly have calcite-cemented sand fillings elsewhere in the unit. Fractures and faults of small normal displacement $(3 \mathrm{~cm})$ occur in a few places.

The fine- to medium-grained sand and silt are composed mostly of quartz, feldspar, and lithic fragments. Lithic fragments are microcrystalline quartz and quartzclay aggregates, which may have been derived from the dark gray silicified claystone of Unit 7. Up to 5 per cent volcanic glass, heavy minerals, pyrite, and carbonate occur in the sand-silt size range, and clay minerals com- pose up to 20 per cent of the rock. The sandstone is classified as a lithic arenite to lithic wacke.

Some variability in bedding comes near the base of Unit 5. Calcite-cemented intervals and gravelly coarse sandstone occur together with a few pebbles (daciteaphanitic igneous rock). The dip of bedding near the base is about $10^{\circ}$, but bit deviation was also about $10^{\circ}$. A sharp transition occurs to the conglomerate of Unit 6 below.

\section{Lithostratigraphic Unit 6 (Cores 439-32-2-439-37-1, 1098.0-1145.5 m sub-bottom, upper Oligocene)}

The conglomerate and breccia of Unit 6 is 47.5 meters thick and contains angular to subrounded clasts from granule to boulder size (maximum $65-\mathrm{cm}$ diameter) set in a sandy clay to clay matrix. The conglomerate beds are poorly sorted, moderately indurated, and have an overall medium to dark gray (N2 to N4) color. Clasts consist almost totally of light bluish gray to gray green $(5 B 7 / 1-5 / 1,5 G 6 / 1-3 / 2)$ intermediate to acidic volcanic rocks (mostly dacite) and dark gray to black (N3 to N1) silicified claystone and silty claystone. The claystone clasts have a maximum $5-\mathrm{cm}$ diameter and average less than $1 \mathrm{~cm}$. These claystone clasts are identical to the basal lithology (Unit 7) drilled at Site 439. Reworked Cretaceous radiolarians are also present in Unit 6. The boulders of volcanic rock (bluish to greenish gray, fine- to coarse-grained, porphyritic) must have had a local source as well, although we recovered no igneous material other than the boulders. Radiometric ages obtained by using the $\mathrm{Ar}^{39} / \mathrm{Ar}^{40}$ method are $23.4 \pm 5.5 \mathrm{Ma}$ (see Moore and Dalrymple, this volume) amd $22.2 \pm 0.7,22.5 \pm 1.3$ and $22.8 \pm 1.5$ Ma. (Yanagisawa et al, this volume). Only a few exotic clasts (e.g., tan cherty mudstone, green talc) are present. Most of the interbedded coarser and fine conglomerate clasts and more minor breccia clasts are matrixsupported. Drilling deformation and recovery limit interpretation of bed thickness or sedimentation units.

The boulder conglomerate unit is devoid of indigenous marine fossils. The coarse boulder size, angularity of many clasts, and the uniform clast lithology suggest a local source. The lack of marine fauna and the position of Unit 6 in the overall depositional sequence suggest a nonmarine environment for its deposition. Unit 6 overlies the dark gray silicified, silty claystone of Unit 7, which is of Cretaceous age. A major unconformity lies between the two units, and sub-basinal erosion is suggested by the presence of reworked Cretaceous pollen and radiolarians (Sato, this volume; Reynolds, this volume). A gray $(5 \mathrm{Y} 4 / 1) 65$-cm-thick firm but sticky or plastic clay lies between the two units. This stratum may be a paleosol, but this interpretation is difficult to prove.

Volcanic Rocks in Unit 6. The boulders reach a maximum size of about $70 \mathrm{~cm}$ and are somewhat rounded in shape. The grain size of individual boulders varies from fine-grained to rather coarse-grained. These volcanic rocks are andesitic to rhyolitic in composition.

In hand specimen, slightly altered plagioclase phenocrysts are scattered randomly in an altered fine-grained, 
firm groundmass. No definite flow structures or dike structures are observed. Small amounts of mafic minerals, pale green to dark green hornblende, and rare biotite are also observed; they are slightly to completely altered to secondary clay minerals. Thin section examination shows that the color index of volcanic rocks is quite low. The amount of mafic minerals ranges from 7 to 14 per cent. The amount of modal plagioclase is extremely high and is greater than that of alkali feldspar. The texture of the volcanic rocks is always porphyritic, intersertal, intergranular, and rarely subophitic. Therefore these volcanic rocks can be classified as andesite, dacite, and rhyolite (see Fujioka, this volume).

Plagioclase phenocrysts, nearly euhedral and up to 3 $\mathrm{mm}$ in size, sometimes show very strong chemical zoning. Rather compositionally homogeneous broad calcic cores are surrounded by narrow, normally zoned rims. In some rocks, plagioclase phenocrysts include various sizes and shapes of blebs, thought originally to be glass, which are now completely devitrified and replaced by small aggregates of smectite-group clay minerals. The estimated chemical composition of phenocryst plagioclase (optical determination) is around $\mathrm{An}_{50}$ in andesitic rocks. However, that of the groundmass is less calcic and less zoned than the phenocrysts. Groundmass plagioclase occurs as small laths with intersertal, hyalophitic to intergranular texture and always has small amounts $(10 \%)$ of interstitial glass now devitrified and otherwise altered in various degrees. For example, if the interstitial glass has been transformed into small aggregates of brownish green smectite-group clay minerals, it will appear green in hand specimen. Phenocryst alkali feldspar shows intense perthitic lamellae texture in all samples examined.

Phenocrysts of mafic minerals, hornblende, and biotite range from 2 to 14 per cent in mode and are almost totally replaced by small aggregates of secondary minerals such as spherulitic dark green chlorite and smectites. The original grain size of these phenocrysts is up to $2 \mathrm{~mm}$ and sometimes shows euhedral tabular shape and, rarely, anhedral round shape. Rarely, the hornblende crystals are partly replaced along their rims whereas the core of the crystal remains unaltered; these cores show pale brownish green, weak pleochroism indicating slightly low temperature crystallization process. Very small amounts of (less than 5\%) very fine-grained opaque minerals (magnetite and ilmenite) are scattered in the groundmass. These volcanic rocks may belong to an iron-depleted trend that is the calc-alkali rock series.

\section{Lithostratigraphic Unit 7 (Cores 439-37-2-439-39, 1145.5-1157.5 sub-bottom, Late (?) Cretaceous}

Only 12.5 meters of this dark to very dark gray (N2-N4) silicified claystone and interbedded thin, graded, calcareous clayey siltstone were penetrated. Unit 7 is thought to represent local acoustic basement below an unconformity that marks a long hiatus (Late Cretaceous to latest Oligocene). The less than $1-\mathrm{cm}-$ thick siltstone interbeds are faintly graded and have fairly sharp basal contacts. Most of the unit is contorted into broad folds, interpreted as having resulted from synsedimentary slumping, but horizontal bedding does occur (e.g., 439-38-1). The unit is fractured, and slickensides appear on many fracture surfaces.

The siltstone layers contain quartz, feldspar, clay, and carbonate minterals in varying proportions. A sparse foraminiferal fauna is present.

\section{Interpretation of Sediment Lithofacies, Sedimentation History, and Regional Implications}

\section{Regional Geology}

The distribution of Tertiary basins in Japan and its offshore vicinity is illustrated in Figure 4 . The offshore part of the map is based on single and multichannel seismic data, aeromagnetic surveys, and core and dredge samples. Three Tertiary sedimentary basins aligned in a trough have been recognized along the western deep sea terrace of the Japan Trench. From north to south these are the Ishikari-Hidaka, the Kitikami, and the Joban basins (Ishiwade and Ogawa, 1976).

The Kitikami basin, in the center, contains sediment less than $2 \mathrm{~km}$ thick, whereas near the ends the other two basins contain sediment up to $5 \mathrm{~km}$ thick. The Joban and Kitakami basins are elongate with axes trending slightly east of north, subparallel to the local Japan Trench. The Ishikari-Hidaka basin axis trends northnorthwest toward Hokkaido.

Sites 438 and 439 are located at the southern end of the Hidaka basin. Sedimentary thicknesses are from 1 to $2 \mathrm{~km}$ at this point in the basin. The basin trend continues north-northwest across the western part of Hokkaido Island, as shown in Figure 4, where its sedimentary thickness increases to 3 to $5 \mathrm{~m}$. Ishiwada and Ogawa (1976) suggest that the basin was formed by subsidence of the Paleozoic basement in the fore-arc area and that the Mesozoic and Cenozoic strata overlying this basement are little deformed. They also entertain the idea that imbricated accretionary materials associated with processes of subduction may floor the inner slope of the trench seaward of Sites 438 and 439.

A relatively complete Neogene section was recovered at Sites 438 and 439.

Acoustic basement was reached at Site 439 after failure to do so at Site 438 , and with recovery came surprises. The sequence of sediment and fauna in lithologic Units 5 through 7 are all consistent with the interpretation that the area of the deep sea terrace was emergent during the Paleogene and subsided below sea level by the late Oligocene to the early Miocene. A second surprise is the occurrence of intermediate to acidic volcanic rocks in Unit 6 so near to the trench inner slope. That continental-type rocks might floor the deep sea terrace to the terrace edge has been proposed by several workers (Ishiwada and Ogawa, 1976; Honza et al., 1977). However, because global plate studies imply that as much as $1500 \mathrm{~km}$ of oceanic crust was subducted since the Miocene, it is difficult to imagine that the imbricate wedge (in the sense of Seely et al., 1974) did not extend farther landward from the trench (proposed as an alternative by Ishiwada and Ogawa, 1976) under the nearly flat-lying Neogene sediment of the inner slope trench and deep sea terraces. 


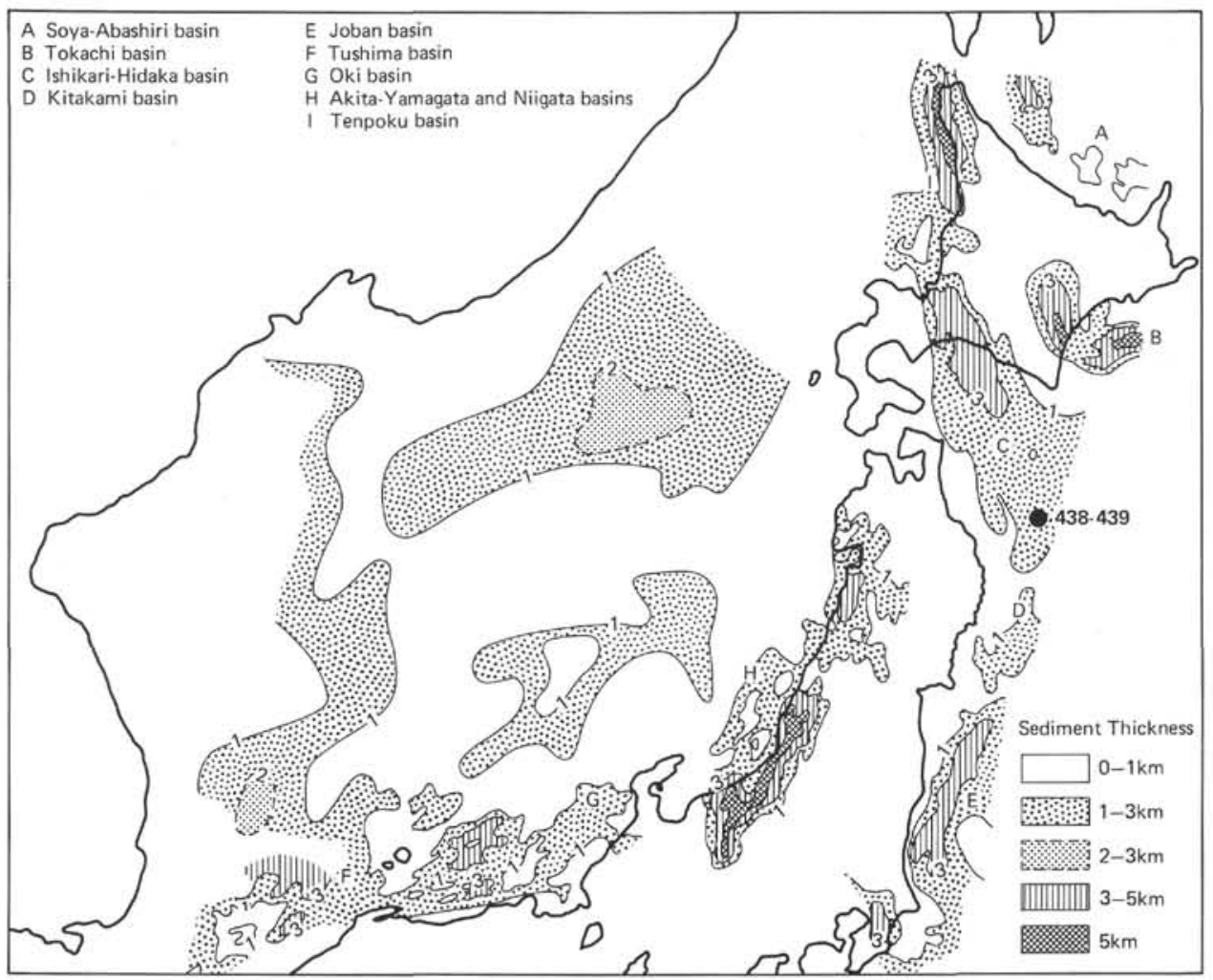

Figure 4. Distribution of Neogene basins off northern Honshu (modified after Ishiwada and Ogawa, 1976).

\section{Depositional Environments and Sedimentary Evolution}

The sedimentary units in Sites 438 and 439 may be interpreted as demonstrating subaerial exposure and erosion some time after deposition of Unit 7 (Cretaceous), followed in sequence by deposition of 1) nonmarine boulder conglomerate beds (Unit 6); 2) massive shallow water mollusk-bearing sands, possibly in a shelf environment (Unit 5); 3) rapid transition to deep-water $(500-1500 \mathrm{~m})$ turbidites and claystone (Unit 4$) ; 4)$ diatomaceous clayey sediment (Units 3 through 1). The transition from shallow- to deep-water deposition probably occurred during latest Oligocene-early Miocene (see section on Foraminifera). Sedimentation probably continued in water depths of $1500-2000$ meters in the postearly Miocene.

The stratigraphically lowest rocks recovered at Site 439 are Cretaceous. These sedimentary rocks, which correspond to the highly diffractive acoustic basement, are designated Unit 7. This unit consists of black, hard, fractured, silicified claystone with thin, calcareous quartzose siltstone interbeds, some of which are graded. Bedding is commonly contorted in what has been interpreted as a fine-grained turbidite sequence. Only 12.5 meters of this unit were penetrated, but the broad extent of the unit is demonstrated by the many fragments of it in cores from overlying beds at Sites 438 and 439. An unconformity occurs at the top of Unit 7, and boulder to pebble conglomerate and breccia of Unit 6 overlie it; the two units are separated by a $60-\mathrm{cm}$ interval of plastic clay. Angular to subrounded clasts of Unit 7 lithologies occur in the conglomerate breccia beds, and on the basis of this and the disparity of age between Unit 7 and Unit 6 , we conclude that the unconformity is an erosional one. Age-diagnostic fossils were not recovered from Unit 6, but it directly underlies sediment from the latest Oligocene.

Unit 6 contains pebbles, cobbles, and boulders of two basic lithologies: black claystone and silty claystone very similar to Unit 7 rocks and highly altered greenish gray to blue-gray porphyritic, dacitic (intermediate to acidic) igneous rocks. In addition, some light-colored rhyolitic-tuff fragments were also noted as clasts. Dacites are igneous rocks commonly associated with island arc magmatism. The dacite boulders and cobbles are somewhat rounded and up to $70 \mathrm{~cm}$ in diameter, but many smaller clasts are angular to subangular. The angular nature of many clasts and the large size of the boulders preclude long-distance transport. The predominance of dacite clasts is also suggestive of local derivation. Phenocrysts in the igneous rocks are abundant, fairly large (up to $3 \mathrm{~mm}$ ), and are set in a felted microcrystalline groundmass (in the dacite). All phenocrysts are randomly oriented and lack flow texture. These igneous clasts may have derived from flows interbedded in a sedimentary sequence or be hypabyssal dike rocks or other shallow intrusives. A few clasts of extrusive rhyolite tuff are present. The dacites have been radiometrically dated between about 22.2 and $23.4 \mathrm{Ma}$ (Moore and Dalrymple; Yanagisawa et al., both this 
volume). This indicated cooling age is almost coeval with that of the sediment overlying the conglomerate in which the igneous boulders occur. The weathered character of some surfaces and the indication of transport raise the possibility of a former subaerial environment. The erosion of at least Unit 7 and possibly later deposited rocks (Cretaceous-Paleogene), the inclusion of clasts of Unit 7 rocks in Unit 6, and the lack of marine fossils in Unit 6 all suggest subaerial exposure. In addition, Sample 439-37-1, 70-135 cm, is an interval of poorly indurated, very plastic clay containing a few lithic fragments which overlies Unit 7 black claystone; this sample may be a soil or weathering horizon above the erosional unconformity.

A rather abrupt lithologic transition occurs near the Oligocene/Miocene boundary. About 105 meters of massive olive gray to dark gray sandstone and siltstone bearing numerous shallow water mollusks and upper bathyal foraminifers (150-500 depth) overlie conglomeratic (Unit 6). Unit 5, which consists of friable clastic rocks, seems to indicate deposition near a shallowwater, high-energy environment. Gastropods and articulated pelecypods occur oriented randomly in the sandsilt matrix. The sediment is moderately well sorted and exhibits almost no sedimentary structures. Bedding indicators such as lamination or oriented fossils are rare, but those that exist suggest at some levels rather steep dips (up to 60) and at other near horizontal (near the base). The dips may be due either to steep cross-bedding or to postdepositional slumping and deformation. None of the molluscan shells, which are thin and delicate, were observed in growth position, but since many remain articulated, they may have lived as part of an infauna and been little reworked. An alternate hypothesis is that this sand may represent a massive density or grain flow deposited in deeper water at the base of a slope. This hypothesis still requires a local shallowly submerged shelf. The composition of the sand and silt in Unit 5 (typically lithic arenite to lithic wacke) could indicate reworking of the detritus from dacitic igneous rocks and the black, silicified silty claystone of Units 6 and 7 . Quartz, feldspar, and fine-grained rock fragments (microcrystalline quartz-clay mixtures) predominate.

Unit 5 passes rapidly into an early Miocene age deepwater interbedded turbidite-claystone sequence (Unit 4). The depth is inferred from the predominance of benthonic foraminifers that indicate an upper middle bathyal depth $(500-1500 \mathrm{~m})$ and from the rather finegrained nature of the turbidite sequence. The turbidite sequence shows a trend toward more "distal," finergrained, and thinner individual turbidites upward, suggesting continued subsidence of the source area, increasing distance from the source, or migration of the active lobes of a submarine fan away from the site. The composition of the sand and silt fraction in Unit 4 is similar to that of the sand and silt in Unit 5; the same source region is suggested for both units. Unit 4 at Site 439 is about 86 meters thick and is age-equivalent and generally lithologically equivalent to Unit 4 at Site 438 , except that there are almost no graded sequences (although the lower portion of Unit 4 was not penetrated at Site 438). Thus it appears that this phase of the evolution of the outer deep sea terrace represents the continued subsidence of the once greatly exposed landmass. Sediment from the eroded, subaerially exposed sedimentary "outer arc" was probably shed to the area of the sites at least through the early Miocene.

The sedimentary sequence of middle Miocene through Pleistocene (Units 3 through 1) at Sites 438 and 439 has little coarse terrigenous clastic material, especially considering the position of the sites on the outer deep sea terrace only $170 \mathrm{~km}$ seaward of a tectonically active island arc. Whereas many coastal Neogene stratigraphic sections of Japan are typified by thick turbidite sequences through most of middle Miocene through Pleistocene (Ishiwada and Ogawa, 1976; Ingle, 1975; Ujiie, Saito et al., 1977), the location of Sites 438 and 439 seems to have been isolated from that flood of terrigenous detritus. Many basins on the Pacific side of the Tohoku arc seem to have thick Plio-Pleistocene marineclastic deposits, but even the sequence of pebbly silt and sand in the upper Pliocene-Pleistocene at Site 438 is relatively thin and of local extent. The deep sea terrace is characterized by tectonically controlled canyons and ridges which probably resulted from a Pleistocene deformational episode (Honza et al., 1977). It is likely that the position of Sites 438 and 439 on the seaward flank of one of the local topographic noses or domes (Figure 2) has isolated them from much of the Plio-Pleistocene clastic material from the Tohoku arc. It is also possible that some structures have existed since at least the early Miocene, because reflectors representing Units 2 and 3 in the sedimentary sequence at Site 438 progressively pinch out against and over the structural and topographic high to the west on JNOC-1 (Figure 17A). Therefore this high may have afforded a barrier against much of the clastic influx to the outer slope in the vicinity of Site 438 since the Miocene. Alternatively, the sites may have been high enough on the flank of the high to have been above the level of coarse-sediment influx and deposition. Another factor may be the broad terrace between the active island arc and the sites. Much coarse sediment is probably trapped in interior shelf basins and never reaches the outer terrace or slope. In addition, much of the present drainage from the mountainous regions dumps westward into the Japan Sea rather than into the fore-arc basin off northern Honshu.

Rates of deposition of Miocene and Pliocene clay and clayey diatom ooze ranged from about 40 to 120 $\mathrm{m} / \mathrm{m}$.y. Maximum rates of sedimentation of diatoms occurred during the Pliocene, averaging nearly 50 per cent of the total sediment. Clay minerals were an important component throughout the Neogene section; the relative proportion of clay was greatest during the Miocene and again in the late Pliocene. The finer terrigenous fraction might have reached the site via wind transport, sedimentation from the nepheloid layer, and by turbid layer traansport. The rate of influx was quite high. Volcanic ash also contributed to the relatively high sedimentation rate. The lower Miocene and Plio-Pleis- 
tocene volcanic phases on the Tohoku arc are best represented in the sequence at Site 438 as disseminated glass and ash horizons.

The bottom waters were apparently oxygenated throughout deposition of most of the diatomaceous sequence, as evidenced by intense bioturbation of the sediment (burrow-mottling, with the exception of upper Pliocene-Pleistocene of 438A-1 to 438A-16), a fauna of benthonic foraminifera, and numerous siliceous sponges (observed in upper Miocene through Pliocene sediment). Although middle Miocene diatomaceous muds and oozes which were anoxic or near-anoxic during that time were deposited in a number of basins in the northwest and northeast Pacific, no fine lamination or lack of burrowing, which might indicate anoxic bottom conditions, was noted here. However, the rapidly deposited hemipelagic sediment at Site 438 must have become anaerobic below the sediment/water interface soon after deposition owing to bacterial oxidation of organic matter and consequent sulfate reduction, because authigenic pyrite is a ubiquitous component of the sediment. Organic carbon values range from $0.35 \mathrm{wt}$. per cent in the middle Miocene to $0.72 \mathrm{wt}$. per cent in the upper Pliocene (an interval in which no bioturbation was noted in the cores).

Benthic foraminifers indicate depths of deposition of about 2000 meters for most of the Neogene at Site 438 . Some shallowing occurred during from Pleistocene to the Holocene (present depths at site are approximately $1550 \mathrm{~m}$ ) accompanying deformation of the Japan outer slope region (Honza et al., 1977).

The Neogene stratigraphy at Sites 438 and 439 corresponds well with that of Sites 434 and 435 (Leg 56) and 440 and 441 (Leg 57), which were drilled on the upper trench slope seaward of Site 438. Diatoms, clay, and ash were the main sedimentary components from the late Miocene through the Pleistocene at these sites. However, little late Pliocene-Pleistocene terrigenous clastic sediment reached any of these sites. Pliocene and Pleistocene erratic pebbles (ice-rafted or floated in the case of pumice) were common to all sites, and pumice pebbles occur throughout the late Neogene sequences at all sites.

\section{Volcanic Materials}

Products of Neogene volcanic activity, probably from the Japan volcanic arc some $200 \mathrm{~km}$ upwind, occur throughout the sequence at Site 438: pumice fragments, ash layers, and disseminated volcanic glass occur in most intervals, whereas reworked volcanic detrital sand-silt rock fragments are more scarce. Continuous coring and good recovery allow for conclusions on the timing of volcanic activity in the arc.

Pumice fragments or pebbles are present throughout the sediment at Site 438 as recognizable rounded or angular pebbles from 0.3 to $8 \mathrm{~cm}$ in diameter. Color is generally white or light gray and sometimes black. Pumice fragments are abundant in Unit 1, scarce and small in Unit 2, and rather abundant and gravel-size in Unit 3 . Most were probably transported by oceanic currents as floaters from near the original volcanic area; some small ones may have been transported by wind drift and some by ice-rafting during the Plio-Pleistocene.

Volcanic glass occurs both as grains disseminated within sediment and concentrated in distinct layers and patches. Disseminated volcanic glass shards are mostly clear and colorless and possess a low refractive index. They are abundant in the Plio-Pleistocene of Holes 438 and $438 \mathrm{~A}(5-15 \%$ of the sediment) and in the middle and lower Miocene of Holes 438A and 438B (up to $20 \%$ ), with generally small amounts $(2-5 \%)$ through the remainder of the section. Colored varieties of glass (orange and yellow) are also present but are rare throughout the sediment recovered.

Ash layers are variable in character and very numerous (more than 100 in Hole 438B). Color is usually white, light gray, and bluish gray to darker gray. Average thickness of ash horizons is 2 to $3 \mathrm{~cm}$, but they reach a maximum thickness of $10 \mathrm{~cm}$ (Sample 438-10,-6). The ash layers consist of silt-sized to coarse sand-sized glass shards $(65-95 \%)$ which are angular, clear, and colorless and contain minor amounts of feldspars (euhedral in places and zoned), quartz, hornblende, rare biotite, augite-hypersthene, magnetite, and pyrite. Preliminary examination suggests that the glass shards are aciditic to intermediate in composition.

\section{Mode of Deposition}

Fine ash was transported primarily from the nearby Japan arc by the prevailing westerly wind in this area and by fall through the water column. This seems to be a viable model for most very pure (greater than $90 \%$ glass) and fine-grained ash layers interbedded with clay or claystone (e.g., Samples 438A-20-2 and 438A-25-3). Most commonly, ash layers show a bit of mixing of other components such as quartz (up to $20 \%$ - e.g., Sample 438-3-2), diatoms, and clay. Indistinct grading occurs in some thicker beds. This suggests some redistribution and resedimentation by either turbidity or other bottom currents. However, grading may also be the result of normal settling-rate differences among particles of different sizes in their fall through the water column. It is usual for ash beds to be partially reworked by burrowing organisms and disrupted into ash pockets of irregular shape. Bioturbation may explain contamination in some beds. Nevertheless, when reworking is not too great, individual ash layers or groups of ash layers are probably related to a single phase of volcanic activity in the Japan volcanic arc system to the west of the site. Preliminary conclusions are that the distribution of ash layers in time is uneven; ash beds appear near the top of the lower Miocene, become extremely abundant within the Pliocene, and decline to relatively low levels in the Pleistocene; however, these last are greater than the maximum within the Miocene (see Figure 5 and Cadet et al., this volume).

\section{BIOSTRATIGRAPHY}

\section{Introduction}

In Hole 438, 81.9 meters of olive gray diatomaceous muds intercalated with ash layers was recovered span- 


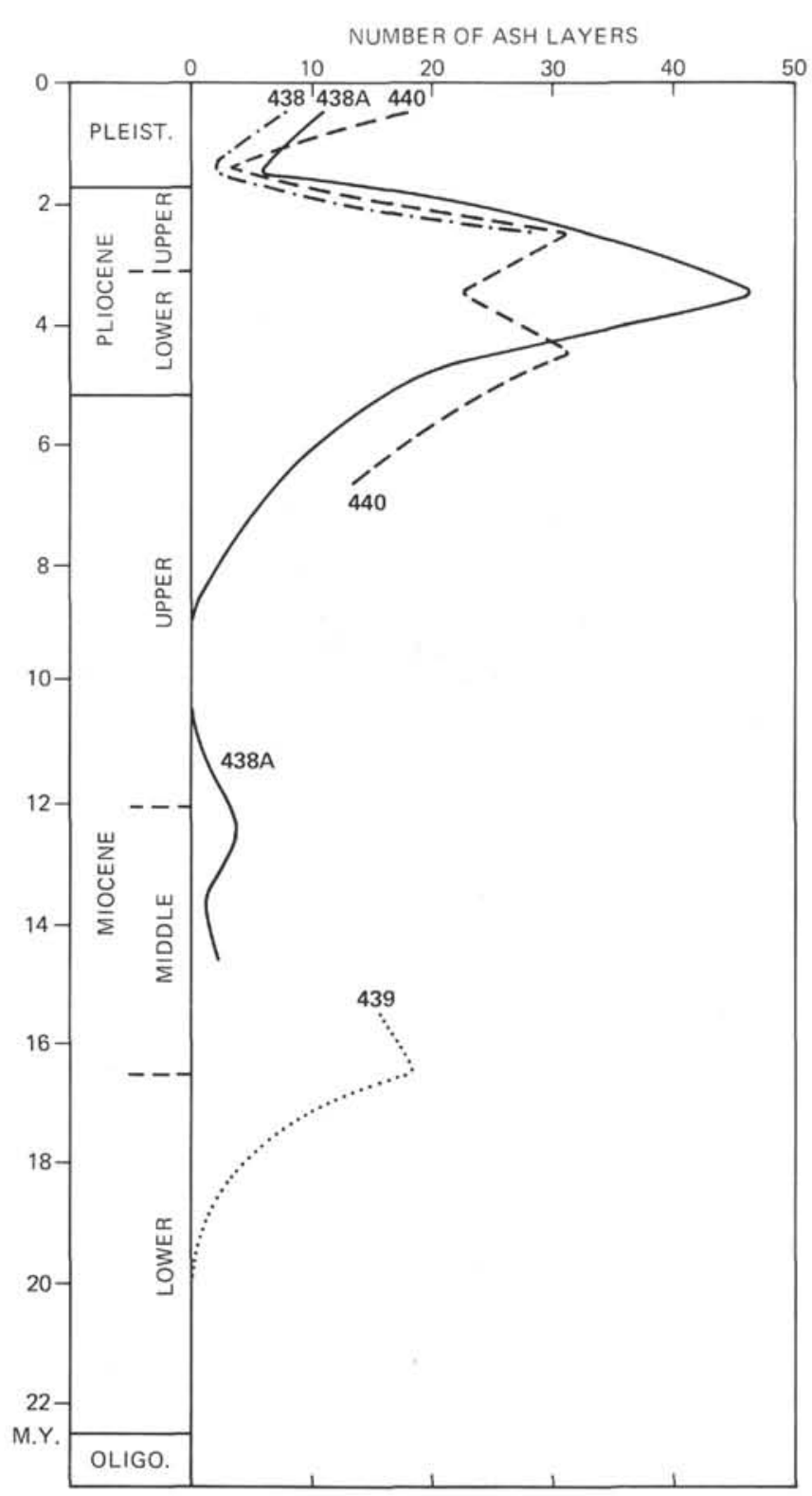

Figure 5. Ash layer frequency through time in Leg 57 sites (see Cadet and Fujioka, this volume).

ning the late Pleistocene to middle Pliocene. Cores 4 and 6 were not recovered at this site. A total of 575 meters of similar sediment was recovered at Hole 438A spanning the Pleistocene to early Miocene.

The sediments from Hole 438B contained diatoms, radiolarians, nannofossils, and rare benthic foraminifera but were barren of planktonic foraminifera. The time interval represented by the cores recovered at this hole was from late Miocene through early Miocene (Cores 438B-1-438B-24,CC). As at the previous sites, diatoms were the most abundant fossil group present; radiolarians were common to rare. Nannofossils were absent below Core 438B-15,CC. Figure 6 shows the correlation of the holes drilled at Sites 438 and 439. Correlation of the microfossil zones for Sites 438 and 439 is illustrated in Figures 7 through 10.

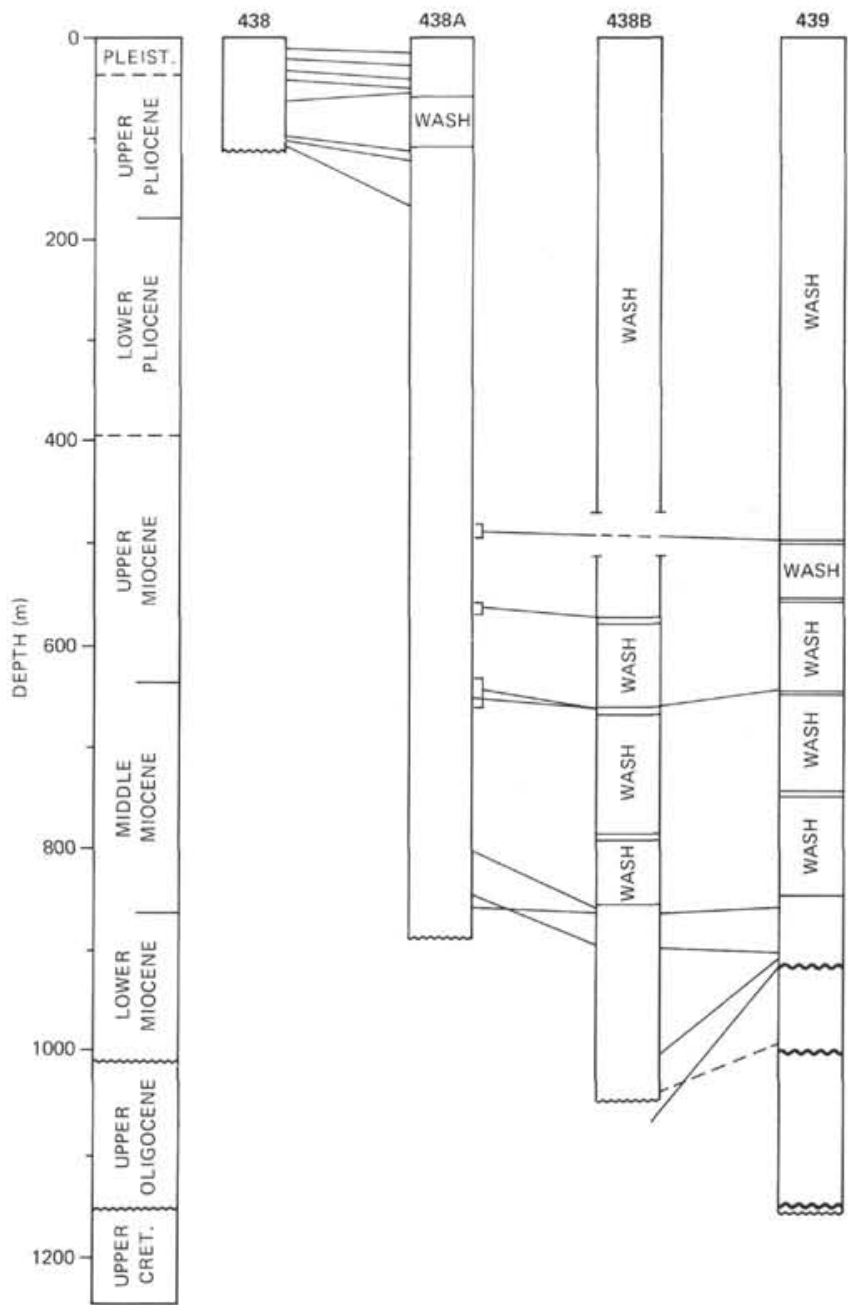

Figure 6. Biostratigraphic correlation of holes at Sites 438 and 439 based on zonations shown in Figures 7-10. Brackets indicate error margin.

Figures 11 and 12 represent sediment accumulation rates for Holes 438 and 438A, respectively. Sedimentation rates are based on known data planes of various microfossil groups which have been paleomagnetically calibrated and/or radiometrically dated. At Holes 438 and 438A siliceous microfossils were most abundant; therefore the sediment accumulation rates are primarily based on data of these two microfossil groups. Calcareous microfossils occur only sporadically.

\section{Hole 438}

Sedimentation rates based on microfossil data appear to increase significantly below about 60 meters from 25 $\mathrm{m} / \mathrm{m} . \mathrm{y}$. during the Pleistocene to late Pliocene to 145 $\mathrm{m} / \mathrm{m}$.y. during the rest of the Pliocene (Figure 11).

\section{Hole 438A}

Between 2 and about 5.4 m.y. the sediment accumulation rate increased significantly from about 25 $\mathrm{m} / \mathrm{m}$.y to $110 \mathrm{~m} / \mathrm{m}$.y. (Figure 12 ). Below Core 438A-36, CC upper Miocene and upper middle Miocene sedi- 


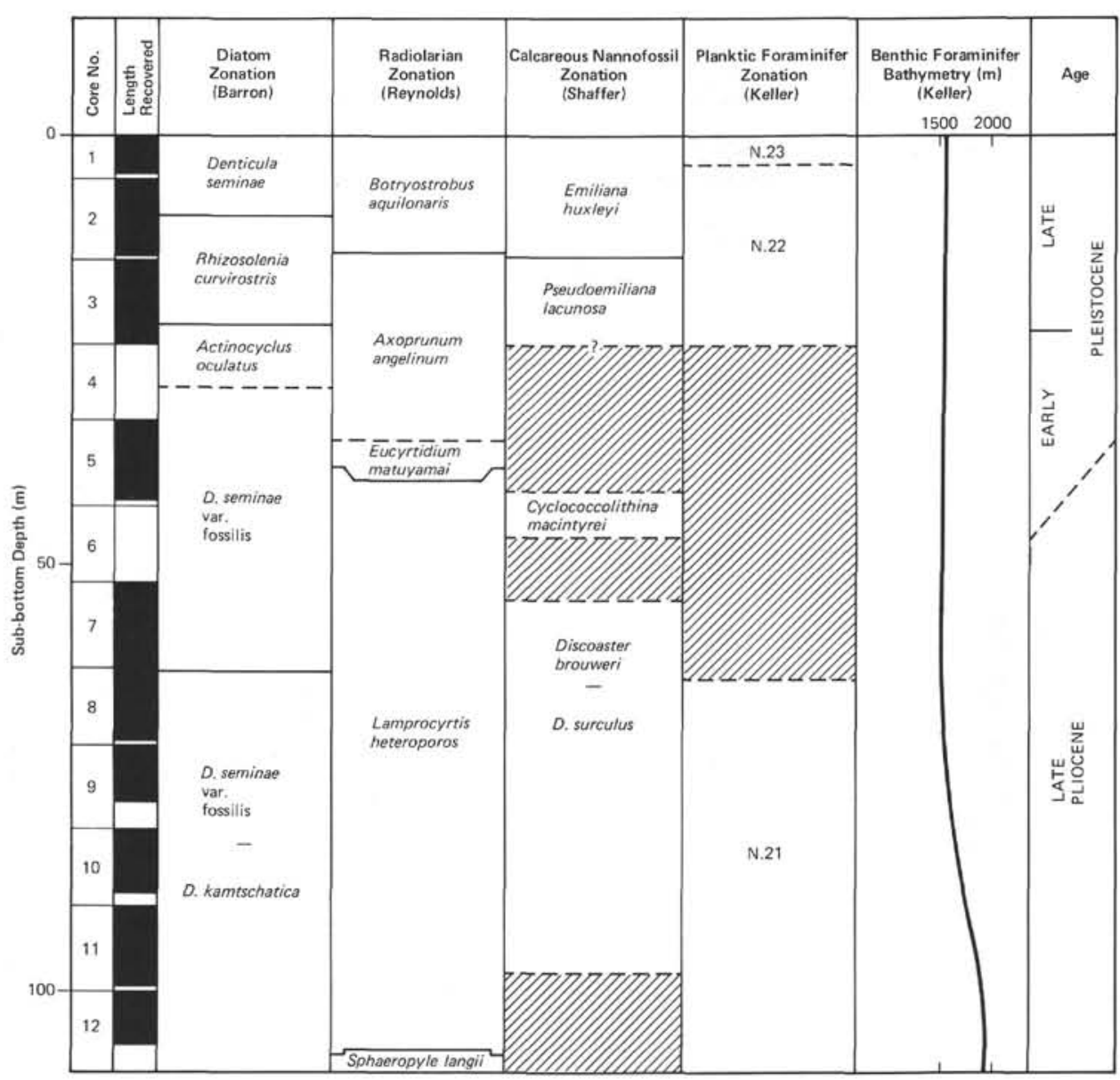

Figure 7. Planktic biostratigraphy and generalized paleobathymetry at Hole 438.

ments accumulated at a rate of about $37 \mathrm{~m} / \mathrm{m} . \mathrm{y}$. This slower accumulation rate is thought to reflect in part compaction of the sediments.

\section{Site 439}

Site 439 was cored continuously from 849 meters to 1157 meters, and spot cores were taken above this interval at $498,555,649$, and 745 meters to establish correlation points with respect to the Site 438 holes. A good paleontological correlation was established between Holes 439 and 438B (Figure 6). Spot Cores 439-1 and 439-2 (498 m, $55 \mathrm{~m})$ are late Miocene and correspond to Cores 438A-35 through 438A-77 in Hole 438A. Core 439-3 (649 m), middle Miocene, is coeval with Cores 438A-61 and 438A-62 in Hole 438A and Core 439B-2 in Hole 438B, whereas Core 439-4 (745 m), also middle Miocene, correlates with Core 438A-73 (diatoms) and Cores 438A-66 to 438A-84 (radiolaria) in Hole 438A. Cores $439-5$ and $439-6$ at the top of the continuously cored section correspond to Cores 438A-83 and 438A-84 in Hole $438 \mathrm{~A}$ and encompass the early to middle Miocene boundary.

The early Miocene is represented by approximately 138 meters of sediment between Cores 439-6 and 439-2. Two distinct lithologies occur in this interval; the upper 55 meters (Cores 439-6-439-11) consist of olive gray diatomaceous claystone and turbidite layers, and the lower 83 meters (Cores 439-12-439-21) is dominantly olive black silty claystones and turbidites. Diatom data suggest that a hiatus occurs between these two lithologies (Figure 10). Benthic foraminifera present in this interval indicate deposition occurred in an upper middle bathyal environment (500-1500 m).

Between Cores 439-24 and 439-32, only rare diatoms, very small coccoliths, and reworked Cretaceous radiolarians were recovered. However, diverse assemblages of shallow-water benthic foraminifera were recovered between Cores 439-22 and 439-25, which indicates the late Oligocene and deposition in a shelfal environment. Very rare benthic foraminifera were recovered between Cores 439-26 and 439-36, including the 33 meters of conglomerate. These isolated specimens elude age assignment.

Very poorly preserved arenaceous benthic foraminifera from the Upper Cretaceous age were recovered from the black fissile shale which unconformably underlies the conglomerate. This benthic assemblage indicates deposition in a deep bathyal environment $(4000 \mathrm{~m}+)$.

\section{Diatoms}

\section{Site $\mathbf{4 3 8}$}

Diatoms are well represented throughout the cornposite section (Holes 438, 438A, and 438B) cored at Site 


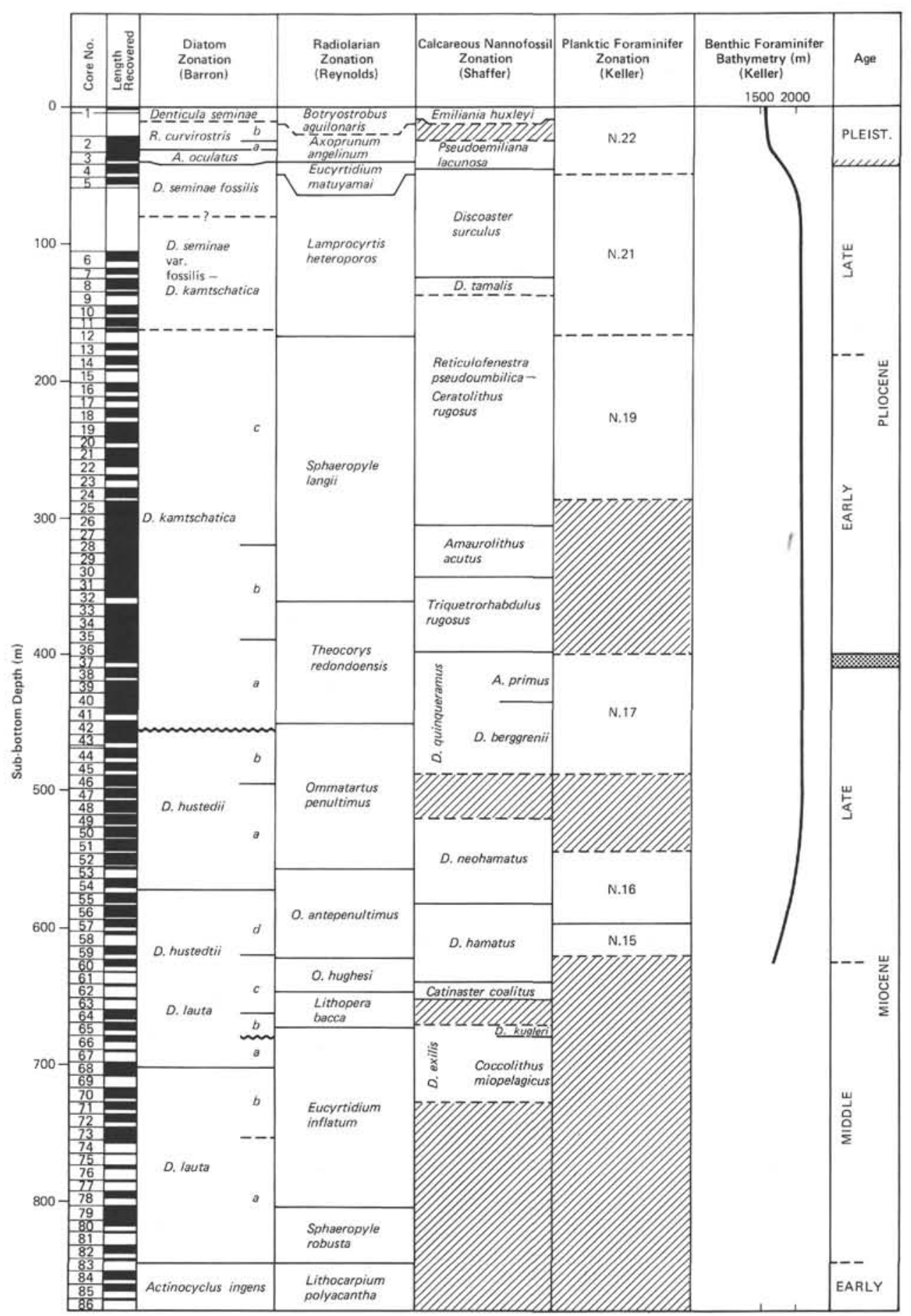

Figure 8. Planktic biostratigraphy and generalized paleobathymetry at Hole $438 \mathrm{~A}$.

438. Lower Miocene through Recent diatom assemblages were recovered. The mixture of high and low latitude assemblages that results from the location of Site 438 near the present-day confluence of the warm water Kuroshio Current and the cool water Oyashio Current occurs throughout the fossil record.

\section{Hole 438}

Abundant to common late Pliocene to Recent diatoms are present in the 106.9-meter section cored in Hole 438; preservation is good to moderate. Samples 438-1-4, $13-15 \mathrm{~cm}$, through $438-2-3,24-26 \mathrm{~cm}$, are assigned to 


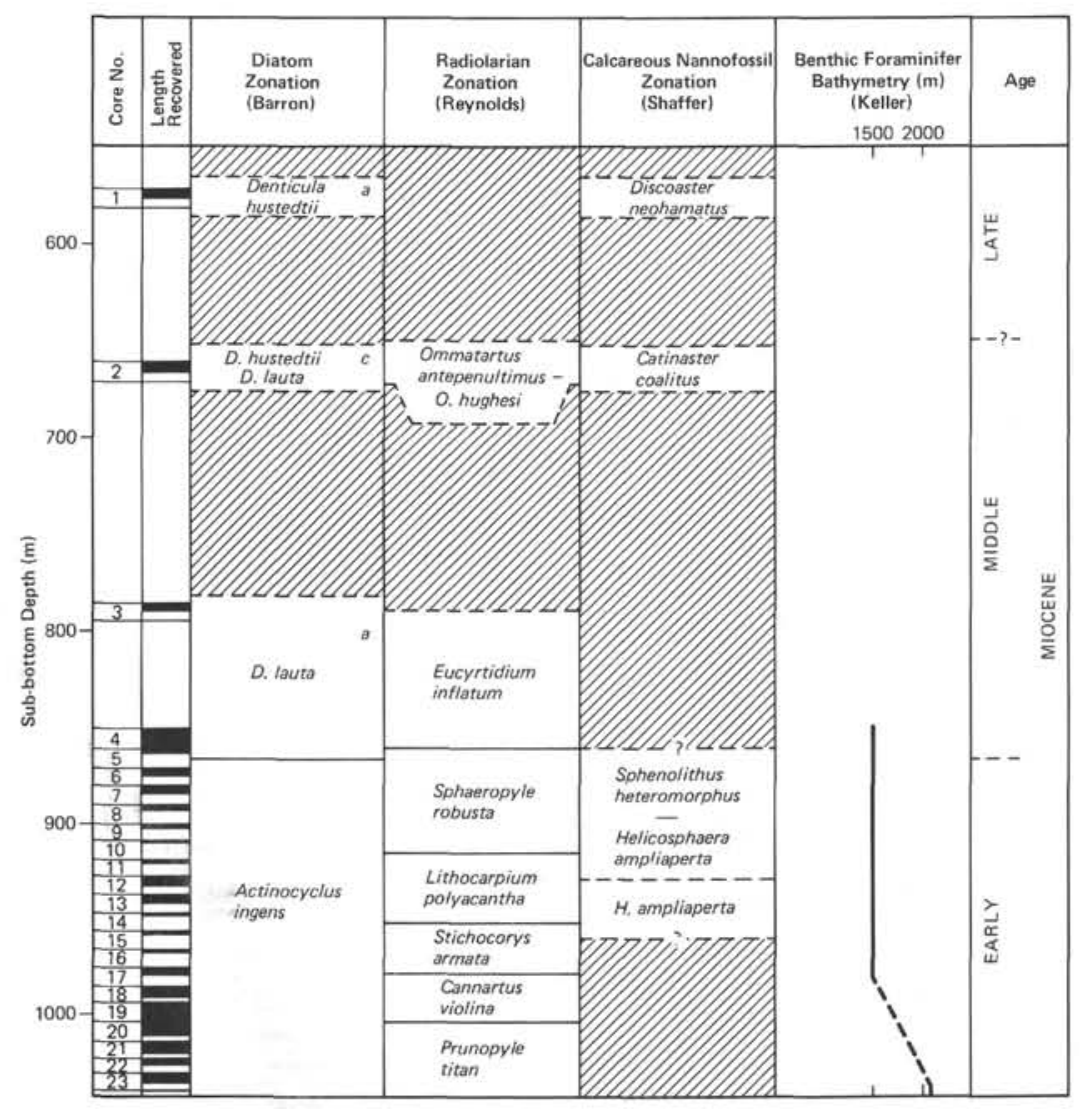

Figure 9. Planktic biostratigraphy and generalized paleobathymetry at Hole $438 B$.

the uppermost Pleistocene Denticula seminae Zone of Koizumi (1975) (0-0.26 m.y.B.P.).

The interval from 438-2-4, 79-81 cm, through 438-3-4, 140-142 cm, correlates with the upper Pleistocene Rhizosolenia curvirostris Zone of Koizumi (1975) (0.26-0.9 m.y.B.P.).

The lower Pleistocene Actinocyclus oculatus Zone of Koizumi (1975) (0.9- 1.7 m.y.B.P.) occurs in samples 438-3-6, 141-143 cm, and 438-3, CC.

Samples 438-5-1, 140-142 cm, through 438-7, CC correlate with the $D$. seminae var. fossilis Zone (1.7-2.43 m.y.B.P., upper Pliocene) (Barron, this volume).

Samples $438-8-1,120-123 \mathrm{~cm}$, through $438-12, \mathrm{CC}$ (base of hole) are placed in the $D$. seminae var. fossilis-D. kamtschatica Zone and are late Pliocene (2.43-3.0 m.y.).

\section{Hole 438A}

A section nearly identical to that of Hole 438 was recovered in the upper 120 meters of Hole 438A. Other than a coring gap from 58.5 meters (Core 5) to 106.5 meters (Core 6), Hole 438A was continuously cored to a depth of 868.5 meters, where upper lower Miocene sediments were recovered. Diatoms are abundant to common throughout the hole, whereas the quality of preservation decreases with depth. Preservation is good to moderate above Core $63(650 \mathrm{~m})$, generally moderate between Core $63(650 \mathrm{~m})$ and Core $75(764 \mathrm{~m})$, and moderate to poor below Core 75 .
Zonal assignments in the upper part of Hole 438A are as follows: Samples 438A-1-1, 110-112 cm, through 438A-1,CC - D. seminae; Samples 438A-2-1, 140-142 $\mathrm{cm}$, through 438-2-4, 140-142 $\mathrm{cm}-R$. curvirostris; Samples 438A-2,CC through 438A-3,CC A. oculatus; and Sample 438A-4-2, 140-142 cm, through 438A-5,CC D. seminae var. fossilis. Assemblages of Core 4 appear somewhat younger than those of Core 5 and contain glauconite, an indication that a hiatus may occur at the base of Core 4.

Samples 438A-6-1, 122-124 cm, through 438A-12-1, $138-140 \mathrm{~cm}$, are approximately correlated with the $D$. seminae var. fossilis-D. kamtschatica zone, based on the last occurrence of Thalassiosira nativa in Sample 438A-12, CC (Barron, this volume).

The interval from 438A12,CC through 438A-28-1, $140-142 \mathrm{~cm}$, is assigned to Subzone $c$ of the D. kamtschatica zone as modified by Barron (this volume) and presumably represents the record from about 3.0 to about 4.3 m.y.B.P.

Other diatom zonal assignments for Hole $438 \mathrm{~A}$ are as follows (Barron, this volume): Samples 483-28-4, $118-120 \mathrm{~cm}$, through $438 \mathrm{~A}-35-5,135-137 \mathrm{~cm}$ - Subzone $b, D$. kamtschatica; Samples 438A-35, CC through 438A-42-3, 110-112 cm - Subzone $a, D$. kamtschatica; Samples 438A-42-5, 83-85 cm, through 438A-46-5, $130-132 \mathrm{~cm}$ - Subzone $b$, Denticula hustedtii; Samples 438A-46,CC through 438A-54,CC - Subzone $a, D$. hustedtii; Samples 438A-55-1, 30-32 cm, through 


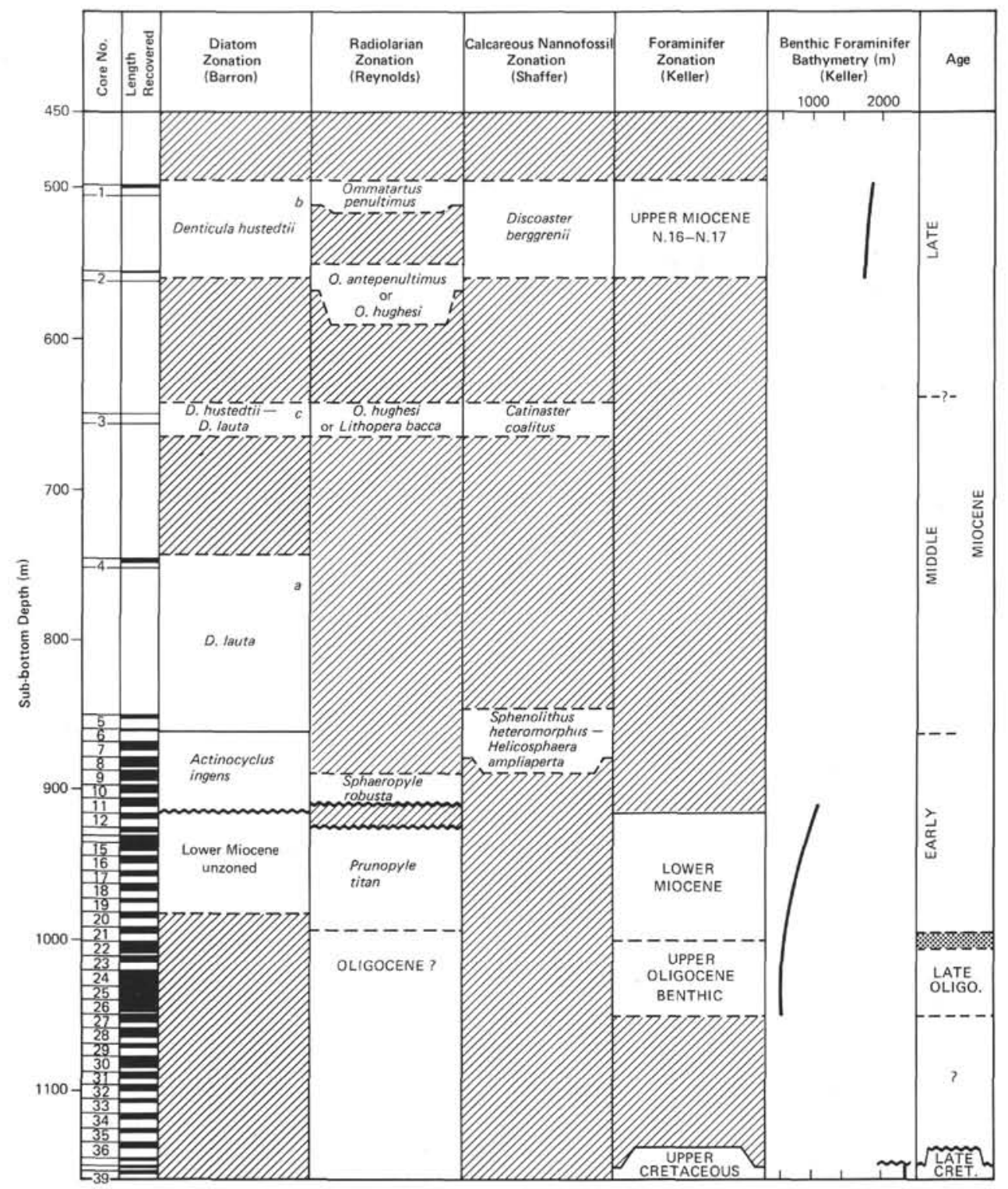

Figure 10. Planktic biostratigraphy and generalized paleobathymetry at Site 439.

438A-59,CC - Subzone $d, D$. hustedtii-Denticula lauta; Samples 438A-60-1, 134-136 cm, through 438A-64-1, $127-128 \mathrm{~cm}$ - Subzone $c, D$. hustedtii-D. lauta; Samples 438A-64-3, 36-38 cm, through 438A-65, CC - Subzone $b, D$. hustedtii-D. lauta; Samples 438A-66-2, 25$27 \mathrm{~cm}$, through 438A-68-1, 101-103 cm - Subzone $a, D$. hustedtii-D. lauta; Samples 438A-68-5, 70-72 cm, through 438A-73-5, 46-48 cm - Subzone $b$, D. lauta; and Samples 438A-84,CC through 438A-86, CC (base of hole) Actinocyclus ingens.

The lower Pliocene/upper Pliocene boundary lies high in the D. kamtschatica zone. The Miocene/Pliocene boundary is placed just below the last occurrence of Rouxia californica in the uppermost part of Subzone $b$ of the D. kamtschatica zone. The middle Miocene/upper Miocene boundary most likely occurs high in Subzone $c$ of the $D$. hustedtii- $D$. lauta zone. The lower Miocene/middle Miocene boundary is approximated by the first occurrence of $D$. lauta sensu stricto at the base of the D. lauta zone (Barron, this volume).

A latest Miocene ( $\sim 5.5-6.6$ m.y.B.P.) hiatus is suggested in the lower part of the Core 42 of Hole 548A by the diatom data (Barron, this volume). This hiatus may very well correspond with the thin $(0.5-\mathrm{m})$ siltstone layer overlain by glauconites in the upper part of Section 4 of Core 42; the occurrence of younger diatoms such as Nitzschia reinholdii in Sample 438A-42-5, 130-132 cm, may be the result of mixing by burrowing organisms. This latest Miocene hiatus can also be detected in Hole 440 and is present in Hole 173 off northern California and in onshore sections in California (Barron, this volume). This hiatus and the initiation of the Messinian Salinity Crisis in the Mediterranean may be the result of the same global climatic factors at the end of the Miocene. A second hiatus of about one million years duration most likely occurs between Cores 65 and 66 . 


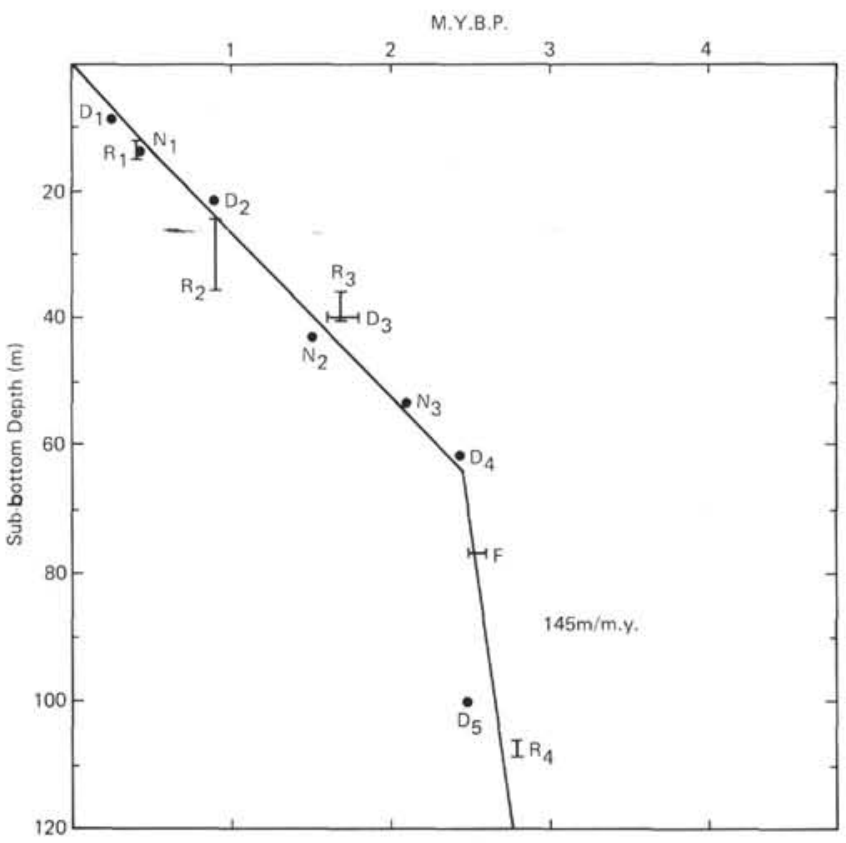

Figure 11. Sedimentation rates for Hole 438, uncorrected for compaction, based on diatom (D), radiolarian $(R)$, nannofossil $(N)$, and foraminifer $(F)$ data levels.
Assemblages typical of the lower part of Subzone $b$ and the upper part of Subzone $a$ of the D. hustedtii-D. lauta zone in California are absent from Hole 438A.

\section{Hole 438B}

Hole 438B extends the stratigraphic record at Site 438 to 1040.7 meters, where lower Miocene sediments of Subzone $a$ of the $A$. ingens zone of Barron (this volume) were recovered. Diatoms are generally common and preservation is moderate to poor above Core $9(900.3$ $\mathrm{m})$. Below that level, diatoms become few to rare and preservation is dominantly poor.

Spot coring above 853.3 meters (Cores 1-3) provides ties with the section cored in Hole 438A.

Sample 438B-1,CC (576.5 m) contains Coscinodiscus endoi without $D$. lauta and correlates with the lower part of Subzone $a$ of the $D$. hustedtii zone in the interval from Samples 438A-52-5, 128-130 cm (552.7 m), through 438A-54-1, 65-67 cm (565 m).

The silicoflagellates Distephanus pseudofibula and Mesocenica hexagona in Sample 538B-2,CC (667.9 m) occur together in the lower part of Subzone $c$ of the Denticula hustedtii-D. lauta within the interval from Samples 438A-60-3, 15-17 cm (626.1 m), through 438A-61, CC $(631 \mathrm{~m})$.

The presence of D. lauta, D. punctata f. hustedtii, and Kisselviella carina in Sample 438B-3-3, 28-30 cm (789.3 m),

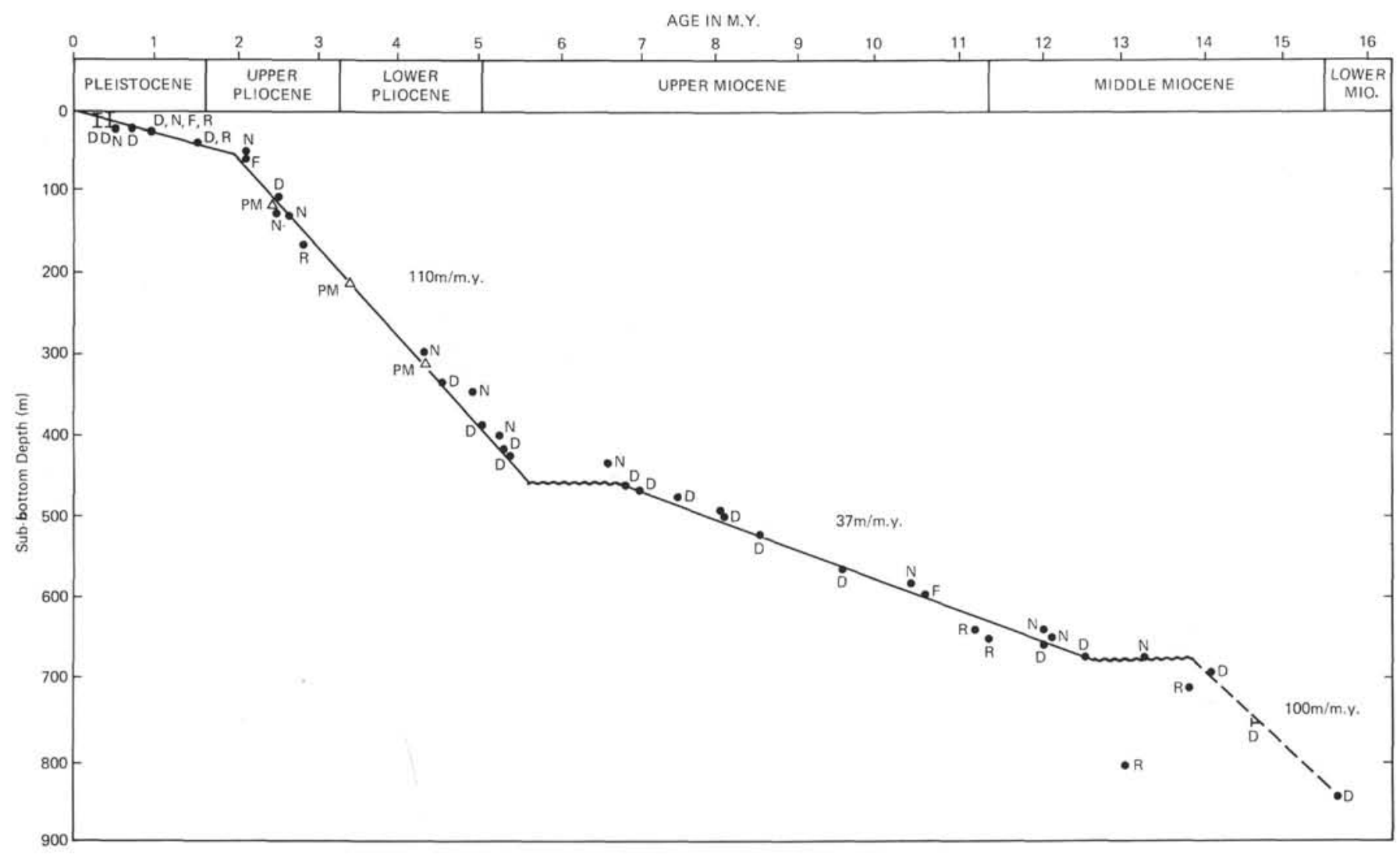

Figure 12. Sedimentation rates for Hole 438A, uncorrected for compaction, based on diatom (D), radiolarian (R), nannofossil $(N)$, foraminifer $(F)$, and paleomagnetic (PM) data. Paleomagnetic dates represent Matuyama/Gauss boundary, Gauss/Gilber boundary, and top of C, event of Gilbert Epoch (see Hall and Smeltzer, this volume). 
argues for correlation with Subzone $a$ of the D. lauta zone in the interval of Cores 73 through 79 of Hole 438A.

Cores 4 and 5 of Hole 439 are also assigned to lower middle Miocene Subzone $a$ of the D. lauta zone.

Diatom assemblages in Cores 6 through 23 are placed in the upper lower Miocene $A$. ingens zone of Barron (this volume). Assemblages in Sample 438B-24,CC (the base of the hole) are too poor to allow correlation. These assemblages contain good $A$. ingens; this species first occurs within the Helicopontosphaera ampliaperta (calcareous nannofossil) zone in the southern California continental borderland and in the North Atlantic (DSDP Site 407) (Barron, unpublished data).

\section{Site 439}

Spot coring (Cores 1-4) provides ties with nearby Hole 438A. Sample 439-1,CC (499 m) contains the diatom Thalassiosira antiqua and the silicoflagellate Distephanus pseudofibula, an overlap that is restricted to the interval from Samples 438A-44-5, 71-73 cm (476.2 m), to 438A-47-1, 70-72 cm (498.7 m) (Subzone $b$ of the Denticula hustedtii).

Sample 439-2,CC, cored over 50 meters below Core 1 , has the same species overlap, and sample contamination from 439-1,CC is suggested.

The presence of $R$. barboi, $R$. praebarboi, and the silicoflagellate Distephanus pseudofibula in 439-3,CC $(649 \mathrm{~m})$ argues for correlation with Cores 60 or 61 of Hole 438A (621.5-640.5 m) (Subzone $c$ of the Denticula hustedtii-D. lauta Zone).

D. Iauta, D. punctata f. hustedtii, and Delphineis penelliptica in 439-4,CC (749.3 m) indicate Subzone $a$ of the Denticula lauta Zone. Correlation with the interval from Core 72 through Core 79 of Hole 438A is suggested.

Continuous coring in Hole 439 began with Core 5 at 849.5 meters. Diatoms were present, although they were generally rare and poorly preserved through Core 20. Below Core 20, no more than one or two specimens were observed on any given microscope slide. These individuals were usually specimens of the long-ranging, robust species $C$. marginatus.

Sample 439-5, CC is assigned to the $D$. lauta Zone (middle Miocene). Although Sample 439-6,CC is barren, Samples $439-7, C C$ through $439-11, C C$ correlate with the upper lower Miocene $A$. ingens Zone of Barron (this volume). The presence of $C$. endoi and Coscinodiscus lewisianus in $439-11, \mathrm{CC}$ is indicative of the upper part of the zone of Cores 6 through 8 and Sample 438B-9-1, 85-87 cm, in Hole 438B.

Below this interval in Hole 439, Cores 12 through 20 contain lower Miocene diatoms older than the $A$. ingens Zone. It is suggested that a hiatus between Cores 11 and 12 of Hole 439 removes Subzone $a$ of the $A$. ingens Zone.

The poorly preserved lower Miocene diatom assemblage of Cores 12 through 20 resembles the lower Miocene diatom assemblage reported from Hole 348 in the Norwegian Sea (Schrader and Fenner, 1976). Species observed include C. symbolophorus varieties, Synedra jouseana (large form), Cestodiscus spp., Thalassiosira fraga, T. spinosa, T. spinosa var. aspinosa, and T. spumellaroides. These taxa and the lack of Oligocene diatoms argue strongly for an early Miocene time assignment.

Diatoms are generally common to few with moderate preservation above Cores $6(859.0 \mathrm{~m})$. They become few to rare with moderate to poor preservation in the interval from Core 6 to Core $9(887.5 \mathrm{~m})$. From Core 10 through Core $20(982.5 \mathrm{~m})$, diatoms are rare and are poorly preserved.

\section{Radiolaria}

\section{Site $\mathbf{4 3 8}$}

Site 438 provides common to rare, well to poorly preserved, relatively diverse radiolarian assemblages. Preservation and abundance decrease with depth. Abundances of few to common with good to moderate preservation may be found from the surface (Section 438-1-1) to a depth of approximately 960 meters. Below this depth faunas are poorly preserved and rare.

Pleistocene to Recent radiolarian faunas are present in Sections 438-1-1 to 438-5-3 and 438A-1-1 to 438-4-5. The following radiolarian zones are represented in this interval: Botryostrobus aquilonaris (Sections 438-1-1438-2-5 and 438-1-1-438A-1,CC), Axoprunum angelinum (Sections 438-3-1-438-5-1 and 438-2-1-438A-3-5), Eucyrtidium matuyamai (Sections 438-5-3 and 438A-41-438A-4-3), and top of the Lamprocyrtis heteroporos (Section 438A-4-5).

Pliocene sediments may be found from 438-5-5 to $438-12, \mathrm{CC}$ and $438 \mathrm{~A}-5-1$ to $438 \mathrm{~A}-30-4$. The Miocene/ Pliocene boundary is interpreted as the first occurrence of $L$. heteroporos. Sections 438-5-5 to 438-12-5 and 438A-5-1 to 438A-12-1 (L. heteroporos Zone), 438-12, $\mathrm{CC}$, and 438A-13-1 to 438A-32-4 (Sphaeropyle langii Zone) mark the intervals in which the Pliocene radiolarian zones occur.

Miocene radiolarian zones recognized in Site 438 are as follows: Stichocorys peregrina (Section 438A-33-2438A-42-1), Ommatartus penultimus (Sections 438A42-3-438A-52-6), Ommatartus antepenultimus (Sections 438A-53-2-438A-59-5 and 438B-2,CC), Ommatartus hughesi (Sections 438A-59-5-438A-62-1), Lithopera bacca (Sections 438-63-1-438-65-1), Eucyrtidium inflatum (Sections 438A-65-3-438A-78-3 and 438-3-3438-4-5), Sphaeropyle robusta (Sections 438A-79-2438A-82,CC and 438B-5-1-438B-10-1), Lithocarpium polyacantha (Sections 438A-84-2-438A-86, CC and 438B11-1-438B-13,CC), Stichocorys delmontensis (Sections 438-15-2-438B-17-1), Cannartus violina (Sections 438B17-3-438B-19-5), and Prunopyle titan (Sections 438B20-1-438B-24,CC).

A lower Pleistocene hiatus is interpreted between Sections 438-5-1 and 438-5-3 and between Sections 438A3-5 and 438A-4-1. Evidence for this is the reduced thickness of the E. matuyamai zone and the results shown on the sediment accumulation curve for Sites 438 and 438A (see Figures 11 and 12). The top of the $E$. matuyamai Zone may occur within Core 438-4. The 
poor representation of E. matuyamai in Hole 438 made it difficult to determine precisely its last occurrence.

Reworked Cretaceous and Paleogene(?) radiolarians are found in the lower portion of Hole 438B. Since they are recrystallized, infilled, and poorly preserved, specific identifications are impossible The following forms are present: Dictyomitra, Porodiscus, Acaeniotyle, Phaseliforma, and Archeospongoprunum.

\section{Site 439}

Radiolarian assemblages in Site 439 range widely in preservation and in diversity. Radiolarian are common and show good preservation from depths of approximately 500 (Section 439-1-1) to 650 (Section 439-3,CC) meters, less abundant from 750 (Section $439-4, C C)$ to 850 (439-5,CC) meters, rare from 870 (Section 439-7-1) to 1090 (Section 439-31-1) meters, has moderate preservation from 750 (Section 439-4,CC) to 910 (Section 439-11-3) meters, and has poor preservation from 916 (Section 439-12-1) to 1090 (Section 439-31-1) meters. Unlike any of the other sites drilled on Leg 57, many of the samples are barren of radiolarians - in particular, Samples 439-25-5, 439-26-5, 439-31-3, and from 43933-1 to $439-39, \mathrm{CC}$.

The diversity of radiolarians is too low in many of the samples to allow for accurate zonal assignments. The following samples allow zonal assignments: 439-1-1 (O. penultimus), 439-2-1 (O. antepenultimus to the top of $O$. hughesi), 439-2, CC to 439-3, CC (O. hughesi) to the top of Lithopera bacca 439-9-5 to 439-11-1 (Sphaeropyle robusta), and 439-13-1 to 439-21-3 ( $P$. titan). Samples below 439-21-3 are too poorly preserved and contain many recrystallized and infilled Cretaceous and (?)Paleogene radiolarians. The following forms are recognized from these cores: Dictyomitra, Acaeniotyle, Eucyrtidium, Archeospongoprunum, Phaseliforma, Porodiscus, Sethocapsa, Eucyrtis, Amphipyndax, and pseudoalophasiids. Not all of these radiolarians have necessarily been reworked, because some of them are present in strata dated as Cretaceous using foraminifers.

\section{Calcareous Nannofossils}

With few exceptions for Site 438 holes, nannofossil abundances were rare to few, species diversities were generally low, and the assemblages were commonly extratropical in aspect. Nannofossil occurrences were also sporadic, and preservation states ranged from poor to moderate with indications of dissolution and overgrowth. Oscillation of the relative influence of the ancient Kuroshio and Oyashio current systems; vertical fluctuation in the calcite compensation depth (CCD), which in turn may be related to eustatic sea level and climatic changes; diagenetic processes; and dilution by hemiterrigenous sediment influx may account for their rare and sporadic quality.

Regardless of the quality of nannofossil assemblages recovered, the Pliocene to Pleistocene sequence comprising Hole 438 could be zoned and dated reasonably well. The interval encompassed by Cores 1 and 2 through 6 belongs in the Emiliania huxleyi zone, and the top of the Pseudoemiliania lacunosa zone is placed in
Core 2, CC on the basis of the last occurence there of $P$. lacunosa. A population of very small gephyrocapsids in Core 3,CC may correspond to Gartner's (1977) zone of small Gephyrocapsa. Core 5,CC is within the lowermost Pleistocene Cyclococcolithina macintyrei zone. It is unfortunate that Core 6 was not recovered, as it apparently spans the Plio/Pleistocene boundary. Rare occurrences of Discoaster brouweri in Core 7-1, along with Discoaster surculus in Cores 7-2 and 8-1, place this interval within the $D$. surculus zone. Cores 9-4 through 11-6 contain sporadic occurrences of $P$. lacunosa, $D$. brouweri, Discoaster pentaradiatus, and D. surculus. In the absence of Reticulofenestra pseudoumbilica and Sphenolithus abies, this sequence is assigned to the $D$. surculus/D. tamalis zones. Samples from Core 12 were barren.

Estimated sediment accumulation rates for Hole 438 were higher in the Pliocene than in the Pleistocene. This discontinuity in sedimentation rates, interpolated between Core 5,CC and Core 7-1, may represent a minor hiatus involving the uppermost Pliocene and the lowermost Pleistocene.

Nannofloras were sufficiently developed in Hole $438 \mathrm{~A}$ to zone all but a few intervals in the middle Miocene to Pleistocene sequence, although a lack of continuity of occurrences rendered zonal boundary determinations difficult. Core 1 is assigned to the Emiliania huxleyi zone. Pseudoemiliania lacunosa occurs at least as high as Core 2-3, and the top of the $P$. lacunosa zone is postulated to occur in the wash gap between Cores 1 and 2. Assemblages characteristic of Gartner's zone of small Gephyrocapsa were noted in Cores 2,CC and 3,CC.

A minor hiatus involving the Plio/Pleistocene boundary is suspected, because neither the upper Pliocene $D$. brouweri zone nor the lower Pleistocene $C$. macintyrei zone was recognized. Cores 4-6 through 7,CC are assigned to the upper Pliocene $D$. surculus zone, and Core $8-2$ is within the $D$. tamalis zone. The tentative top of the $R$. pseudoumbilica zone in Core 8,CC approximates the top of the lower Pliocene. The lowermost Pliocene Ceratolithus acutus zone occurs in Cores 26-3 and $30, \mathrm{CC}$. Indicator species used to determine the Miocene/Pliocene boundary, which probably occurs between Cores 31 and 35, were not present.

The upper Miocene Amaurotithus primus zone occurs in Cores 36,CC and 40-6, and the underlying Discoaster berggrenii zone is present in Cores 40,CC and 45,CC. Nannofloras assigned to the Discoaster neohamatus zone (Cores 49 through 55) are generally rare and sporadic. The Discoaster hamatus zone, which approximates the top of the middle Miocene, is assigned to the interval between Cores 56-1 and 61,CC. Core $62, \mathrm{CC}$ belongs within the Catinaster coalitus zone, andCores 66,CC through 70,CC delineate the Coccolithus miopelagicus subzone, as indicated by the presence of Cyclocargolithus floridanus. Samples from Cores 71 through 86 were barren or contained very rare nondiagnostic species.

Estimated sediment accumulation rates for Hole 438A (Figure 12) were considerably higher for the 
Pliocene than for the Pleistocene. Although the rates are different, the sedimentation patterns for the Plio-Pleistocene in Holes 438 and 438A bear striking resemblance, including the abrupt change in accumulation rates occurring near the Plio/Pleistocene boundary (Figures 11 and 12).

Cores 1,2 , and 3 of Hole 438B were spot cores taken at selected intervals for the purpose of establishing correlation points with Hole 438A. Core 1 is with the Discoaster neohamatus zone and correlates with the interval in Hole 438A from Cores 49 through 55. Core 2, assigned to the middle Miocene Catinaster coalitus zone, is coeval with Core 62 in Hole 438A. Cores 3 and 4 were barren.

Cores 5 through 11 are placed in the Sphenolithus heteromorphus/Helicosphaera ampliaperta zones undifferentiated, and Cores 12 through 15 belong to the lower Miocene Helicosphaera ampliaperta zone. Cores 16 through 24 were barren of nannofossils.

\section{Foraminifera}

Foraminifers in Site 438 are abundant and well preserved in upper Pleistocene sediments and common to rare in upper Miocene to lower Pleistocene sediment, with preservation ranging from poor to moderate. However, sporadic samples containing well-preserved and diverse planktonic faunas permit assignment of the standard planktonic foraminiferal zones in late Miocene sediments, and the standard zonation can be extrapolated to the Pliocene cool water fauna by correlation with mid-to-low latitude faunas. (Ingle, 1973; Vincent, 1975; Keller, 1978). Several intervals of intense dissolution can be recognized based on microfossil datum levels and extrapolation from sediment rate curves. The following dates, in millions of years, for these dissolution intervals are estimated: 0.9 to $2.4,2.8$ to 3.0 (?), 3.2 to 3.3 (?), 3.5 to $5.5,6.0$ to 10.0 (?), 12.0 to lower Miocene. (Extrapolated dates are marked with a question mark; absolute dates are based on microfossil datum levels: $\mathrm{F}=$ foraminifera, $\mathrm{N}=$ nannofossil, $\mathrm{D}=$ diatom, $\mathrm{R}=$ radiolarian.)

\section{Site 438}

Planktonic foraminifers in Hole 438 are common to abundant during the latest Pleistocene $(0.9$ m.y. $(\mathrm{N}$, D)-to Holocene), absent because of intense dissolution between $0.9(\mathrm{~N}, \mathrm{D})$ and 2.4 m.y. (D), and rare to few between 2.4 and 2.8 (?) m.y. Cores 1 to 3 contain an upper Pleistocene fauna younger than 0.9 m.y. (N, D). The Plio/Pleistocene boundary falls within the dissolution interval encompassing the uppermost Pliocene to lower Pleistocene (2.4 (D)-0.9 (N. D.) m.y.). Upper Pliocene assemblages (N.21) are present in Cores 8 to 10 and are characterized by Globorotalia puncticulata and Globorotalia inflata.

\section{Hole 438A}

Benthic foraminifers are consistently present except in Core 7 and Core sections 8-3 and 8-6. The late Pleistocene fauna is characterized by the deep-water species Elphidium batialis, Nonion labradoricum, Epistomin- ella pacifica, Buccella inusitata, and Uvigerina akitaensis. This group of species is characteristic of the late Pleistocene benthic faunas observed in the Japan Trench sites and is indicative of the present water depth of 1550 meters at this site. Late Pliocene faunas suggest deposition occurred in somewhat deeper water, between 1550-2000 meters, during this time.

Because of intervals of dissolution, sediments from Hole 438A yielded a relatively discontinuous Miocene to Pleistocene planktonic foraminiferal record. As in Hole 438 , late Pleistocene faunas $(0.9$ (N, F, D)-to Holocene) are abundant in Cores 1 and 2, and dissolution encompasses the latest Pliocene to early Pleistocene interval (Cores 2,CC-4-5). Upper Pliocene faunas (N 21) are present in Cores $4, C$ C to 10 and include $G$. puncticulata, Globoquadrina venezuelana, Neogloboquadrina humerosa, Globorotalia inflata modern variety, and abundant Neogloboquadrina pachyderma forms 2 and 3. The first appearance of $G$. inflata modern var. and the last appearance of $G$. puncticulata in Core 4,CC suggest an age of 2.0-2.2 m.y. In mid-latitudes of the North Pacific the N.19/N.21 boundary is approximated by the first appearance of primitive forms of $G$. inflata associated with a marked short cold even dated about 3.0 m.y. (Keller, 1978). In Hole 438A this short, cold interval may be represented in Cores 9 and 10, which contain only rare and severely dissolved specimens. Early Pliocene faunas are present in Cores 10 to $25, \mathrm{CC}$ and are characterized by Globorotalia juanai, Globorotalia conomiozea, Globigerina nepenthes, Globorotalia cf. suterae, Globoquadrina venezuelana, and Neogloboquadrina pachyderma forms 2 and 3.

The Plio/Pleistocene boundary falls within the dissolution interval encompassed by Cores 26 to $37, \mathrm{CC}$. Planktonic foraminiferal faunas of the upper Miocene (N17) occur in Cores 36 through 45 and are marked by the last appearance of Globoquadrina dehiscens, Globorotalia lenguaensis, Globorotalia menardii, and Globorotalia cibaoensis. Between Cores 45 and 51 planktonic foraminiferal are rare to absent. Cores 52 to 59 contain diverse warm water faunas of the upper Miocene (N16) characterized by Globorotalia merotumida, and G. conoidea. Planktonic foraminifers are absent throughout the lower and middle Miocene.

Benthic foraminifers occur in varying abundance throughout Hole 438A and reflect a dissolution pattern similar to that observed in Hole 438. Early Miocene benthic foraminiferal assemblages indicate that deposition occurred in an upper middle bathyal environment $(500-1500 \mathrm{~m})$. No data are availabe for middle Miocene sediments. During late Miocene to early Pliocene deposition occurred at lower bathyal depth $(2000 \mathrm{~m}+)$, indicating that subsidence has been going on since the early Miocene time. A gradual shallowing is indicated from 2000 meters + to 1500 meters during the late Pliocene to late Pleistocene.

\section{Site 439}

Planktonic foraminifers are extremely rare in Site 439. Core 1 contains an upper Miocene planktonic foraminiferal assemblage (N.17). Planktonic foramini- 
fers are absent throughout the Upper Cretaceous to Middle Miocene sequence with the exception of very rare specimens of Catapsydrax unicavus in Cores 14 and 15 , which suggests that this interval is no younger than lower Miocene.

Benthic foraminifers in Site 439 are generally rare to few and poorly preserved except for intervals in the upper Miocene, lower Miocene, and upper Oligocene in which relatively diverse faunal assemblages are preserved. The benthic assemblage in Core 1 (upper Miocene) suggests that deposition occurred in lower middle bathyal (1500-2000 m) to bathyal $(2000 \mathrm{~m}+)$ environment. Cores 2 to 11 are barren of foraminifers. Cores 13 to 15 contain a diverse lower Miocene benthic assemblage indicating deposition occurred in upper middle bathyal depth $(500-1500 \mathrm{~m})$. Shallow water $(<500 \mathrm{~m})$ benthic species characteristic of the upper Oligocene are present in Cores 22 to 25 . This fauna is dominated by species of Elphidium sumitomoi, Elphidium iojimaensis, Gyroidina iojimaensis, Bolivina substriatula, and Epistominella danvillensis. Between Cores 26 and 36 only rare nondiagnostic benthic foraminifers are present. The dacite conglomerate underlying this unit is barren of foraminifera. The hard black siliceous shale which unconformably underlies the dacite conglomerate yielded a very poorly preserved arenaceous fauna of the Upper Cretaceous. The following genera and species have been identified from this unit: Haplophragmoides cf. formosus, Involutina (= ?Spirillina) hashimotoi, Involutina (= ?Spirillina) cretacea, Ammobacculites sp., Bathysyphon sp., Lenticulina sp., and Ammodiscus sp. This fauna suggests deposition occurred below 4000 meters.

\section{GEOCHEMISTRY}

Shipboard geochemical studies of samples from Sites 438 and 439 , which are 5 to $6 \mathrm{~km}$ apart, consisted of analysis of interstitial water, monitoring of hydrocarbons for drilling safety purposes, and evaluating the sediments for their hydrocarbon source rock potential.

\section{Interstitial Water Analysis}

Water samples for chemical analysis were collected about every 50 meters by squeezing 10 -cm core samples, carefully freed from drilling mud, at approximately $5^{\circ} \mathrm{C}$ in a stainless steel mechanical press. The water samples were forced from the press through filters at a pressure of $1.77 \mathrm{~kg} / \mathrm{cm}^{2}$ directly into sealed syringes. $\mathrm{PH}$ and titration alkalinity determinations, most subject to change with time, were then made immediately, followed by determinations of salinity (by refractive index), $\mathrm{Cl}^{-}, \mathrm{Ca}^{2+}$, and $\mathrm{Mg}^{2+}$ (Figures 13 and 14). These analyses closely agree with complementary interstitial water samples taken with an in-hole sampler (Moore and Gieskes, this volume).

Both the salinity and chloride content show a fairly uniform decline with subbottom depth, such that at the bottom of the hole they have about 60 per cent of the values of surface sea water. We considered several pos- sible causes for this relationship, including a dilution by nonsaline water expelled from clay minerals during compaction. That mechanism may be unlikely, however, because samples from subsequent Site 440, on the midslope terrace, do not show a similarly large reduction in salinity despite being similar in other respects.

An explanation that seems to fit the evidence better is that in the geologic past a fresh-water artesian system existed in the sandstone and conglomerate near the base of the drilled section, and the connate water above it was diluted during water expulsion accompanying compaction. This explanation has previously been offered for similar relationships at other continental margin drill sites - for example, at Site 241 off eastern Africa (Gieskes, 1974). The recharge area for the artesian system on the Japan Deep Sea Terrace was probably the Oyashio landmass, the last vestige of which probably submerged below sea level during the Pliocene.

The carbonate system was studied by means of the $\mathrm{Ca}^{2+}, \mathrm{Mg}^{2+}, \mathrm{pH}$, and alkalinity values. Alkalinity reaches a maximum at a depth of about 200 meters, probably owing to bacterial decomposition of organic matter during sulfate reduction, as is also attested to by the presence of tiny authigenic pyrite spherules in the deposits. The alkalinity maximum coincides with a $p \mathrm{H}$ minimum, and the calcium-ion concentration remains relatively constant throughout the section. Minor amounts of replacement chalk occur in places in the cores, and concretionary limestone layers are conspicuous below 650 meters.

Artesian dilution is insufficient explanation for the degree to which the magnesium-ion concentration declines with depth. Magnesium may enter into authigenic magnesian calcite, and it may enter clay minerals to replace iron extracted to form the pyrite.

\section{Gas Analysis}

As recommended by the Pollution-Prevention and Safety Panel (Claypool et al., 1976), each core was checked immediately for gas indications and fluorescence. The gas usually was collected on the deck from the full cores before cutting them into sections, by inserting a vacuum needle through the transparent core tube into a sediment gap. The percentage of methane was determined by a Carle gas chromatograph. To reduce the masking effect of the large methane excess, the gas was then adsorbed into chilled activated alumina, the methane removed by a 2-minute flow of helium at $-70^{\circ} \mathrm{C}$, and the higher hydrocarbons desorbed at $100^{\circ} \mathrm{C}$ for analysis in a Hewlett Packard gas chromatograph (Whelan, this volume).

Some cores, especially short ones, were clearly contaminated by gases from the sea water drilling fluid or by air during handling. In this report only the data on cores longer than 2 meters are considered. Samples were not taken below 1080 meters, because deeper cores indicated no obvious gas pressure when the needle was pulled - possibly because high permeability permitted the gas to escape from sandy strata upon arrival on the deck. 


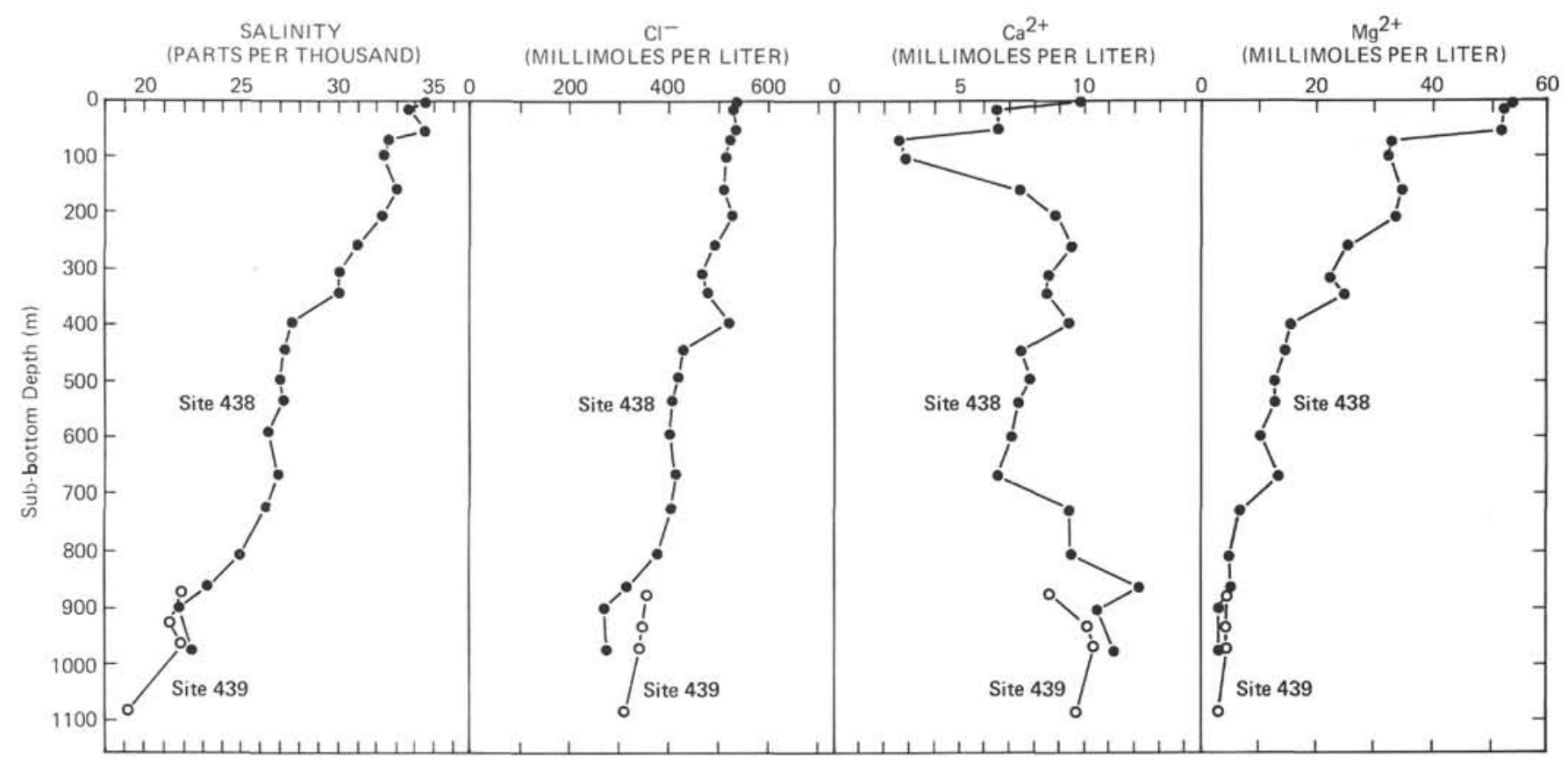

Figure 13. Relationship between sub-bottom depth and salinity, $\mathrm{Cl}^{-}, \mathrm{Ca}^{2+}$, and $\mathrm{Mg}^{2+}$ of interstitial water, Sites 438 and 439.

We smelled a strong hydrogen sulfide odor in the shallowest samples, and no appreciable methane was detected to a depth of approximately 90 meters (Figure 14). Once methane was detected, it remained at a level of less than 40 per cent to about 175 meters, and then increased to 60 per cent. At 250 meters the $\mathrm{H}_{2} \mathrm{~S}$ odor disappeared. Ethane appeared at 103 meters, but the amount was small, as indicated by a methane/ethane ratio of 1300 , in which the methane content of the core gas is 4 per cent (Figure 14). The ethane content stabilized at about 200 meters, and propane, butane, andpentane appeared at 118,133 , and 213 meters, respectively (Sato and Whelan, this volume). Neopentane (tetramethylmethane) occured from 250 meters to the base of the sections. The increase in methane and decrease in $\mathrm{H}_{2} \mathrm{~S}$ odor between 200 and 250 meters probably delineates the top of the bacterial methane production zone, as methane generally occurs below the zone of bacterial reduction of $\mathrm{SO}_{4}{ }^{2-}$ to $\mathrm{H}_{2} \mathrm{~S}$ (Claypool and Kaplan, 1974).

The level of methane was fairly constant to the base of the hole, and the ethane and propane contents increased gradually. This might at first suggest that the bacterial methane zone was grading into the thermochemical petroleum-generating zone, but the following factors suggest that such is not the case: (1) the temperature of $32^{\circ} \mathrm{C}$, obtained by extrapolation from time-sequential in-hole measurements at 862 meters, is less than the $50^{\circ} \mathrm{C}$ which is generally recognized as the minimum required for generating petroleum; (2) the methane/ethane ratio at the base of the hole is too high for the oil-generating zone; (3) the presence of neopentane near the base of the hole indicates that the thermochemical-reaction zone had not been reached, because neopentane is a relatively rare constituent of true petroleum (Erdman, 1961). Therefore the ethane seems to have been produced by diagenesis rather than by normal oil-generating processes.

At other Deep Sea Drilling Project sites the methane/ethane ratio shows a similar systematic change with depth (Claypool et al., 1976), but at Sites 438 and 439 the relative amounts of ethane at successive depths are less than in most previously drilled areas. The temperature of $32^{\circ} \mathrm{C}$ at 862 meters and the sea-floor temperature of $1{ }^{\circ} \mathrm{C}$ give a moderate geothermal gradient of $3.6^{\circ} \mathrm{C}$ per 100 meters, but the low starting temperature at the sea floor results in low temperatures at given depths. This evidence confirms that the diagenetic accumulation of ethane relative to methane is inhibited by low temperature.

The relatively low ethane curves at these sites might seem surprising in view of the underlying magmatism suggested by the late Oligocene-early Miocene dacitic conglomerate, but the heat flow at this crustal source probably has been reduced by the later protracted subduction of cool oceanic crust, here below a sub-bottom depth of about $15 \mathrm{~km}$.

\section{Organic Carbon and Pyrolysis-Fluorescence Analysis}

Organic carbon and pyrolysis-fluorescence measurements were carried out for source rock evaluation on sediment samples taken about every 50 meters. For the pyrolysis-fluorescence analysis, 0.1 gram of sediment was heated to redness in a test tube, cooled, and extracted with trichloroethane. The fluorescence values, on the basis of a solvent volume of $3 \mathrm{~cm}^{3}$, are reported in PF per cent units. To avoid self-absorption effects, greater dilution was generally used in the analysis to achieve maximum values when computed on the $3-\mathrm{cm}^{3}$ basis. 


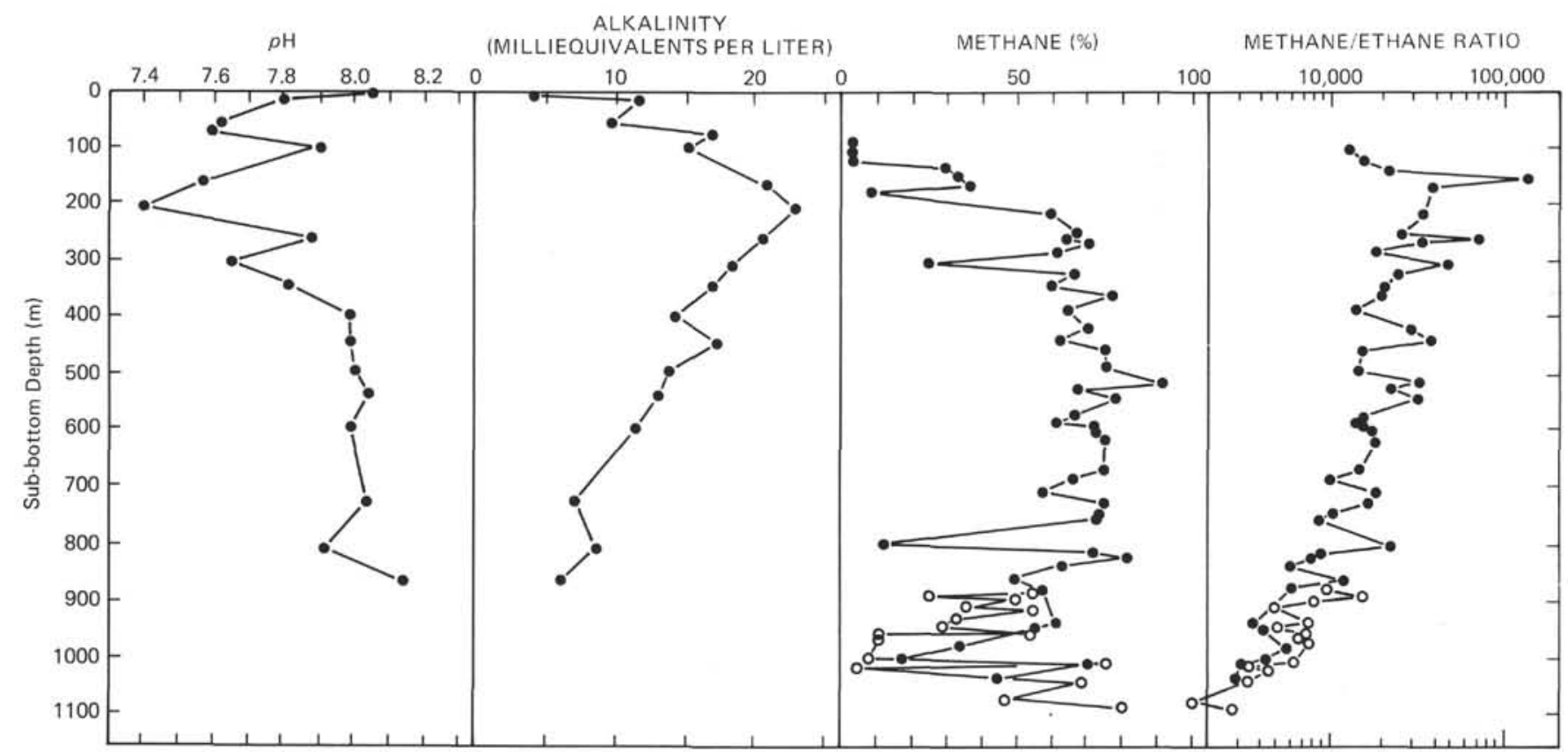

Figure 14. Relationship between sub-bottom depth, $\mathrm{pH}$, and alkalinity of interstitial water, and methane and methane/ethane ratio of core gas, Site 438 and 439.

The values of the analyses range from 0.20 to 0.72 per cent organic carbon and from 30 to $20 \mathrm{PF}$ units (Figure 15). Little relationship to sub-bottom depth is evident in the analyses. The range of values seems to depend more on differences in the source material and variations in lithology. Because the sediments from these sites have only small quantities of organic carbon and low values of pyrolysis-fluorescence, their hydrocarbon richness would be classified as low with respect to petroleum generation. Hood et al. (1976) consider PF values of less than 30 to eliminate sediments as potential source rocks for economic oil accumulations. If more than about 1 per cent organic matter were present in rocks in a nearby setting, and temperature conditions at depth were suitable, the potential for generating petroleum might be considered more favorable.

\section{PHYSICAL PROPERTIES}

Wet bulk density, porosity, sonic velocity, water content (per cent wet weight), shear strength, and thermal conductivity were determined for the majority of the cores collected at Sites 438 and 439 . The results are presented in Site Summary Chart, Sites 438 and 439 (back pocket) and the data tabulated in Appendix 1. Holes 438A and 439 were logged and the processed density and sonic velocity logs included in the Summary Chart for comparison with laboratory determinations.

Recovery was excellent at this site, and for the most part the sediments were only moderately disturbed. Physical property determinations were made on what appeared to be the least disturbed portions of the cores. Hence sampling was neither random nor uniform and tended to favor consolidated or indurated sections.

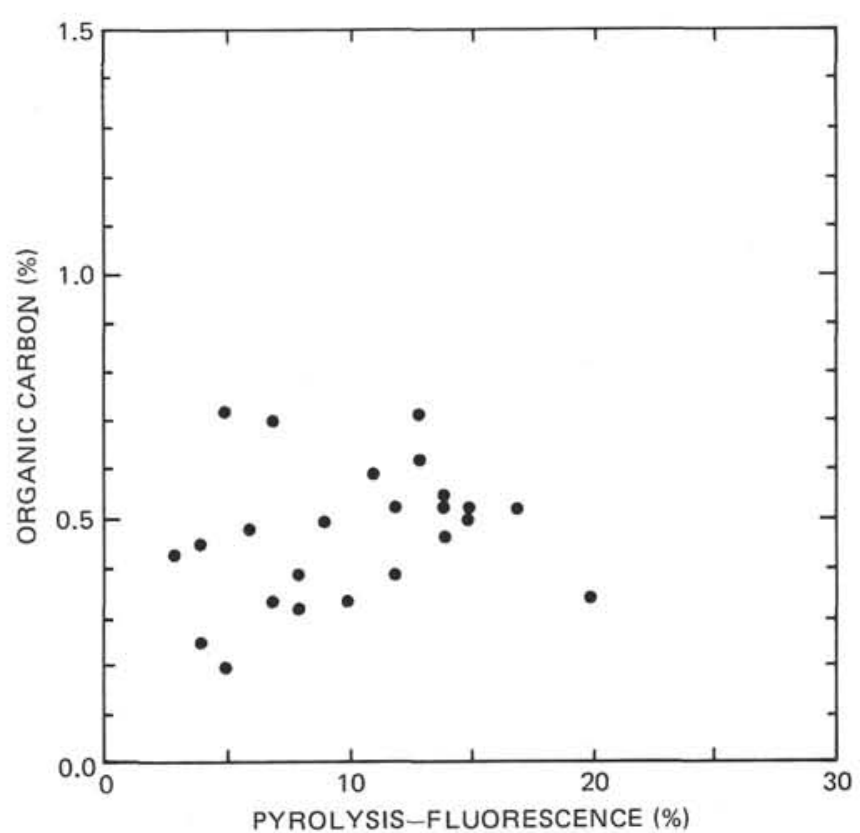

Figure 15. Relationship between organic-carbon content and pyrolysis-fluorescence of core samples from Sites 438 and 439.

\section{Wet Bulk Density, Water Content, and Porosity}

Bulk density (see Site Summary Chart) decreases from approximately $1.7 \mathrm{Mg} / \mathrm{m}^{3}$ at the base of Lithologic Unit $1(100-110 \mathrm{~m})$. There is some suggestion that this pattern is reversed (i.e., density increases with depth) between 25 and 50 meters, probably in response to increas- 
ing (with depth) pebble frequency in this interval. The overall pattern within the upper 100 meters, however, reflects a general decline in grain size (sand content) from top to bottom of (lithologic) Unit 1 .

From $\sim 100$ meters to $\sim 360$ meters (Lithologic Subunit $2 \mathrm{~A}$ ) bulk densities remain relatively constant at $\left.\sim 1.35 \mathrm{Mg} / \mathrm{M}^{3}\right) .\left(\sim 1.45 \mathrm{Mg} / \mathrm{M}^{3}\right.$ in situ logs $)$ and exhibit low variability $\left(s=0.05 \mathrm{Mg} / \mathrm{m}^{3}\right)$. The constancy of density values across this interval suggests incomplete compaction, at least within the lower portion of the section, and indicates that these deposits are underconsolidated.

Below 350 meters, bulk density increases rapidly to $\sim 1.48 \mathrm{Mg} / \mathrm{m}^{3}$ and then more gradually (with some broad excursions) to $\sim 1.60 \mathrm{Mg} / \mathrm{m}^{3}$ at 780 meters. Lithologic Sub-units 2B (365-593 m) and 2C (593-817 m) are indistinguishable on the basis of density, except for the fact that Sub-unit $2 \mathrm{C}$ contains several limestone beds with densities ranging from 2.3 to $3.2 \mathrm{Mg} / \mathrm{m}^{3}$. The base of Unit $2(780-817 \mathrm{~m})$ exhibits scattered densities whose lower values $\left(\sim 1.40 \mathrm{Mg} / \mathrm{m}^{3}\right)$ are less than any samples in Unit 2, except those at the top of $2 \mathrm{~A}$ $(360-440 \mathrm{~m})$. Comparison with the lithologic section reveals no apparent change in lithology which might correspond to these low densities, and they probably reflect the small-scale faulting which characterizes this interval.

Between 817 meters and 830 meters there is a marked increase in density (from $\sim 1.45 \mathrm{mg} / \mathrm{m}^{3}$ to $\sim 1.65$ $\mathrm{mg} / \mathrm{m}^{3}$ ), which is mirrored by a decrease (to $\sim 1.60$ $\mathrm{Mg} / \mathrm{M}^{3}$ ) from 830 meters to 855 meters. This density high marks the top of Lithologic Unit 3 and is apparently controlled by increased sand content. Widely scattered $\left(1.35 \mathrm{Mgm}^{3}\right.$, sandy claystone, to $2.7 \mathrm{Mg} / \mathrm{m}^{3}$, pumiceous-vitric claystone) density values in the lower portion (855-970 m) of Unit 3 reflect local variations in texture and cementation.

Bulk densities increase markedly below 970 meters (Unit 4) to an average value of $2.15 \mathrm{Mg} / \mathrm{m}^{3}$ ) appears to reflect the lithologic inhomogeneity of turbidites and intercalated silty claystones. The in situ density log confirms this pattern, at least as far as it extends into Unit 4.

Lithologic Unit 5 can be divided into upper (993-1050 m) and lower (1050-1097 m) portions on the basis of physical properties. Bulk densities in the upper portion are well grouped and increase from $\sim 2.10$ $\mathrm{Mg} / \mathrm{m}^{3}$ to $\sim 2.3 \mathrm{Mg} / \mathrm{m}^{3}$ with depth, even though the sandstones in this interval are extremely friable. In the lower portion of Unit 5, the bulk density is more variable, ranging from $2.0 \mathrm{Mg} / \mathrm{m}^{3}$ to $2.5 \mathrm{Mg} / \mathrm{m}^{3}$, with no apparent depth-density trend. The high-density sections consist of sandstones which are well-cemented with calcite. Interbedded with these indurated sections are friable sands similar to those in the upper portion of the unit.

Unit 6 contains igneous boulders with densities greater than $2.4 \mathrm{Mg} / \mathrm{M}^{3}$, sedimentary (or meta-sedimentary) clasts with densities of $\sim 2.35 \mathrm{Mg} / \mathrm{m}^{3}$, and a finergrained matrix with a bulk density of $\sim 2.2 \mathrm{Mg} / \mathrm{m}^{3}$.
There is no apparent increase in bulk density with depth within this unit.

The boundary between Units 6 and 7 consists of gray clay with a density of $2.17 \mathrm{Mg} / \mathrm{m}^{3}$. Unit 7 is a claystone with a bulk density $\left(2.5 \mathrm{Mg} / \mathrm{m}^{3}\right)$ equivalent to some of the overlying igneous material. We suggest that the high density is due to post depositional silicification and not to simple compaction.

The water content at Sites 438 and 439 varies from about 7 to 65 per cent (wet weight), and porosity values (excluding limestones) range from 10 to 84 per cent. The distribution of water content-porosity mirrors the density distribution, so that high density sections are zones of low water content and low porosity. As a result, the discussion concerning, and the implications drawn from, the density profile apply equally to the distribution of water-filled voids.

\section{Sonic Velocity}

In general, the velocity profile resembles the density distribution. Velocity highs occur at the surface $(\sim 1.63$ $\mathrm{km} / \mathrm{s})$ and between 30 and 45 meters $(\sim 1.66 \mathrm{~km} / \mathrm{s})$ in Lithologic Unit 1 and near the top of Unit $3(\sim 1.91$ $\mathrm{km} / \mathrm{s}, 830-850 \mathrm{~m})$. Low-velocity zones at 15 to 30 meters $(1.55 \mathrm{~km} / \mathrm{s}$, Unit 1$)$ and 780 to 815 meters $(\sim 1.56 \mathrm{~km} / \mathrm{s}$, Unit $2 \mathrm{C})$ confirm the position of lowdensity sections and reflect lithologic (Unit 1) or, perhaps, fracture control (Unit 2C).

Within Units 4 and 5, the sonic velocity increases almost linearly with depth, but the boundaries between units are defined by offsets of 0.15 to $0.25 \mathrm{~km} / \mathrm{s}$. Unit 4 velocities are highly varible, with most values ranging between 1.9 and $2.4 \mathrm{~km} / \mathrm{s}$. Such variability is not unusual in a turbidite sequence. Velocities in the Unit 5 sandstones vary from $\sim 2.5 \mathrm{~km} / \mathrm{s}$ (top) to $\sim 3.3 \mathrm{~km} / \mathrm{s}$ (bottom), which may indicate increased induration toward the base of the interval.

Dacitic and rhyolitic boulders and cobbles in Unit 6 exhibit an average velocity of $4.4 \mathrm{~km} / \mathrm{s}$. The velocity in the conglomeritic matrix between boulders is probably about $3.0 \mathrm{~km} / \mathrm{s}$ (based on one laboratory determination and extrapolation of the velocity $\log$ ). The overall velocity of Unit 6 is undetermined.

Unit 7 velocities range from 3.4 to $3.75 \mathrm{~km} / \mathrm{s}$. The high values reflect the cementation of the deposit.

\section{Shear Strength}

There appear to be two distinct zones defined by shear strength at Site 438. The upper zone, which encompasses most of Lithologic Unit 1, is characterized by variable but low $(<30 \mathrm{kPa})$ shear strengths. There is no regular increase in shear strength with depth; rather the data seem to define a maximum at $\sim 30$ meters. This value may reflect the density minimum (increased clay content) which lies between 25 and 30 meters.

Below 100 meters, shear strengths increase with depth to maximum values between 80 and $90 \mathrm{kPa}$. This increase occurs despite the uniform density, water content, and lithology over this interval. 


\section{GEOPHYSICS}

\section{Seismic Reflection}

Two single-channel and one multichannel seismic reflection records were made across Sites 438 and 439 . The single-channel instruments recorded coherent reflectors up to 0.8 seconds below the sea floor. The multichannel instrument recorded acoustic basement about 1.5 seconds below the sea floor, as well as faint intrabasement reflections, and the record was used prior to Legs 56 and 57 to select and define site objectives. The reflection record including Sites 438 and 439 is shown in Figure 16.

An interpretative sketch of the multichannel seismic reflection record section (Figure 17) was made by tracing reflections at the lithologic boundaries assigned from study of the drill cores. The lithologic unit boundaries were picked on the Hole 438A velocity log at the velocity break nearest a unit boundary; the corresponding seismic horizon was determined using velocity from the log. Unit 1 is thin, and its seismic character is obscured by reverberations from just below the sea floor. Subunit $2 \mathrm{~A}$ is characterized by weak continuous seismic reflections. Sub-unit $2 \mathrm{~B}$ has the strongest sequence of coherent reflections, particularly in the upper part of the unit. Sub-unit $2 \mathrm{C}$ has weaker reflections much like Sub-unit $2 \mathrm{~A}$, but they are broken by small faults. Unit 3 also has strong reflectors, but they return lower frequency components of the seismic signal than Unit 2 reflectors do. The reflections in Unit 3 are broken and hard to follow, which is possibly as much a function of depth as it is a greater degree of folding and faulting. Unit 4 cannot be followed in the seismic record. The lowest coherent reflection, at the top of the acoustic basement, has a very low frequency response, and its highly diffractive character indicates point reflective sources, probably from small broken areas.

This seismic character is very consistent with the character of the sonic log. Unit 1 was not logged because 100 meters of drill stem was required to be in the drill hole. In Sub-unit $2 \mathrm{~A}$ the velocity trace was generally linear with few interruptions, consistent with the weak reflections. In Sub-unit 2B there are many deflections with a magnitude of $0.1 \mathrm{~km} / \mathrm{sec}$, consistent with strong reflections, although some of them are noisy. In Sub-unit $2 \mathrm{C}$ the trace is again more uniform, consistent with weak reflections. Sub-unit $2 \mathrm{C}$ and Unit 3 are separated by a strong inflection $(1.8-1.95 \mathrm{~km} / \mathrm{s})$ that is reflected in all the logs.

The main units defined at Site 438 were traced to Site 439. Two fault zones lie between these sites, and the correlation of reflections across the faults introduces uncertainty in correlation of reflections, especially the lower ones shown in Figure 17. Three interpreters correlated the lower reflections slightly differently and disagreed by one phase on the Sub-unit 2C/Unit 3 boundary.

The velocity analysis developed for Site 438 from the seismic data was also used for initial depth determinations at Site 439. Prior to drilling, the depth to the acoustic basement was estimated to be 1100 meters from the sea floor. Coring established the boundary between the 105-meter-thick massive sandstone (Unit 5) and the 48-meter-thick boulder conglomerate (Unit 6) at 1098 meters below the sea floor. This correspondence with the initial estimate is probably fortuitous rather than precise, because neither the seismic reflection time intercept along the section nor the velocity analysis could possibly be determined to better than 15 or 29 meters ( $1 / 4$ wavelength of the dominant recorded frequency) in terrain as deformed as that of this area. Unfortunately, the velocity change across the Units $5 / 6$ boundary was not logged because the hole bridged at the top of the conglomerate when the drill stem was removed before logging. However, it seems likely that the contact between a massive sand and a boulder conglomerate would produce the diffracted acoustic basement signature. Alternately, the unconformable boundary between the conglomerate and the silicified claystone could also produce a diffractive reflection. The laboratory measurements of physical properties, which extend below the logged interval, indicate a sharp velocity break at the bottom of Unit 5 where the sandstone becomes well cemented, and they suggest a velocity shift at the Unit 5/Unit 6 boundary. However, since the measurements were made either on boulders or on the matrix of the conglomerate rather than across a significant part of the unit, the magnitude of the velocity change is uncertain. From sparse measurements of the silicified claystone, there is a lesser shift in velocity across the Unit 6/Unit 7 boundary. Therefore, a correspondence of the acoustic basement and the Unit 5/Unit 6 boundary is favored at Site 439. Whatever its origin, the acoustic basement reflection probably originates from some change in lithology or surface morphology associated with the unconformity. The conglomerate penetrated at this site is probably of limited areal extent, and the less diffracted, more continuous stretches of acoustic basement may originate from other lithologies.

The section at Sites 438 and 439 dips gently seaward and is broken by high angle faults that occur at 3-km intervals and dip predominately west. Lower reflectors on either side of the faults generally have greater displacement than upper reflectors, suggesting faulting during and since the time represented by the section that is, the Miocene. Many large faults have expression at the sea floor. The vertical displacement is down on the west, indicating a geometry of regional extension rather than compression. A conjugate and much less developed east-dipping fault pattern is recorded best near Site 438.

The lowest reflectors end or pinch-out one by one against the acoustic basement (Figures 16 and 17). This structural relation suggests that the basal part of the reflective section is older landward and becomes younger seaward.

\section{Logging}

Hole 438A was logged with the following tools: gamma-sonic, gamma-neutron density, gamma-laterolog, and high resolution temperature (logs in back pocket). The sonic and density logs may not be precise enough 


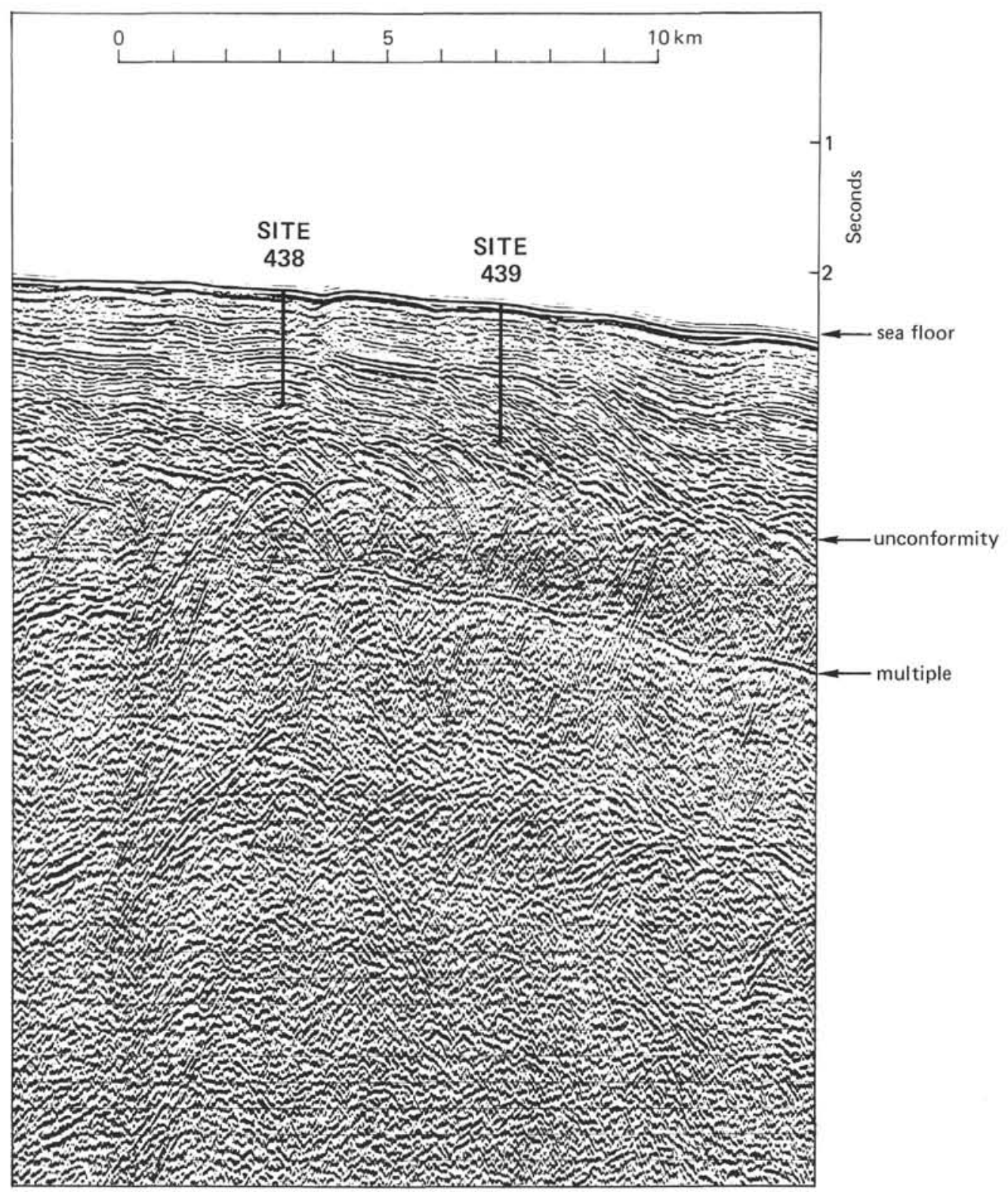

Figure 16. Section of JNOC-1 on deep sea terrace showing location of Sites 438 and 439.

for quantitative interpretation, because aboard the Challenger the tools must pass down the small-diameter drill stem rather than through a larger-diameter casing. As a result, the standard centralizer, excentralizer, and calipers could not be used, and those modified aboard the ship were not completely satisfactory. In addition, the sonic and neutron-density logs were operated beyond their normal working ranges. Despite these difficulties, the logs are highly informative and added much lithologic resolution, even in this hole, which had high core recovery.

Interpretation of the logs is limited to a qualitative assessment of log character correlation with lithology. The following are thus only general observations. Comparison of the sonic and neutron density logs with the physical properties of the sediments is covered in Carson and Bruns (this volume).
The high resolution temperature tool was run last, after the hole had been filled with mud for 25.75 hours. Maximum reading thermometers were included on each previous run, and the chronology of temperature measurements is shown in Table 3 .

Precision of the thermometer was $0.5^{\circ} \mathrm{F}$. The maximum readings of the first three runs were obtained during a 1-minute or shorter interval on the bottom. During the fourth run the thermometer was left on the bottom for 10 minutes. The calculated gradient of $2.9^{\circ} \mathrm{C} /$ 100 meters is considered typical of the area off northern Japan.

The laterolog shows a very homogeneous resistivity in the section. The small amplitude deviations follow those of the other logs. In particular the laterolog recorded sharp peaks at limestone horizons, and it seems to reflect general changes at lime-rich intervals. 


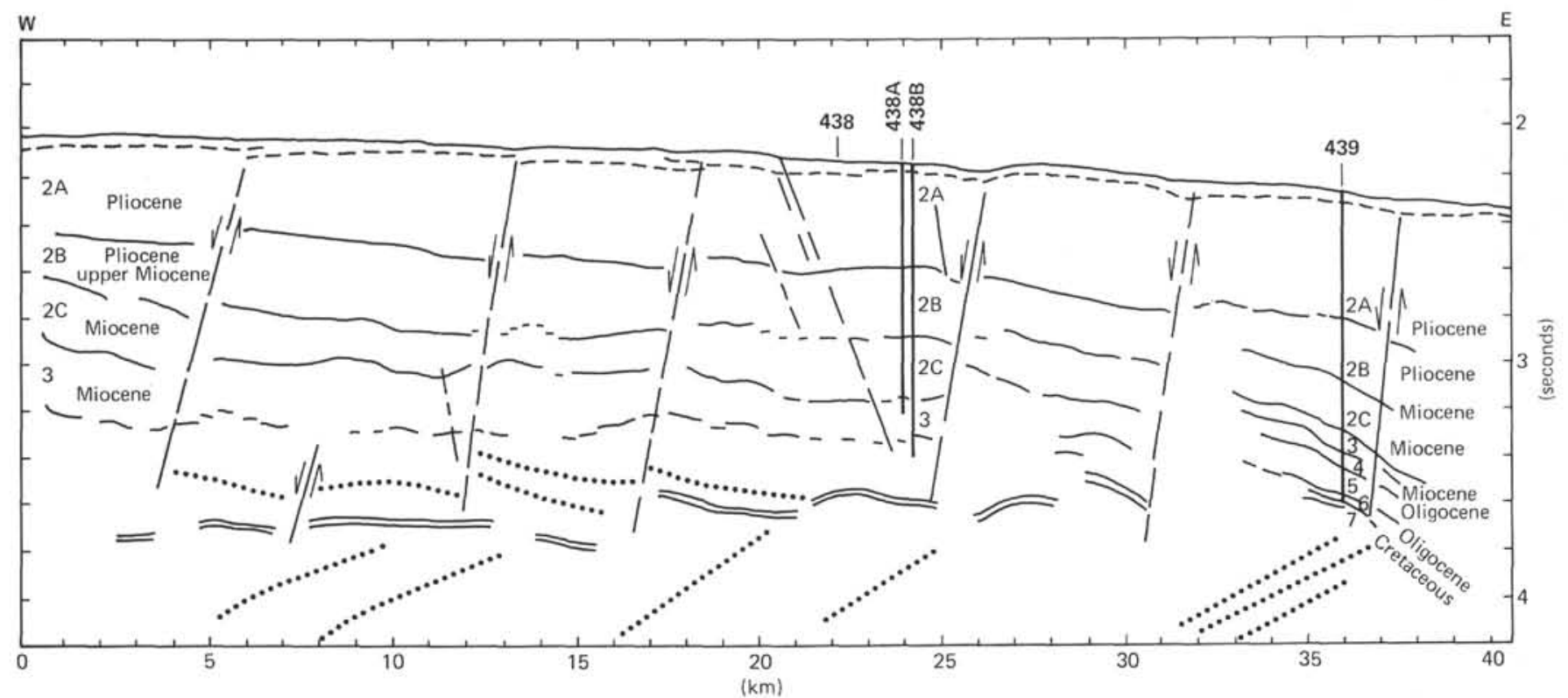

Figure 17. Tracing of mutichannel seismic reflection profile JNOC-2 showing approximate boundaries of lithologic units as solid lines. Double line is tracing across acoustic basement reflection. Dashed line shows approximate lower boundary of Unit 1 .

TABLE 3

Maximum Reading Thermometer Data

\begin{tabular}{|c|c|c|c|}
\hline Run & Max. Depth Reached by MRT & $\begin{array}{c}\text { Time } \\
\text { (hours since circulation) }\end{array}$ & $\begin{array}{l}\text { Average Temp } \\
\left({ }^{\circ} \mathrm{F}\right)\end{array}$ \\
\hline \multicolumn{4}{|c|}{ Hole 438A } \\
\hline 1 (BHC) & 2437 & 6 & 66 \\
\hline 2 (FDC) & 2438 & 12 & 74 \\
\hline 3 (LL-D) & 2425 & $19 \%$ & 77 \\
\hline 4 (HRT) & 2406 & $25 \%$ & 79 \\
\hline \multicolumn{4}{|c|}{ Hole 439} \\
\hline 1 (BHC) & 2757 & $13 \%$ & $75(74.5,74.5,75.5)$ \\
\hline 2 (FDC) & 2614 & 20 & $73(72.5,72.5,73.5)$ \\
\hline 3 (LL-D) & 2613 & $25 \%$ & $75(74.5,74.5,75.5)$ \\
\hline 4 (HRT) & 2613 ? & $301 / 4$ & $77(76.5,76.5,78.0)$ \\
\hline
\end{tabular}

aUndetermined - could be slightly less.

The record also reflects changes in sand content at the top and bottom of the hole.

The sonic log correlates well with lithology and with the velocities derived from seismic measurements. In many places the log is noisy, which may be caused by weak signal return and poor centralization. Therefore quantitative interpretation in these areas is difficult. However, the noisy sections often correspond to lithologies with highly variable thin horizons. The log seems to reflect mainly changes in lithification and cementation.

The density log has the greatest "character" of all logs and corresponds well with observed changes in lithology. It appears more sensitive than other logs to the subtle changes in this generally massive section.

The gamma-ray log was used on each run to provide correlation between logs. It has distinctive character and seems sensitive to lime-rich zones and fluctuations in sand content. However, the normal polarity of the gamma-ray log appears to be reversed; limestone and sandstone (much of it volcanic ash) have relatively high rather than low gamma values when compared to siltstone and claystone.

The logs were correlated with lithologic units observed in drill cores. A brief description of this correlation follows. Because communication between the ship and the hole was maintained by having about 100 meters of drill pipe in the hole, the upper unit was logged through the pipe by the gamma tool. The gamma log of Lithologic Unit 1 is relatively uniform, with one small positive deviation at 28 to 32 meters.

Sub-unit $2 \mathrm{~A}$ is characterized by a smooth trace on all logs. This trace is punctuated by spikes, all in a positive direction, that appear to correlate with limestone beds (especially strong at $65-75,212$, and $280 \mathrm{~m}$ ). The $\log$ seems consistent with the homogeneous clayey diatom ooze described in the drill cores.

Sub-unit $2 \mathrm{~B}$ is separated from Sub-unit $2 \mathrm{~A}$ by change in the character of the logs from smooth to variable. In particular the upper parts of the velocity and density logs in Sub-unit 2B are highly variable. This variability correlates well with the alternating indurated and nonindurated layers of diatomaceous clay cored here. Some strong spikes suggest limestones (e.g., at $368 \mathrm{~m}$ ). Logs of the lower part of this unit are less variable and noisy. This character correlates with a zone of more uniform cementation and/or induration.

Sub-unit $2 \mathrm{C}$ is distinguished from Sub-unit $2 \mathrm{~B}$ by an increase in the gamma and density values. The velocity and density traces continue noisy, and large spikes, characteristic of limestone beds, continue also. The increased number of limestone beds found in cores below the 700-meter level correspond well to deviations in all of the logs.

Unit 3 is marked by a shift in all log traces to higher values at about 820 meters. This shift seems to correspond well with the increased vitric sand content in cores from that unit. 
Logging at Site 439 was accomplished with the same suite of tools run at Site 438. In addition to the seismic reflection and paleontological control, logs provided the greatest detail for correlation between the two sites.

Temperature. The high resolution temperature tool was run last, $30 \frac{1}{4}$ hours after circulation of mud in the hole, during which time the other logs were run. Table 3 gives measurements with maximum reading thermometers (reading precision $0.5^{\circ} \mathrm{F}$ ) on all tools which were run to the total depth available at the time. Because of its light relative weight, the maximum depth of the temperature run could not be accurately determined by weight loss on touch down. Readings were taken on the way down. Since the hole deviated more than $10^{\circ}$ near the bottom, the tool was probably in contact with the side of the hole. Two stationary readings were made 5 minutes apart near total depth after the mud had already been disturbed by the run down the hole.

Gamma-Ray Log. The upper part of this log is of equivalent character in both holes, and near the Unit 2/ Unit 3 boundary the logs are virtually identical. Spikes interpreted as limestone beds at Site 438 showed well in places at 439 and were used for correlation between the two holes. In Sub-units $2 \mathrm{~A}$ and $2 \mathrm{~B}$ the shifts are less pronounced in 439 than in 438 .

Sonic Log. Averaged velocity gradients with depth below the sea floor are the same in both holes, and the $439 \log$ shows fewer shifts near unit boundaries than 438. The lower part of the trace is noisy in 439 , probably because the tool was inadequately centralized and rough hole conditions caused the tool to come up the hole in a jerky manner. A greater burial depth of units in 439 corresponds to an increased velocity over equivalent units in 438 . The reflector at the Sub-units $2 \mathrm{~A} / 2 \mathrm{~B}$ boundary, recognized in Hole 438, is also distinct at 439 . The diagenetic and compaction changes responsible for the variability beginning near 350 meters in 438 occur at about the same level in 439 , despite the change in units.

Formation Density Log. Traces from both holes have similar character, although the one from 439 appears to have greater sensitivity. The change from a relatively smooth to a variable trace occurs at 350 meters in both holes, consistent with the inferred compaction and diagenetic changes as a function of depth. Gross changes in density over tens of meters are recognizable in both units, and many of the sharp variations are easily correlated between holes.

Laterolog. Traces from both holes are similar, and correlation is very good below about 500 meters. Above this zone, some of the features that look similar can be correlated, but the log lacks the distinctiveness of the other logs and correlation is less certain.

The correlation of distinctive features between logs (Figure 18, back pocket) is in Table 4, which illustrates apparent eastward thickening of the lower Pliocene and middle Miocene units. This same trend is shown on a larger scale by the pinching out of reflective section at the acoustic basement. This apparent change of thickness may be affected by subsurface structure out of the plane of the seismic record; however, the change (about $1300 \mathrm{~m}$ over a distance of $20 \mathrm{~km}$ ) in the seismic record
TABLE 4

Points Correlated by Geophysical Logs, Holes 438A and 439

\begin{tabular}{lcrrrrr}
\hline $\begin{array}{c}\text { Lithologic } \\
\text { Units }\end{array}$ & Point & $\begin{array}{c}\text { Sub-bottom } \\
\text { Depth } \\
438\end{array}$ & $\begin{array}{c}\text { Sub-bottom } \\
\text { Depth } \\
439\end{array}$ & $\begin{array}{c}\text { Difference } \\
439-438\end{array}$ & $\begin{array}{c}\Delta \\
\text { Thickness }\end{array}$ & $\begin{array}{c}\Sigma \\
\text { Thickness }\end{array}$ \\
\hline $\begin{array}{c}\text { I } \\
\begin{array}{c}\text { Pleistocene } \\
\text { and }\end{array}\end{array}$ & 7 & 210 & 284 & 74 & -74 & 82 \\
$\begin{array}{c}\text { Sub-unit 2A } \\
\text { Pliocene }\end{array}$ & $6 \mathrm{~A}$ & 283 & 348 & 65 & $-17(?)$ & Thicken to East \\
\hline Sub-unit 2B & 6 & 363 & 445 & 82 & $37(?)$ & \\
E. Pliocene & 5 & 567 & 612 & 45 & 7 & 44 \\
L. Miocene & $4 \mathrm{~A}$ & 596 & 633 & 37 & 7 & Thicken to West \\
\hline & 4 & 622 & 652 & 30 & -5 & 25 \\
Sub-unit 2C & $3 \mathrm{~A}$ & 659 & 694 & 35 & 5 & 25 \\
L. Miocene & 3 & 700 & 721 & 21 & 14 & Thicken to West \\
M. Miocene & 2 & 745 & 751 & 13 & 8 & \\
\hline
\end{tabular}

seems sufficiently large at least to establish a trend (Figure 16).

\section{SUMMARY AND CONCLUSIONS}

Sites 438 and 439 are on the outer continental slope of the Tohoku Island arc system, the tectonic province that includes the Japan Trench. Honza et al. (1977) describe the Pacific side of the Tohoku arc as a narrow shelf, a short continental slope, a broad, gently sloping deep sea terrace, and then a steep trench inner slope. Sites 438 and 439 are near the outer edge of the deep sea terrace. In the vicinity of the sites, the terrace is warped into a broad, faulted arch with a low topographic profile. The crestal axis of the arch is subparallel to the principal morphology of the shelf. But the reflective sequence of beds is relatively little deformed, particularly when compared with contemporaneous beds on the Sea of Japan side of the Tohoku arc.

Recent investigations of the Japan Trench area have been based on a network of single-channel reflection records and on two multichannel seismic reflection records (Honza, 1977; Honza et al., 1977; Nasu and Kobayashi, 1980; Ishiwada and Ogawa, 1976). These data formed the basis for selection of drill sites. A multichannel seismic reflection section across the sites (Figure 16) transects the arch perpendicular to its strike. The record illustrates a reflective sequence down to 1.4 seconds, floored by a strong acoustic basement. There are faint landward-dipping intrabasement reflections which are underlain in the eastern part of the record by another strong diffracting reflective sequence representing the top of igneous oceanic crust. The reflective sequence is broken into structural blocks by a series of west-dipping faults that are locally complemented by conjugate eastdipping faults with much less displacement. The vertical offset on the west-dipping faults is down to the west; this geometry indicates extension. The acoustic basement is a low-frequency diffraction horizon of regional extent. Some authors have proposed that this acoustic basement is the top of a Cretaceous section deposited on a Paleozoic basement that has subsided in the fore-arc region (Ishiwada and Ogawa, 1976). Other authors have suggested that the Tohoku arc may have been quiescent 
during the Paleogene and that tectonic activity resumed during the late Oligocene, accompanied by subsidence of the foot of the continental slope, followed by the rise of the slope above sea level near the end of the Pliocene and renewed subsidence during the Pleistocene (Honza et al., 1977). Alternatively, it has been suggested informally that acoustic basement is the top of an imbricate stack in a structural setting similar to that illustrated by Seely and others (1974). This is thought to be a possibility because the basement can be traced landward from the mid-slope terrace above the Japan Trench, a structural position commonly occupied by the imbricate stack theoretical models of convergent margins. Furthermore, the progressive seaward pinch-out of strata above basement indicates a younger basement surface seaward as predicted by the Seely model. The result of testing these hypotheses has significant implications for the dynamics and kinematics of the convergent-margin tectonic processes. Therefore the principal drilling objective at Sites 438 and 439 was to sample the acoustic basement as well as the overlying sediment section to study the Neogene history of the continental margin.

Three holes were drilled at Site 438 and one at 439; the first, Hole $438(109 \mathrm{~m})$, was aborted because of a medical emergency; the second, Hole 438A ( $878 \mathrm{~m})$, was a pilot hole for a re-entry hole; the third, Hole 438B $(1040 \mathrm{~m})$, a re-entry hole, failed to reach acoustic basement because the hole caved continuously in the lower part. However, a good set of down-hole logs and good recovery were achieved. Acoustic basement was reached at Site 439. The four holes were cored continuously in overlapping intervals, providing a sample sequence of the Cretaceous and of the Oligocene to Pleistocene.

The sequence of lithologies encountered at the sites, rather than any single line of evidence, indicates rapid subsidence of a continental landmass from a probable subaerial position in the Oligocene to upper middle bathyal (500-1500 m) depths at the beginning of the early Miocene time and lower bathyal in the early Pliocene. The sequence is divided into six units.

Unit 7 is below the upper reflector of the acoustic basement where a hard dark silicified claystone of the Late Cretaceous was cored. An erosional surface is inferred across the top of the claystone because of a long hiatus, the rough surface topography indicated in seismic records, and because the claystone is found as clasts in the overlying conglomerate and breccia. The conglomerate and breccia (Unit 6) consist mostly of boulders of porphyritic dacite. The angular shape of some of the dacite clasts, their large size, and their nearly monolithologic composition indicate a nearby source, either shallow hypabyssal or volcanic. The fact that it lacks marine fossils and is underlain by clay that may have been formed from weathered products may indicate that the conglomerate was formed subaerially. The 48meter-thick conglomerate and breccia are overlain by a massive 105-meter-thick sandstone of the latest Oligocene (Unit 5), deposited near a surf zone. The rock has moderate sorting, dominantly medium to fine grain size, lack of bedding, and a composition of lithic arenite to lithic wacke. The unit contains numerous megafos- sils, including articulated pelecypods (not in growth position), essentially unbroken gastropods, and upper bathyal benthic foraminifers. The foraminiferal assemblage in the overlying unit (Unit 4) is middle bathyal, and the lithology changes abruptly to a fine-grained turbidite-claystone sequence of the early early Miocene. This sequence is in turn overlain by Unit 3, which is the beginning of the thick hemipelagic sequence deposited at bathyal depths.

In general, Units 3 through 1 show isolation of the site from down-slope terrigenous influences in the early Miocene until the effect of the late Cenozoic glacial period are sufficiently marked to be recorded.

The sedimentary sequence of Units 2 and 3 is mostly of hemipelagic origin, remarkably homogeneous in composition, and lacking significant coarse terrigenous debris, considering the proximity of this site to a tectonically active island arc. The principal compositional variants are diatoms and clay; secondary variants are ash, replacement carbonate minerals, and sand. Superimposed on the original compositional variation is a sequence of diagenetic stages that occur with increasing depth and age. At 510 meters and 8 m.y. of age, we reached the onset of lithification. In a gross sense the sediment ranges normally from soft, through firm, to hard, but reversals of consolidation occur as silicification, and carbonate cementation was enhanced or retarded. This is more apparent in the Formation Density Log than by visual inspection. The number of observed ash layers is greatest in strata deposited during the period between 2 and $4 \mathrm{~m} . \mathrm{y}$. and is negligible before $8 \mathrm{~m} . \mathrm{y}$.

Erratic pebbles suggest glacial influence at this latitude beginning in the late Pliocene. However, pumice pebbles are found in most units and may represent material floated to the site by oceanic currents. Unit 4 shows characteristics of more frequent density flows. However, the period of most rapid sedimentation was probably between 2 and $6 \mathrm{~m}$.y., a period of hemipelagic deposition; another interval of relatively rapid deposition occurred between 14 and 16 m.y.

The series of environments interpreted from this lithologic sequence at Sites 438 and 439 begins with an emergent Oligocene terrain of black silicified Cretaceous claystone and dacite (Figure 19). Erosional products, probably first deposited subaerially, were covered during the late Oligocene by sand transported from a nearby surf zone into quieter marine waters. Subsidence continued in the early Miocene, and distance from sources of terrigenous material increased. The area of the site subsided to upper middle bathyal depth at the beginning of the early Miocene, to lower bathyal depth in the late Miocene time, and was essentially isolated from coarse-grained terrigenous material until the late Pliocene. This subsiding section was part of a landmass that was intruded by dacite east of the modern volcanic arc. It appears that local remnants of the landmass were emergent as late as the beginning of the Pliocene.

The location of Site 438 near the confluence of the warm Kuroshio and cold Oyashio currents has influenced the lower Miocene to Pleistocene microfossil assemblages. Diatoms are the most abundant and con- 


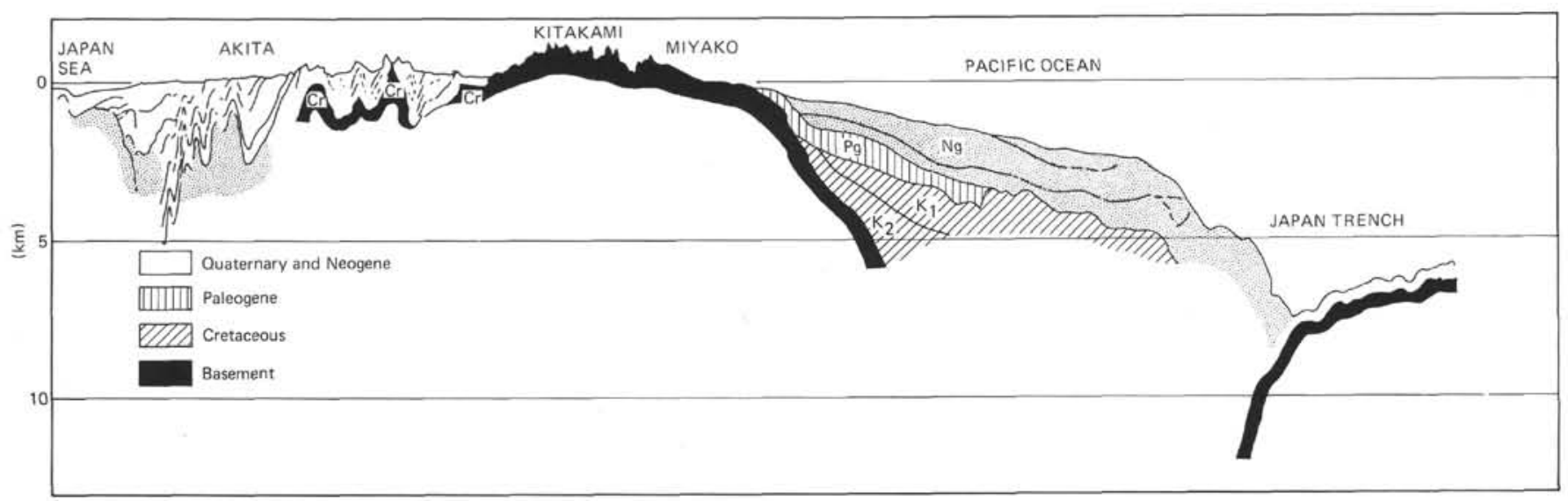

Figure 19. Geological cross section across Japan and the Japan Trench continental margin (from Ishiwada and Ogawa, 1976) along latitude $39^{\circ} 30^{\prime} \mathrm{N}$.

sistent group present and provide the most complete zonation. Zonation from microfossils at the sites is excellent in the lower Miocene and above and less precise in the Oligocene and upper Cretaceous. Diatoms are the most age-diagnostic group down through the lower Miocene and then become very scarce or absent. Benthic foraminifers are generally rare. Benthic foraminiferal assemblages indicate environments that begin in the upper bathyal $(150-500 \mathrm{~m})$ in the Oligocene and are upper middle bathyal to lower bathyal in the early to late Miocene. Planktonic foraminiferal assemblages were recovered in the late Miocene to Pleistocene strata. Environments favorable to nannofossils occurred occasionally. Very small forms indicate a stressed environment in the Oligocene. Many samples are barren of radiolarians, and reworked Cretaceous forms are found in Oligocene sandstone from Site 439.

Rates of sediment accumulation are relatively well controlled over short time intervals by the combined microfossil data. Two short hiatuses are recognized on the basis of these data, and at least one occurs at the end of a period of rapid sedimentation.

A relatively complete suite of organic-geochemical measurements on gases shows a normal zonation of hydrocarbon fractions with depth and age for an environment with low heat flow. Most gas seems to have formed in place, and the lack of evidence for gas migration is consistent with the dense nonpermeable section drilled. Low values of salinity and interstitial water of the Oligocene marine sandstone suggests fresh-water recharge from adjacent emergent areas.

The position of Site 438 is between two fault zones which appear to have been the greatest cause of fracturing in the lower parts of the holes at this site. A dominant west-dipping fault zone is intersected by a well-developed east-dipping conjugate zone about $900 \mathrm{~m}$ deep, which resulted in the intense fracturing of Unit 4 (Figure 17). In addition, faulting and sediment deposition must have been contemporaneous, because the oldest and lowest horizons are the most strongly deformed. The zone of deformation seen in seismic records was manifested as many unhealed fractures in the deep rock encountered by the drill.
Dewatering structures give evidence of increasing stress down-hole. Fractures or veins seem to develop in massive lithifying claystone and mudstone and act as conduits for upward escape of overpressured interstitial water. Under tectonic stress they may develop into slip planes because of their near-vertical orientation and lubrication by pore water.

The correlation of strata between Sites 438 and 439, which are $6 \mathrm{~km}$ apart, was first done by tracing reflections in the multichannel seismic reflection record. Two intervening faults introduced uncertainty in correlation of the lowest reflections, but more detailed correlations by logs and paleontology after drilling confirmed the general correctness of the initial seismic interpretation. Correlation of logs between the sites indicates an apparent seaward thickening of units above Sub-unit 2B (lower Pliocene). Below Sub-unit 2C (lower upper Miocene) apparent thickening occurs in the opposite direction, or landward. An even stronger landward increase in thickness of the pre-middle Miocene section is seen in the seismic record west of Site 438 along an unconformity between the basement and the overlying reflective section. Thus the fore-arc depocenter seems to have shifted seaward during the Miocene and Pliocene. The shift was probably controlled tectonically, and it reveals a timetransgressive subsidence off northern Japan.

The local chronology at Sites 438 and 439 has implications for the history of subduction off Japan, which becomes clearer when the sites are related to the regional geology. The geology on land, $160 \mathrm{~km}$ west of the sites, is dominated by the Kitakami massif of Paleozoic and Cretaceous intrusive rocks, which also contains local remnants of Cretaceous and Paleogene sedimentary rock. The sedimentary rocks of the seaward flank are inferred to have extended much farther and now are represented by a steeply dipping eroded Paleogene sequence along the continental shelf (Honza et al., 1977). They are shown as a layer that continues under the continental slope and deep sea terrace in a cross section (Figure 19) constructed by Ishiwada and Ogawa (1976). The acoustic basement in the JNOC multichannel record across Sites 438 and 439 is a seaward continuation of the top of the Cretaceous layer in the cross section. 
The significance of finding uppermost Paleogene rocks on the unconformity at Sites 438 and 439 is that it supports the implication that the Cretaceous-Tertiary unconformity on land extends across the continental shelf and slope at least to the area of the Leg 57 sites and that it probably corresponds to the acoustic basement recorded there. The duration of the hiatus is about 40 m.y., indicating a profound unconformity. The section above the unconformity is apparently transgressive, and it increases in age toward land as indicated in the seismic record (Figures 16 and 17). From these data and the structure in the section of Ishiwada and Ogawa (1976), an offshore landmass must have existed at the edge of the present deep sea terrace during the Paleogene, and a sea must have lain between the landmass and Honshu Island. We have named this the Oyashio landmass (von Huene, Nasu, and others, 1978). The landmass subsided to bathyal depth between the late Oligocene and perhaps the Pliocene (See Figure 20). The early Miocene transition from turbiditic to hemipelagic sedimentation is one indication of subsidence of the nearby part of the off- shore landmass in this area. The evidence from Sites 438 and 439 and the seismic data are not sufficient to define the late Cretaceous and Paleogene edge of the continent; emergent terrain and Neogene transgression extended at least to about the top of the present trench slope. The most unexpected discovery at Site 439 was the presence of the acidic to intermediate intrusive and volcanic rocks only $90 \mathrm{~km}$ from the Japan Trench, whereas the presently active volcanic arc is $300 \mathrm{~km}$ from the trench. From this discovery it can be implied that in the Oligocene volcanism occurred about $200 \mathrm{~km}$ farther east than the present arc.

The development of a fore-arc basin behind a shelf edge structural high is common along convergent margins, but here the process of formation differs from some present-day examples. Typically steady uplift of a trench slope forms an outer high bounding the fore-arc basin during subduction episodes. However, the Japan trench fore-arc basin formed by subsidence of an emergent terrain during the present episode of subduction, as indicated by arc volcanism on the island of
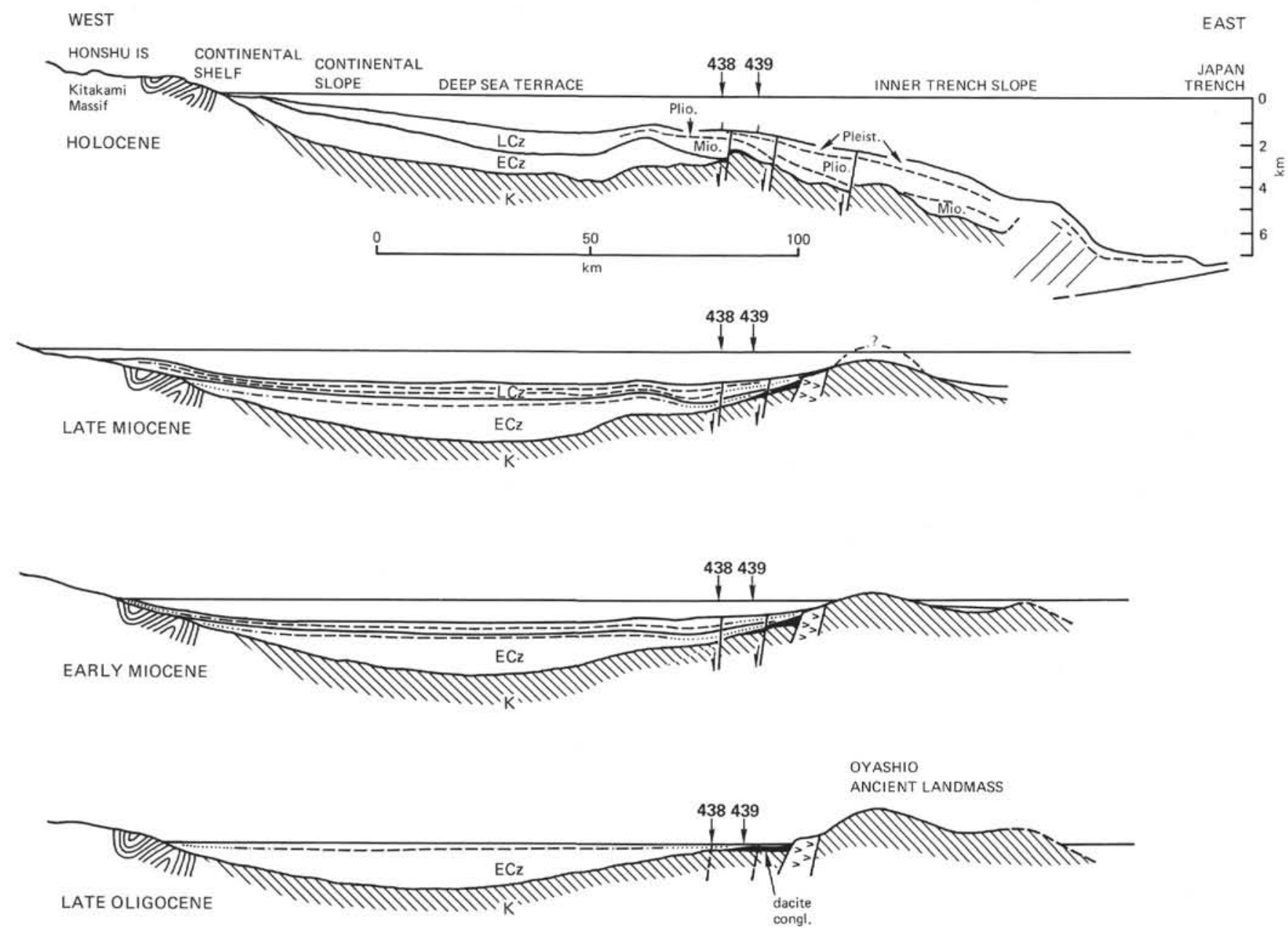

Figure 20. Diagram showing proposed evolution of Japan Trench continental margin from the late Oliogcene to Recent. Note the uplifted Oyashio landmass during the Early Cenozoic (outer arc high?) and its subsequent rapid subsidence. 
Honshu. This subsidence suggests a net loss of material along the frontal edge of the upper plate rather than growth by accretion.

\section{REFERENCES}

Claypool, G. E., Curray, J. R., Ewing, J., et al., 1976. Manual on pollution-prevention and safety. JOIDES Journal, $2,1-23$.

Claypool, G. E., and Kaplan, I. R., 1974. The origin and distribution of methane in marine sediments. In Kaplan, I. R. (Ed.), Natural Gases in Marine Sediments: New York (Plenum) pp. 99-139.

Erdman, J. G., 1961. Some chemical aspects of petroleum genesis as related to the problem of source-bed recognition. Geochim. Cosmochim. Acta, 22, 16.

Gartner, S., 1977. Calcareous nannofossil biostratigraphy and revised zonation of the Pleistocene. Mar. Micropaleont., 2, $1-25$.

Gieskes, J. M., 1974. Interstitial water studies, Leg 25. In Simpson, E. S. W., Schlich, R., et al., Init. Repts. DSDP, 25: Washington (U.S. Govt. Printing Office), 361-394.

Hein, J. R., and School, D. W., 1978. Diagenesis and distribution of late Cenozoic volcanic sediment in the southern Bering Sea. Bull. Geol. Soc. Amer., 89, 197-210.

Honza, E. (Ed.), 1977. Geological investigation of Japan and southern Kuril Trench and slope areas. GH-76-2 Cruise. Geol. Surv. Japan, Cruise Rept., 7, 1-127.

Honza, E., Kagami, H., and Nasu, N., 1977. Neogene geological history of the Tohoku Island Arc system. J. Oceanogr. Soc. Japan, 33, 297-310.

Hood, A., Castaño, J. R., and Kendrick, J. W., 1976. Petroleum-generating potential and thermal history of DSDP Leg 38 sediments. In Talwani, M., Udintsev. G., et al., Init. Repts. DSDP, 38: Washington (U.S. Govt. Printing Office), 801-803.

Ingle, J. C., Jr., 1973. Neogene Foraminifera from the northeastern Pacific Ocean, Leg 18, Deep Sea Drilling Project.
In Kulm, L. D., von Huene, R., et al., Init. Repts. DSDP, 18: Washington (U.S. Govt. Printing Office), 517-567.

Ingle, J. C., Jr., 1975. Summary of late Paleogene-Neogene insular stratigraphy, paleobathymetry, and correlations, Philippine Sea and Sea of Japan region. In Karig, D. E., Ingle, J. C., Jr., et al., Init. Repts. DSDP, 31: Washington (U.S. Govt. Printing Office), 837-855.

Ishiwada, Y., and Ogawa, K., 1976. Petroleum geology of offshore areas around the Japanese Islands. United Nations ESCAP, CCOP Tech. Bull., 10, 23-34.

Keller, G., 1978. Late Neogene biostratigraphy and paleoceanography of DSDP Site 310 Central North Pacific and correlation with the southwest Pacific. Mar. Micropaleont., $3,97-119$.

Koizumi, I., 1975. Late Cenozoic diatom biostratigraphy in the circum-North Pacific region. Geol. Soc. Japan J., 81, 611-627.

Nasu, N., and Kobayashi, K., 1980. Preliminary Report of the Hakuho Maru Cruise KH-77-I (IPOD Site Survey). Ocean Research Institute, University of Tokyo.

Schrader, H. -J., and Fenner, J., 1976. Norwegian diatom biostratigraphy and taxonomy. In Talwani, M., Udintsev, G., et al., Init. Repts. DSDP, 38: Washington (U.S. Govt. Printing Office), 921-1098.

Seely, D. R., Vail, P. R., and Walton, G. G., 1974. Trench slope model. In Burk, C. A., and C. L. Drake (Eds.), The Geology of Continental Margins: New York (SpringerVerlag), pp. 249-260.

Ujiie, J., Saito, T. Kent, D. V. et al., 1977. Biostratigraphy, paleomagnetism and sedimentology of late Cenozoic sediments in northwestern Hokkaido, Japan. Bull. National Sci. Museum, Series C, 3, 49-101.

Vincent, E., 1975. Neogene planktonic foraminifera from the Central North Pacific, Leg 32, Deep Sea Drilling Project. In Larson, R. L., Moberly, R., et al., Init. Repts. DSDP, 32: Washington (U.S. Govt. Printing Office), 765-801.

von Huene, R., Nasu, N., et al., 1978. Japan Trench transected. Geotimes, 23, 16-21. 


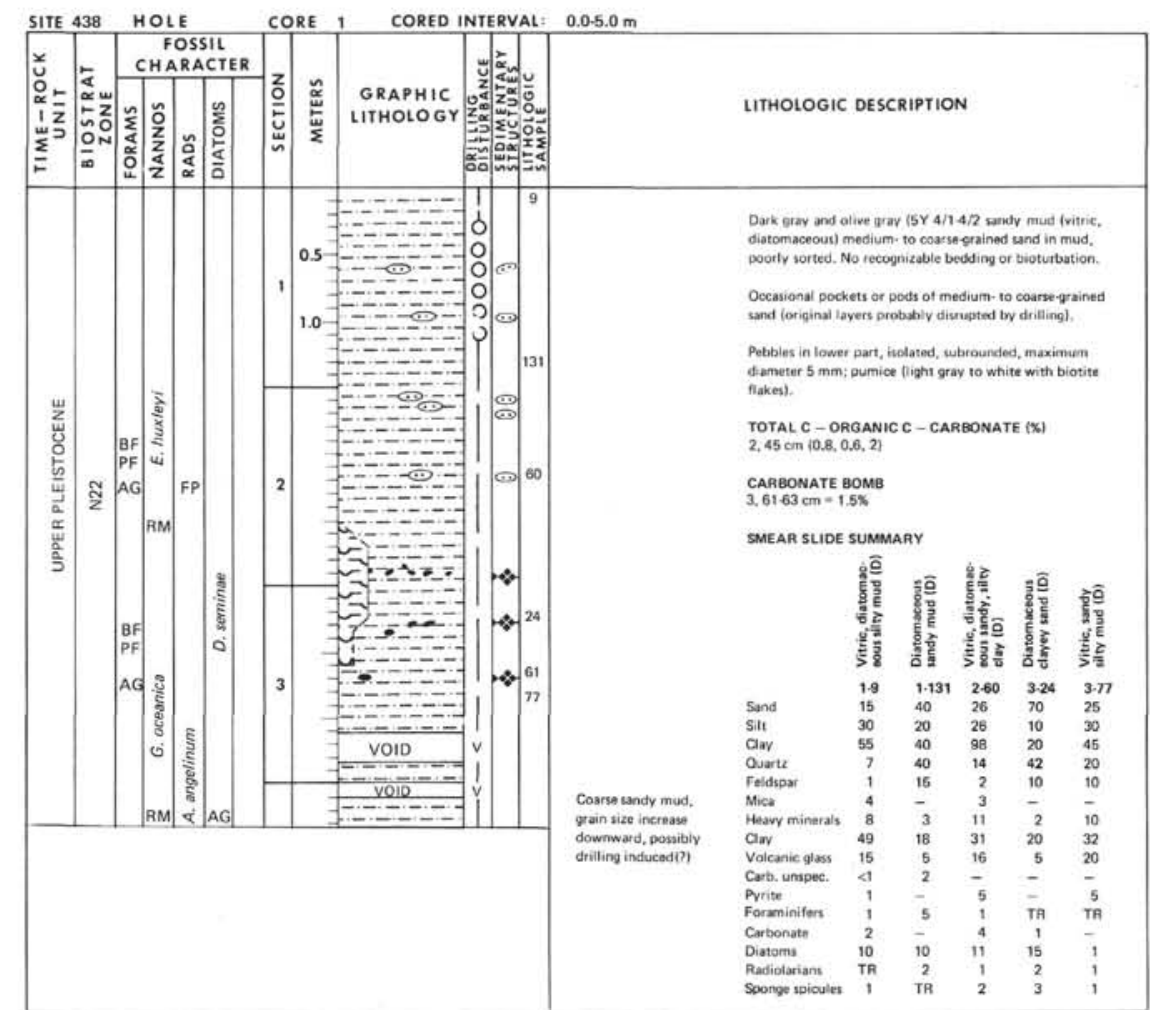

Information on core description sheets, for ALL sites, represents field notes taken aboard ship under time pressure. Some of this information has been refined in accord with postcruise findings, but production schedules prohibit definitive correlation of these sheets with subsequent findings. Thus the reader should be alerted to the occasional ambiguity or discrepancy.

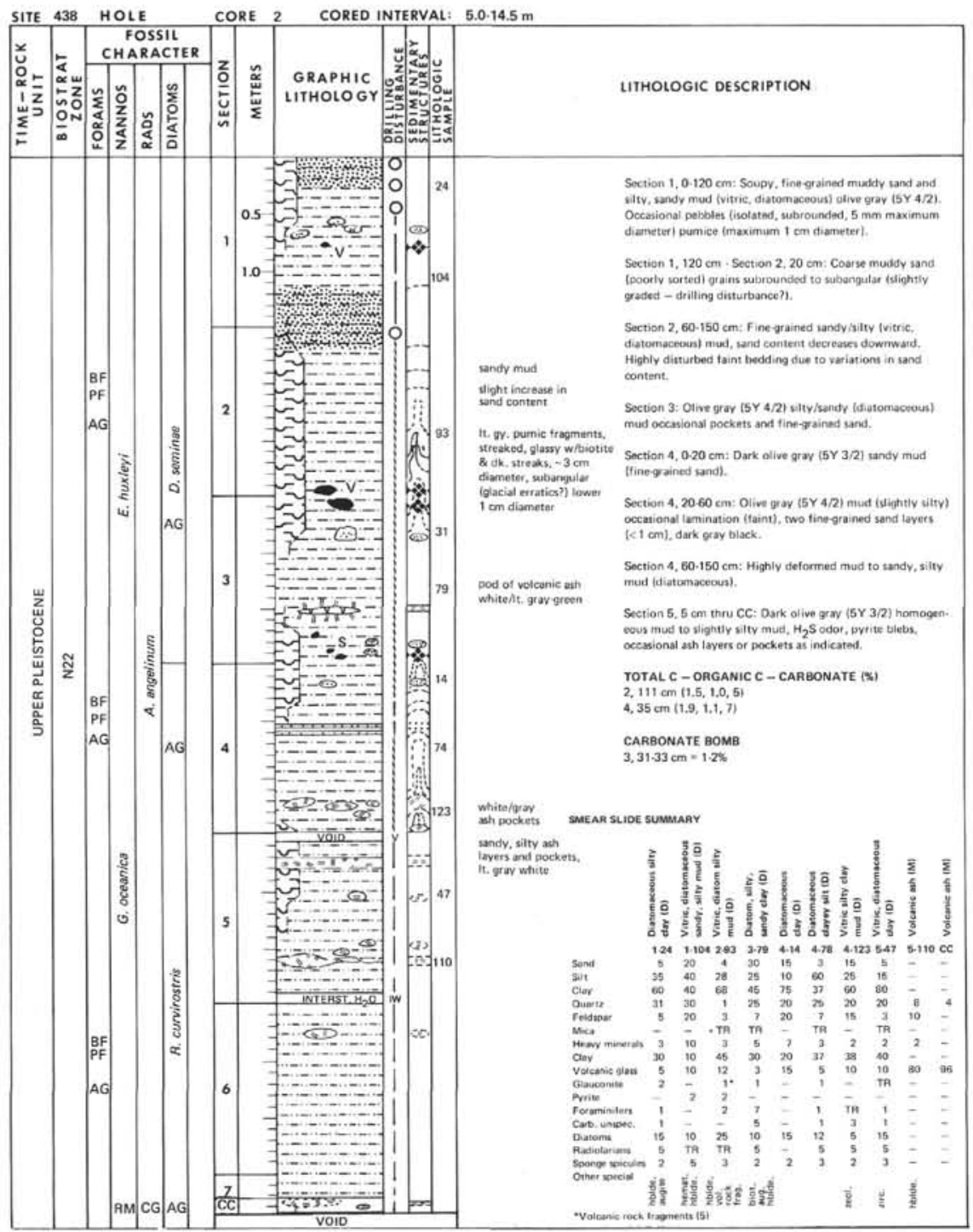



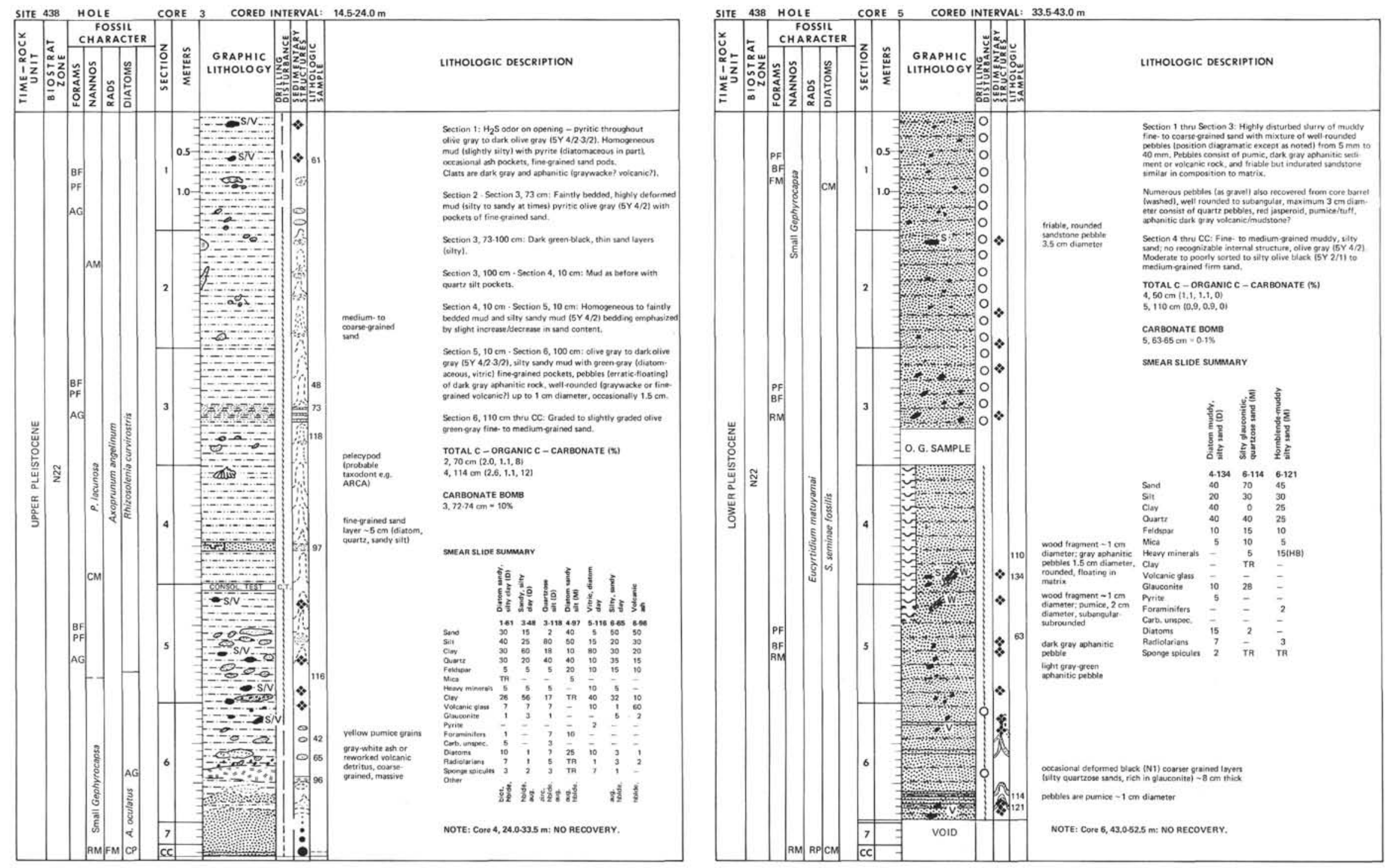

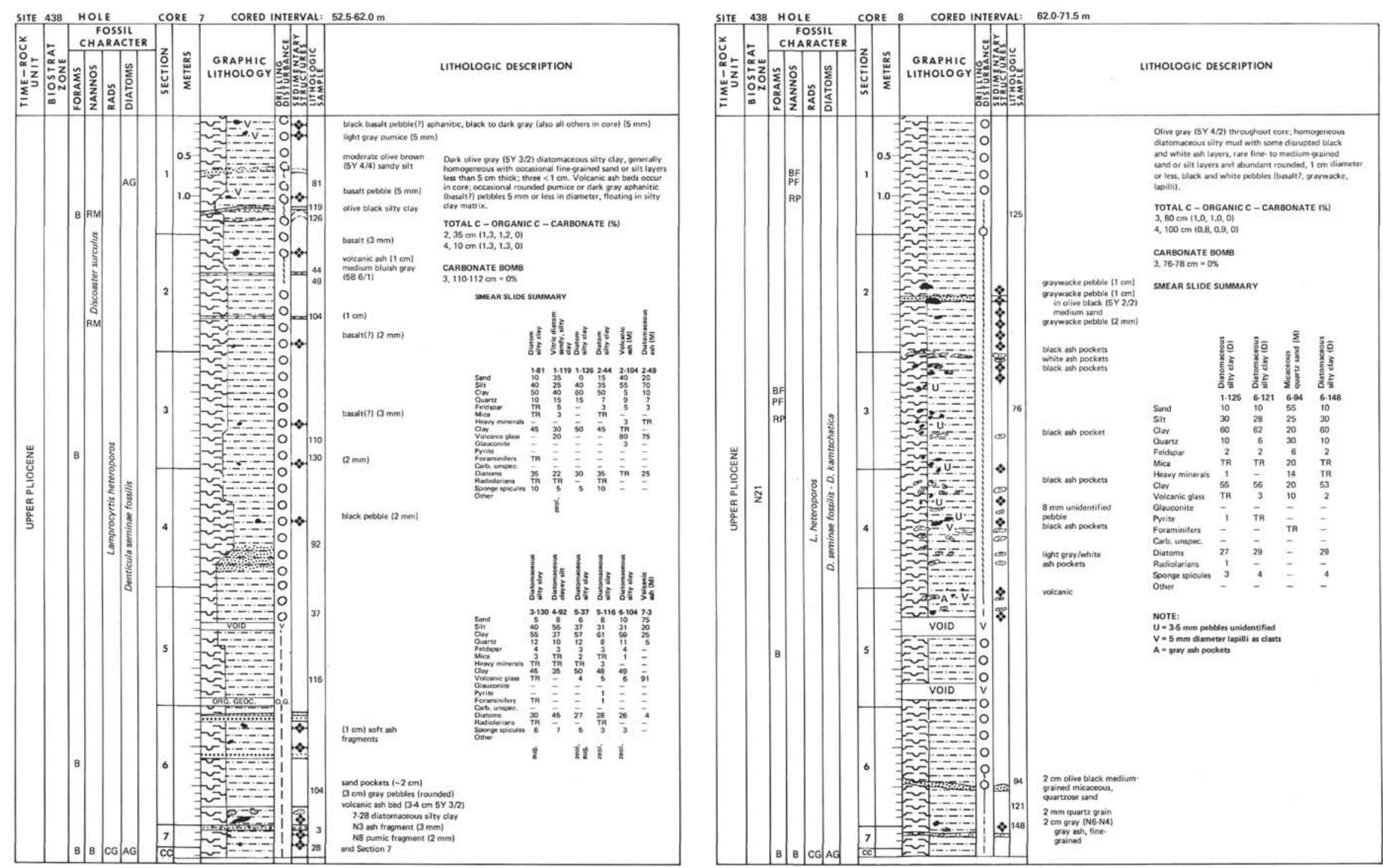

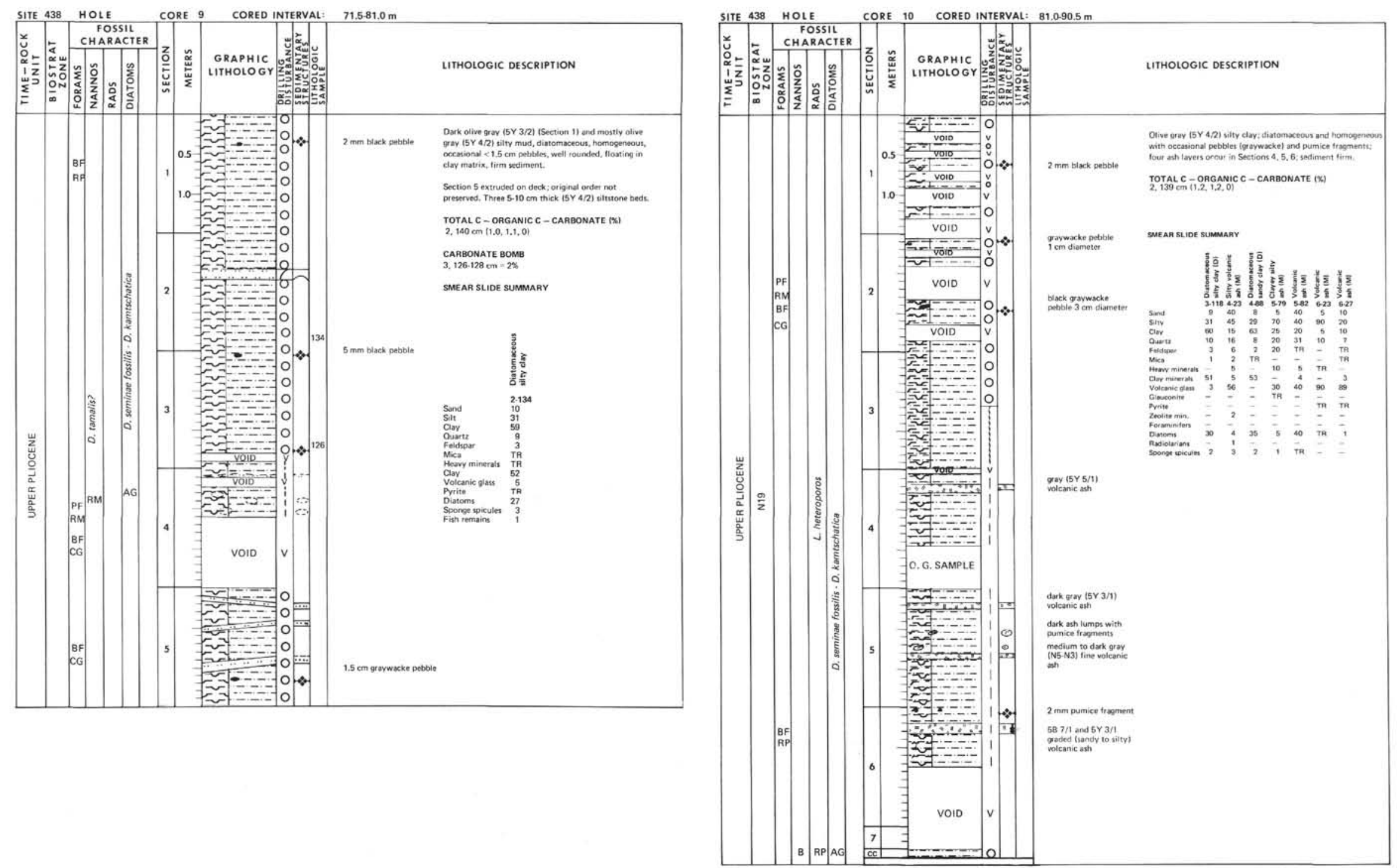


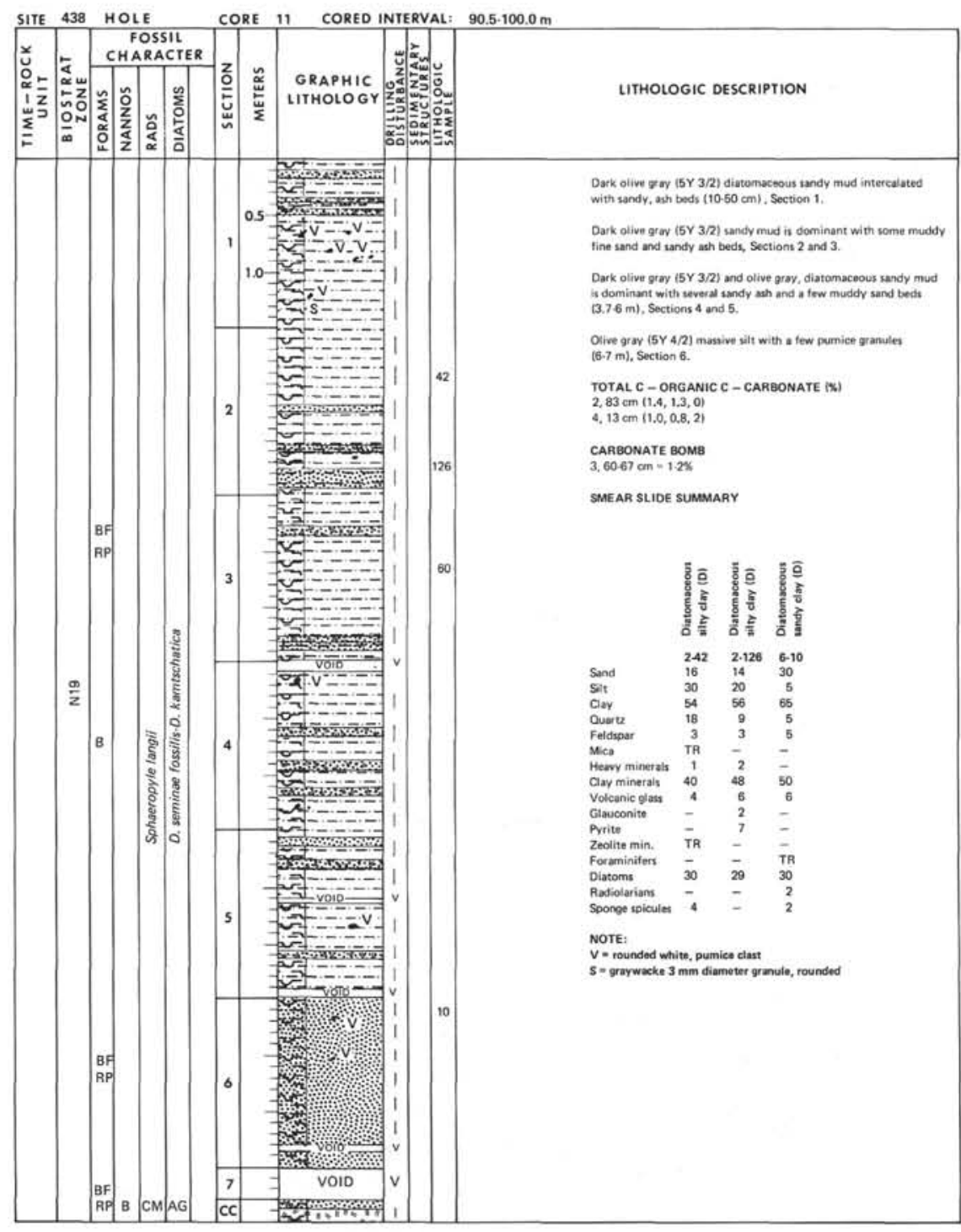

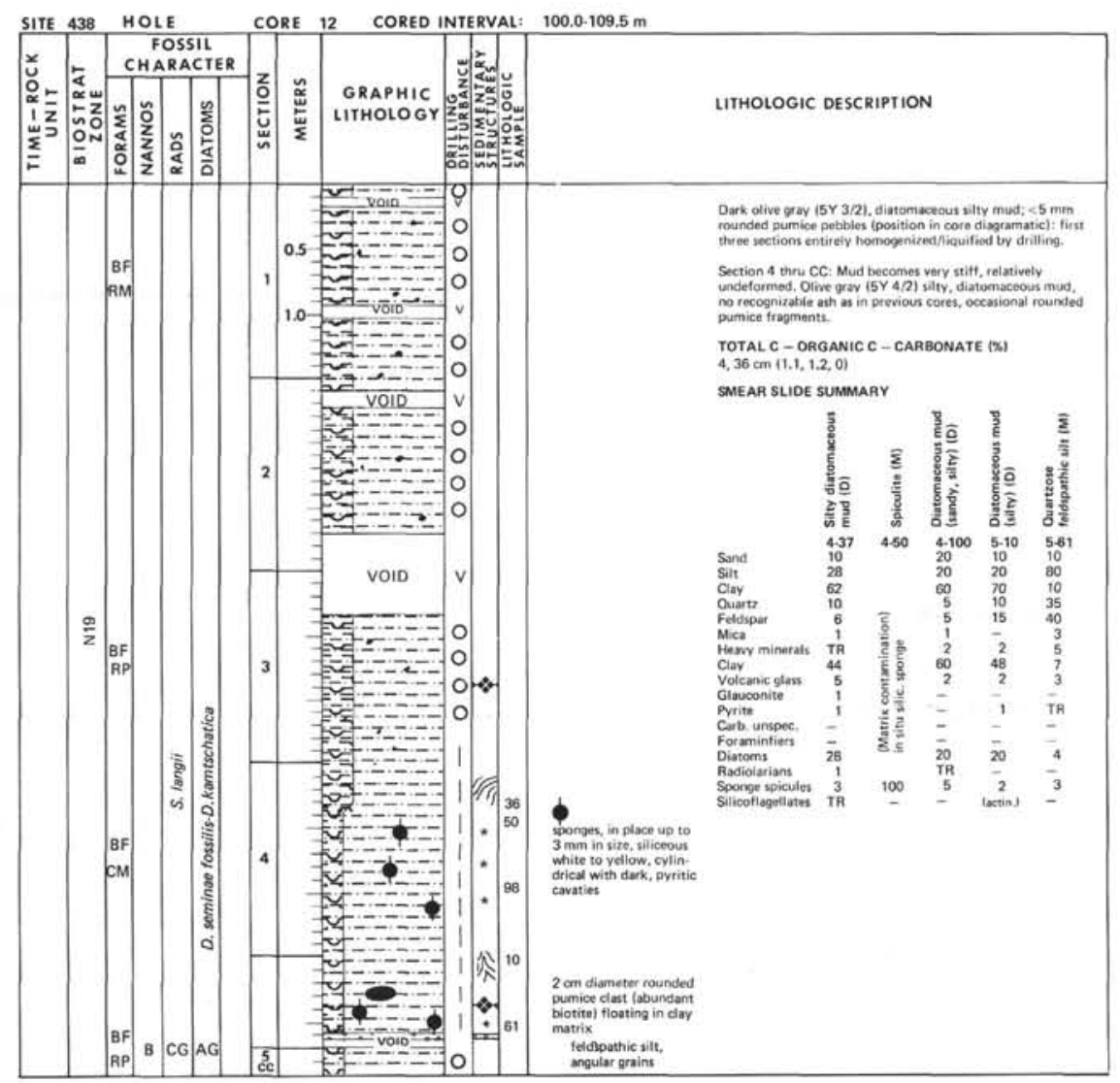



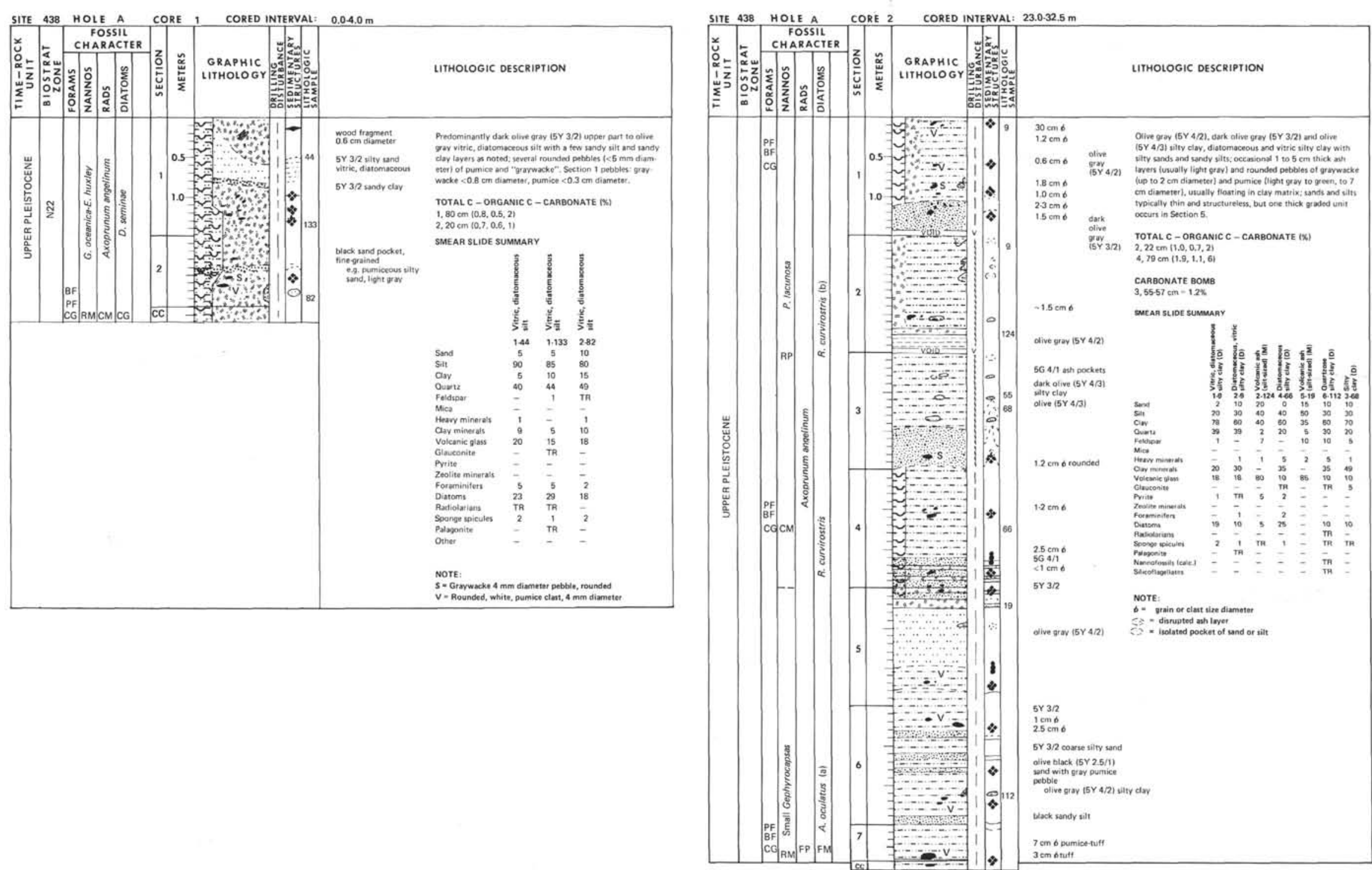

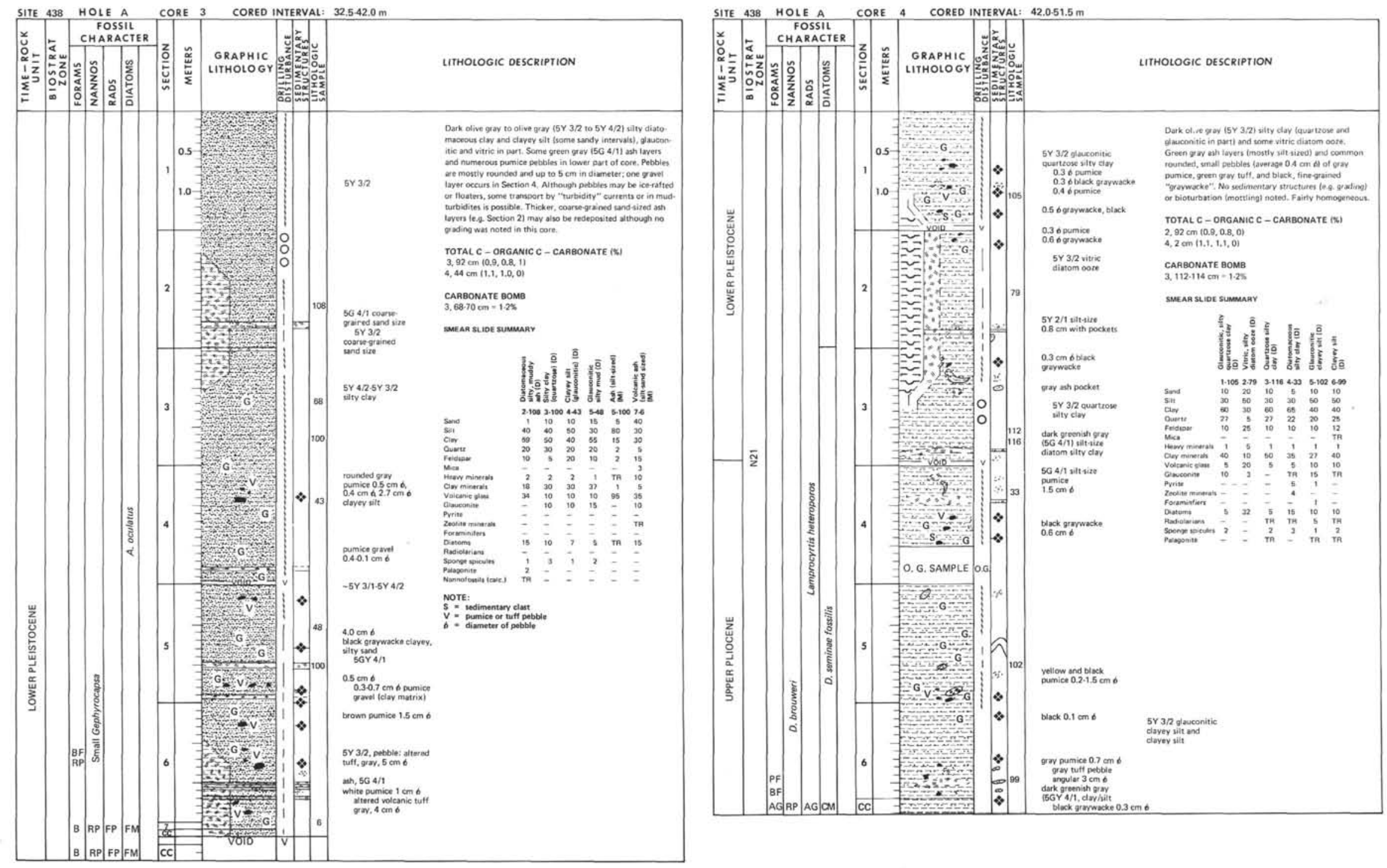

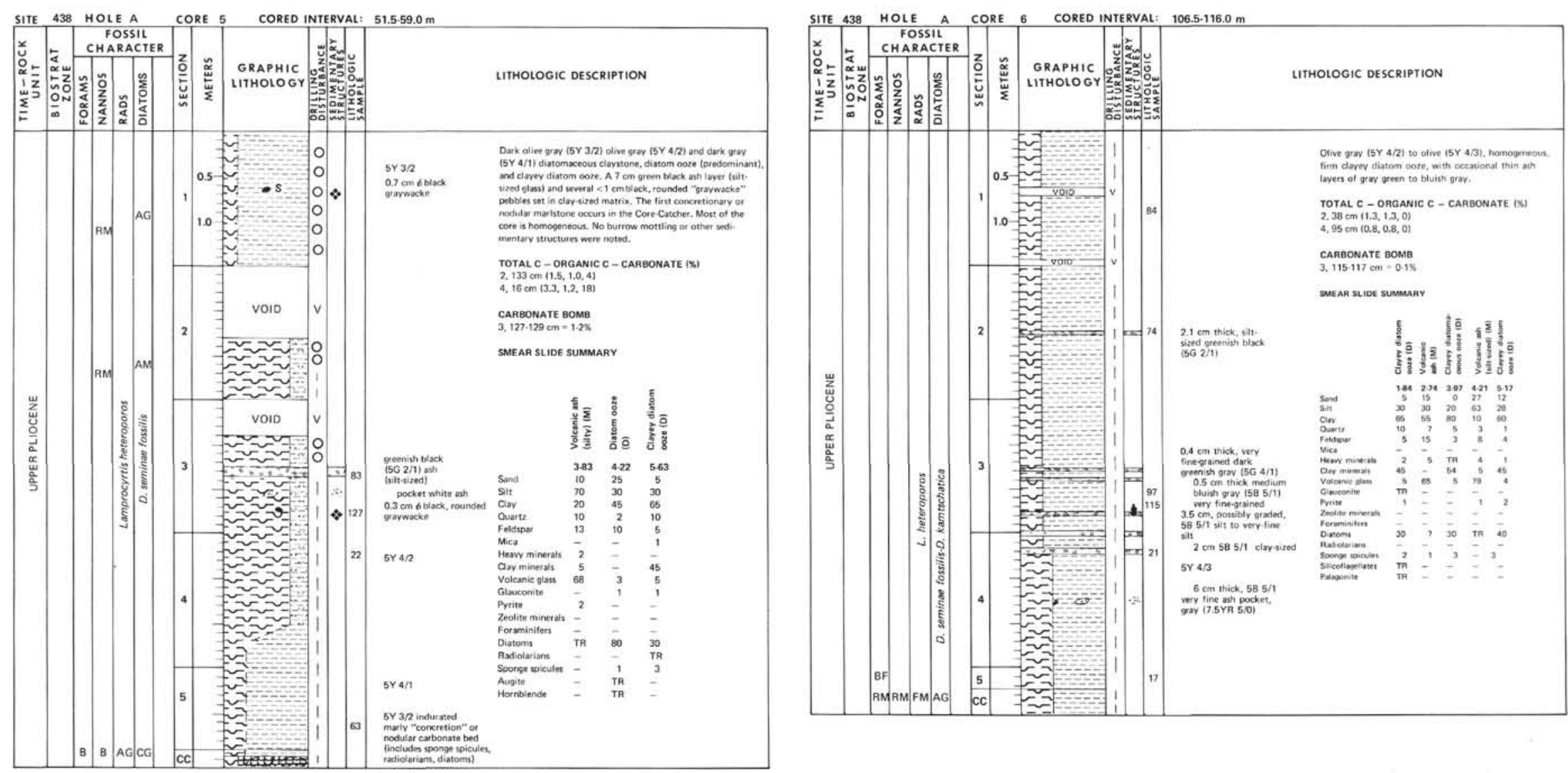


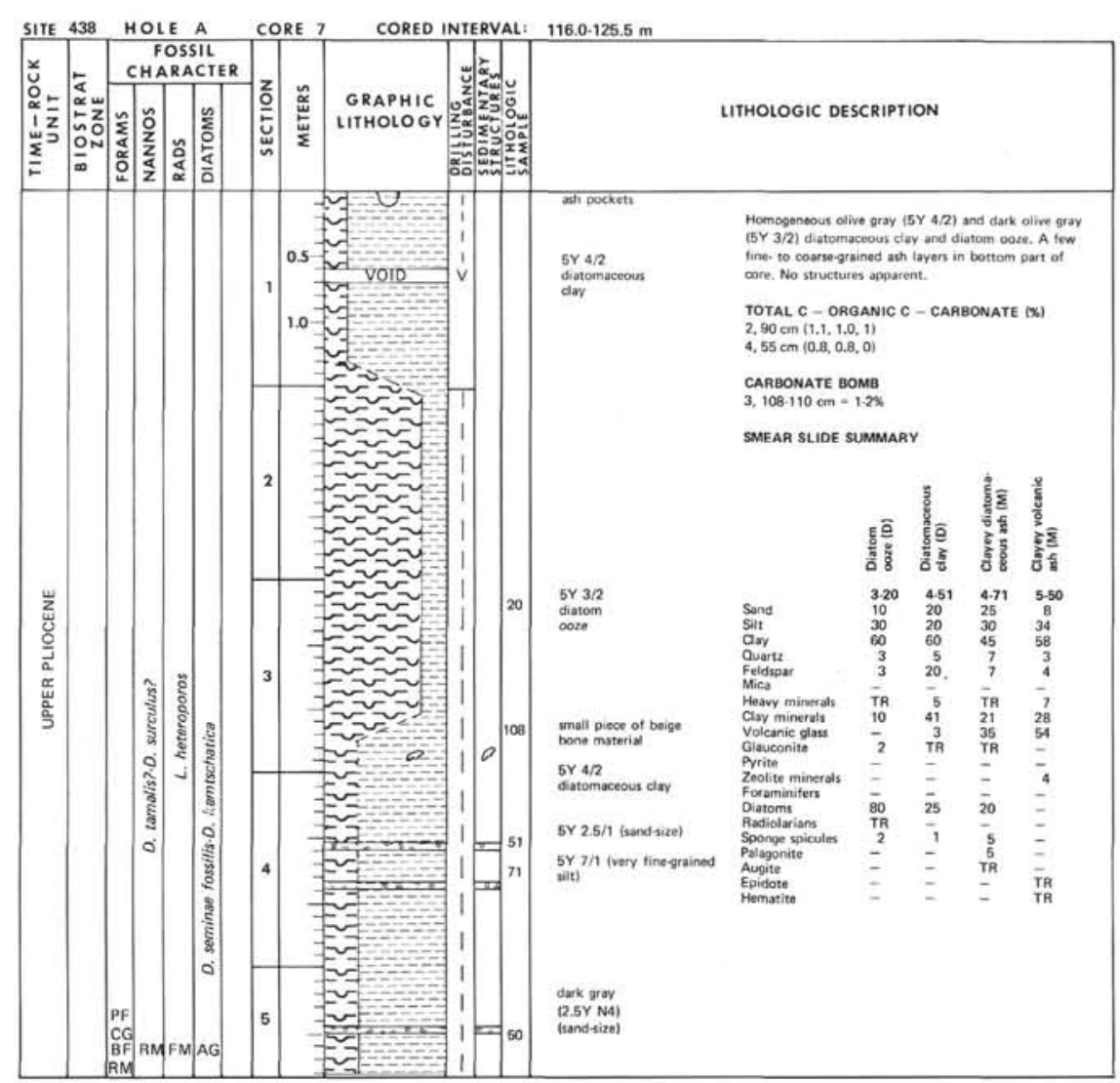

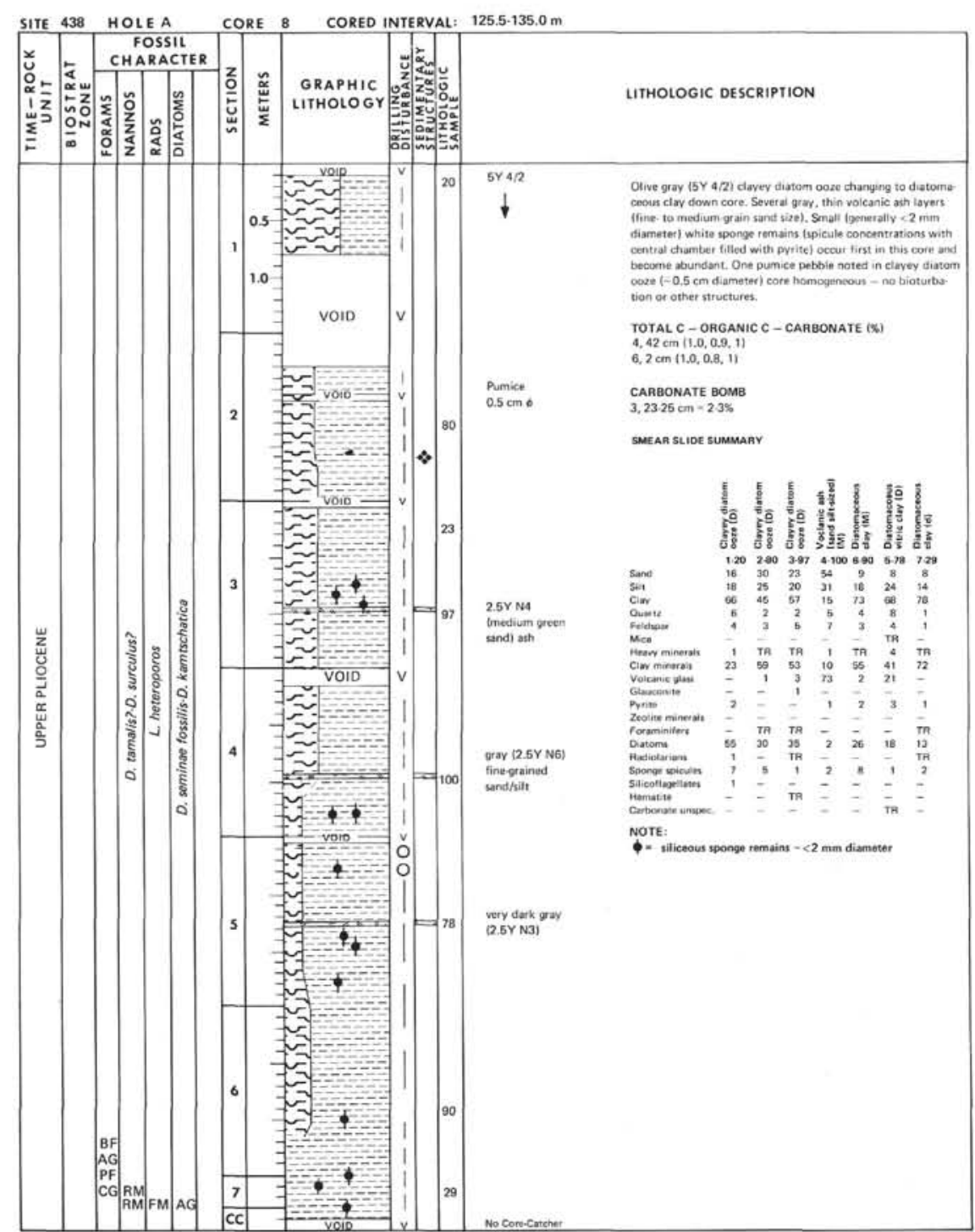




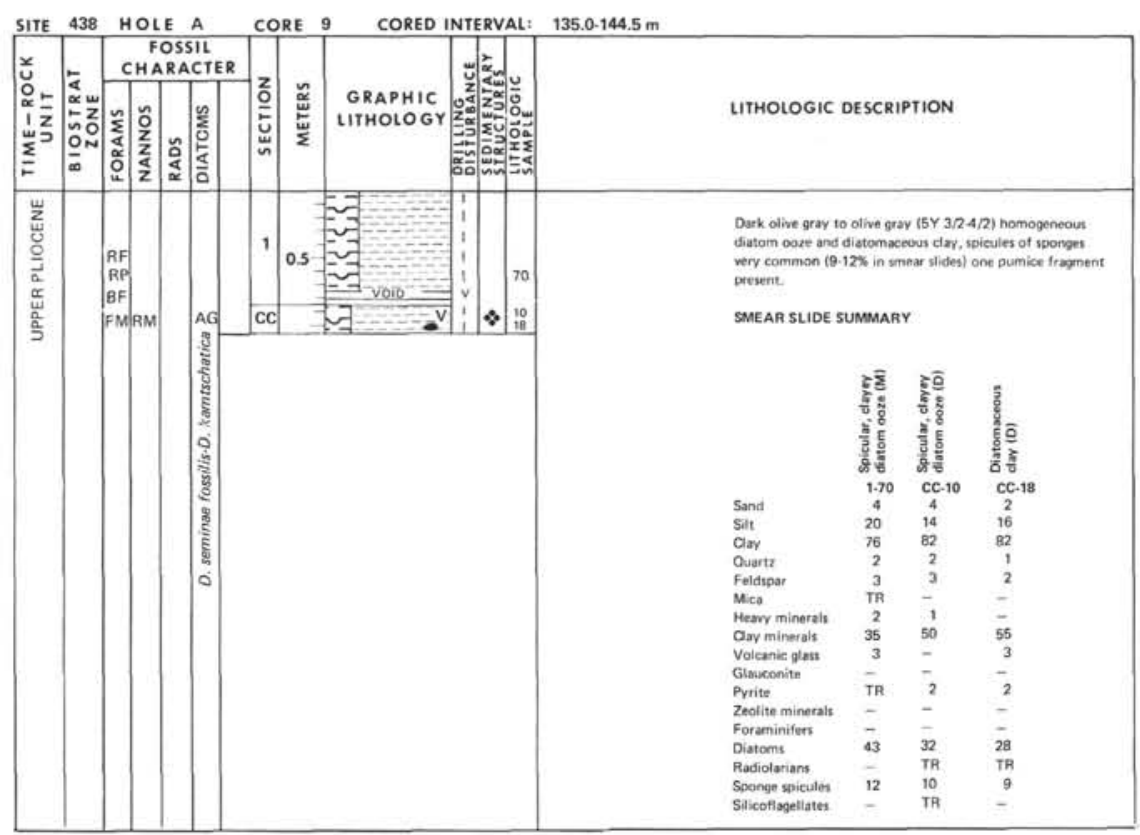

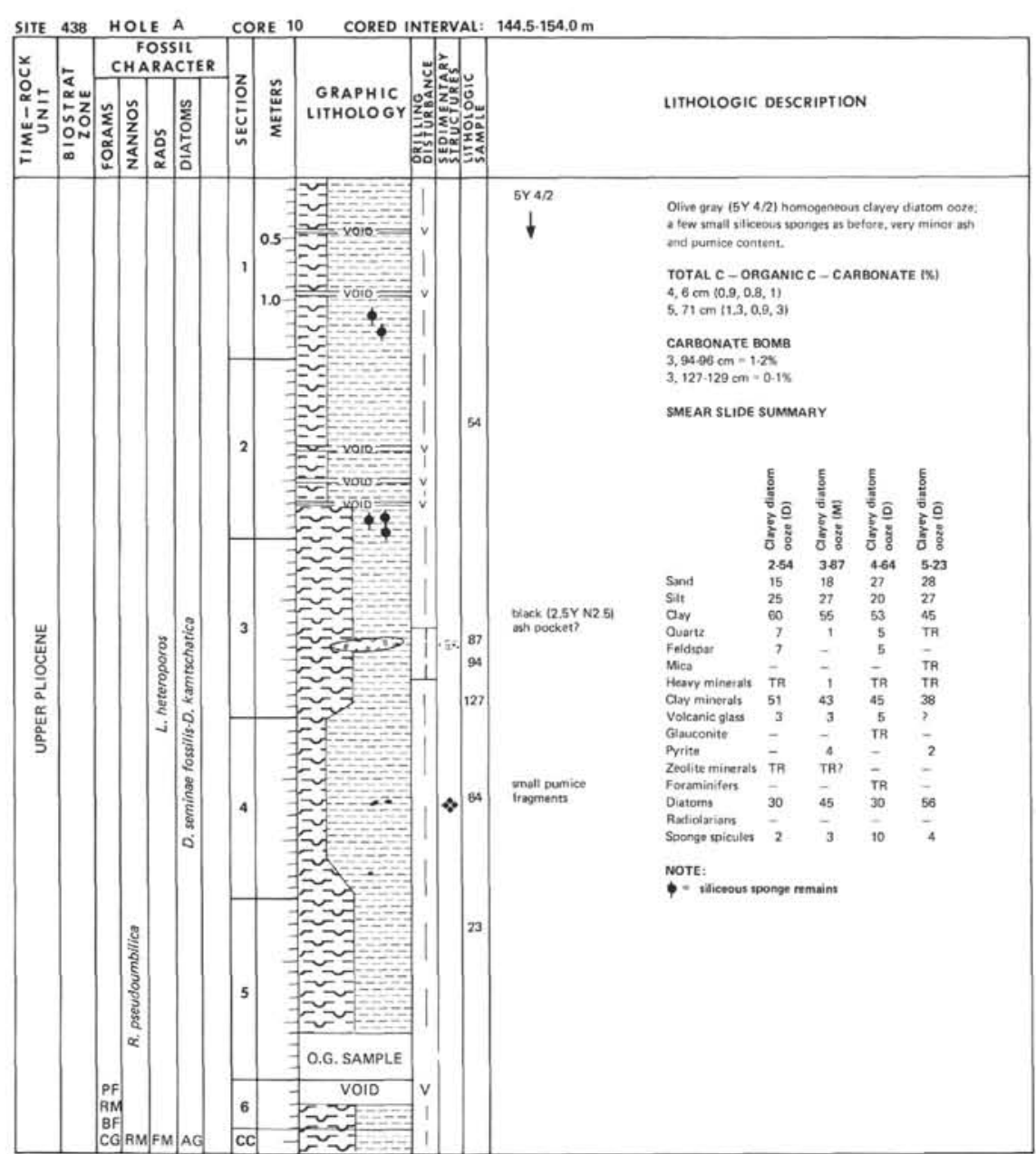



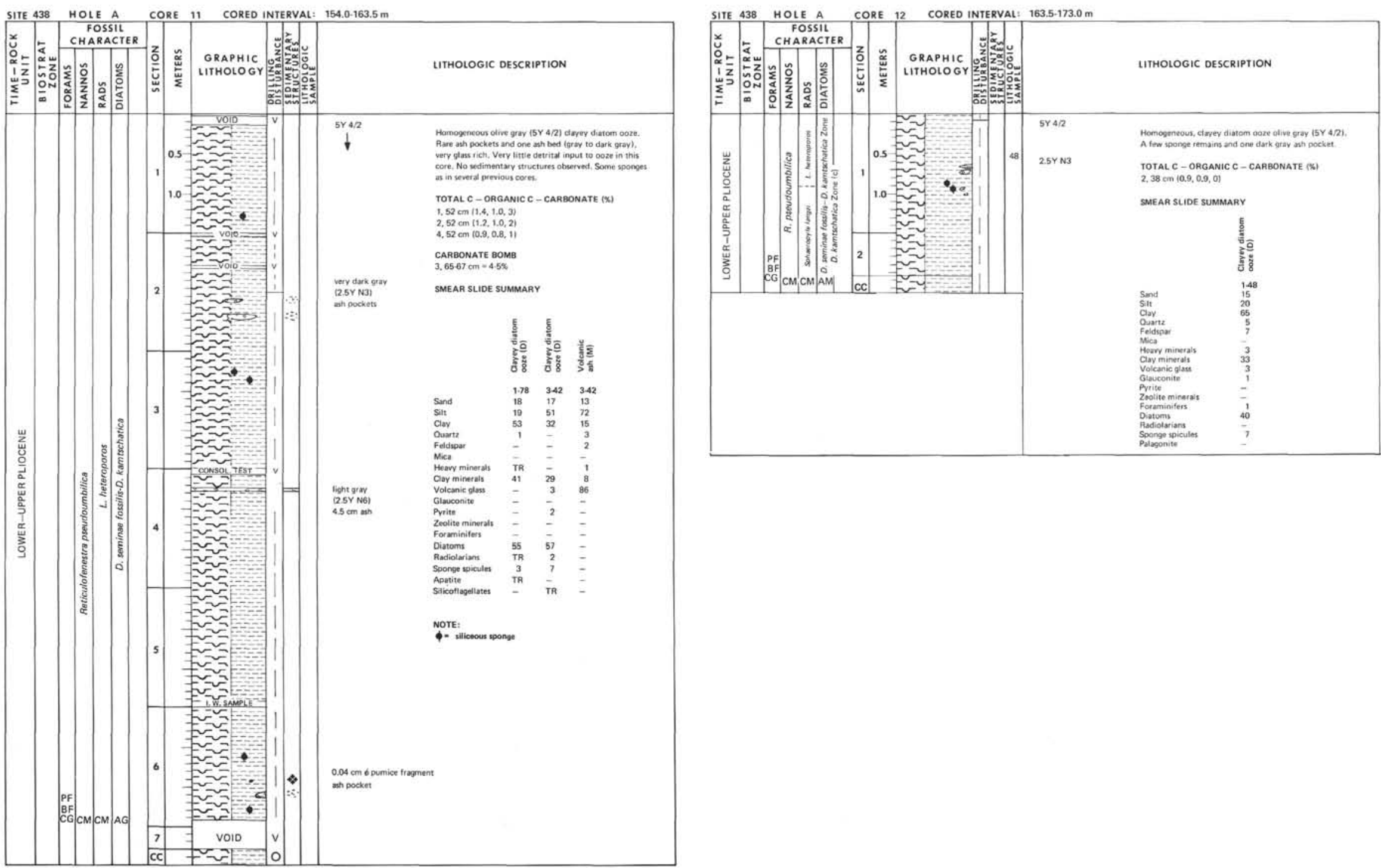


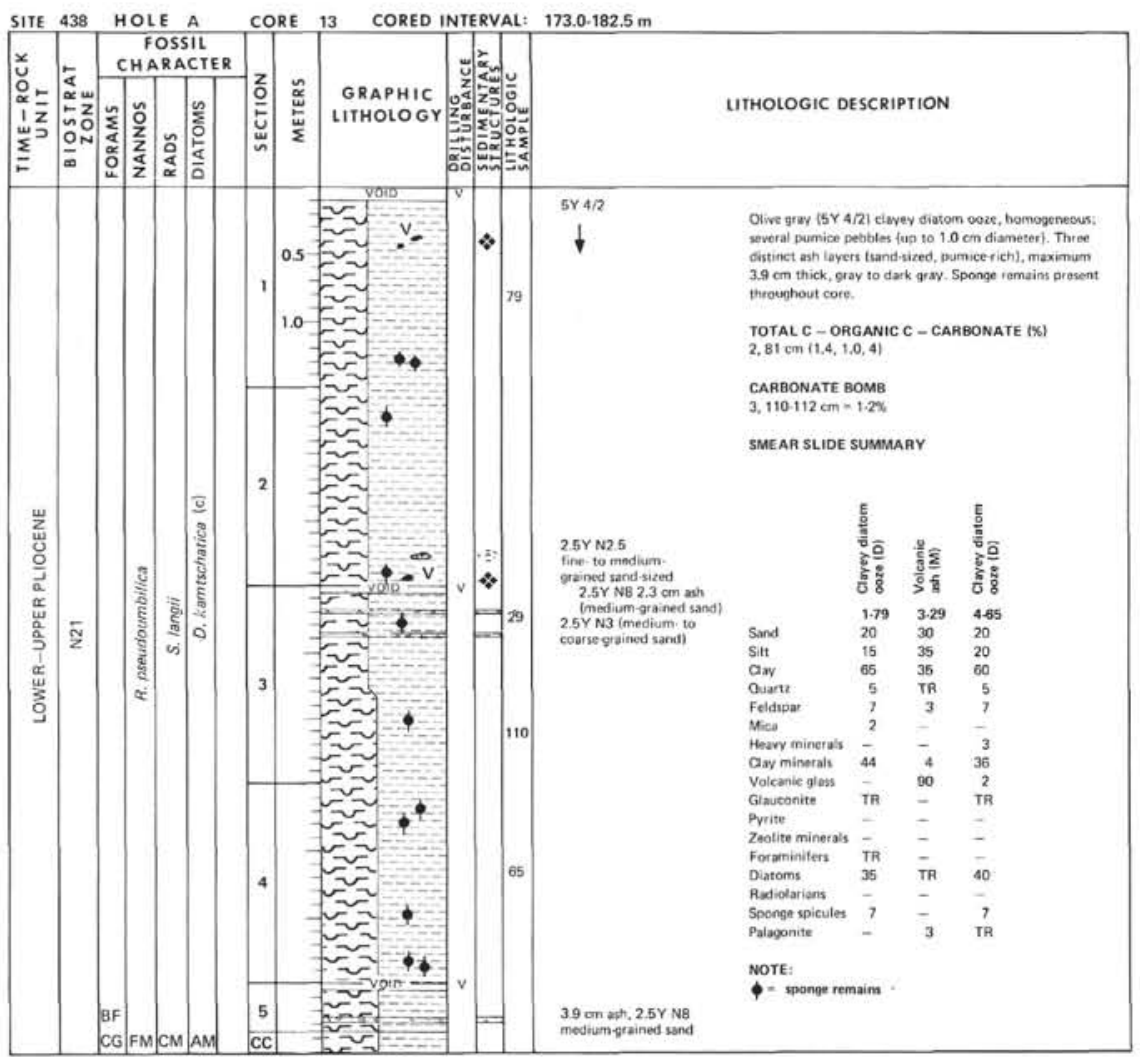

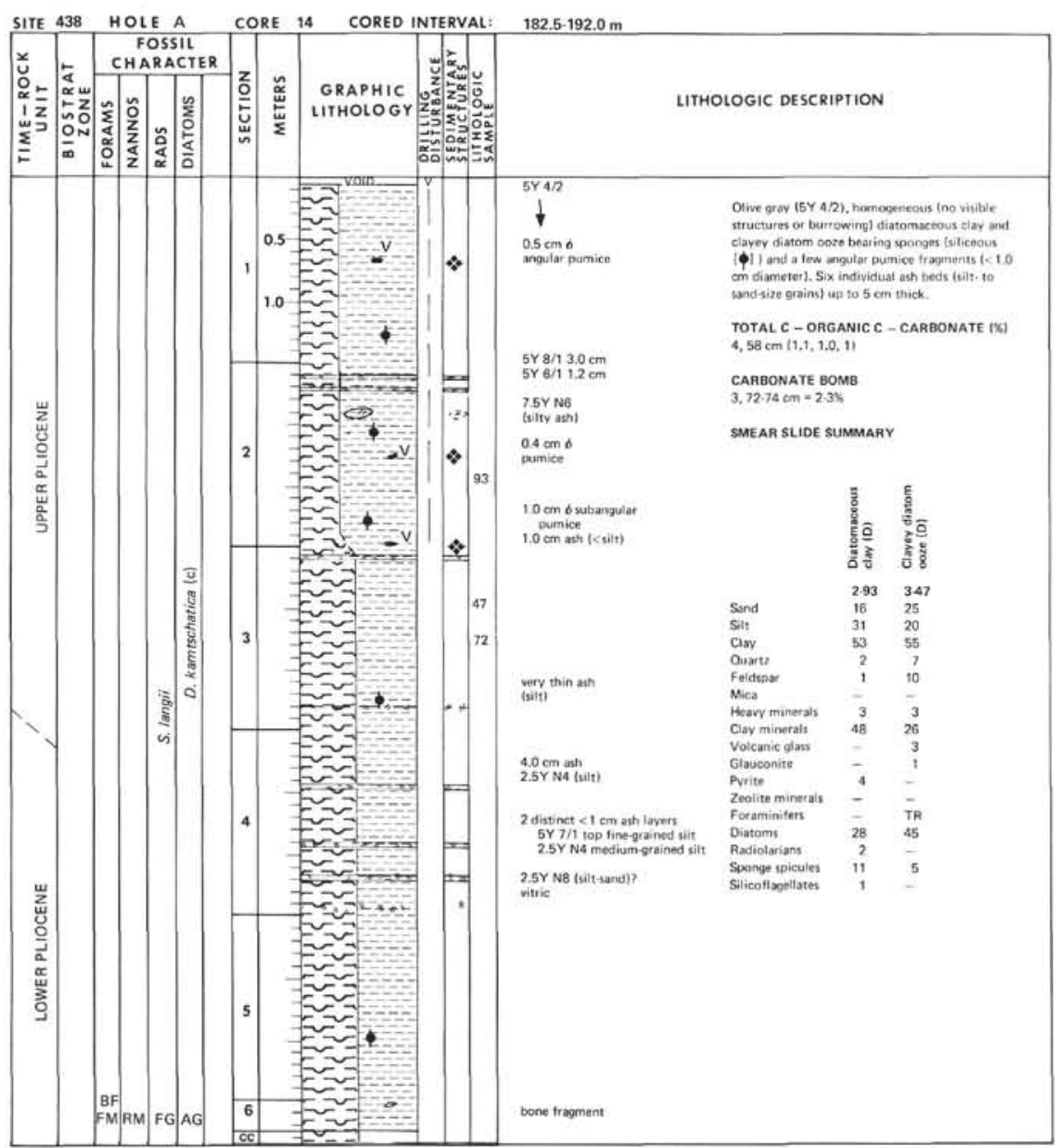



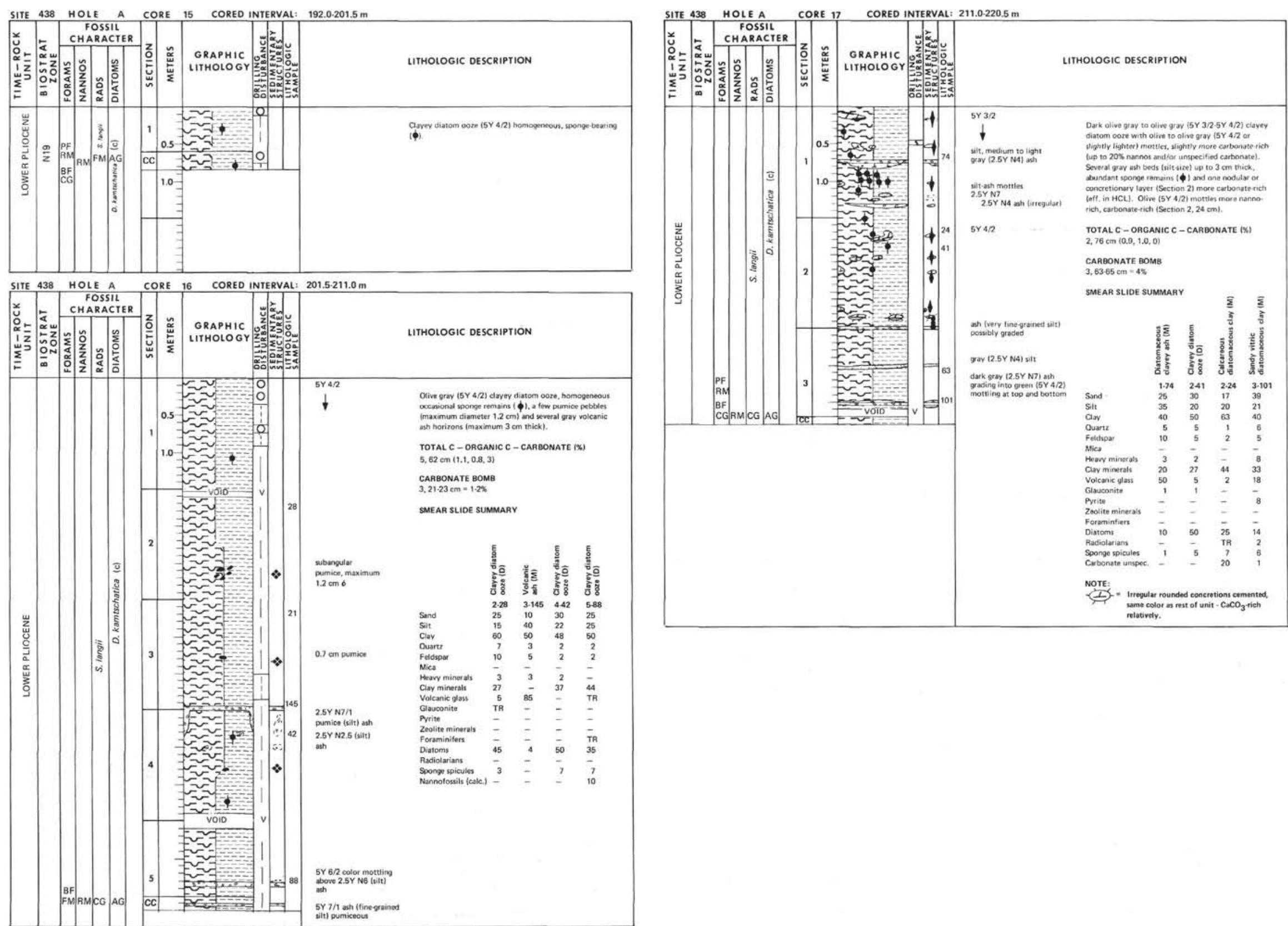

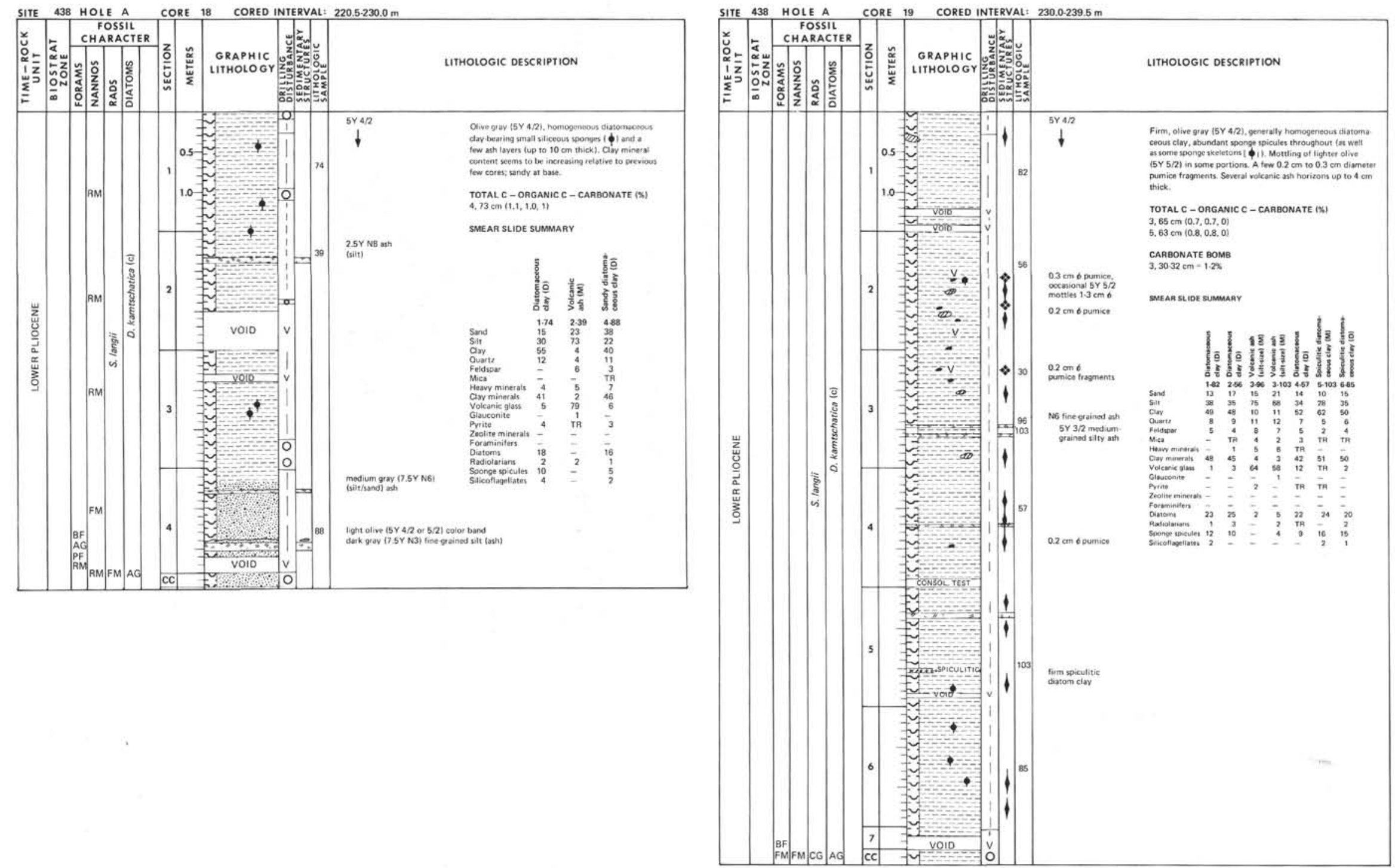

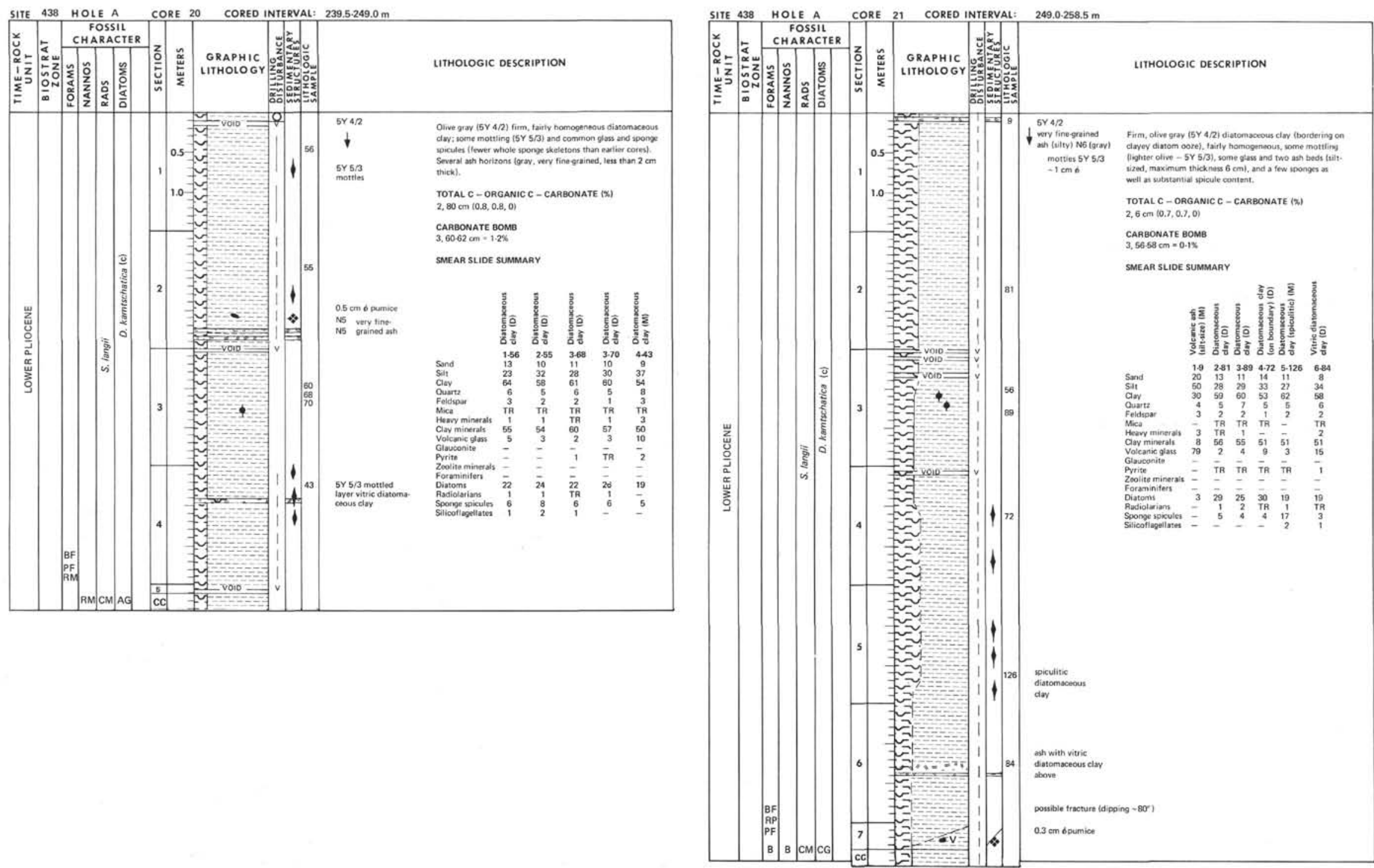


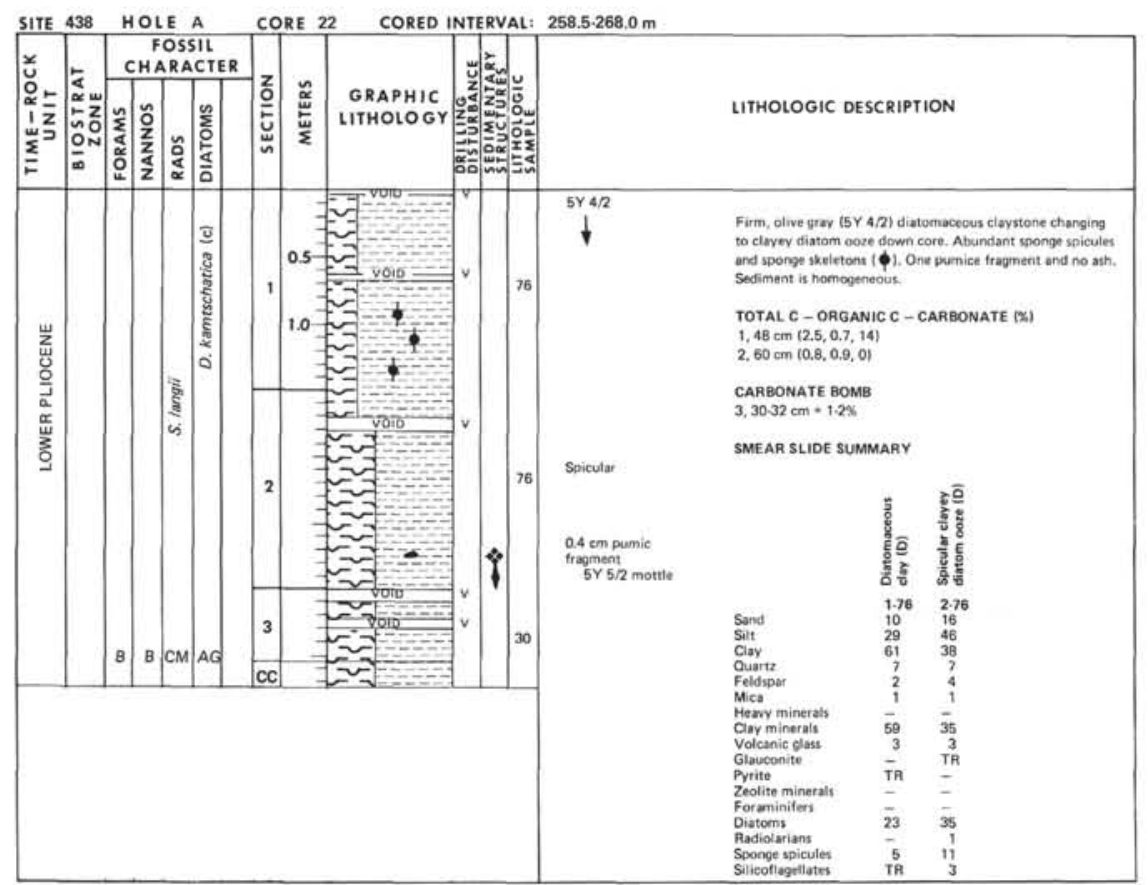

SITE 438 HOLE A CORE 23 CORED INTERVAL: $268.0 .277 .5 \mathrm{~m}$

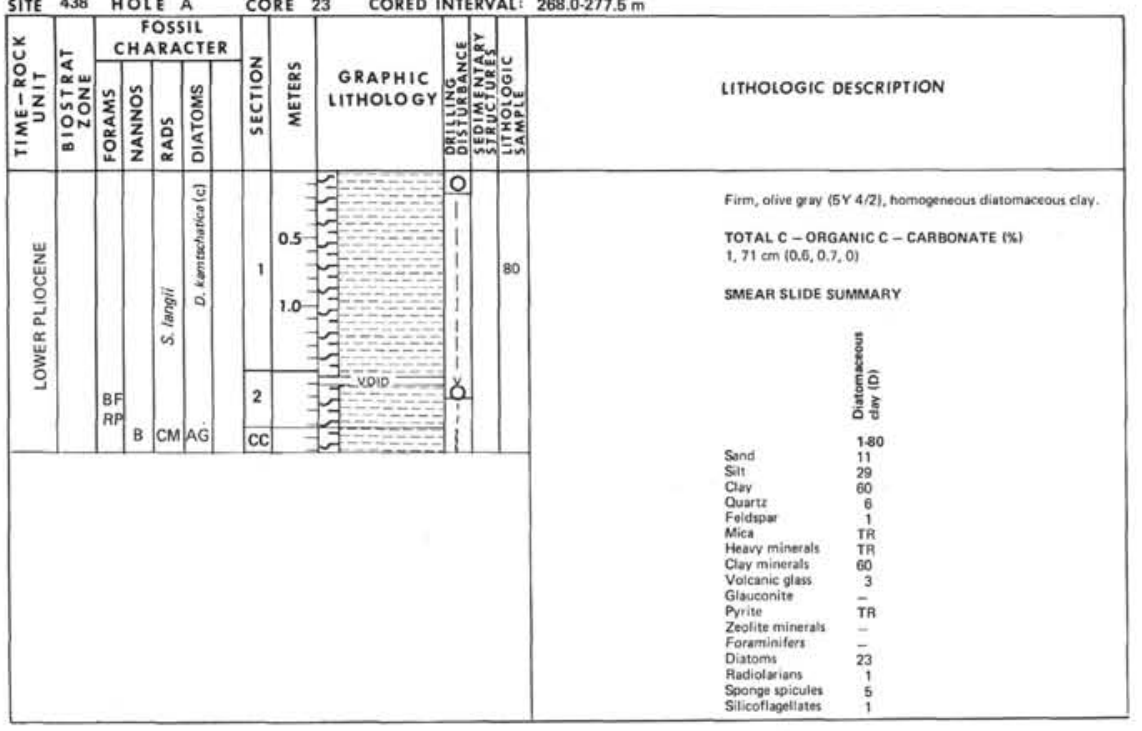

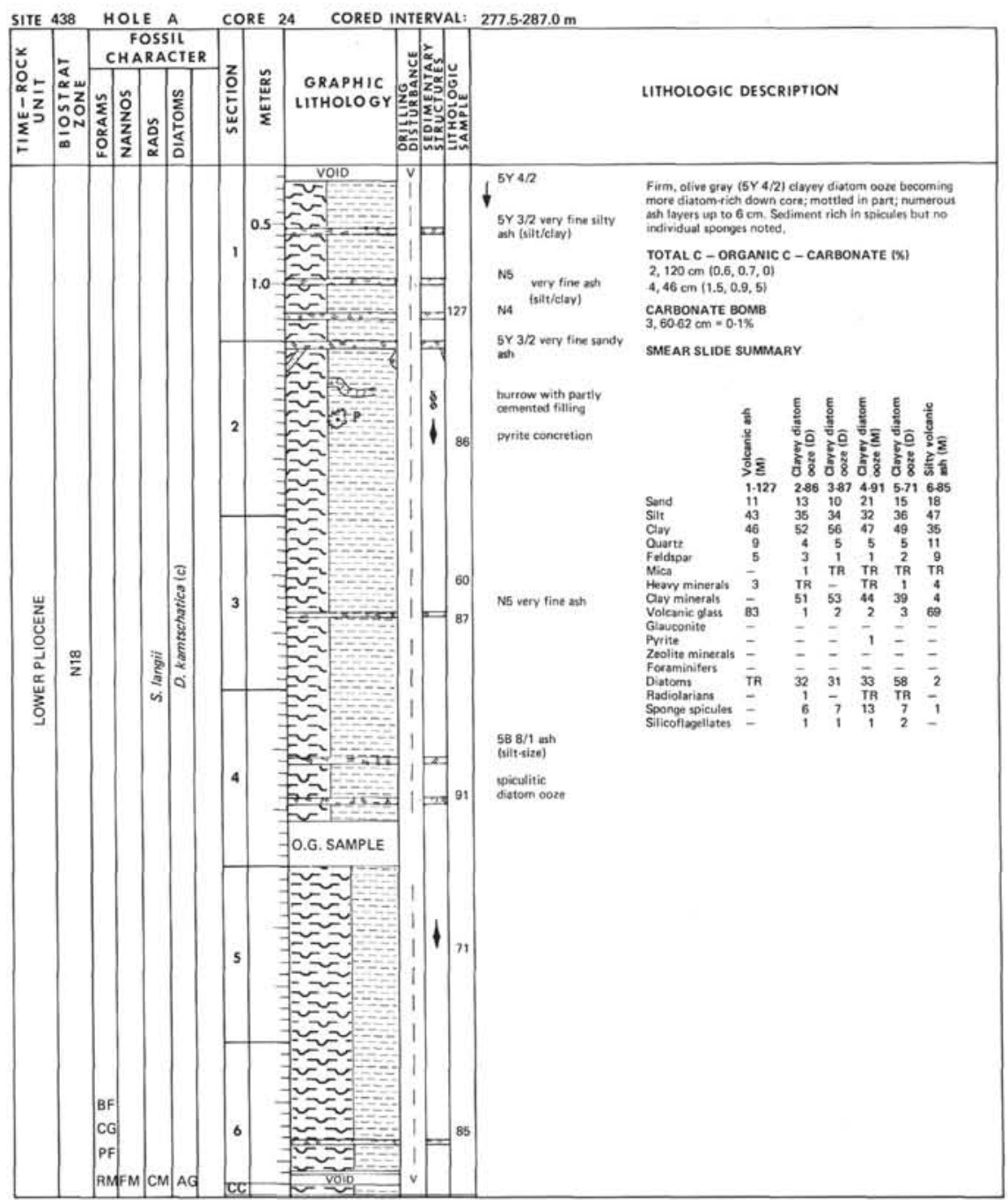



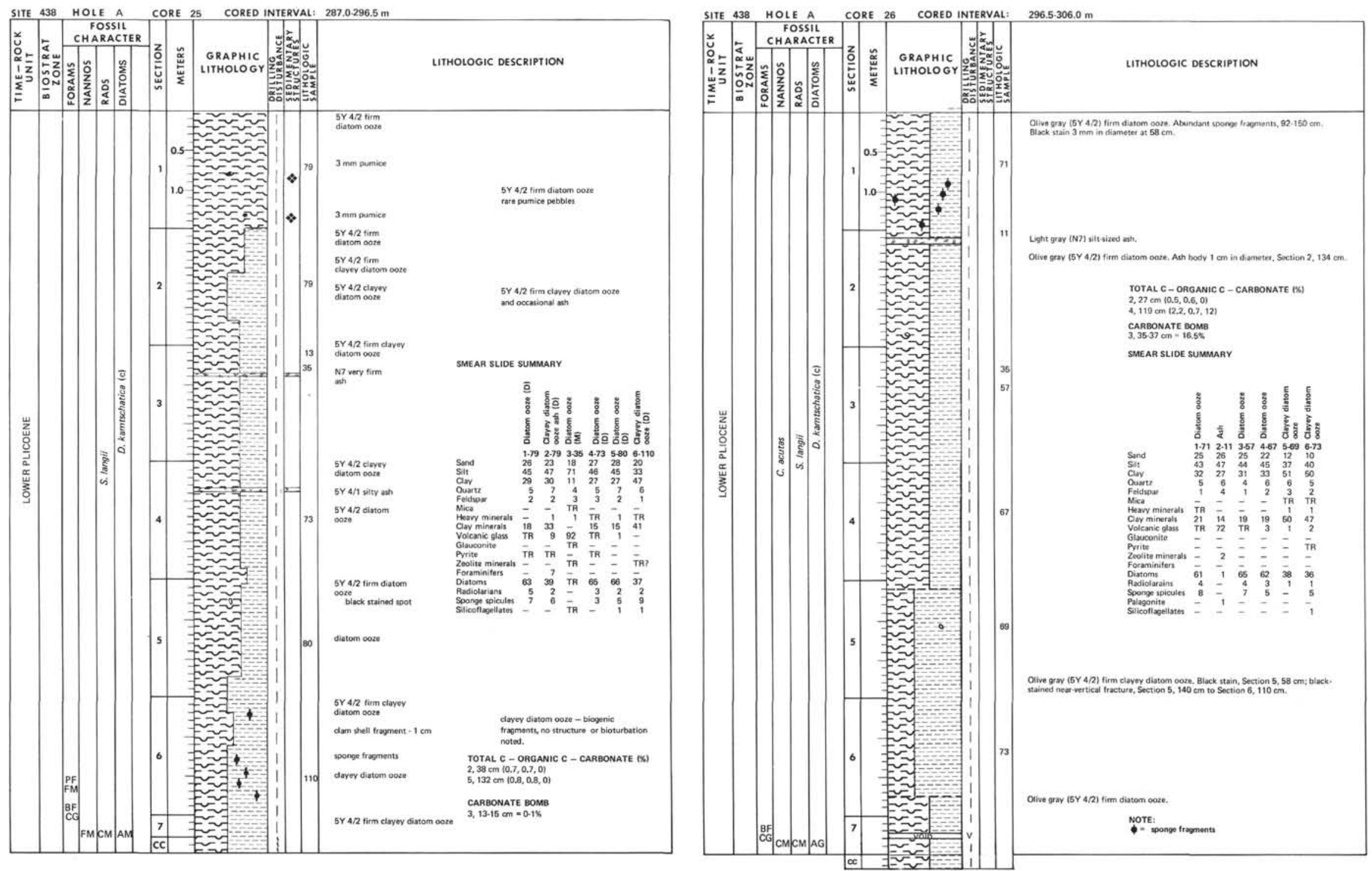

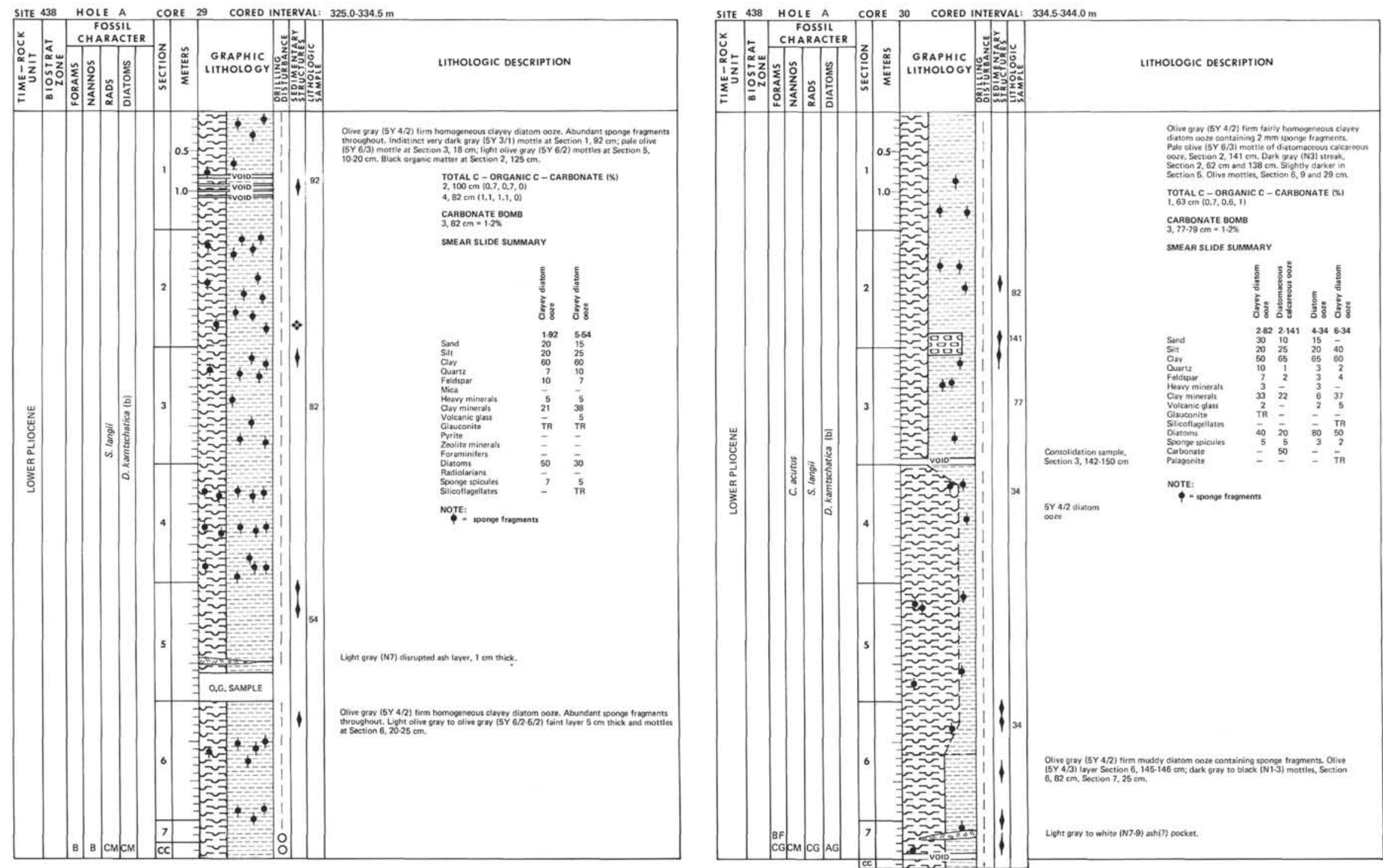


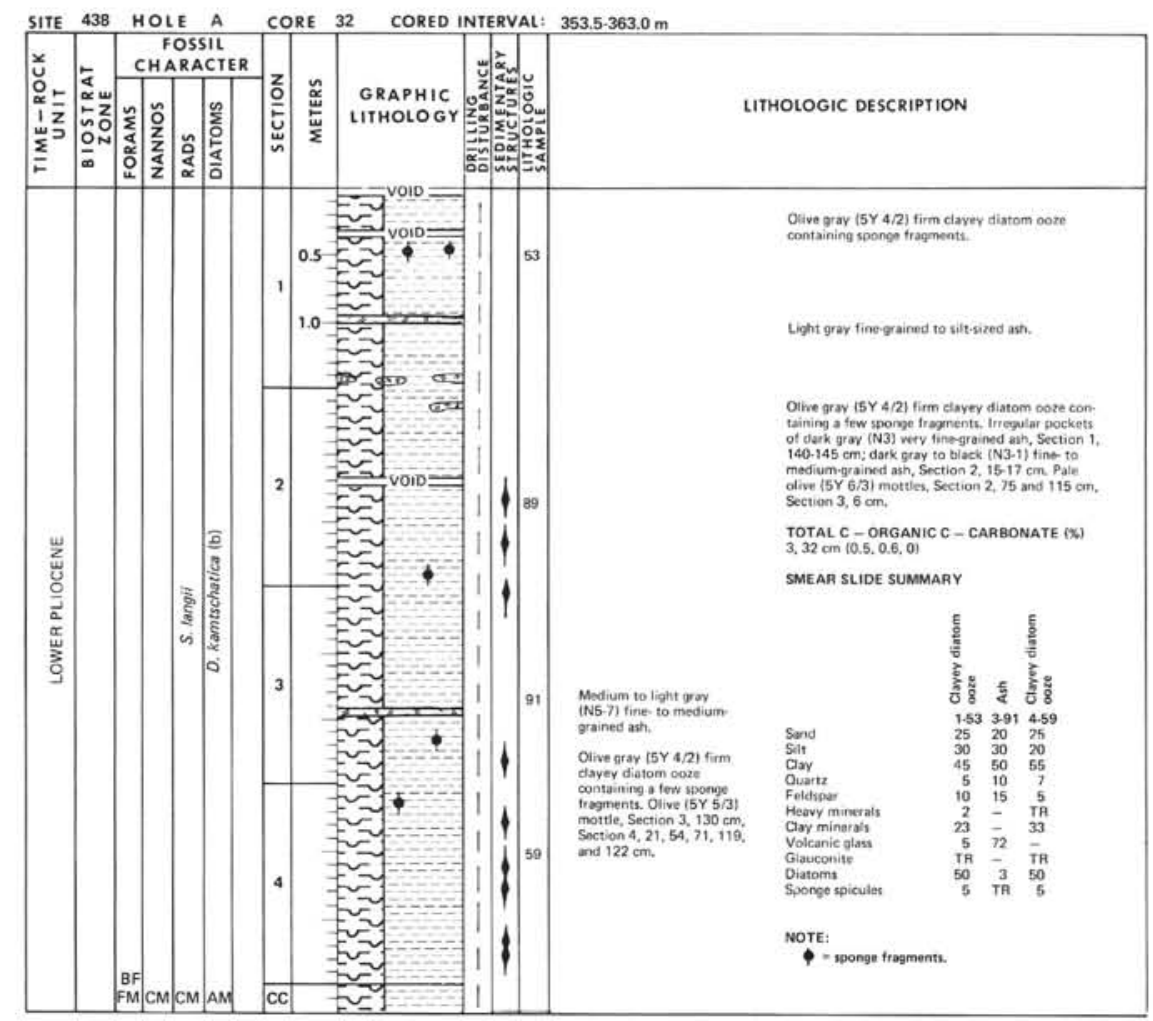



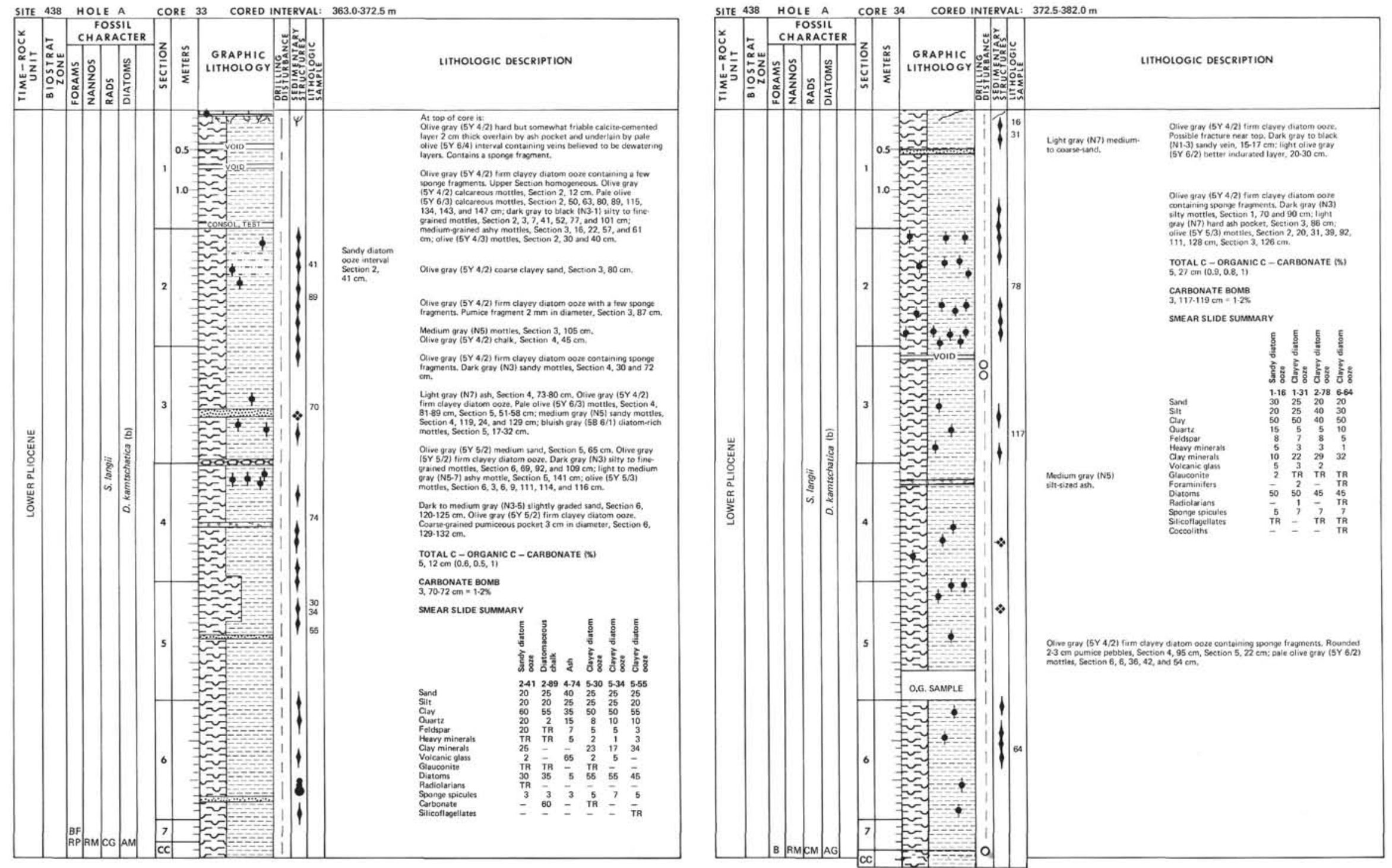

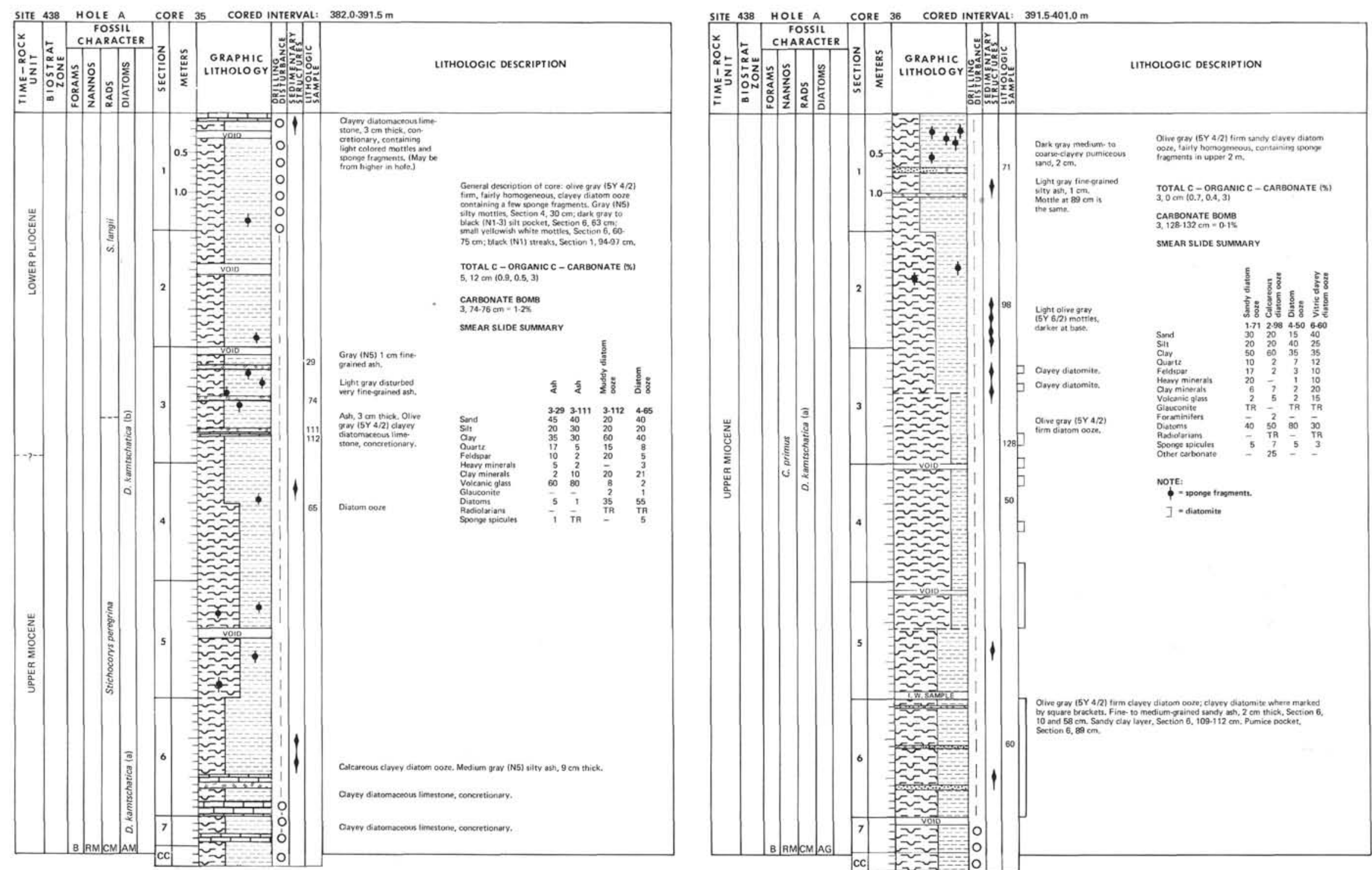

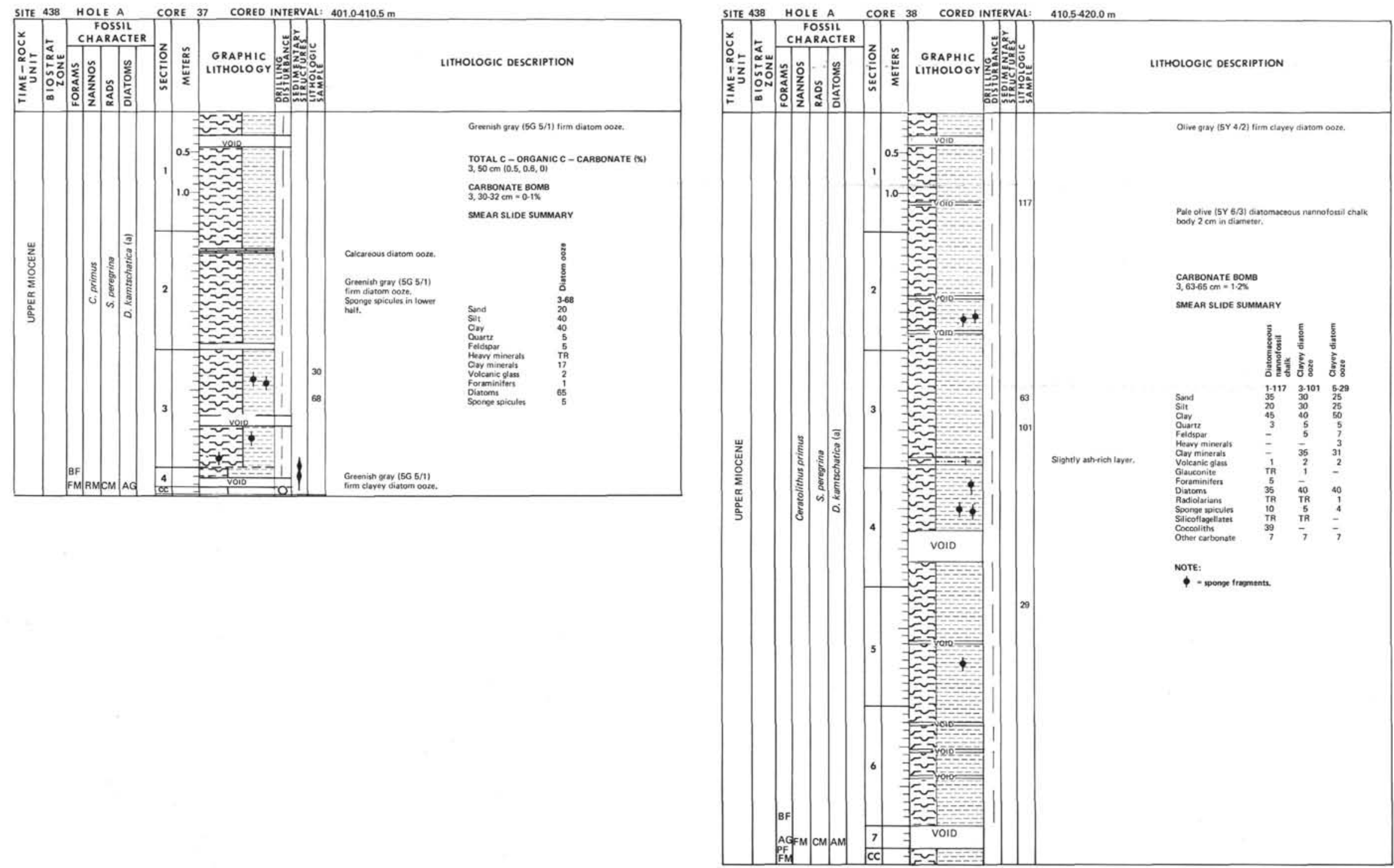


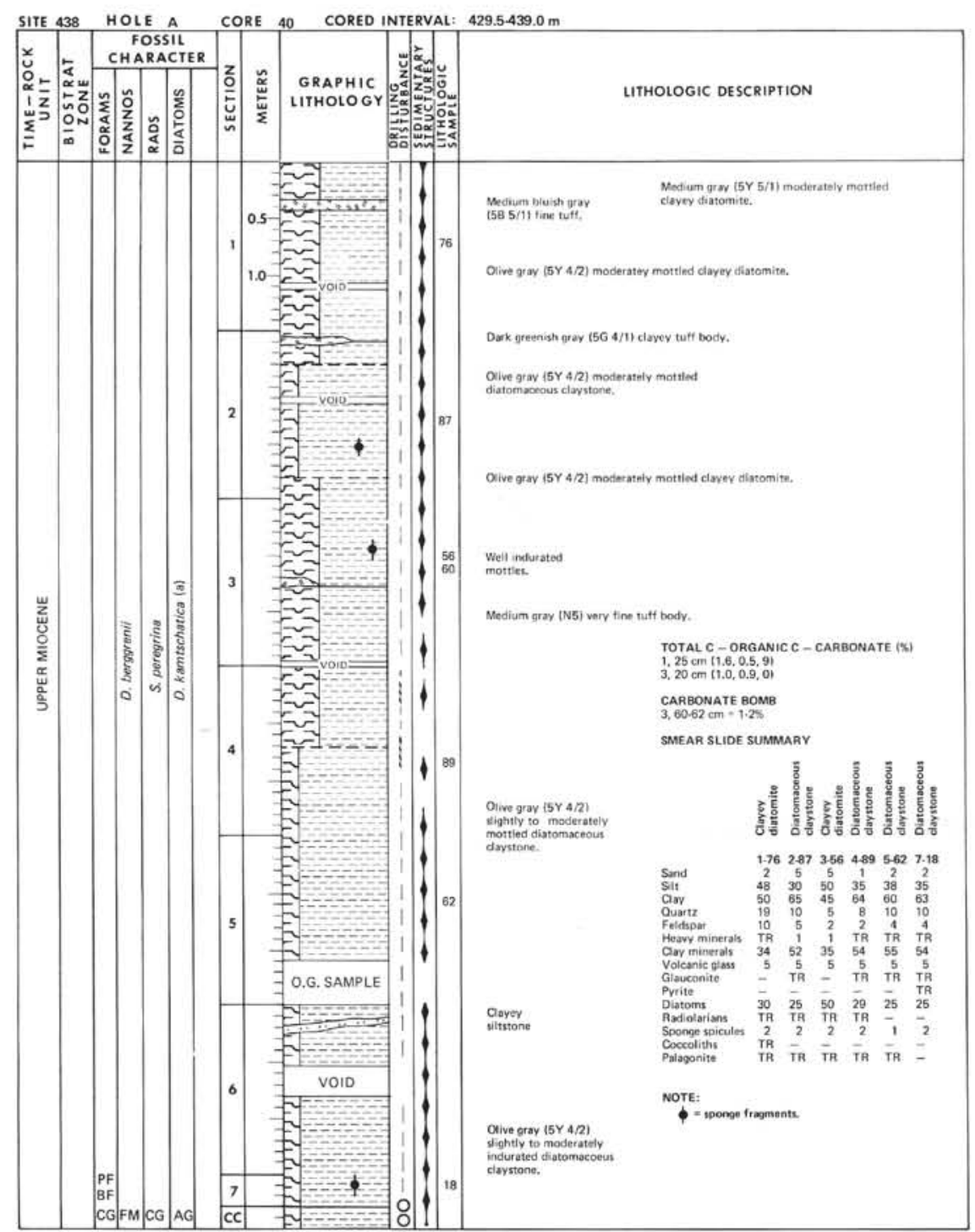




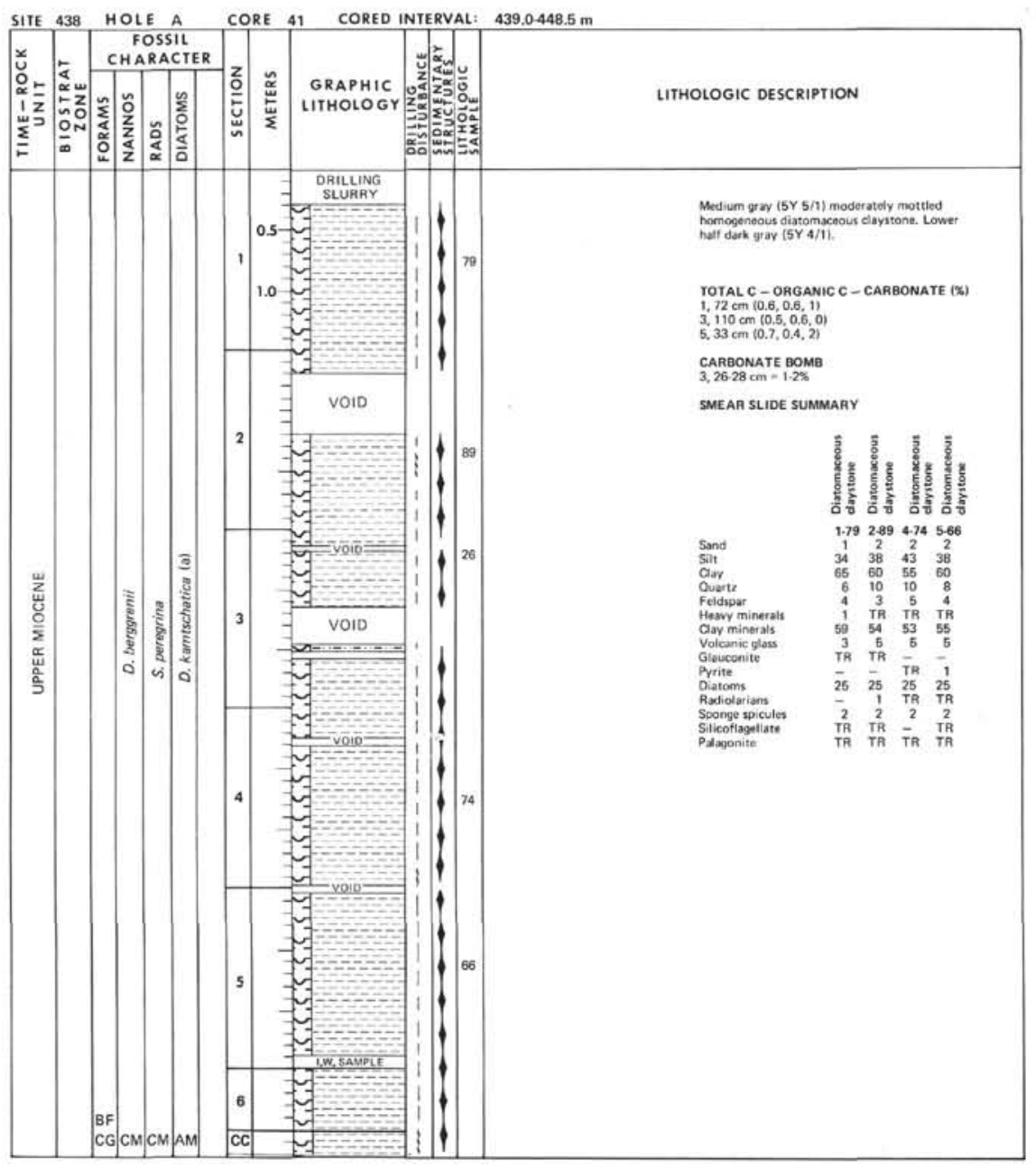

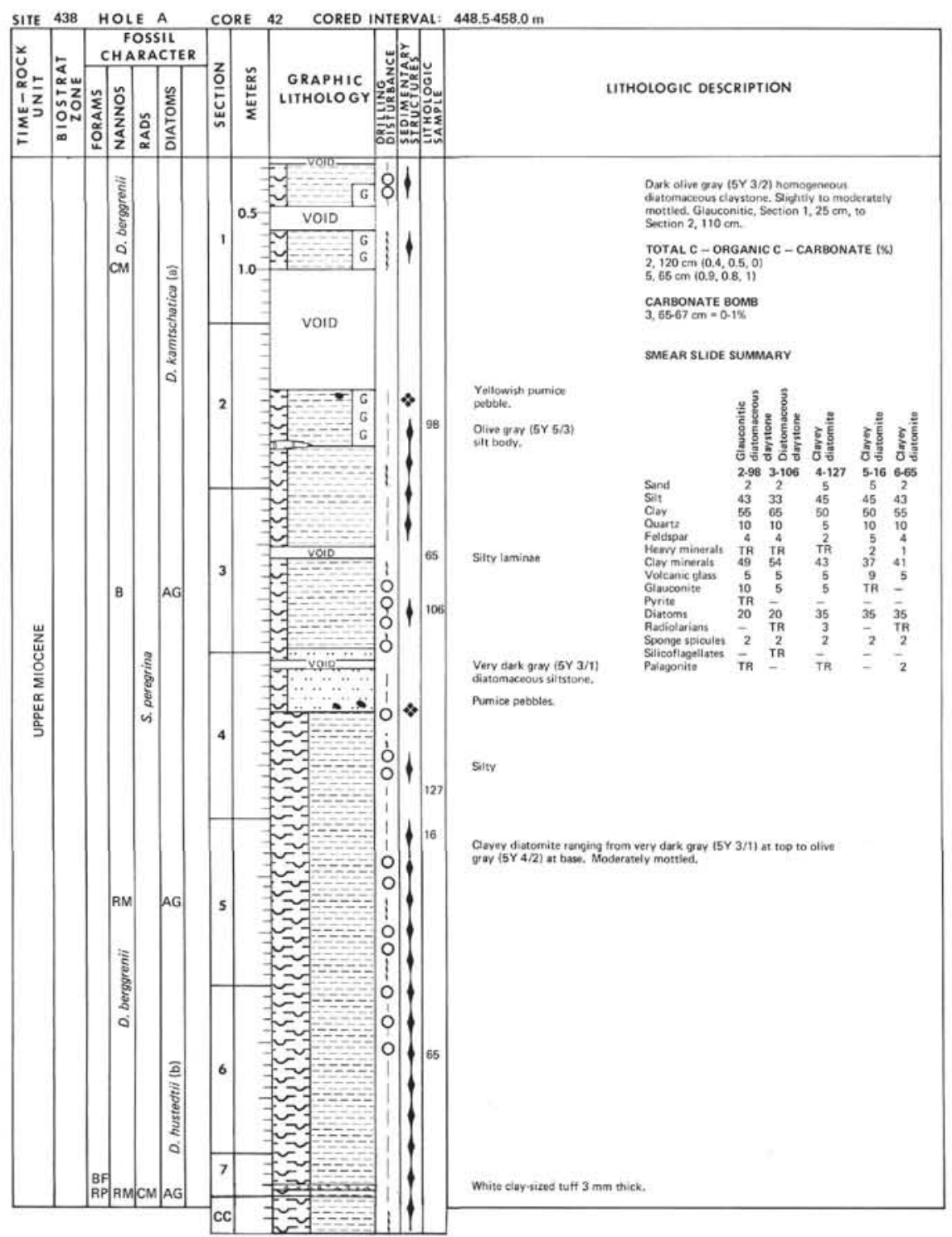



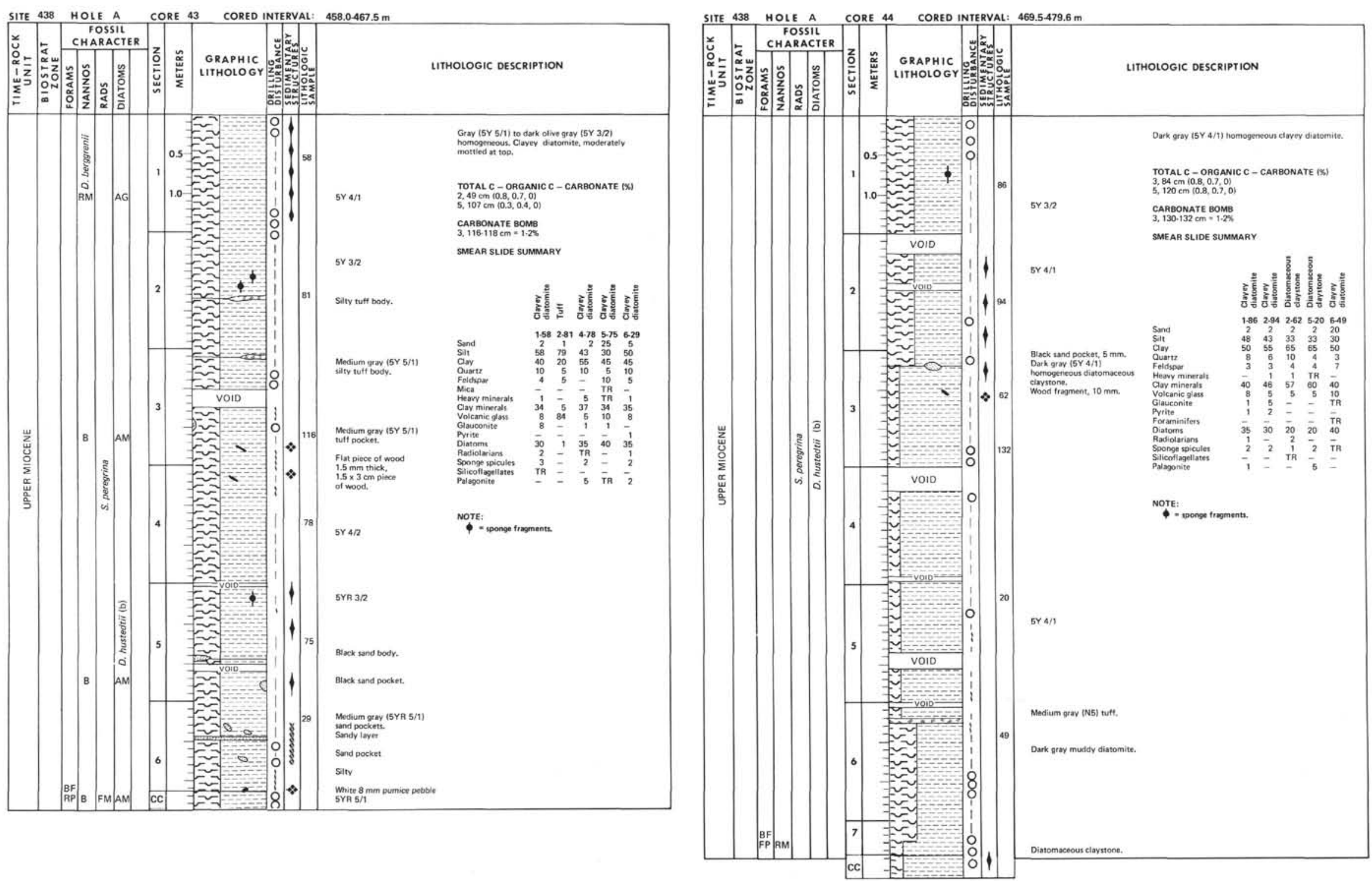

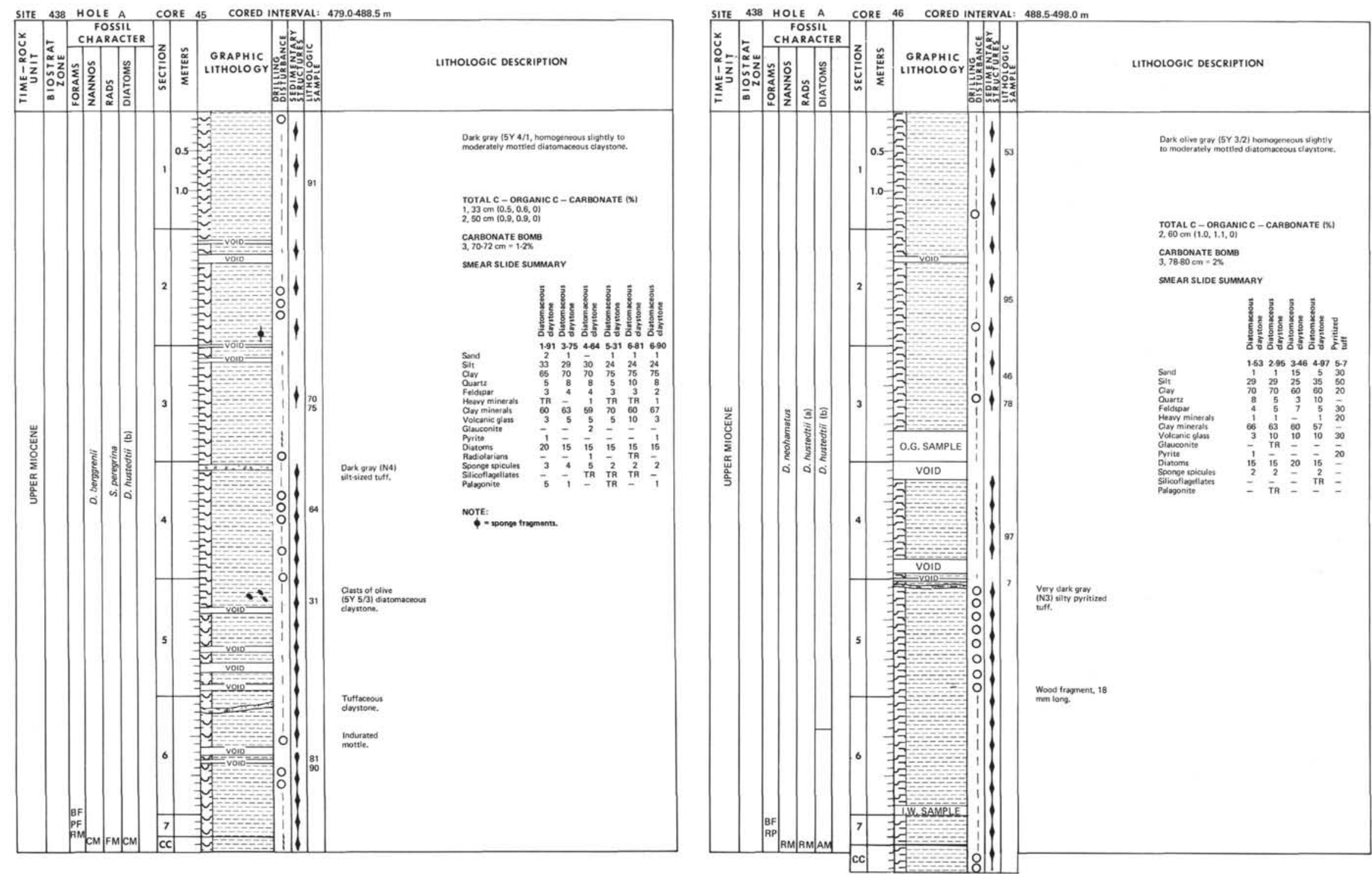
SITE 438 HOLE A CORE 48 CORED INTERVAL: $507.5517 .0 \mathrm{~m}$

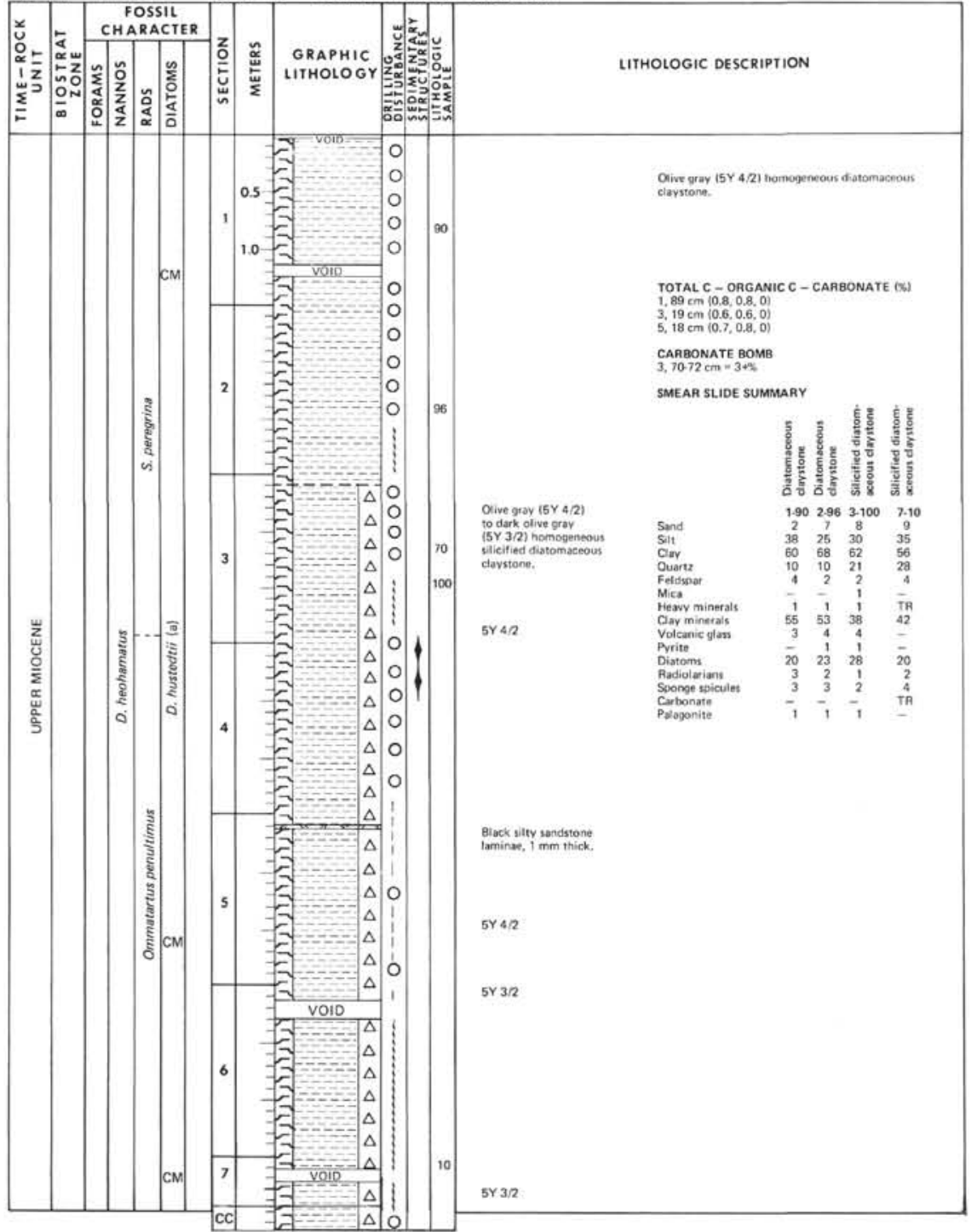


SITE 438 HOLE A CORE 49 CORED INTERVAL: $517.0 .526 .5 \mathrm{~m}$

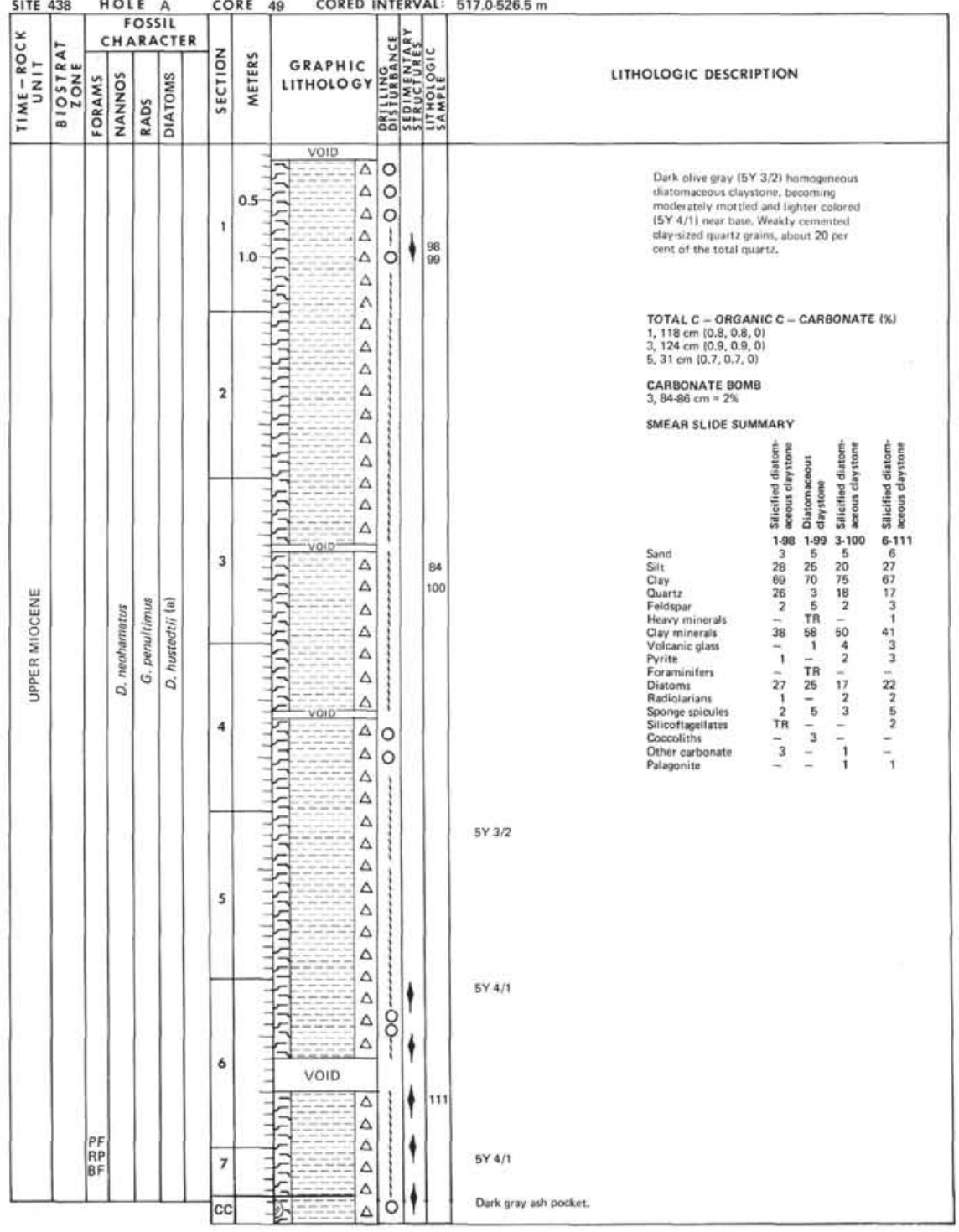

SITE 438 HOLE A CORE 50 CORED INTERVAL: $526.5536 .0 \mathrm{~m}$

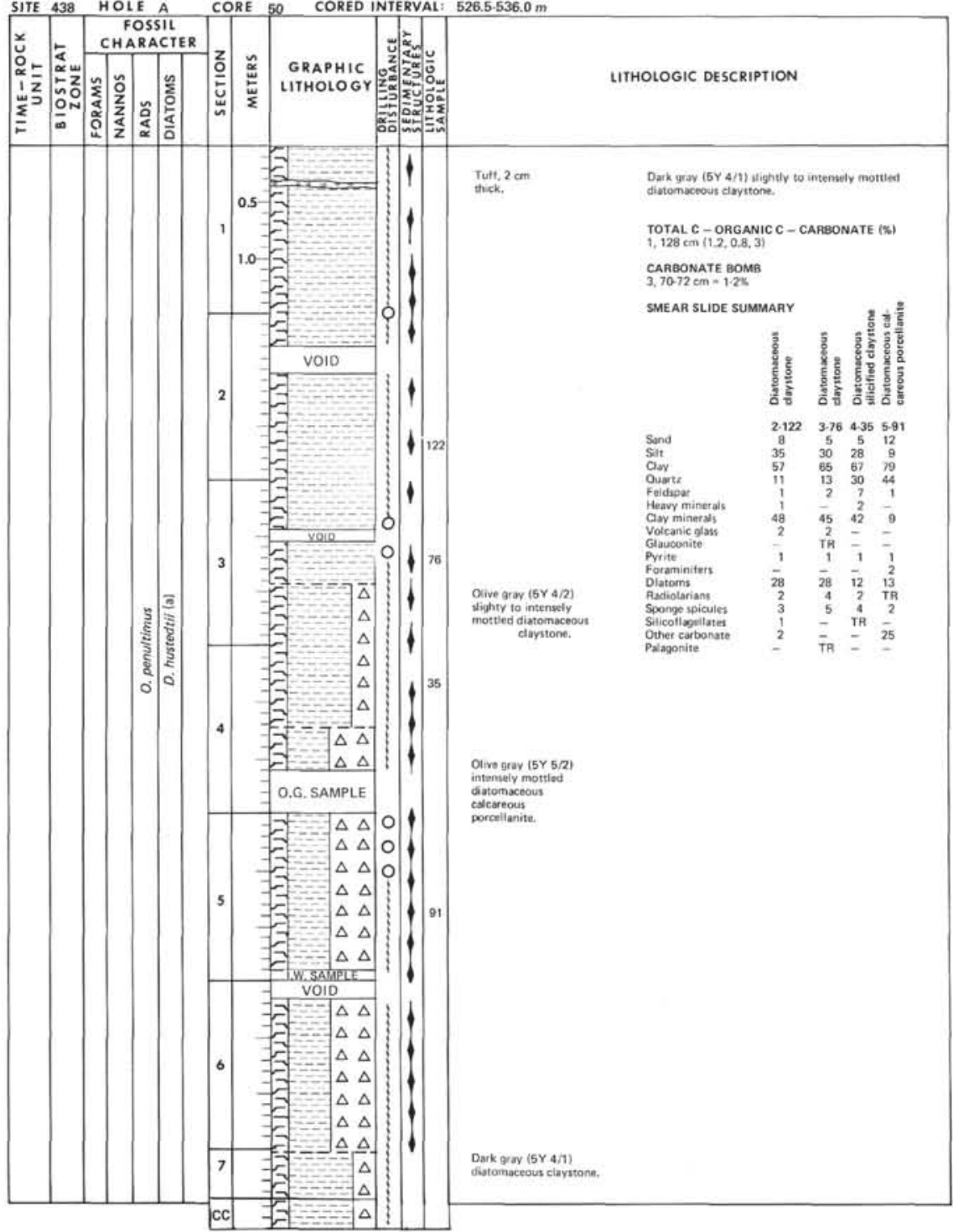


SIIE 438 HOLE A CORE 51 CORED INTERVAL: $536.0545 .5 \mathrm{~m}$

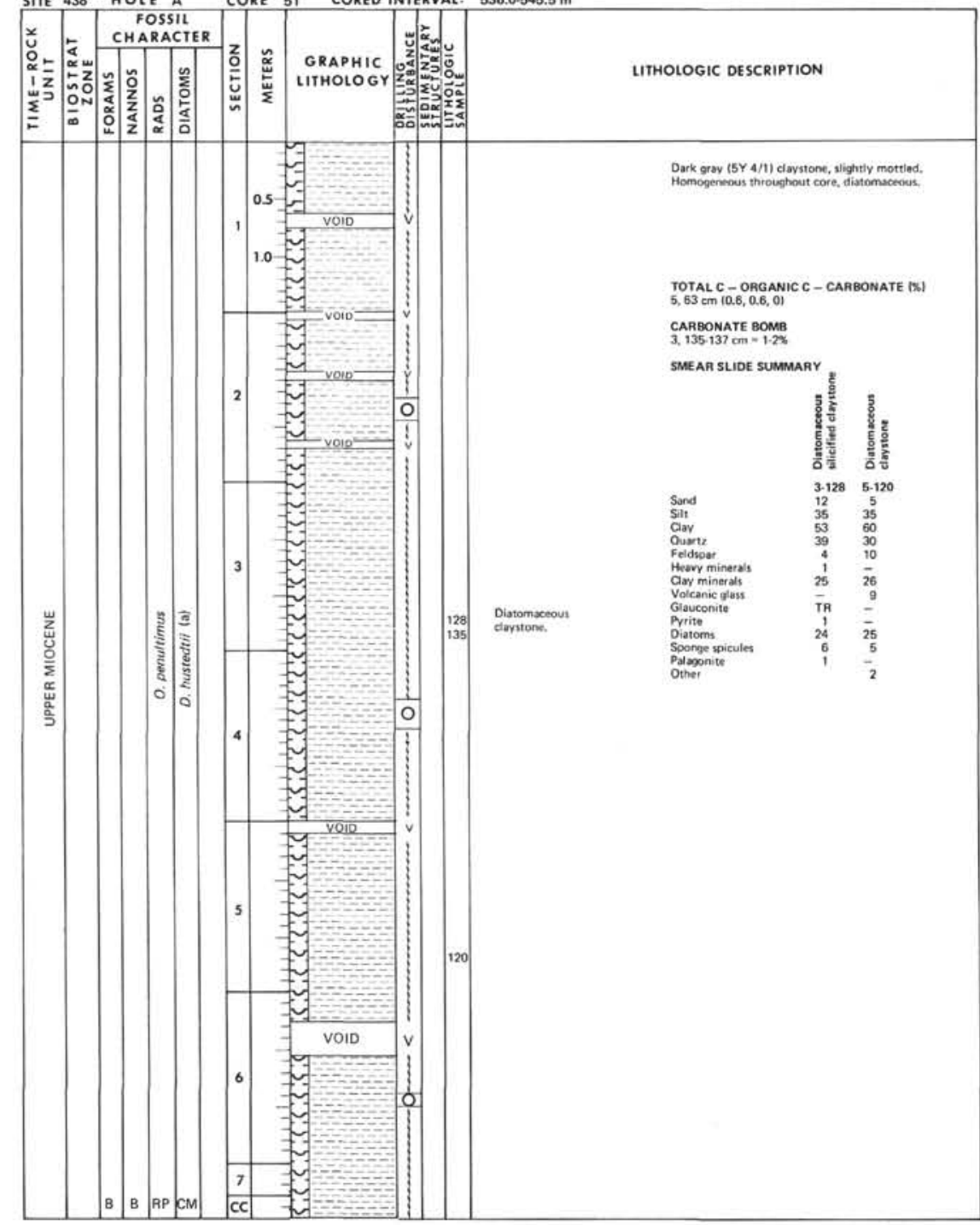

SITE 438 HOLE A CORE 52 CORED INTERVAL: $545.5 .555 .0 \mathrm{~m}$

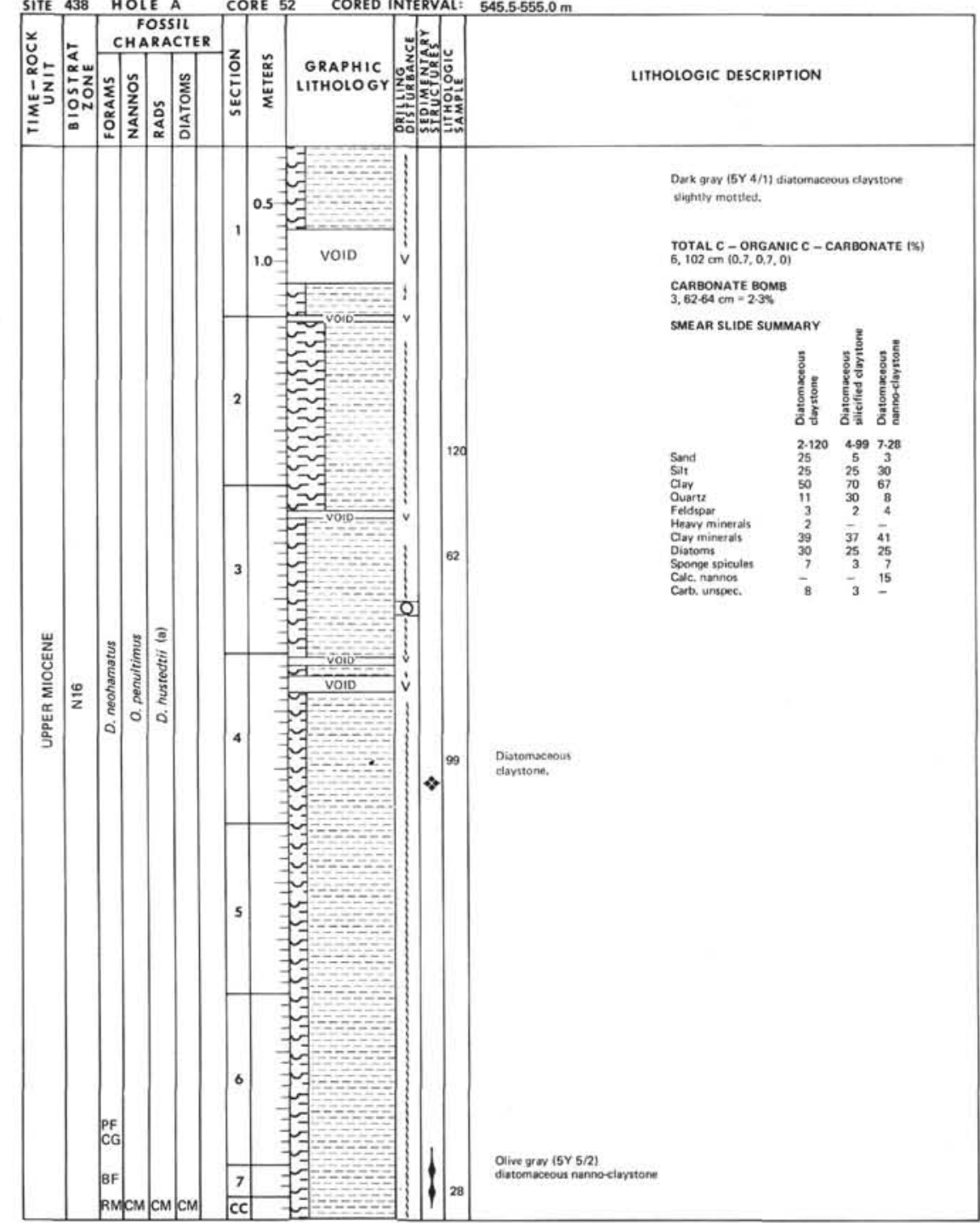



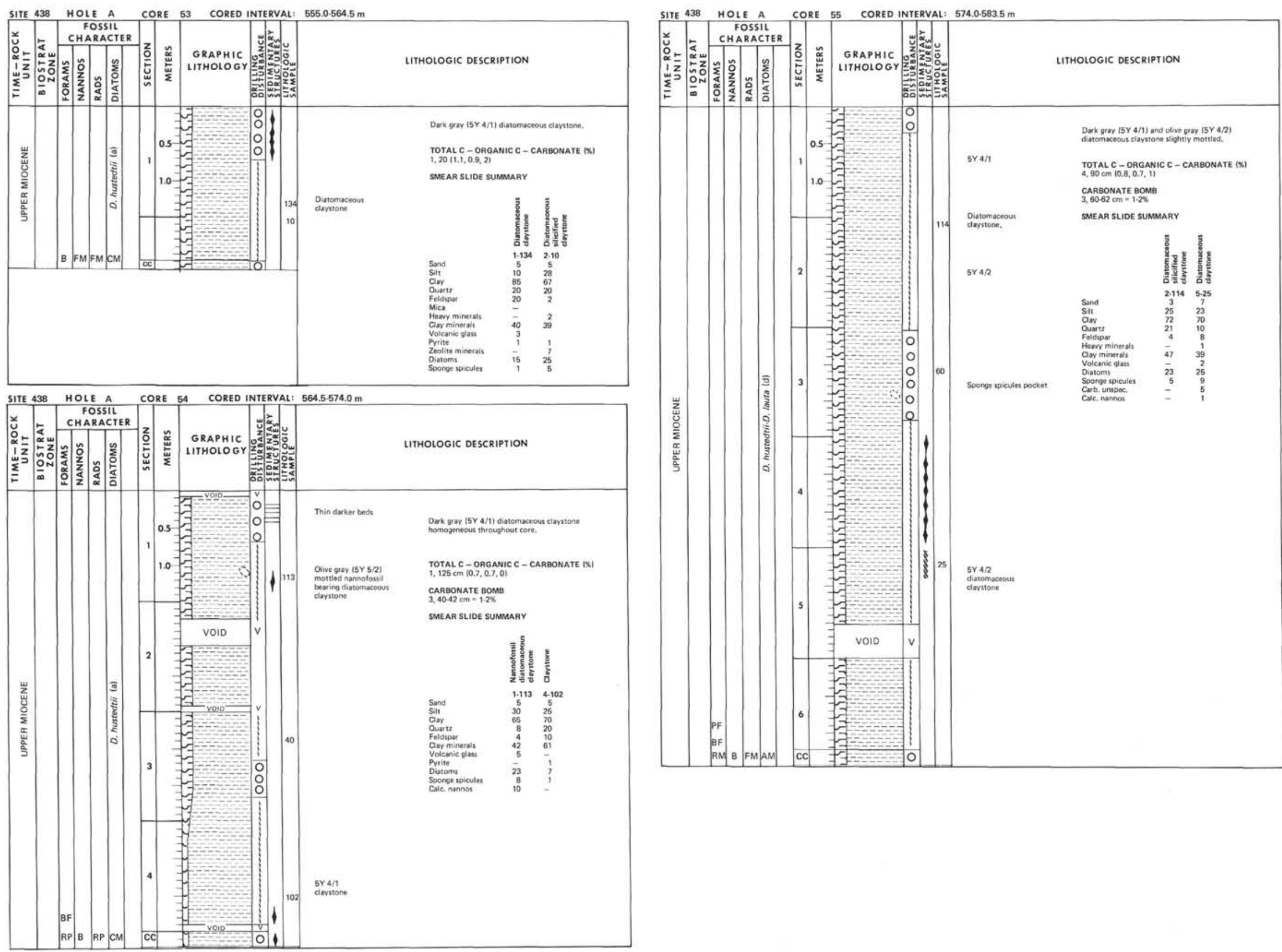

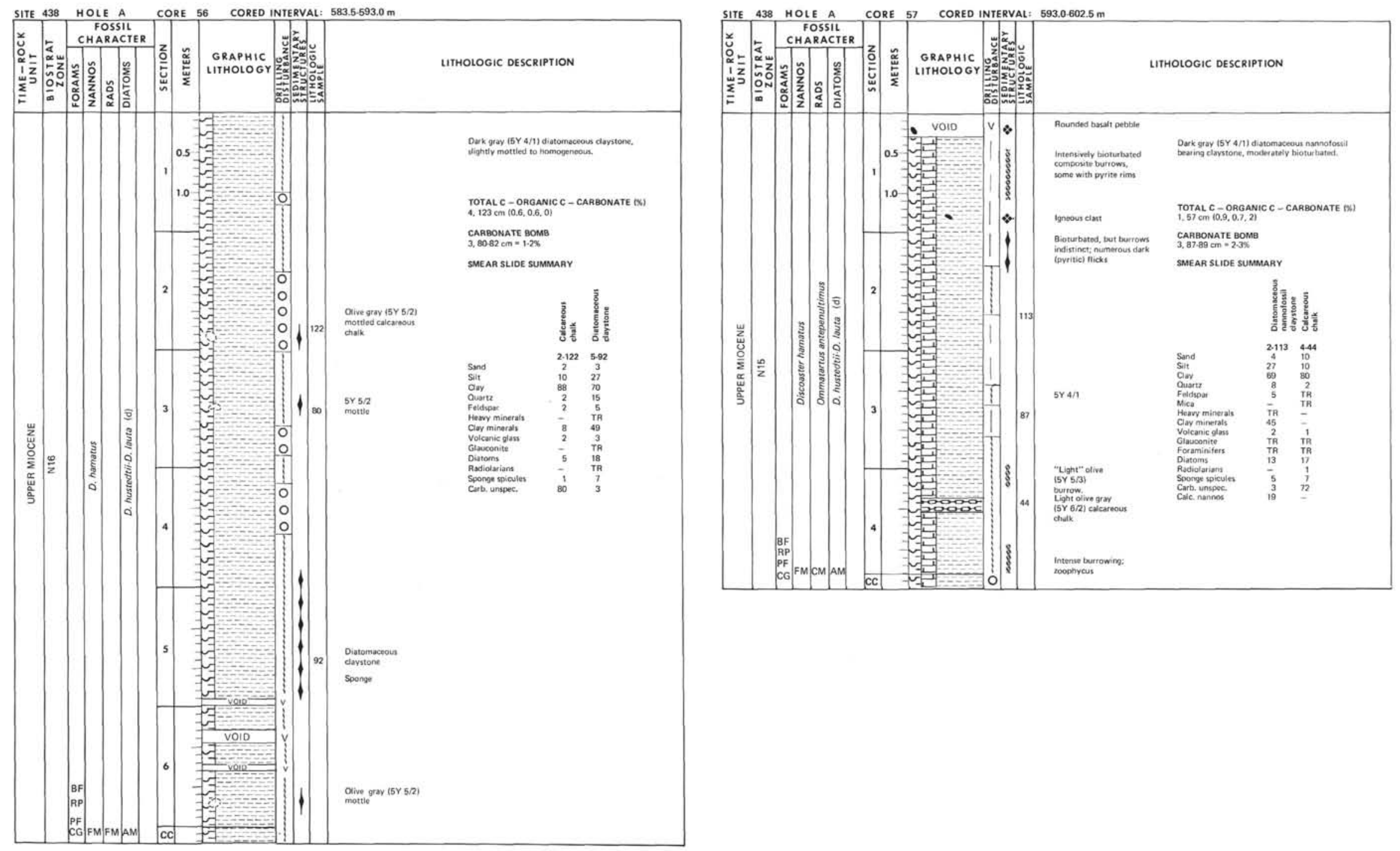


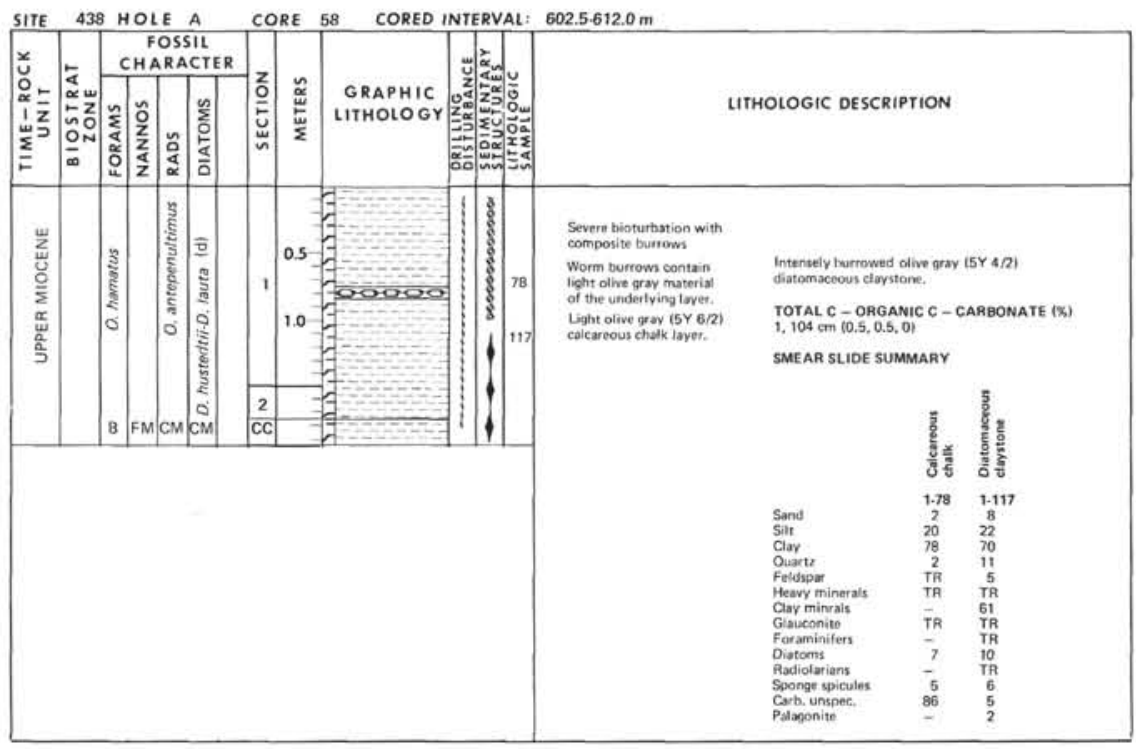

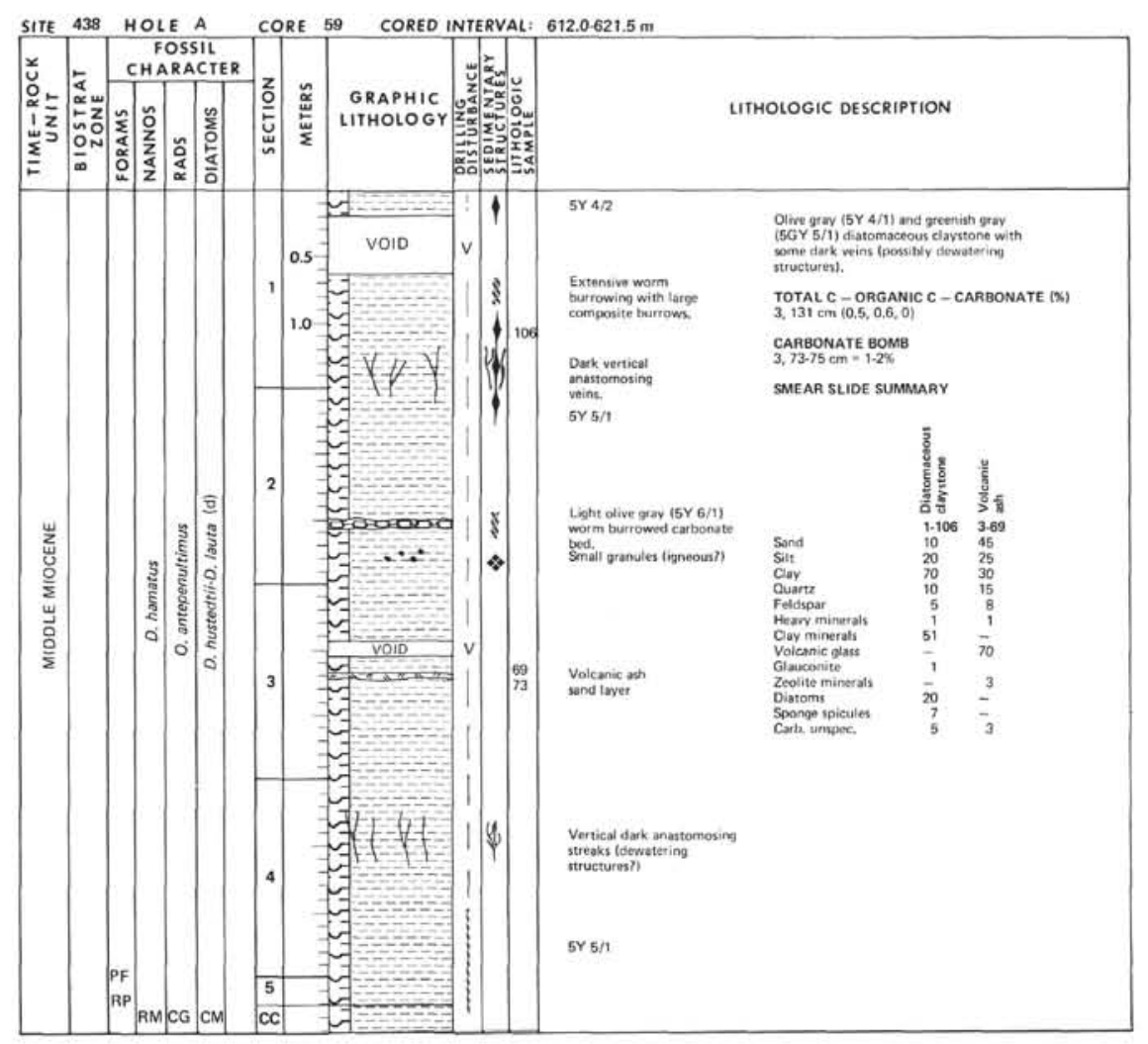



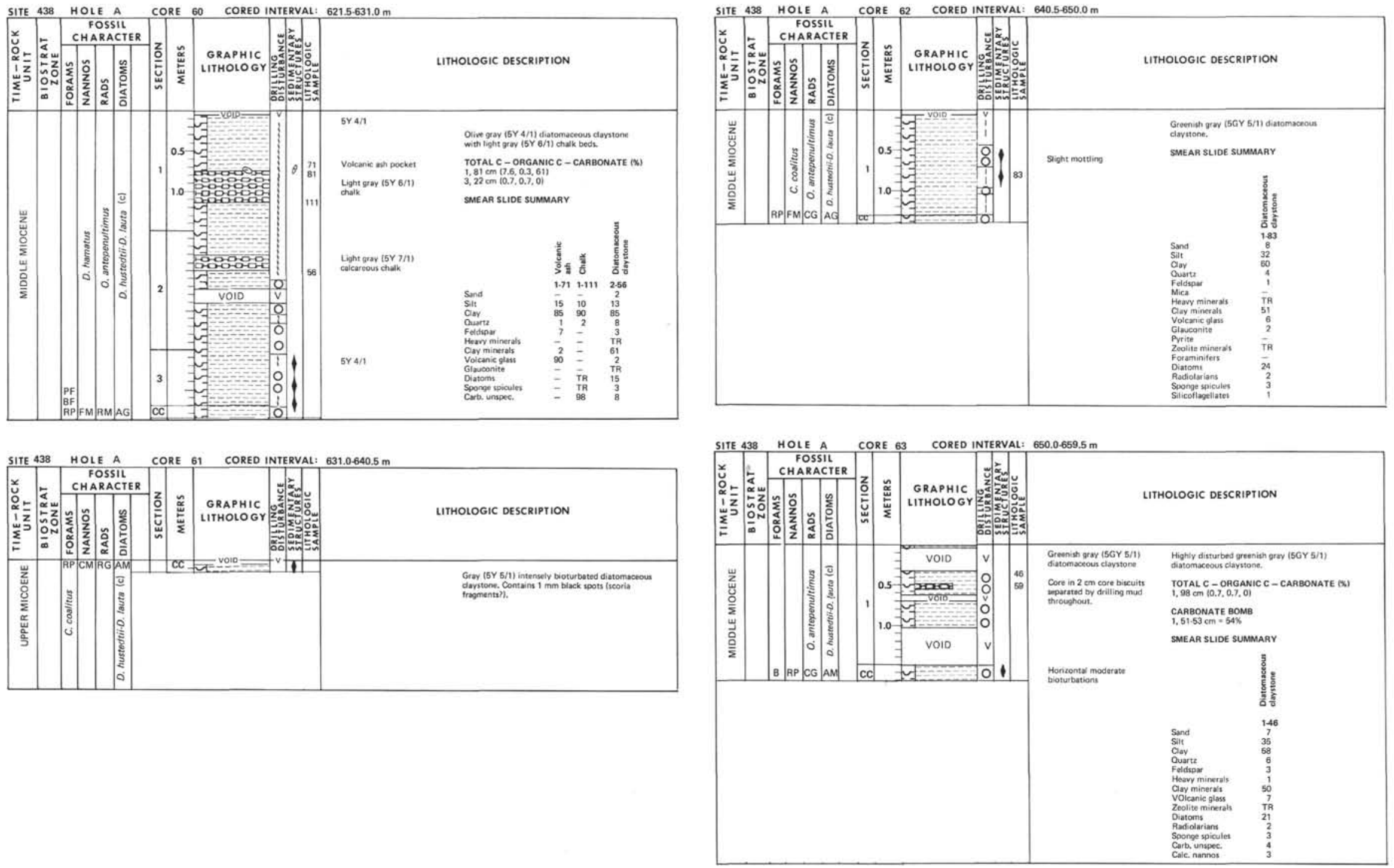

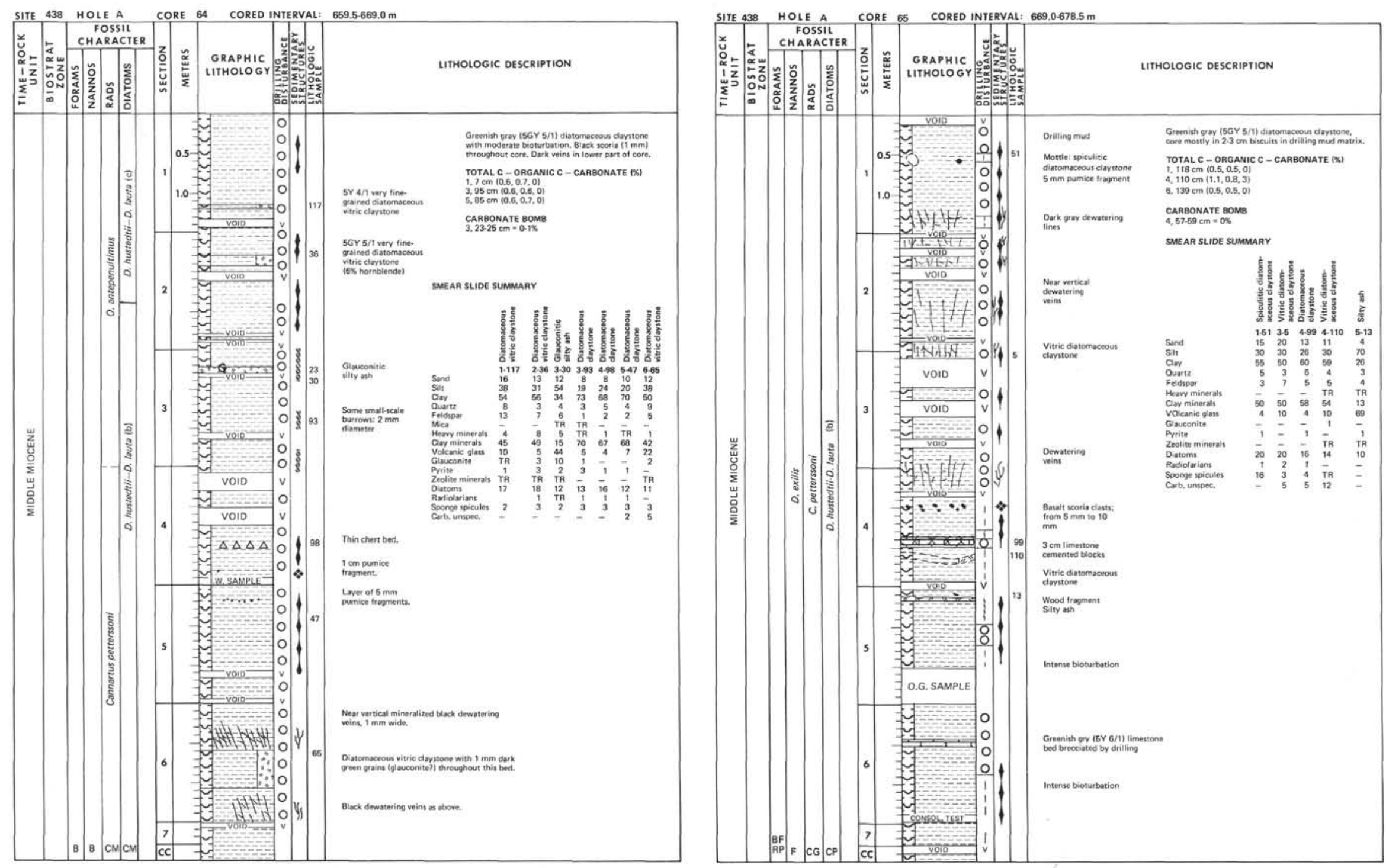

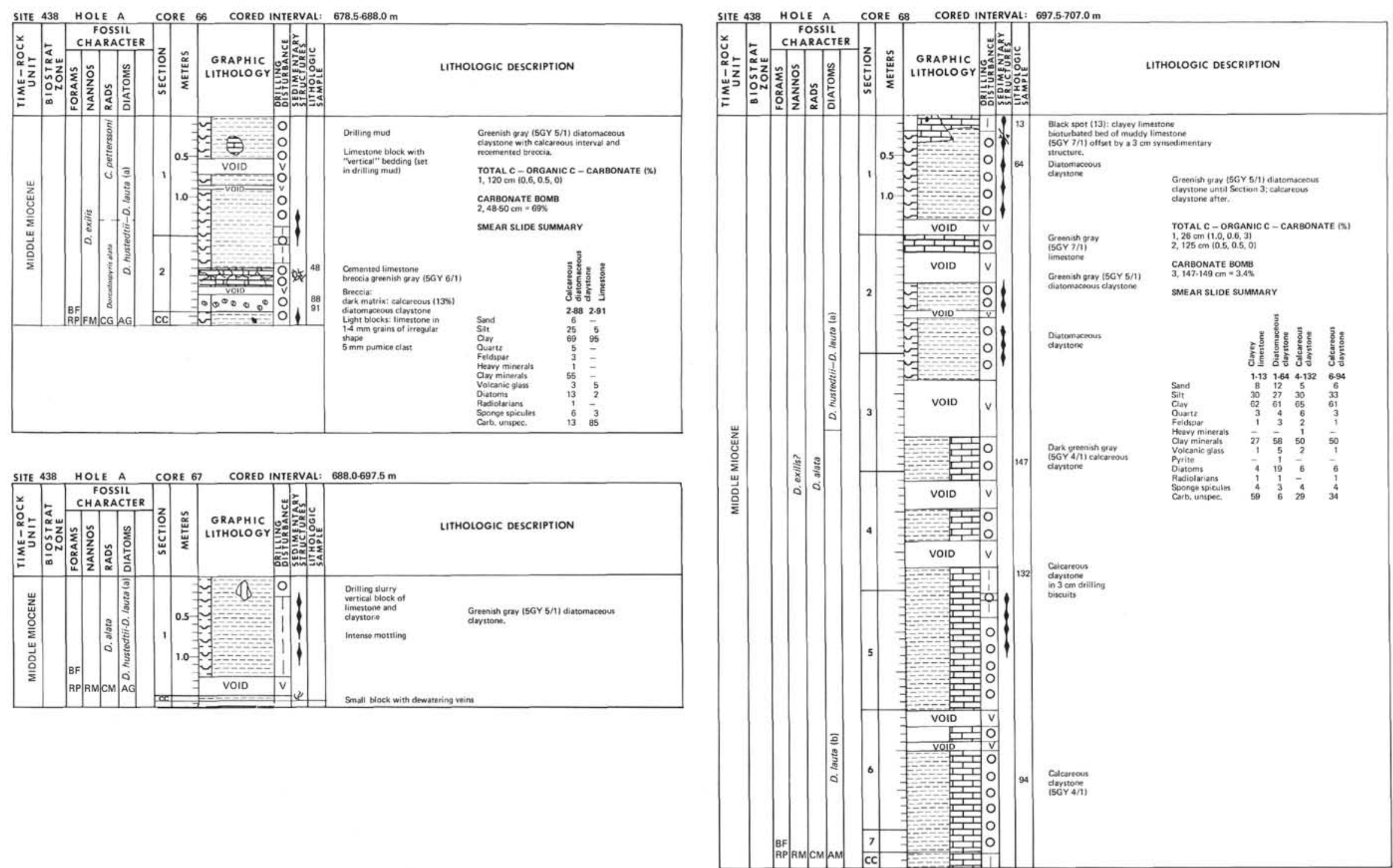


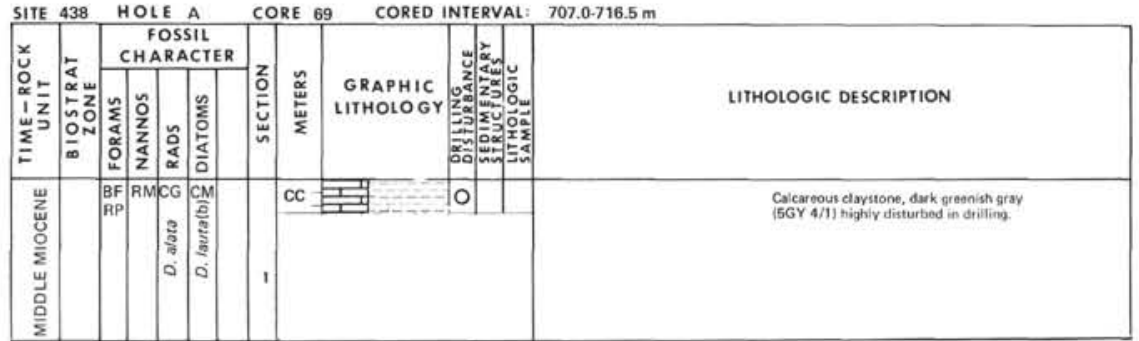

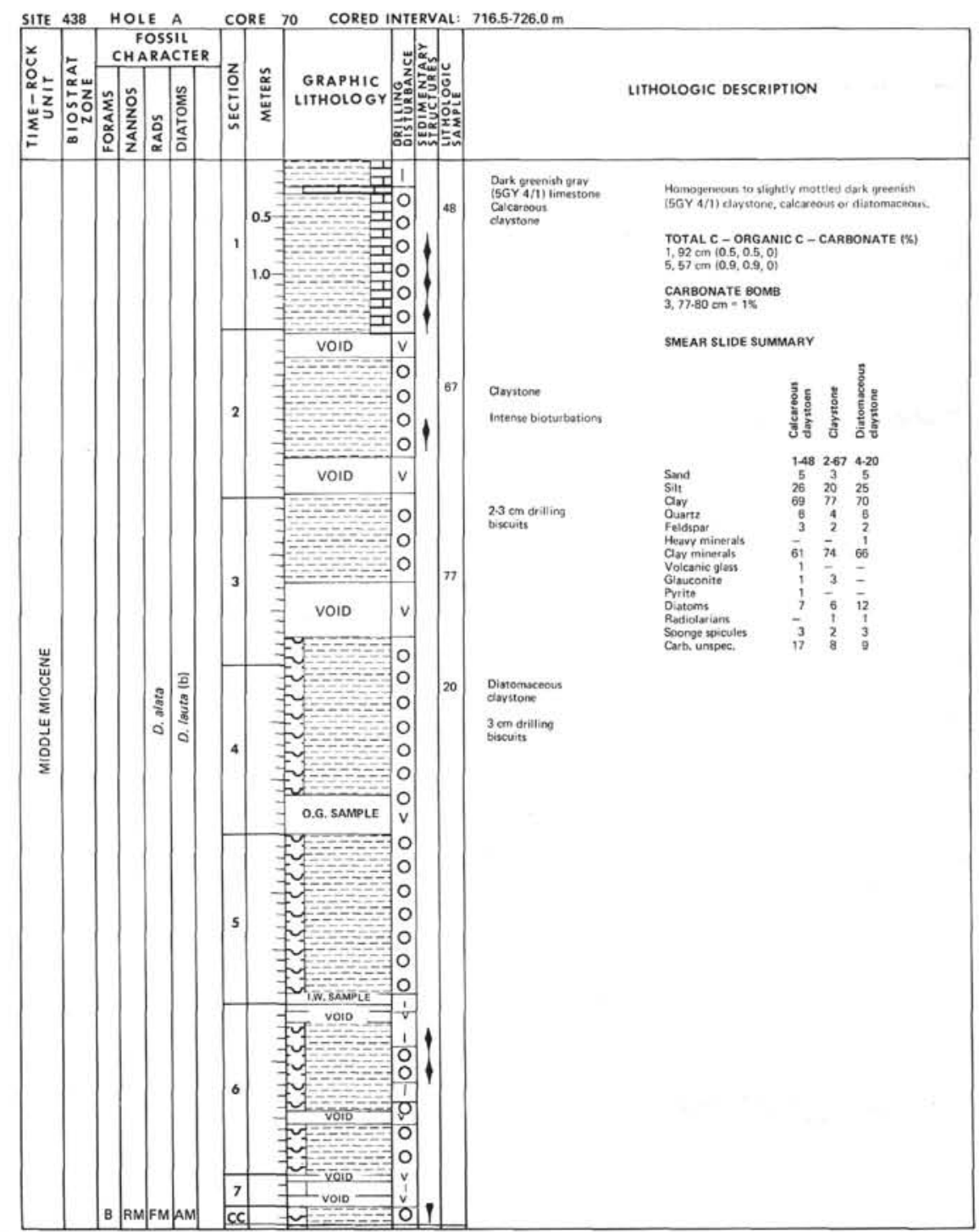



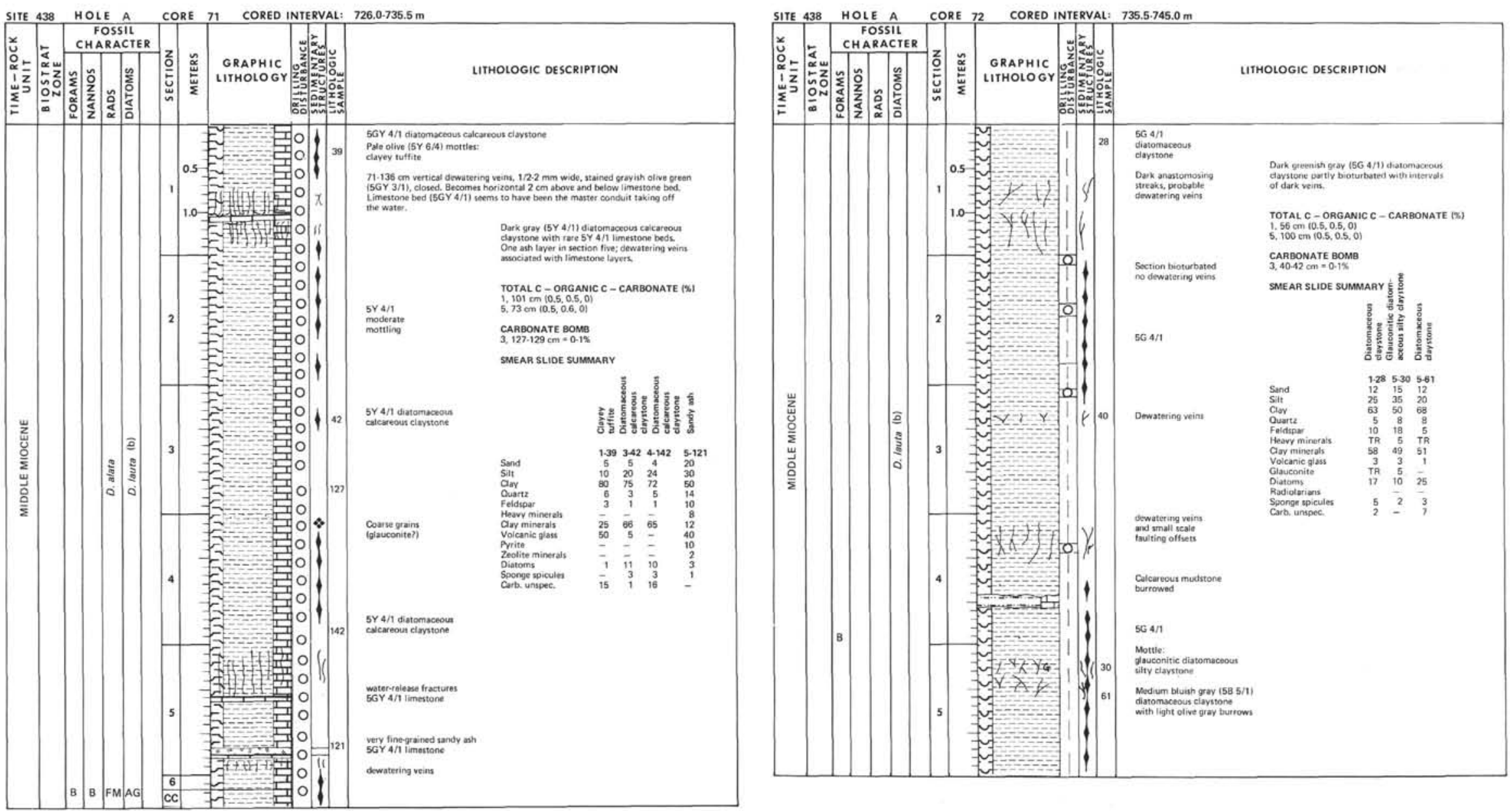


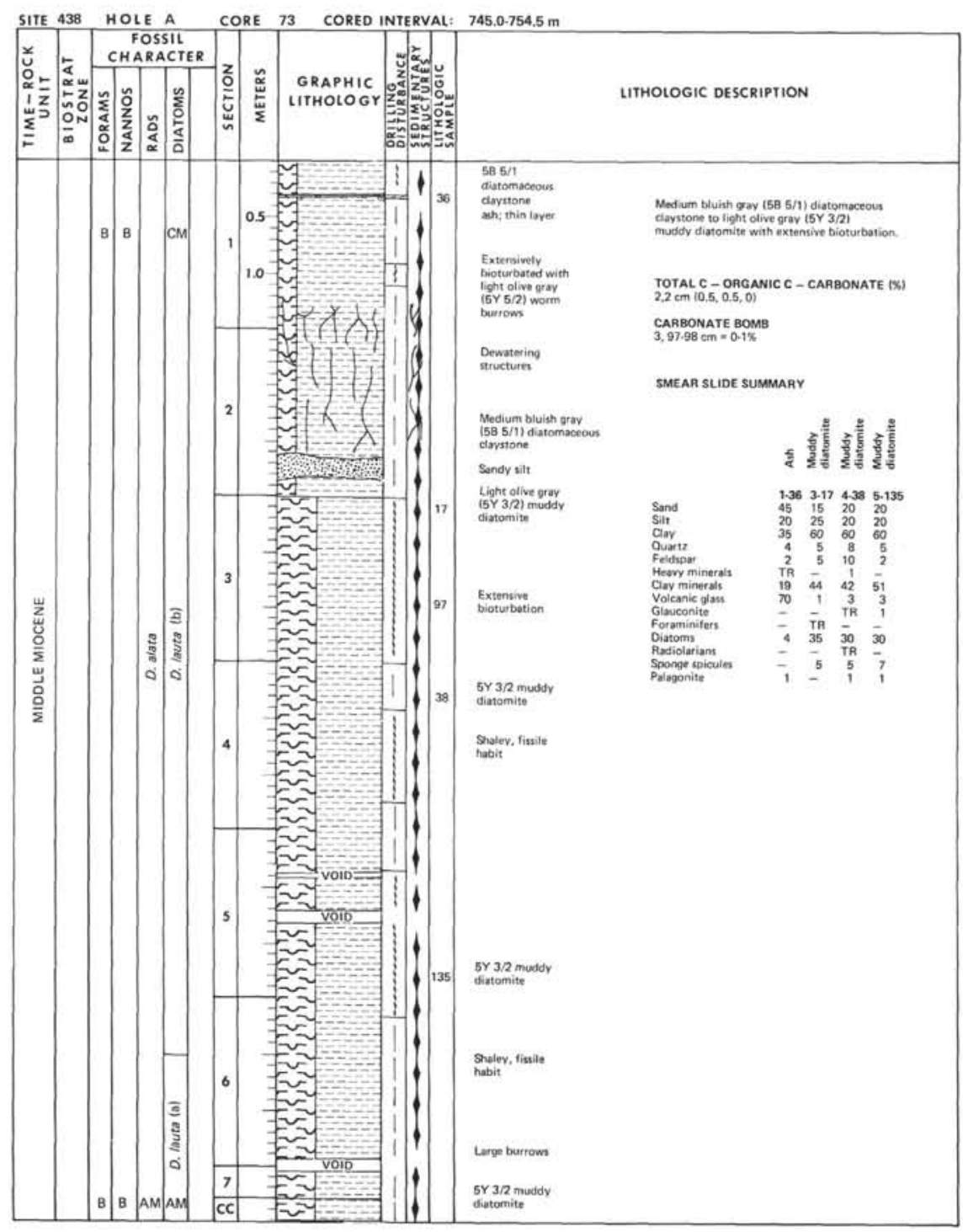

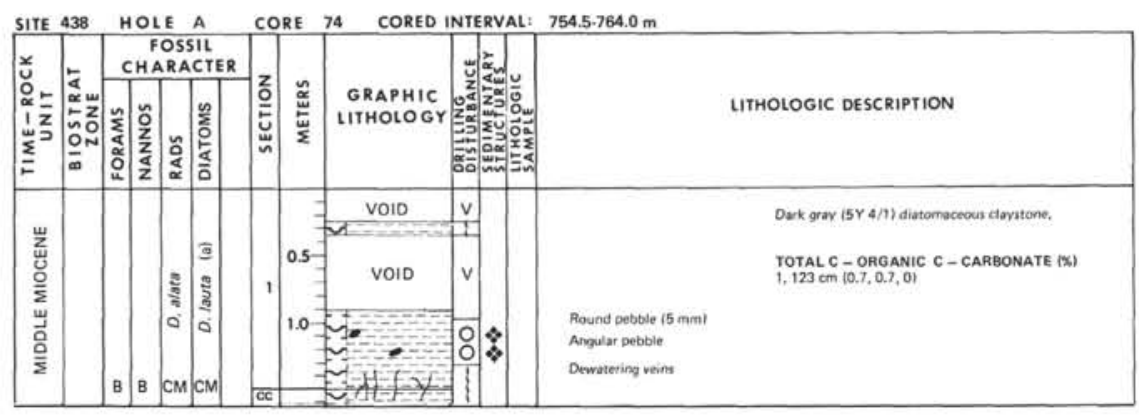

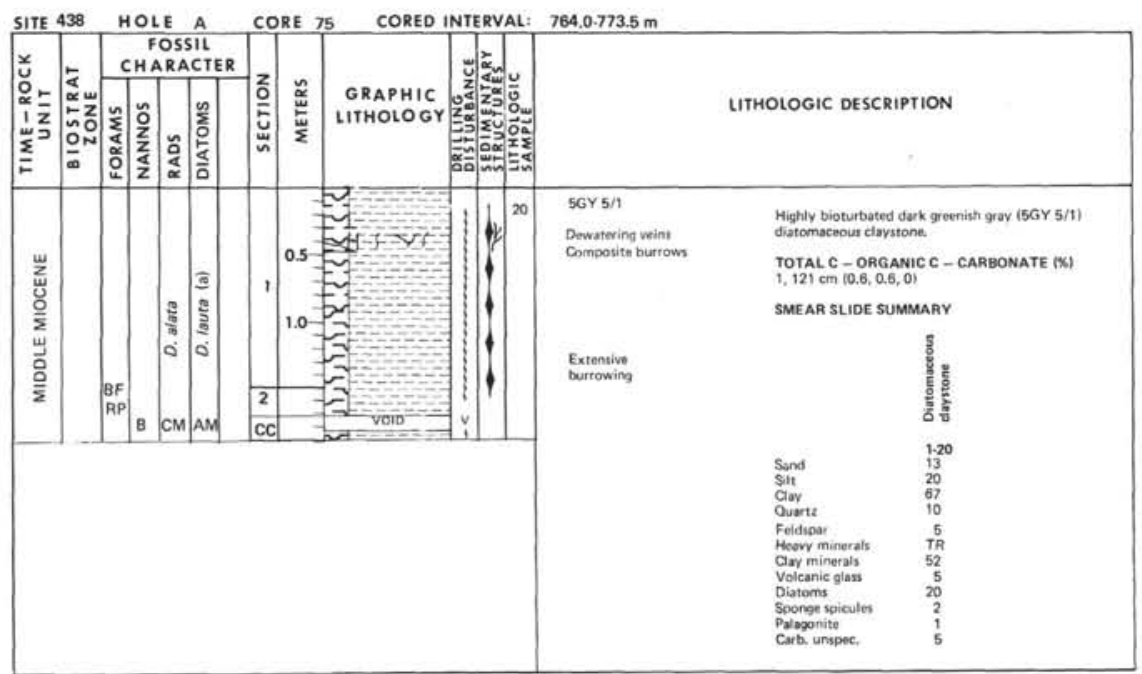




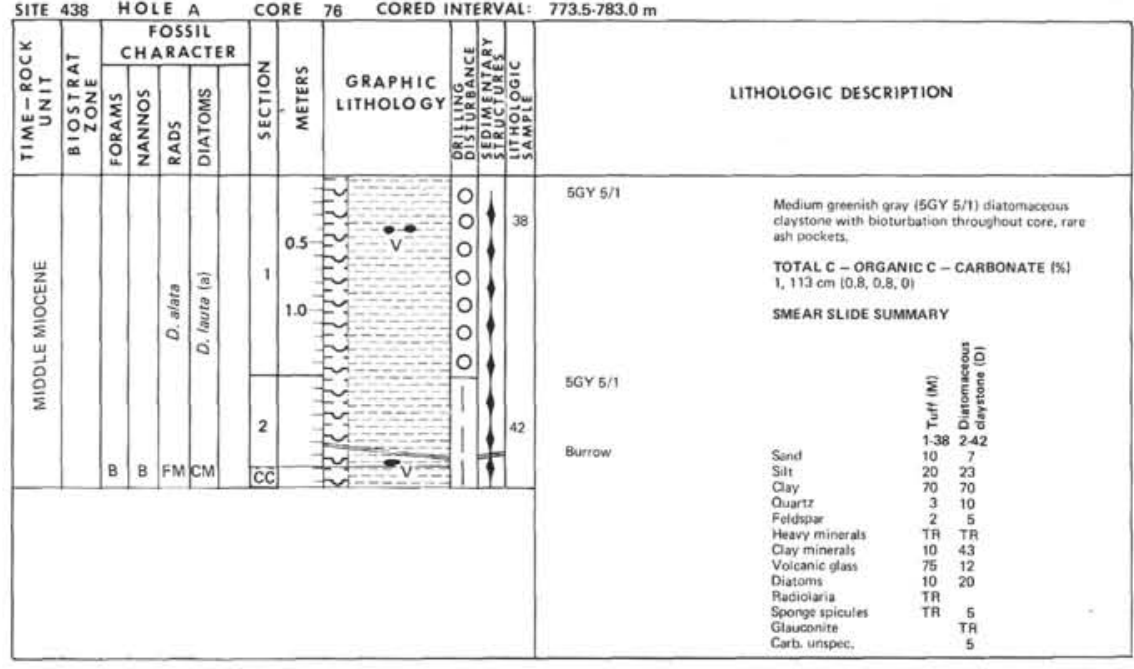

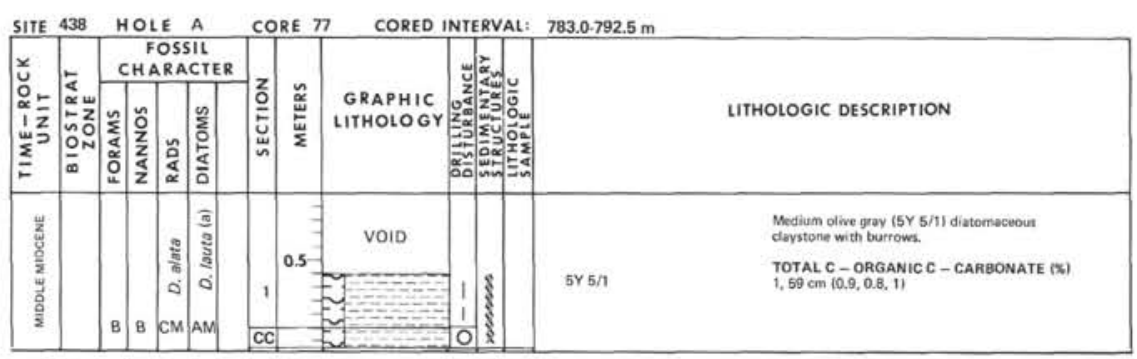

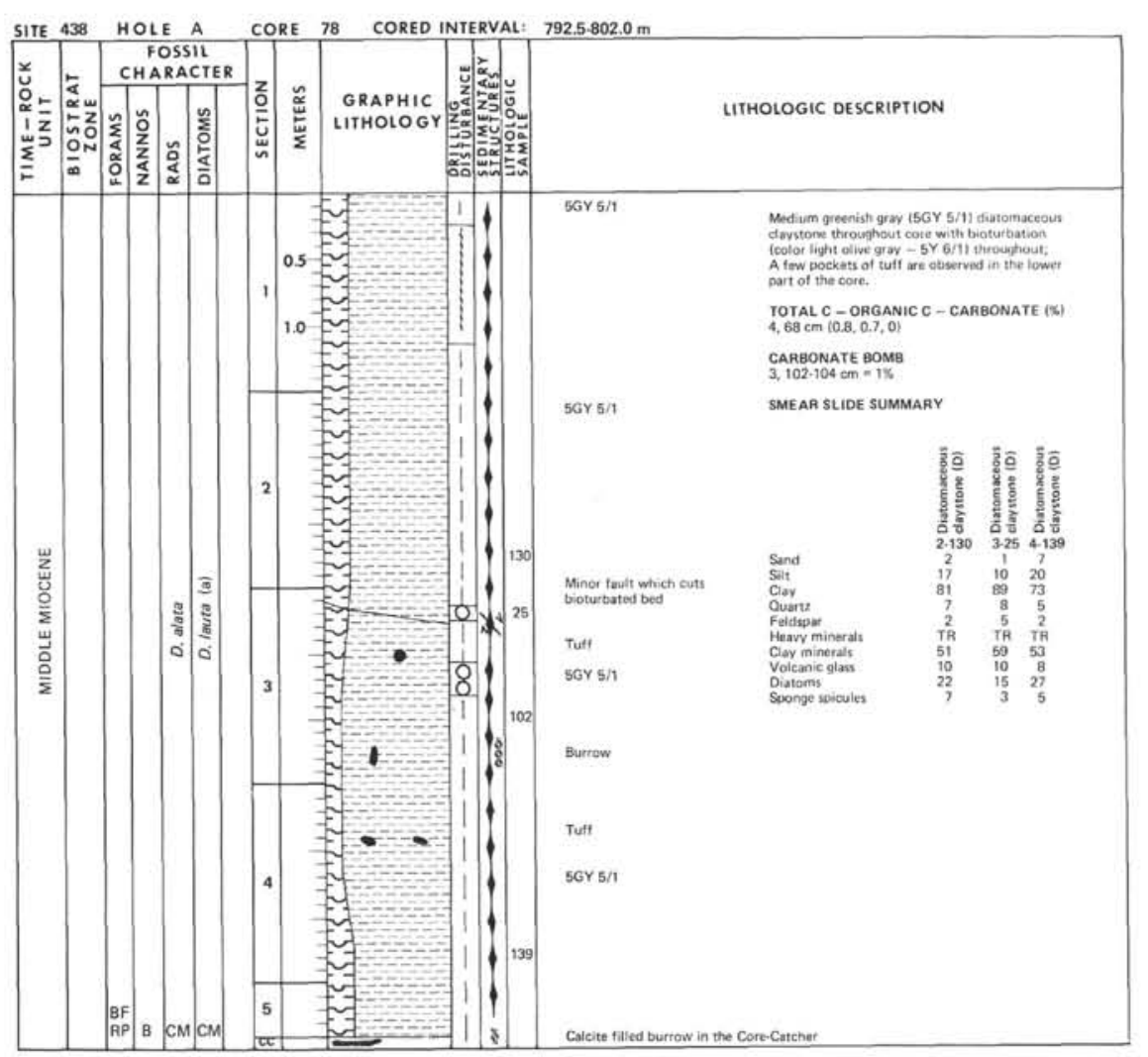



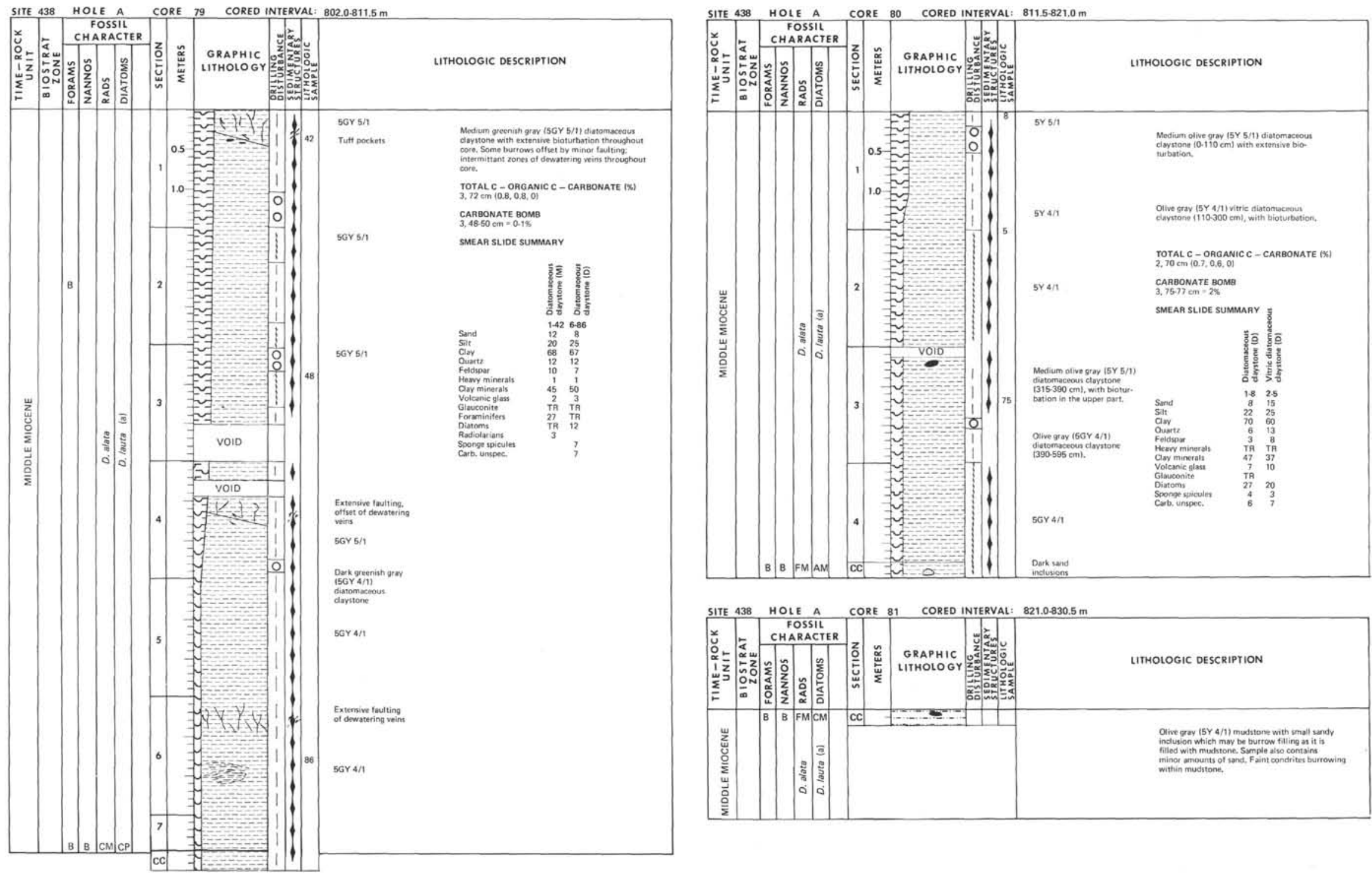

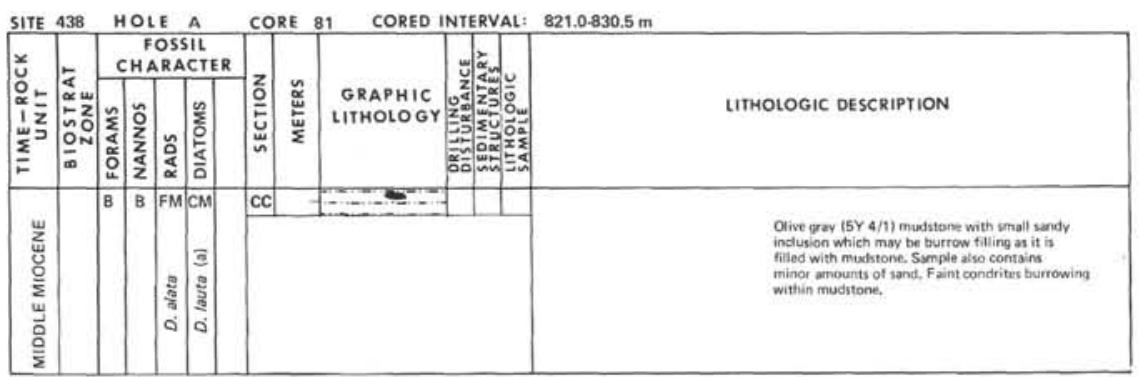



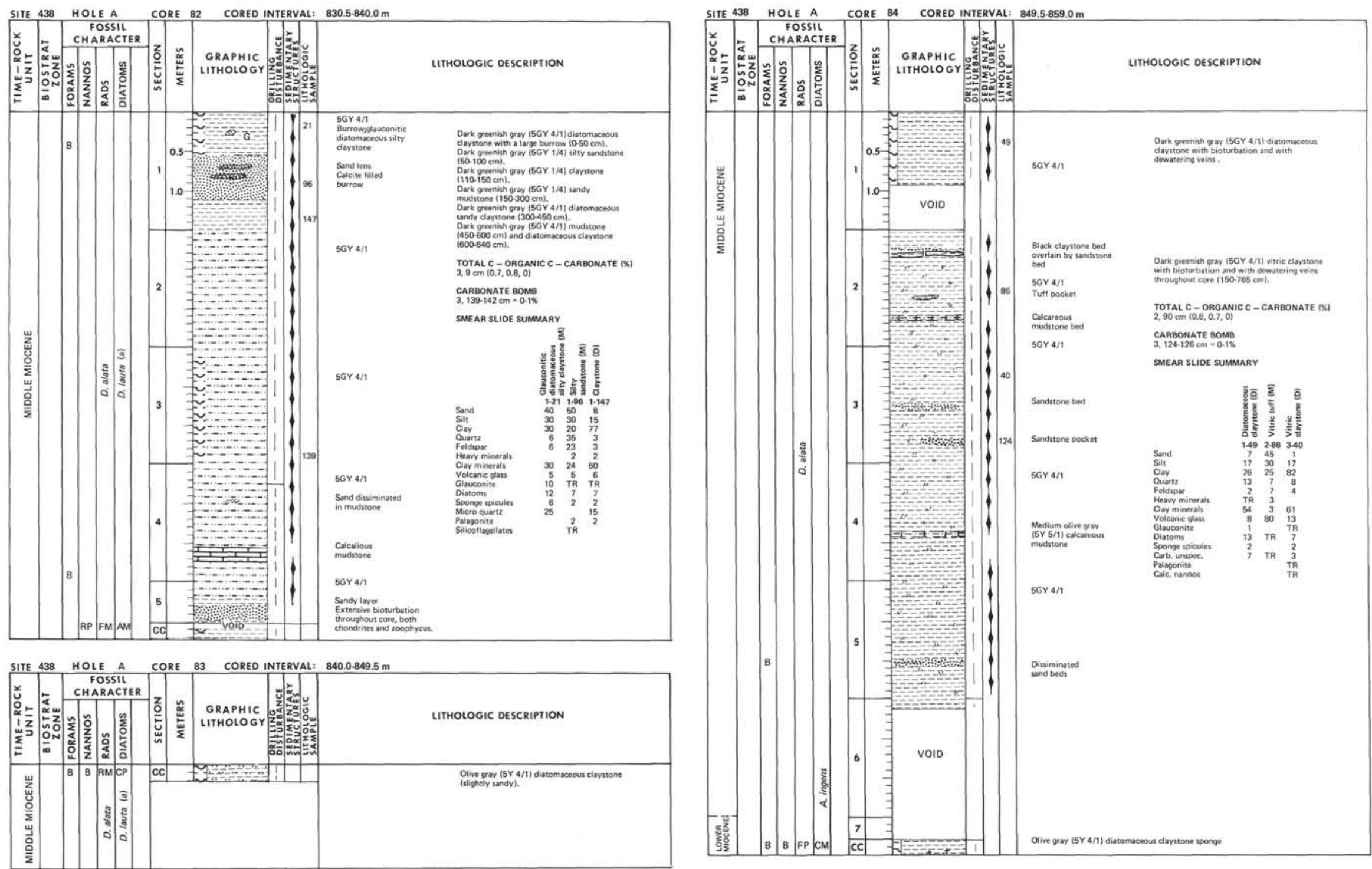


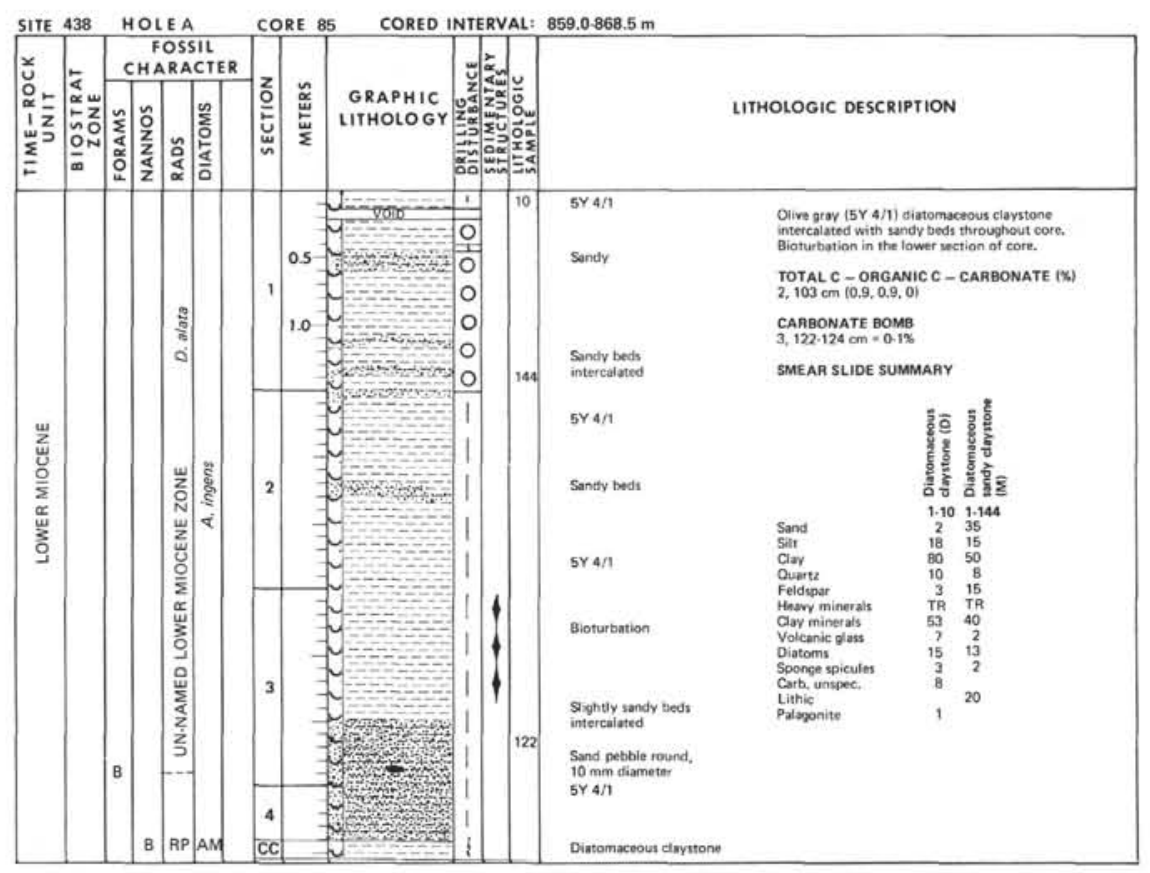

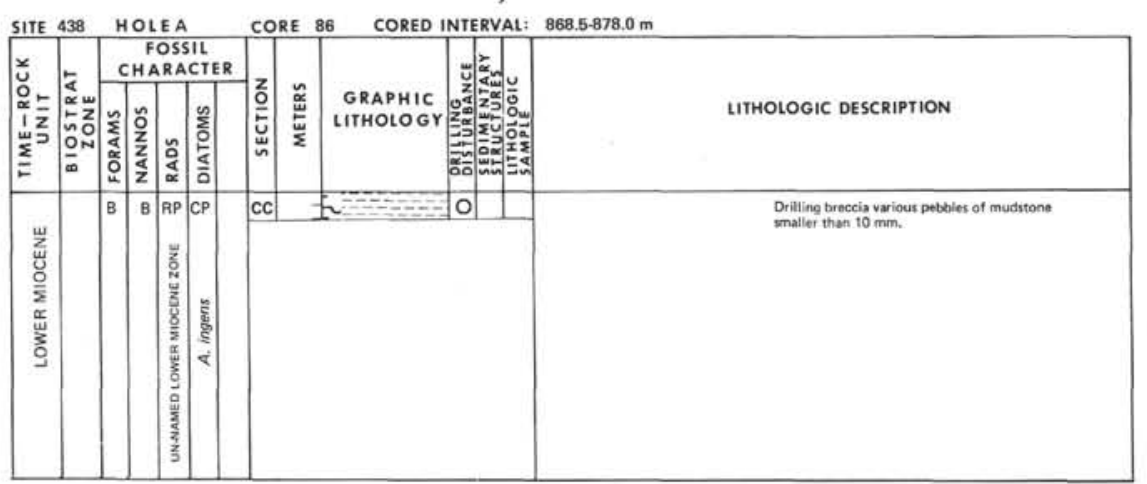



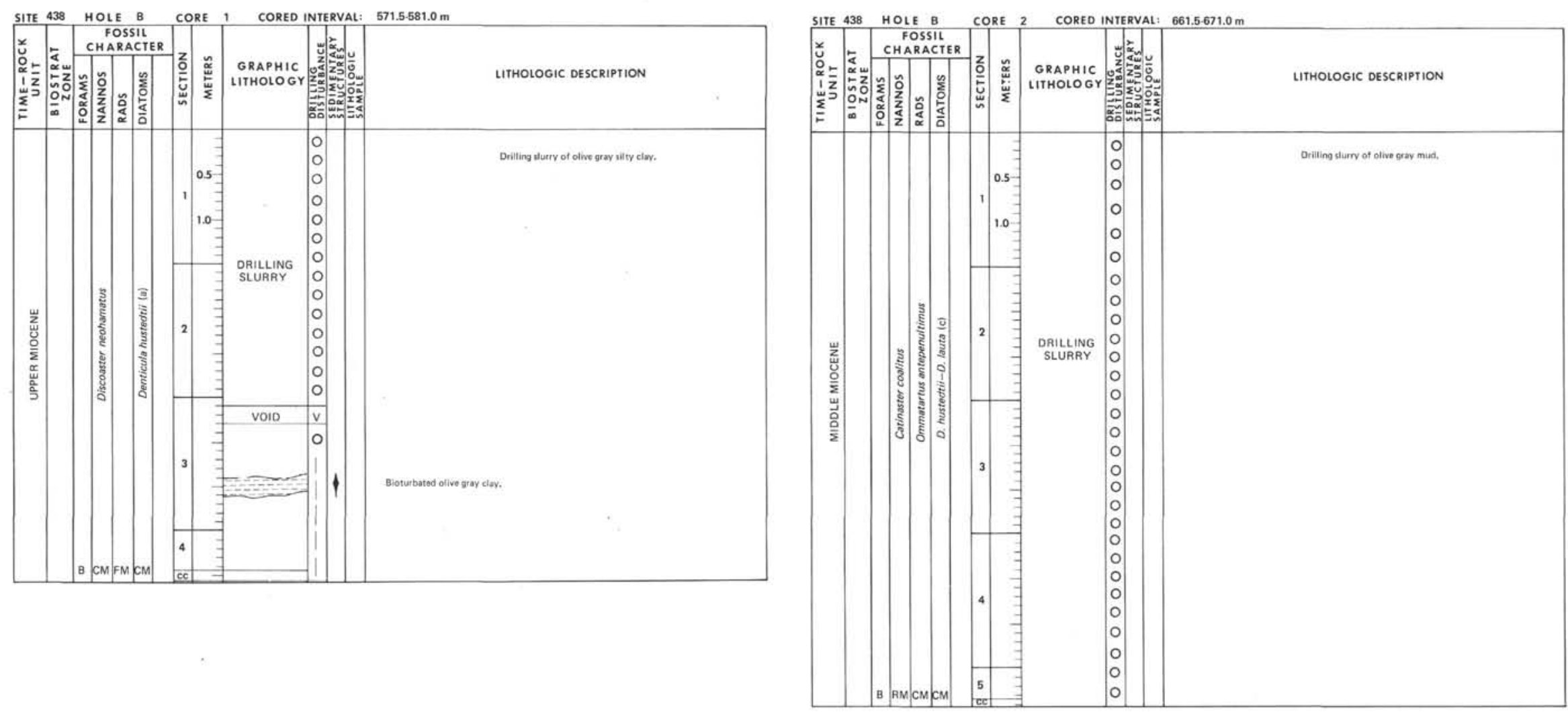

SITE 438 HOLE B CORE 3 CORED INTERVAL: $786.0 .795 .5 \mathrm{~m}$

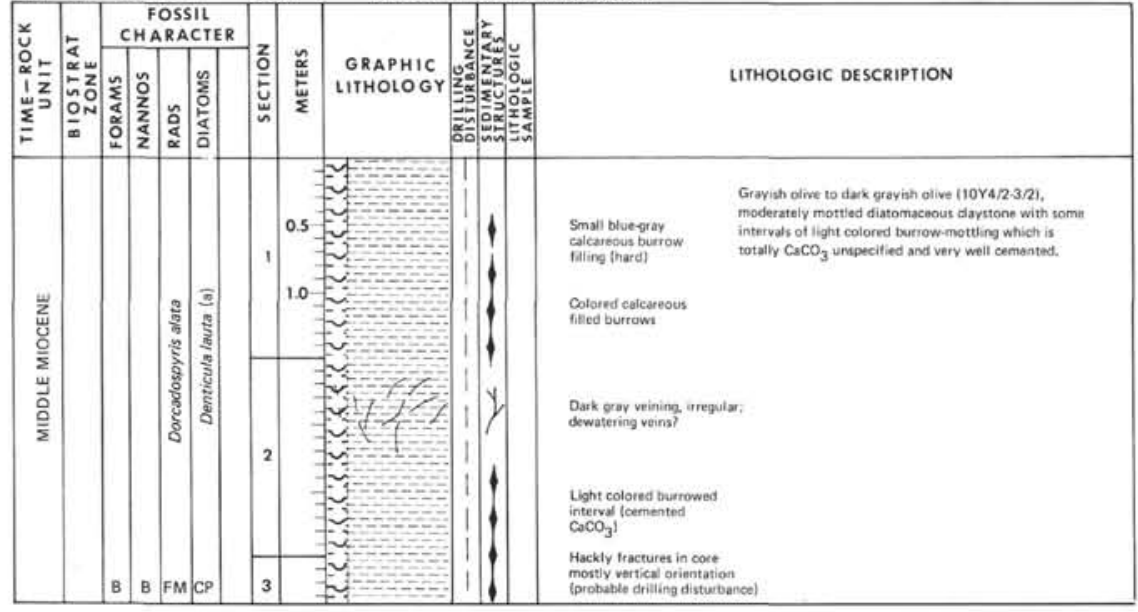




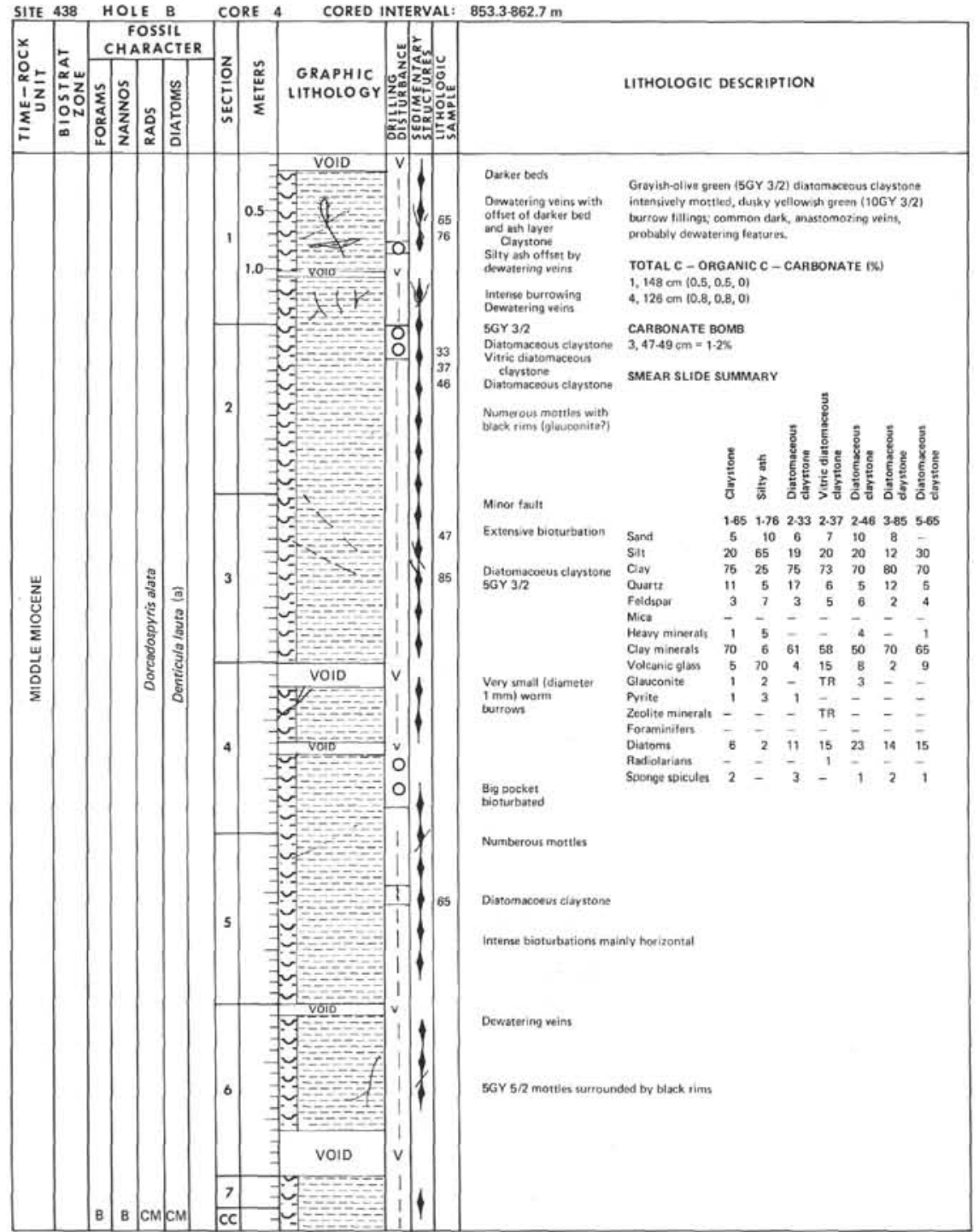

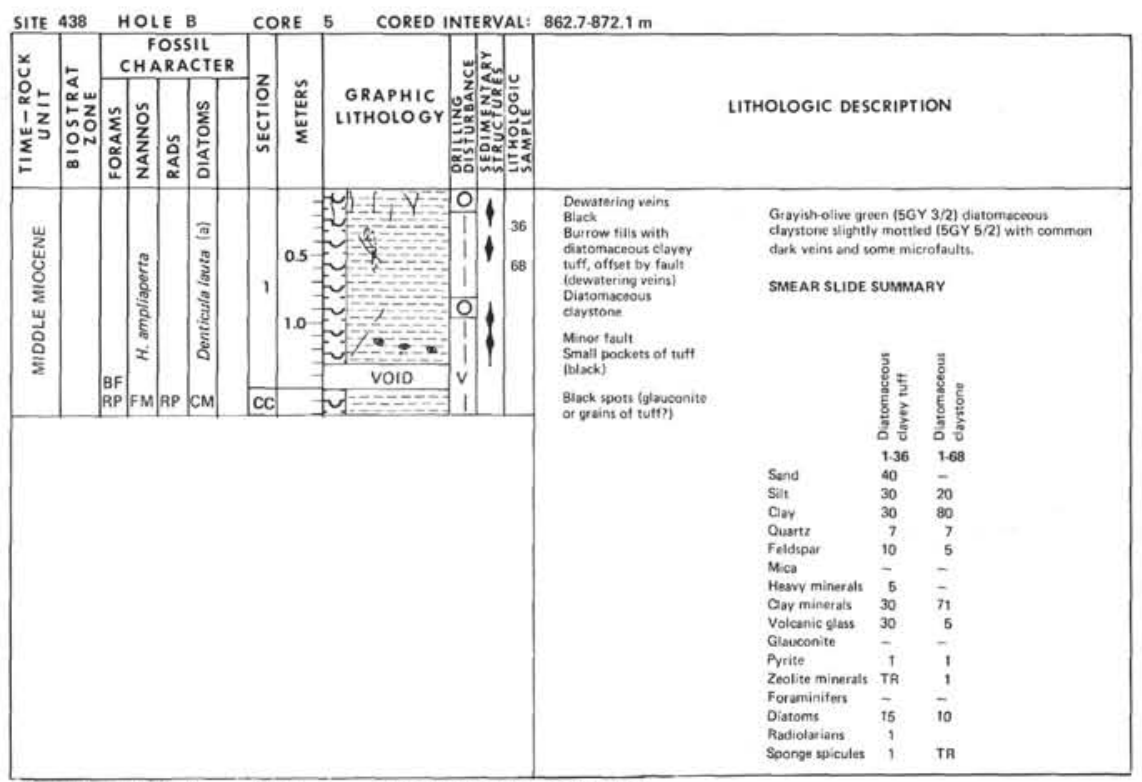

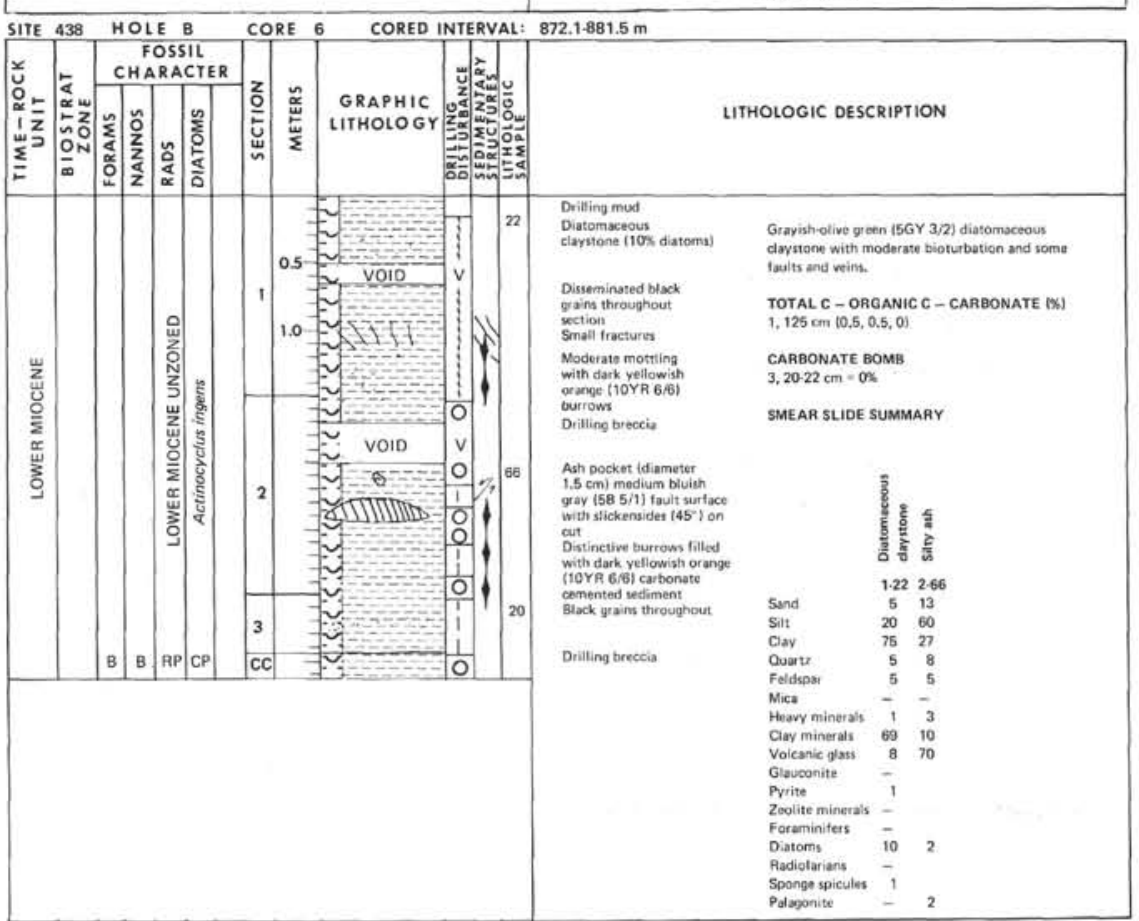



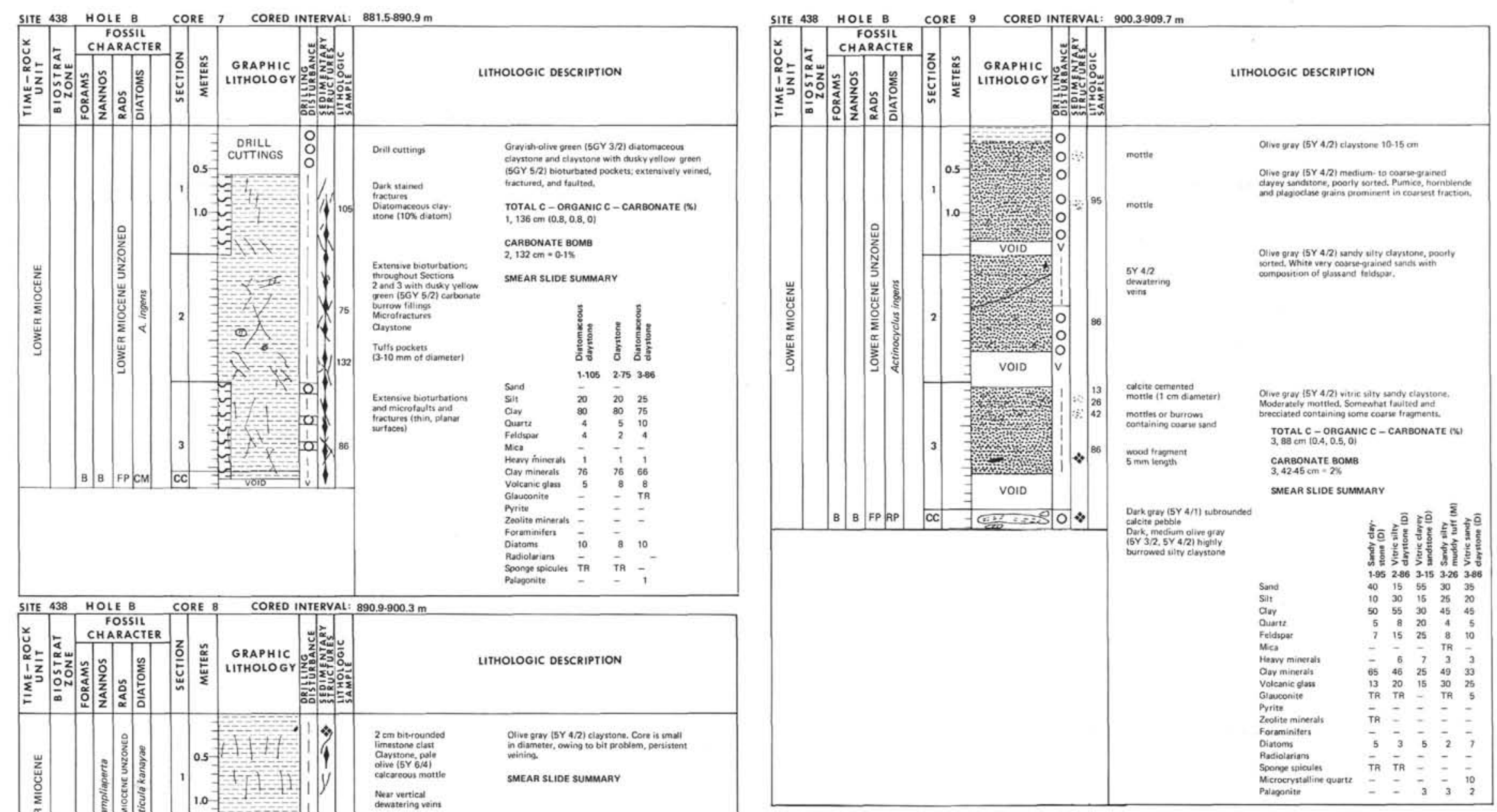

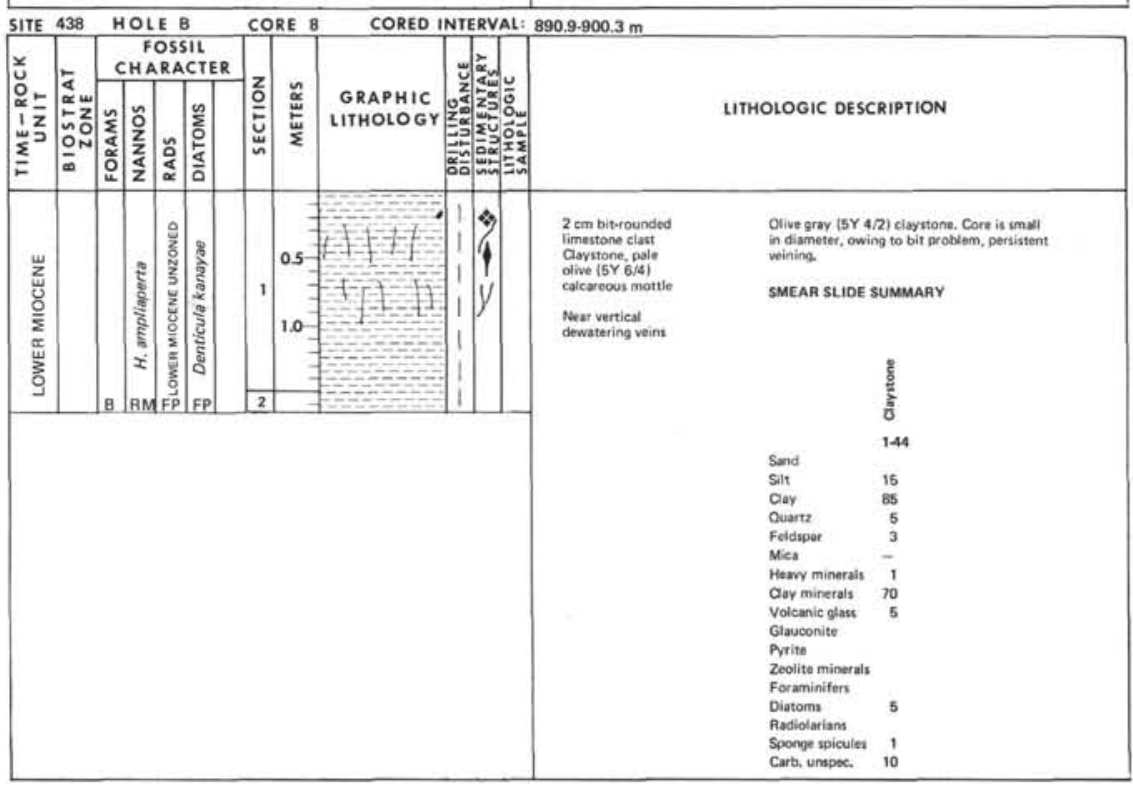




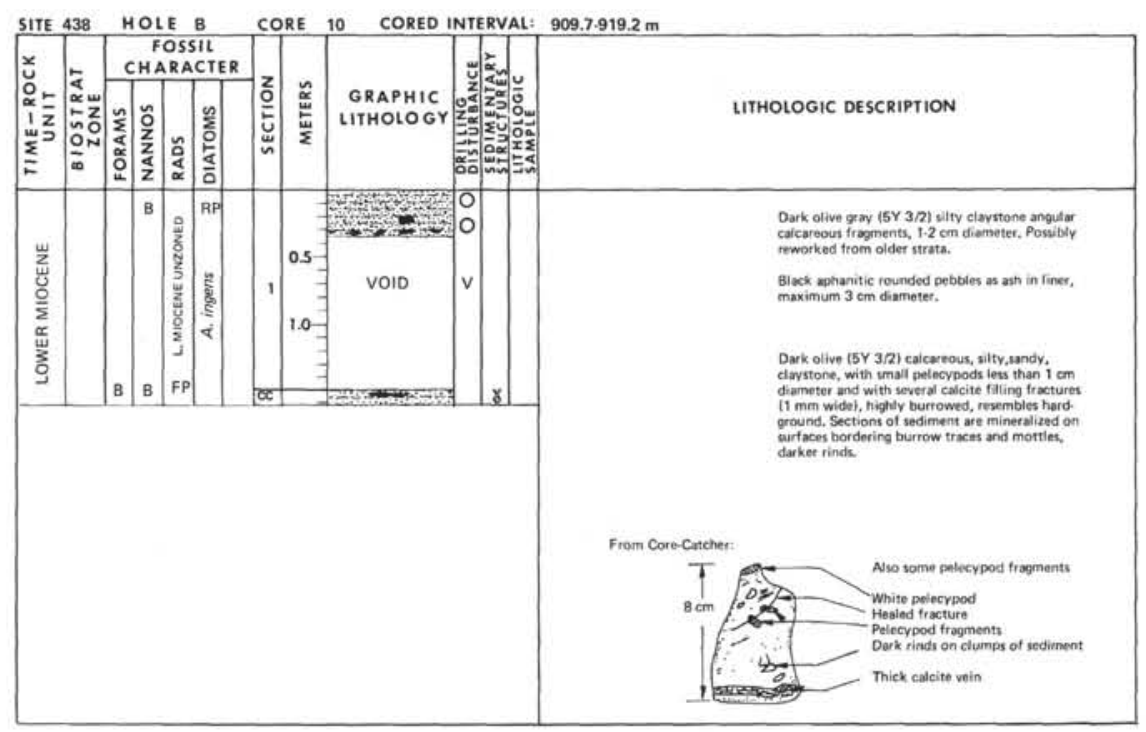

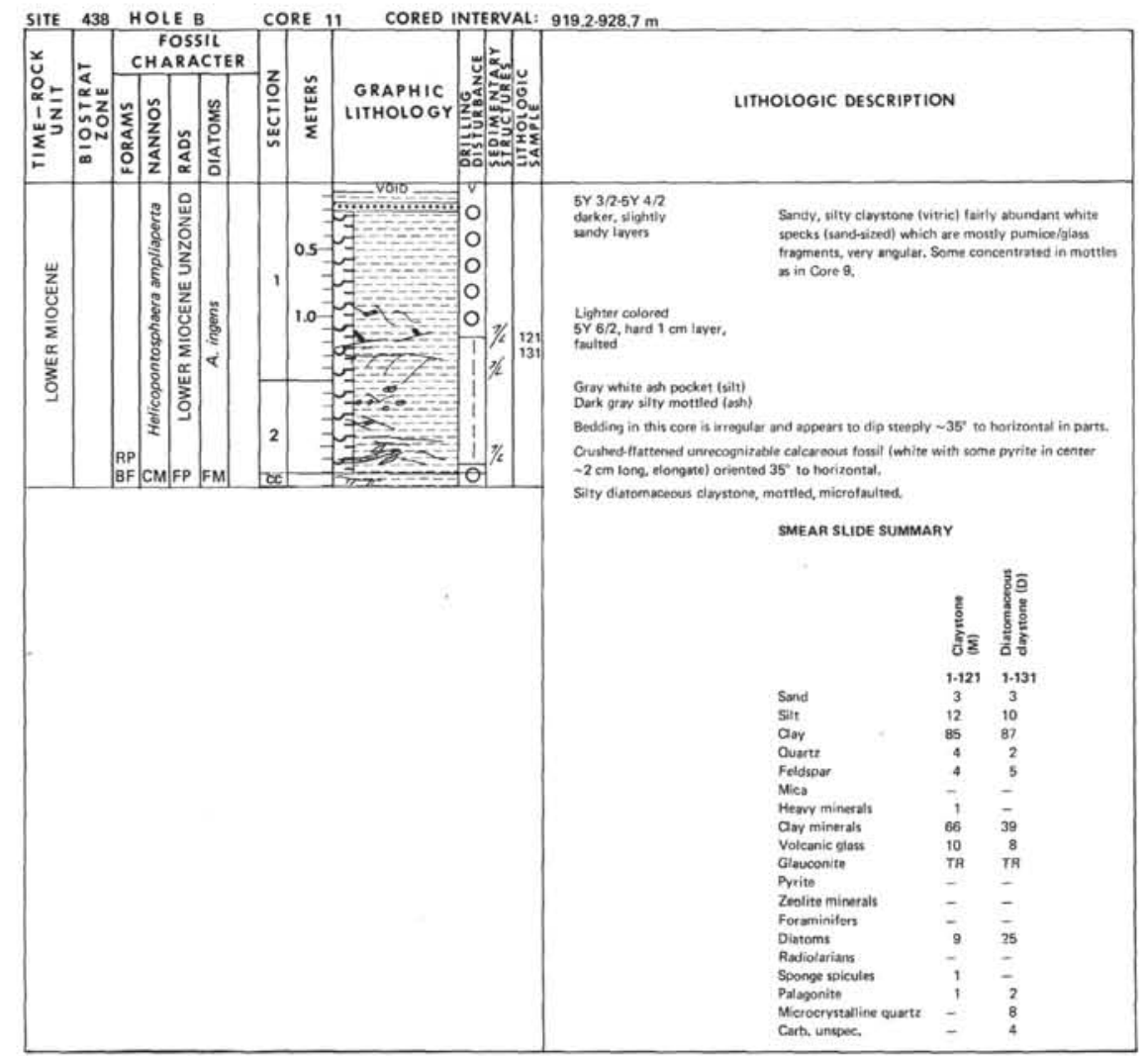




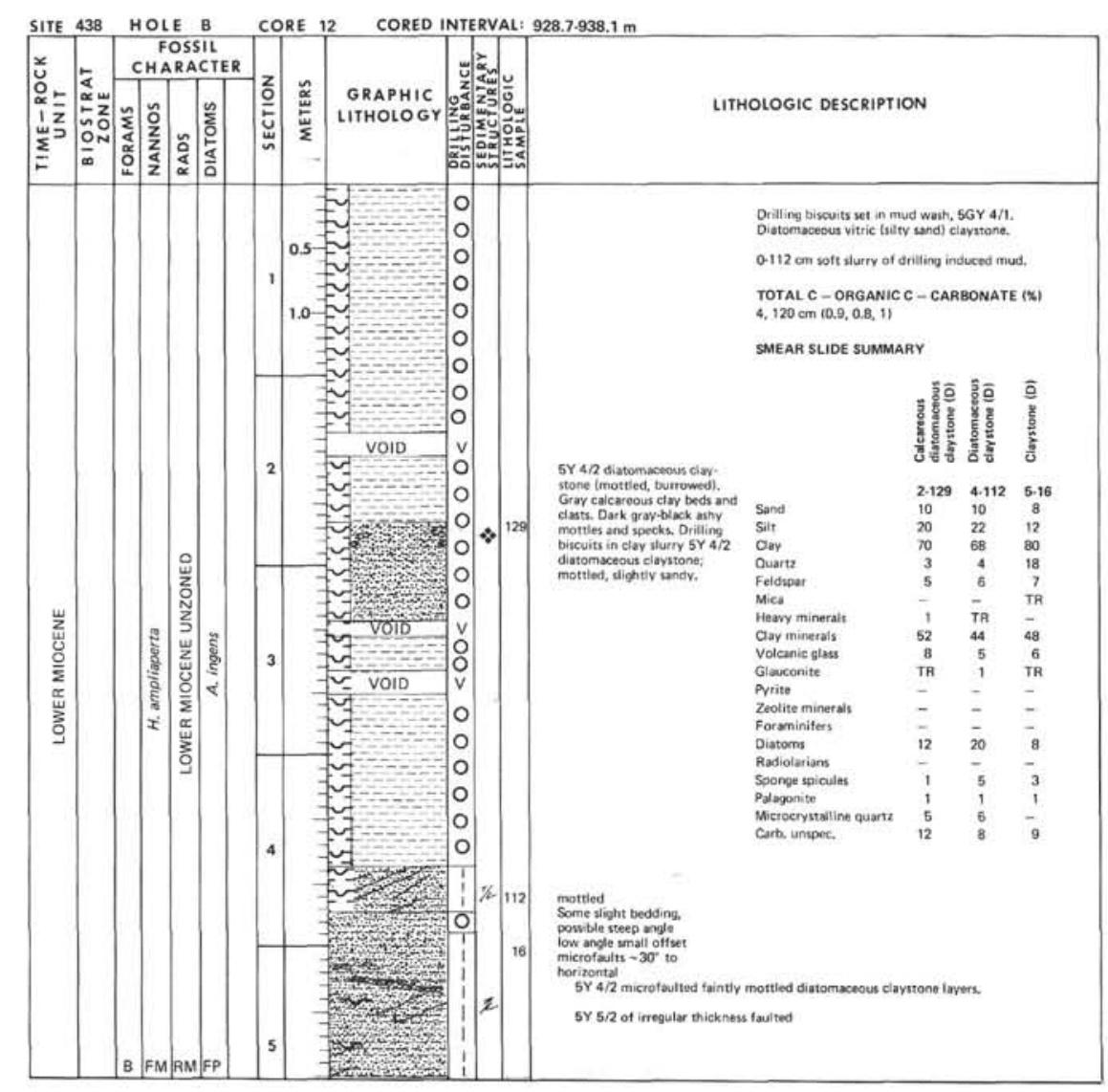

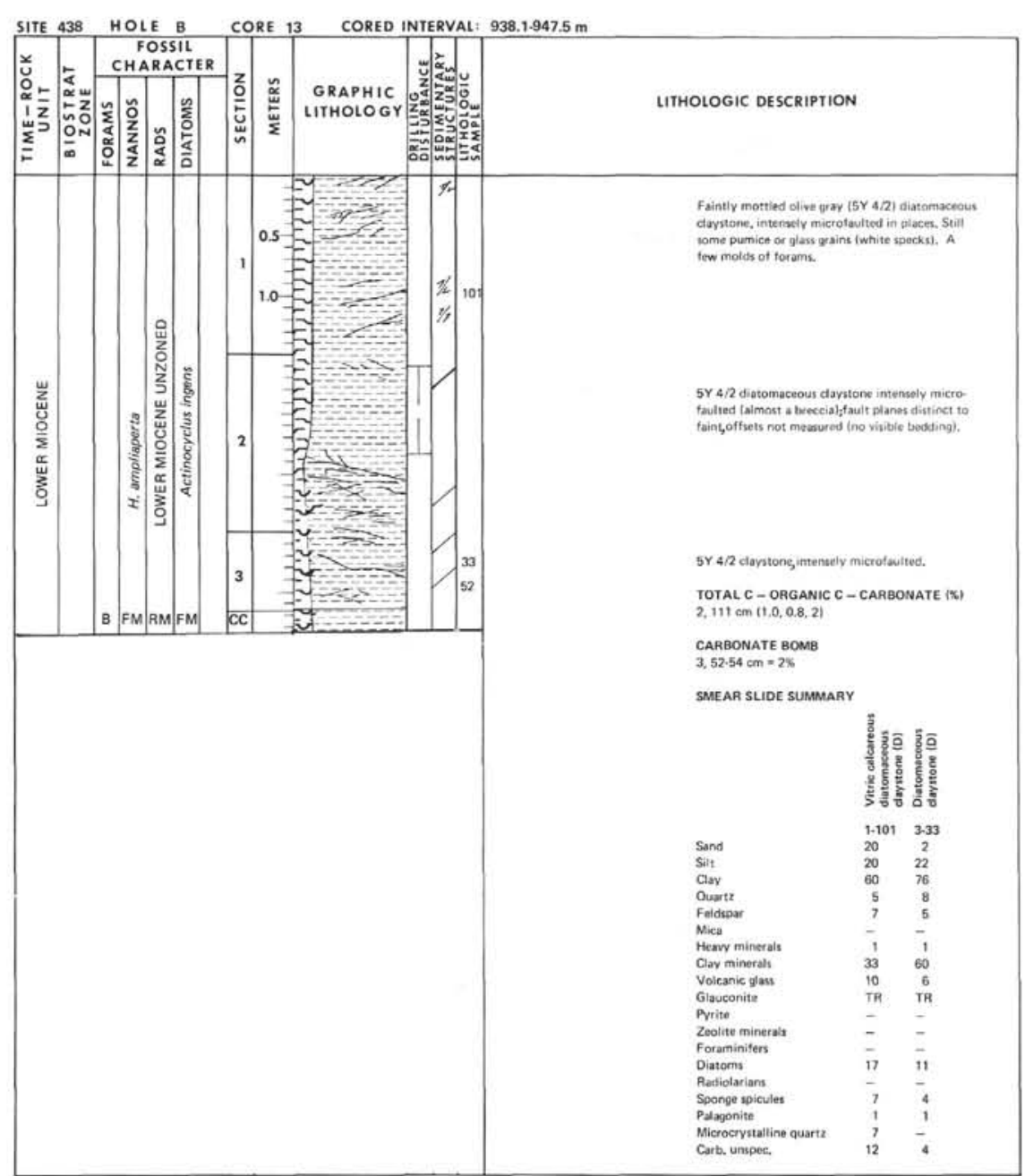




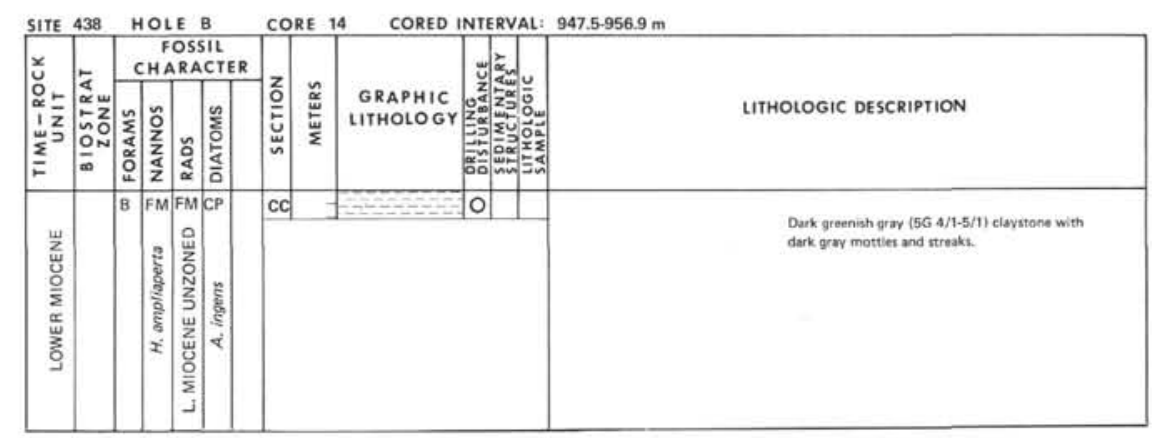

SITE 43B HOLE B CORE 15 CORED INTERVAL: $956.9 .966 .3 \mathrm{~m}$

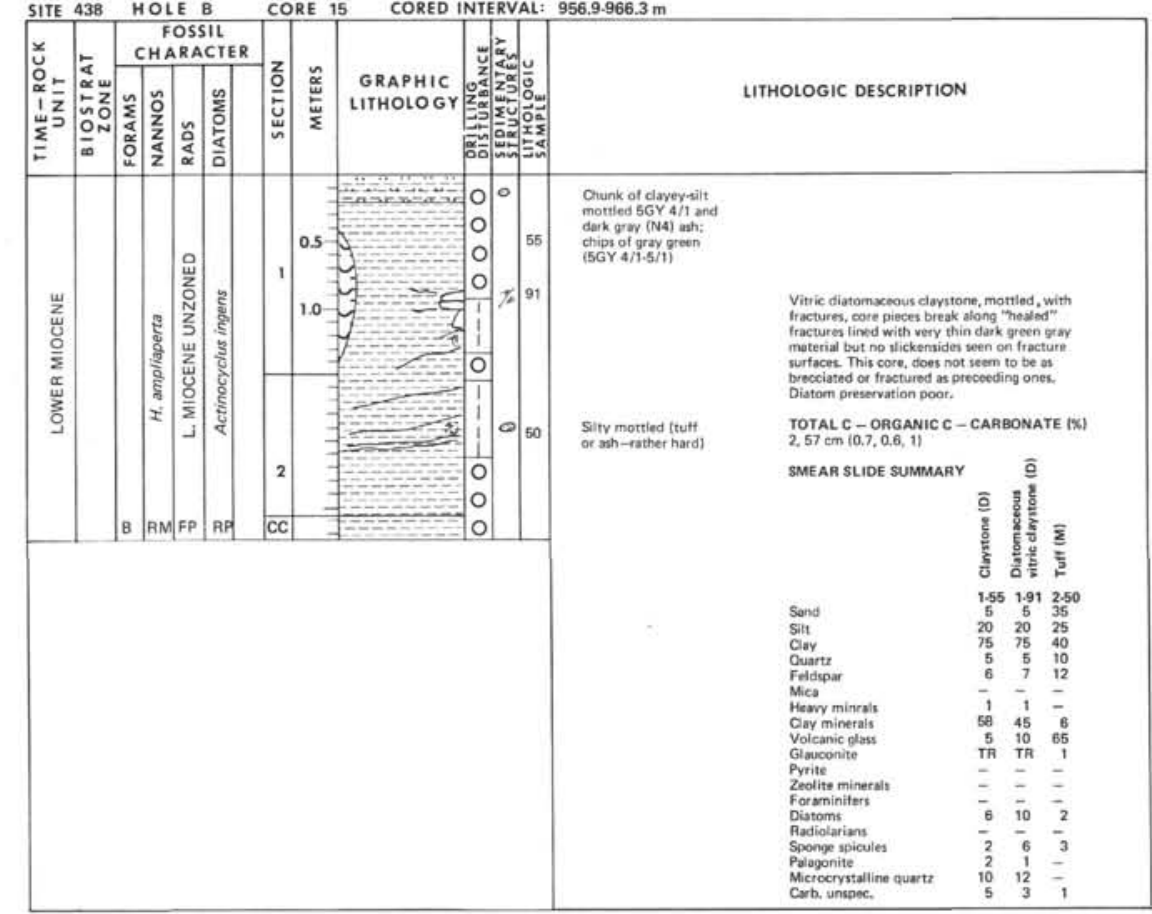

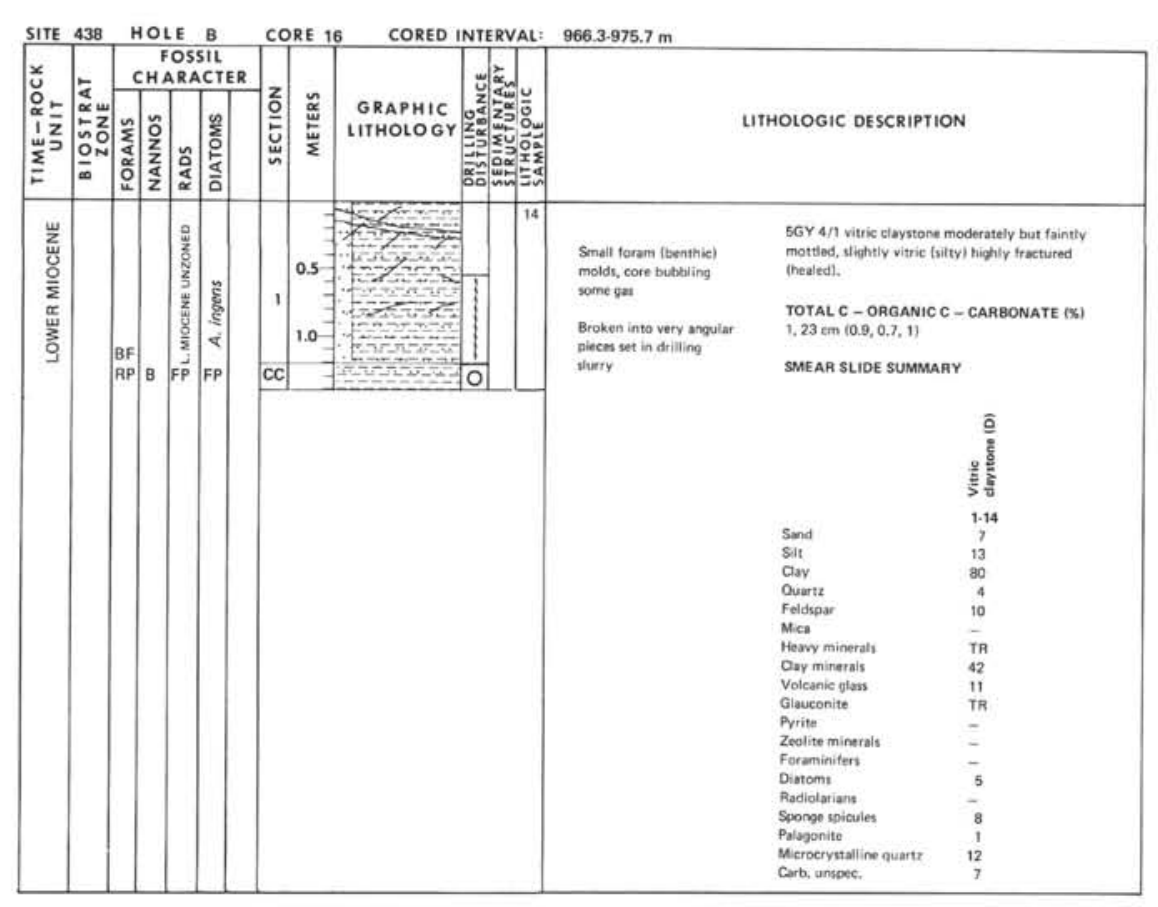



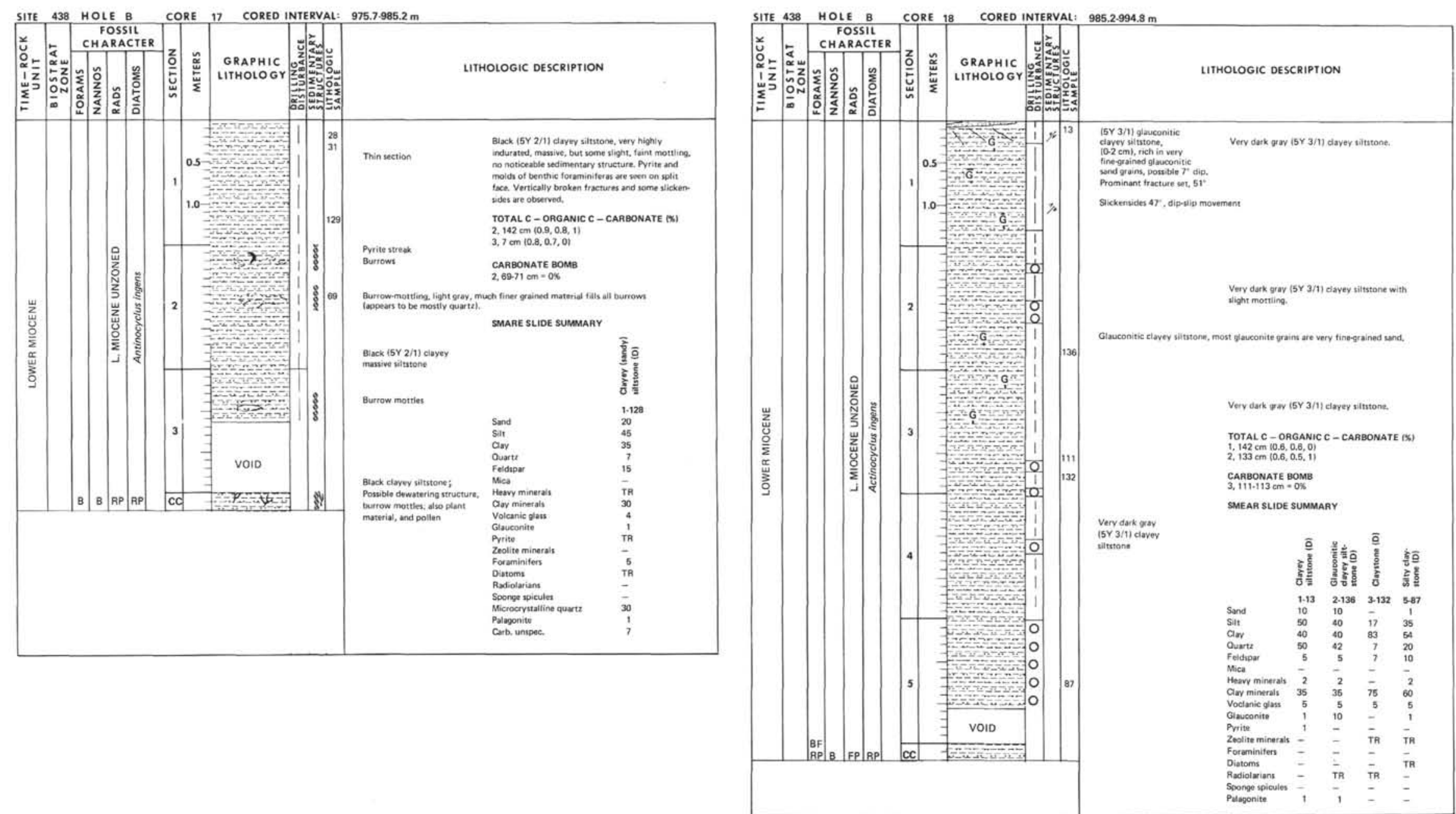

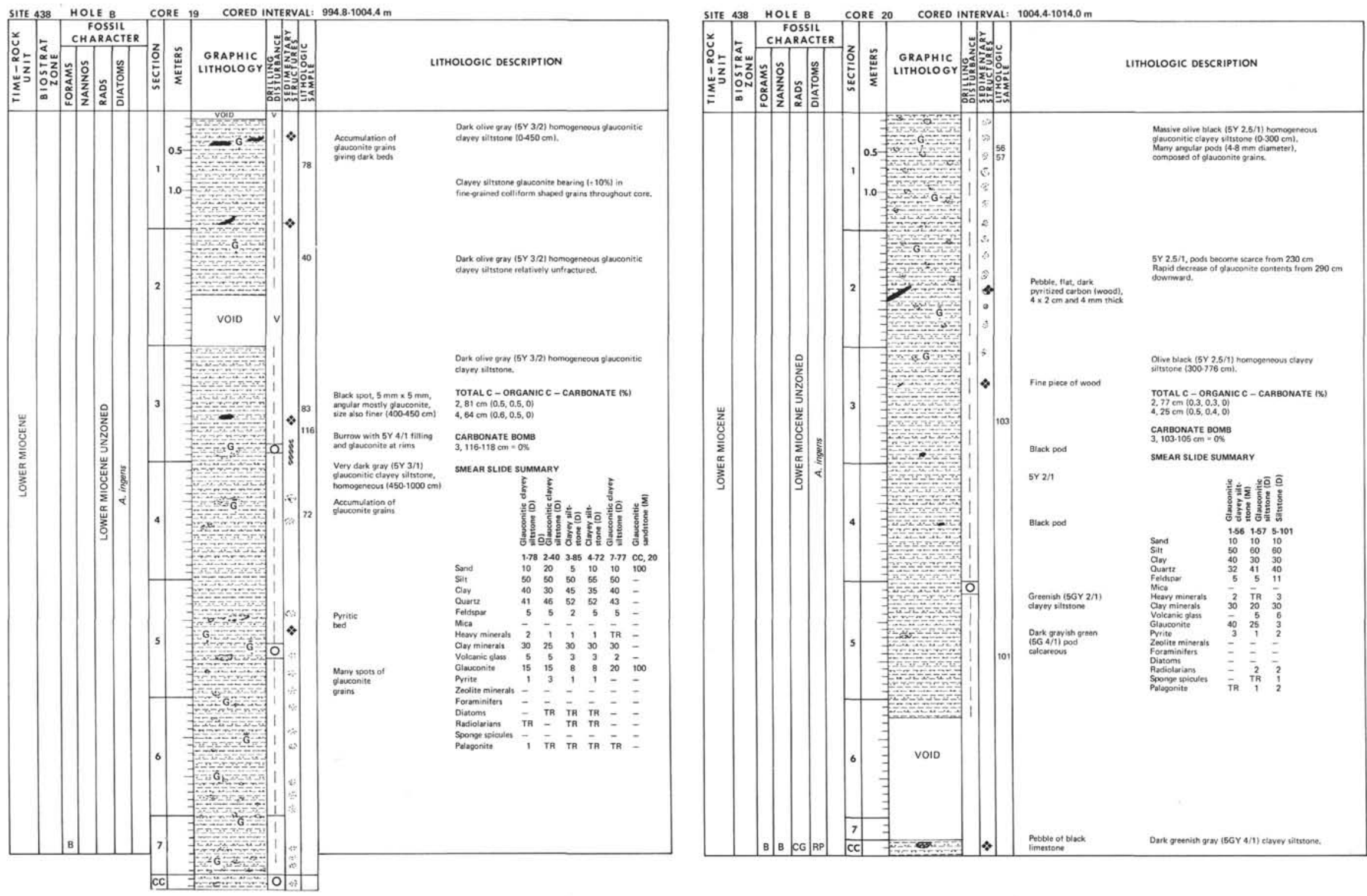

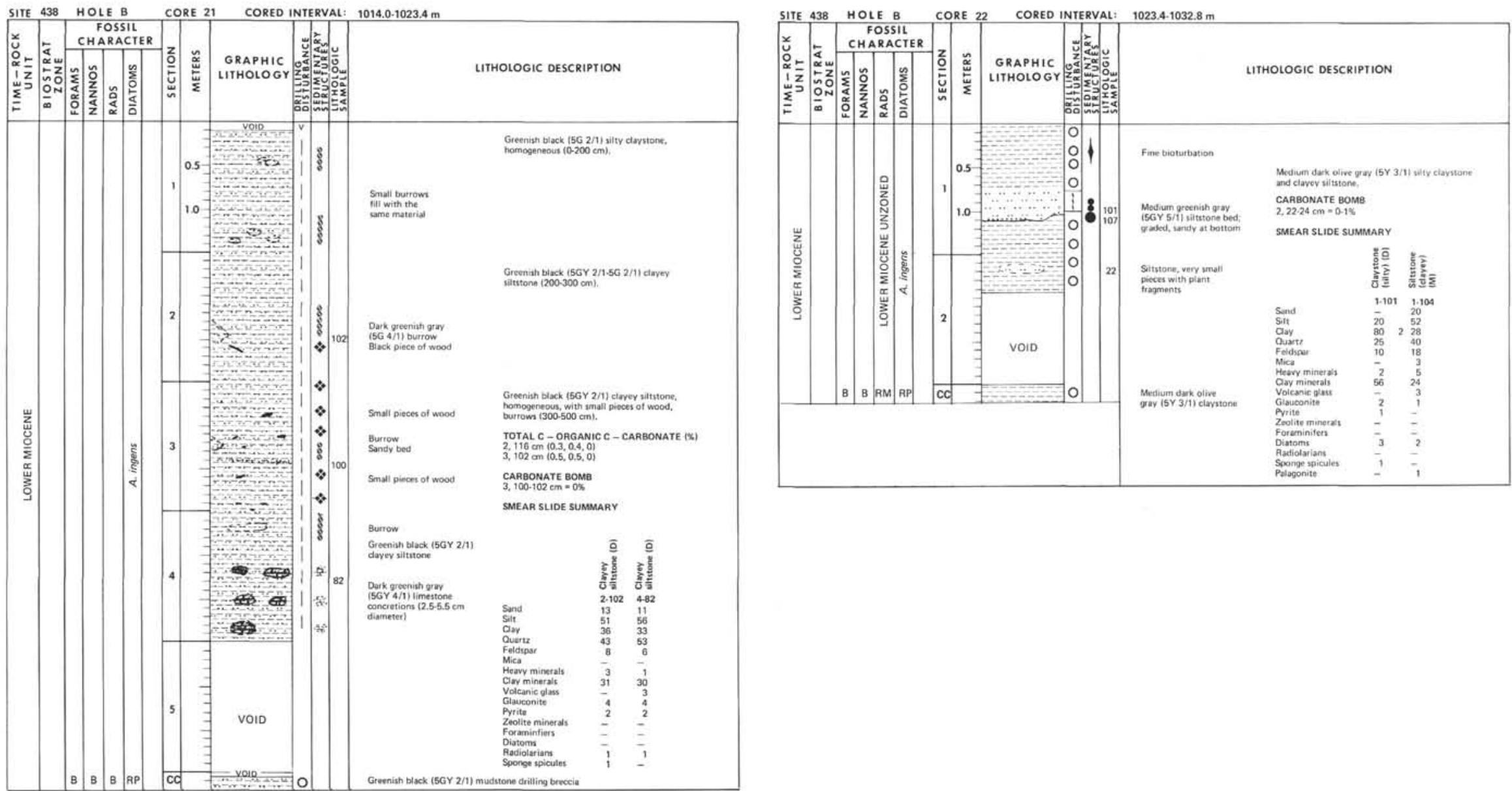


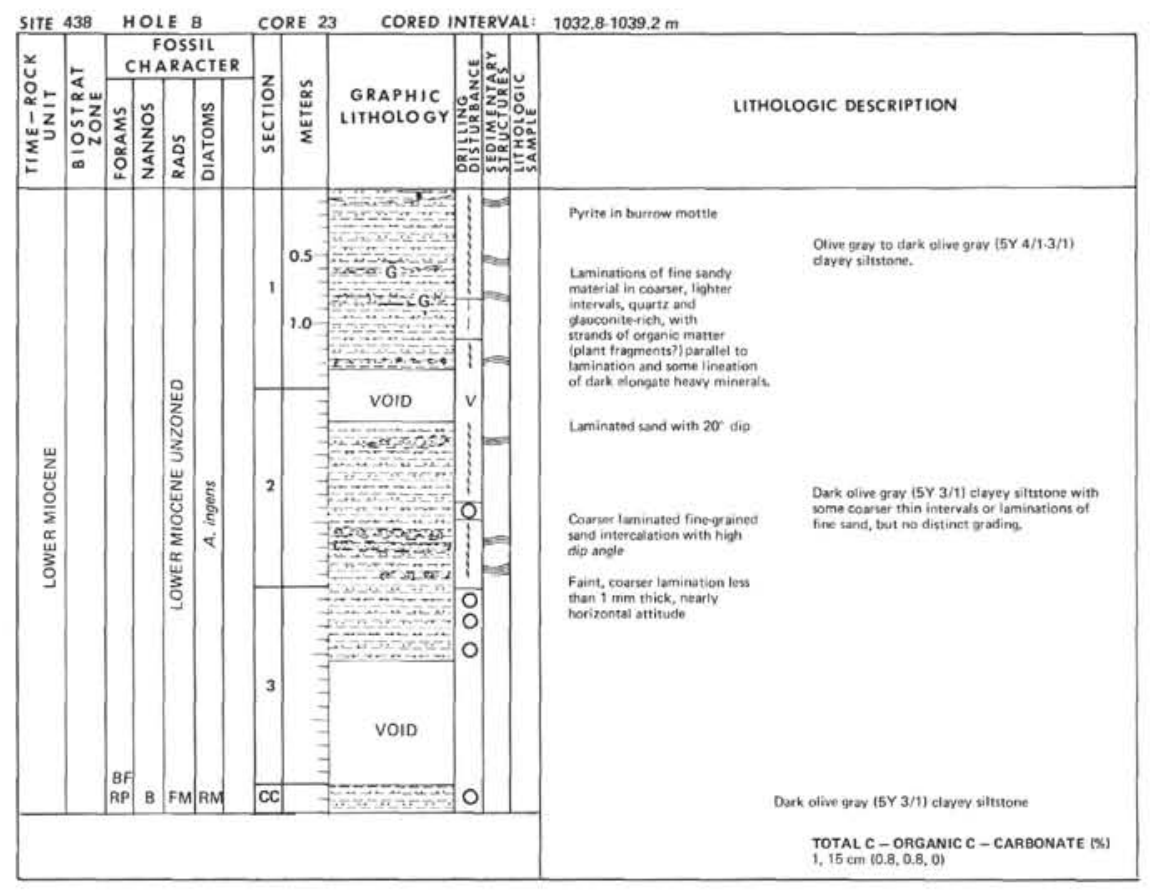

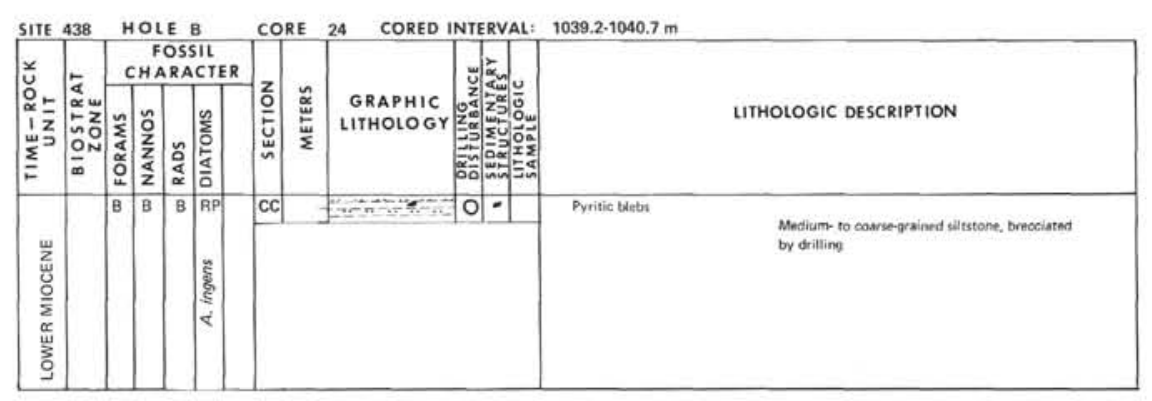



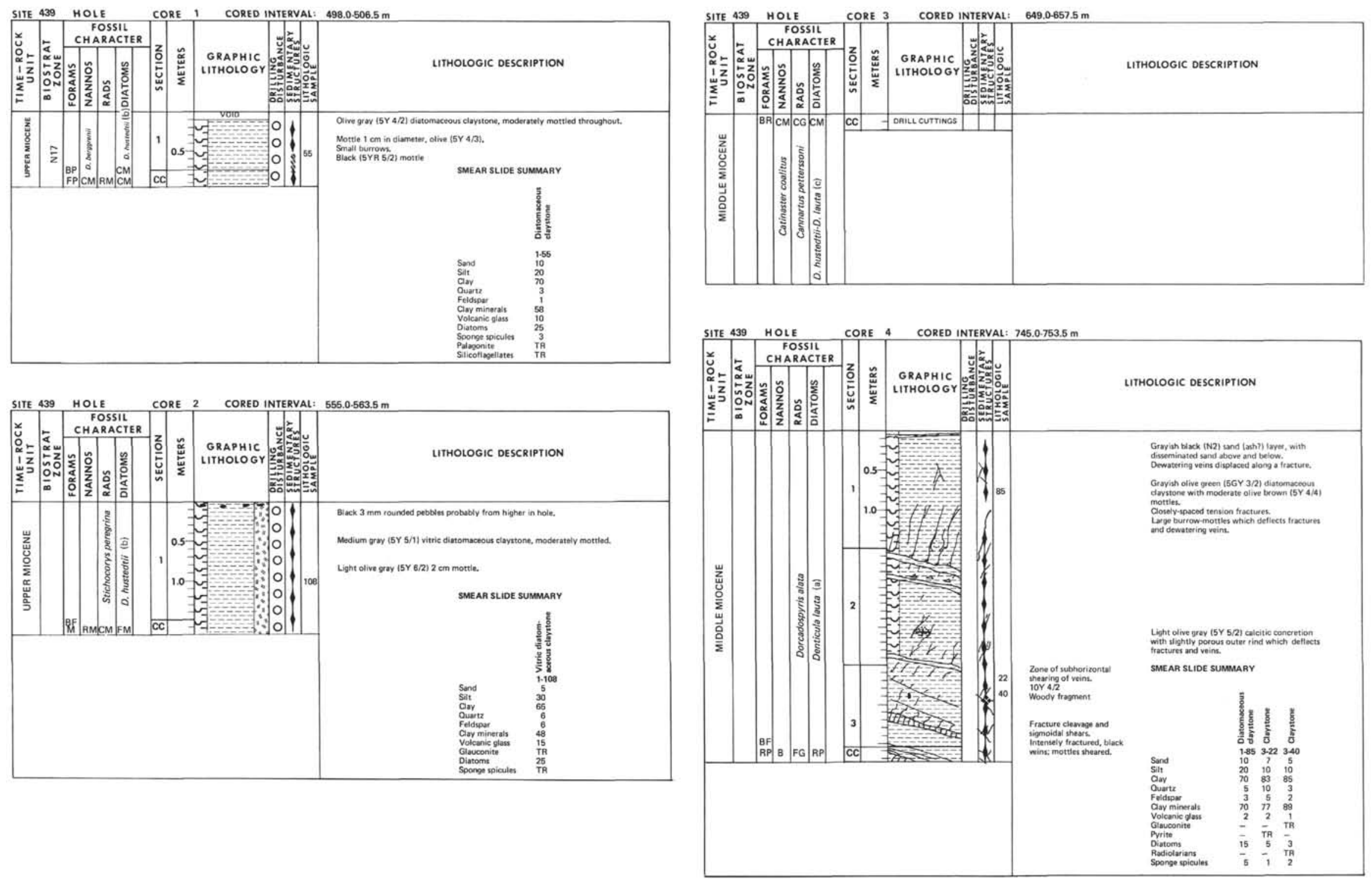


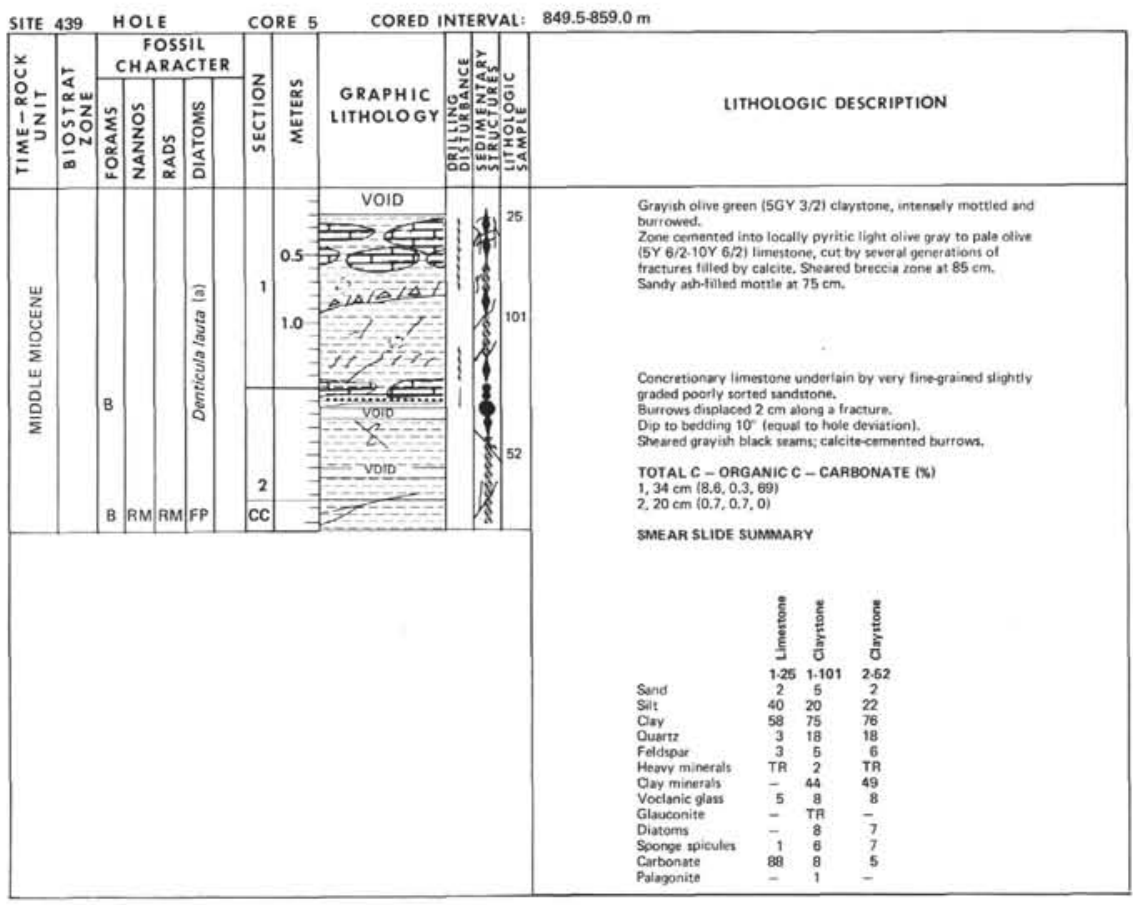

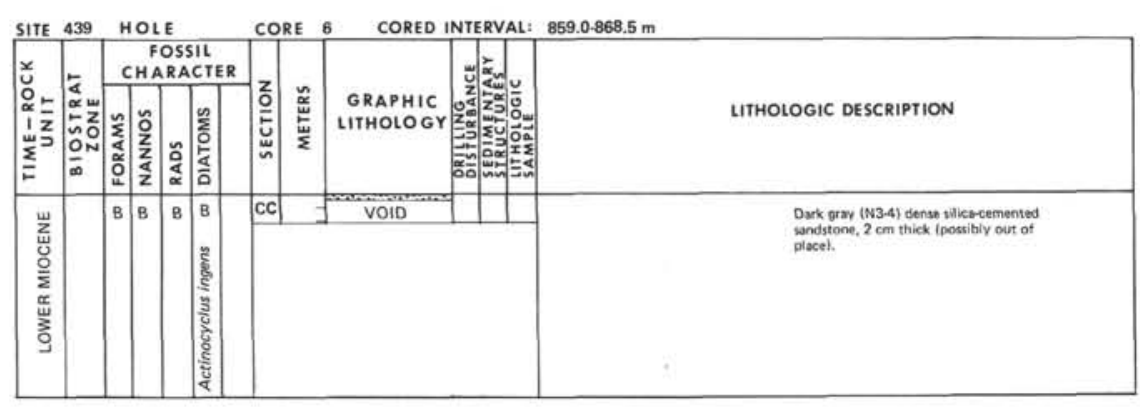

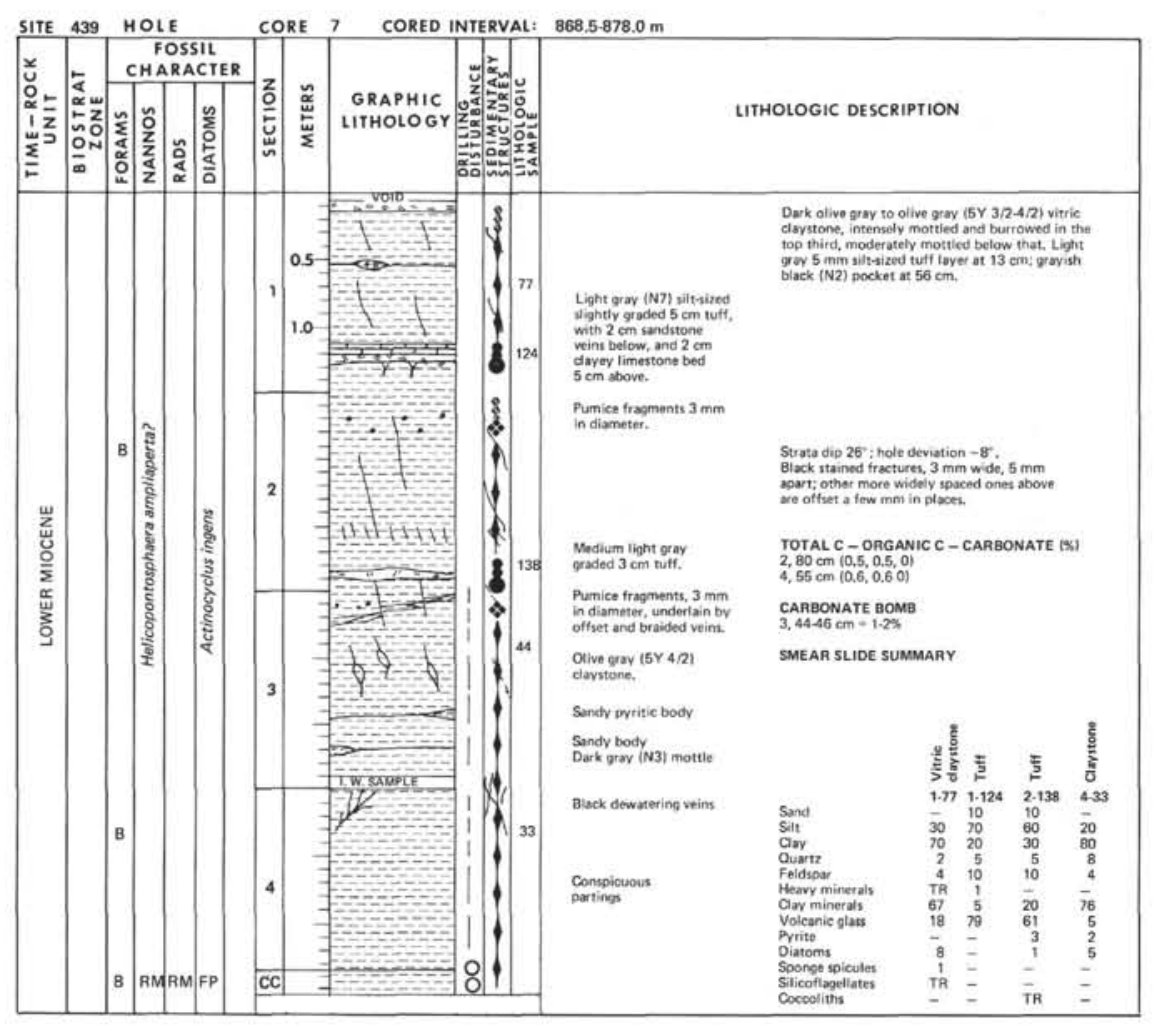



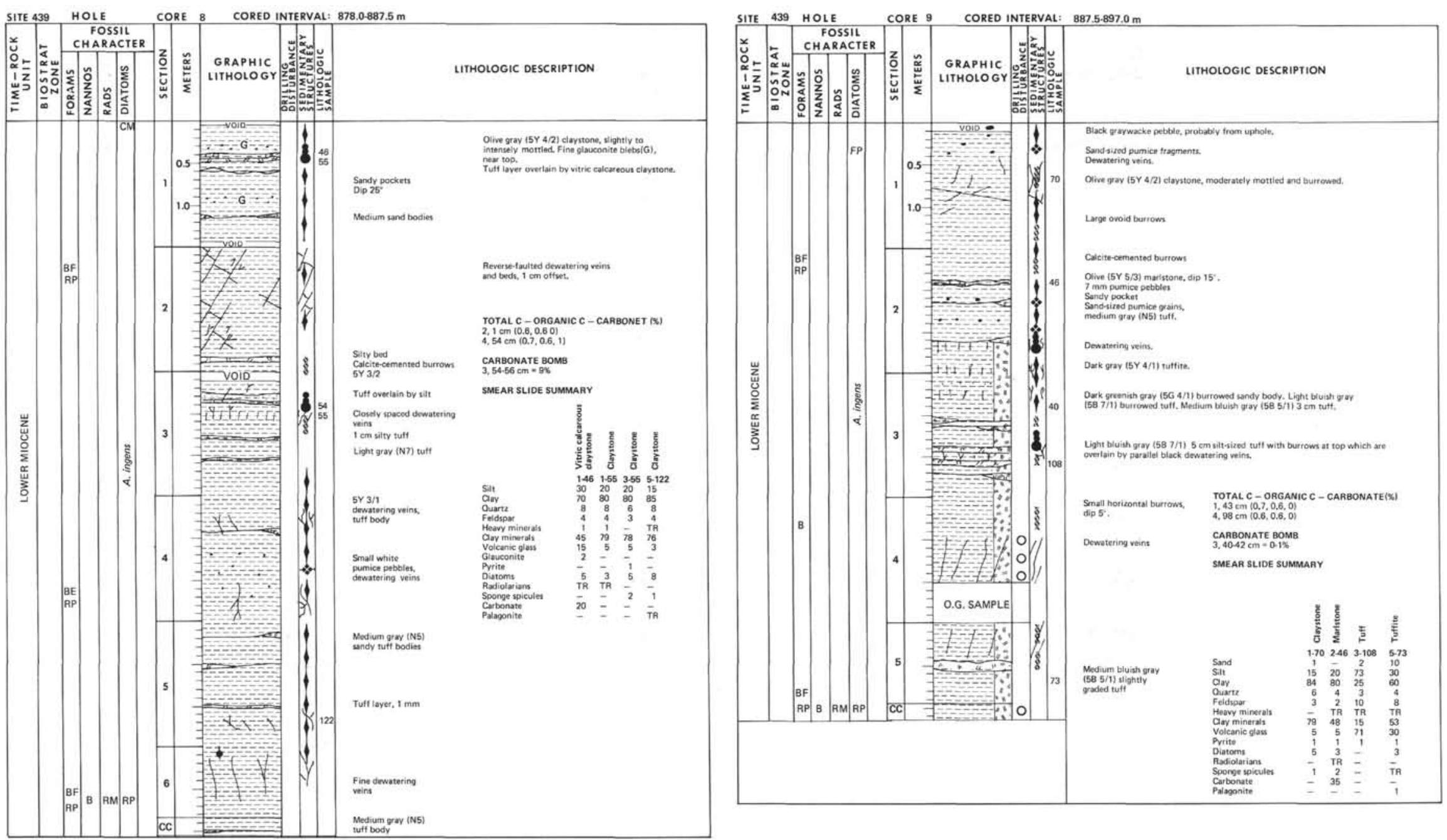

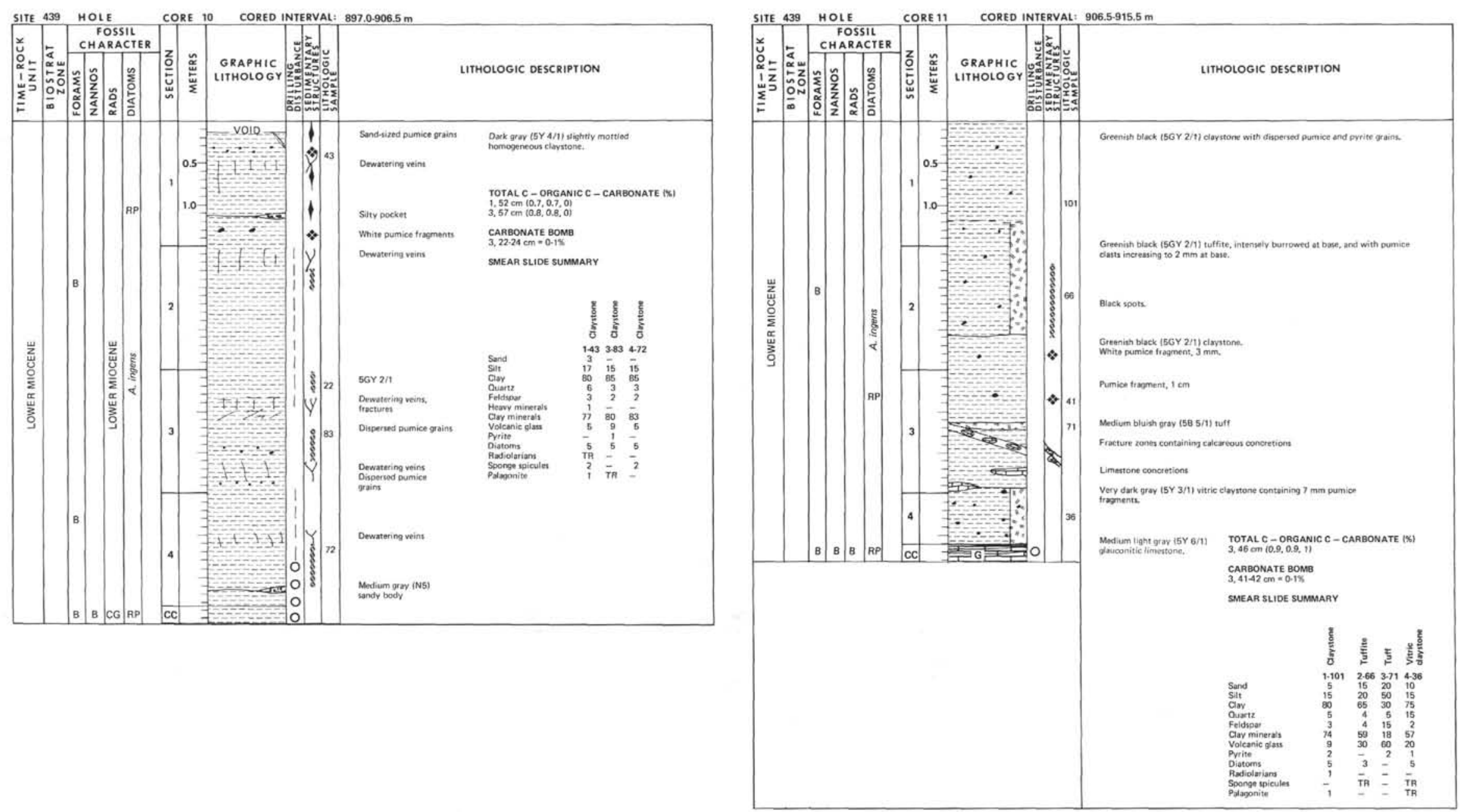

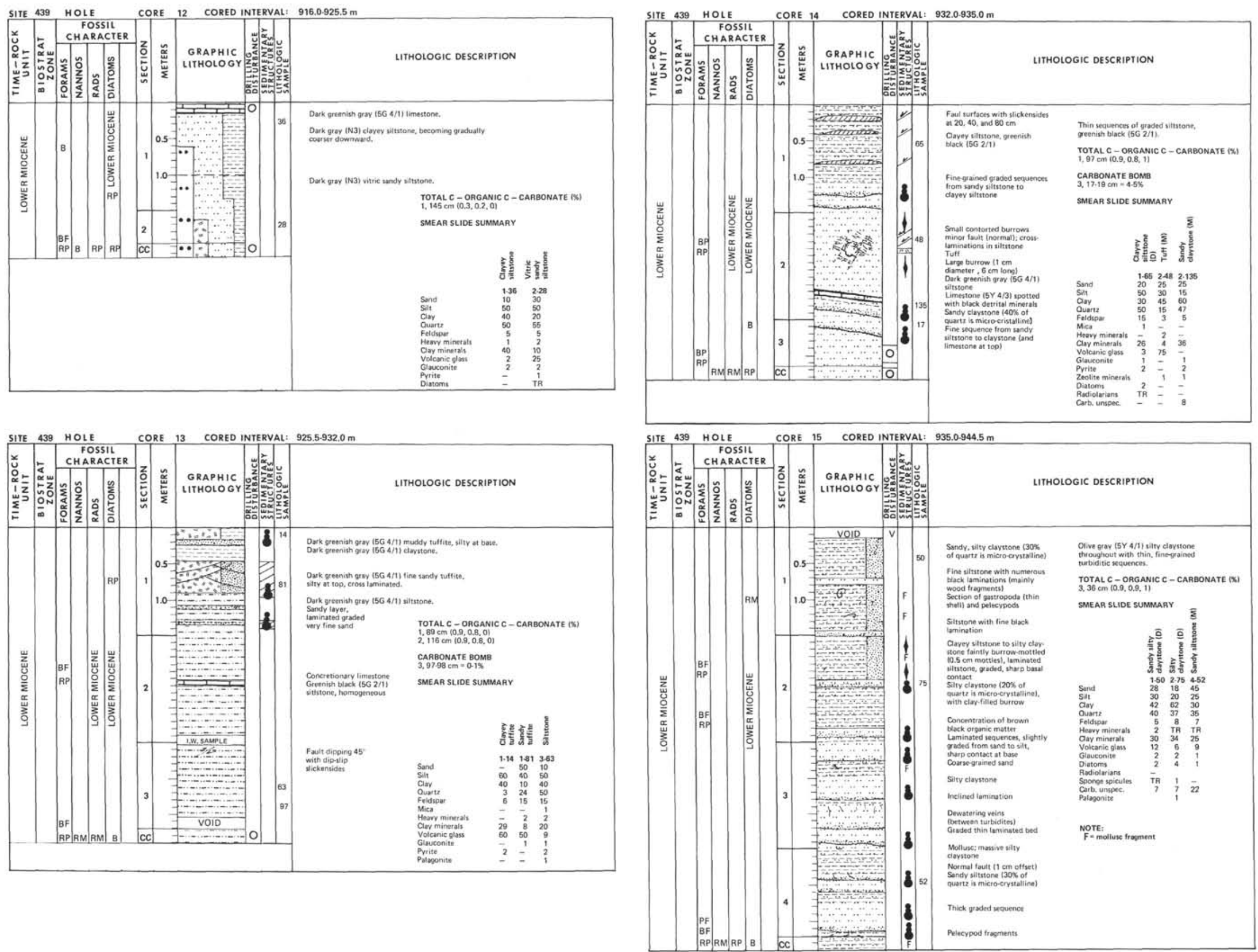

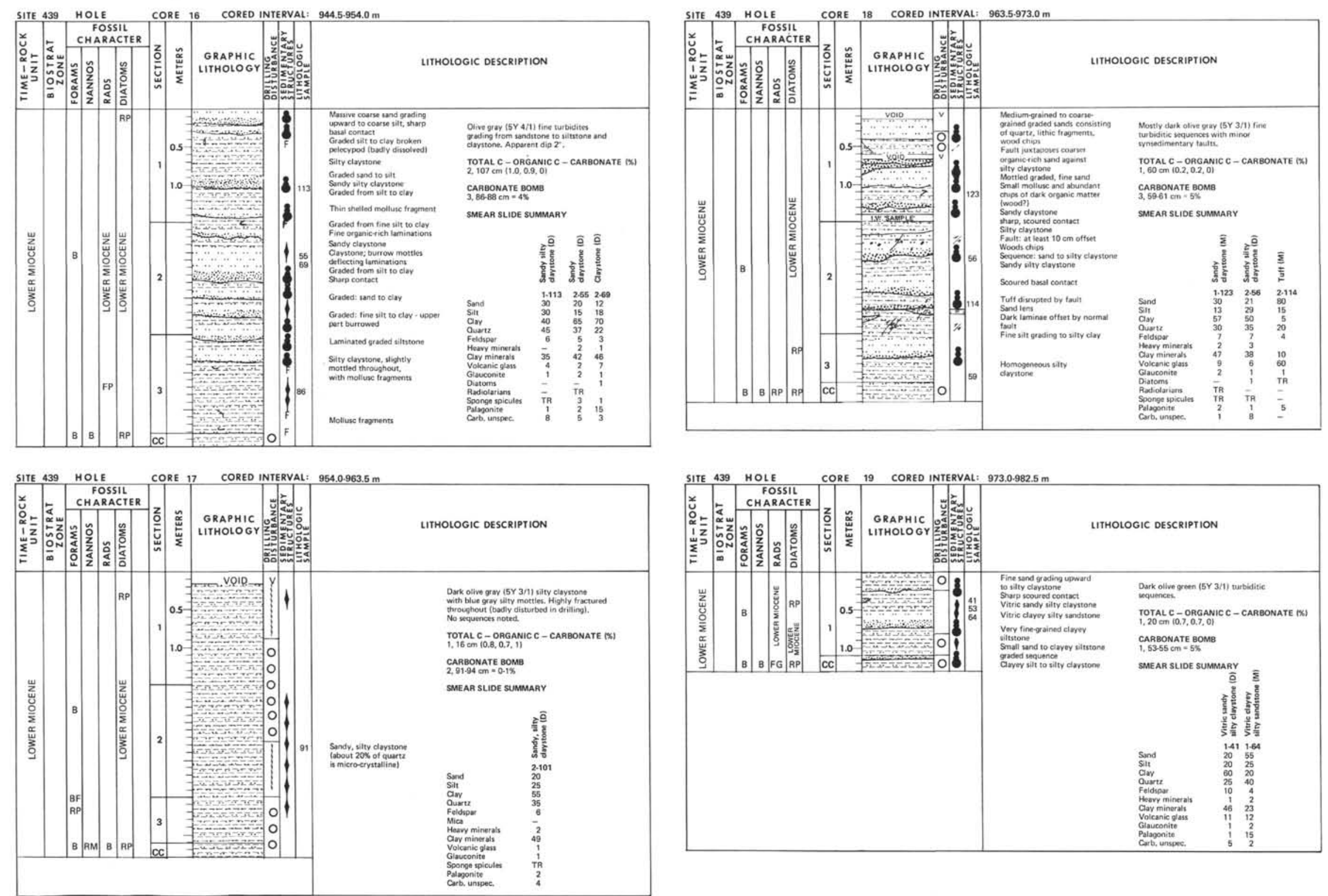

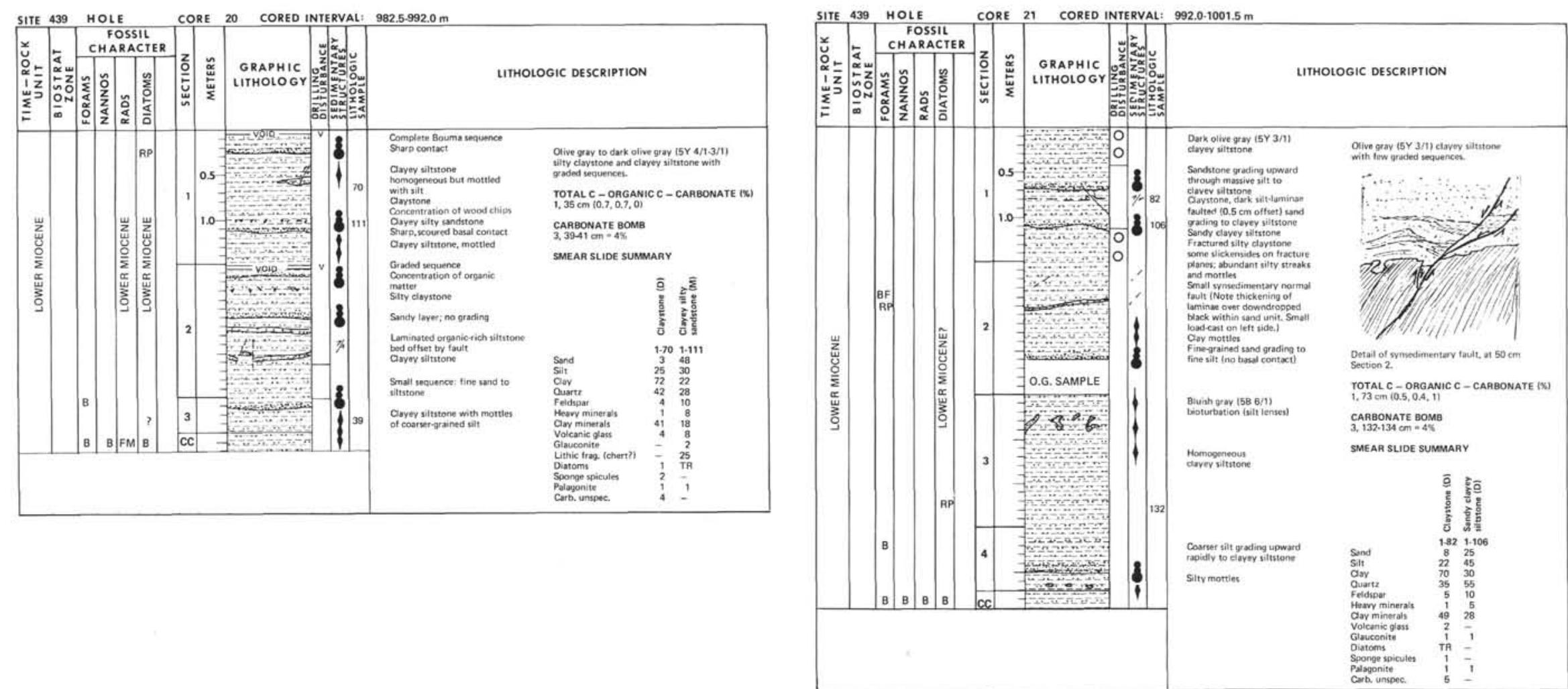


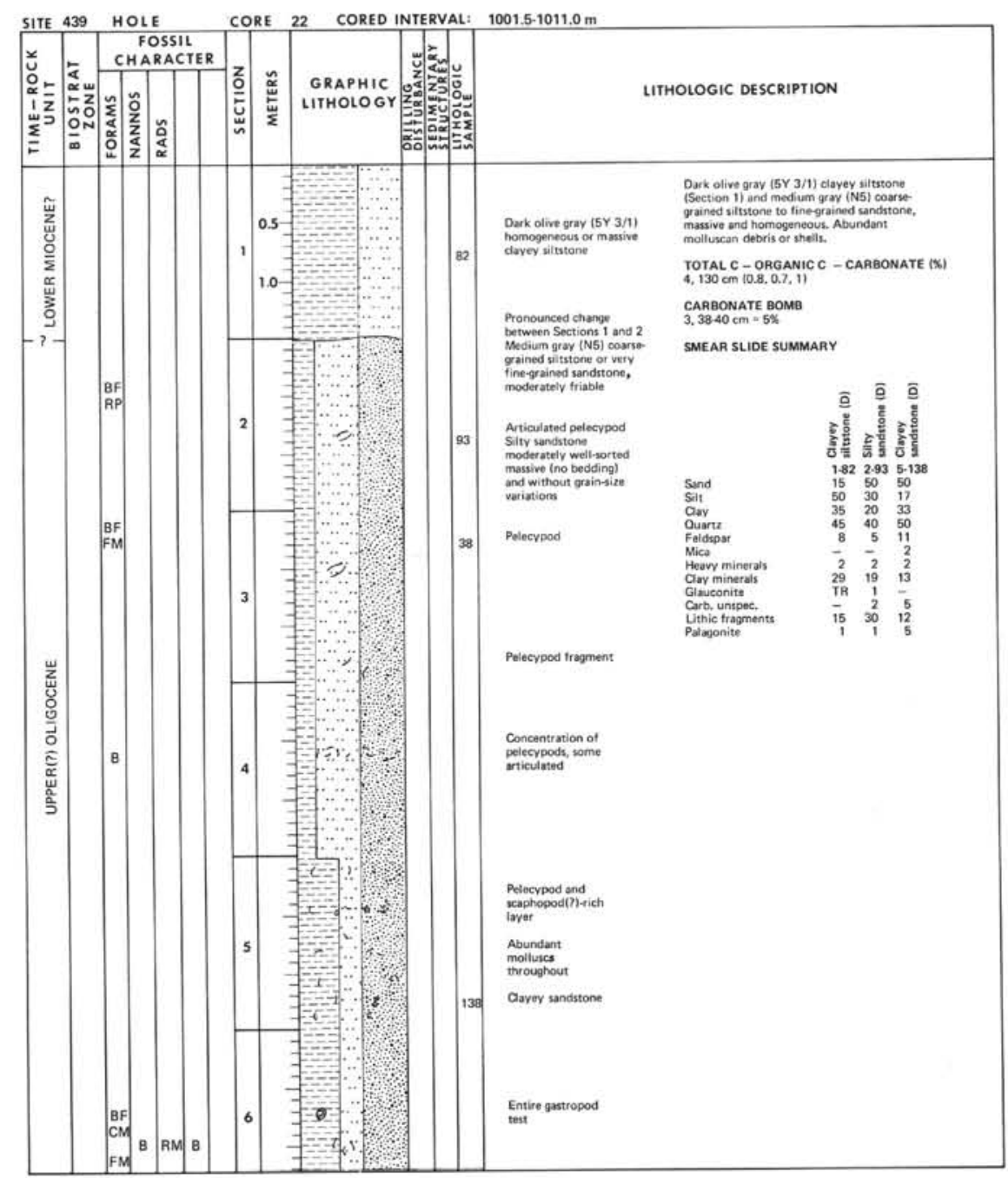

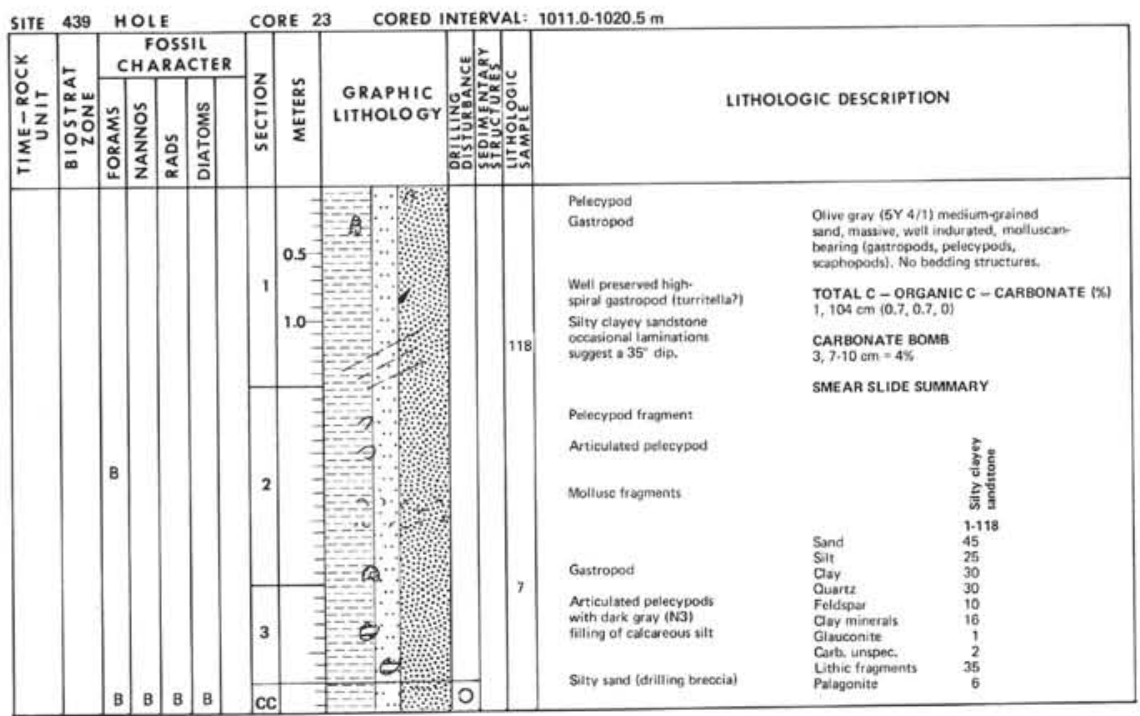



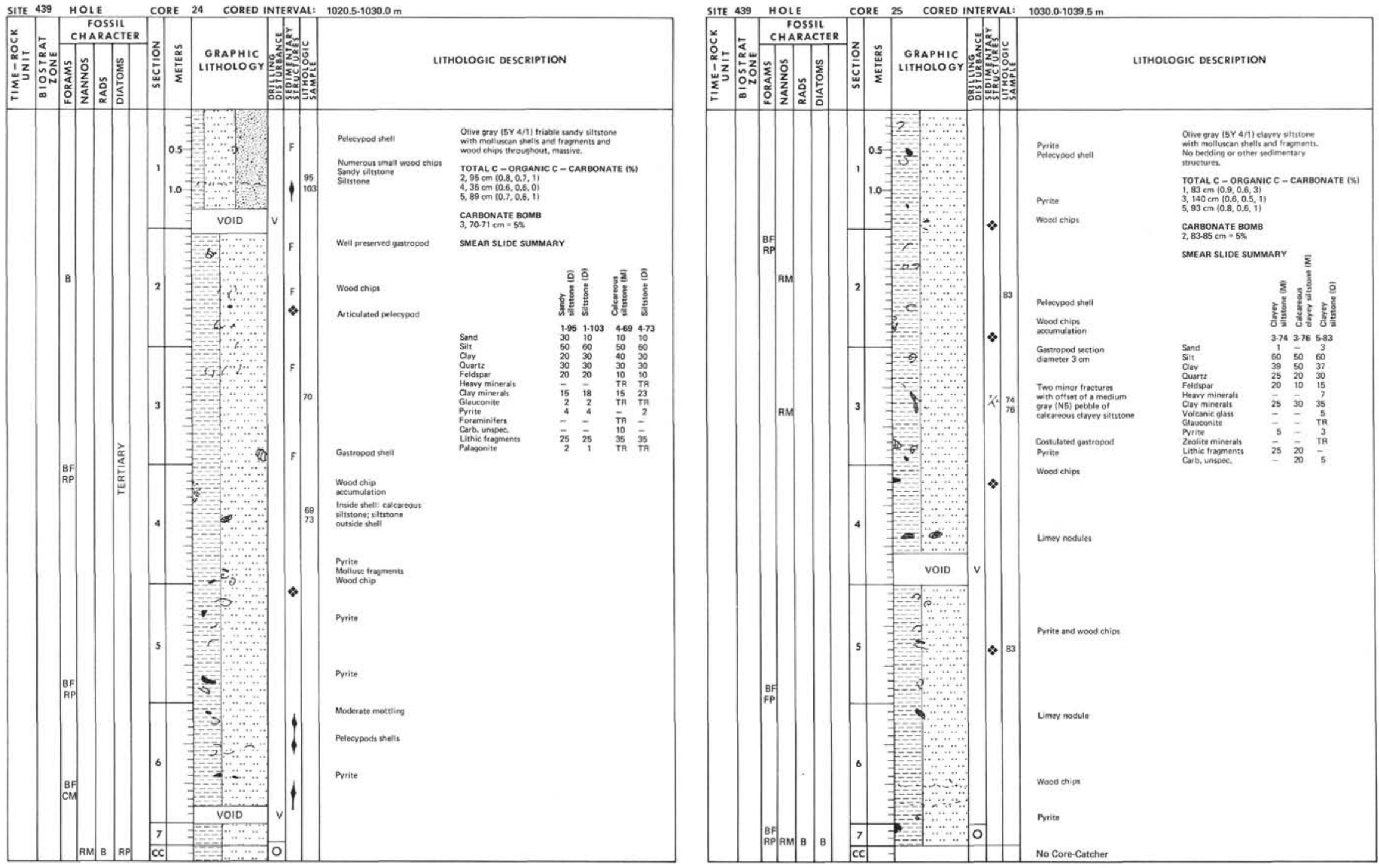


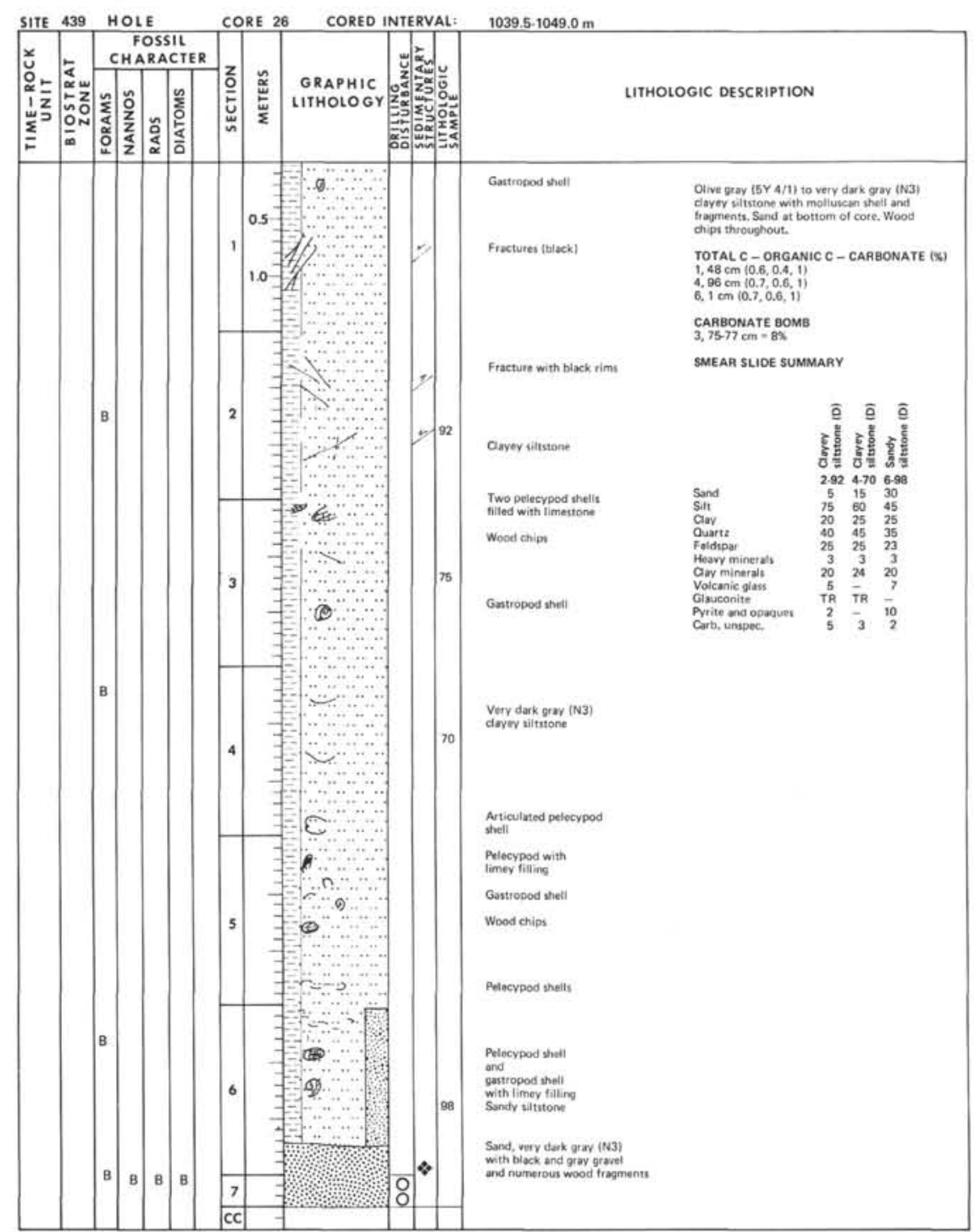

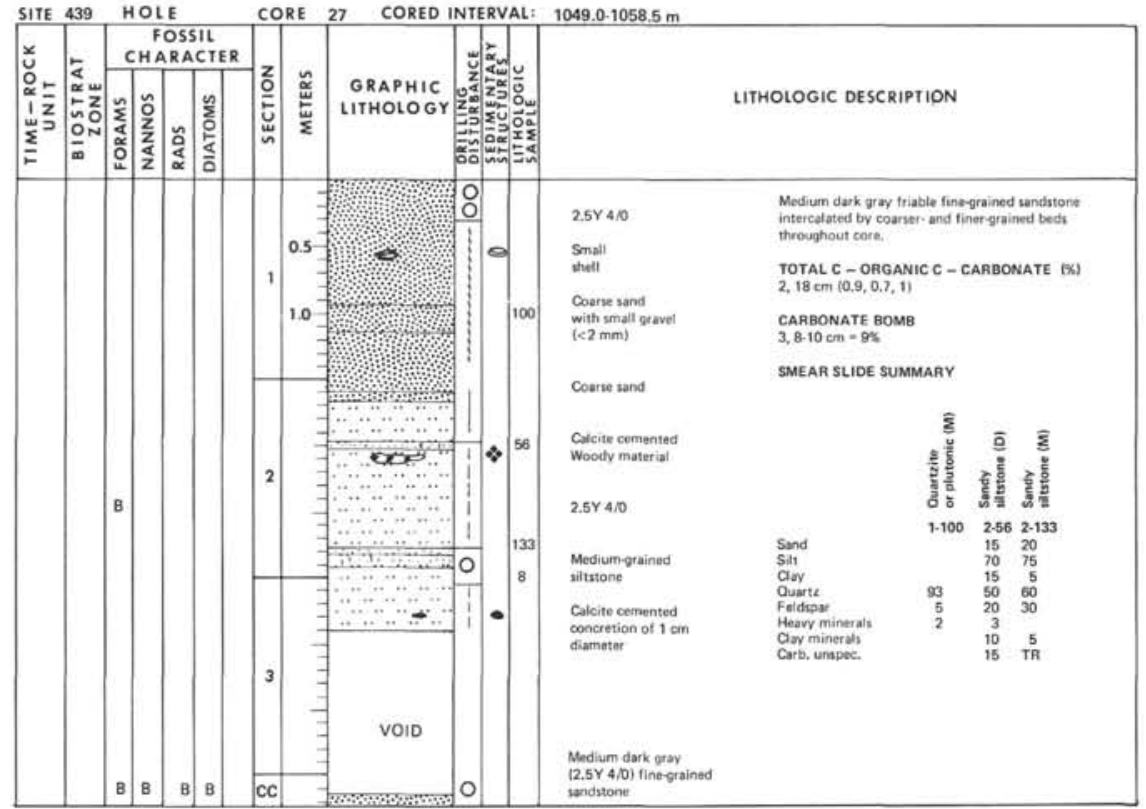



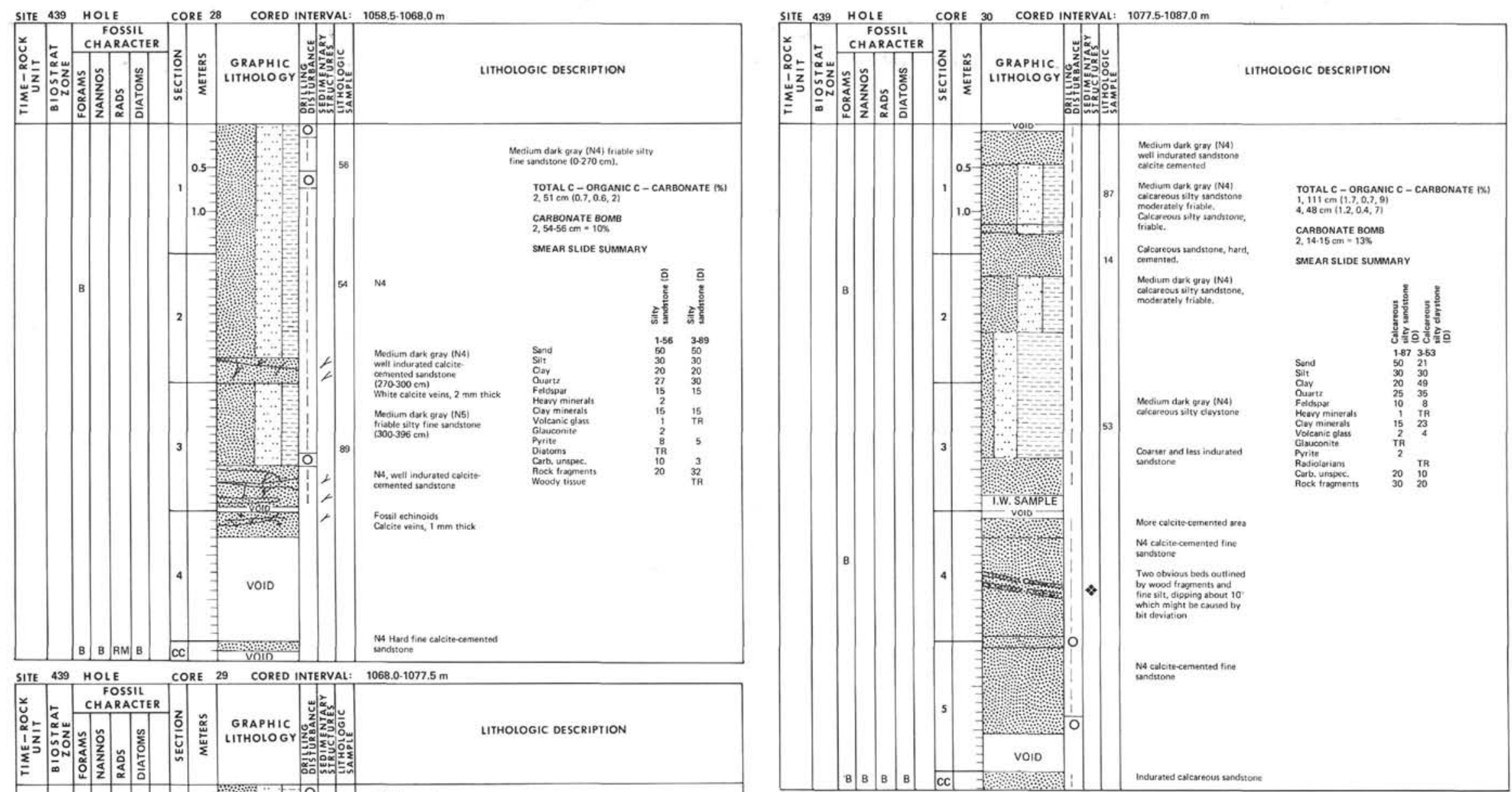

SIIE 439 HOLE CORE 29 CORED INTERVAL: $1068.0 .1077 .5 \mathrm{~m}$

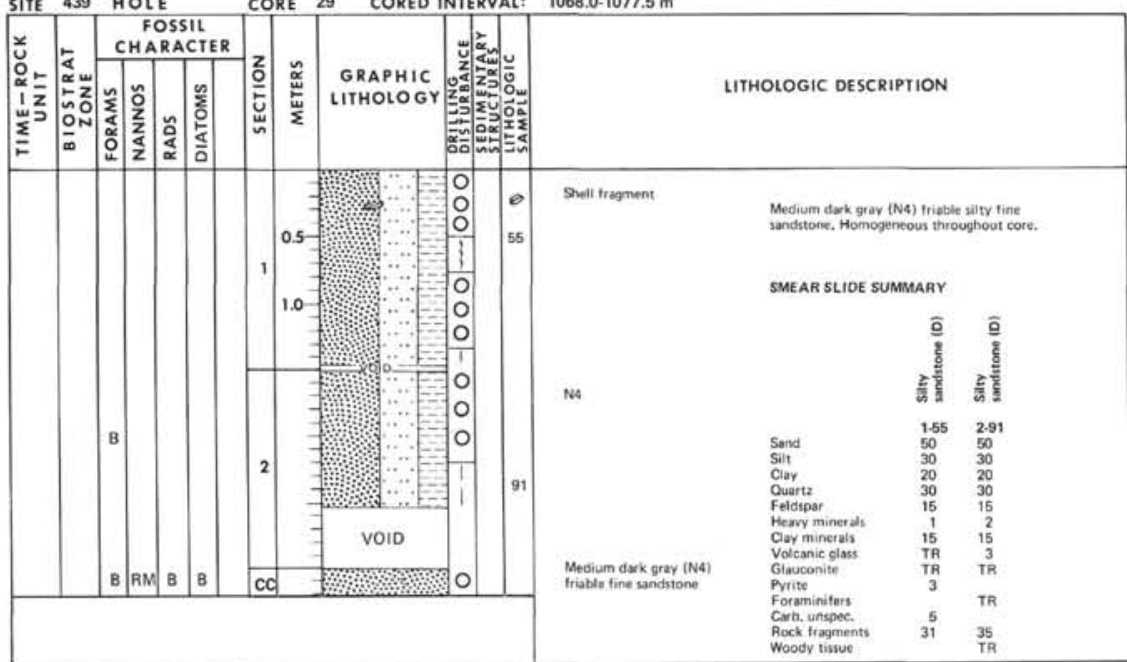




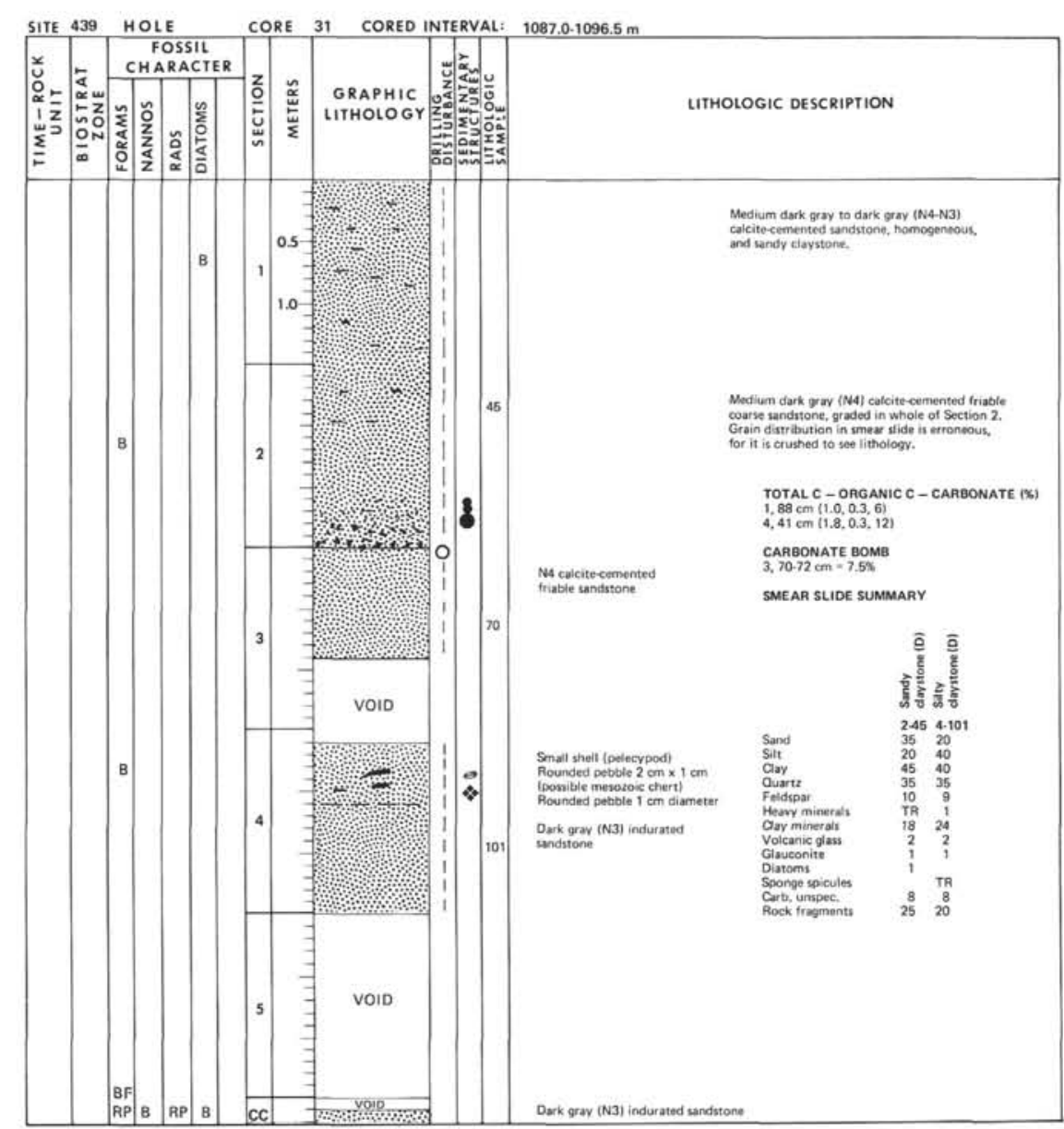

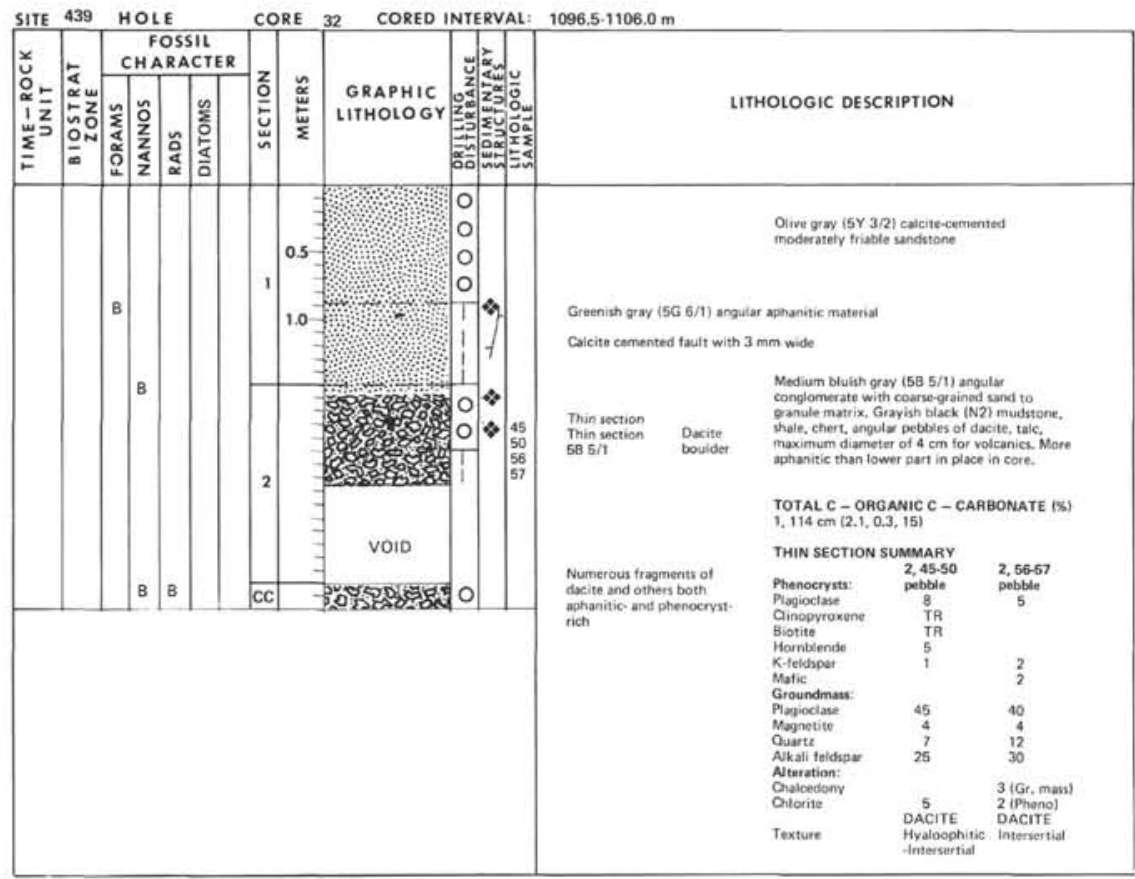

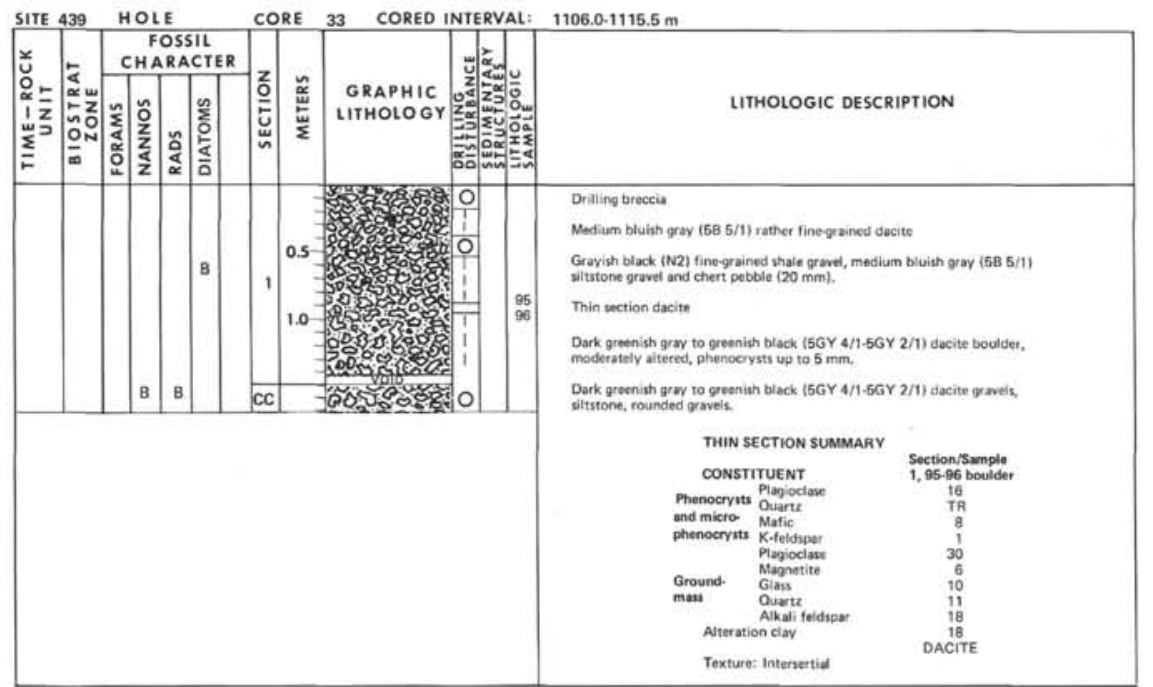



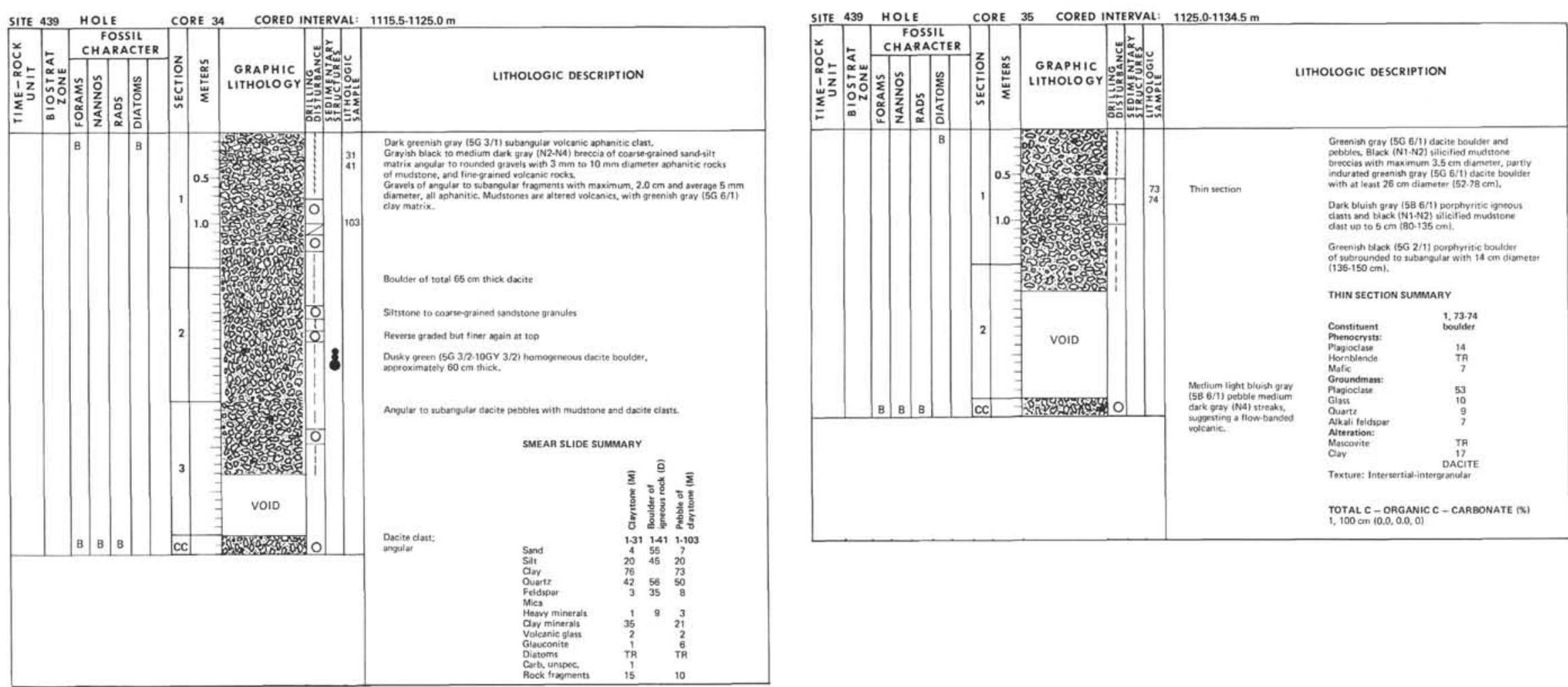

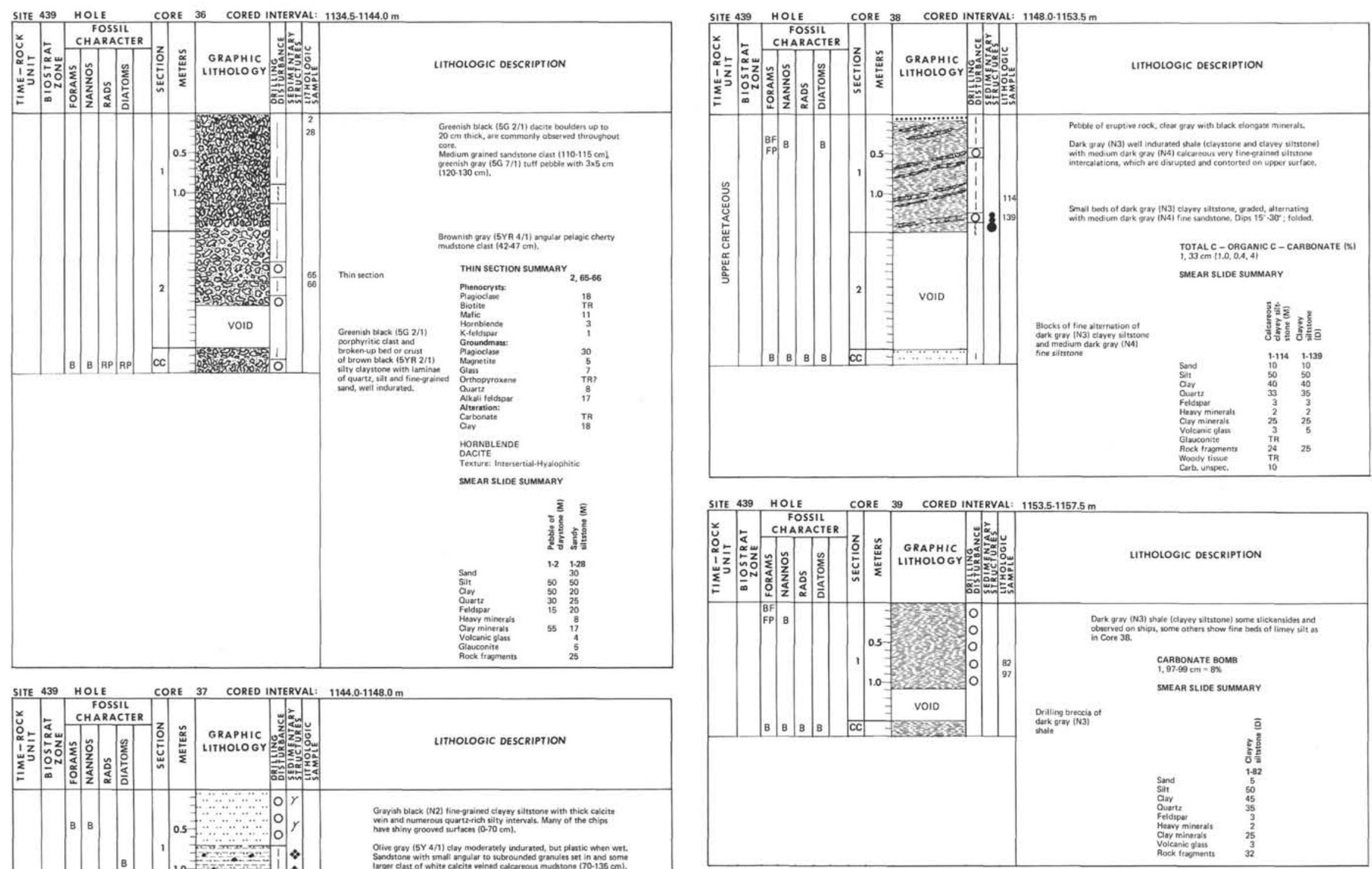

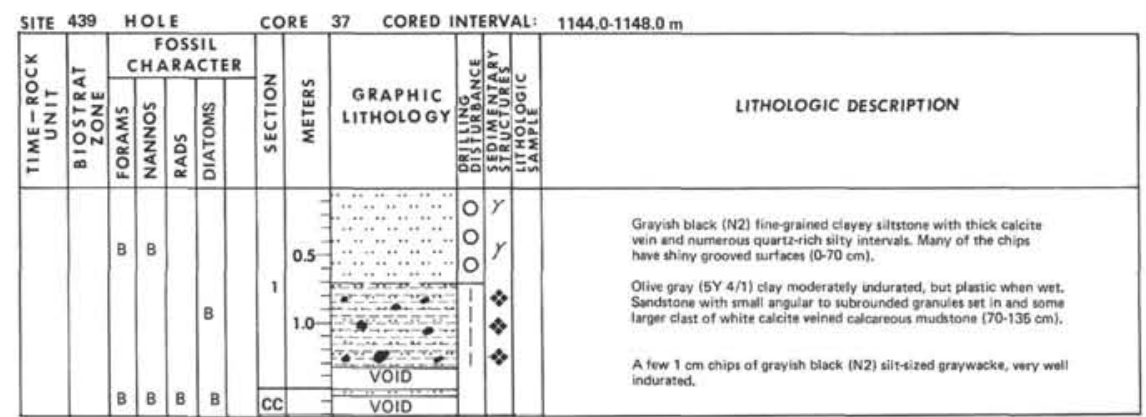


Site 438

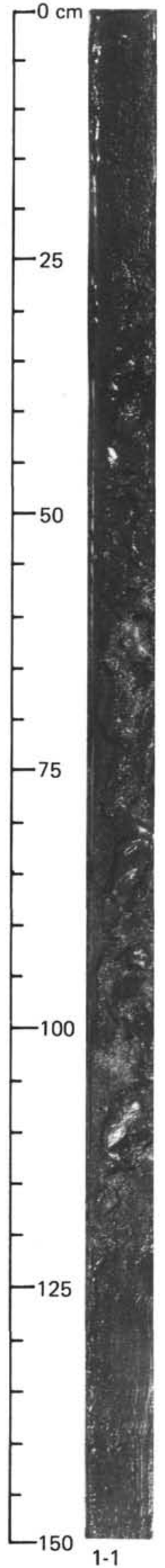

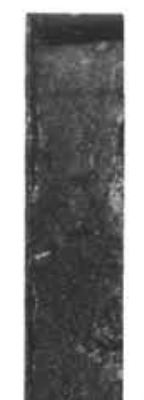

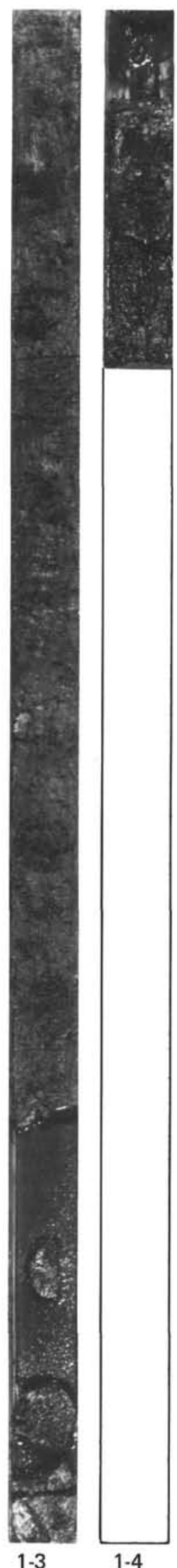

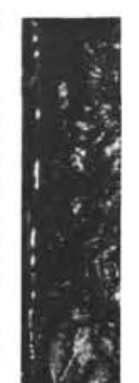
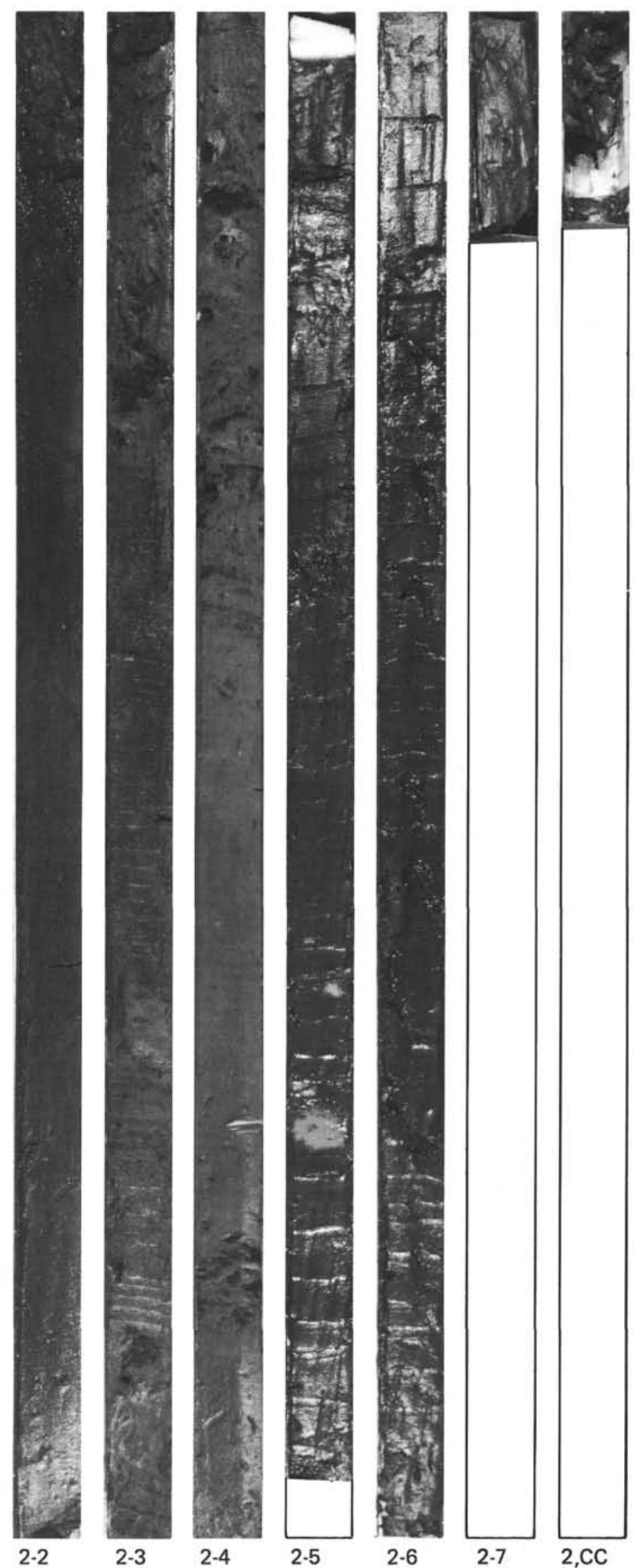
Site 438
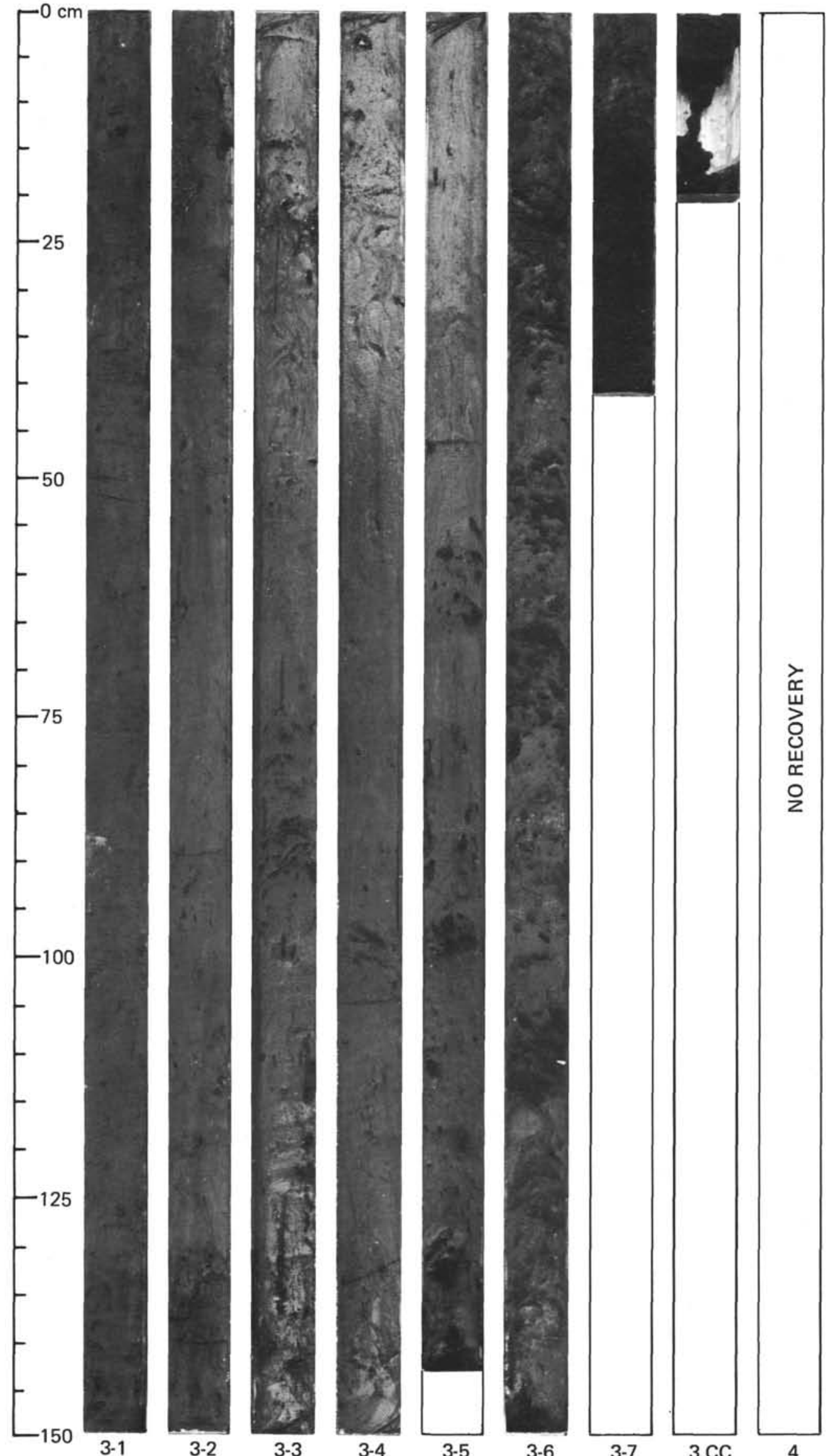

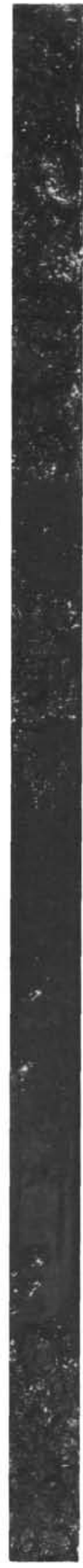

5-1
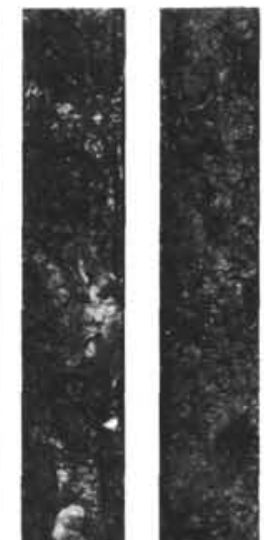

3

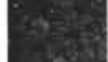

tas

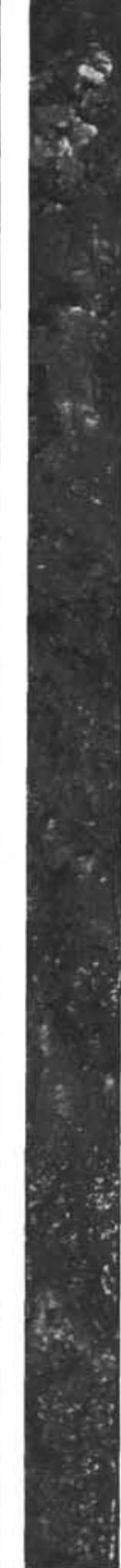

5-2

5-3 
Site 438

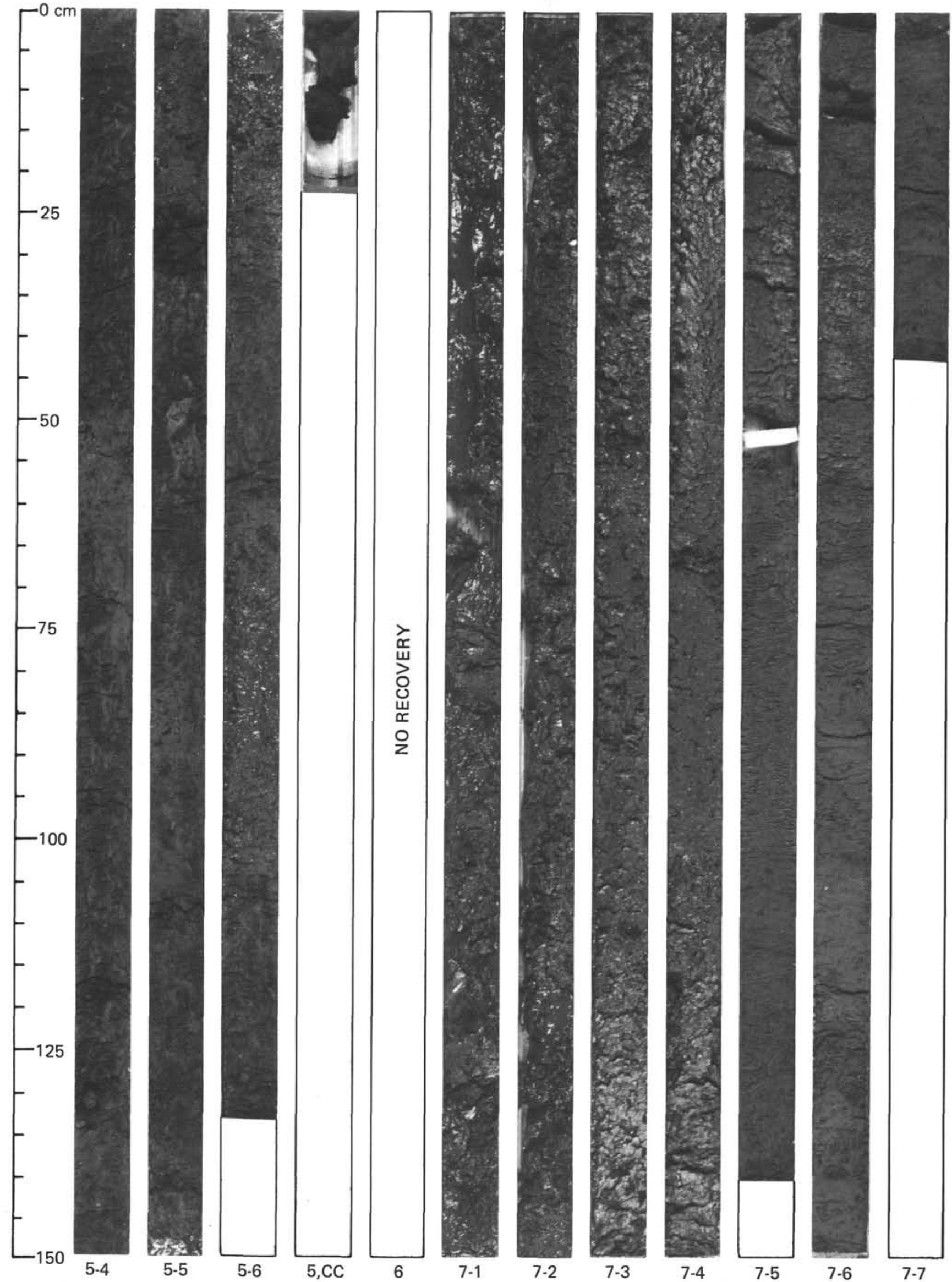




\section{Site 438}
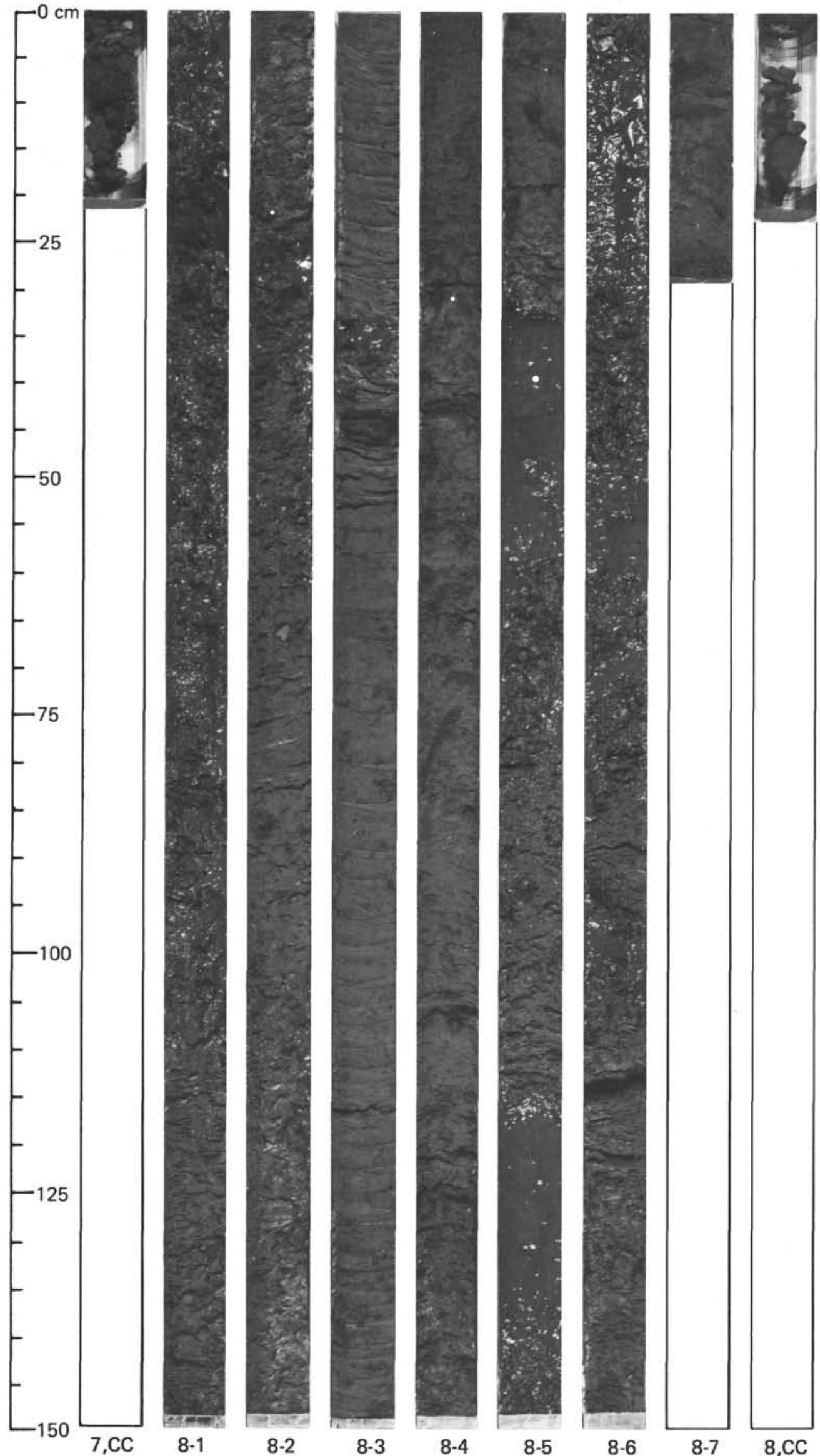

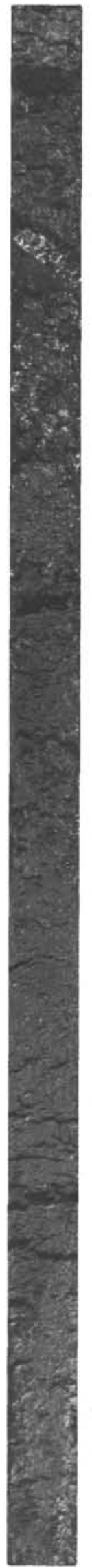

$9-1$

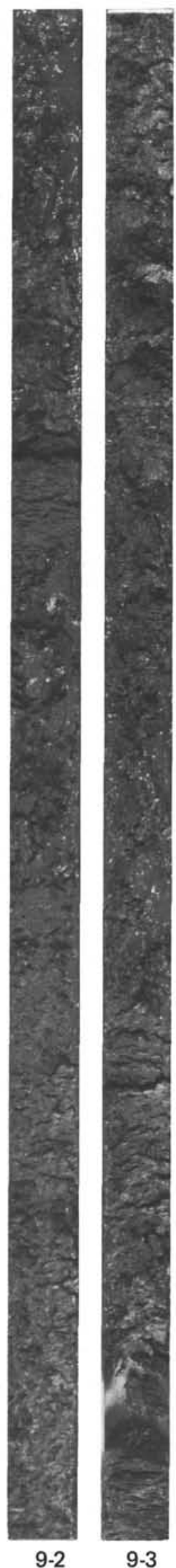


Site 438

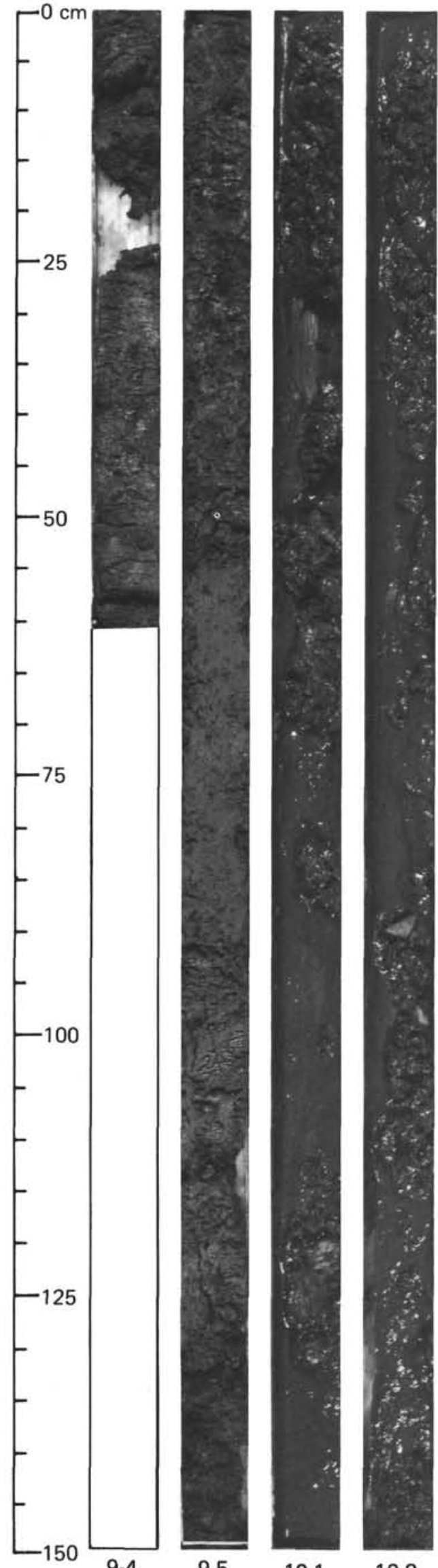

$9-4$

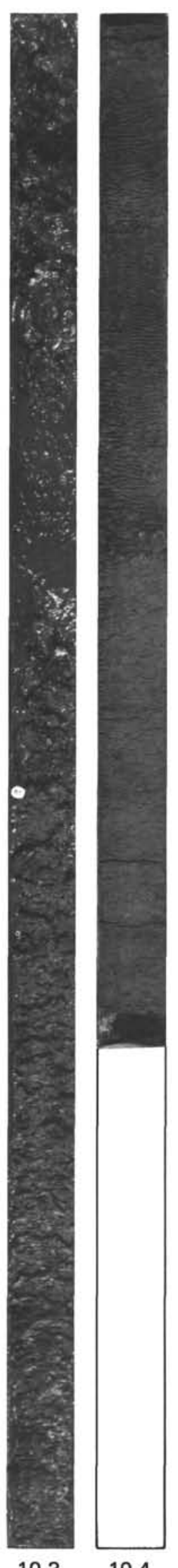

10-3

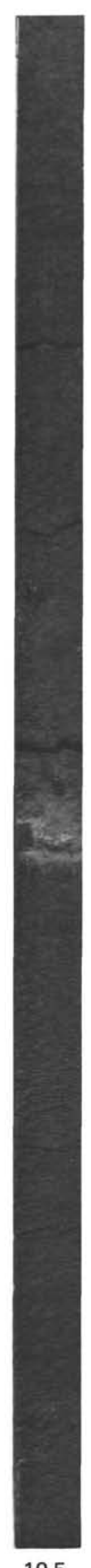

10-5

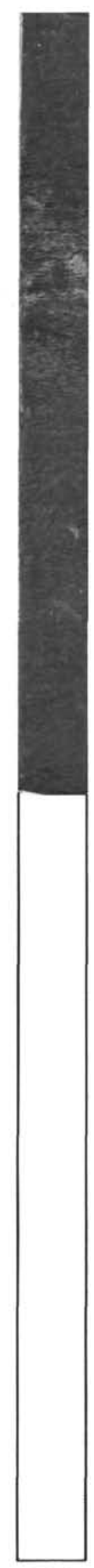

10-6

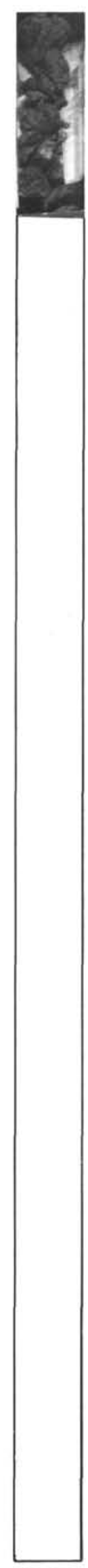

$10, \mathrm{CC}$

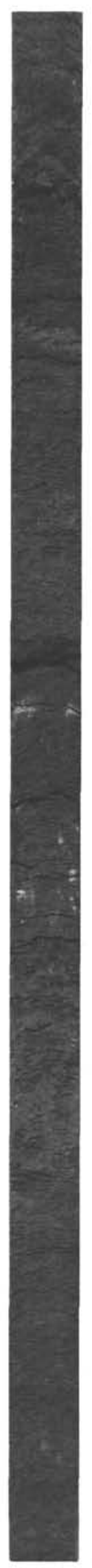

$11-1$

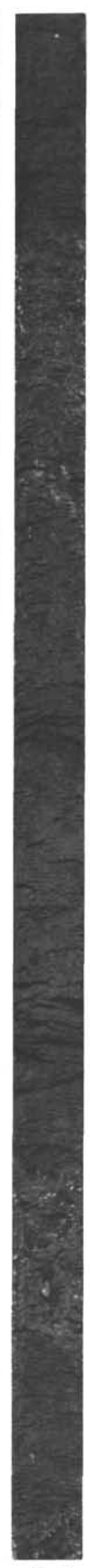

$11-2$

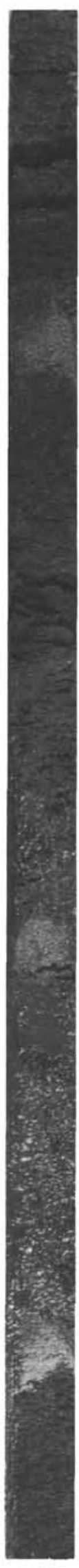

$11-3$ 
Site 438

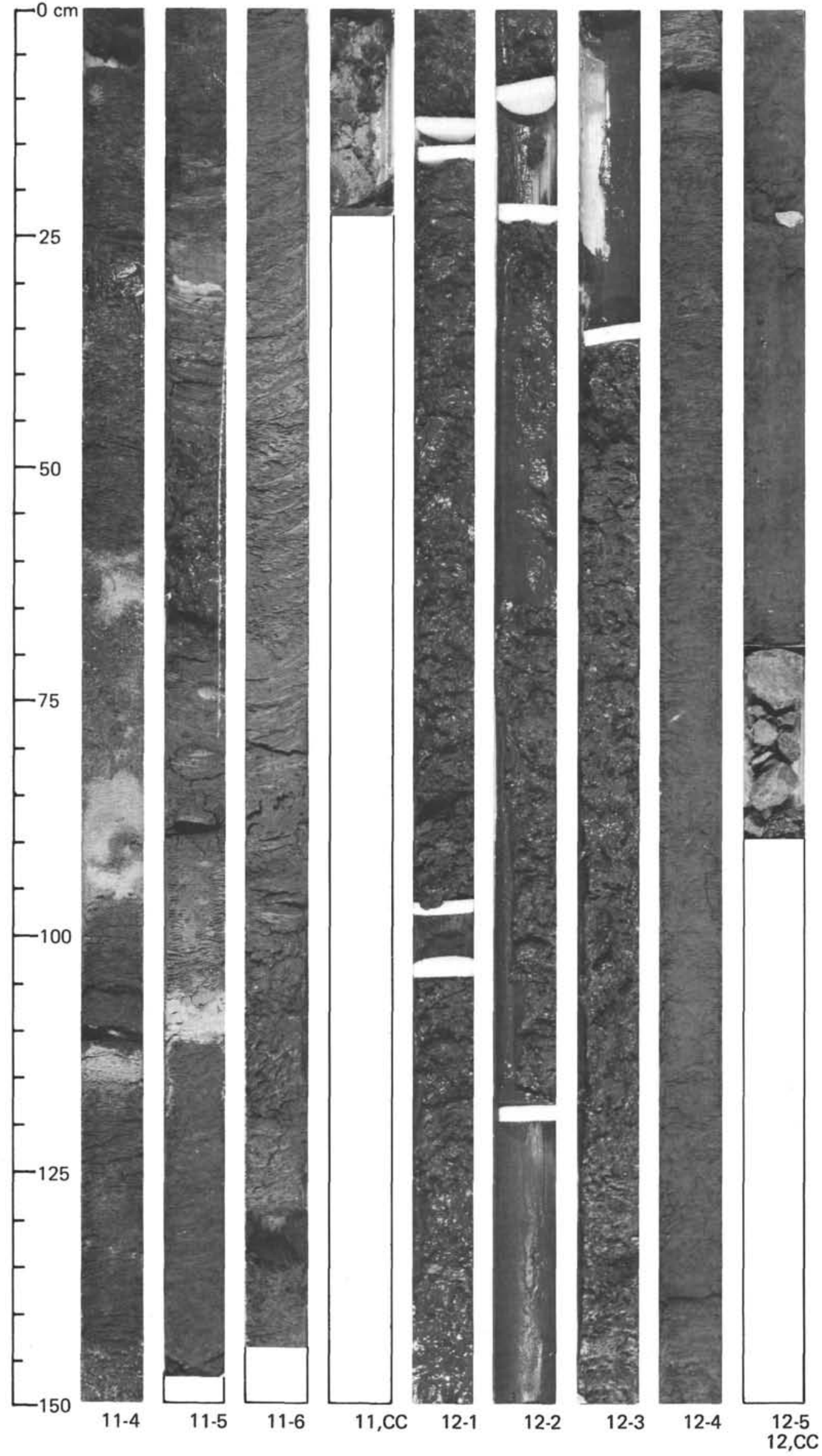


Hole 438A

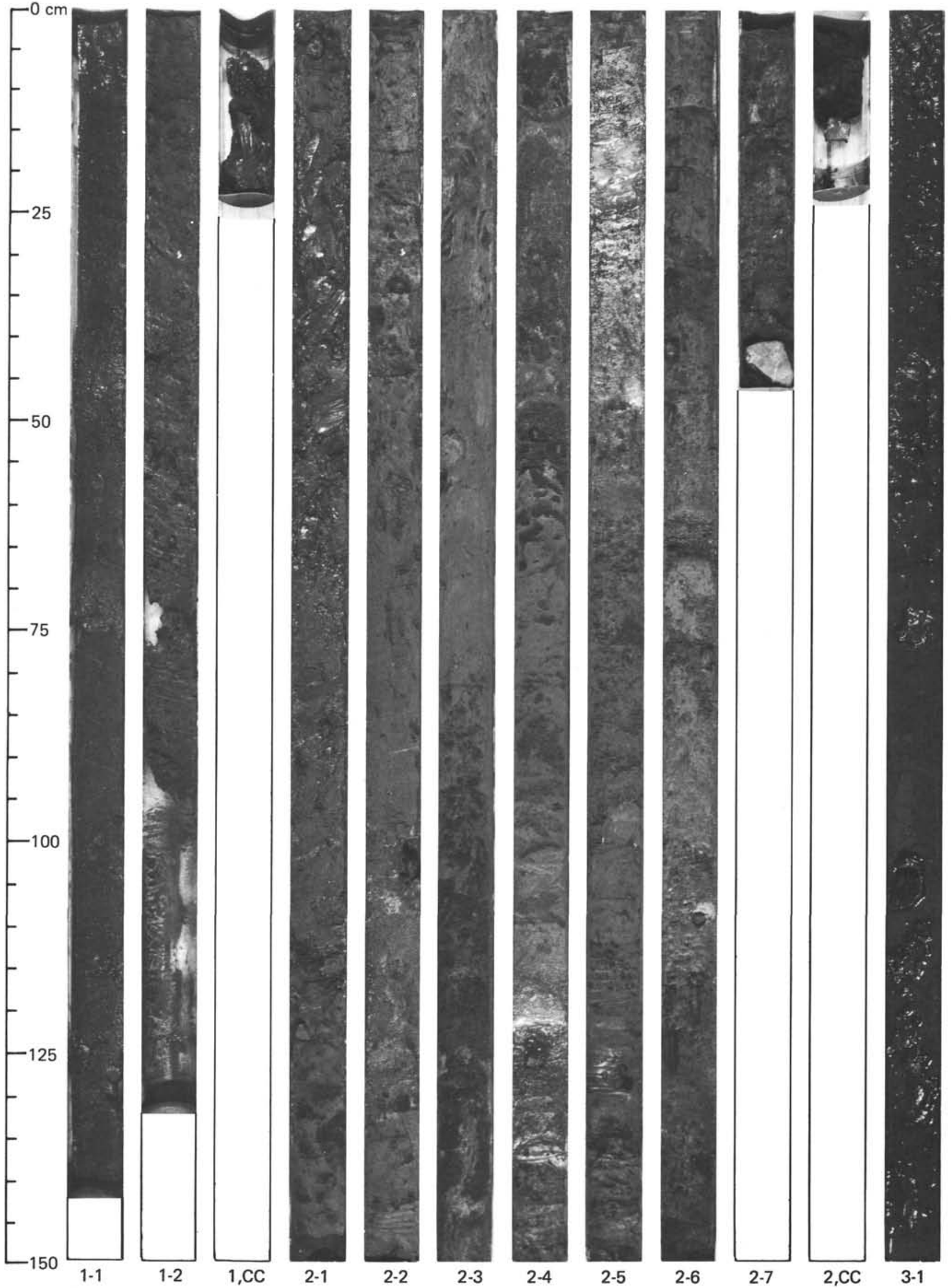


Hole 438A

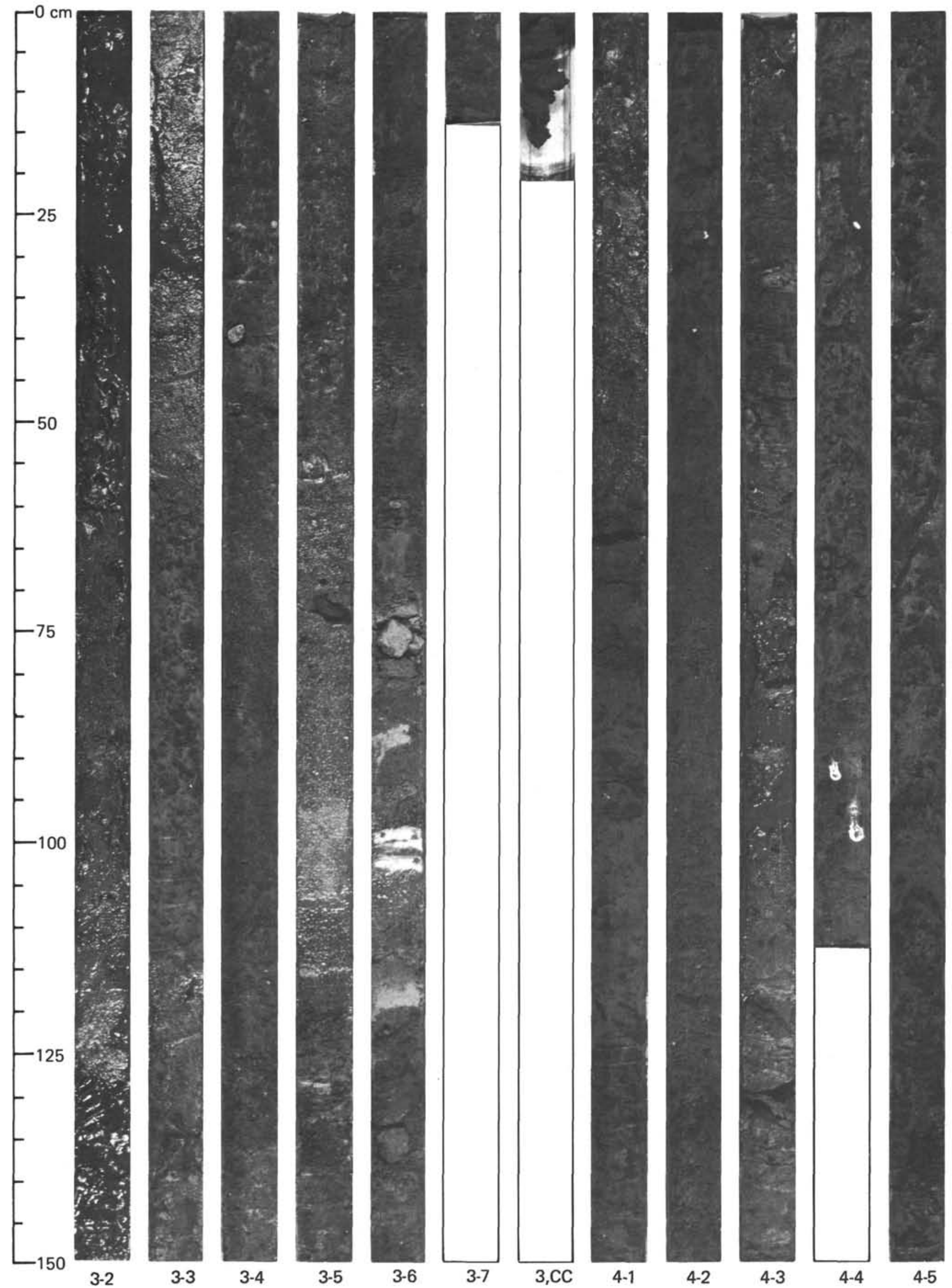


Hole 438A

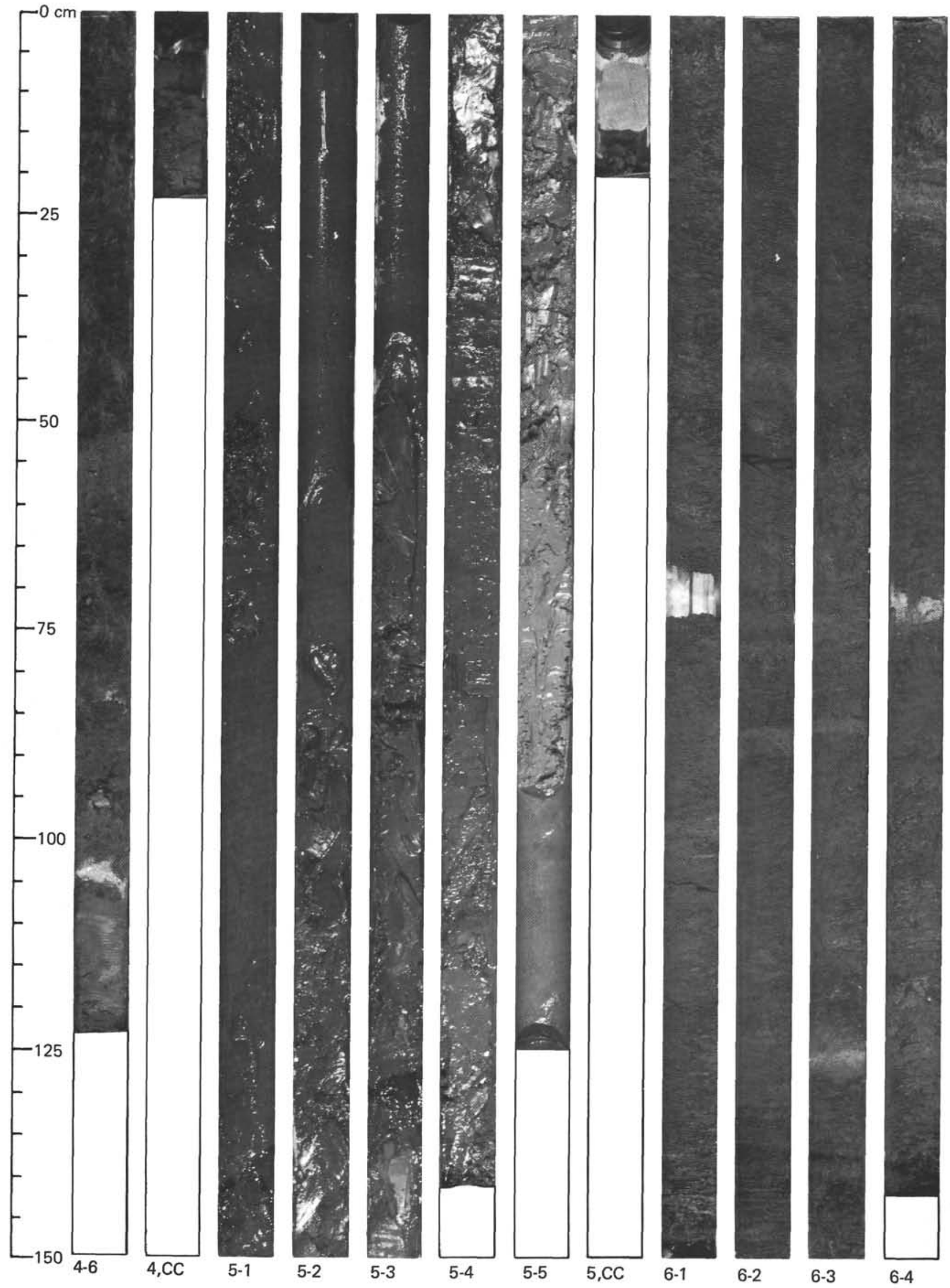


Hole 438A

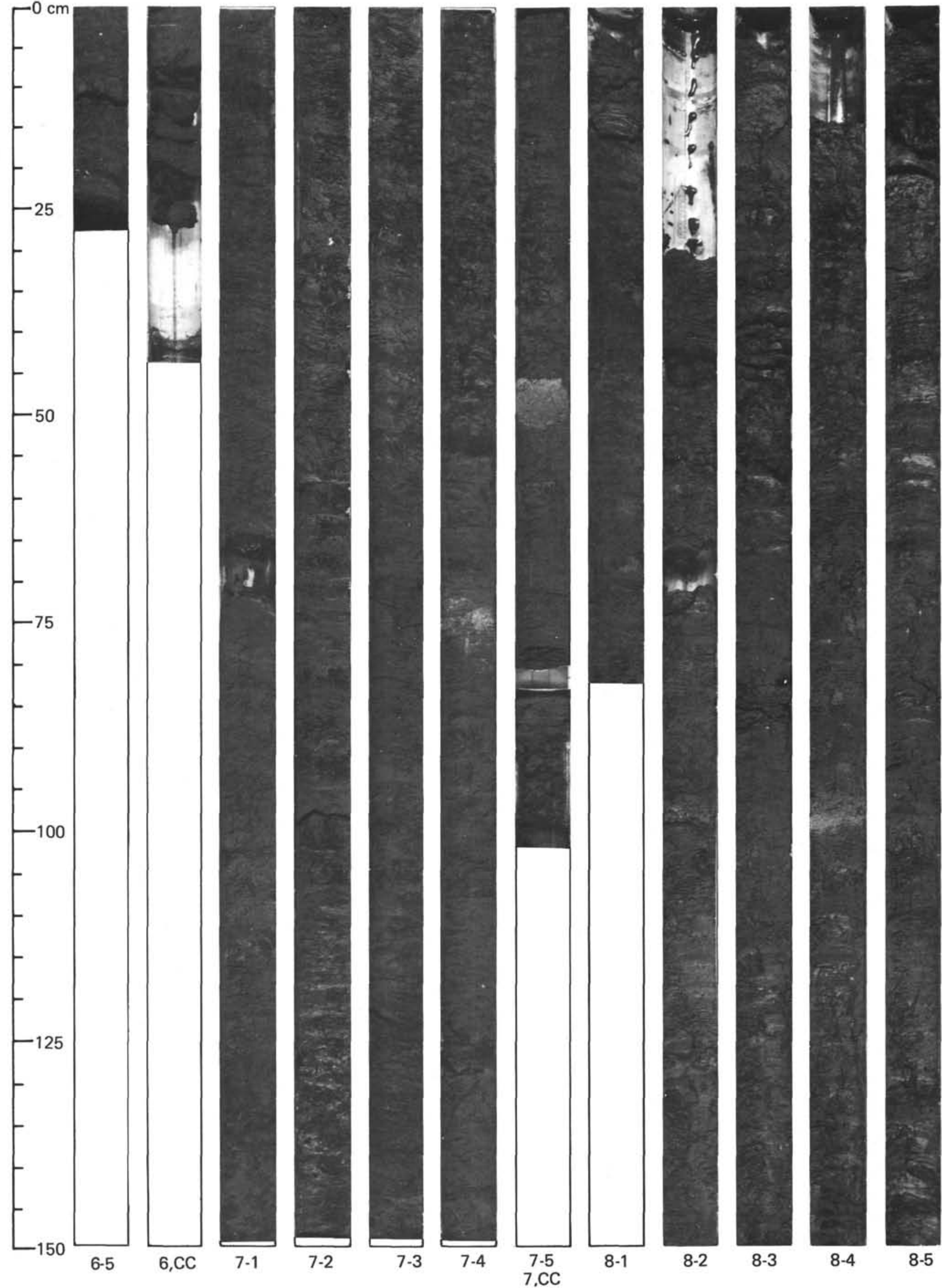


Hole 438A

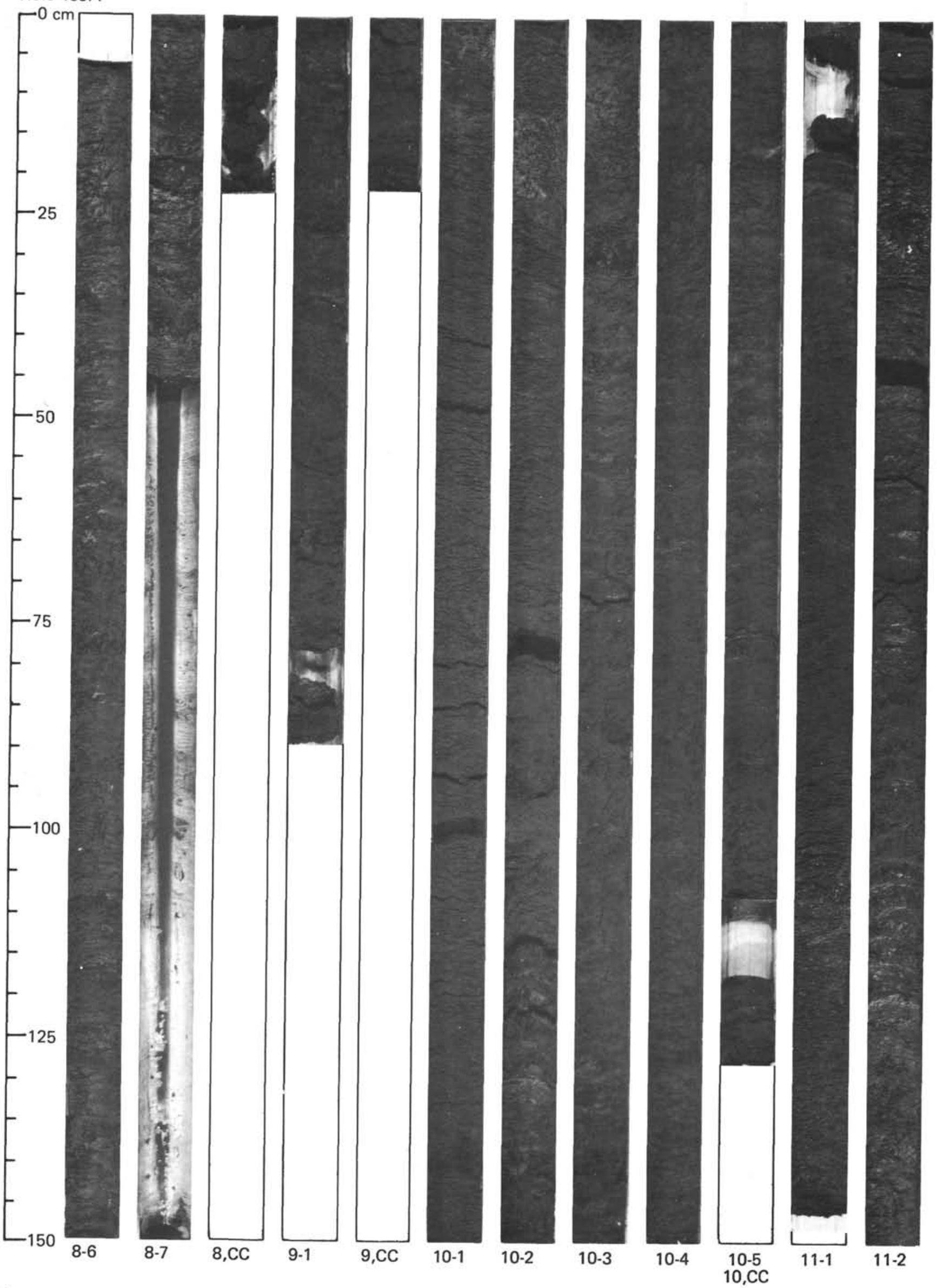


Hole 438A

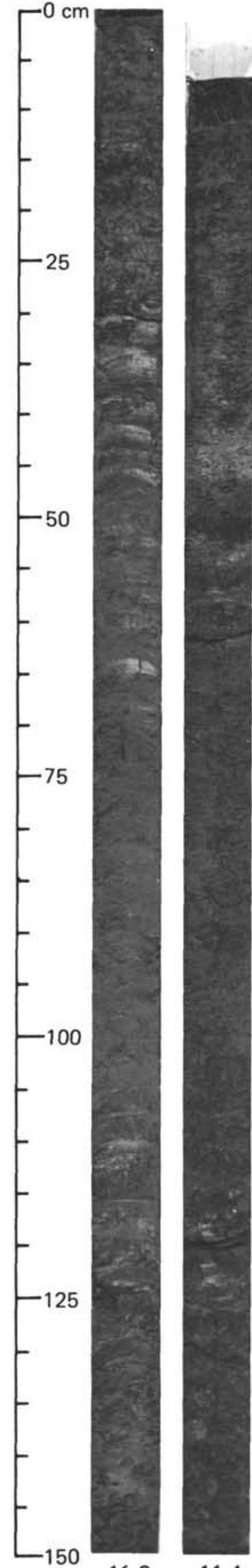

$11-3$

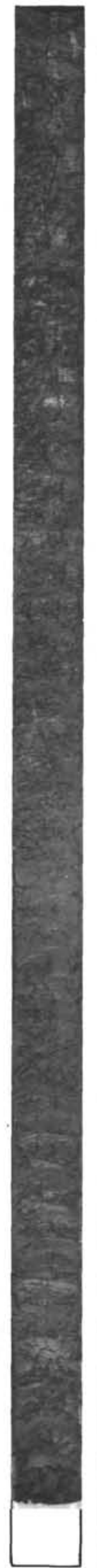

11.5

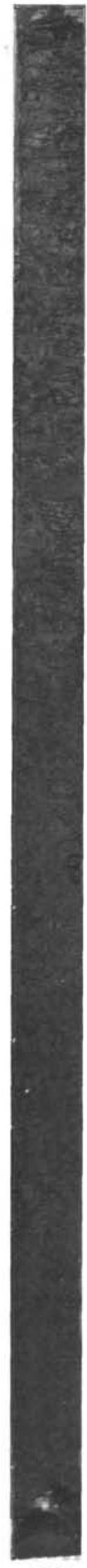

$11-6$
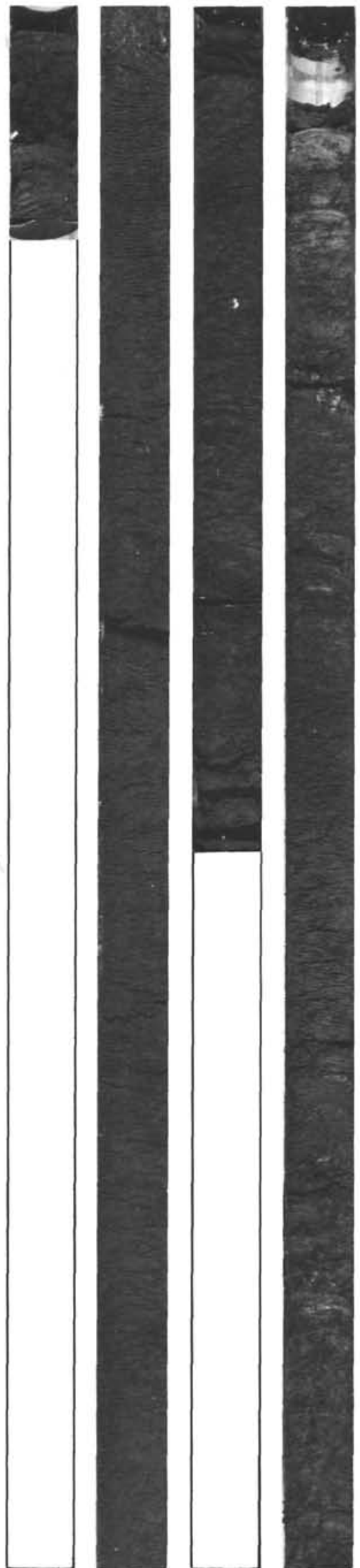

13-1

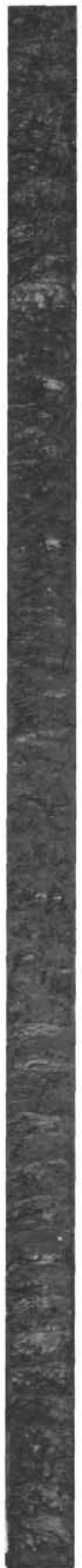

13-2

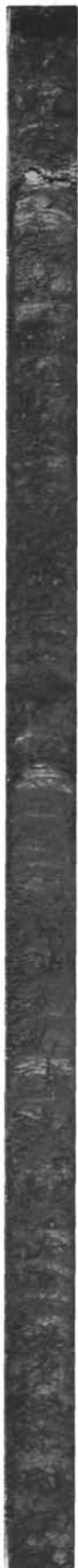

13-3

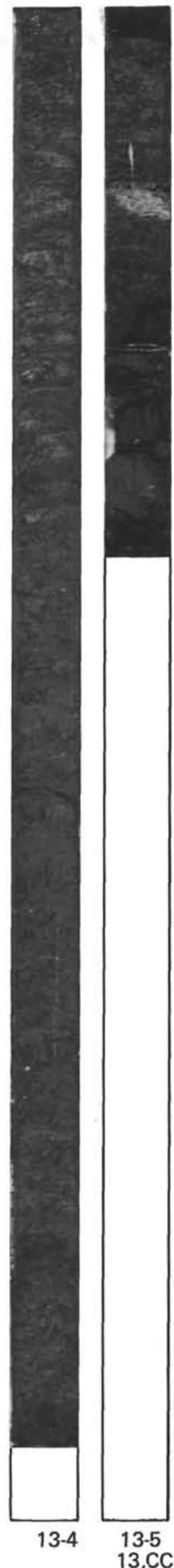



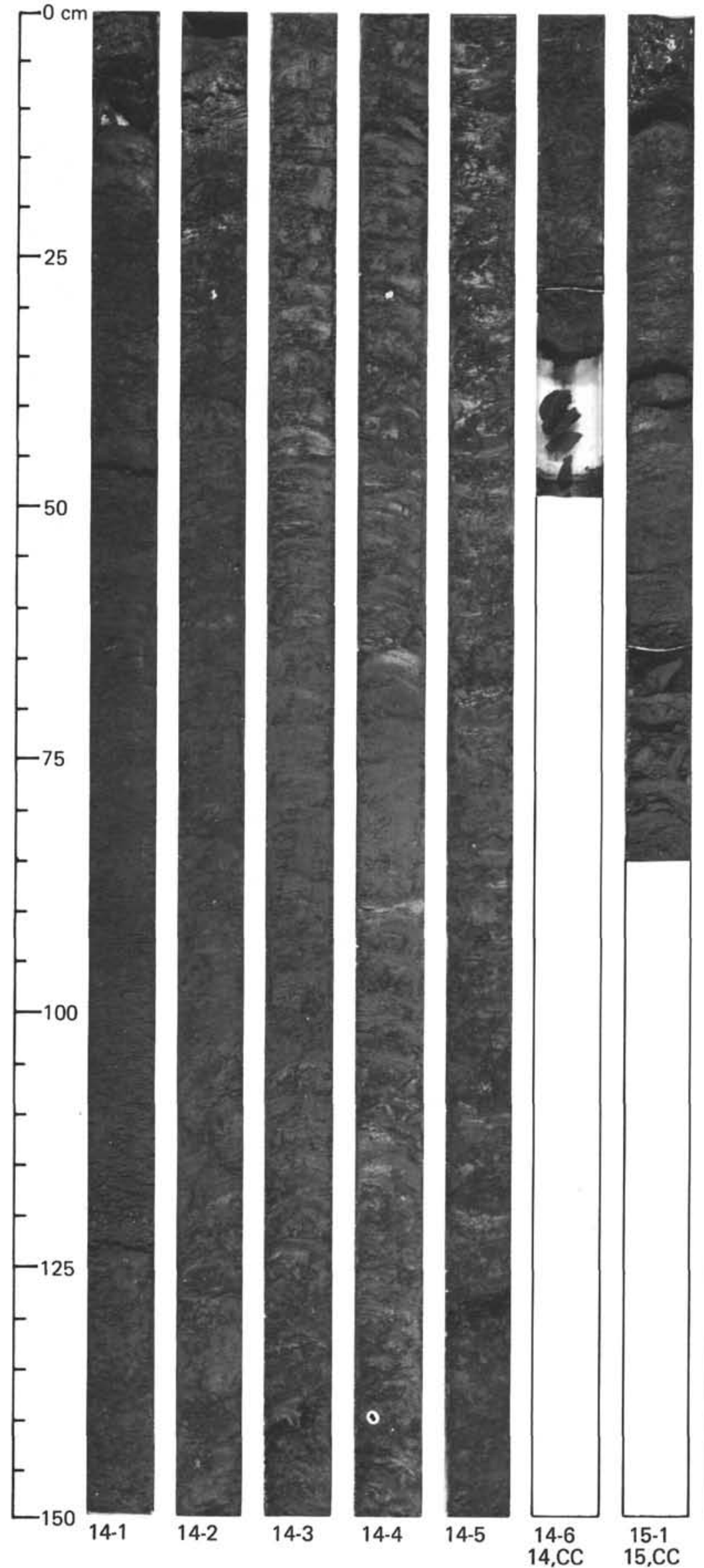

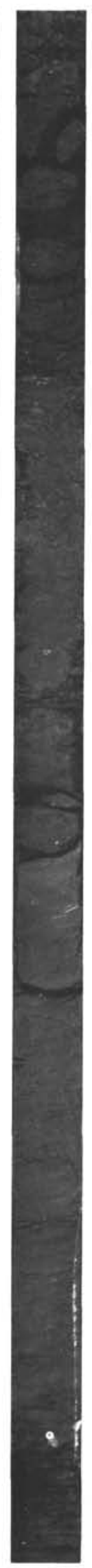

16-1

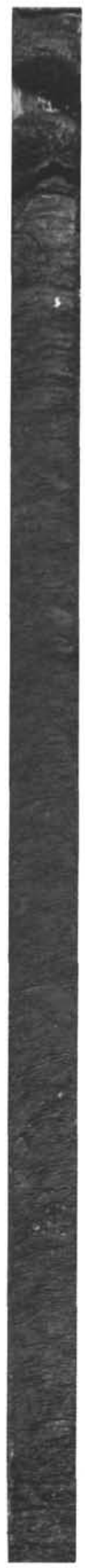

$16-2$

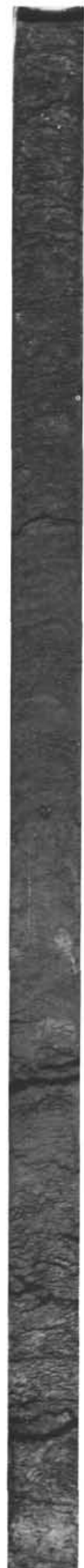

$16-3$
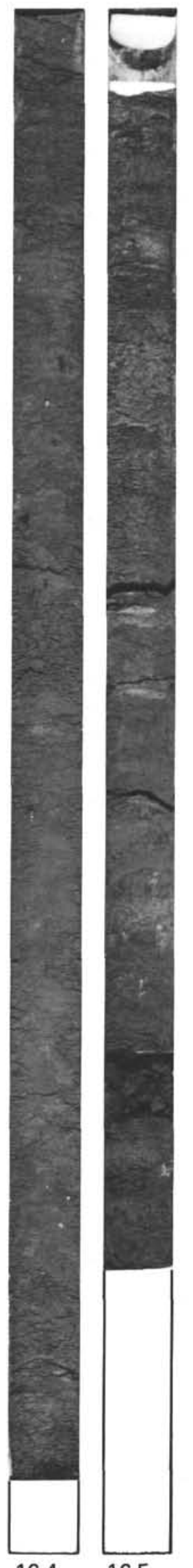

16-4 
Hole 438A

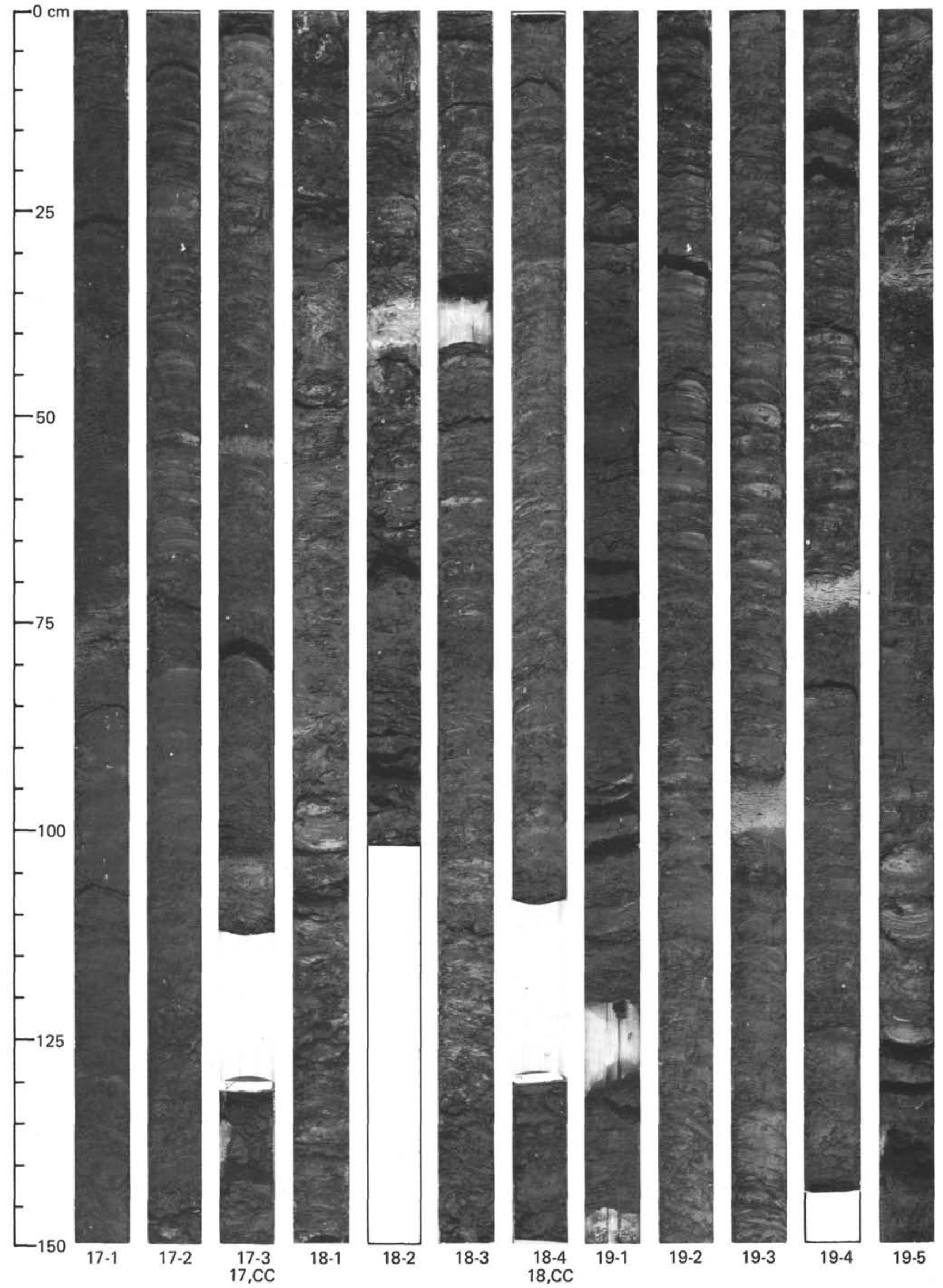


Hole 438A

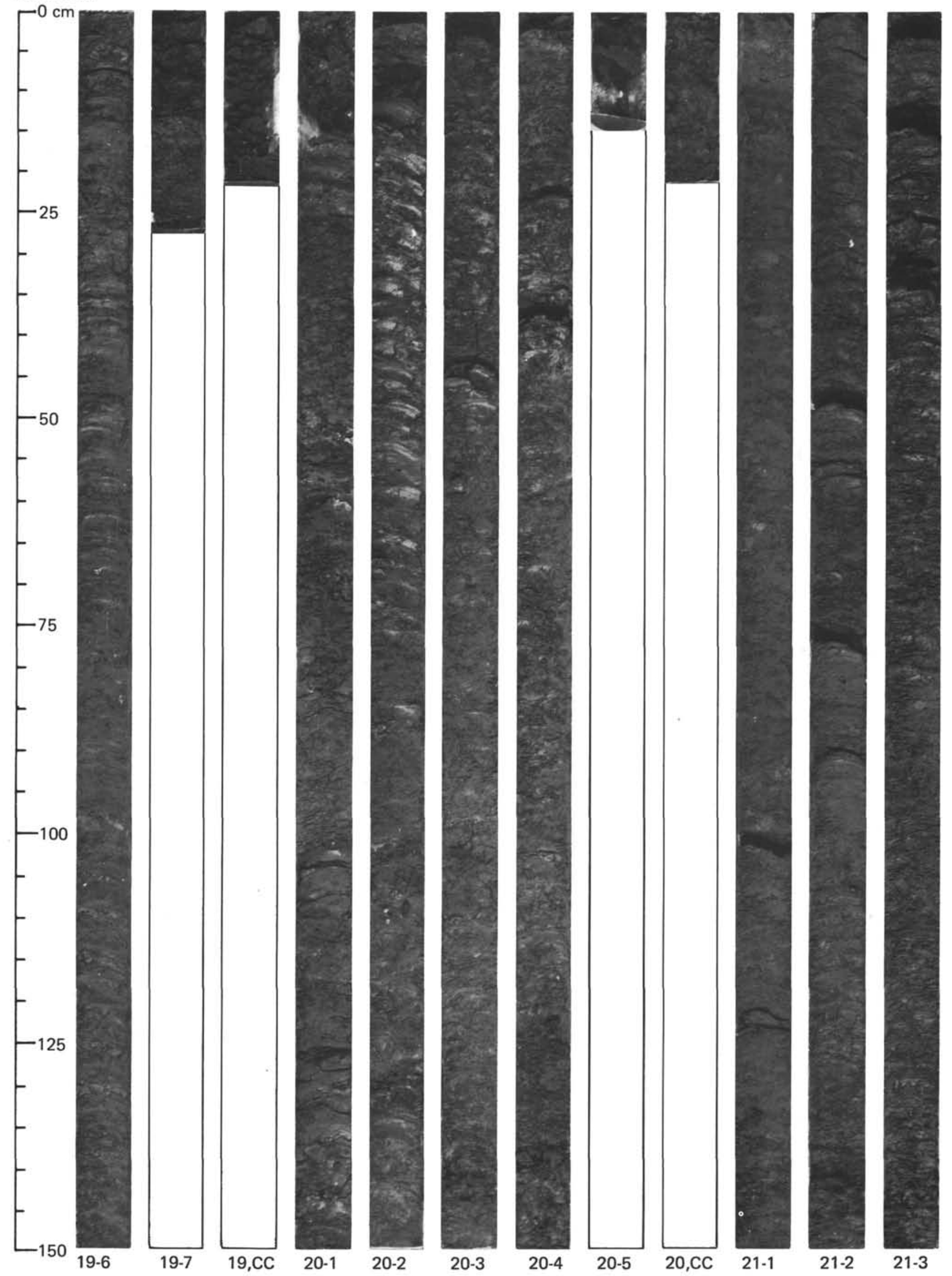


Hole 438A

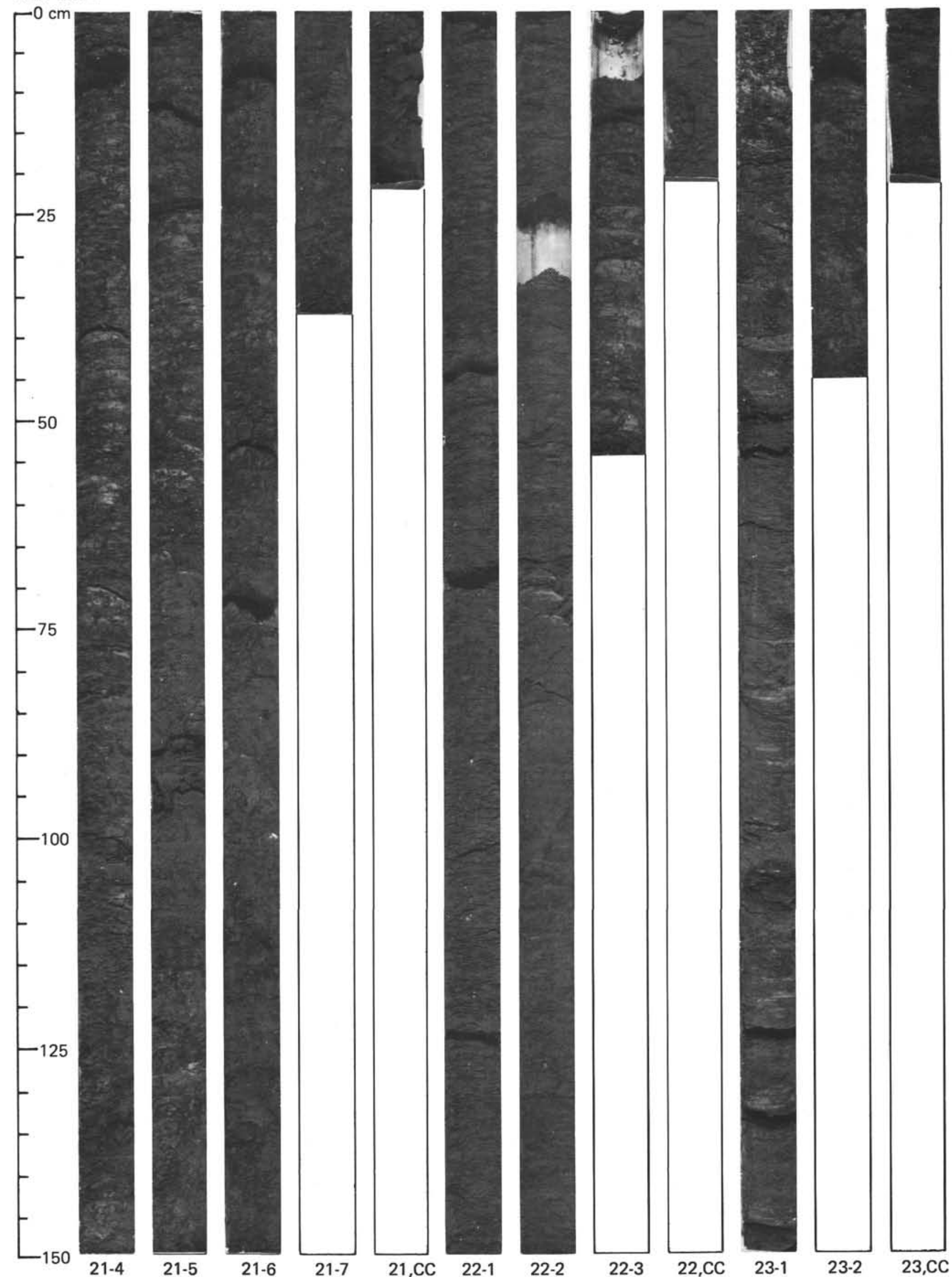


Hole 438A
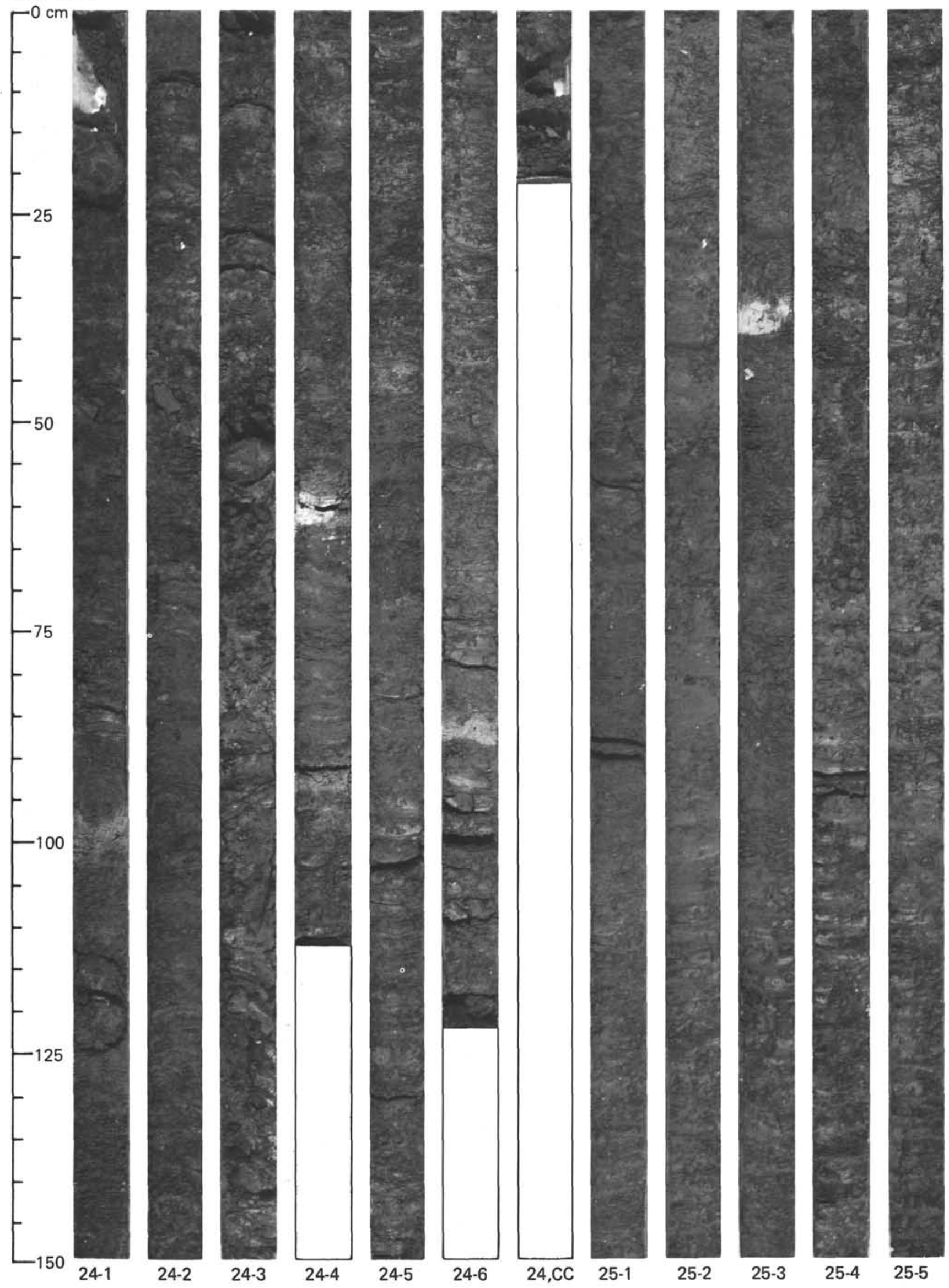
Hole 438A

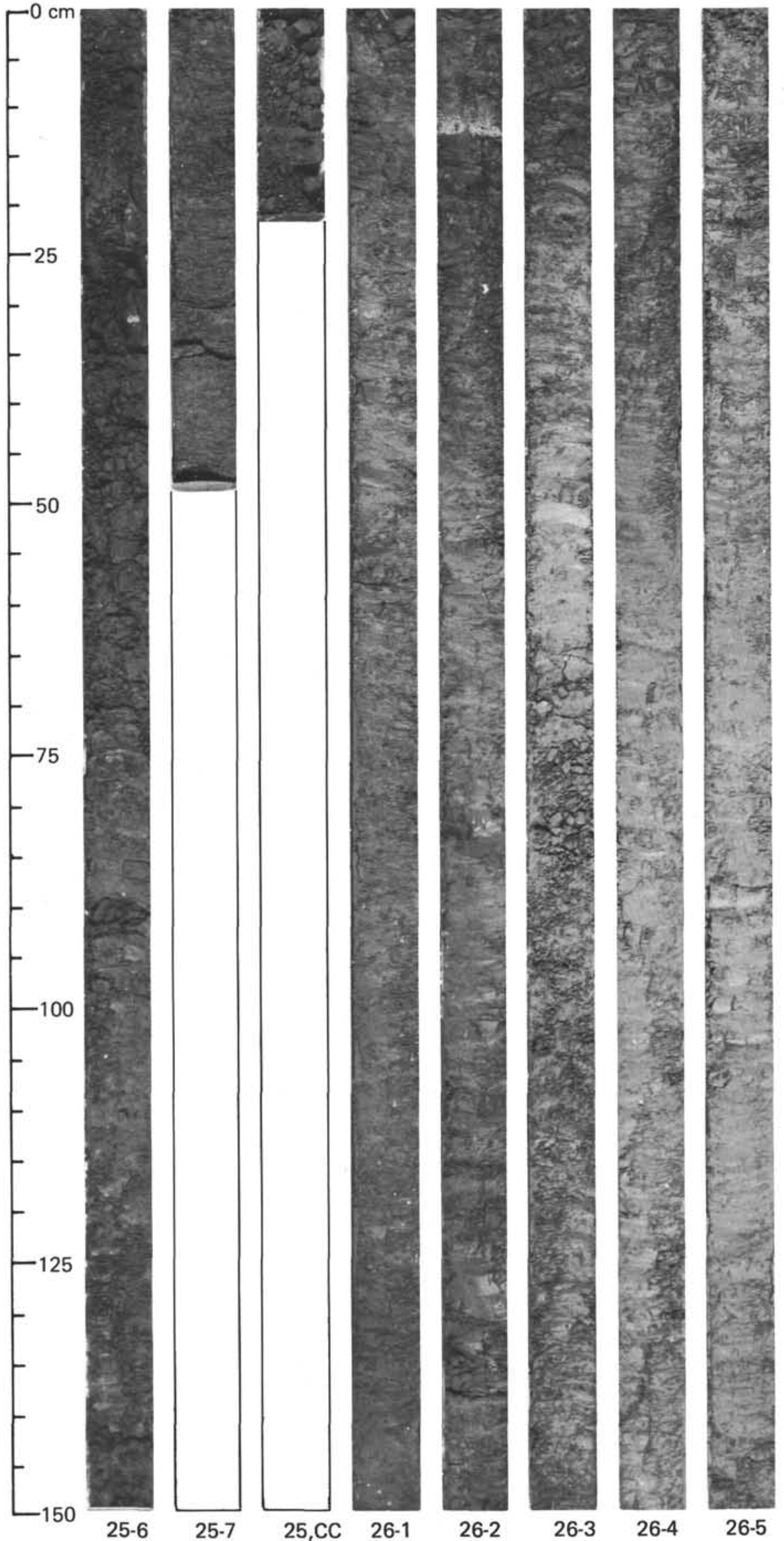


Hole 438A

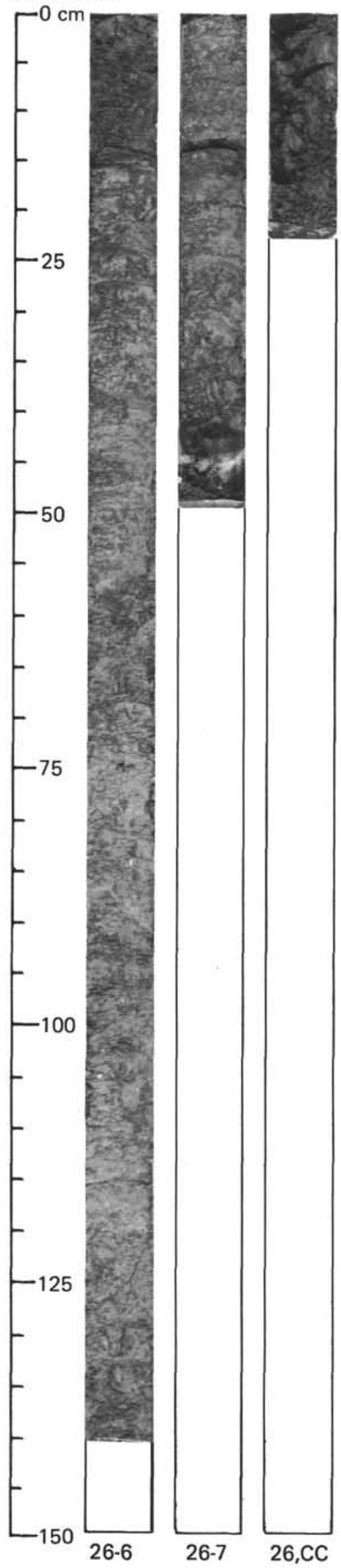

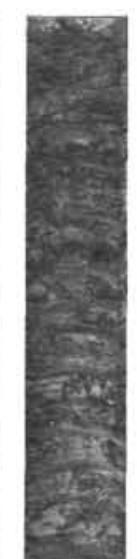
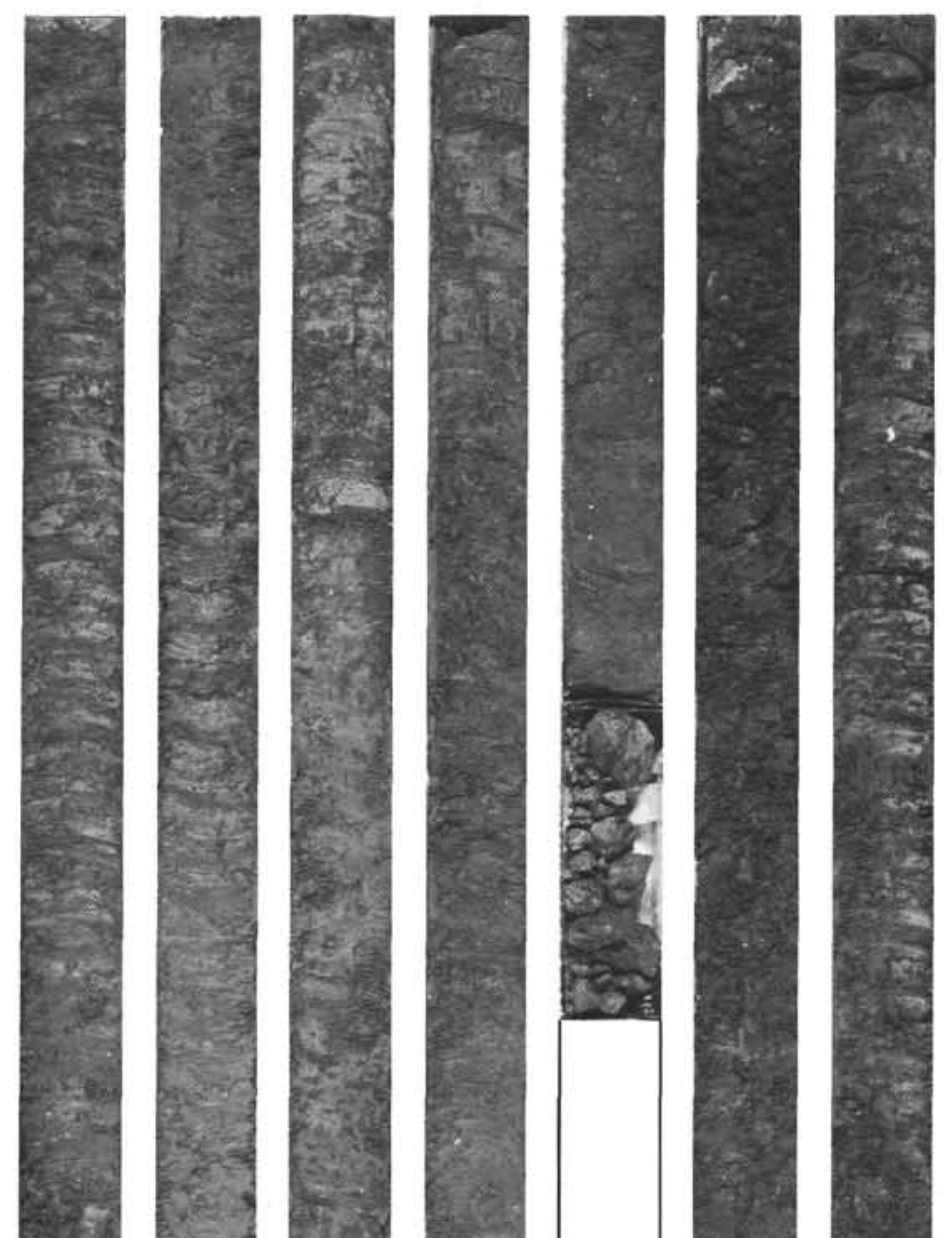

Fing
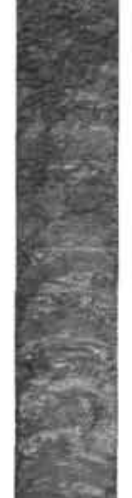

50
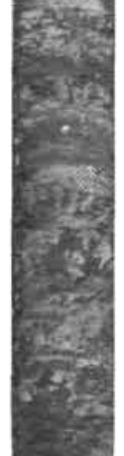

27-3 
Hole 438A

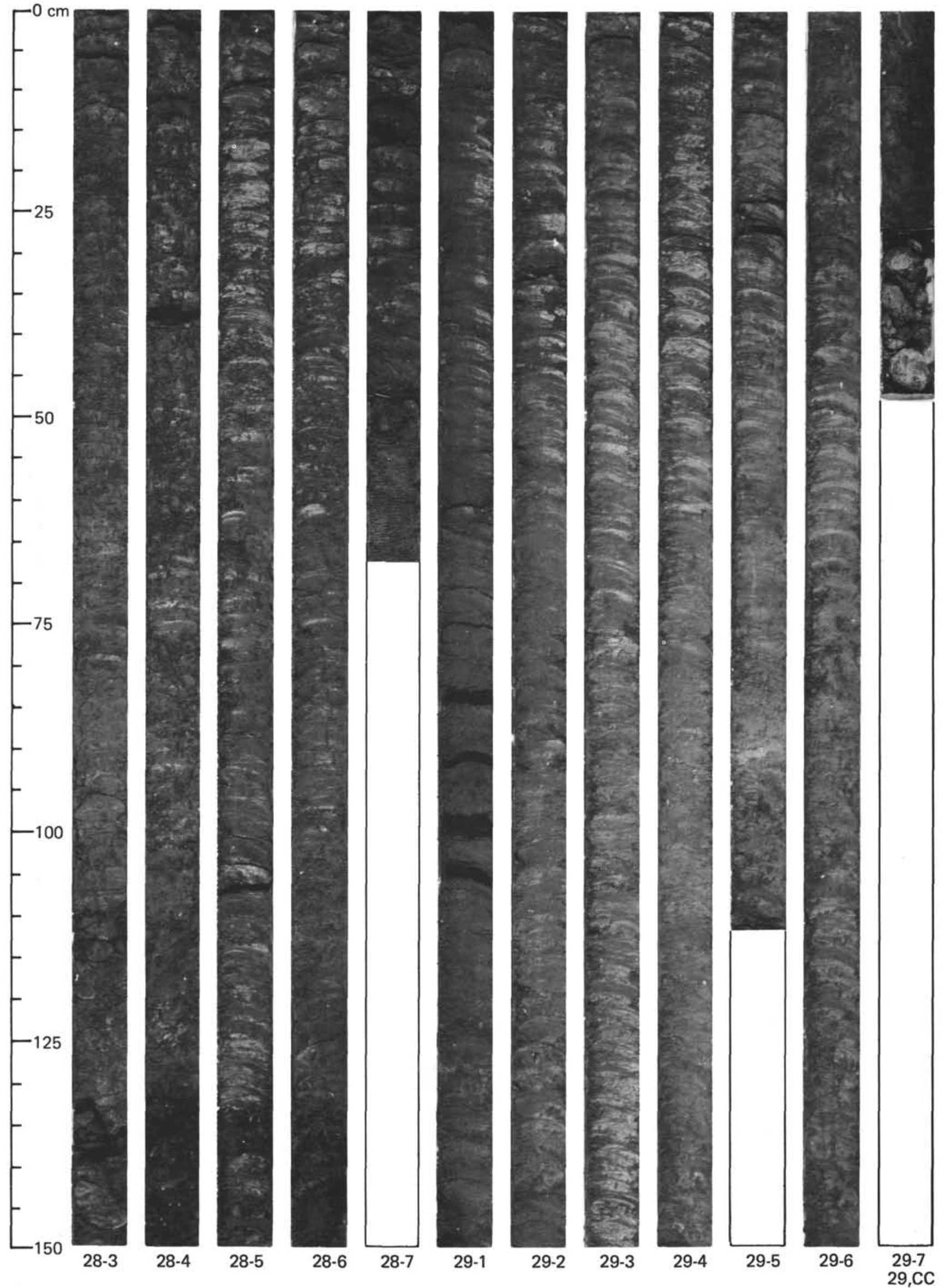


Hole 438A

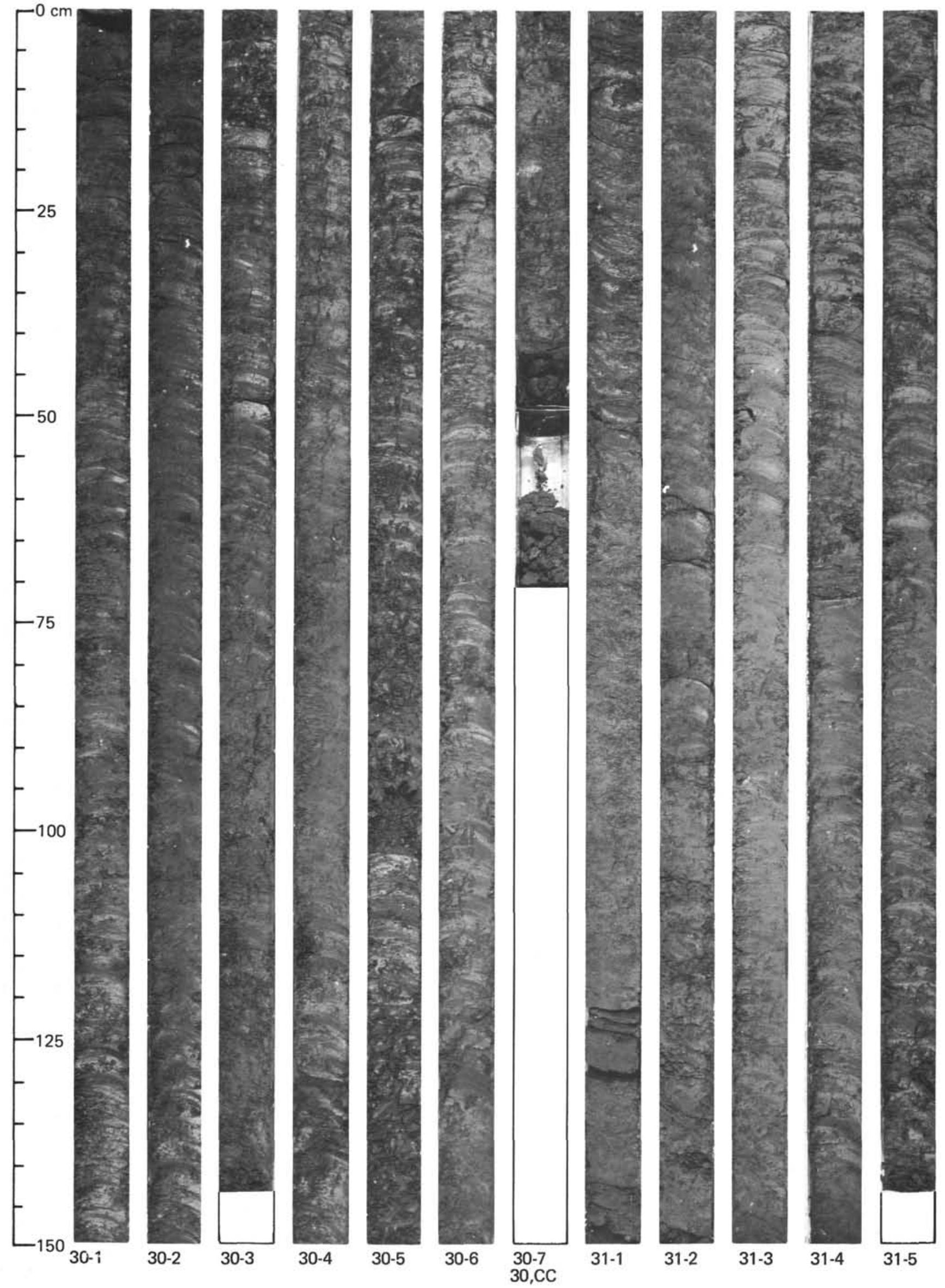


Hole 438A

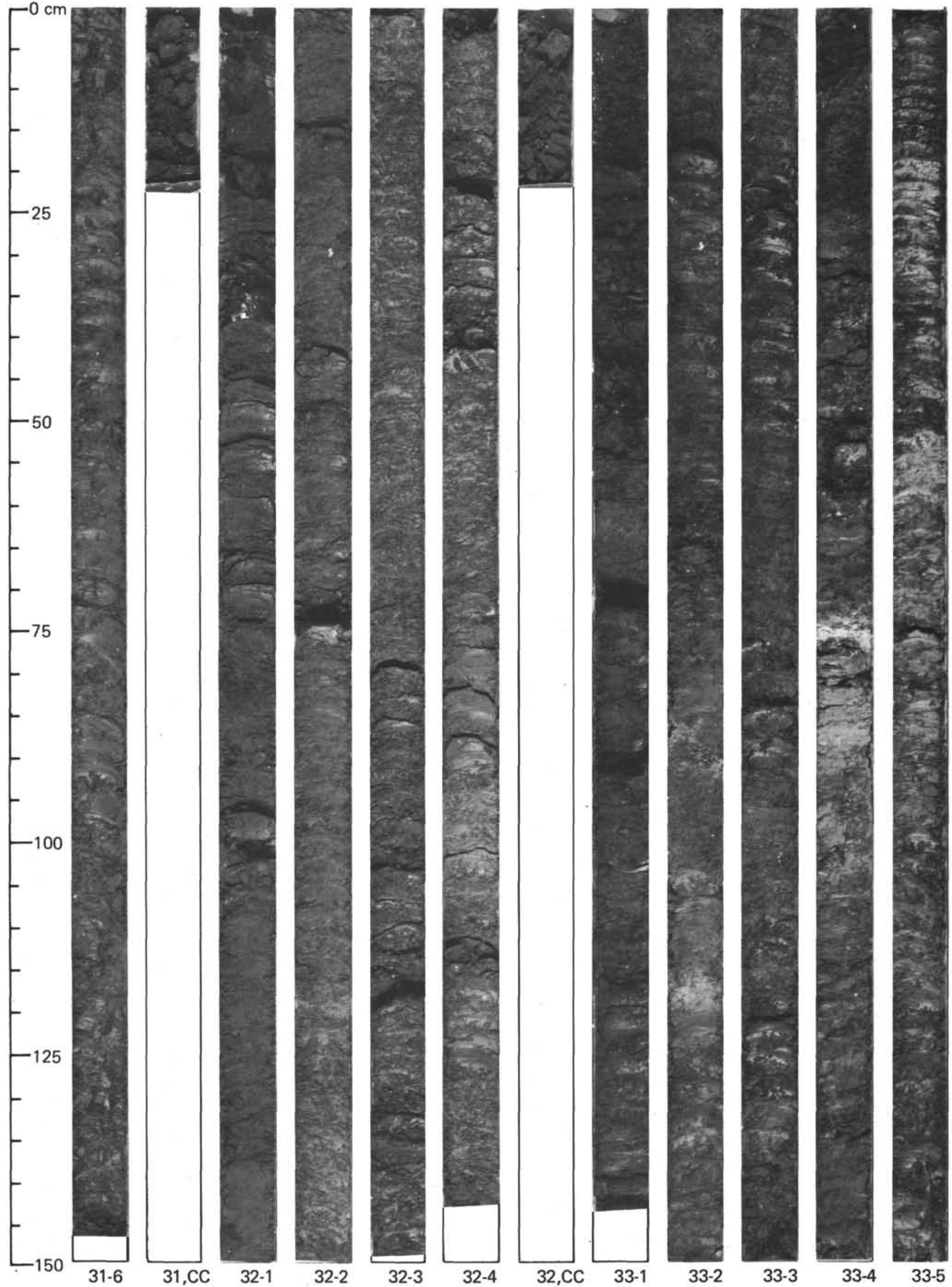


Hole 438A

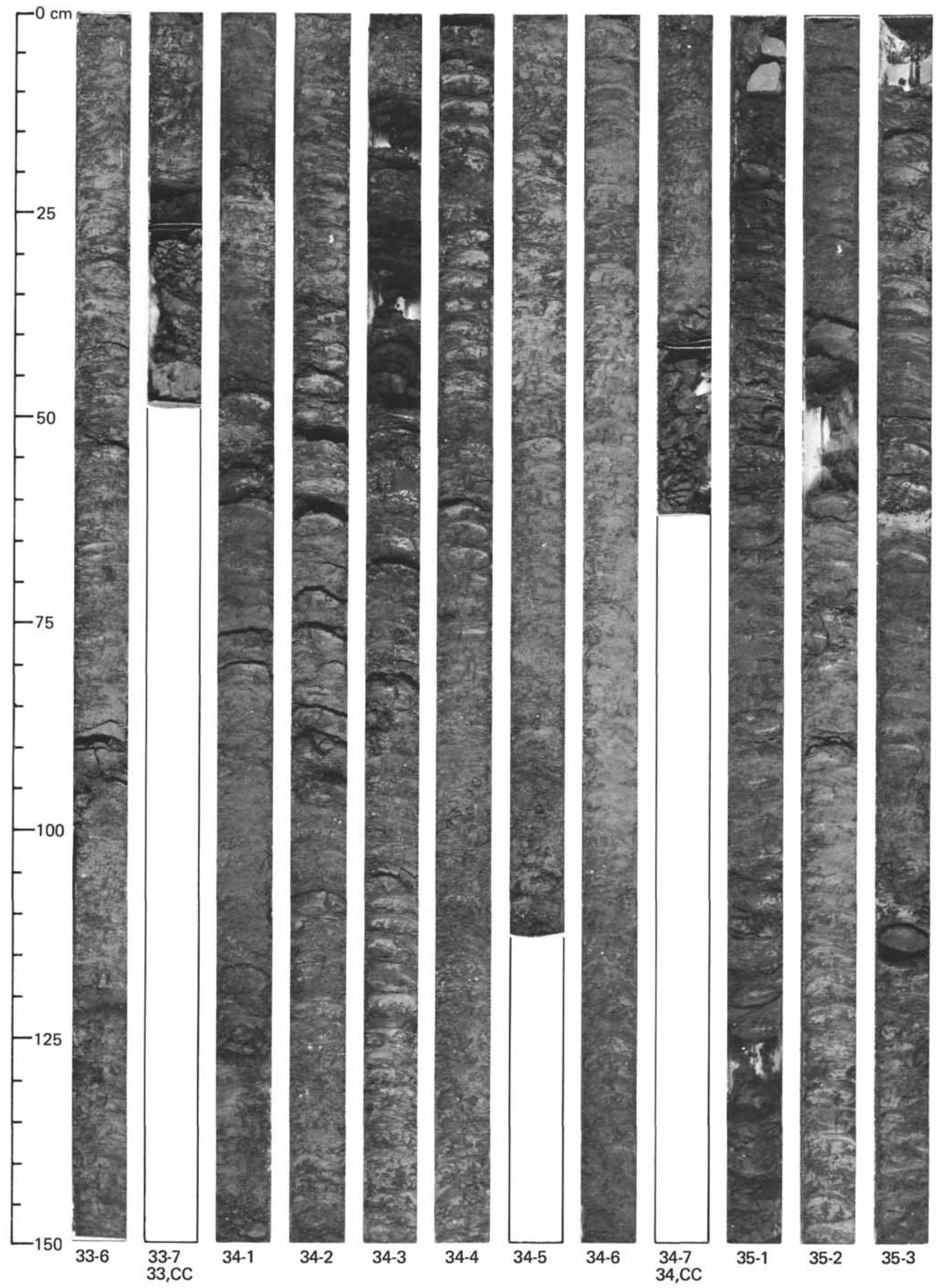


Hole 438A

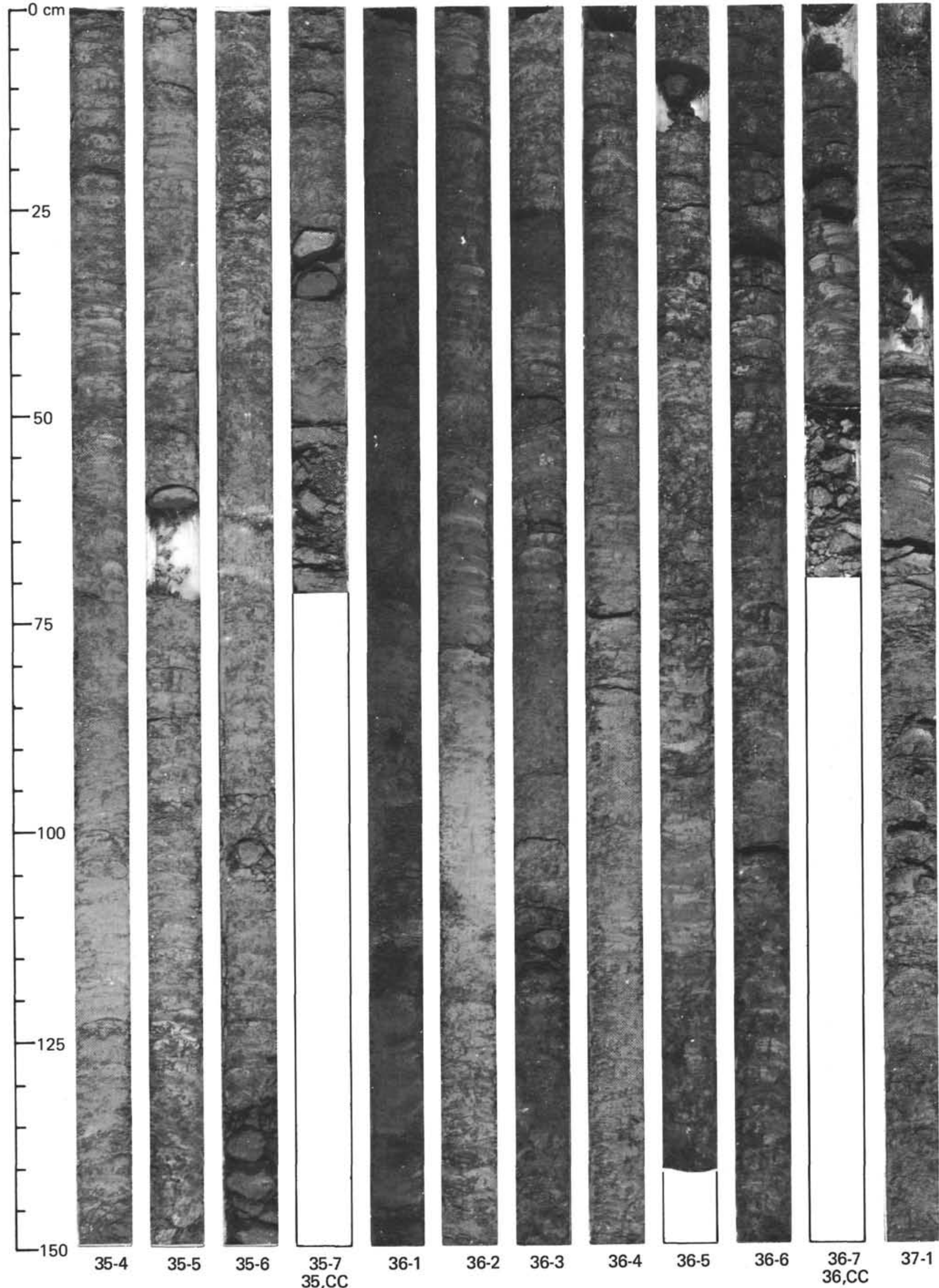


Hole 438A

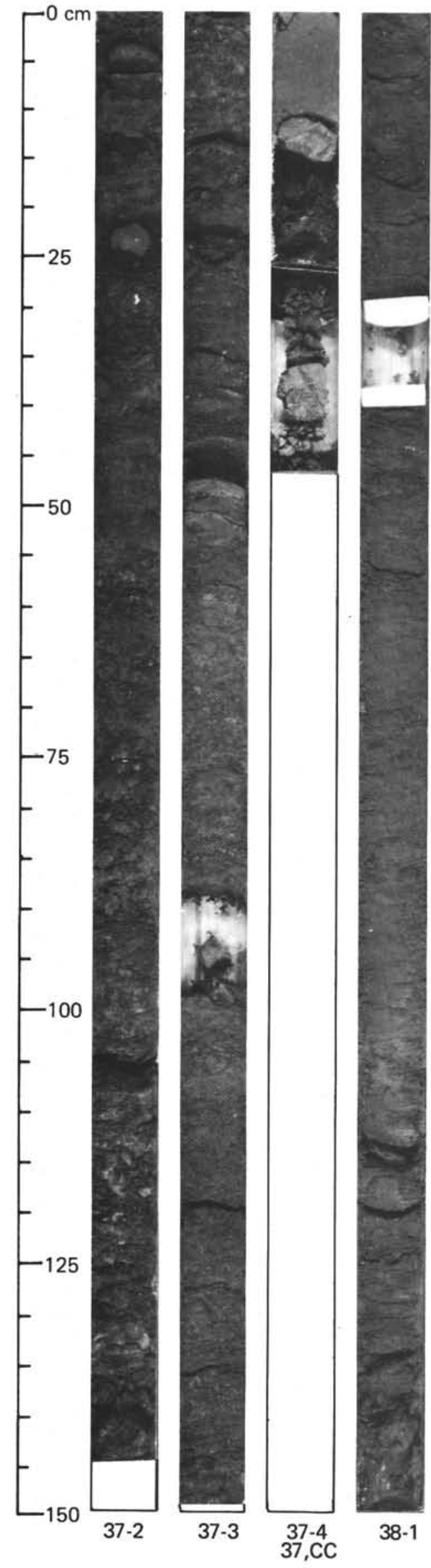

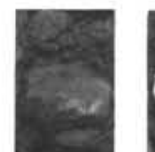
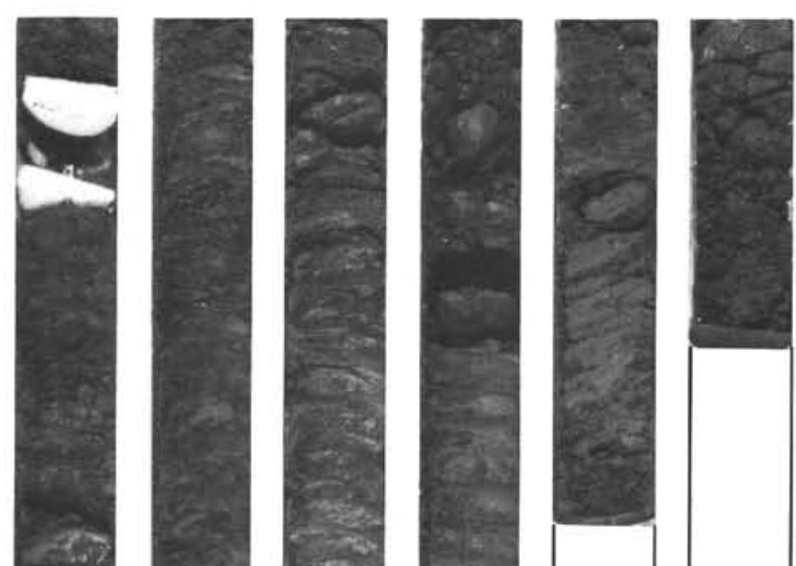

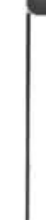
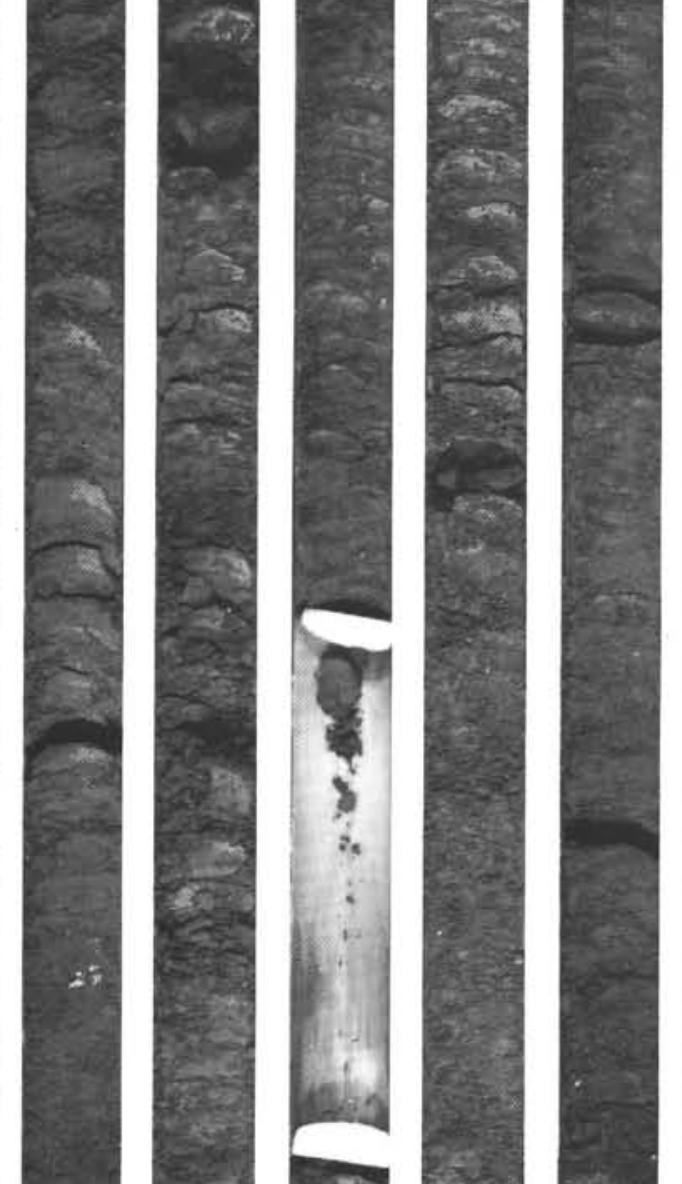
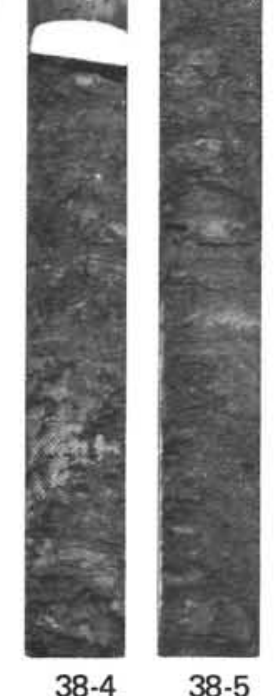

$38-5$
38-3 
Hole 438A

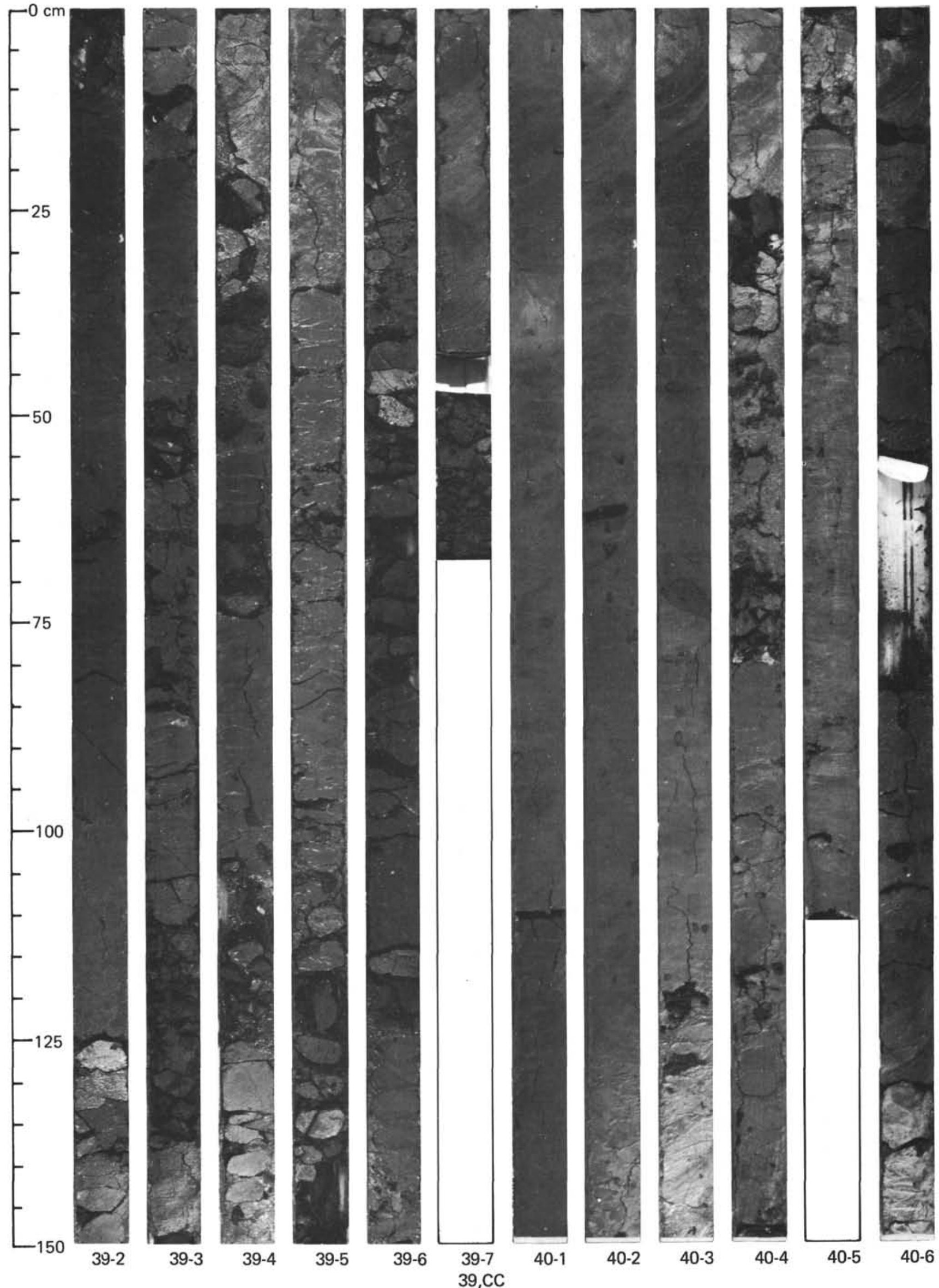


Hole 438A

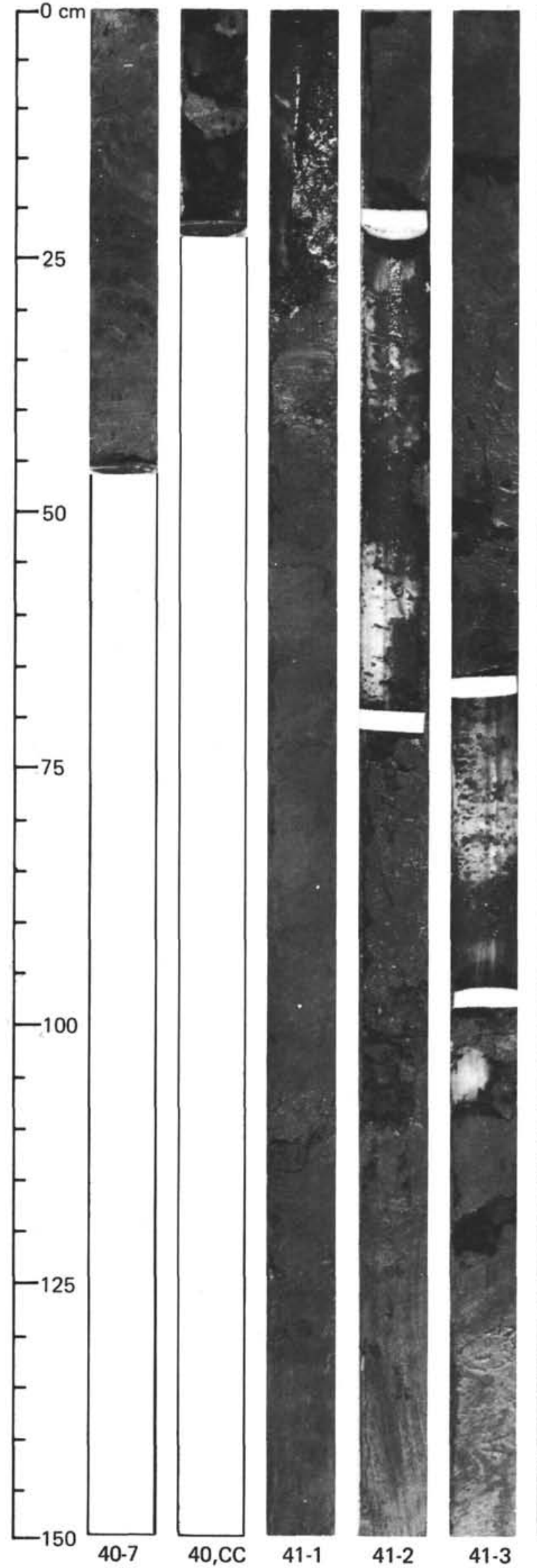

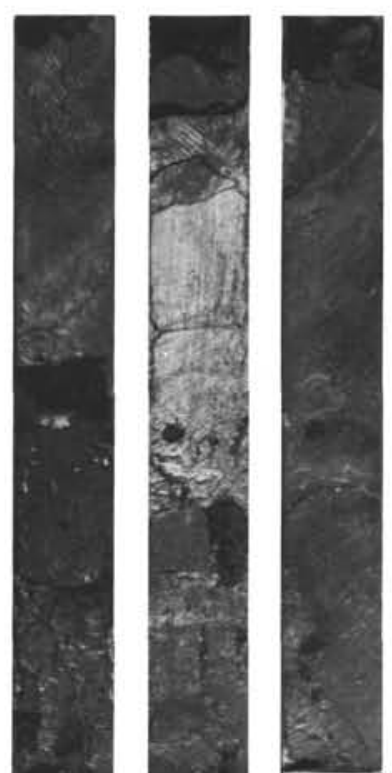
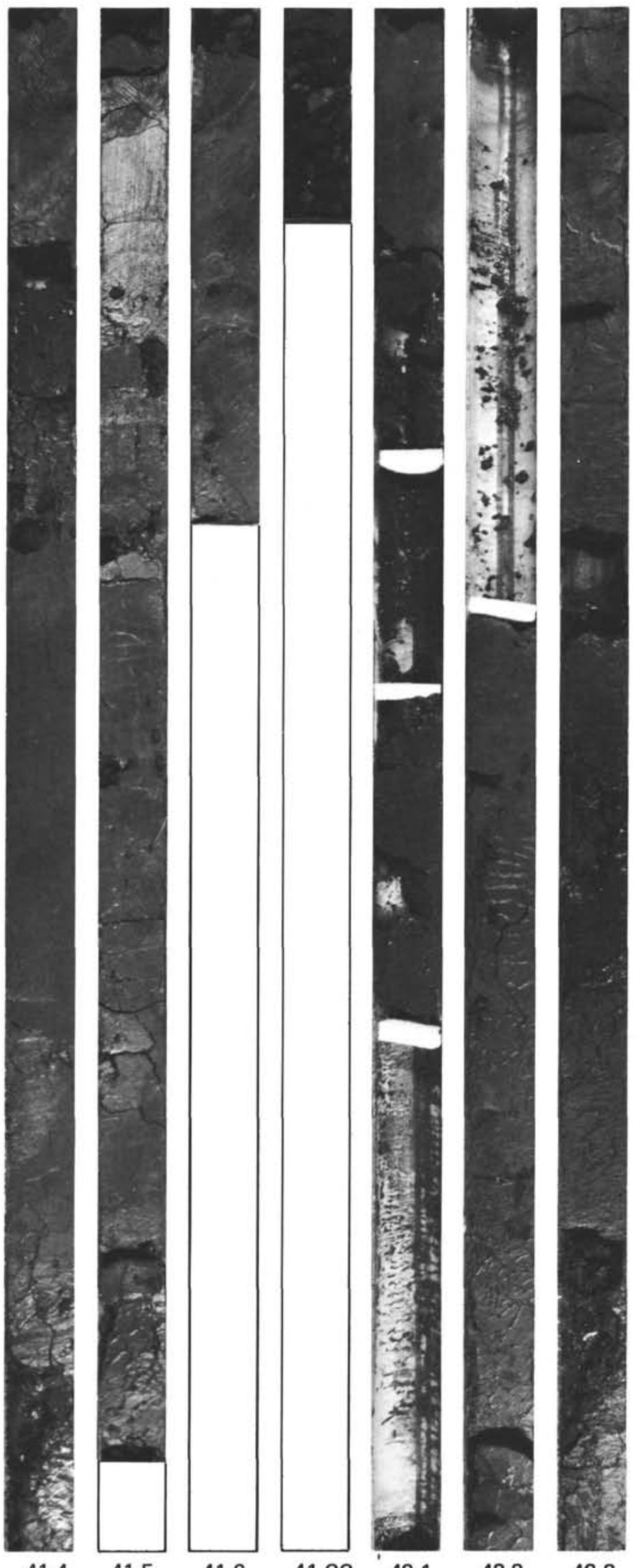

$41-4$
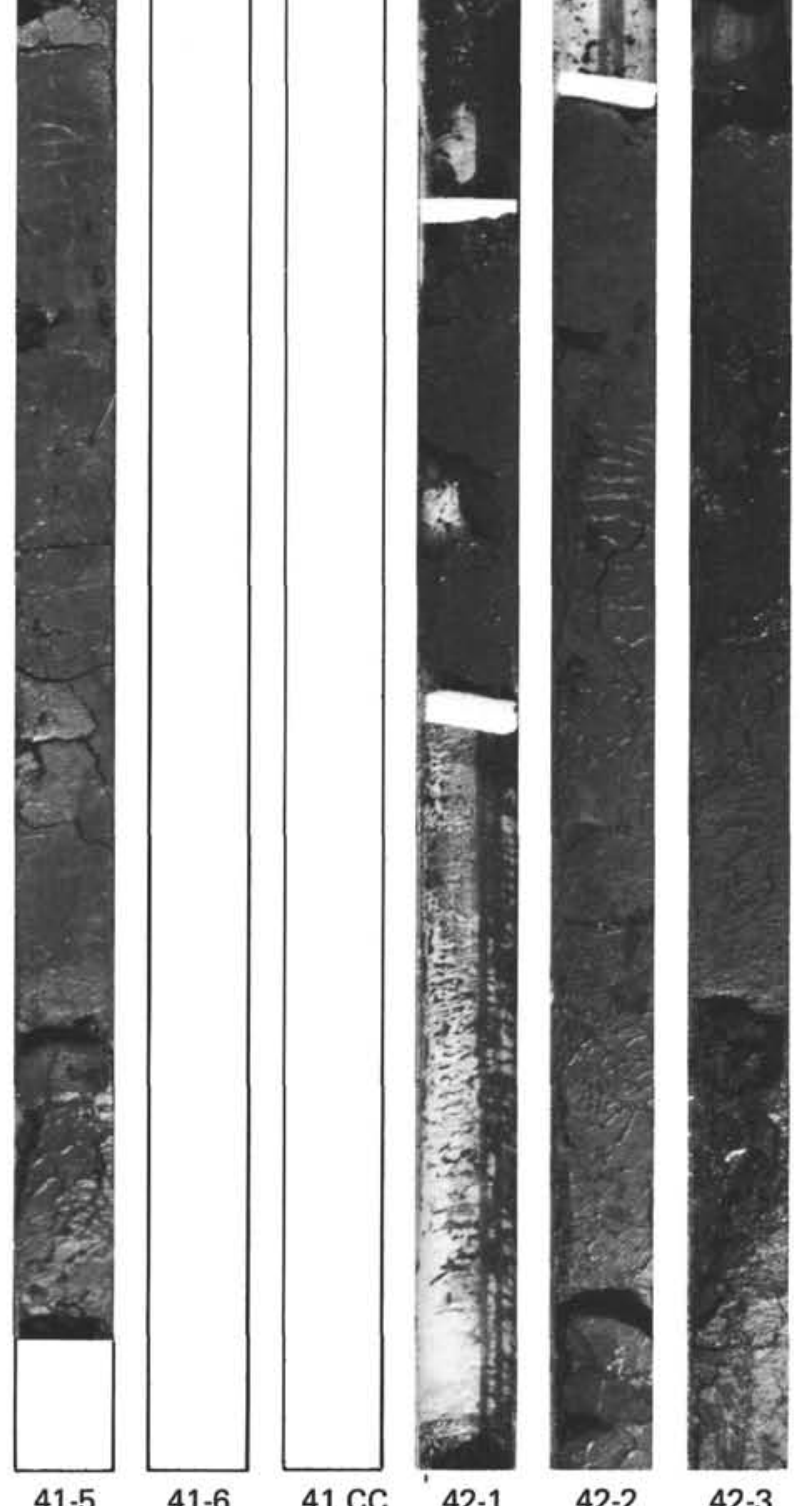
Hole 438A

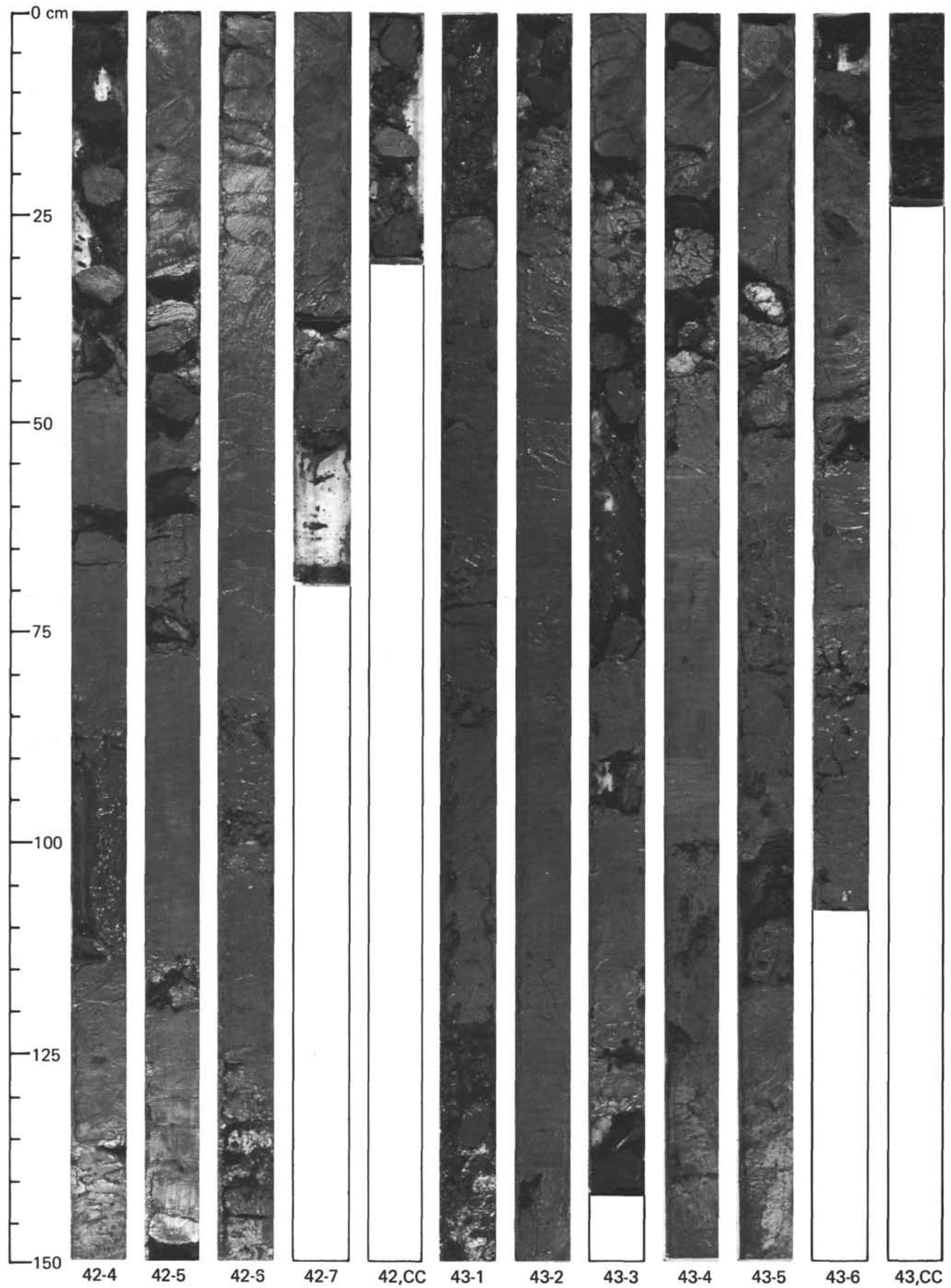


Hole 438A
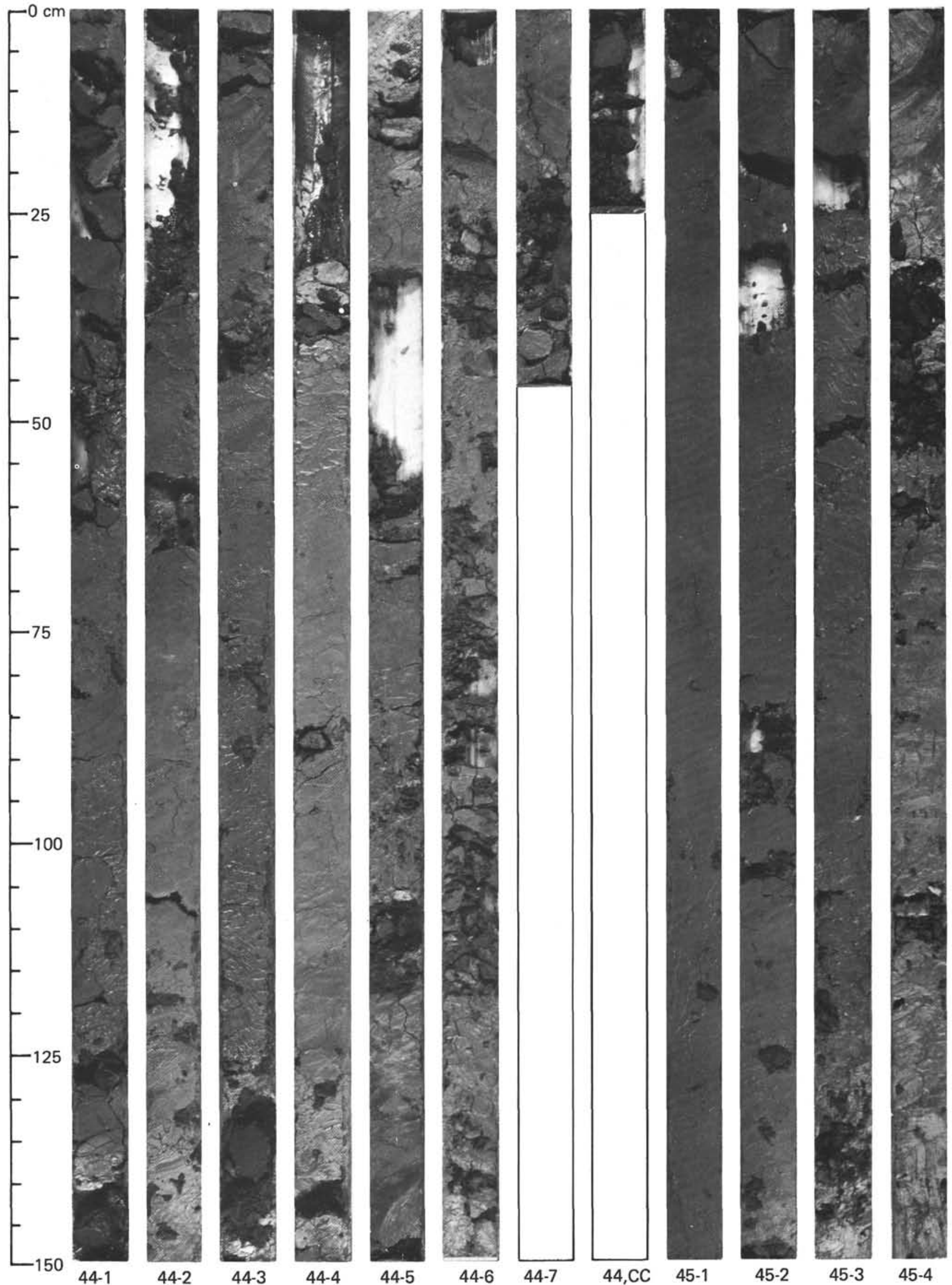
Hole 438A

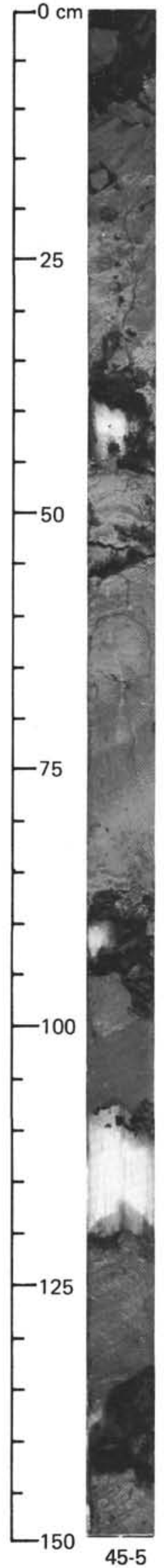

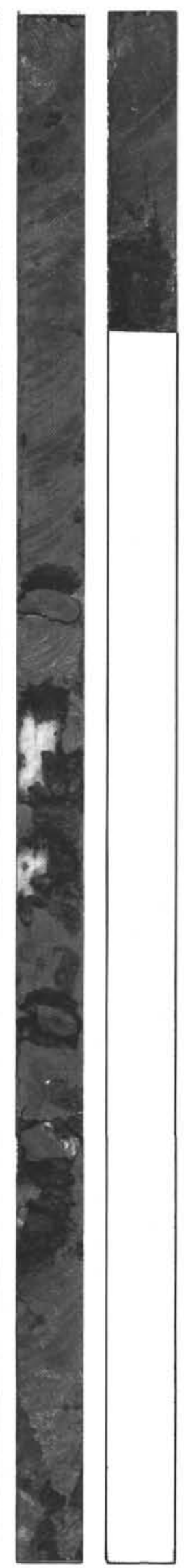

45- 6

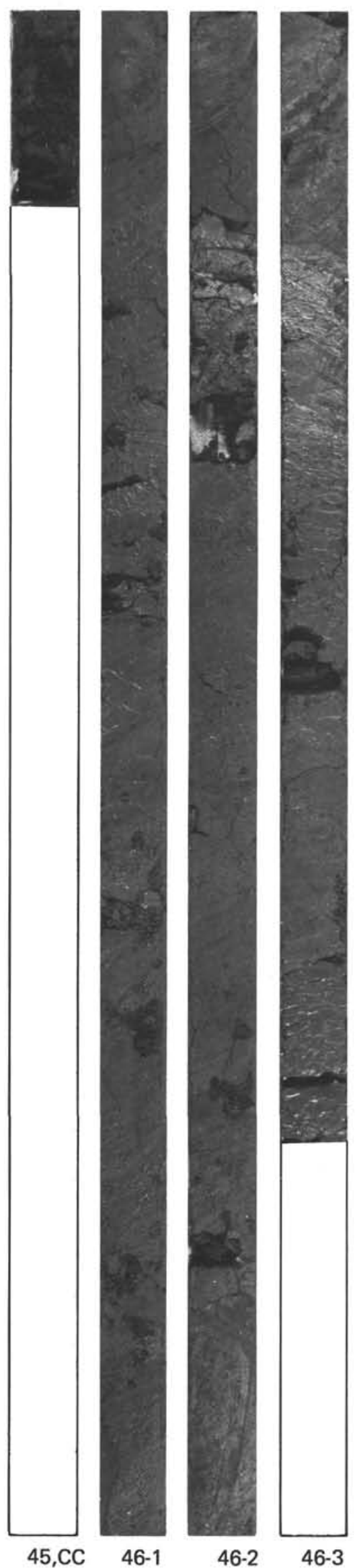

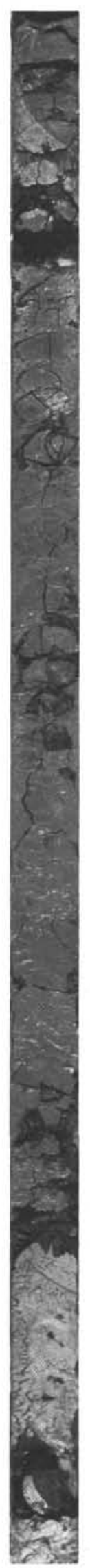

46-5

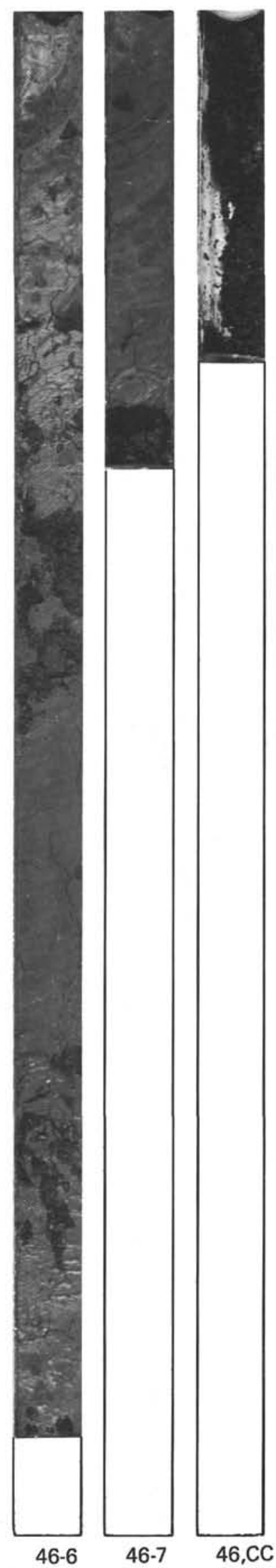


Hole 438A

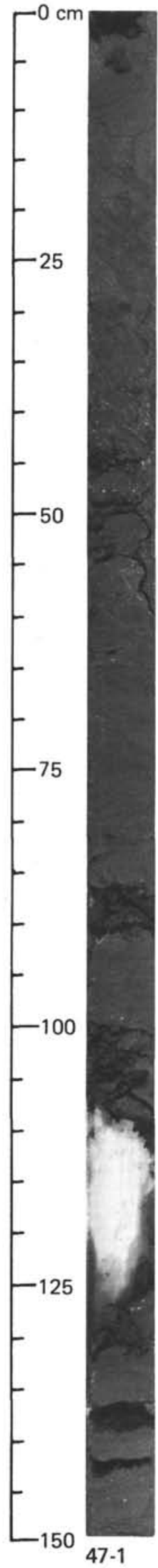

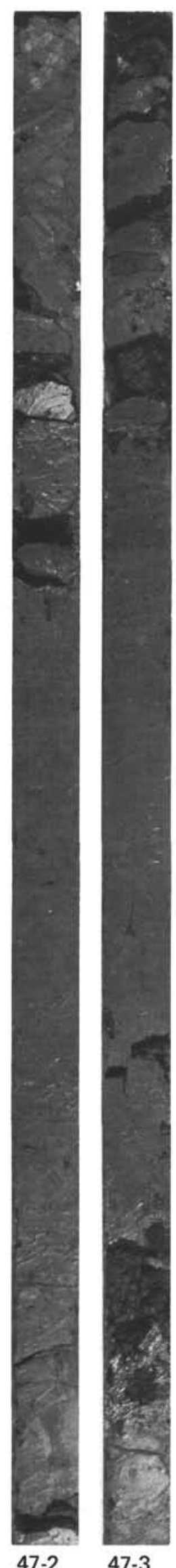
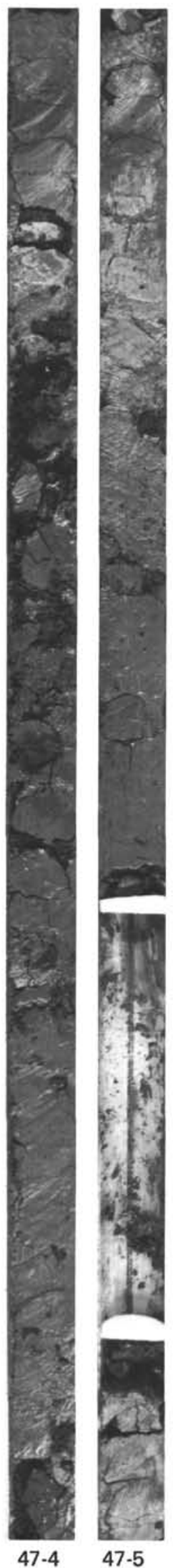

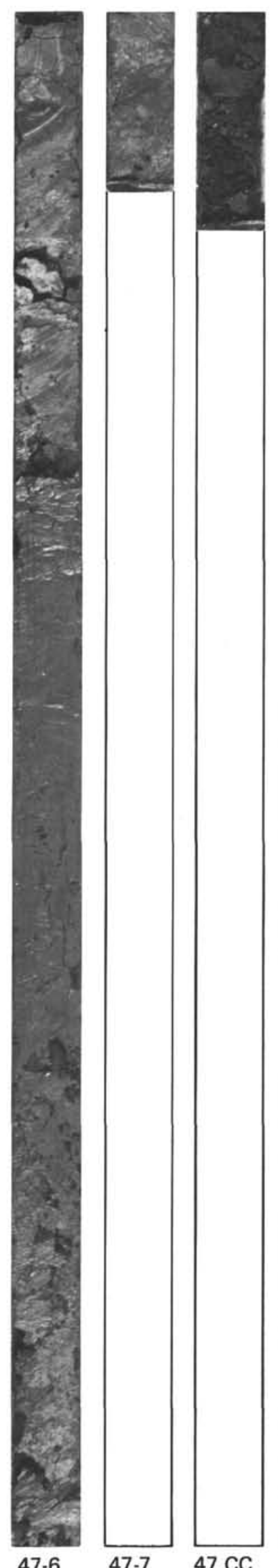

$\begin{array}{lll}47-6 & 47-7 & 47, \mathrm{CC}\end{array}$

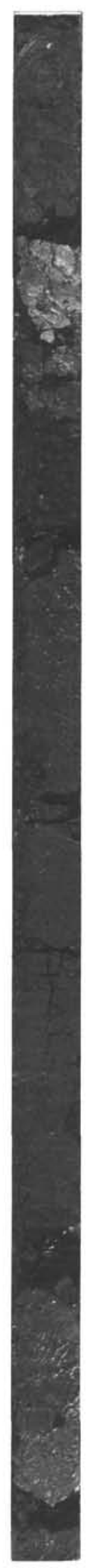

48-1

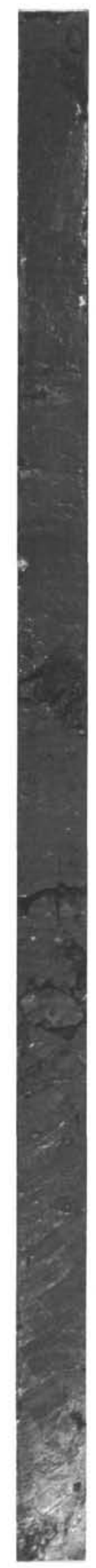

48-2

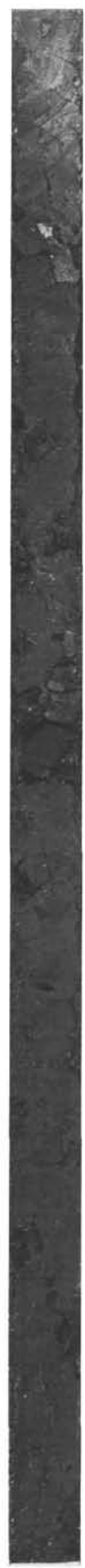

48-3

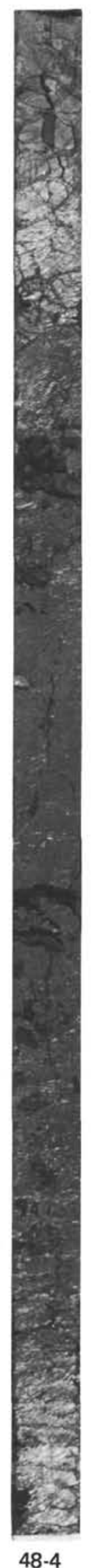


Hole 438A

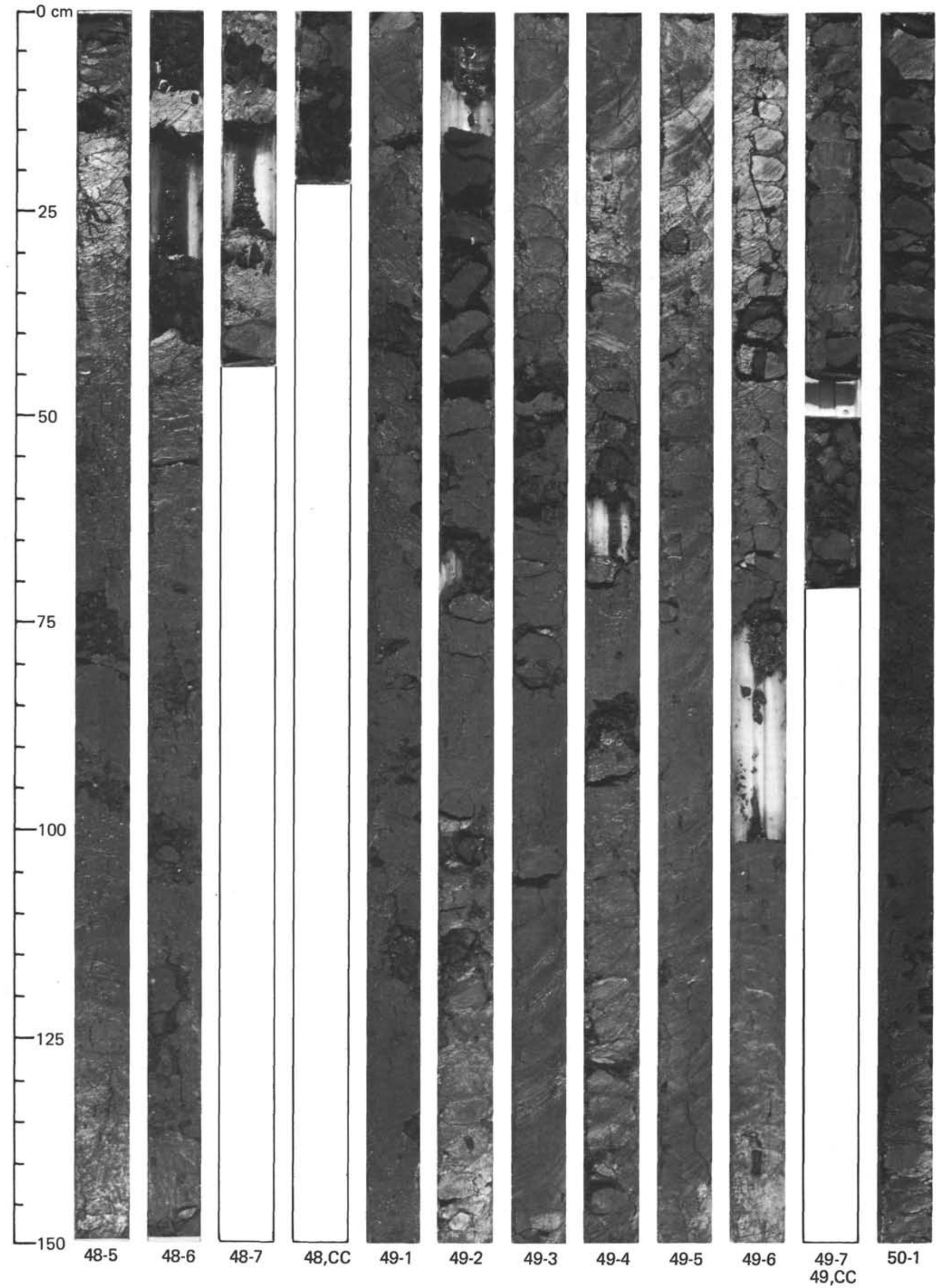


Hole 438A

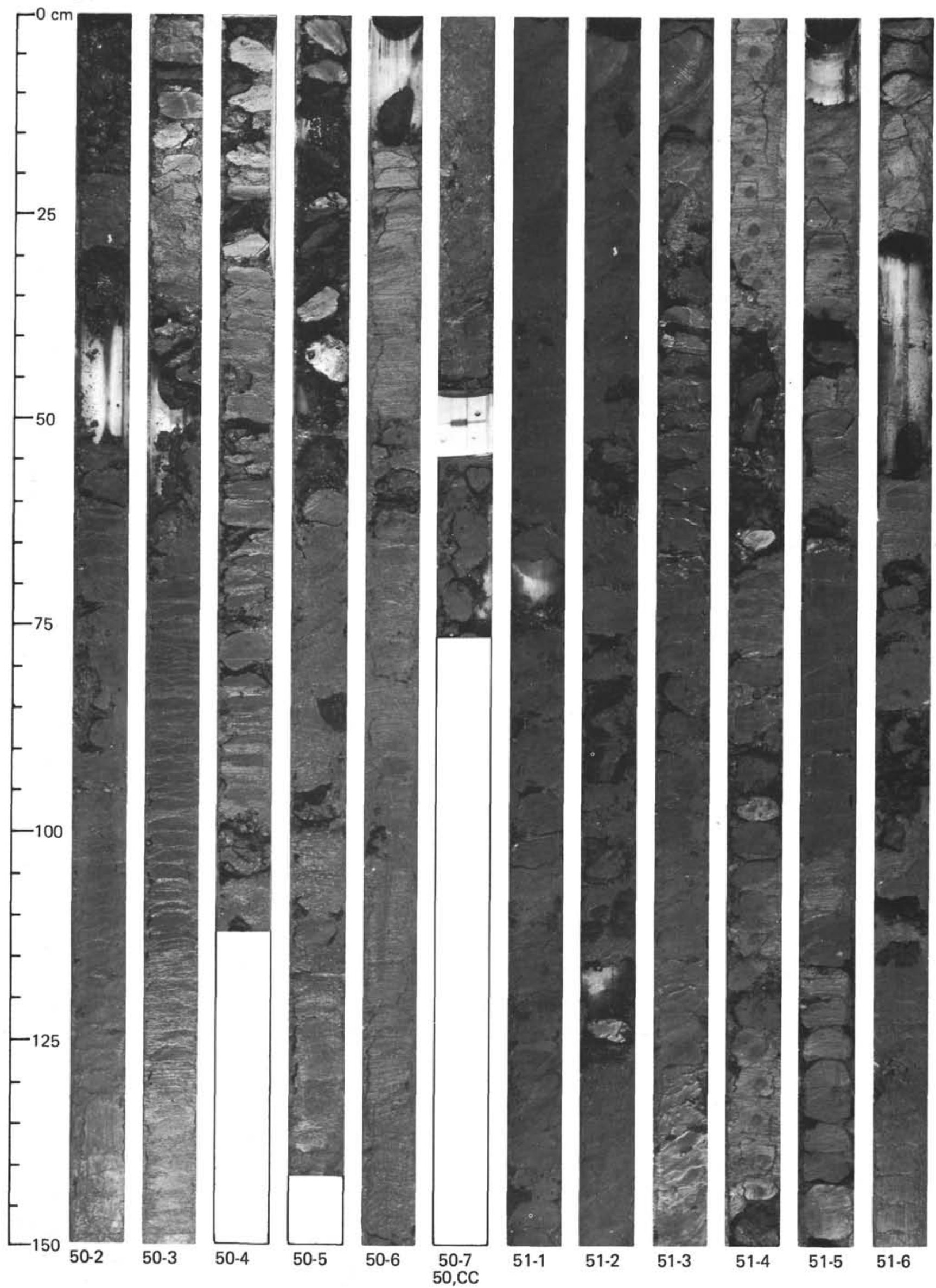


Hole 438A

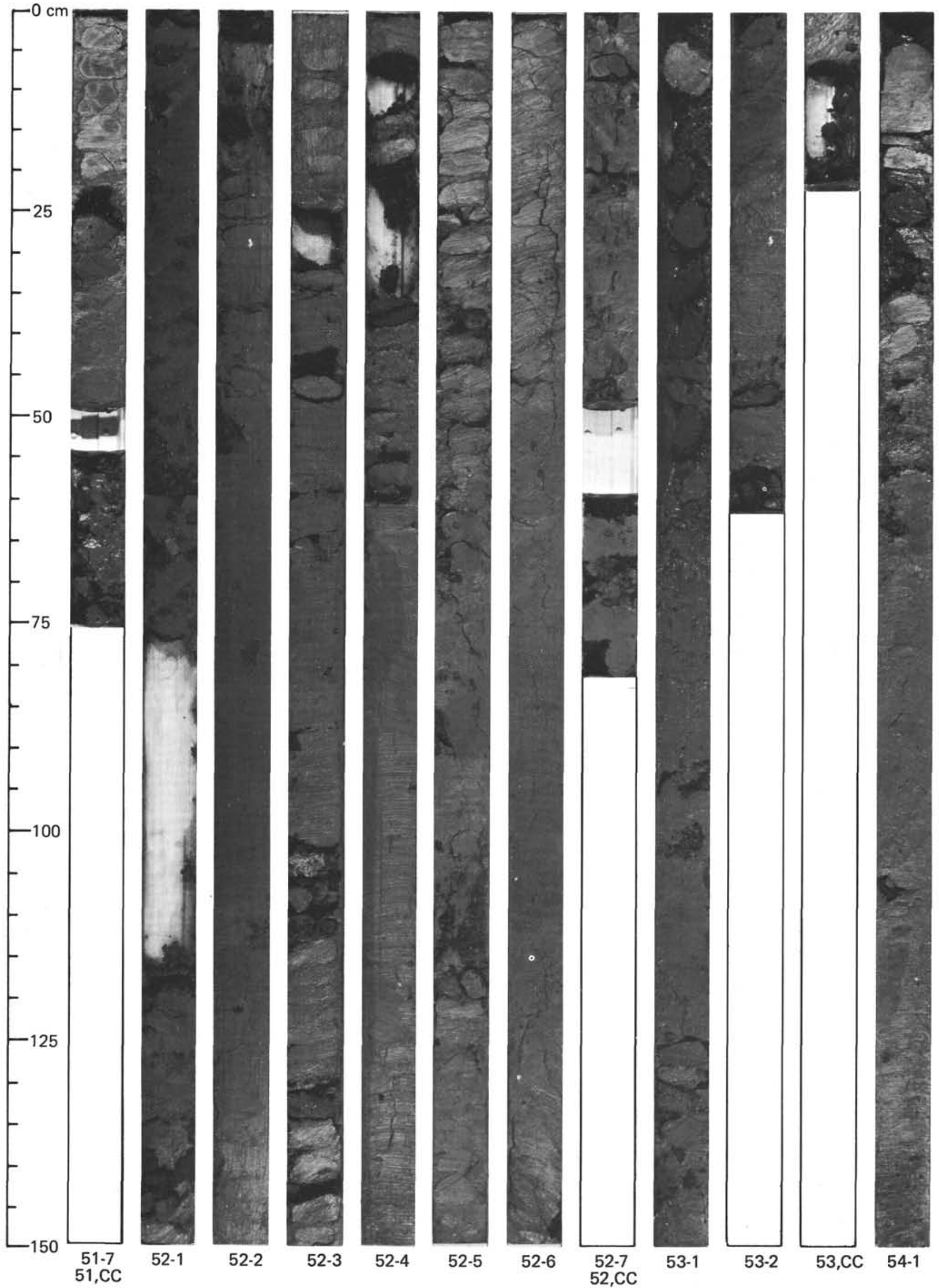


Hole 438A

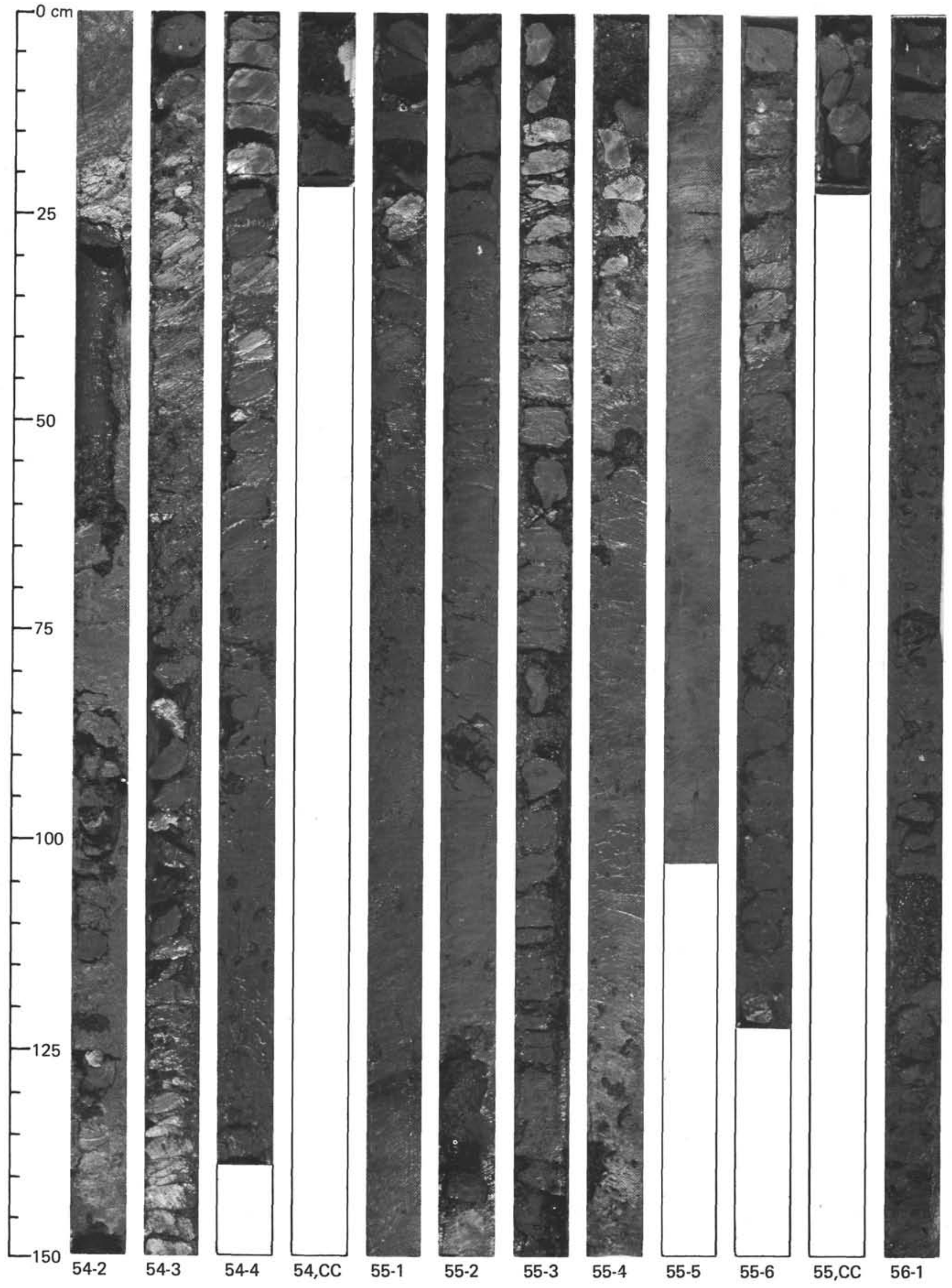


Hole 438A

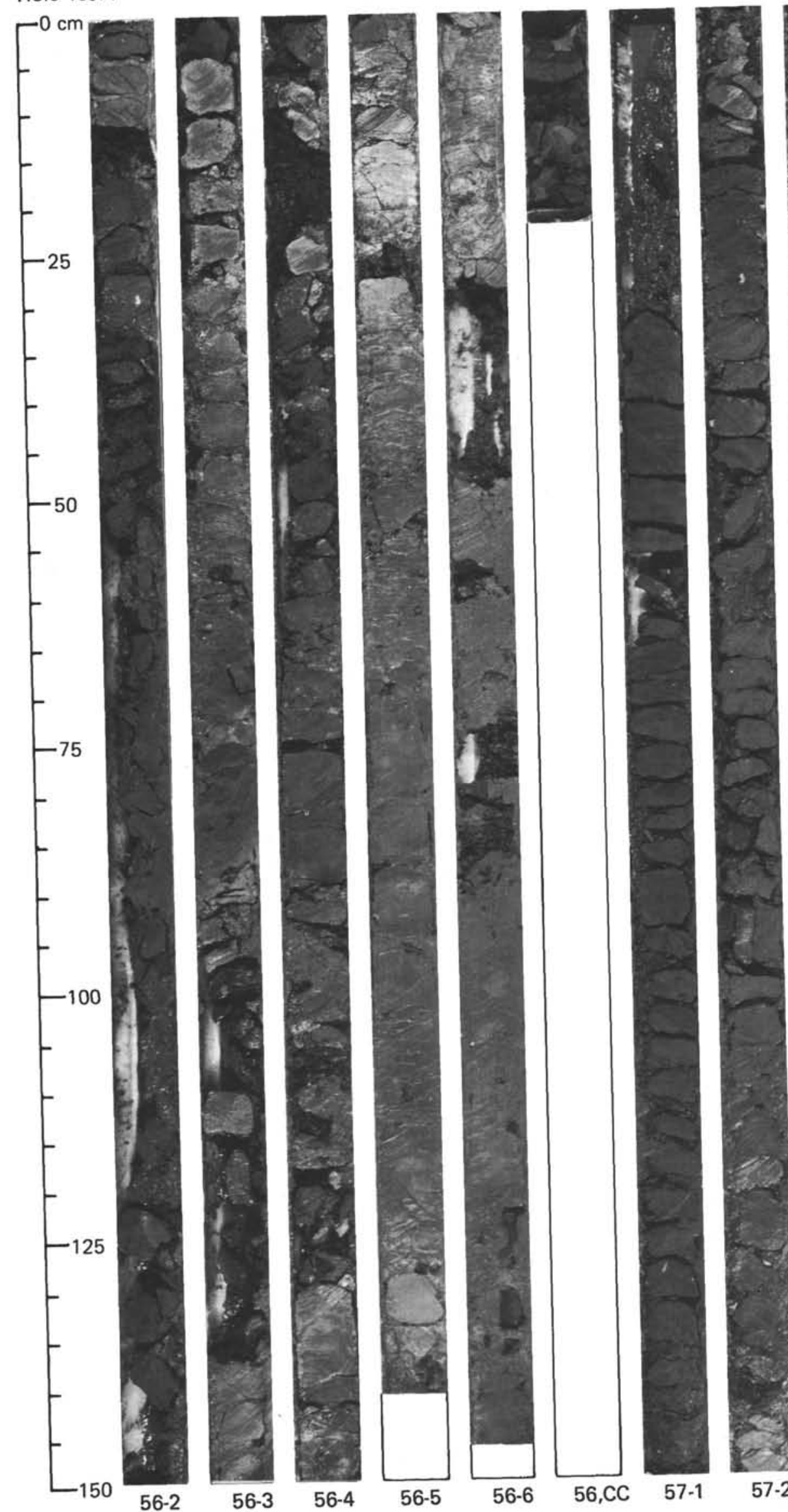

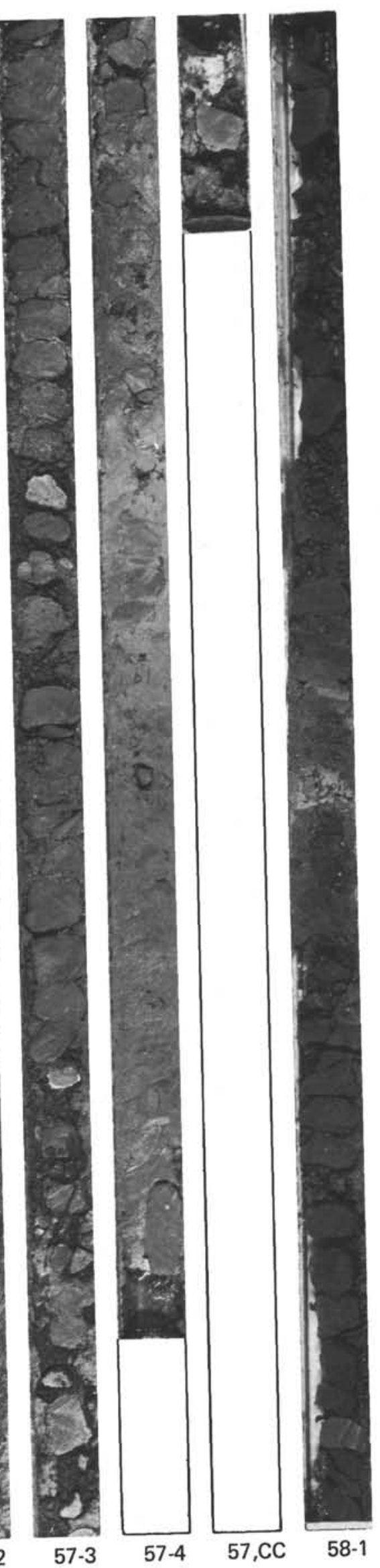


Hole 438A
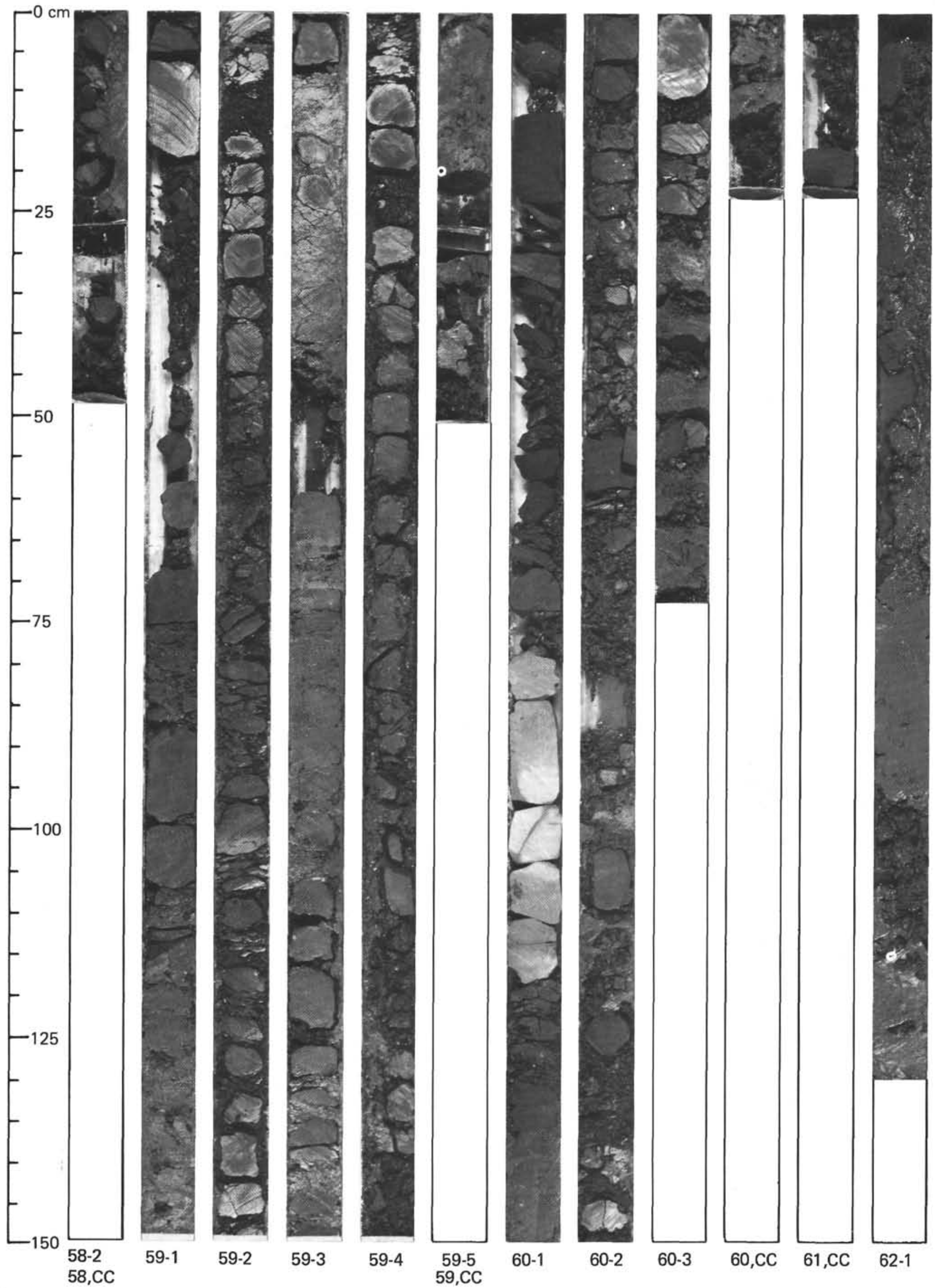
Hole 438A

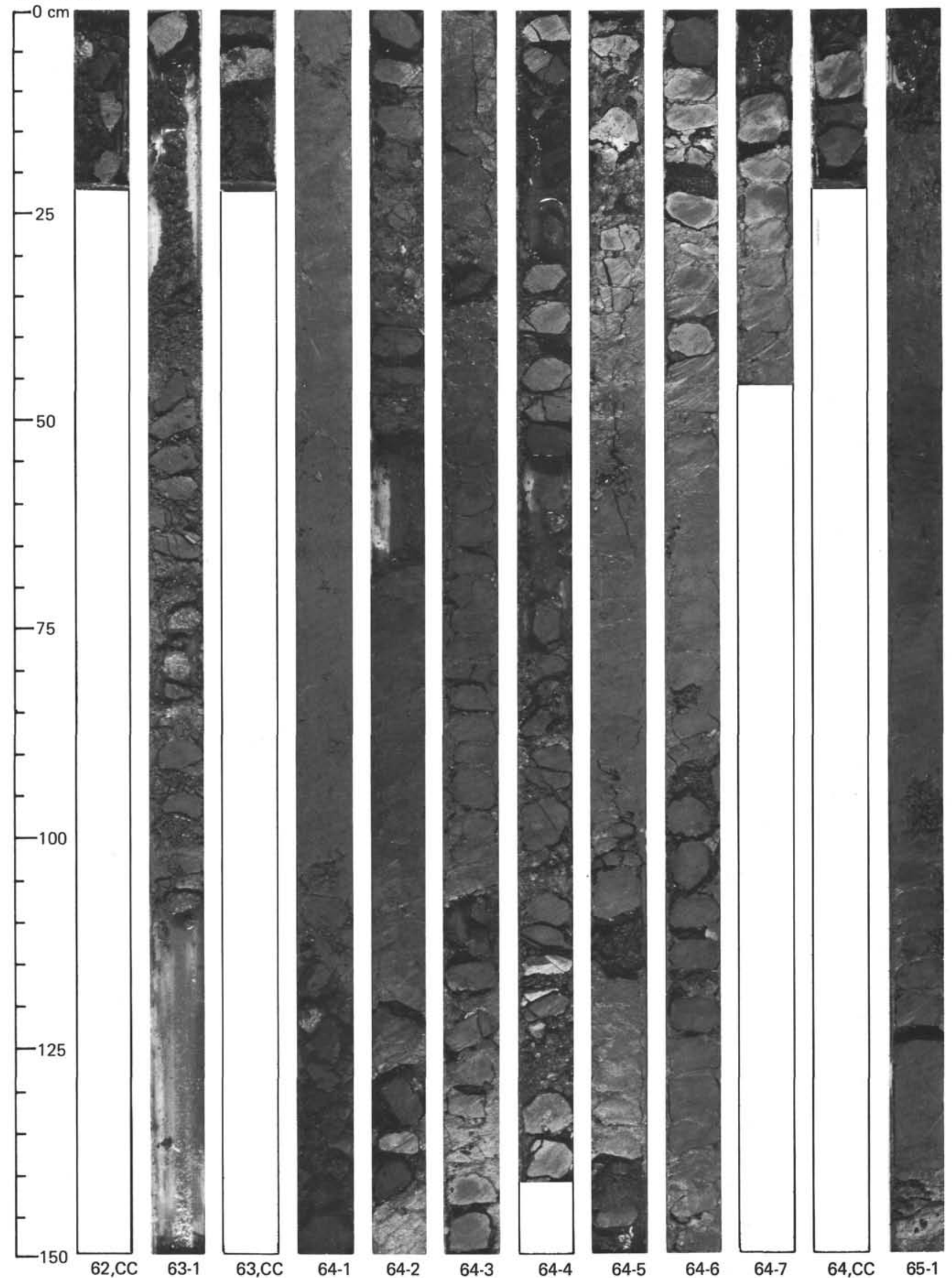


Hole 438A

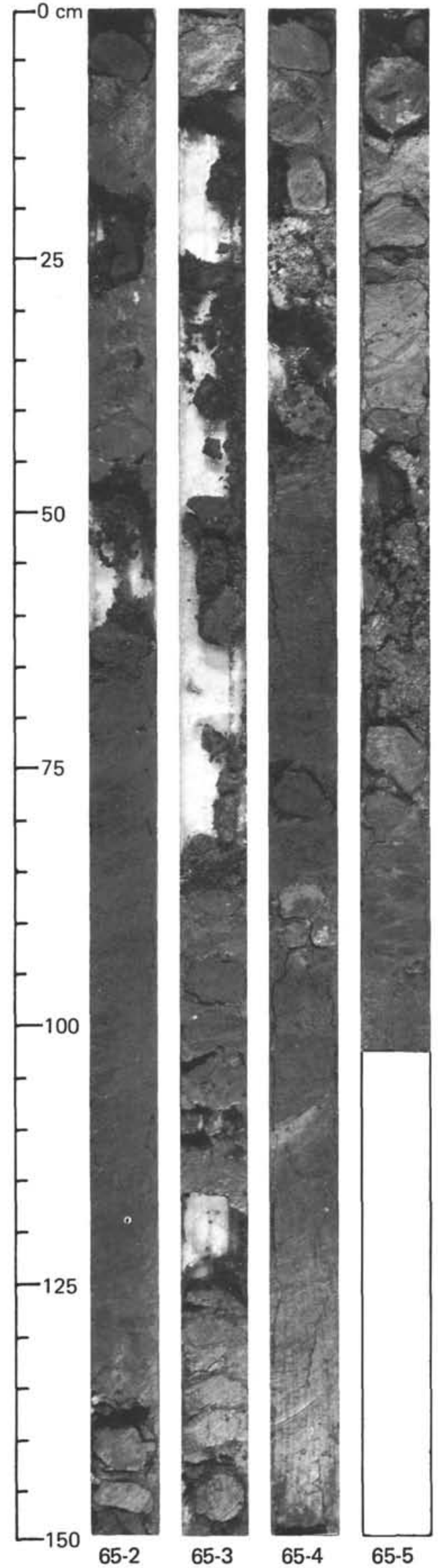

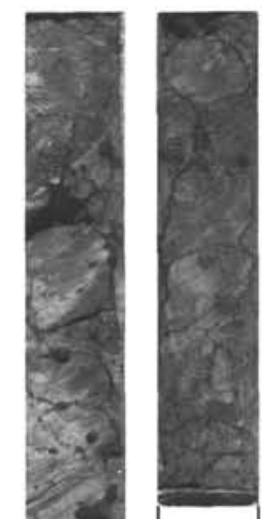
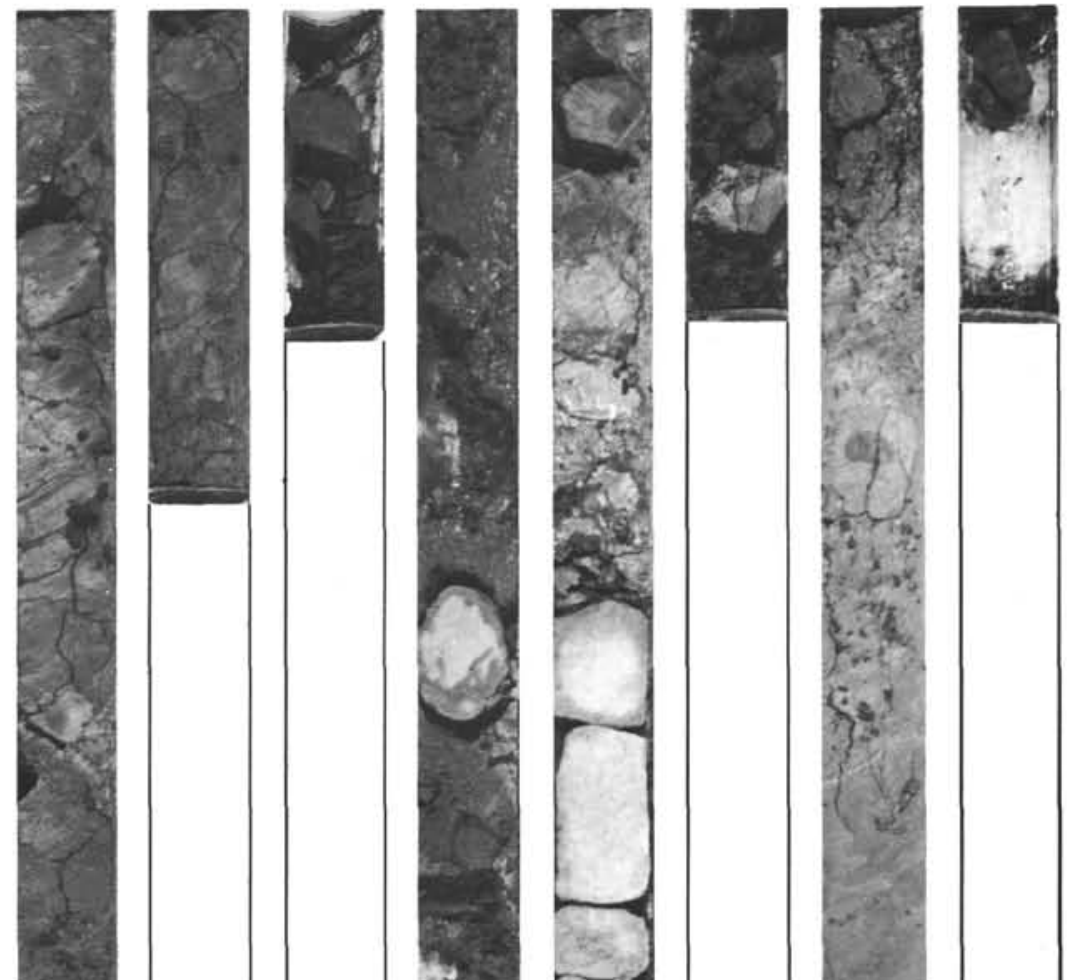

th
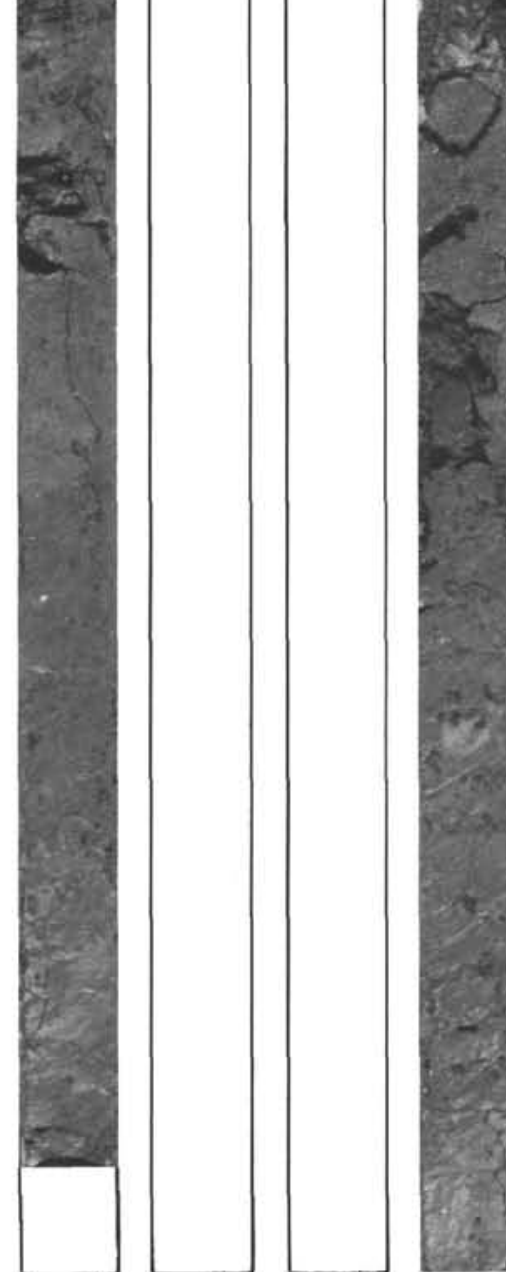

65-6

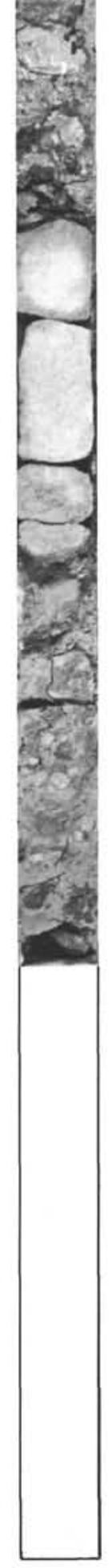

66-2

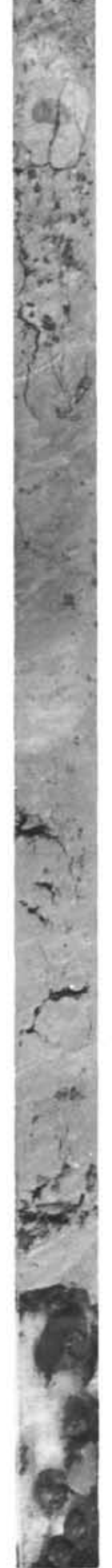

67-1 
Hole 438A

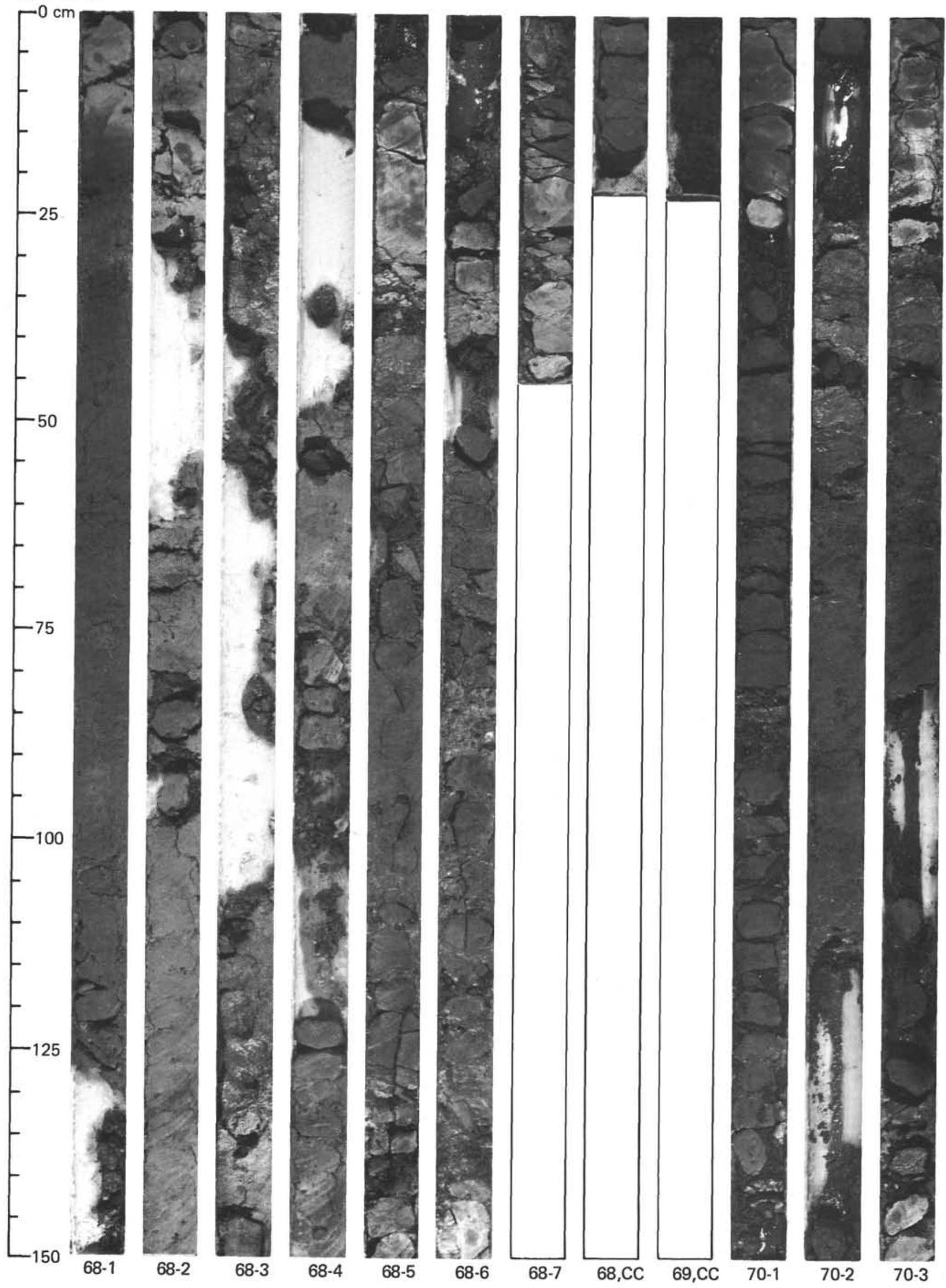


Hole 438A
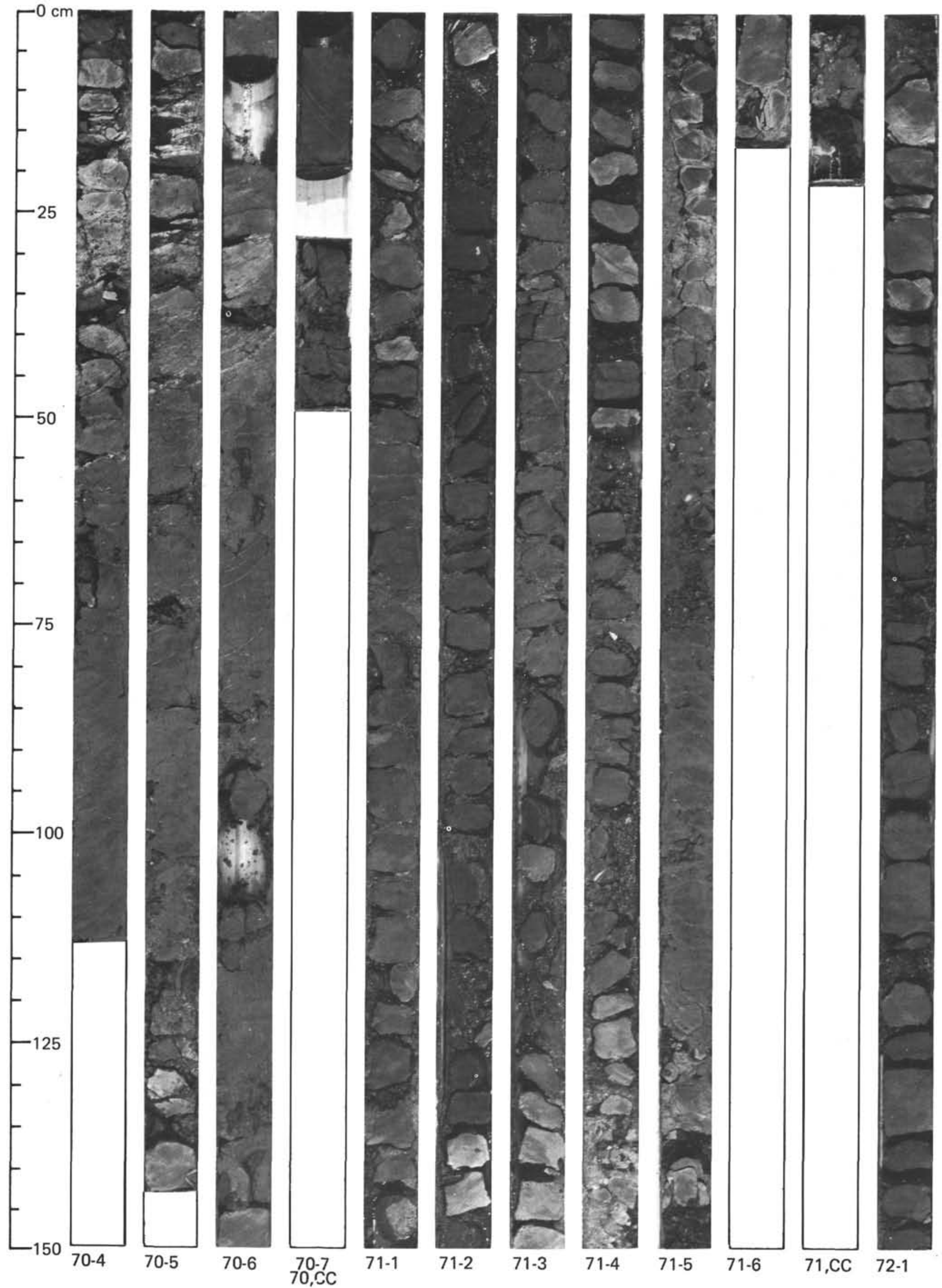
Hole 438A
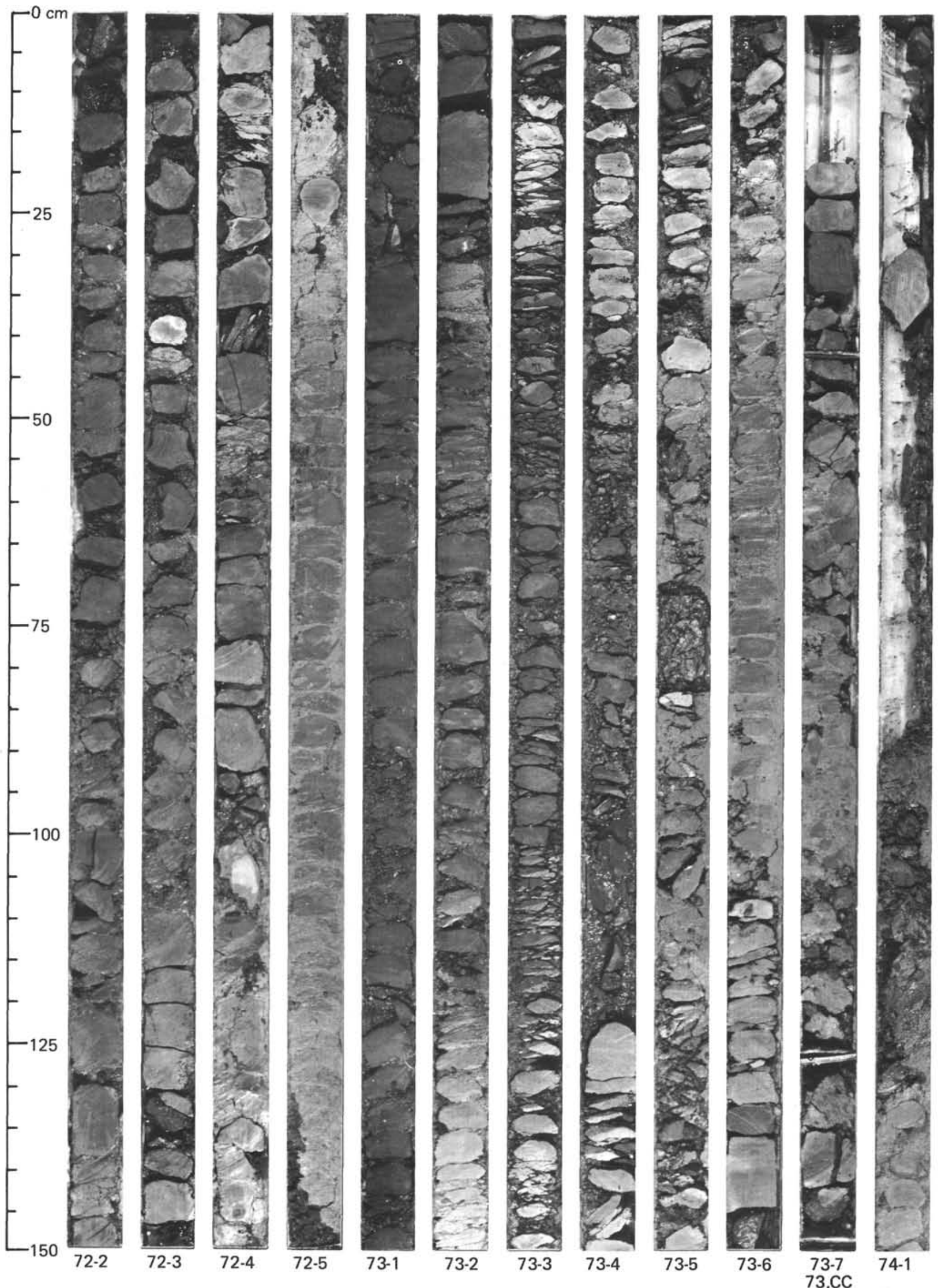
Hole 438A

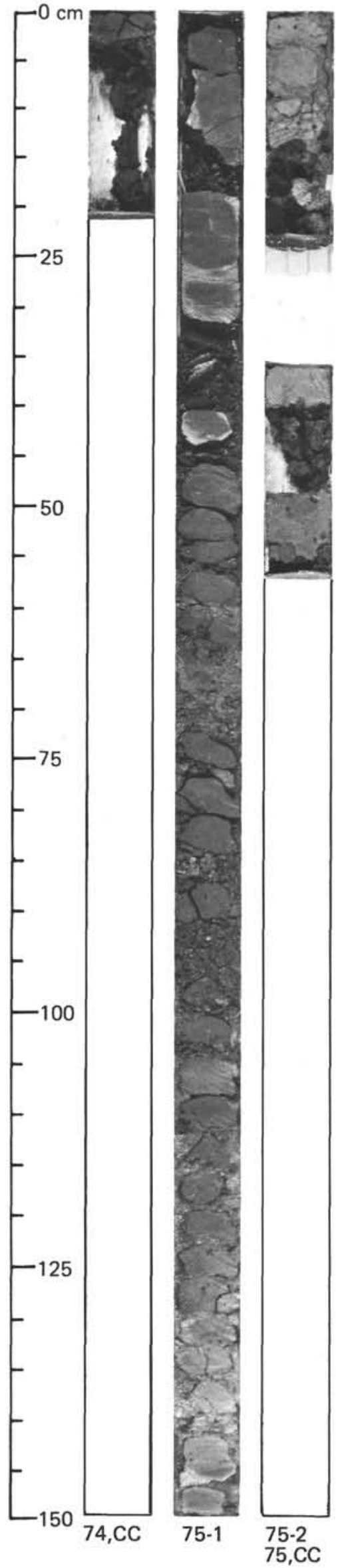

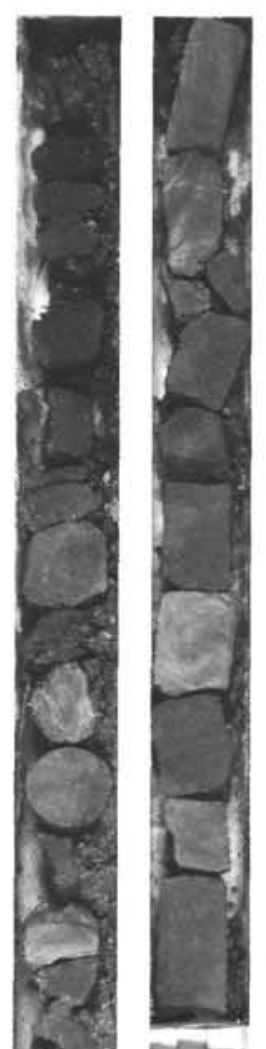
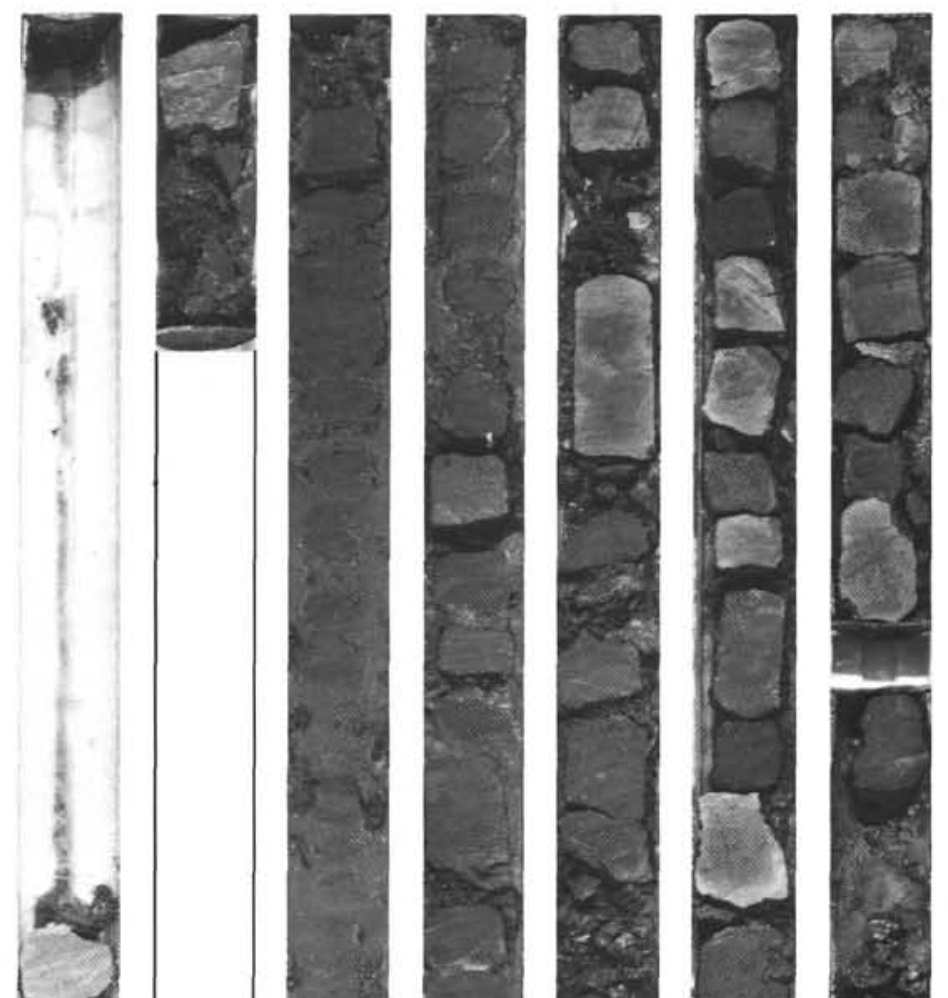

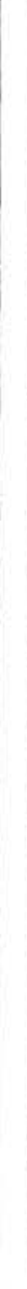

76-2

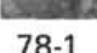

78-1

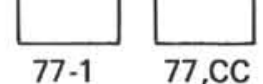

78-2

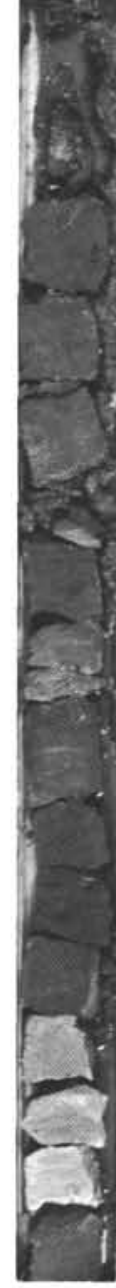

78-3
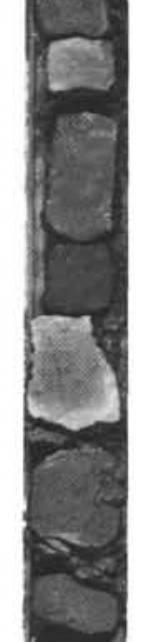

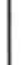
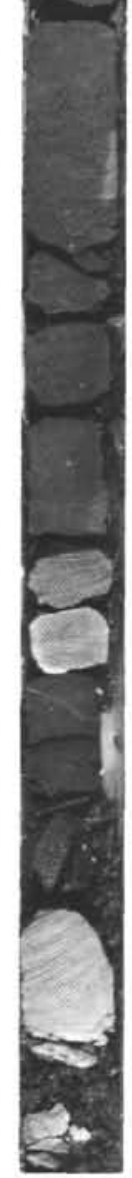

78-4 
Hole 438A
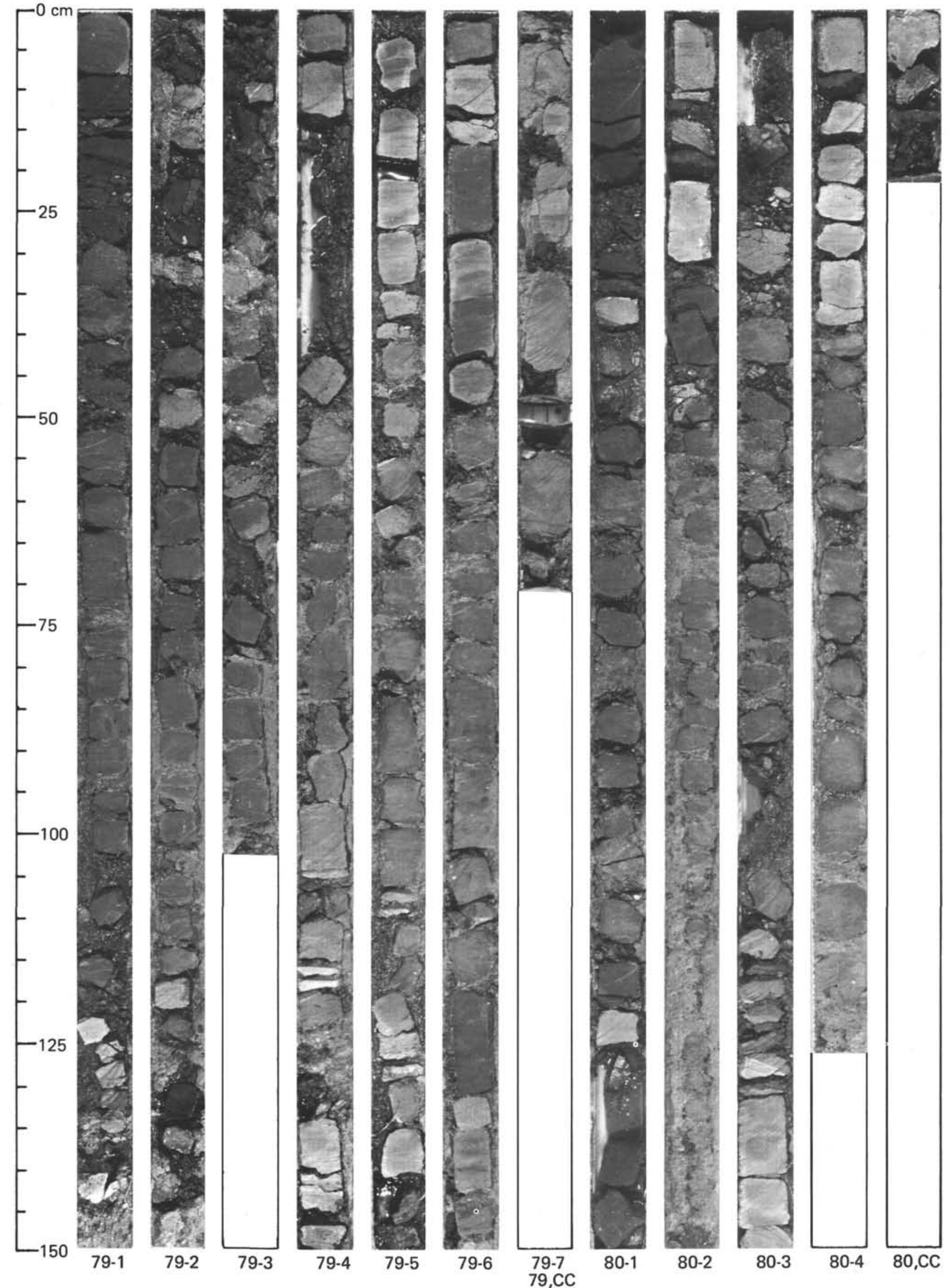
Hole 438A
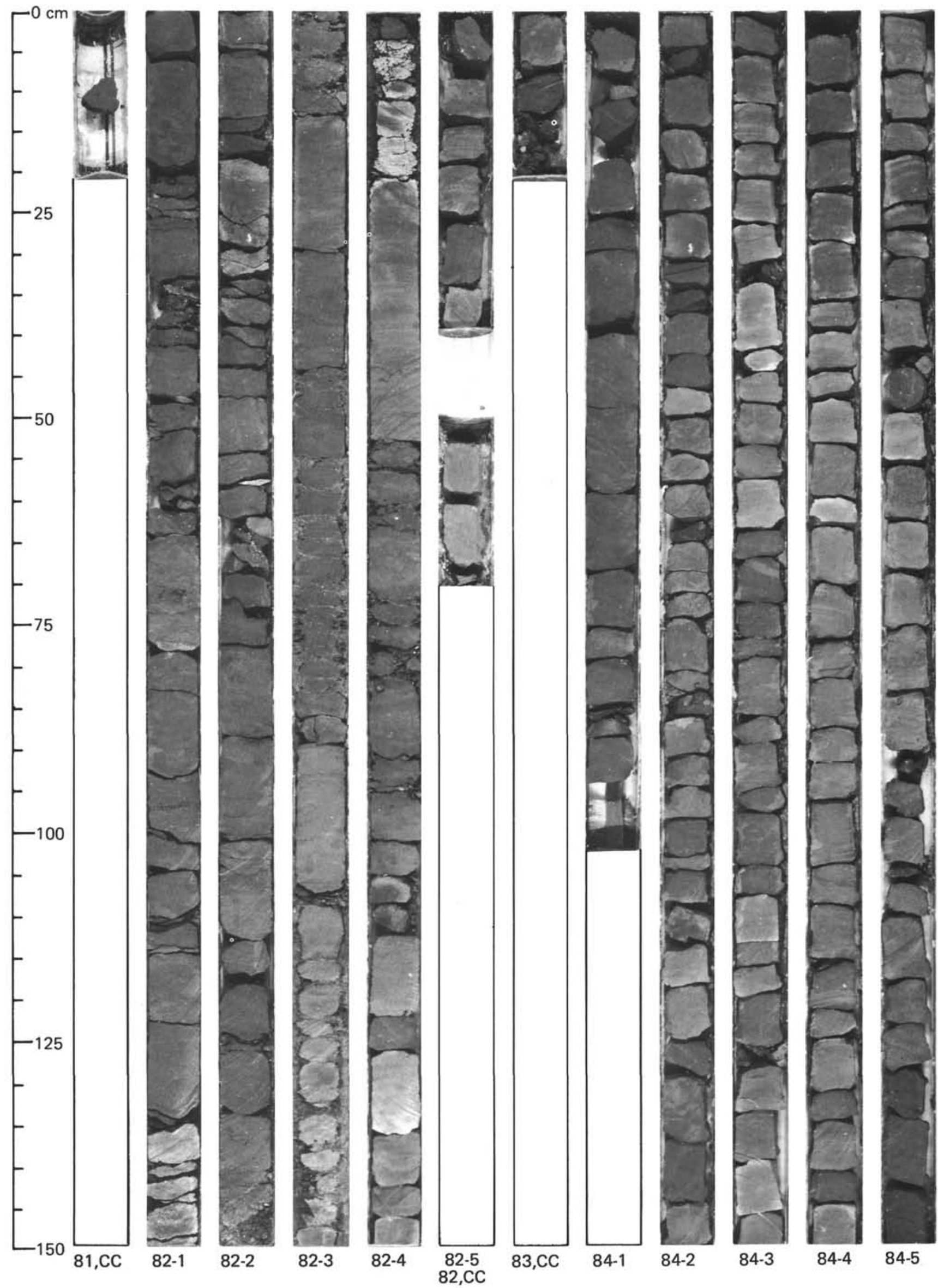
Hole 438A

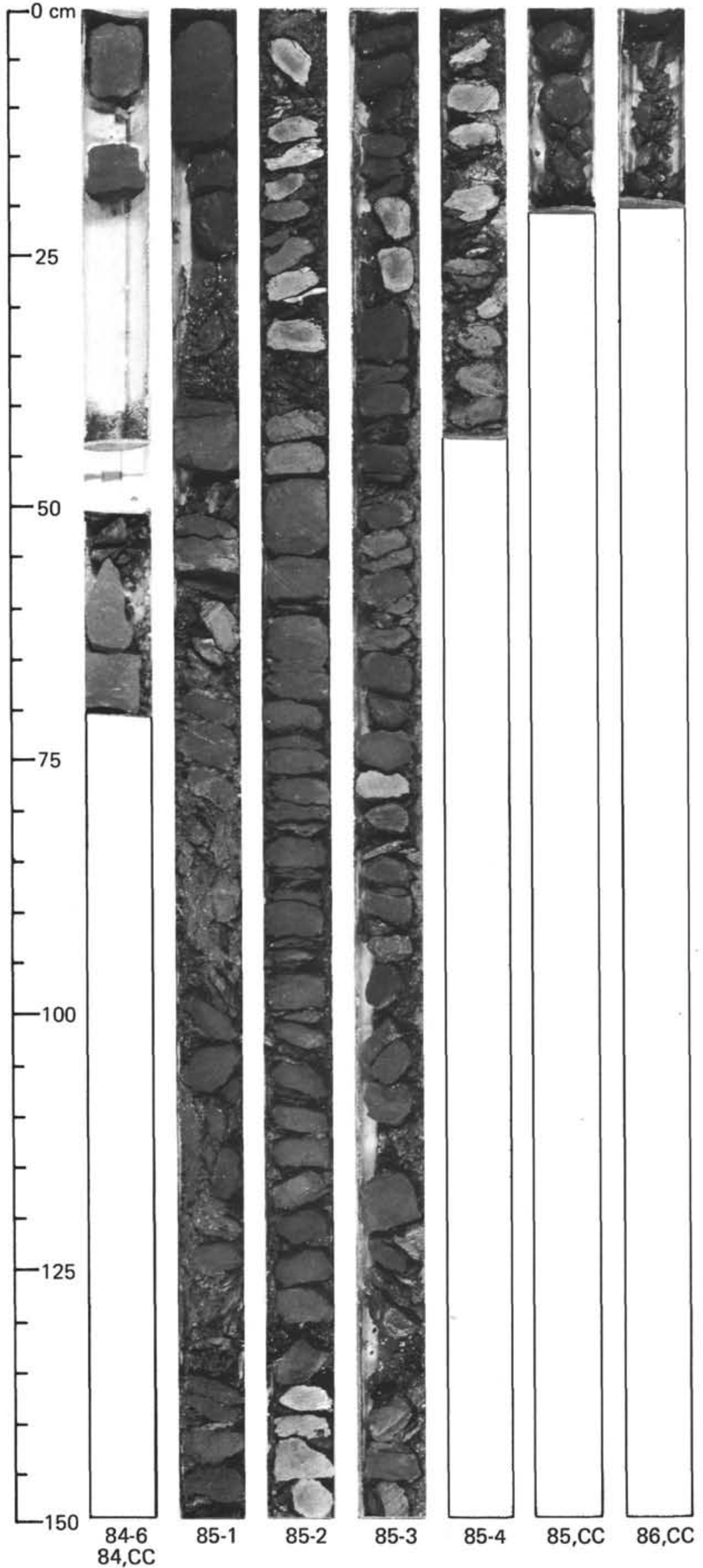


Hole 438B
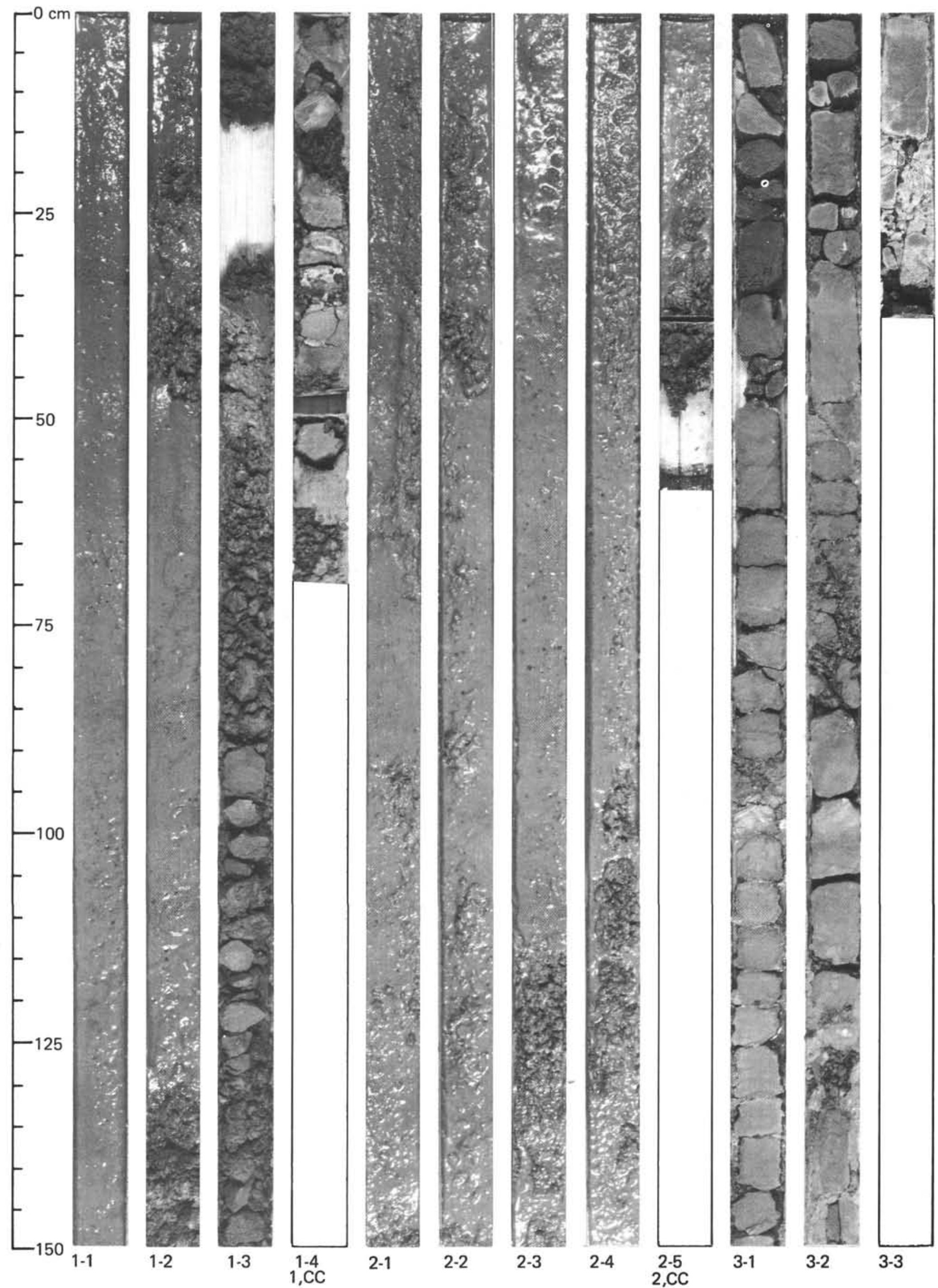
Hole 438B

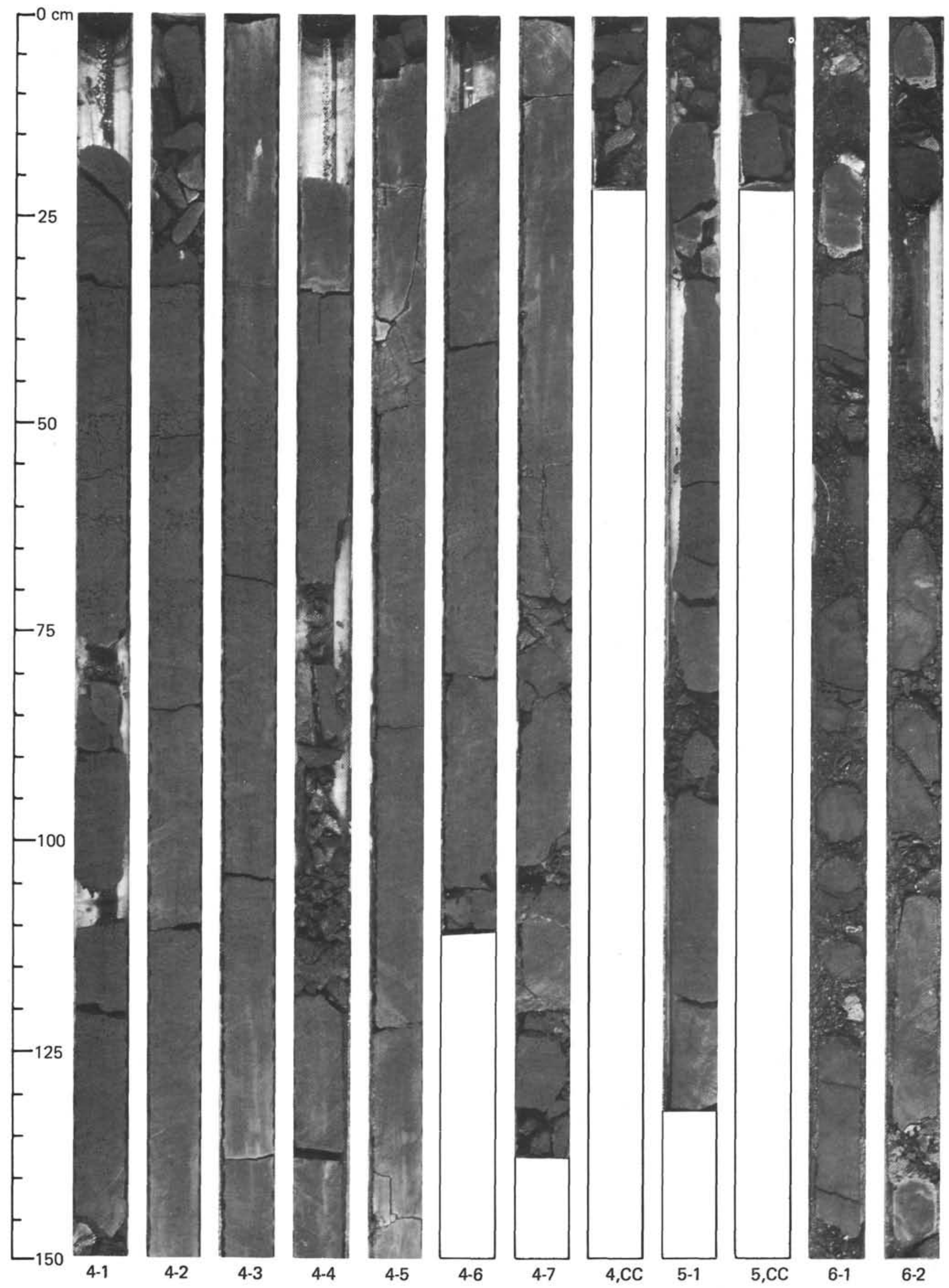



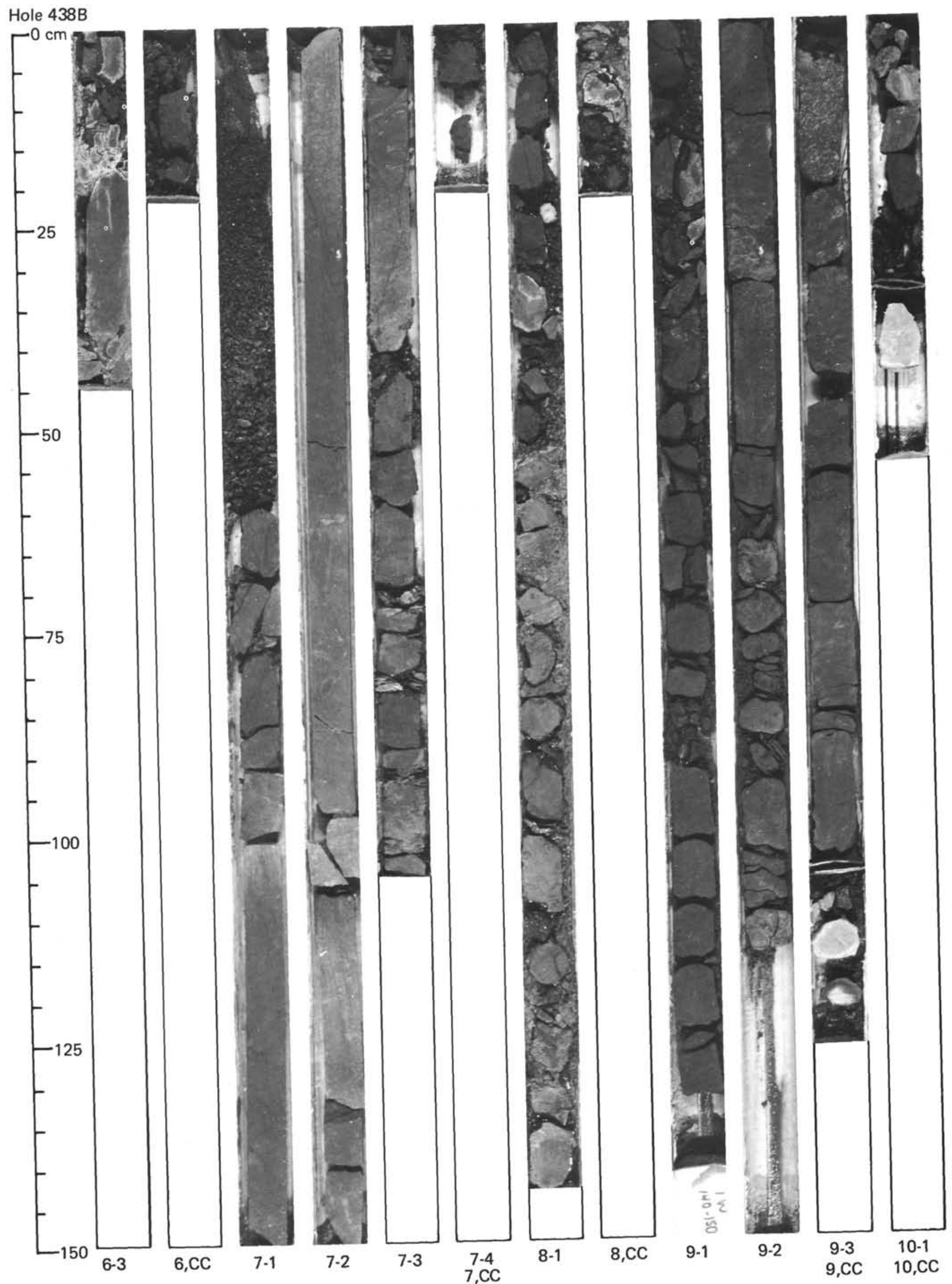
Hole 438B

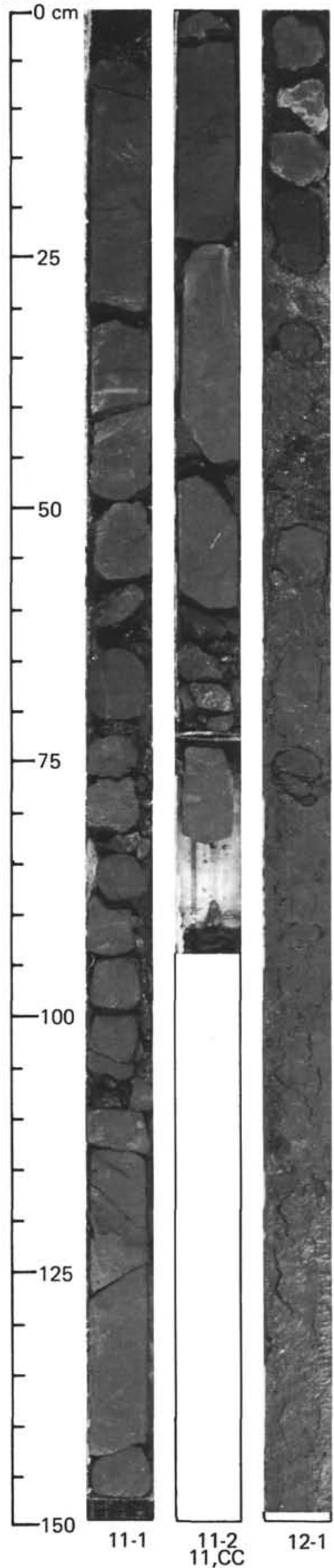

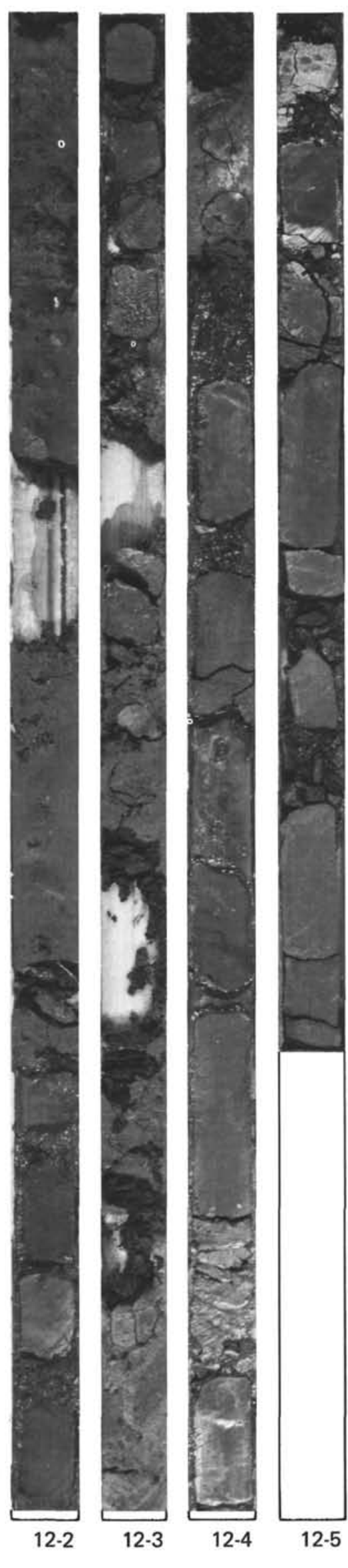
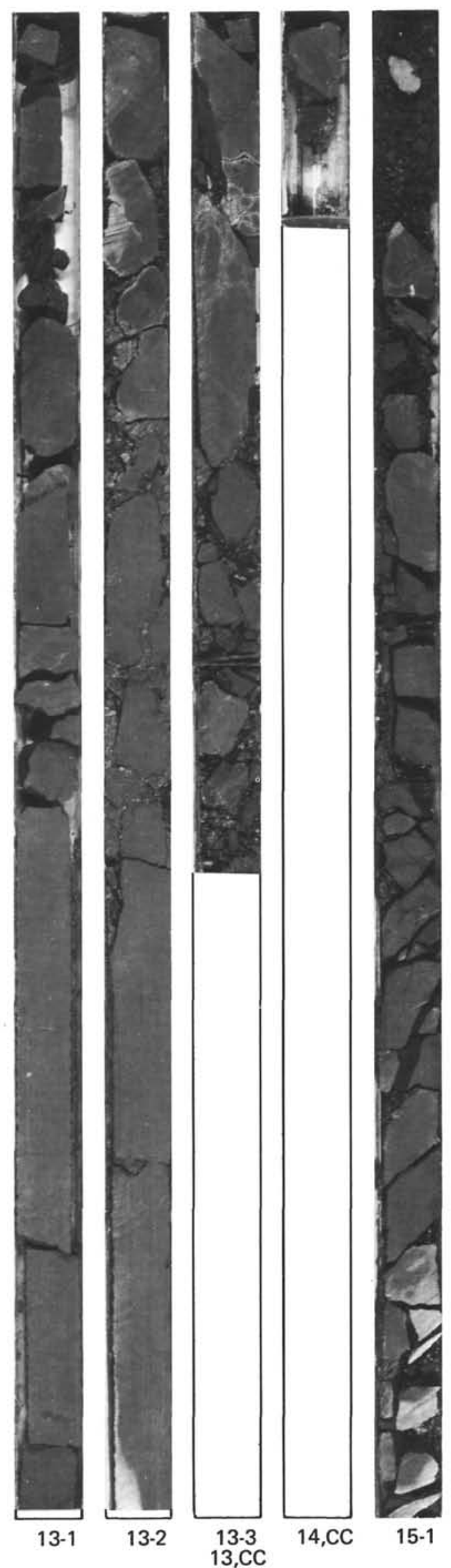
Hole 438B

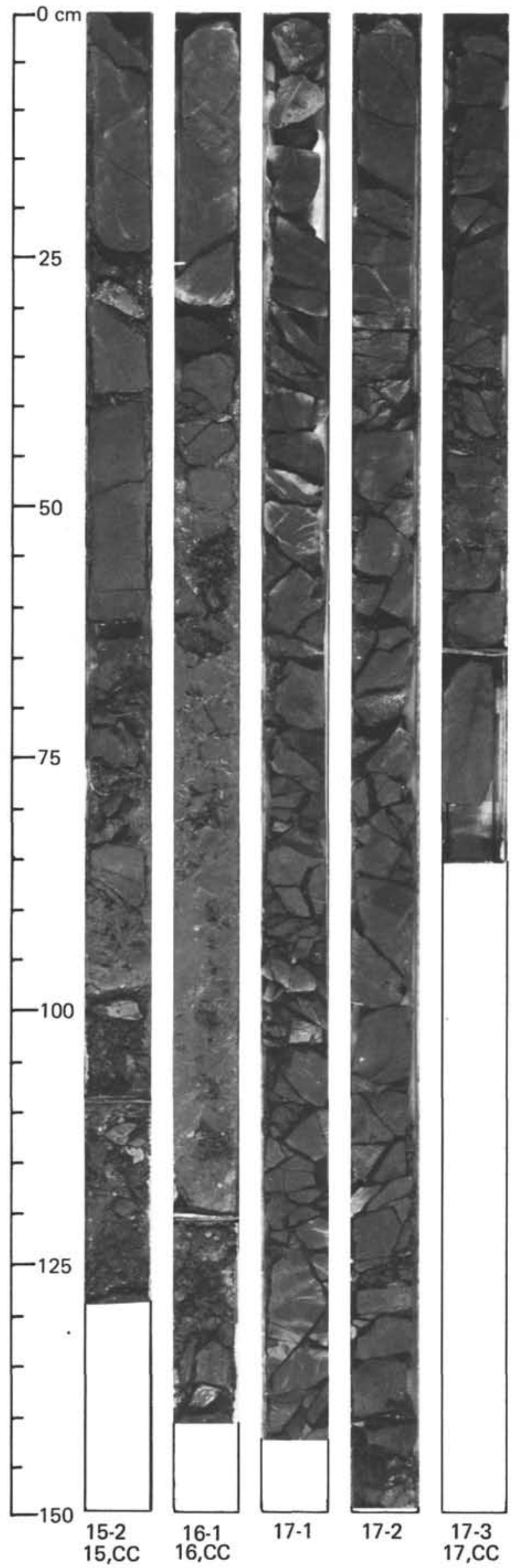

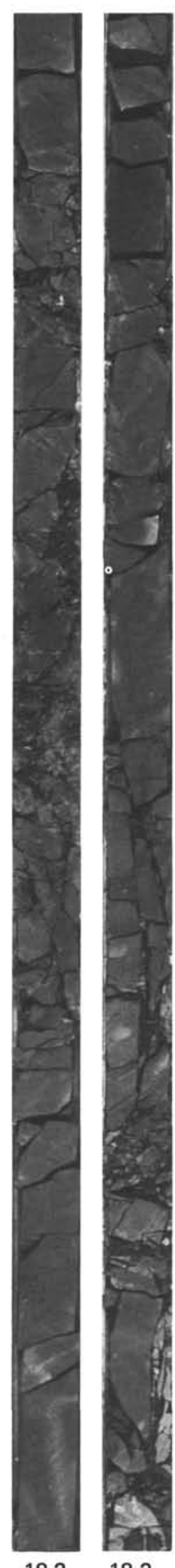

$18-2$

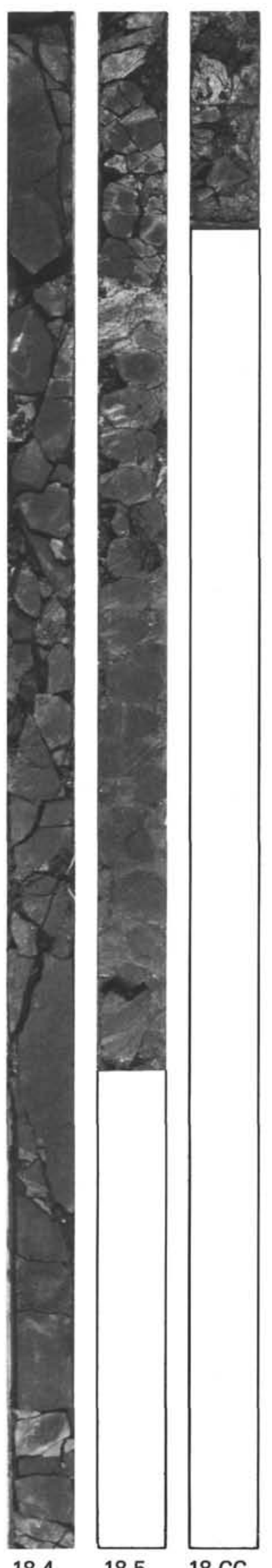

$18-5 \quad 18, \mathrm{CC}$
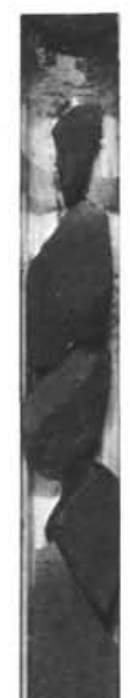

8
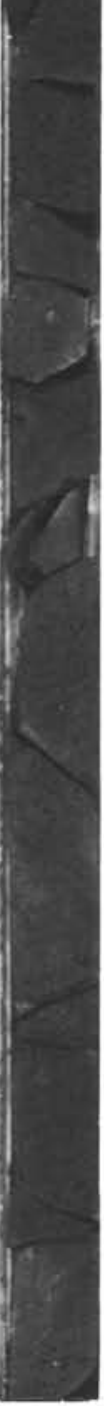

19-1 
Hole 438B

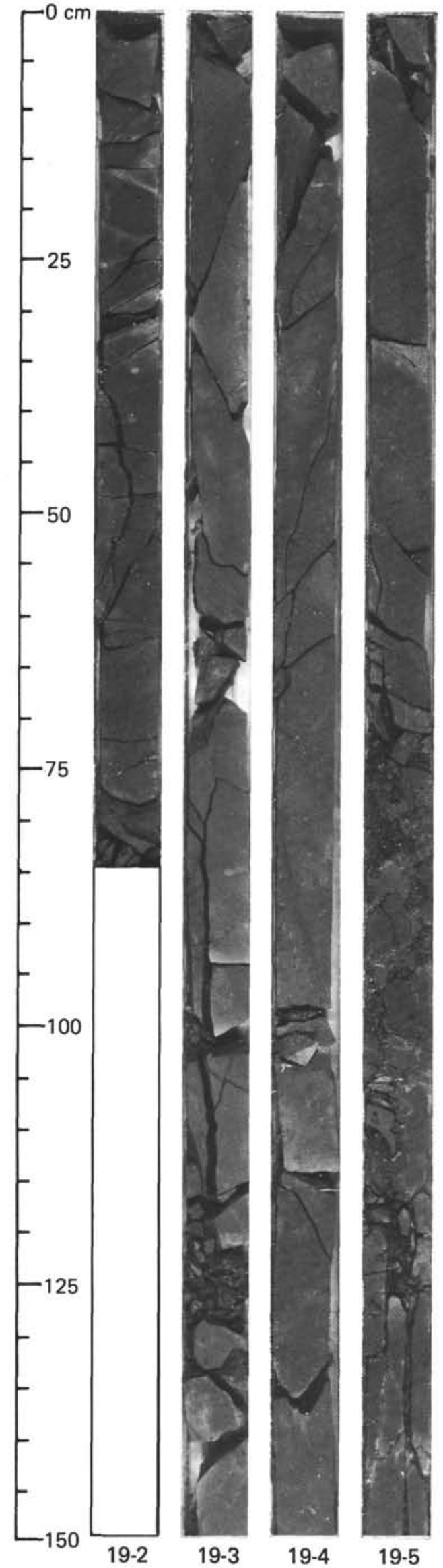

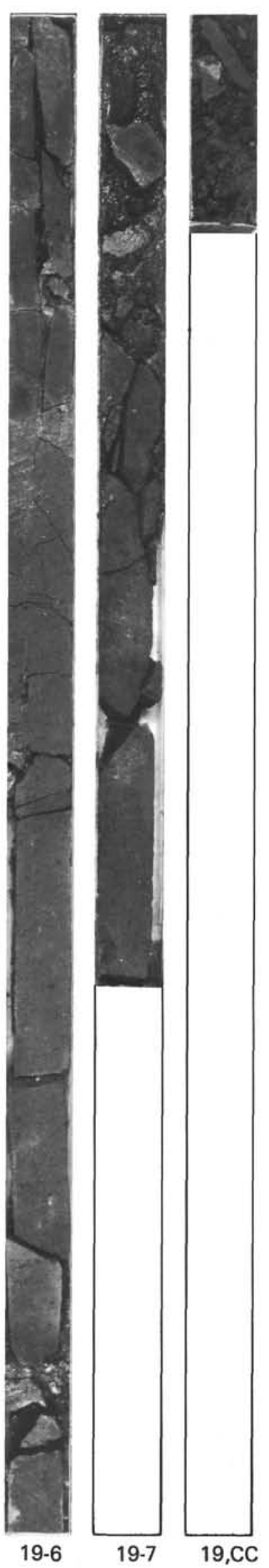

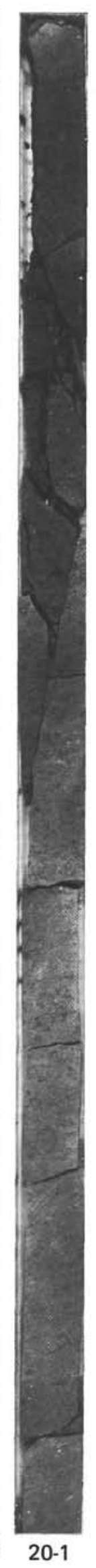

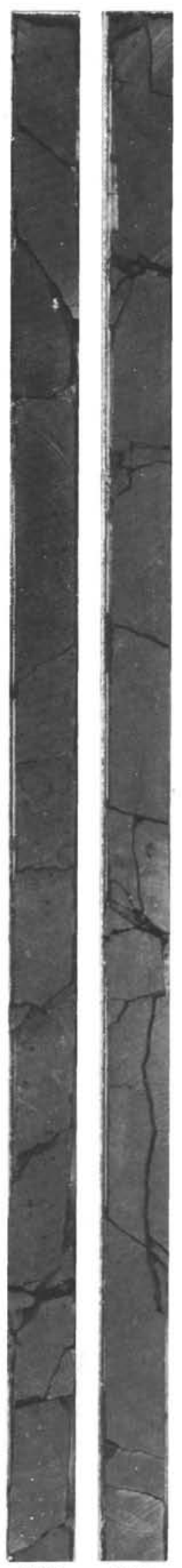

20-2
20-3

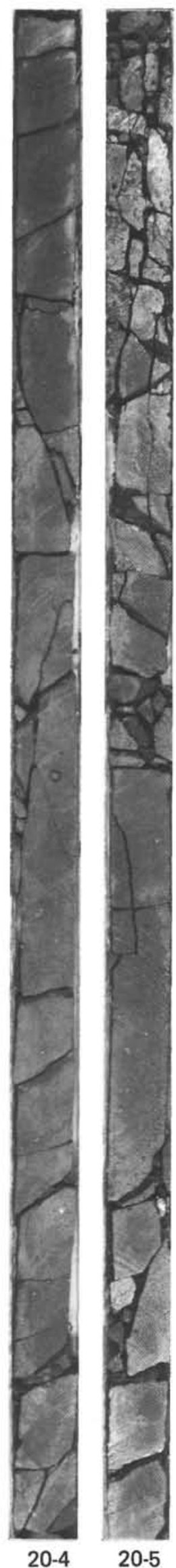


Hole 438B

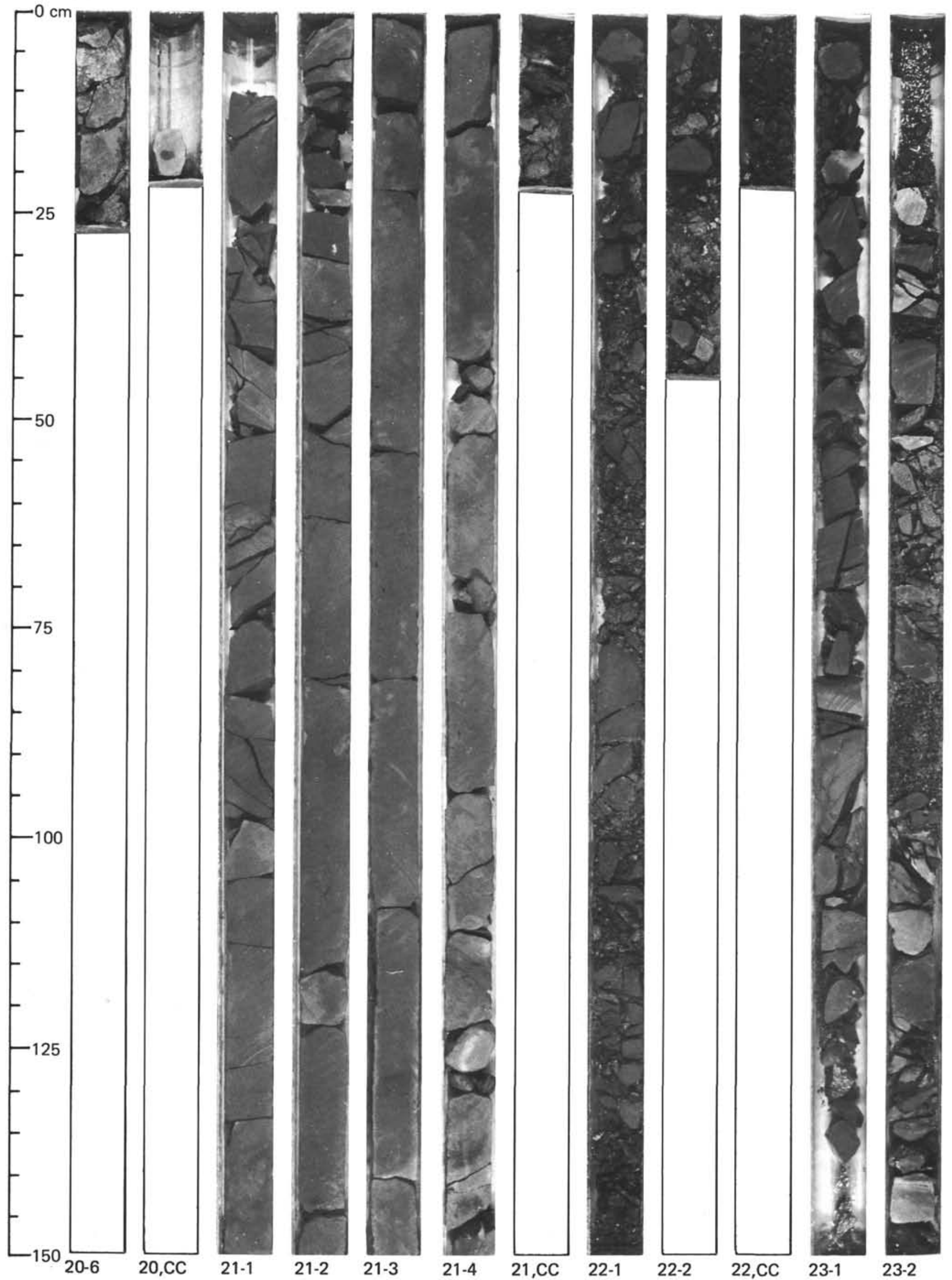


Hole 438B

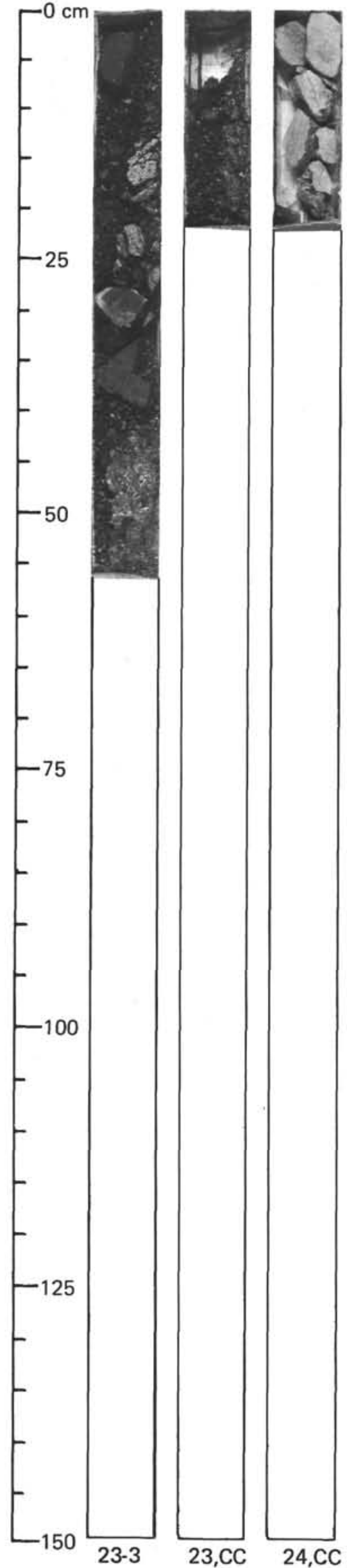




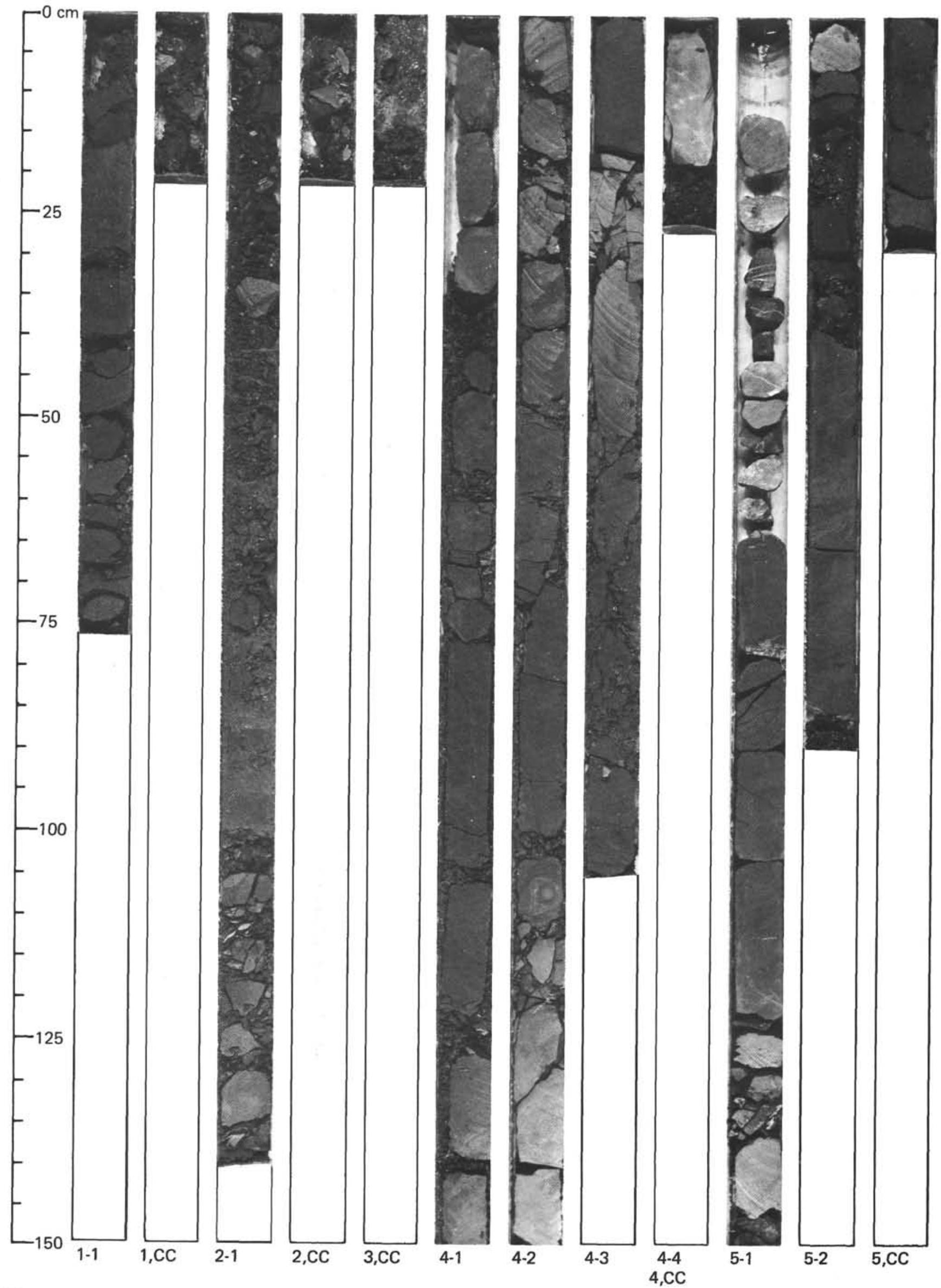


Site 439

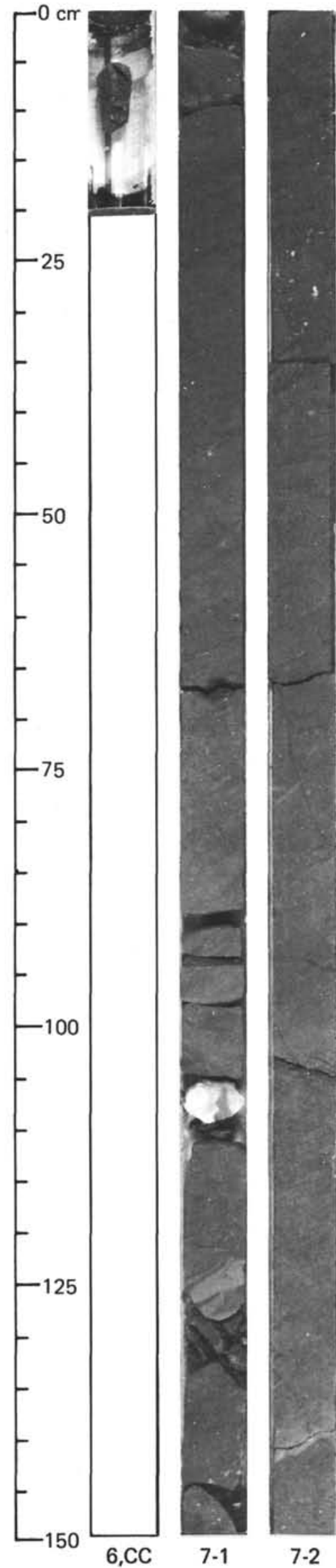

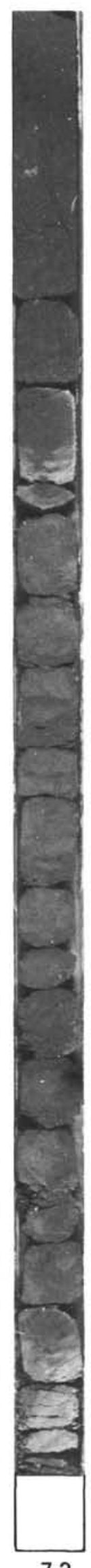

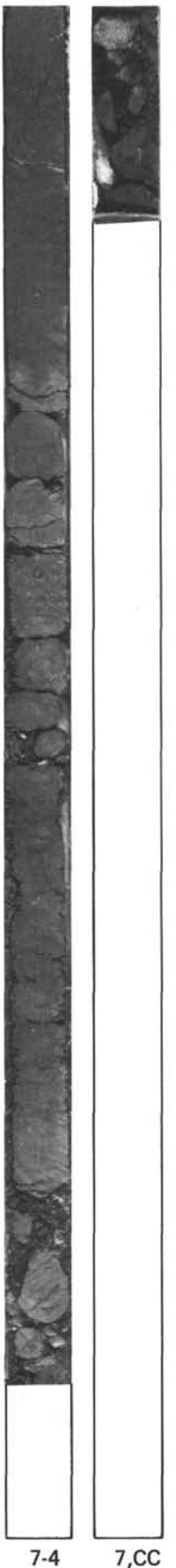

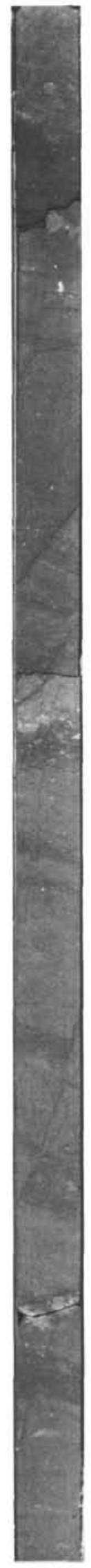

8-1
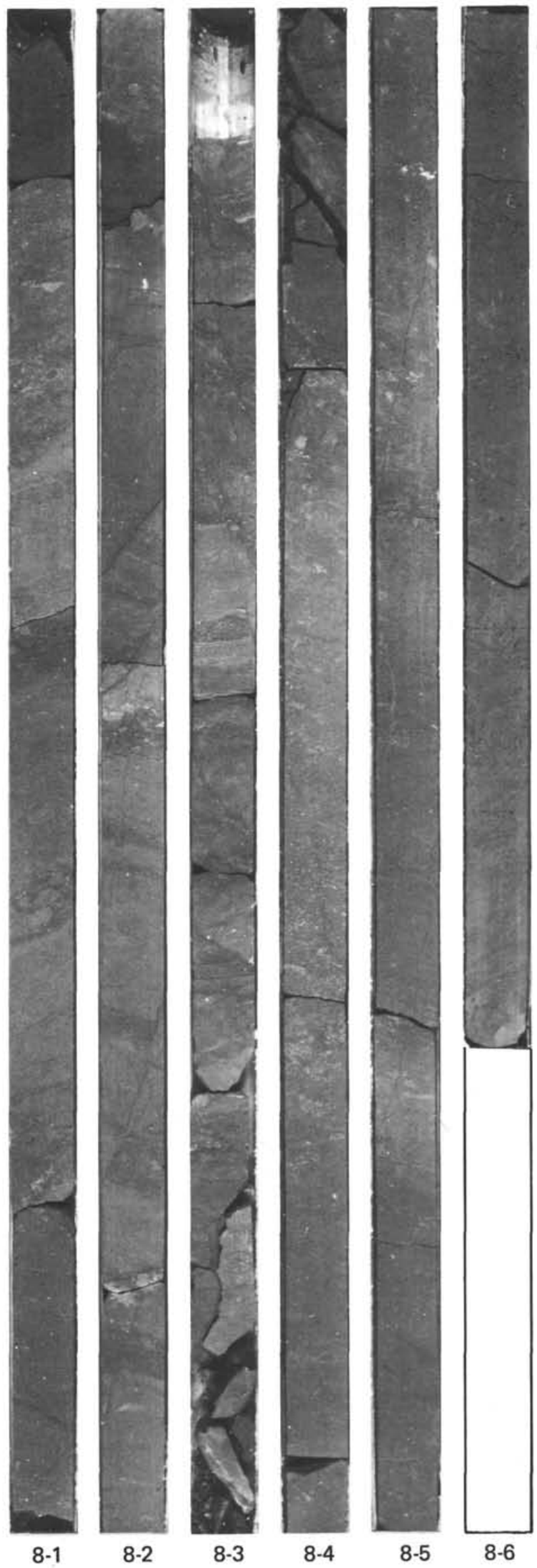

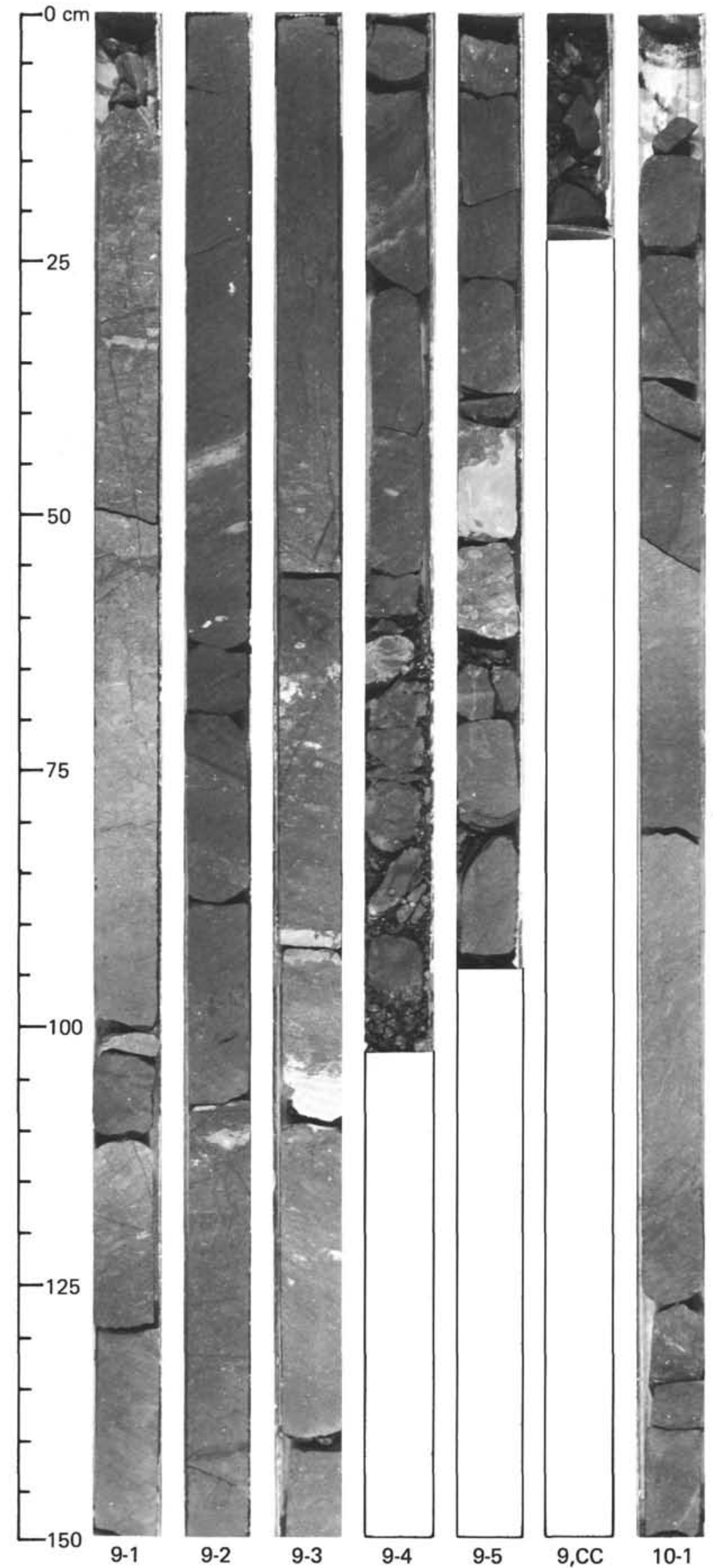
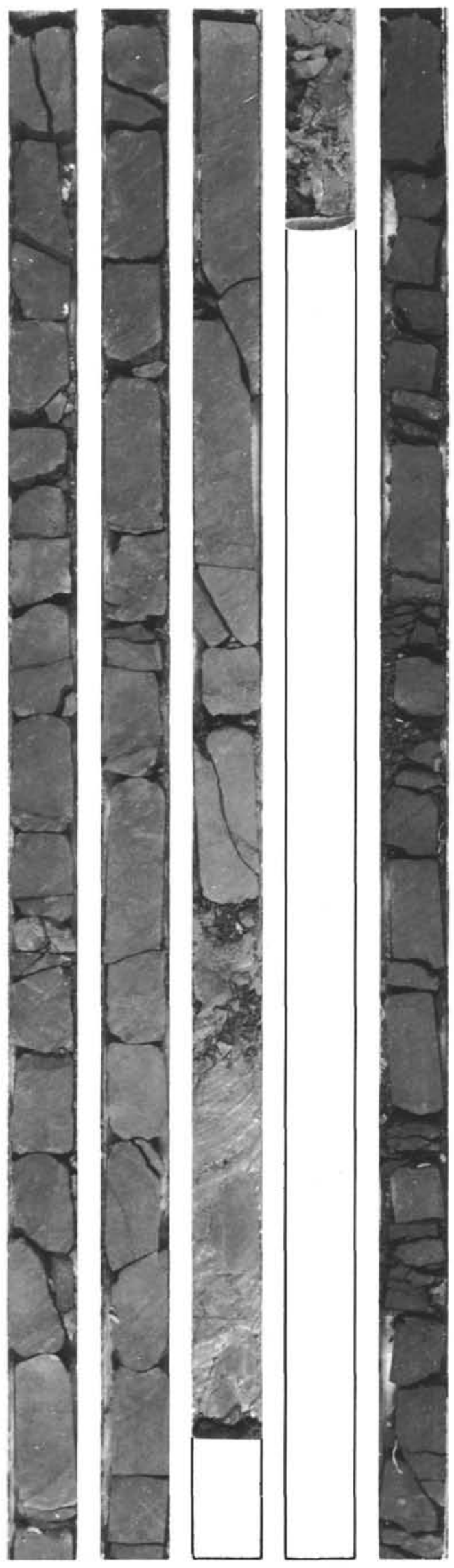

10-4

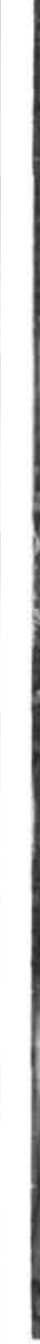
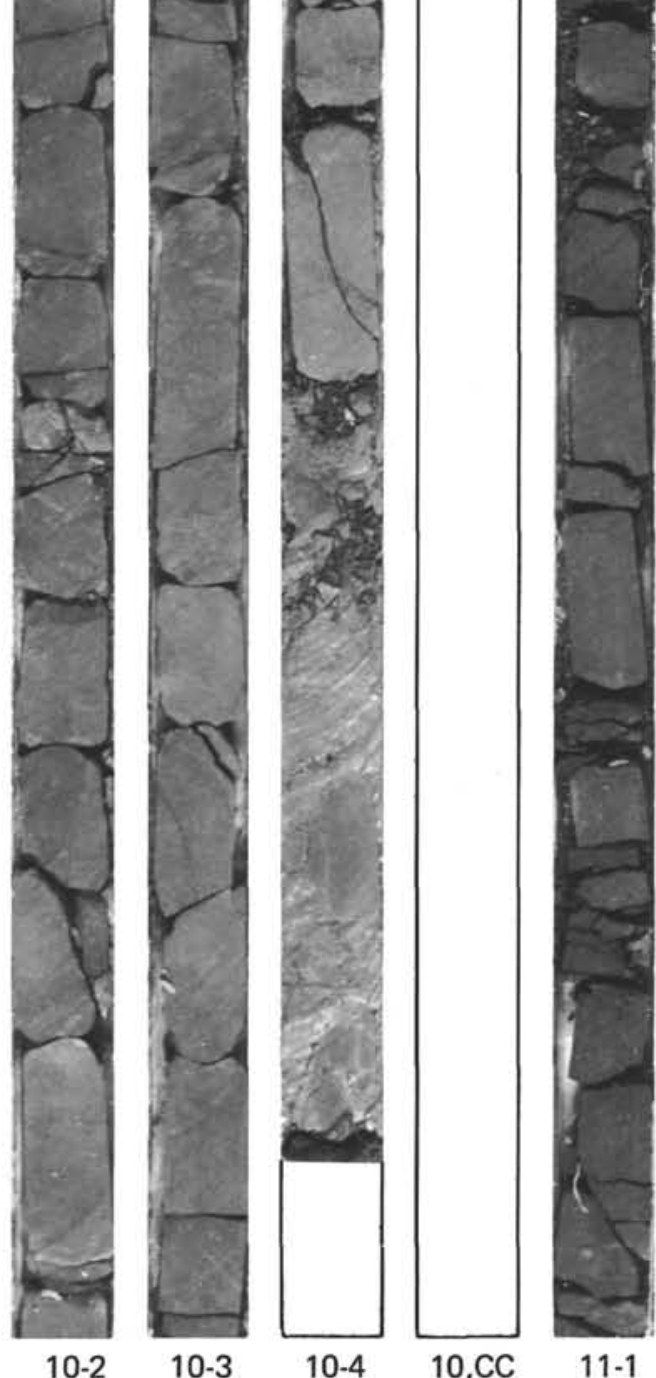
Site 439

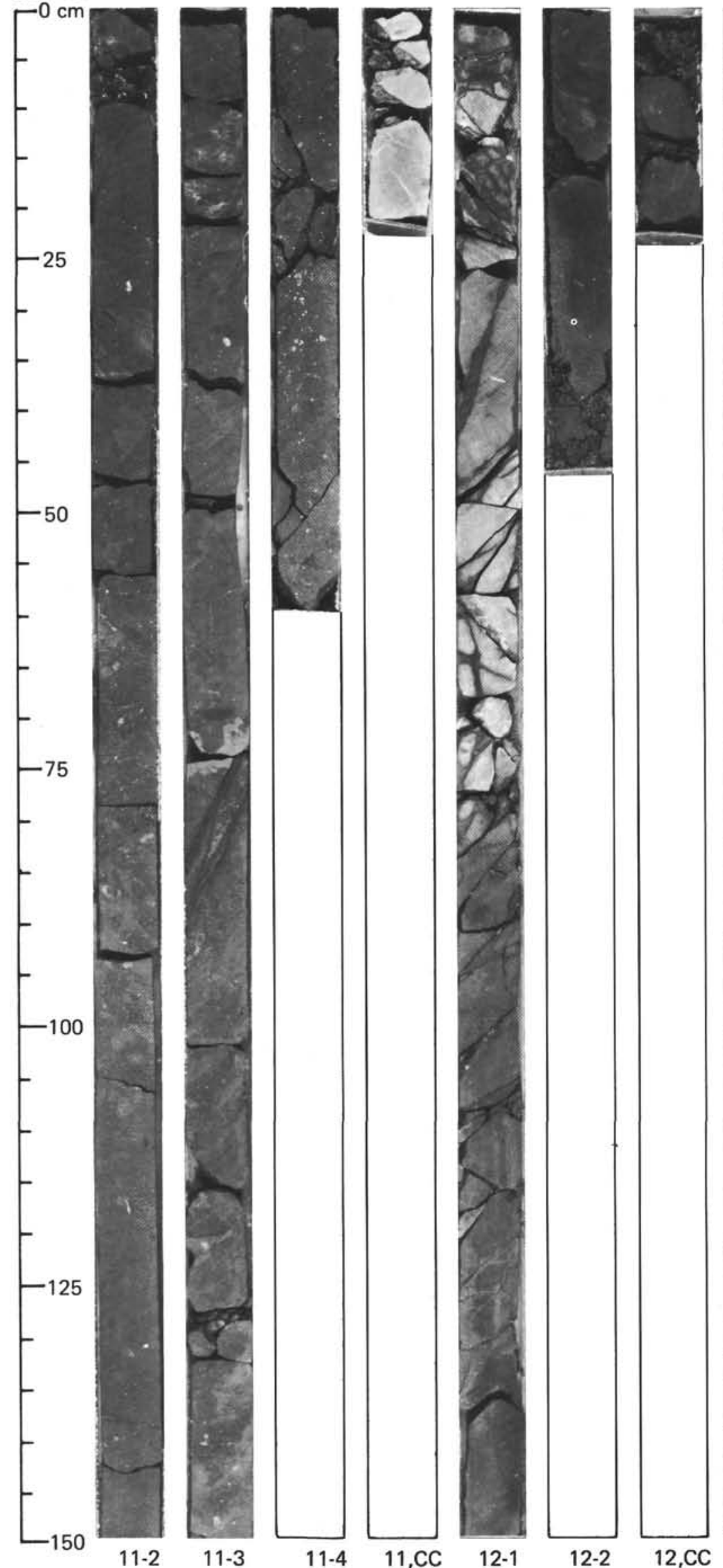

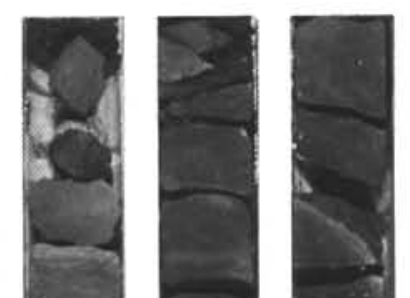
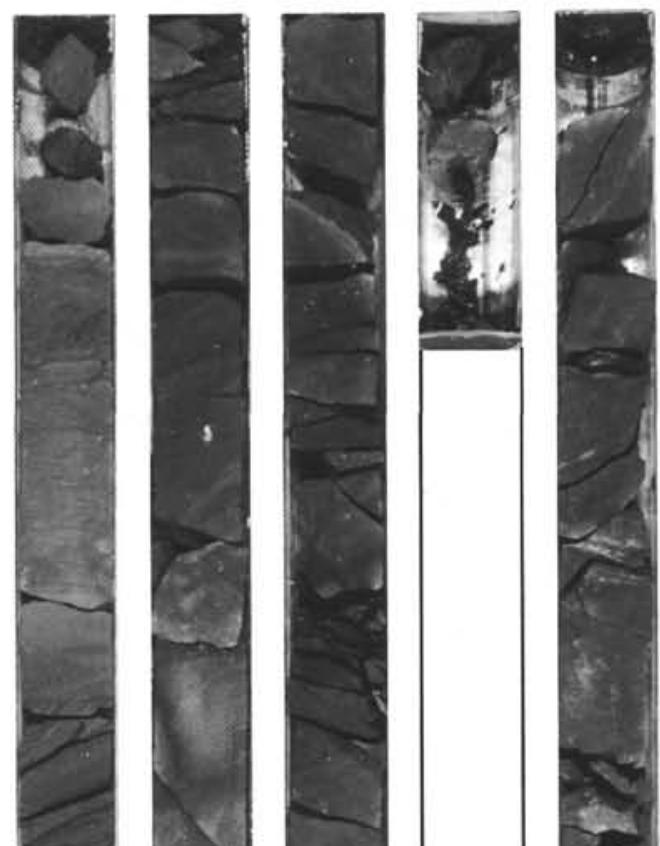

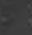
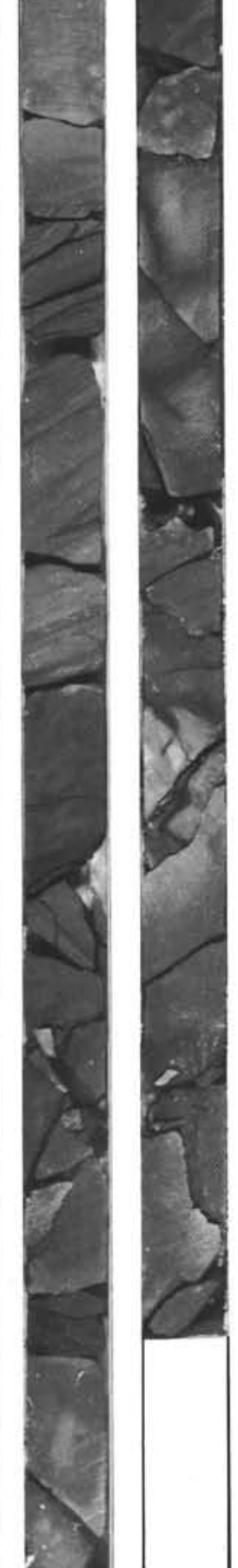

13-1

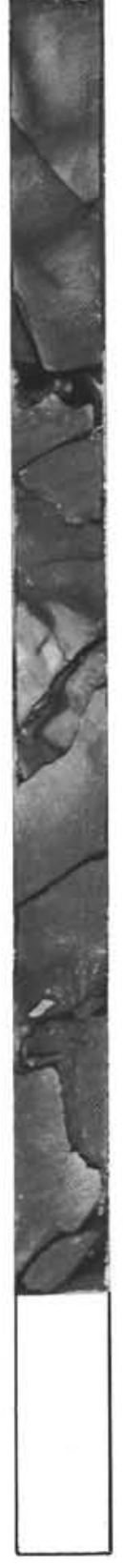

13-2

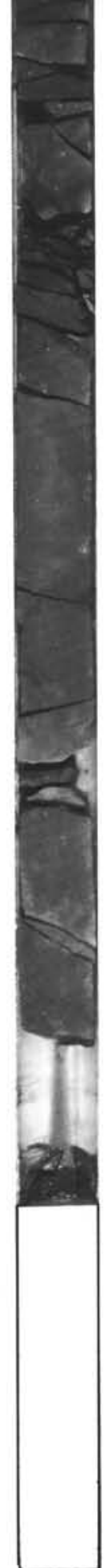

13-3

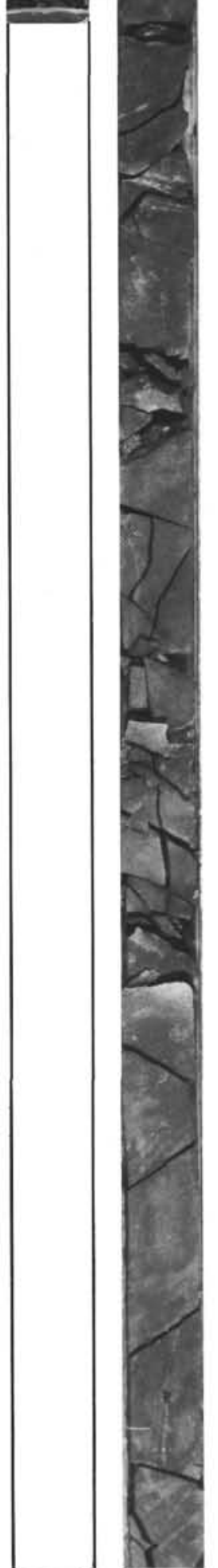

$13, \mathrm{CC}$

14-1 


\section{Site 439}

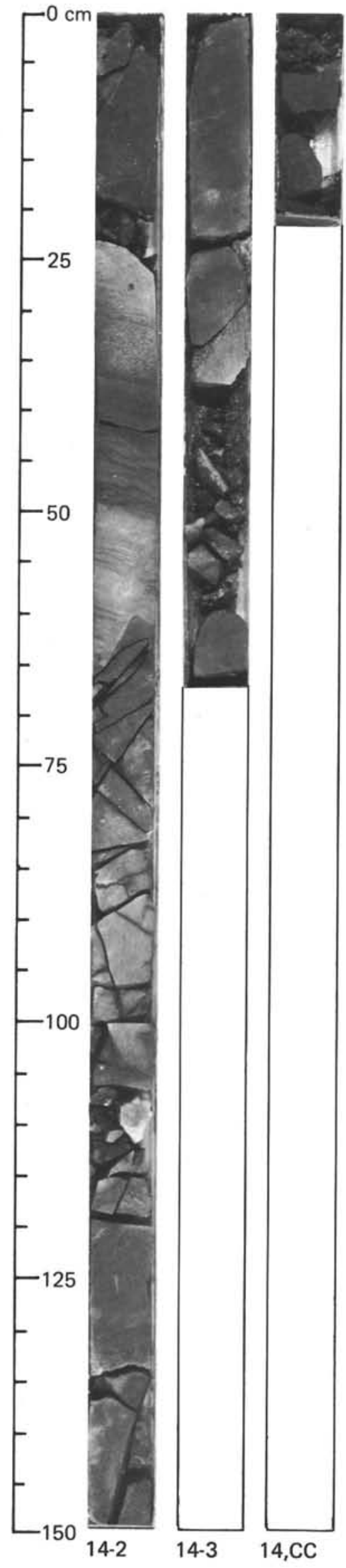

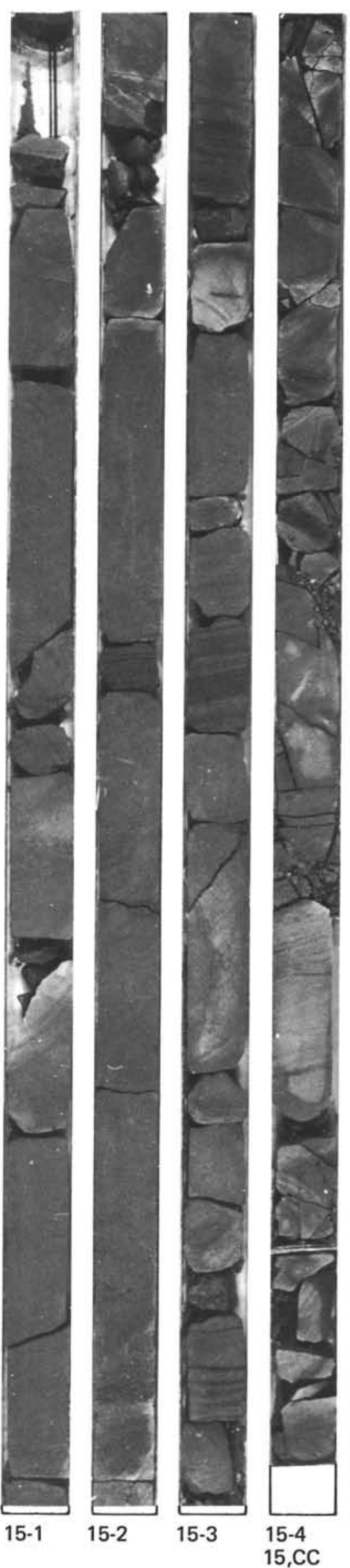
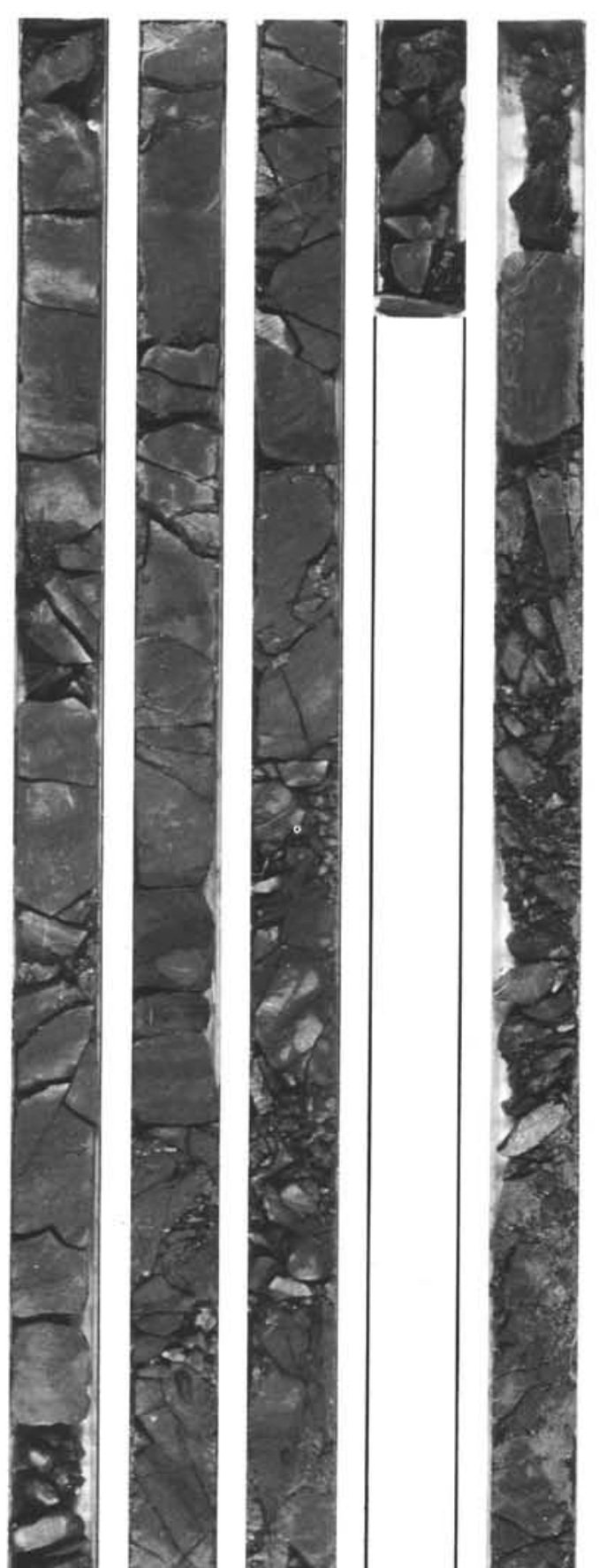

(1)

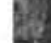

dif
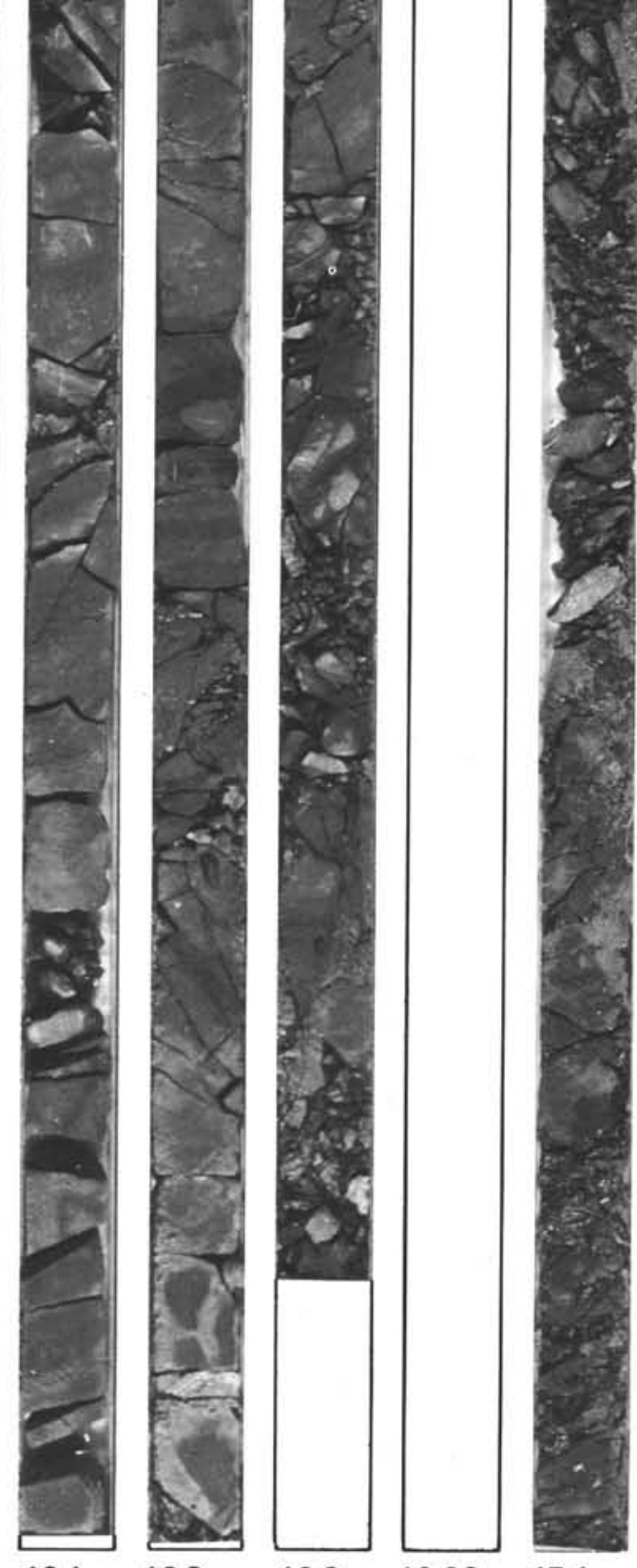

18
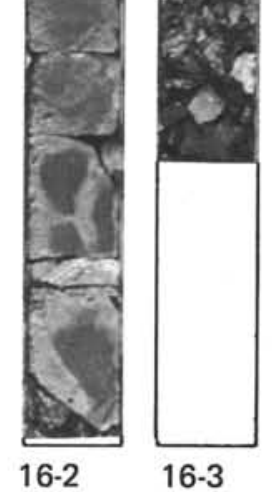
Site 439

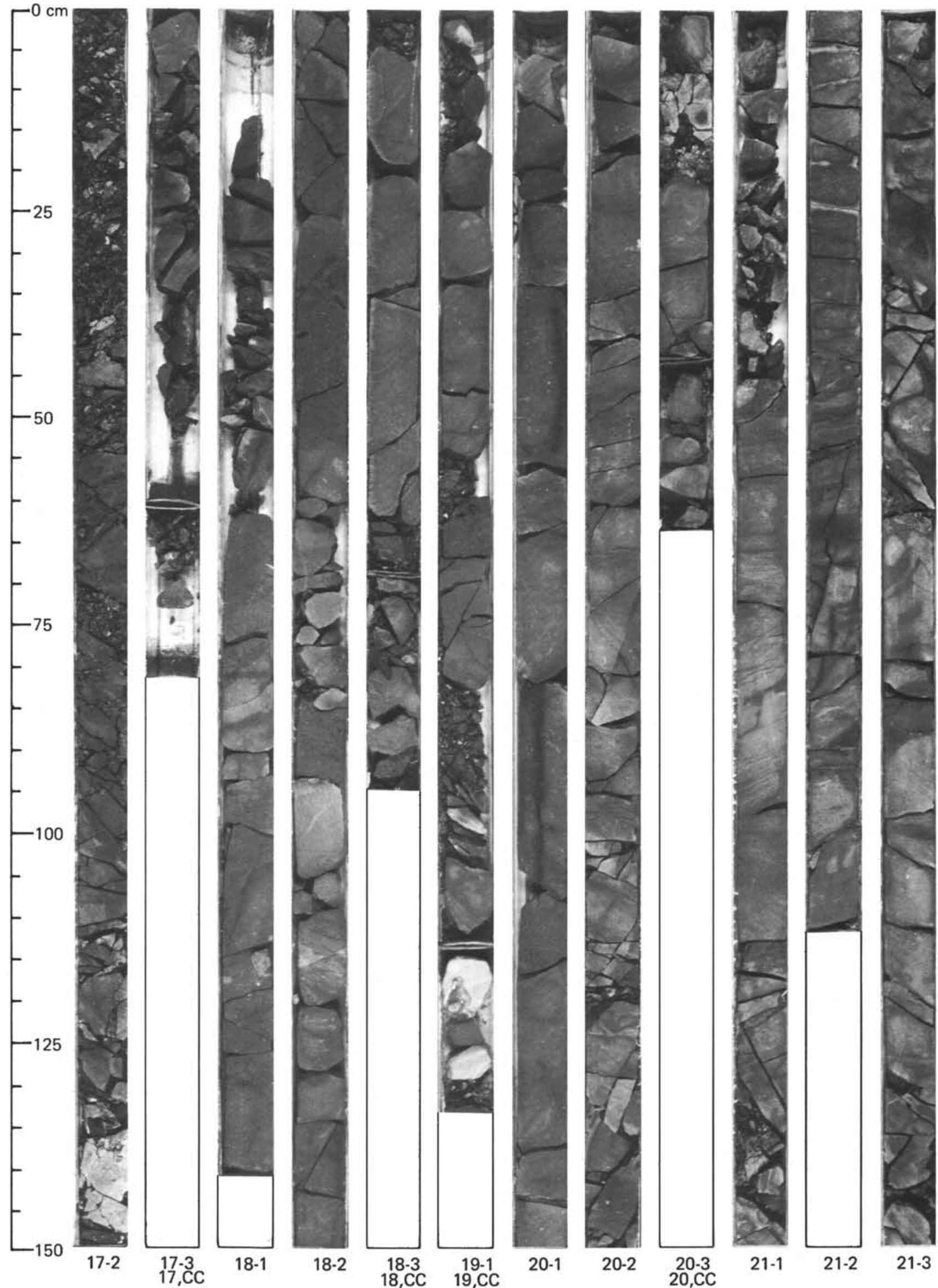


Site 439

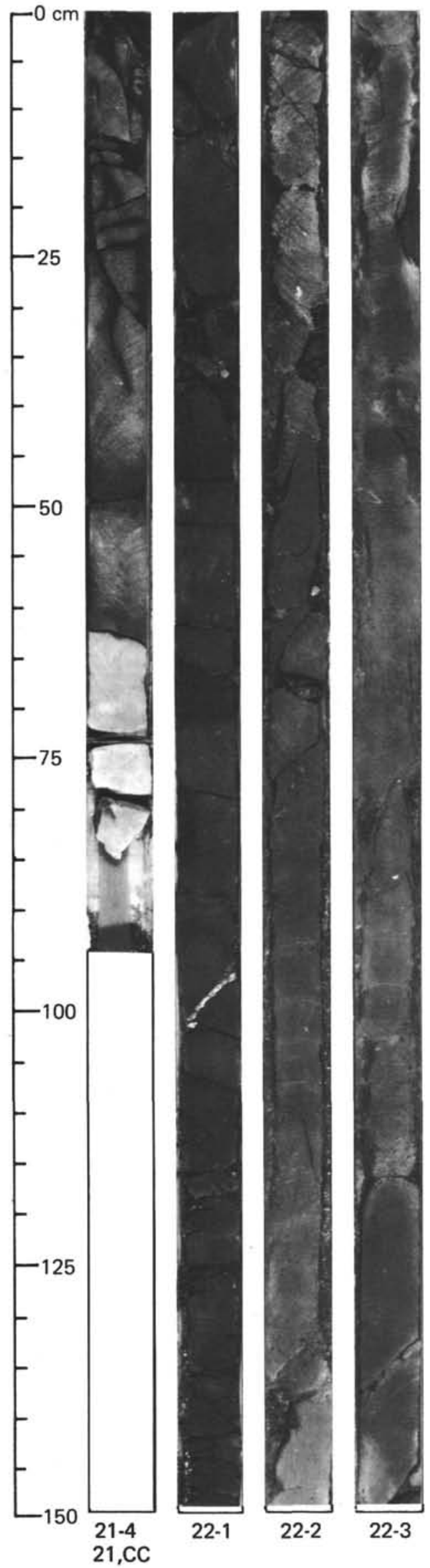

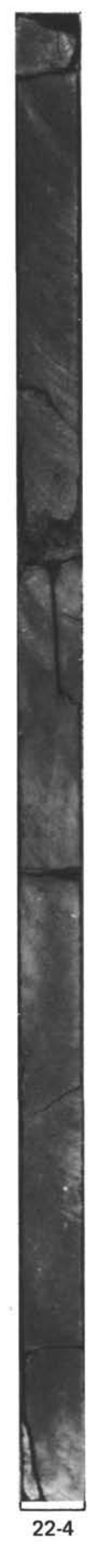
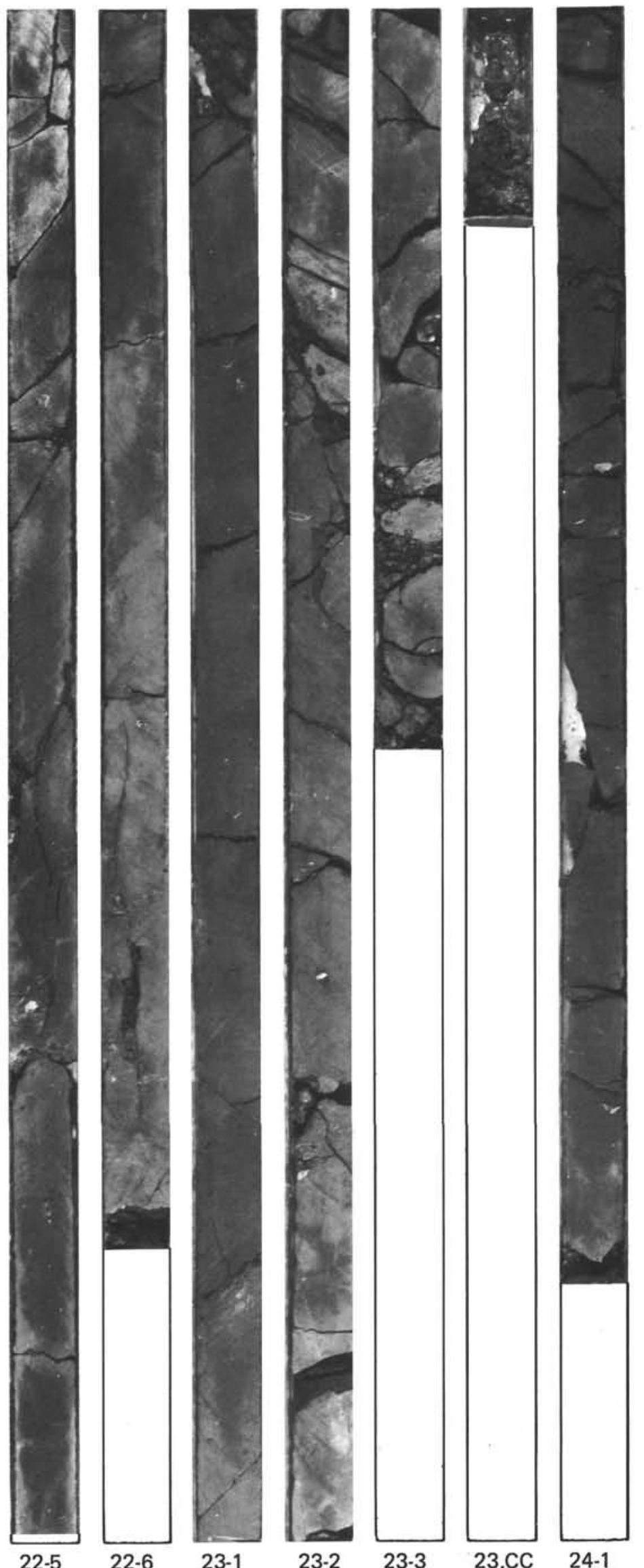

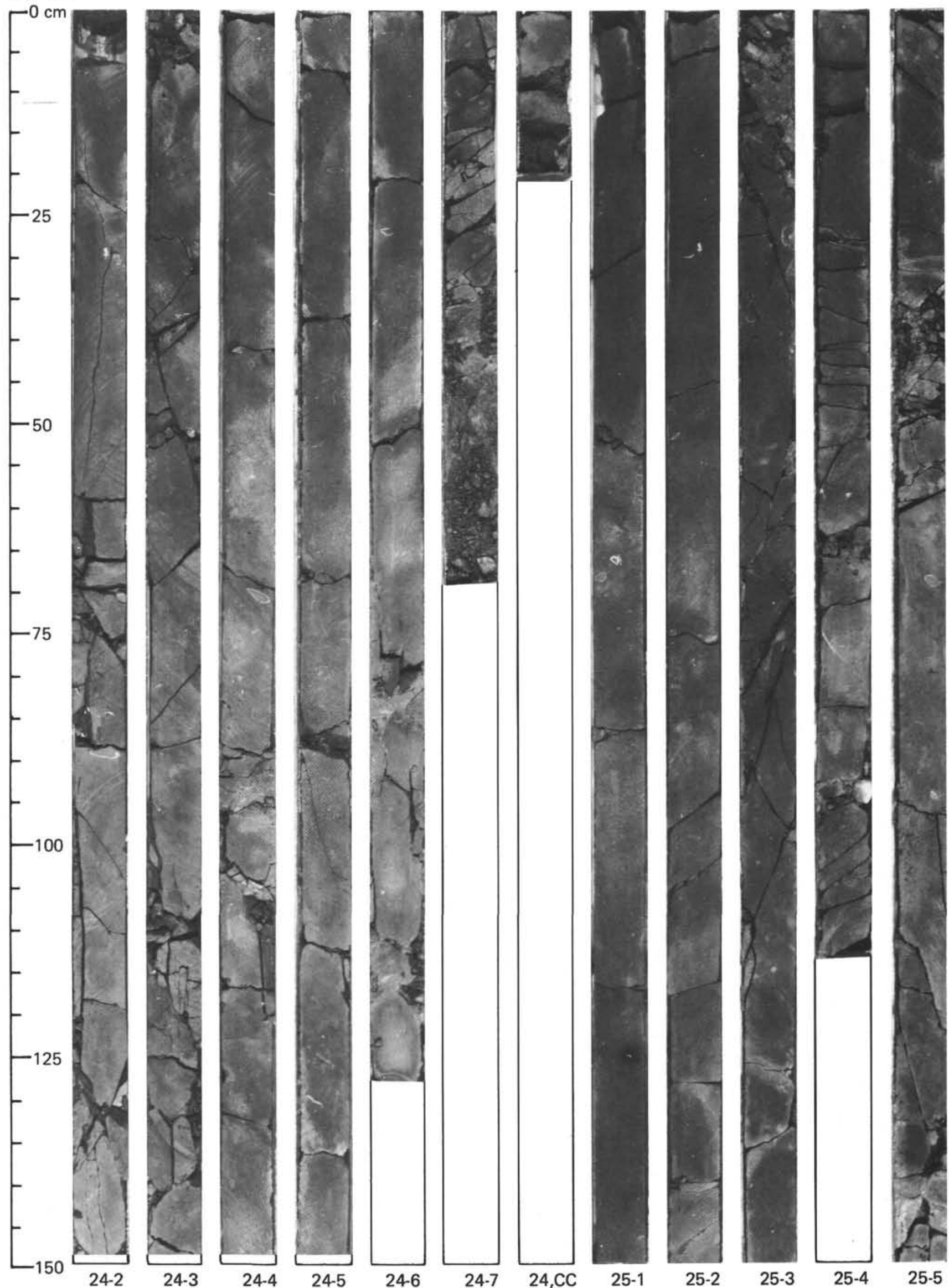

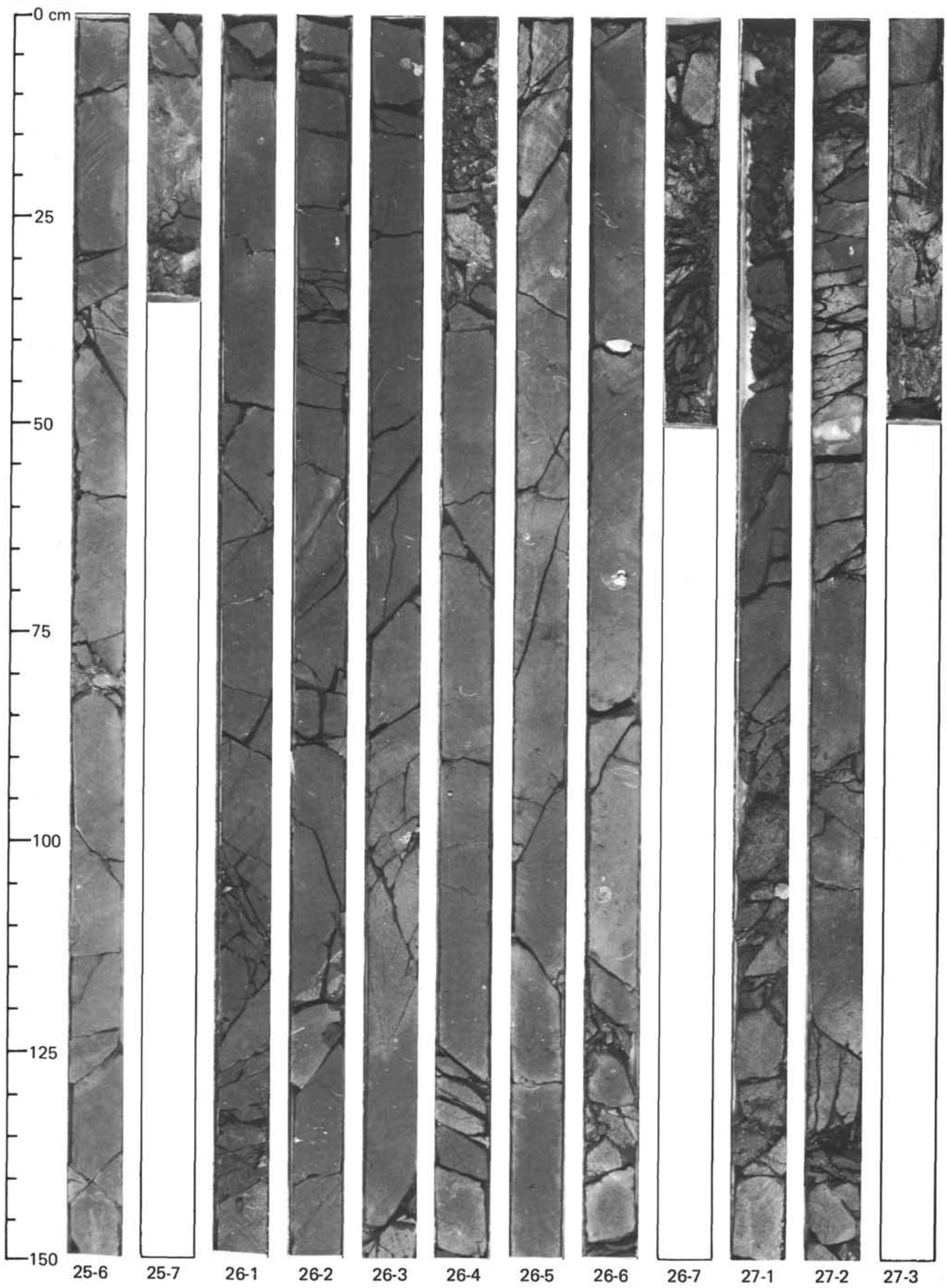
Site 439

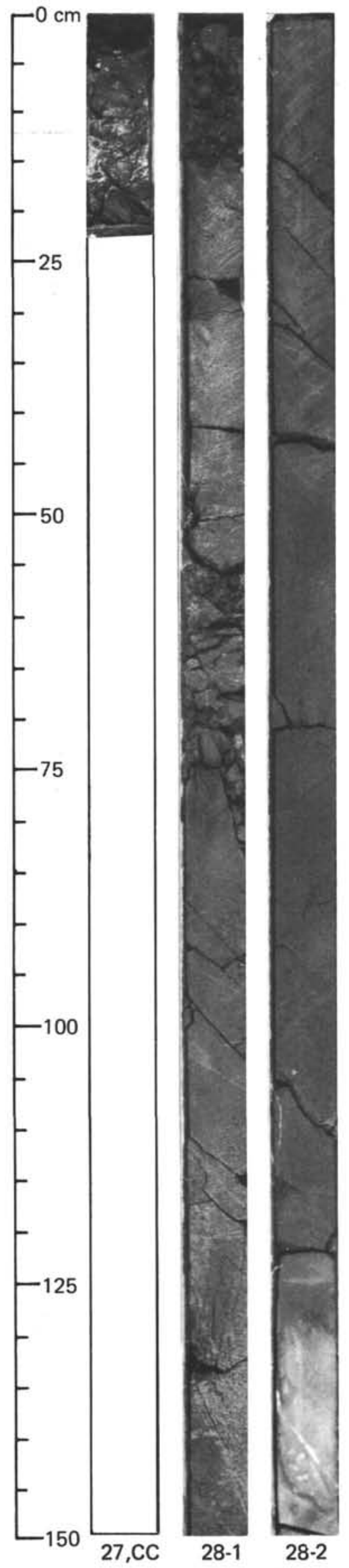

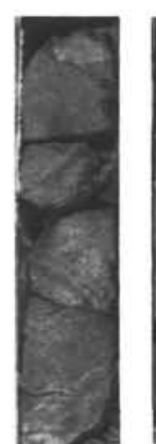
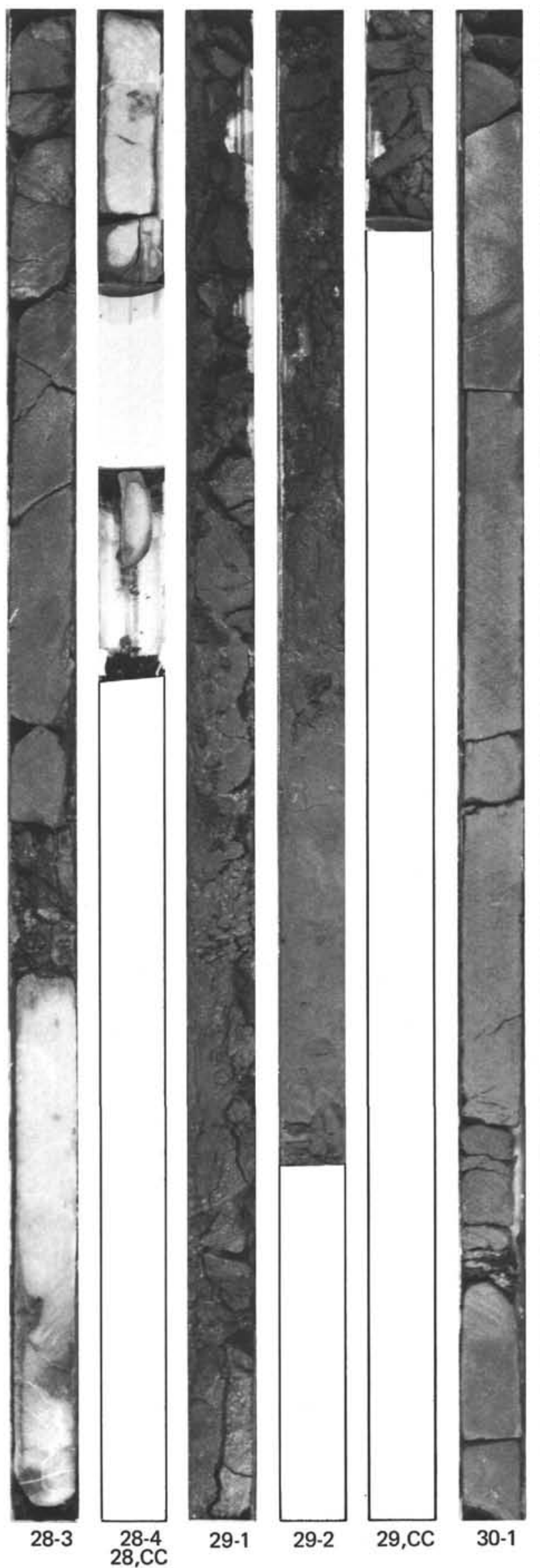

29-1

29-2
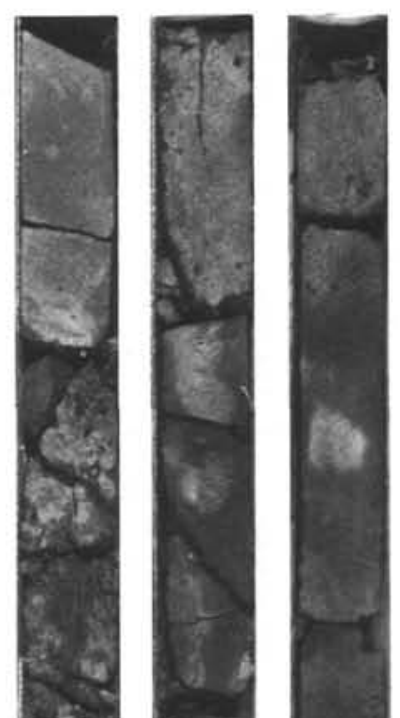

$30-1$
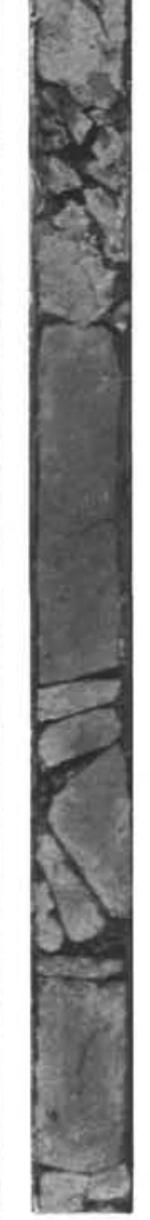

30-2

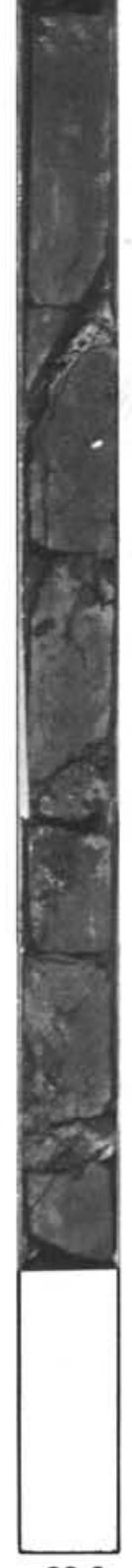

$30-3$

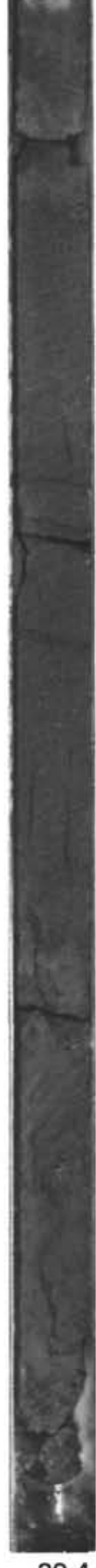


Site 439
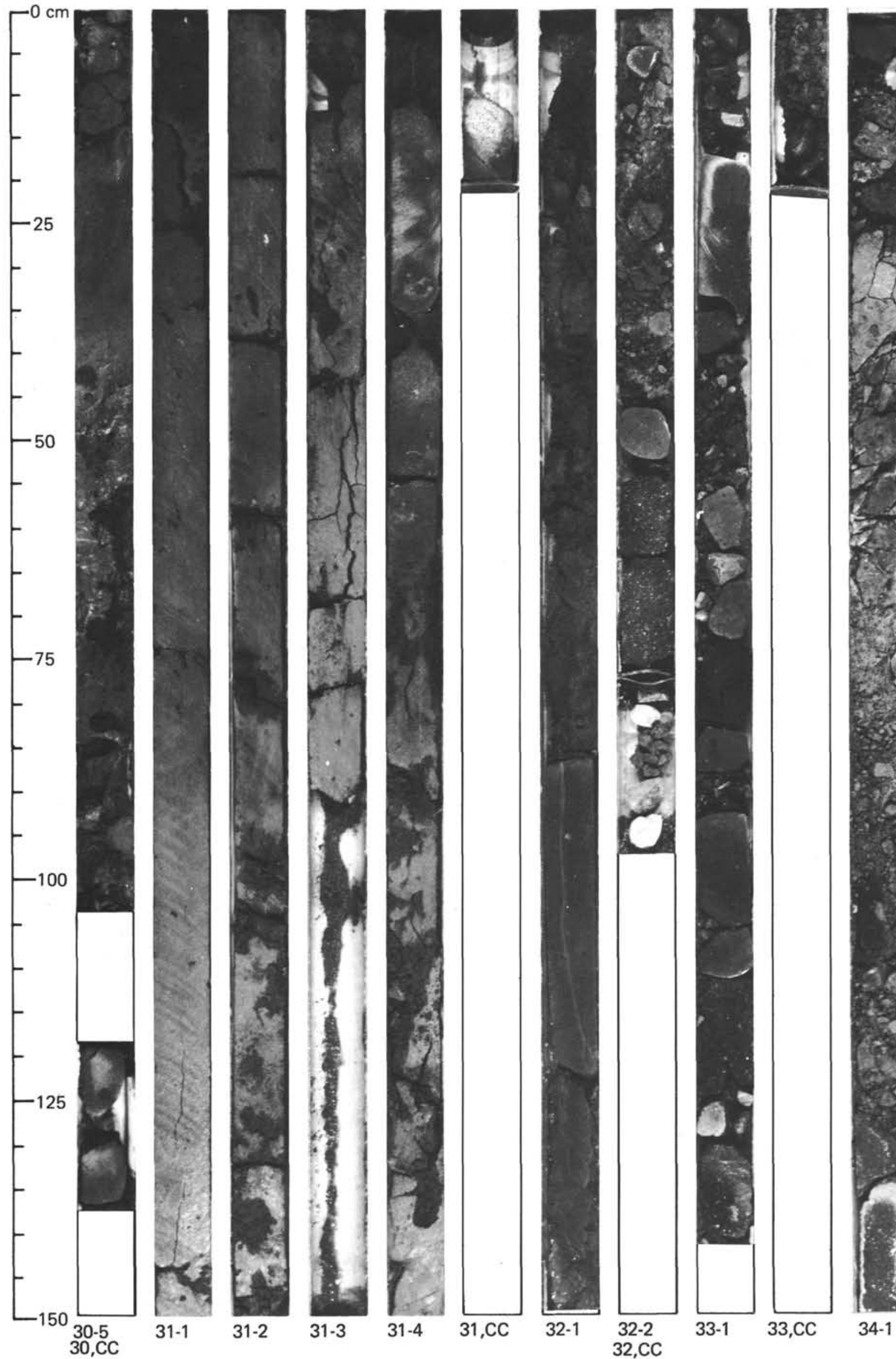

gas
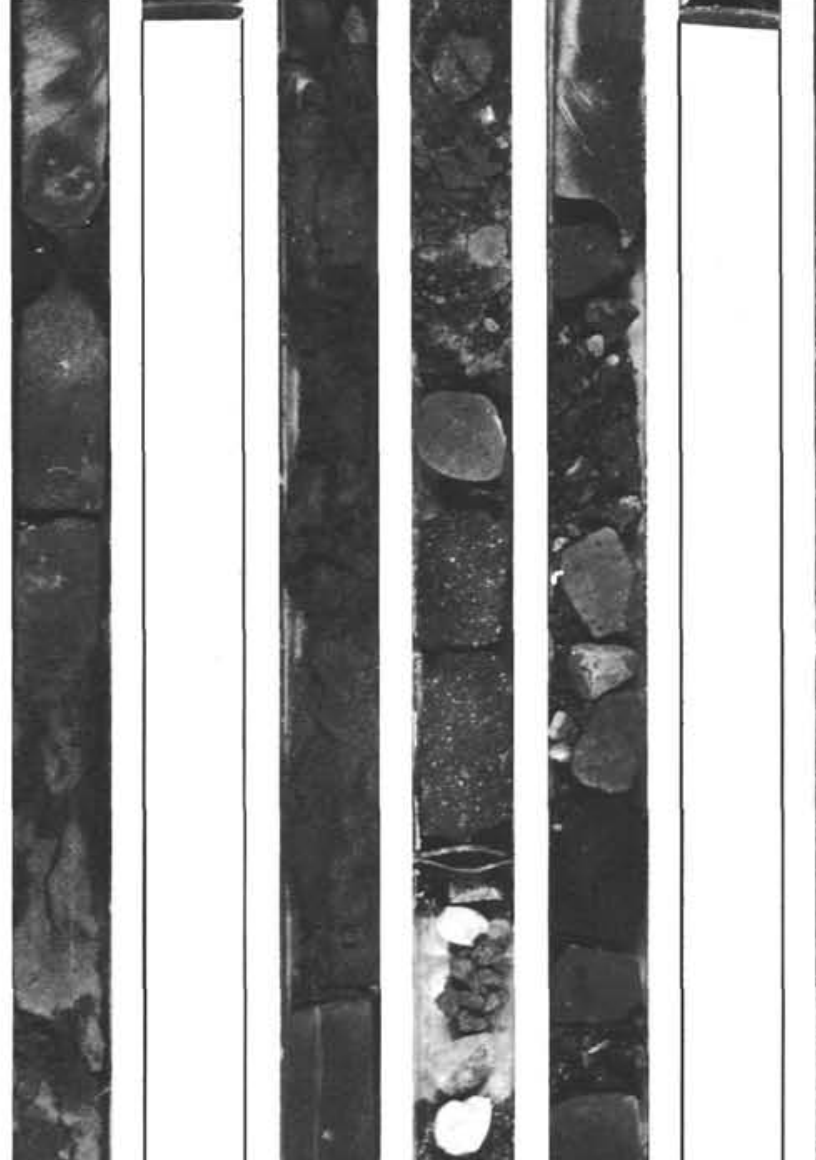

\section{.}
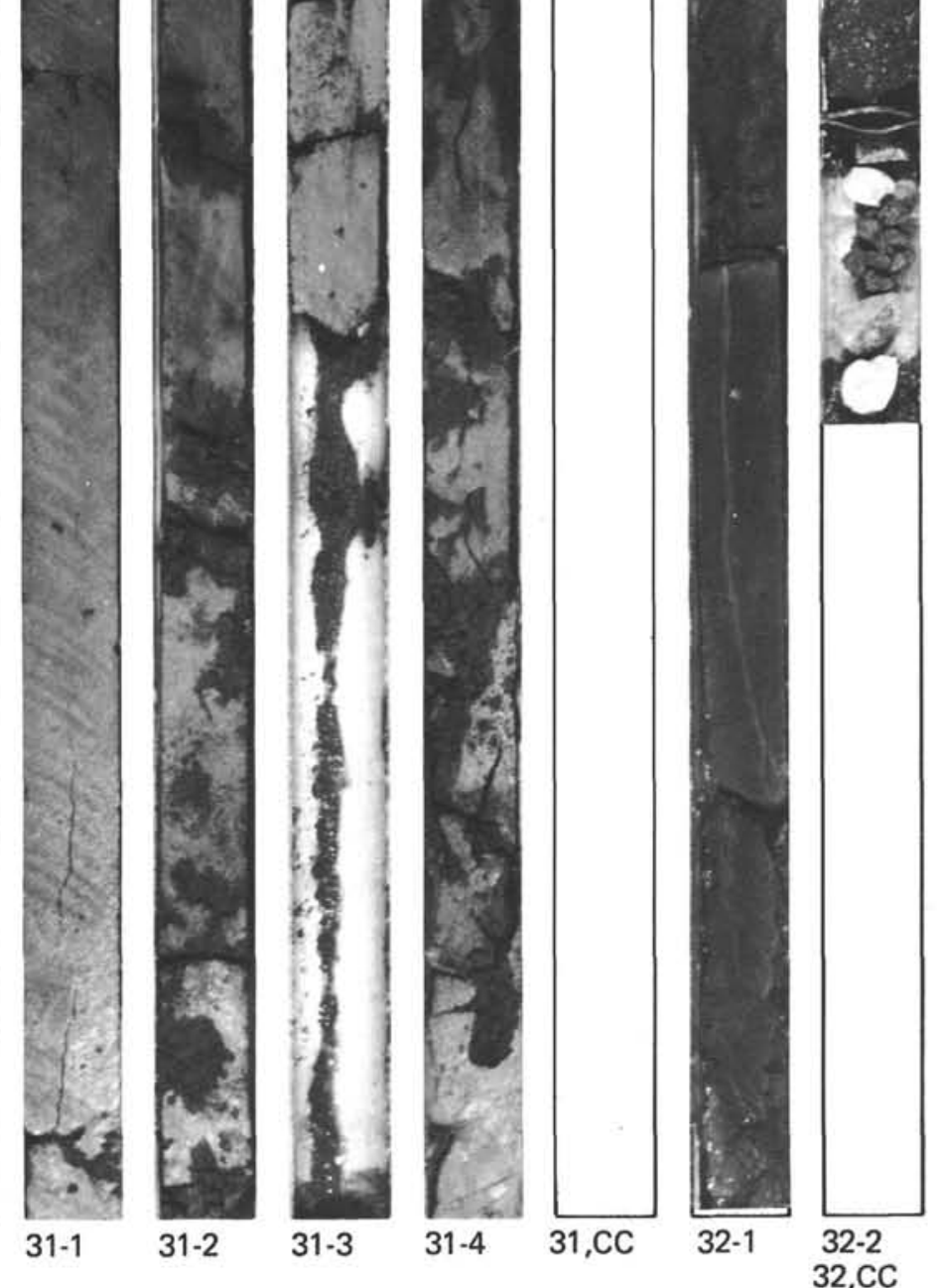

31-2

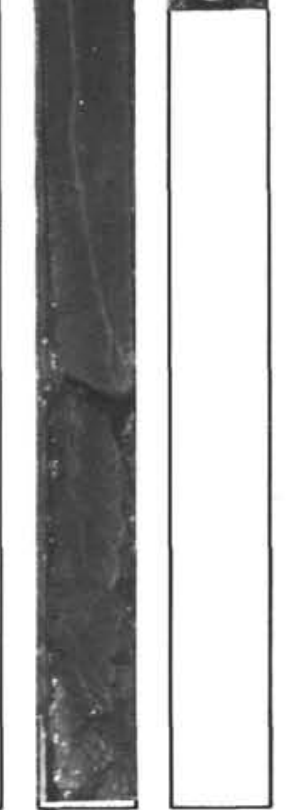

$32-1$
32-2 $32, \mathrm{CC}$

\section{(1)

列

(2) 
Site 439

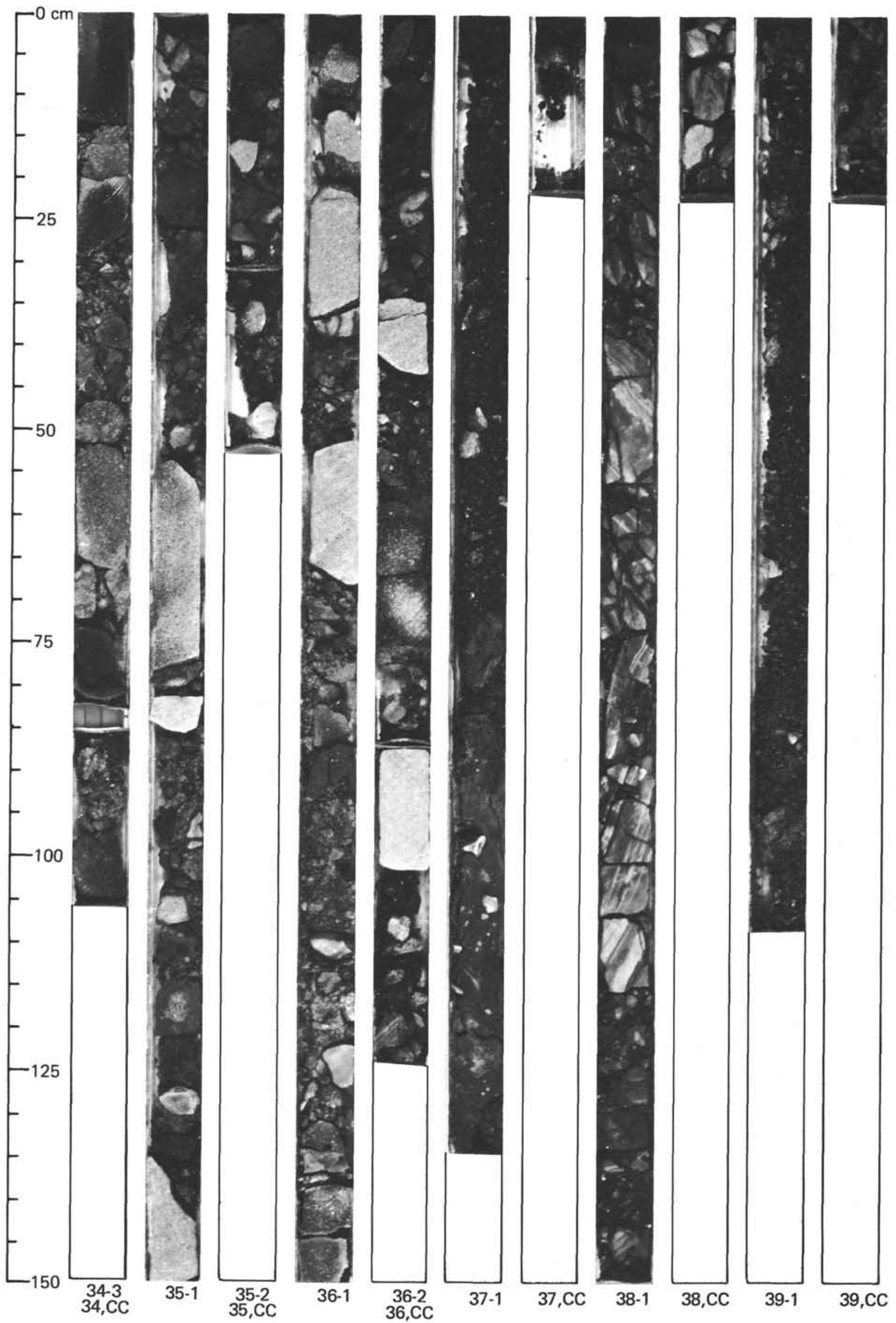

